\title{
Site U1301
}

\author{
Expedition 301 Scientists $^{2}$
}

\section{Chapter contents}

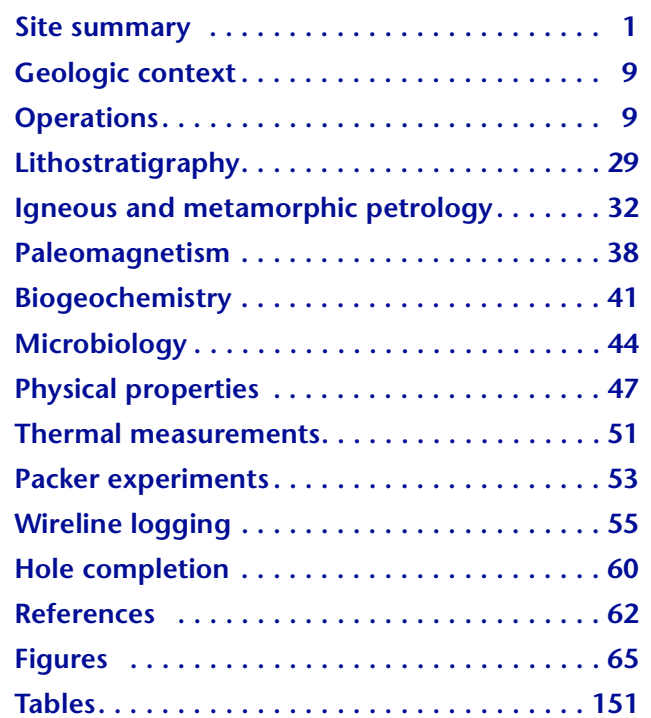

${ }^{1}$ Expedition 301 Scientists, 2005. Site U1301. In Fisher, A.T., Urabe, T., Klaus, A., and the Expedition 301 Scientists, Proc. IODP, 301: College Station TX (Integrated Ocean Drilling Program Management International, Inc.). doi:10.2204/ iodp.proc.301.106.2005

'Expedition 301 Scientists' addresses.

\section{Site summary}

Work at Site U1301 comprised operations in and around four holes (Table T2 in the "Expedition 301 summary" chapter). Hole U1301A operations included penetration of $262 \mathrm{~m}$ of sediment and the upper $108 \mathrm{~m}$ of basement, installation of casing, shortterm hydrogeologic testing, and emplacement of a single-level Circulation Obviation Retrofit Kit (CORK)-II borehole observatory. Hole U1301B penetrated 265 of sediment and $318 \mathrm{~m}$ of basement. This hole was cored with the rotary core barrel (RCB) over the lower $232 \mathrm{~m}$ of basement, logged, subjected to hydrogeologic testing within multiple depth intervals, and fitted with a multilevel CORK-II borehole observatory. Hole U1301C was discontinuously cored with the advanced piston corer (APC) to 265 meters below seafloor (mbsf), and in situ temperatures were determined to evaluate the thermal state of uppermost basement. Hole U1301D was APC spot cored to recover sediment from an interval that had not been cored in Hole U1301C.

\section{Sediments}

The lithology of sediments at Site U1301 was found to be virtually the same as those cored at Site 1026 during Ocean Drilling Program (ODP) Leg 168, 1-2 km north along the same buried basement ridge, comprising fine- to coarse-grained turbidites, debris flows, and hemipelagic clay. Resampling much of the same sedimentary interval during Expedition 301 was justified because APC coring had not previously penetrated below $100 \mathrm{mbsf}$ in this area, and we wished to collect high-quality samples for microbiological and geochemical analyses, especially in the interval close to the sediment/basement interface and the underlying crustal aquifer. Time constraints prevented continuous coring of the complete sedimentary section, but intervals that were cored generally yielded excellent recovery and high-quality samples. Exceptions to this rule included intervals where coarse sand or gravel prevented complete penetration of the APC barrel.

Silt- and clay-rich APC cores from Holes U1301C and U1301D are of exceptionally high quality, even from depths below 250 mbsf. Cores recovered from sandy and gravely intervals are generally of poorer quality and often include intervals within which there is complete resuspension and settling of clastic particles. Because of discontinuous coring, irregular recovery, and extensive wholeround sampling, we were unable to determine well-constrained 
lithologic boundaries for the primary stratigraphic units in Hole U1301C. Unit I is an upward-fining turbidite sequence with gravel interbeds, and Unit II is a hemipelagic clay sequence. The true boundary between Units I and II is present somewhere within the noncored interval between 197 and 236 mbsf. Its approximate location may be inferred from its equivalent depth in Hole 1026C (216 mbsf).

There are differences between the lithologies recovered at Site U1301 and those documented at Site 1026. The coarsest layers recovered at Site 1026 comprised mainly muddy sand and mud clasts, whereas coarse sediments from Hole U1301C included clasts of serpentinite, green amphibolite, quartzite, felsic volcanics, calcareous sandstone, and shallow-water shell fragments. One explanation for the difference is that the two sites sampled different parts of the turbidite distributary channel network, but it seems just as likely that coarse intervals were simply not recovered during extended core barrel (XCB) and RCB coring during Leg 168. The other significant difference was the greater thickness of the hemipelagic clay unit, which is at least $27 \mathrm{~m}$ thick in Hole U1301C but was only $13 \mathrm{~m}$ thick at Site 1026 . This may result from subtle differences in basement relief and depositional regime, which influence whether hemipelagic clay or fine-grained turbidites dominate deposition over basement highs (e.g., Giambalvo et al., 2000; Spinelli et al., 2004).

Pore water chemical-depth profiles from Site U1301 are similar to those from ODP Site 1026. As observed in numerous Deep Sea Drilling Project (DSDP) and ODP holes drilled to basaltic basement, there are two biogeochemical zones identified on the basis of steep geochemical gradients at the seawater/sediment and sediment/basement interfaces. The gradients are particularly well defined in the dissolved sulfate, manganese, and iron profiles. The downhole pattern of sulfate concentrations indicates active sulfate reduction at $\sim 50$ and $\sim 125$ mbsf and diffusive sources from bottom seawater and the basaltic formation fluid, respectively. Concentrations of dissolved barium are high in between these depths. Alkalinity, chlorinity, and ammonium profiles are also nearly identical at Sites U1301 and 1026 and have end-member compositions that approach those of spring fluids from Baby Bare outcrop $6 \mathrm{~km}$ away.

However, there are several significant differences in the profiles from these two sites for the minor elements, most notably for dissolved iron. Data from Integrated Ocean Drilling Program (IODP) Site U1301 have a maximum iron concentration of 133 $\mu \mathrm{mol} / \mathrm{kg}$, compared to $14.8 \mu \mathrm{mol} / \mathrm{kg}$ at Site 1026 . This highlights the importance of squeezing the sediment under a nitrogen atmosphere. There are differ- ences between chemical profiles from Site U1301 and Site 1026 in Mn, B, Sr, and Li concentrations. For these elements, the upper portion of the profiles are identical, but there are significant differences present within the basal sediments. These differences are unlikely to have resulted from sampling artifacts, as was the case for iron, because these elements do not oxidize rapidly like iron. The carbon content of the pore water increases in the uppermost $40 \mathrm{~m}$ of sediment, reaching a maximum at 47 mbsf. From 179 mbsf to the bottom of the hole, dissolved carbon concentrations are very low.

The depth profile of methane concentrations varies inversely with sulfate and indicates the presence of two sulfate/methane interfaces. Methane concentrations are low in the upper part of the sediment but increase sharply in the depth interval between 60 and 70 mbsf and reach a maximum near 100 mbsf. Higher molecular weight hydrocarbon gases were not detected in samples from Site U1301. The highest methane concentrations are present within the interval where sulfate is nearly depleted. This relationship indicates that the methane results from microbiological production. The disappearance of almost all of the methane at the depths of sulfate depletion indicates that most of this methane is likely consumed by anaerobic methane oxidation.

The solid phase of recovered sediments has relatively low organic carbon, nitrogen, and hydrogen contents. Organic carbon contents are highest close to the sediment/water interface $(0.9 \mathrm{wt} \%)$ but decrease rapidly and fluctuate around $0.3 \mathrm{wt} \%$ throughout the sediment column. Total nitrogen averages $\sim 0.04$ $\mathrm{wt} \%$ and has a depth trend similar to organic carbon. Calculated atomic $\mathrm{C} / \mathrm{N}$ ratios generally indicate organic matter of marine origin. In some discrete sediment layers, however, elevated $\mathrm{C} / \mathrm{N}$ ratios indicate a significant input of terrestrial organic matter. We also find distinct layers with highly elevated carbonate contents below the postulated lower zone of anaerobic methane oxidation. Observed carbonate peaks coincide with elevated carbonate levels found at Site 1026 below the lower zone of anaerobic methane oxidation and at the sediment/basement interface.

Microbiological samples were collected from all sediment cores. Total cell counts decreased slightly with depth, from near-surface concentrations of $7.5 \times 10^{8}$ to concentrations of $1.8 \times 10^{7}$ cells $/ \mathrm{cm}^{3}$ at $248 \mathrm{mbsf}$. Overall, the profile of microbial cell densities follows a trend similar to that defined for other ODP sites. Tiny coccoid-shaped cells dominated throughout the sediment column. Numbers of rod-shaped cells fluctuated strongly. Aggregates of up to 30 microbial cells were detected in four horizons between 63 and 
90 mbsf. Interestingly, an increase in cell numbers was observed near the sediment/basement interface. This increase in biomass may be supported by upward flux of electron acceptors from hydrothermal fluids in the underlying bedrock. Sulfate may be an important oxidant in the deepest part of the sediment column, illustrating how water in the basaltic crust might support microbial growth in overlying sediments.

Approximately 1000 enrichment cultures of indigenous microorganisms were inoculated on board using three methods. Samples were cultured in various forms using different media and incubation temperatures ranging from $5^{\circ}$ to $85^{\circ} \mathrm{C}$. None of the anaerobically incubated enrichments showed growth during Expedition 301. The incubation time was probably too short for most of the microorganisms to grow, and these studies will be continued on shore.

Perfluorocarbon tracer (PFT) was pumped during all coring operations to help in evaluating core contamination. PFT concentrations were evaluated across the cut faces of the cores, and results of these tests indicate that contamination was generally minimal, usually indicating a ratio of introduced to native cells of $10^{-9}$ or fewer. We found no relationship between drilling fluid contamination and core depth or lithology (clay versus sand).

Physical properties from Hole U1301C are highly bimodal, with clay- and sand-rich sediments showing distinctive trends for most measurements. Magnetic susceptibility data show trends that are typical for turbidites, with higher values in the coarse sandy layers and lower values in clay-rich layers. In contrast, natural gamma radiation levels were not particularly helpful in distinguishing primary lithology. Bulk density of the clay layers increases systematically from $\sim 1.4 \mathrm{~g} / \mathrm{cm}^{3}$ at the seafloor to $\sim 2 \mathrm{~g} / \mathrm{cm}^{3}$ at 100 mbsf and correlates with a $\sim 30 \%$ decrease in porosity over the same depth interval. The porosity of sand layers remains relatively constant at $\sim 40 \%$ to a depth of 115 mbsf. Because of time and operational constraints, two large continuous sections below 100 mbsf were not cored, prohibiting analysis of trends at greater depth. Bulk density values from clay lithologies recovered in the $30 \mathrm{~m}$ above basement vary slightly about a mean of $1.9 \mathrm{~g} / \mathrm{cm}^{3}$. The bulk density of sand layers is relatively consistent at $2.0 \pm 0.1 \mathrm{~g} /$ $\mathrm{cm}^{3}$. Grain density is remarkably consistent at $2.8 \pm$ $0.1 \mathrm{~g} / \mathrm{cm}^{3}$ regardless of depth or lithology. The higher than expected grain density could be attributable to pyrite, which has a grain density of $\sim 5 \mathrm{~g} / \mathrm{cm}^{3}$. Thermal conductivity was strongly controlled by lithology, with values for clay being significantly less than values for sand, averaging $1.12 \pm 0.12$ and 1.53 $\pm 0.19 \mathrm{~W} / \mathrm{m} \cdot \mathrm{K}$, respectively. A systematic increase of thermal conductivity is apparent in the upper 100 mbsf within clay-rich layers. A matrix thermal conductivity of $\sim 2.5 \mathrm{~W} / \mathrm{m} \cdot \mathrm{K}$ was indicated for clay-rich layers, a value $\sim 1 \mathrm{~W} / \mathrm{m} \cdot \mathrm{K}$ less than estimated by Shipboard Scientific Party (1997) in Hole 1026A. Pwave velocity values range from $\sim 1480$ to $1780 \mathrm{~m} / \mathrm{s}$ over the $265 \mathrm{~m}$ cored interval, with an increase of $\sim 10 \%$ within the uppermost 50 mbsf. We found no evidence for velocity anisotropy. Undrained shear strength was also found to increase with depth through the sediment section.

Two attempts to determine in situ temperatures in Hole U1301C were made with the APC tool and three were made with the Davis-Villinger Temperature Probe (DVTP). One of each kind of measurement was unsuccessful, but the remaining data were sufficient to determine both the temperature of uppermost basement and heat flow through the sediments. The upper basement temperature is $\sim 62^{\circ} \mathrm{C}$, approximately the same as that measured at nearby Sites 1026 and 1027, and heat flow through the sediments is $280 \mathrm{~mW} / \mathrm{m}^{2}$ and entirely conductive.

\section{Basement}

The geology of the uppermost $85 \mathrm{~m}$ of basement is poorly known at Site U1301 because no coring was attempted from the sediment/basement interface to this depth. The decision to drill and case uppermost basement at Site U1301 was made during planning for Expedition 301 on the basis of general and local experience, as discussed earlier (see "Operational strategy" in "Operational strategy and overview of expedition achievements" in the "Expedition 301 summary" chapter). RCB core recovery was only 5\% within the upper $40 \mathrm{~m}$ of Hole 1026B (Shipboard Scientific Party, 1997), and that hole required installation of a liner at depth to keep basement "open" for testing and monitoring.

Records of drilling penetration rates within the upper $100 \mathrm{~m}$ of basement at Site U1301 provide limited lithostratigraphic insight (Fig. F9 in the "Expedition 301 summary" chapter). Penetration rates $<3-4 \mathrm{~m} / \mathrm{h}$ generally corresponded to relatively massive rock and stable hole conditions, whereas penetration rates $>8-10 \mathrm{~m} / \mathrm{h}$ were usually accompanied by hole instability. Although there is not a one-to-one correspondence between penetration rates at equivalent basement depths in the two holes, there are gross similarities. For example, the interval from 55 to 65 $\mathrm{m}$ into basement drilled relatively slowly in both holes, whereas the interval from 65 to $80 \mathrm{~m}$ into basement drilled much more quickly. We initially attempted to place casing across this fast-drilling interval in Hole U1301A but failed to land the original 
casing string. We had to shorten this string and cased only the uppermost $15 \mathrm{~m}$ of basement in this hole. We subsequently cased most of this fast-drilling interval in Hole U1301B.

Basement was cored in Hole U1301B from 351 to 583 mbsf ( 86 to 317.6 meters subbasement [msb]) in Hole U1301B. The $69.1 \mathrm{~m}$ of recovered core, comprising recovery of $30 \%$, consisted of (1) basalthyaloclastite breccia, (2) aphyric to highly phyric pillow basalt, and (3) massive basalt. Eight basalt units were defined on the basis of changes in lava morphology, rock texture, and grain size (Fig. F10 in the "Expedition 301 summary" chapter). Pillow lava units (Units 1, 3, 5, 7, and 8) were subdivided based on changes in phenocryst mineralogy and abundances. Massive lava units (Units 2, 4, and 6) were subdivided into individual cooling units based on the presence of chilled margins.

Pillow basalt was the most abundant rock type recovered from Hole U1301B. Pillow lavas were identified by curved chilled margins, oblique to the vertical axis of the core, with perpendicular radial cooling cracks. Pillow fragments have dominantly hypocrystalline textures with a glassy to microcrystalline groundmass. They are sparsely to highly plagioclase \pm clinopyroxene \pm olivine phyric. Observed basalt textures vary from glassy to hyalophitic (typically with sheaf-spherultic or plumose textures) to glomeroporphyritic, seriate, and intersertal. The pillows are sparsely vesicular, containing $1 \%-5 \%$ round gas vesicles, and slightly to moderately altered. Alteration styles include interstitial groundmass replacement, vesicle fill, vein formation (with associated alteration halos), and the complete replacement of olivine phenocrysts. An almost complete section through a single pillow was recovered in one $45 \mathrm{~cm}$ long interval of essentially continuous core.

Several pieces of basalt-hyaloclastite breccia were recovered and defined as subunits. These thin breccias ( $<1 \mathrm{~m}$ of recovered core) are composed of clasts of basalt that are similar to the underlying basalts, some with glassy margins. Given the low recovery of these intervals, and the dedicated use of most of the recovered rock for microbiological analysis, it is not possible to determine the relationship between the hyaloclastite portions and underlying lavas, specifically whether or not they are part of the same cooling unit.

Massive basalts consist of continuous sections of up to $4.5 \mathrm{~m}$ of similar lithology, which increases in grain size toward the center of the flows. Some massive flows have upper and/or lower planar glassy chilled margins. High recovery, up to $100 \%$ in one case, allows individual lava flows or cooling units to be distinguished. Mineralogically, the massive lavas are very similar to the sparsely phyric pillow basalts, containing plagioclase, olivine, and clinopyroxene as phenocryst as well as groundmass phases. The massive basalts are sparsely to highly vesicular, with an average of $1 \%-5 \%$ round gas vesicles, up to $3 \mathrm{~mm}$ in diameter. The vesicles are generally concentrated in the upper portions of the flows, but one unit has a distinct $20 \mathrm{~cm}$ wide band in its center, of which $\sim 15 \%$ is vesicles. The massive flows are slightly to moderately altered and exhibit similar alteration styles to the pillow basalts: vesicle fill, vein formation (and the development of associated alteration halos), and the complete replacement of olivine phenocrysts. However, the massive basalts contain fewer fractures and veins than the pillow basalts, allowing better core recovery and the retrieval of individual pieces up to $94 \mathrm{~cm}$ long.

Geochemical analysis of basalt samples indicates that they are normal depleted mid-ocean-ridge basalt (MORB). The consistency of cross plots such as $\mathrm{TiO}_{2}$ versus $\mathrm{Zr}$ suggests that all the basalt recovered from Hole U1301B came from the same magmatic source. All of the basement rocks recovered from Hole U1301B have undergone alteration. Most pieces are slightly to moderately altered, with secondary minerals (1) lining or filling vesicles and cavities, (2) filling fractures and veins, (3) replacing phenocrysts, or (4) replacing interstitial mesostasis and glass. Thin section observations indicate that the degree of alteration varies from $\sim 5 \%$ to $25 \%$, excluding the hyaloclastite breccia, which is $\sim 60 \%$ altered. The freshest rocks are the interior dark gray cores of most pieces, which have a saponitic background alteration. Fresh olivine appears only as microphenocrysts in some glass margins and elsewhere is completely replaced. Clay minerals are the most abundant secondary minerals and are the principal constituent of all four styles of alteration (vesicle fill, vein fill, phenocrysts replacement, and background mesostasis alteration). Saponite is the most abundant of the clay minerals, identified in every thin section. It is present as cryptocrystalline granular or fibrous aggregates and varies in color from black to dark greenish brown to pale blue in hand specimen and tan-brown to olivegreen in thin section. Saponite lines or fills vesicles, is the most common olivine phenocryst replacement, appears in mono- and polyminerallic veins, replaces mesostasis and glassy margins, and forms the matrix of the hyaloclastite breccia.

Celadonite, bright blue-green in hand specimen and bright green in thin section, also fills vesicles and veins and replaces olivine phenocrysts and mesostasis. However, celadonite is typically restricted to the alteration halos, frequently present as intergrowths 
with saponite and/or iron oxyhydroxide. Iddingsite, a mixture of clay minerals and iron oxyhydroxide, is the second most abundant alteration product identified in Hole U1301B cores, producing a characteristic red-orange or reddish brown color in both hand specimen and thin section. It fills veins and vesicles, stains primary minerals, and is intergrown with the clays that replace olivine. Calcium carbonate was observed in only six cores, filling vesicles and veins and as a minor component of the basalt-hyaloclastite breccia matrix. Secondary pyrite was observed lining vesicles, as fine grains within saponite vesicle linings, with saponite \pm calcium carbonate in veins, and as disseminated fronts bounding some alteration halos. Zeolites (analcime and phillipsite) were tentatively identified in several basalt samples in veins as well as in the matrix of the hyaloclastite breccia.

A total of 2301 veins were identified in the core recovered from Hole U1301B, with an average frequency of 31 veins $/ \mathrm{m}$ of recovered core. Saponite is the most abundant vein-filling mineral, present in $98 \%$ of the veins. Iron oxyhydroxide was documented in 1010 veins, whereas celadonite was identified in only 93 veins, typically appearing with iron oxyhydroxide \pm saponite. Pyrite was observed in 59 veins and is typically associated with saponite. Calcium carbonate was observed in 38 veins, with saponite \pm pyrite. Clay-bearing veins are ubiquitous in the rocks recovered from Hole U1301B and vary in width from $10 \mu \mathrm{m}$ to $6 \mathrm{~mm}$, averaging $0.2 \mathrm{~mm}$. The maximum width of the simple dark green saponite veins is $2 \mathrm{~mm}$. These predominantly narrow veins are common in pillow fragments, with saponite filling many of the radial cooling cracks along pillow margins. Iron oxyhydroxide- and celadonite-bearing clay veins vary in width from $10 \mu \mathrm{m}$ to $6 \mathrm{~mm}$, and average $0.2 \mathrm{~mm}$. They are most common in the pillow lavas, but the most spectacular iron oxyhydroxide-bearing vein appears in a massive lava flow and is $6 \mathrm{~mm}$ wide with a $10-25 \mathrm{~mm}$ wide alteration halo. Goethite and minor celadonite were identified within this vein by X-ray diffraction.

The dips of 647 veins and fractures were measured in the recovered cores from Hole U1301B. Four types of fractures were distinguished in the cores: (1) veins flanked by alteration halos, (2) veins not flanked by alteration halos, (3) calcite-filled shear veins with slickenfibers (microfaults with contemporaneous displacement and secondary mineral growth), and (4) microveins $(<0.05 \mathrm{~mm}$ wide), identified in thin sections. Haloed veins were the most frequently observed structures, typically $3-10 \mathrm{~mm}$ wide and predominantly black to dark green, depending on the secondary clay alteration assemblage present. Non- haloed veins were identified in the massive lavas and some pillow lava pieces. Calcite-filled shear veins or faults were identified in three of the recovered pieces. These steeply dipping structures have calcite slickenfibers or overlapping fibers. The fibers define a steeply plunging lineation with asymmetrical calcite crystals, indicating dip-slip motion. This extensional style of deformation may relate to regional normal faulting. Interestingly, a compilation of dip angles shows that rocks recovered from Hole U1301B have dominantly high-angle fracture dips, despite the expected bias toward sampling of low-angle features by coring a vertical hole.

Paleomagnetic measurements of basement rocks from Hole U1301B were made on 158 discrete samples. Characteristic remanent magnetization directions from the samples thought to be most reliable are highly scattered when plotted versus depth in the hole. The mean inclination within the upper 100 $\mathrm{m}$ of the cored interval is $50^{\circ}-60^{\circ}$, somewhat shallower than that expected based on the current (and past) latitude of the site, and data from the lowest $150 \mathrm{~m}$ of the hole show a more complex pattern. There is more variability in apparent inclinations, and some intervals include dominantly negative inclinations. Given the known basement age, it seems unlikely that these rocks cooled from magma during a period of dominantly reversed magnetic polarity. It might be supposed that there could have been short periods of magnetic reversal within dominantly positive magnetic polarity, but the samples yielding negative inclinations are often closely associated with other samples that yielded positive inclination.

Two other explanations are self-reversal or remagnetization. Reversed magnetization could occur if alteration and magnetic mineral replacement occur during a period of time with an opposite magnetic polarity. This seems the most likely explanation for negative inclinations in some Hole U1301B samples because geologic observations indicate pervasive hydrothermal alteration and because shipboard paleomagnetic studies point to multiple magnetization components as well as the appearance of pyrrhotite in some samples. Pyrrhotite is a mineral that is a common by-product of the dissolution of magnetic minerals, such as magnetite, and the conversion of the iron into iron sulfide minerals. If this interpretation is correct, then the negative inclinations may correspond to zones where greater alteration has occurred.

Of $69.1 \mathrm{~m}$ of hard rock core recovered in Hole U1301B, 9\% was taken as whole-round samples on the catwalk or in the splitting room and dedicated to microbiological analyses. Shipboard scientists attempted to determine total cell counts in samples 
fixed in ethanol and containing small pieces of basalt and basalt that had been crushed to powder. However, the material showed high amounts of celllike structures (small crystals and needles) with strong fluorescent signals. Even after testing a variety of dilutions that had been filtered and stained, it was impossible to distinguish cells from other particulate matter.

We inoculated $\sim 300$ rock and rock-powder samples in test tubes in 12 different growth media at five different temperatures $\left(20^{\circ}-85^{\circ} \mathrm{C}\right)$. After 2 weeks of incubation, we observed cell growth in $<10 \%$ of total cultures. We obtained cells that could grow at near in situ temperature, suggesting successful enrichment of indigenous microbes from the warm, shallow basalt aquifer. Microscopic observations of 4',6diamidino-2'-phenylindole-dihydrochloride (DAPI)stained cells revealed coccoid-shaped cells attached to iron sulfide particles. These particles were part of the growth medium. Curiously, in these enrichments no cells were found in association with basalt particles. Considering the chemical composition of the growth medium, these microorganisms probably grow with the provided substrates as carbon sources and ferrous iron as an electron donor. In other enrichments at room temperature, we found anaerobic mesophilic microbes, likely to be fermenters and/or heterotrophic sulfate reducers. There are three conceivable explanations for the retrieval of mesophilic strains: microbes might be derived from sediment above basement, contaminants imported by drilling fluid, or relics transferred to the basaltic oceanic crust by hydrothermal circulation. Further physiological and phylogenetic characterizations of retrieved microbes will be performed as part of shorebased studies.

PFT analyses were completed to evaluate potential for microbiological contamination and the efficacy of cleaning and heating techniques for removing PFT. PFT removal by flame-heating and washing was highly effective for sample exteriors, and little or no PFT was detected in solid rock interiors.

Parts of whole-round basalt cores were run through the multisensor track (MST) prior to splitting. Magnetic susceptibility was as high as $\sim 4000 \times 10^{-6} \mathrm{SI}$, with the highest values corresponding to massive lava flows. Other lithologies (pillow lava and hyaloclastite) generally yielded much lower values.

Moisture and density properties were determined on 83 discrete samples from Hole U1301B. Bulk density values were $1.86-3.03 \mathrm{~g} / \mathrm{cm}^{3}$, with an average of 2.75 $\pm 0.13 \mathrm{~g} / \mathrm{cm}^{3}$. Grain density exhibited a range of $2.23-3.11 \mathrm{~g} / \mathrm{cm}^{3}$, with a mean of $2.86 \pm 0.09 \mathrm{~g} / \mathrm{cm}^{3}$. The lowest values of both grain and bulk density were made in a highly brecciated hyaloclastite sam- ple, whereas the highest densities come from the boundary between massive and pillow basalt. Porosity values span the range of $1.9 \%-30.3 \%$, with a mean of $5.8 \% \pm 3.5 \%$. Grain density variability decreases with decreasing porosity, as seen in previous studies of upper basement rocks. Similarly, seismic velocity and porosity are inversely correlated, and velocity displays a weak positive correlation with grain density.

Sixty-eight basalt samples were tested for thermal conductivity, yielding values of $1.17-1.84 \mathrm{~W} / \mathrm{m} \cdot \mathrm{K}$, with an average of $1.70 \pm 0.10 \mathrm{~W} / \mathrm{m} \cdot \mathrm{K}$ over the depth range of 351.2-576.3 mbsf. There is no statistically significant change in thermal conductivity with depth. Values $>1.75 \mathrm{~W} / \mathrm{m} \cdot \mathrm{K}$ consistently came from large, massive samples (length $>6 \mathrm{~cm}$ ), recovered in either massive flows or pillow basalts. The lowest values of 1.17 and $1.37 \mathrm{~W} / \mathrm{m} \cdot \mathrm{K}$ correspond to the two hyaloclastite samples, suggesting that recovery and sampling biases toward unfractured basalt skew the data toward higher values and likely provide an upper bound on the effective thermal conductivity of uppermost basement in this region.

$P$-wave velocities were measured on 106 discrete samples, yielding values of 3.9-5.8 km/s (Fig. F10 in the "Expedition 301 summary" chapter), with an average of $5.1 \pm 0.3 \mathrm{~km} / \mathrm{s}$. This average value is greater than that estimated at a regional scale based on seismic reflection data but is consistent with shipboard values from Leg 168. This value is also slightly greater than the $5.0 \mathrm{~km} / \mathrm{s}$ interval velocity determined for 110-160 msb by the vertical seismic profile (VSP) experiment. The lowest velocity was measured on a highly vesicular sample recovered from within a massive flow unit. Additional samples recovered from the same lithologic unit include velocities as great as $\sim 5500 \mathrm{~m} / \mathrm{s}$, demonstrating the extent of small-scale heterogeneity. There is no statistically significant overall velocity trend with depth, although $P$-wave velocity may be reduced locally by alteration and fracturing.

Four wireline logging strings were run in Hole U1301B to characterize formation properties at a scale intermediate between hand samples and regional seismic data. The triple combination (triple combo) tool string (natural gamma ray, lithodensity, porosity, and spontaneous potential) penetrated essentially to total depth (TD), yielding excellent data over most of the open hole (350-580 mbsf; 100-320 $\mathrm{msb}$ ). Unfortunately, subsequent logging tool strings (Formation MicroScanner [FMS]-sonic, borehole televiewer, and VSP) could not penetrate across an obstruction at $410 \mathrm{mbsf}(150 \mathrm{msb})$, limiting data collection to the uppermost part of the cored interval. 
Data were also collected through casing, but data from this interval are highly attenuated.

Much of the upper $100 \mathrm{~m}$ of open hole is washed out, with the caliper logs open to full scale near 400 mbsf (Fig. F10 in the "Expedition 301 summary" chapter). The lower $120 \mathrm{~m}$ of the hole is almost entirely in gauge, being only slightly larger in diameter than the $97 / 8$ inch coring bit. Formation bulk density varies from 1.5 to nearly $3.0 \mathrm{~g} / \mathrm{cm}^{3}$, but the lowest apparent values were measured in washed-out zones and should be used cautiously. In the deeper part of Hole U1301B, variations in bulk density are consistent with observations from numerous other basement holes and with physical property measurements (Fig. F10 in the "Expedition 301 summary" chapter). There are thin (meter scale) intervals of lower density separated by thicker ( $10 \mathrm{~m}$ scale) intervals of higher density, interpreted to comprise more fractured and massive rock, respectively. Nearhole formation resistivity generally increases with depth in the hole, particularly below the upper 100 $\mathrm{m}$. The spontaneous potential log shows several regions where the curve deflects to the higher values, but it is difficult to interpret these signals hydrogeologically because the logs were collected so soon after drilling, while the formation was still thermally disturbed. Collectively, logging data from the triple combo tool string help to define two main regions in basement. The uppermost $100 \mathrm{~m}$ of open hole is enlarged, with highly variable bulk density and very low electrical resistivity. The lower $120 \mathrm{~m}$ of open hole has a diameter close to that of the coring bit, less variable bulk density, and higher electrical resistivity. The boundary between these two zones, at $\sim 460 \mathrm{mbsf}$ (210 msb), is an important one for subsequent packer testing and CORK monitoring, as described later (Fig. F10 in the "Expedition 301 summary" chapter).

$P$-wave velocities determined with the sonic $\log$ in the upper $80 \mathrm{~m}$ of open basement are generally in the range of $4-6 \mathrm{~km} / \mathrm{s}$ and are broadly consistent with physical property measurements (Fig. F10 in the "Expedition 301 summary" chapter). A VSP run over a depth range of $~ 360-420$ mbsf (100-160 msb) indicates an interval velocity in upper basement of $5.0 \mathrm{~km} / \mathrm{s}$ (Fig. F10 in the "Expedition 301 summary" chapter).

Unfortunately, no data are available at present from the borehole imaging tools (FMS and borehole televiewer). There are apparently problems with the new wireline heave compensator and/or the acceleration module used with the tools; hopefully, postcruise processing will allow useful images to be generated.

Drill string packer experiments were conducted in Holes U1301A and U1301B to assess hydrogeologic properties near the boreholes (Fig. F10 in the "Expedition 301 summary" chapter). We originally intended to run the packer in "straddle mode" in Hole $\mathrm{U} 1301 \mathrm{~B}$, to assess permeabilities within one or more narrow zones, but because of difficulties encountered in passing a gap in the $103 / 4$ inch casing (see "Operations"), we elected to run the packer only in single-element mode.

Inflation of the packer within the open-hole section of Hole U1301A was precluded by poor hole conditions and the large diameter of the hole, which was drilled with a $143 / 4$ inch bit. The packer was positioned at $267 \mathrm{mbsf}, 10 \mathrm{~m}$ above the casing shoe. A depth check before testing found an obstruction at $34 \mathrm{msb}$, compared to total drilled depth of 107.5 msb. We assume that the obstruction was incomplete and that the hydraulically tested interval comprises the $92.6 \mathrm{~m}$ section between casing and total drilled depth. After packer inflation, we recorded sealed-hole pressure and then ran a series of five constant-rate injection tests at 15-100 strokes/min (spm). Following each period of injection, the pressure recovery was monitored for a period of the same duration as the respective pumping time.

Pressure records recovered from downhole gauges after these tests will require considerable processing in order to determine formation properties because of the confounding influences of pressure changes induced through density differences between cold ocean water and warm formation fluids and of formation recovery from the disturbance because of drilling. However, a crude estimate of apparent formation permeability suggests a value on the order of $10^{-11}$ to $10^{-10} \mathrm{~m}^{2}$, considerably greater than that determined by packer or flow testing within the upper part of basement in Hole 1026B.

A longer series of packer tests was conducted in Hole U1301B, with the packer set at three depths in open hole. The three packer seats were at 472 mbsf (207 msb), 442 mbsf (177 msb), and $417 \mathrm{mbsf}$ (152 msb). These test depths allowed us to assess bulk hydrogeologic properties within the lower formation around Hole U1301B and (by difference) conditions within the upper part of the hole. Packer inflation in the open hole also allowed us to test potential CORK packer seats. After setting the packer at each seat, we conducted two to three injection tests at pumping rates of 11-30 spm. As with data from Hole U1301A, considerable effort will be required to separate the influence of pressure differences associated with formation recovery from drilling and pumping of cold ocean water during the tests themselves. Nevertheless, a crude estimate of near-borehole formation permeability suggests values on the order of $10^{-11} \mathrm{~m}^{2}$, 
possibly with lower values in the deeper part of the hole.

A CORK system was installed in Hole U1301A to monitor a single depth interval including up to $92 \mathrm{~m}$ of open hole. The large diameter of the borehole (143/4 inches) precluded setting a CORK packer in open hole, so the packer was set near the bottom of the $103 / 4$ inch casing. Slotted $4 \frac{1}{2}$ inch casing was extended below the packer element to protect the OsmoSamplers and temperature loggers.

The CORK in Hole U1301A used an umbilical comprising a single $1 / 2$ inch packer inflation line, six $1 / 4$ inch pressure-monitoring and sampling lines, and one $1 / 8$ inch sampling line. The $1 / 4$ inch and $1 / 8$ inch lines were run through the packer and ended in small wire-wrapped screens. Four of the screens attached to $1 / 4$ inch lines were attached to the $4 \frac{1}{2}$ inch casing just below the packer element, and the remaining screens and lines were terminated roughly in the middle of the $4 \frac{1}{2}$ inch slotted casing. As with the Hole 1026B CORK, the pass-through across the $103 / 4$ inch casing seal that was not plumbed to a formation sampling or monitoring line was connected to a three-way valve and manifold for future installation of pressure-monitoring instrumentation at the wellhead. This plumbing will allow monitoring of fluid pressure below the casing seal and above the packer element, to evaluate system integrity. An OsmoSampler was attached to one of the fluid-sampling manifolds at the wellhead for short-term collection of fluids during the initial few weeks of CORK equilibration.

The Hole U1301A instrument string includes four OsmoSampler packages. The uppermost OsmoSampler contains a copper coil for gas sampling. The next OsmoSampler contains minerals to investigate microbiological growth and biological alteration. The third OsmoSampler has Teflon tubing for fluid sampling and rare earth element tracer injection. The final OsmoSampler includes a module for acid injection into the sampling line, to prevent precipitation of metal compounds. There is a single, self-contained temperature logger in each of the OsmoSamplers (3.7 $\mathrm{m}$ apart), and two additional temperature instruments were installed 2.5 and $7.5 \mathrm{~m}$ above the bottom plug. Thus, temperature monitoring in Hole U1301A extends across $\sim 24.2 \mathrm{~m}$ of upper basement.

The CORK borehole observatory installed in Hole U1301B includes monitoring of three intervals. We initially attempted to set a CORK system in Hole U1301B with three casing packers, all set in open hole, but this system was seriously damaged during deployment and we had to modify its design. The final Hole U1301B CORK system included two casing packers set in open hole. The lowermost packer element isolates the deepest $\sim 120 \mathrm{~m}$ of the hole, whereas this and the shallowest packer isolate a $42 \mathrm{~m}$ thick interval above. A third monitored interval includes uppermost basement and the $103 / 4$ inch casing string below the cone but includes only pressure and temperature monitoring. It should be possible to assess the quality of the hydrogeologic seal at the seafloor using the pressure monitoring line and valve into this interval.

The Hole U1301B CORK system used an umbilical containing nine separate lines: a single $1 / 2$ inch packer inflation line, four $1 / 4$ inch pressure-monitoring and sampling lines, and four $1 / 8$ inch sampling lines. There was a separate $1 / 2$ inch Tefzel (Teflon variant) microbiological sampling line run to the deepest monitored zone. Four small intake screens were deployed below each of the packer elements. The bottom of the CORK installation included $35 \mathrm{~m}$ of drill collars and cross-overs below the lower packer, comprising $\sim 10,000 \mathrm{lb}$ of metal. This configuration was selected to provide enough weight to pull the long CORK casing string into the hole. Sampling and monitoring valves at the wellhead were left open during deployments, and three OsmoSamplers were attached to the fluid-sampling manifolds for shortterm collection of fluids during the initial few weeks of CORK equilibration. Two of these were recovered during remotely operated vehicle (ROV) servicing in September 2004, whereas the third was left installed for the first year of reequilibration. This OsmoSampler will be recovered during servicing by submersible in summer 2005.

The downhole sensor and sampling string in Hole U1301B included 14 autonomous temperature loggers, six OsmoSampler packages, and three microbiological incubation packages. Temperature monitoring extends from $\sim 1 \mathrm{~m}$ below the top of basement to $263 \mathrm{~m}$ into basement, with typical sensor spacing of 20-25 m. All of the downhole OsmoSamplers and incubators have their intake lines extending beyond the bottom of the CORK casing system, in open hole. The uppermost OsmoSampler contains a copper coil for gas sampling. The next OsmoSampler contains minerals to investigate microbiological growth and biological alteration and flow cell. The third OsmoSampler has Teflon tubing for fluid sampling and additional incubation substrate. The fourth OsmoSampler includes a module for acid injection into the sampling line, to prevent precipitation of metal compounds. The fifth OsmoSampler is injecting rare earth element tracers, and the final OsmoSampler module is configured for acid addition.

After deployment of the submersible/ROV platform, we "reentered" the cone through a hole in the land- 
ing platform and pumped a plug of bentonite followed immediately by cement, in an effort to seal the annulus between 103/4 inch and 16 inch casing strings. Final operations around Hole U1301B included fishing one remaining piece of CORK casing from the initial deployment that was sticking vertically from the seafloor. We conducted a camera survey of the area around Holes U1301A and U1301B and found no other items on the seafloor that might pose a hazard for future operations at the site.

\section{Geologic context}

Operational and scientific objectives for Site U1301 are described in the "Expedition 301 summary" chapter, CORK configuration and experimental goals are discussed by Fisher et al. (this volume), and regional survey data are presented by Zühlsdorff et al. (this volume). Selected aspects of these discussions are presented in this section.

Site U1301 is located $\sim 100 \mathrm{~km}$ east of the Endeavour Segment of the Juan de Fuca Ridge, over relatively flat seafloor, above a buried basement high. The basement age has been determined from seafloor magnetic anomalies to be $3.5 \mathrm{Ma}$. Site U1301 comprises four holes located $0.9-2.0 \mathrm{~km}$ south of holes drilled at Site 1026 during Leg 168. A line connecting the two sites is oriented along the trend of basement structural strike; the sites are located along the peak of the same buried basement high. Sites 1026 and U1301 are located between two basement outcrops, Mama Bare outcrop to the north and Baby Bare outcrop to the south, which are the seafloor exposures of partially buried volcanic edifices built upon a ridge-flank abyssal hill (Fig. F1). ODP Site 1027 is located $2.2 \mathrm{~km}$ to the east.

Site U1301 is located on the western edge of a major Pleistocene distributary channel for turbidites flowing from the north. Sediments recovered from Sites U1301 and 1026 are dominated by this sedimentary sequence, including some very coarse grained layers that indicate high velocities during transport. The sediment/basement contact is generally clear in seismic lines across Second Ridge, although this boundary often has the rough (diffuse) character that is typical of the uppermost extrusive basalt lavas (Figs. F2, F3). In some places, the basement reflectors are horizontal and clear and appear to be highly layered (e.g., near common depth points [CDPs] 550 and 570 of Line GeoB00-466). A sill was previously cored and recovered in nearby ODP Hole $1027 \mathrm{C}$, but it is not clear if there could be intrusive rocks above true basement at Sites U1301 and 1026. No intrusive rocks have been recovered from these sites.
The blocky nature of upper basement is readily apparent on the expanded segments of the seismic lines (Fig. F3), particularly on Line GeoB00-468, which shows an abrupt offset between uppermost basement near CDP 400. In addition, there are weak events below the eastern side of the highest basement block (where Holes U1301A, U1301B, U1301C, and U1301D were drilled) that may be reflectors from out of the plane of the seismic lines, illustrating characteristics of local basement relief in the alongstrike direction.

The thermal state of the crust around Site U1301 has been documented through numerous heat flow surveys, drilling, and postdrilling experiments, although there has not been a heat flow profile run directly across this drill site. Uppermost basement is roughly isothermal in this area, with a temperature of $62^{\circ}-64^{\circ} \mathrm{C}$, making heat flow higher above the buried basement high (where sediment is thinnest) than over the surrounding area. Isothermality of upper basement is caused by rapid fluid convection within basement. Uppermost basement is also known to be overpressured in this area, but the sediment at Site U1301 is too thick to allow upward fluid seepage at thermally or chemically significant rates. The chemistry of uppermost basement fluids at Sites 1026 and 1027 is very similar to that of fluids from seeps on the top of Baby Bare outcrop, suggesting that the shallow basement aquifer in this region is well mixed at a lateral scale of kilometers.

\section{Operations}

This section describes the sequence of drilling, coring, and engineering operations conducted during Expedition 301 at Site U1301. Operations at Site 1026 are described in "Operations" in the "Site 1026" chapter. Expedition 301 operations are summarized in Table T1 in the "Expedition 301 summary" chapter.

\section{Astoria, Oregon, port call}

After the 17 day transit across the Pacific Ocean, the ship arrived in Astoria, Oregon (USA), 1.5 days ahead of schedule at $1600 \mathrm{~h}$ on 18 June 2004. All times presented in this report are local ship time, which was Universal Time Coordinated $-7 \mathrm{~h}$. The Astoria port call leading up to Expedition 301 was extensive because of the activities required to remobilize the JOIDES Resolution for IODP operations as well as loading all of the special hardware required for Expedition 301. The mobilization actually began long before Astoria with the official acceptance of the drillship JOIDES Resolution on 31 May in Gama- 
gori, Japan. In Japan we (1) loaded laboratory equipment and supplies required to bring the shipboard laboratories back up to operational status, (2) loaded some bits and bottom-hole assembly (BHA) subs, and (3) had the active heave compensator serviced.

In Astoria, 40 truckloads of materials required for remobilization and Expedition 301 were delivered. Items loaded included drill pipe, all bulk materials (mud and cement), casing, all remaining operations drilling equipment, a new heave-compensated logging line/winch, laboratory equipment and supplies, and most of the specialty hole completion equipment required for replacing two existing CORKs and installing two new CORK systems.

The Astoria port call was scheduled for 8 days but was completed in just over 7 days. The Expedition 301 portion of the Astoria port call officially began at $0600 \mathrm{~h}$ on 27 June. Because of the early ship arrival, excellent weather, and exceptionally efficient loading activities and coordination, the ship was ready to depart Astoria only $1 \mathrm{~h}$ after the "official" Expedition 301 port call began. Once the oncoming captain was satisfied with the ship's readiness for sea and the last of the expedition hardware was loaded, the ship was deemed ready to depart Astoria for the first site.

\section{Site U1301}

\section{Transit to Site U1301 (proposed Site SR-1A)}

All major operations conducted during Expedition 301 are listed in Table T1 in the "Expedition 301 summary" chapter. The last line away from Pier 1 took place at $0833 \mathrm{~h}$ on 27 June 2004. The forward and aft tugs were released, and the JOIDES Resolution proceeded down the Columbia River and across the Columbia Bar. The pilot departed the ship via helicopter, and at $1030 \mathrm{~h}$, the vessel was under way at full speed on a course of $302^{\circ}$ for Site U1301 (SR-1A). The transit was quick and uneventful, $172 \mathrm{nmi}$ in $16.6 \mathrm{~h}$ at an average speed of $10.4 \mathrm{kt}$. After reducing speed upon approach to the site, the thrusters and hydrophones were lowered and the vessel switched to dynamic positioning (DP) control at $0321 \mathrm{~h}$ on 28 June.

\section{Hole U1301A}

\section{Arrival on site and jet-in test}

The DP operator positioned the ship over the Global Positioning System coordinates for Site U1301, and a Datasonics model 354M, $15 \mathrm{KHz}, 208 \mathrm{Db}$ beacon (SN 2202) was deployed at $0722 \mathrm{~h}$ on 28 June 2004. For the jet-in test only, we offset the ship $10 \mathrm{~m}$ north and $10 \mathrm{~m}$ west from the primary site coordinates. Operations in Hole 1301A are summarized in Table T1 in the "Expedition 301 summary" chapter and
Table T1, and final formation and casing depths are given in Table $\mathbf{T} 2$.

The initial operation was to move the previously assembled reentry cone off of the moonpool doors, lay out the upper guide horn, and pick up eight drill collars from the forward pipe rack. The BHA and other drill string components were strapped (measured) and drifted (through bore clearance check) as they were made up and lowered through the rig floor. The camera/sonar system was deployed, and the bit was observed tagging the seafloor at 2667.5 meters below rig floor (mbrf) as measured from the dual elevator stool. This depth was later adjusted to $2667.3 \mathrm{mbrf}$.

A jet-in test to verify how much 20 inch casing could be washed beneath the reentry cone was initiated using an $18 \frac{1}{2}$ inch tricone drill bit fitted with three number 16 jets. The jet-in test required more strokes per minute with the rig circulating pumps and higher weight on bit (WOB) than was required for the Leg 168 jet-in test conducted for Hole 1026B located $\sim 1 \mathrm{nmi}$ away. The jet-in test was terminated after $5.75 \mathrm{~h}$ at $41.4 \mathrm{mbsf}$. After recovering the jet-in assembly, we discovered that one of the bit jets was plugged. This may partially explain the higher pump pressures and slower jetting process; however, we decided to reduce the length of 20 inch casing from $\sim 75$ to $\sim 39 \mathrm{~m}$.

\section{Deployment of reentry cone and 20 inch casing}

We painted the reentry cone for Hole U1301A with a black rim around the top of the cone and one internal panel painted black with white lettering that reads "1301A" (Fig. F4). The opposite panel was left gray but lettered with white lettering that reads "1301A." We also painted a black ring internally halfway down the cone. On the outside there were two opposing panels painted with white numbers that read "1301A."

After moving the reentry cone back over center in the moonpool, the rig floor was prepared for running 20 inch casing. This casing assembly consisted of a shoe joint cut to the appropriate length and welded out to a standard 20 inch Texas pattern casing shoe, two joints of 20 inch casing $(94 \mathrm{lb} / \mathrm{ft}$; K-55; range-3; buttress thread), a standard 20 inch casing pup joint, and a 20 inch Dril-Quip (DQ) casing hanger. The hanger was latched into the reentry cone bore, and latch ring engagement was verified by visually observing that the latch ring was in the appropriate position as viewed through the disengagement holes. Because the typical "audible" latch ring engagement snapping sound was not heard, the hanger was tack-welded in four places in the casing hanger flutes. This was done to avoid inadvertent disengagement during the trip to the seafloor. After 
assembling the $\mathrm{BHA}$, the DQ casing running tool was made up to the 20 inch casing hanger and the entire assembly was ready for lowering. At $1600 \mathrm{~h}$ on 29 June, Hole U1301A was spudded as the 20 inch casing shoe tagged the seafloor. Jetting of the 20 inch conductor casing proceeded well, and $7 \mathrm{~h}$ later we landed and released the reentry cone base at the seafloor. The DQ running tool was released at $2300 \mathrm{~h}$, and the drill string was tripped back to the surface.

\section{Drilling 20 inch hole in sediment for 16 inch casing}

The first change to the initial operations plan for this site came with the drilling of the hole for the 16 inch casing string. The original plan called for drilling a nominal 211/2 inch diameter hole using a bicentered reamer (Downhole Design, Inc. [DDI]; B182X215). This tool was used successfully during ODP Leg 206 to drill two basement holes. In talking with members of the drill crew and the ODP Operations Superintendent for that leg, we learned that the tool did not perform as intended. They were able to drill successfully in basement rock; however, the $97 / 8$ inch tricone bit used as a pilot for the bicentered reamer assembly catastrophically failed twice, leaving bit cones in the hole. This was attributed to lateral loading of the bit during the bicenter functioning of the reamer head. For our expedition, DDI provided a $97 / 8$ inch stabilizer sub to run directly above the pilot bit. In addition, a specially designed $97 / 8$ inch pilot "wobble" bit was provided to replace the conventional $97 / 8$ inch tricone bit. The Leg 206 crew also indicated that the bicenter reamer did not drill a very good hole in the softer sediments overlying the hard basement rock. It was believed that this may have contributed to problems emplacing the 16 inch casing strings during Leg 206. With this added knowledge, we modified the operations plan for Expedition 301. We decided to deploy a more conventional "arm-style" underreamer to drill the sediment section of the hole, to be followed, after a drill string round trip, with the bicenter reamer assembly to drill the upper $\sim 15 \mathrm{~m}$ of basement. We decided to accept the extra time for another pipe trip in order to avoid both the problems experienced during Leg 206 and having to drill with the conventional arm-style underreamer in basement rock, which historically has had integrity problems that led to underreamer failure.

A Hole Opener Company (HOC) model DTU 1175 underreamer outfitted with three number 12 jets was made up with the same $18^{1 / 2}$ inch tricone bit (fitted with three number 16 jets) and used in jetting-in the 20 inch casing and reentry cone. The underreamer was function-tested in the moonpool by pumping with a circulating head and visually observing and measuring the opening or extension diameter of the underreamer arms at 20 inches. This underreamer had recently been refurbished on shore, and the function test was successfully completed by $1230 \mathrm{~h}$ on 30 June.

The drilling assembly was lowered, the camera/sonar system was deployed, and Hole U1301A was reentered for the first time after $<5 \mathrm{~min}$. Once inside the 20 inch casing the top drive was picked up, the camera was recovered, and drilling commenced at 1530 $\mathrm{h}$. After an initial slow advance of $6 \mathrm{~m}$ directly below the 20 inch casing shoe (to keep from opening the underreamer arms inside the casing), the underreamer was opened up and drilling continued to 262.2 mbsf. An abrupt change in rate of penetration (ROP), coupled with the typical "basalt bounce" associated with hard rock drilling, was a clear indication that we had reached our basement target, originally projected to be at $\sim 275$ mbsf. Overall net ROP (including connection time) with the conventional underreamer in sediment was $16.5 \mathrm{~m} / \mathrm{h}$. Actual drilling ROP was $22.3 \mathrm{~m} / \mathrm{h}$. Control drilling techniques were employed to ensure that a good quality hole was obtained.

The hole was swept with $50 \mathrm{bbl}$ of sepiolite drilling mud. The drill string was recovered, and the underreamer and pilot bit were laid out by $1130 \mathrm{~h}$ on 1 July.

\section{Drilling $21 \frac{1}{2}$ inch hole in basement for 16 inch casing}

A DDI bicenter reamer (BCR; B182X215) assembly, including a $97 \% 8$ inch stabilizer and a $97 / 8$ inch pilot wobble bit, was made up to the BHA and lowered to the seafloor. This BCR configuration is designed to drill a $21 \frac{1}{2}$ inch diameter hole yet be able to pass through a diameter of 181/4 inch-this would allow it to safely pass through the 20 inch casing string, which has a nominal internal diameter (ID) of $191 / 8$ inch. After another 5 min reentry, the drilling assembly was lowered to 233.7 mbsf without incident. The top drive was picked up, and the pipe was lowered the remaining distance to the bottom of the hole. At $1900 \mathrm{~h}$ on 1 July, basement drilling with the BCR commenced. Drilling proceeded well at first, with $7.3 \mathrm{~m}$ of advance drilled at an average ROP of $1.5 \mathrm{~m} /$ $\mathrm{h}$. The last $1.8 \mathrm{~m}$ only drilled at $0.6 \mathrm{~m} / \mathrm{h}$, and, after sweeping the hole with $50 \mathrm{bbl}$ of sepiolite mud, a wiper trip back above the basement contact at 262.2 mbsf was made. Two more wiper trips were made through this interval, interspersed with two more 50 bbl sepiolite mud sweeps. The lowermost 2-4 m of hole never did clean up adequately, and it was felt that attempting to advance the hole further with this drilling assembly was not prudent and risked 
tool failure. Significantly elevated drilling torque, $>450$ A rather than the earlier $150 \mathrm{~A}$, led us to abandon further attempts at deepening the hole with the BCR assembly, and we elected to recover the drill string short of our original target depth of 272-276 mbsf. The hole was displaced with sepiolite mud, and the drill string was recovered on the rig floor at $1400 \mathrm{~h}$ on 2 July.

\section{Deploying and cementing 16 inch casing}

The subsea release (SSR) plug assembly was made up to the DQ casing running tool and secured in the derrick. After conducting a safety meeting, preparations were made for running 16 inch casing. The shoe joint was picked up, and the cementing float shoe was attached to the lowermost joint of 16 inch casing. Another 19 joints of standard 16 inch $(75 \mathrm{lb} /$ $\mathrm{ft}$ buttress) casing were made up, and the 16 inch casing hanger was attached to the top of the string. The casing running tool was engaged with the 16 inch casing hanger, and the string was lowered to $2643 \mathrm{mbrf}$ and spaced out for reentry. Another quick reentry (10 $\mathrm{min})$ was made into Hole U1301A at $0045 \mathrm{~h}$ on 3 July. The casing string was lowered without resistance to 2902 mbrf (234.3 mbsf), where the top drive was picked up. We continued washing down the casing to $2924 \mathrm{mbrf}$ ( $256.3 \mathrm{mbsf}$ ), and the cementing manifold was picked up. The 16 inch hanger was landed and latch-in was verified at 0315 h. The cementing operation proceeded smoothly, with $18 \mathrm{bbl}$ of $15.8 \mathrm{lb}$ per gallon (ppg) cement mixed up and displaced downhole. The cementing dart landed at the proper amount of strokes ( 1220) indicated by a standpipe pressure rise to 2600 psi. The SSR dart/wiper plug assembly also landed at the proper amount of strokes $(\sim 1600)$, and a pressure of 500 psi was maintained. After releasing the pressure at the standpipe, a check was made to confirm that no flowback was occurring. The cementing swivel hose was disconnected, and, after $3^{1 / 4}$ turns to the right, the casing running tool was released. The end of the drill string was pulled clear of the reentry cone and secured for a routine servicing of the drill line (slip and cut) prior to retrieving the drill string. By $1230 \mathrm{~h}$, the drill string was back on the rig floor. The casing running tool was detorqued and laid out with the SSR assembly.

\section{Drilling $143 / 4$ inch hole in basement for $103 / 4$ inch casing}

A new 141/2 inch tricone drill bit (Varel type ETD617) was made up, and six $81 / 4$ inch drill collars were picked up from the forward tubular rack. A fivestand drilling BHA was assembled, which allowed us to drill $130 \mathrm{~m}$ past the 16 inch casing shoe without placing the tapered drill collar (TDC) in open hole. Therefore, the drilling assembly exposed to open hole would consist entirely of slickwall pipe (81/4 inch drill collars) all the way down to the top of the $143 / 4$ inch tricone drill bit.

The drill string was lowered to 2658.9 mbrf, stopping to fill the pipe every 30 stands. After spacing out the drill string, another 5 min reentry was made into the Hole U1301A. After retrieving the camera system, the pipe was lowered an additional four stands and the top drive was picked up in preparation for drilling. At $2130 \mathrm{~h}$ on $3 \mathrm{July}$, the top of the 16 inch wiper plug was contacted and we commenced drilling out the wiper plug, dart, and float shoe assembly. Once through the shoe, the hole cleaning continued to 270.3 mbsf (1.0 m off bottom), when the bit was 8.1 $\mathrm{m}$ into basement. Drilling operations then continued with the drilling of the $14 \%$ inch diameter hole for the $103 / 4$ inch casing string.

At $0015 \mathrm{~h}$ on 5 July, we terminated drilling the $143 / 4$ inch hole at $3037.0 \mathrm{mbrf}$ (369.7 $\mathrm{mbsf})$. This was $107.5 \mathrm{~m}$ into basement. The upper $\sim 42 \mathrm{~m}$ of basement drilled at $3.0-3.5 \mathrm{~m} / \mathrm{h}$. At $\sim 304 \mathrm{mbsf}$, the ROP began to steadily increase to $\sim 8.0 \mathrm{~m} / \mathrm{h}$, and this continued to $\sim 357 \mathrm{mbsf}$. Only a few relatively thin spots $(<0.5 \mathrm{~m})$ of $4 \mathrm{~m} / \mathrm{h}$ drilling rates were interspersed through this interval (see Fig. F9 in the "Expedition 301 summary" chapter). The zones of rapid penetration concerned us, and those fears proved to be well founded. The next $20+\mathrm{h}$ were spent fighting hole problems. Multiple wiper trips, reaming operations, mud sweeps, and so on were required before the hole eventually cleaned up to what we considered reasonable for attempting to emplace casing. The hole was displaced with sepiolite mud, and at $2000 \mathrm{~h}$ on 5 July we made one final pipe trip up inside the 16 inch casing hanger at 259.3 mbsf. We then lowered the bit back into open hole without rotation or circulation. The bit reached 3016 mbrf (348.3 mbsf) before taking 20,000 lb weight. The driller then broke circulation and proceeded to wash down to bottom. The hole was swept one final time with $50 \mathrm{bbl}$ of sepiolite and then displaced with sepiolite mud. The drill string was recovered on board by $0400 \mathrm{~h}$ on 6 July.

\section{First attempt at deploying 103/4 inch casing}

Twenty-seven joints of $101 / 2$ inch casing $(40.5 \mathrm{lb} / \mathrm{ft}$; $\mathrm{K}-55$; range 3 ; buttress thread) were made up with a standard Halliburton cementing float shoe on the bottom and a conventional DQ 103/4 inch casing hanger/pup joint at the top. After attaching the casing running tool, the casing assembly was lowered to the seafloor. Once the camera system could see the bottom, we reentered Hole U1301A with the casing 
string within $5 \mathrm{~min}$ (at $1415 \mathrm{~h}$ ). Problems ensued almost immediately. The $103 / 4$ inch casing shoe encountered resistance $\sim 4 \mathrm{~m}$ below the 16 inch casing shoe ( $3 \mathrm{~m}$ into basement). The casing was worked past this ledge, and by $2030 \mathrm{~h}$ we had managed to work the $103 / 4$ inch casing to $355.6 \mathrm{mbsf}$, or $93.2 \mathrm{~m}$ into basement. This was just $4.5 \mathrm{~m}$ shy of our hanger landing depth. With confidence mounting, we shut down circulation and picked up the cementing manifold and swivel assembly. Once operations resumed ( 16 min later), we found that we were unable to move the casing down any further. The hole appeared to be collapsing in above us, although we still were able to maintain unrestricted circulation. We could not pass $3023.3 \mathrm{mbrf}$ (355.6 mbsf), and we also had problems pulling back uphole $(20,000-$ $40,000 \mathrm{lb}$ overpull). The casing could be pulled back up with overpull but would not go back down. After pulling the casing shoe back to $309.3 \mathrm{mbsf}$ (46.9 m into basement), all drilling parameters returned to normal. Speculation was that rocks fell in from above and would only allow movement in the upward direction. Once this material was below us, the casing was once again free to move up or down freely. By $2400 \mathrm{~h}$ on $6 \mathrm{July}$, the casing had been once again lowered to $3010.8 \mathrm{mbrf}$ (343.1 mbsf). At this point, the upper hole problems again prevented us from advancing any further. At $0400 \mathrm{~h}$ on $7 \mathrm{July}$, we stopped attempting to land the casing and decided instead to recover the casing string, shorten it up considerably, and make Hole U1301A an installation to monitor uppermost basement.

After pulling the casing string back to the ship, we laid out the casing hanger and then began to lay out the first of what was supposed to be a total of seven joints of $103 / 4$ inch casing. The first joint was laid out correctly. The second joint appeared to be slightly bent. The next five joints were noticeably bent, so we continued on and checked the next two joints beyond the original number of joints we intended to take out of the casing string. The sixth joint was also bent, but from that point on the string was all right. All bent joints had been above the seafloor during the attempts at getting past the problem zone.

\section{Second attempt at deploying 103/4 inch casing}

A single "replacement" joint of $10^{3 / 4}$ inch casing was picked up and made part of the original casing string. All six of the recovered bent joints were marked and stored in the riser hold. The 103/4 inch casing hanger was then made up, the running tool was attached, the remainder of the BHA was assembled, and the $103 / 4$ inch casing string was lowered for the second time. Space out for the new casing string was designed to place the casing shoe into the upper portion of basement above the zone of rapid ROP and fairly close to the sediment/basement interface so as to have the best chance of a good cement seal and limited lateral dispersion of the cement into the formation. We felt that attempting to place the $10^{3 / 4}$ inch casing shoe too far into the upper "fractured" basement would risk not getting the cement to reach back up to the 16 inch casing shoe, which was essential for sealing the hole for the CORK hydrologic experiment. The objective of the shallow sampling hole was to sample the "upper" few tens of meters of basement; our planned 103/4 inch casing shoe depth would achieve this, and placing it deeper into the "upper" basement would not improve upon this goal.

The subsequent reentry of Hole U1301A was made more interesting than the previous ones due to a cloud of drilling mud that was suspended in and around the reentry cone, significantly obscuring visibility. Instead of the camera, the sonar system was used primarily to locate the cone and was also a major contributor in helping to make the reentry itself. After $45 \mathrm{~min}$, Hole U1301A was reentered for the sixth time, and the shortened version of the $10^{3 / 4}$ inch casing string was lowered into the hole and landed without incident, placing the $103 / 4$ inch casing shoe at $277.1 \mathrm{mbsf}$, or $14.9 \mathrm{~m}$ into basement. Hanger latch engagement was confirmed with $15,000 \mathrm{lb}$ of overpull, and the shoe was cemented in place with $10 \mathrm{bbl}$ of $15.2 \mathrm{ppg}$ class $\mathrm{G}$ cement. The cementing operation using the SSR system was completed without incident, and at $0035 \mathrm{~h}$ on 8 July the casing running tool was released. The initial phase of operations in Hole U1301A was completed with the recovery of the drill string at $0800 \mathrm{~h}$ on 8 July.

We decided to temporarily halt operations in Hole U1301A to allow the cement to set, to allow the hole time to equilibrate, and to initiate operations in Hole U1301B.

\section{Transit to Hole U1301B}

Hole U1301B was located only $36 \mathrm{~m}$ northeast of Hole U1301A, so the ship was offset in DP mode while the drill crew continued to retrieve the drill string. The scientists wanted to have Hole U1301B as close to Hole U1301A as technically possible for the potential of being able to investigate vertical flow. Because of the close proximity of the holes, a jet-in test was considered unnecessary.

\section{Hole U1301B}

Operations in Hole 1301B are summarized in Table T1 in the "Expedition 301 summary" chapter and Table T1, and final formation and casing depths are given in Table $\mathbf{T} 3$. 


\section{Deployment of reentry cone and 20 inch casing}

The reentry cone for Hole U1301B was painted (Fig. F5) so as to readily distinguish it from the Hole U1301A reentry cone. The reentry cone for Hole U1301B had three internally alternating black panels with a black rim on the top of the black panels only; the rims of the nonpainted panels were painted black on the corners only. The center black panel was lettered "1301B" with white lettering. On the outside of the internally lettered panels were letters painted "1301B" in white against a black background.

The newly painted reentry cone was moved over center in the moonpool, and the rig floor was prepared for running 20 inch casing. This assembly consisted of a shoe joint previously cut to the appropriate length and welded out to a standard 20 inch Texas pattern casing shoe, two joints of 20 inch casing (94 lb/ft; K-55; range-3; buttress thread), a standard 20 inch casing pup joint, and a 20 inch DQ casing hanger. The hanger was latched into the reentry cone, and latch ring engagement was verified by visually observing that the latch ring was in the appropriate position as viewed through the disengagement holes. Unlike the previous 20 inch latch-in operation, this time the distinctive "audible snap" was heard as the latch ring engaged. After assembling the BHA, the casing running tool was made up to the 20 inch casing hanger and the entire assembly was ready for lowering. At 2000 h on 8 July 2004, Hole U1301B was spudded as the 20 inch casing shoe tagged the seafloor. Jetting of the 20 inch conductor casing proceeded well, and $6.5 \mathrm{~h}$ later we landed and released the reentry cone base at the seafloor. Release of the DQ running tool was again executed perfectly, and by $0900 \mathrm{~h}$ on 9 July the drill string was back on board ship.

\section{Drilling 20 inch hole for 16 inch casing}

The same Smith 181/2 inch Model 2JS tricone drill bit (jetted with one number 16 and two number 24 nozzles) and the same HOC model DTU 1175 underreamer (outfitted with three number 12 jets) were made up and prepared for running in the hole. As is customary, the underreamer was function-tested by pumping with a circulating head to visually observe that the underreamer arms would open correctly. Even with $90 \mathrm{spm}$ and 900 psi pressure, the arms failed to extend. At $1300 \mathrm{~h}$ on 9 July, we decided to suspend operations long enough to rebuild the single set of large underreamers that we had on board. Drilling the hole only with the $181 / 2$ inch bit was discussed and rejected, as was the use of the $21 \frac{1}{2} 2$ inch BCR (per previous experience discussed earlier). The underreamer was torn down by placing the body ver- tically in the rotary table. The seals were replaced, and $3.75 \mathrm{~h}$ later the tool had been rebuilt and successfully function-tested.

The drilling assembly was lowered to the seafloor, the camera system was deployed, and the drill crew serviced the drill line (slip and cut). Prior to reentry, we lowered the pipe and visually observed the bit tag the seafloor adjacent to the reentry cone. Seafloor depth for Hole U1301B was confirmed to be $1.0 \mathrm{~m}$ higher than Hole U1301A at 2666.5 mbrf. This depth was later adjusted to 2667.8 mbrf. Hole U1301B was reentered for the first time in virtually seconds. As the bit was lifted off the seafloor, it swung directly over the reentry cone and the reentry was made at $2245 \mathrm{~h}$ on 9 July.

Once inside the 20 inch casing, the top drive was picked up, the camera was recovered, and drilling commenced at $0015 \mathrm{~h}$ on 10 July. After an initial slow advance of $\sim 9 \mathrm{~m}$ directly below the 20 inch casing shoe (to keep from opening the underreamer arms inside the casing), the underreamer was opened up and drilling continued to $2933.0 \mathrm{mbrf}$ (265.2 mbsf). An abrupt change in ROP at $1015 \mathrm{~h}$, coupled with the typical "basalt bounce" associated with hard rock drilling, was a clear indication that we had reached our basement target $4.1 \mathrm{~m}$ shallower than we did in Hole U1301A. The underreamer, with arm extension set at 20 inches, was installed $\sim 8 \mathrm{~m}$ above the bit. The $18 \frac{1}{2} 2$ inch tricone bit with the 20 inch underreamer above drilled the sediment at an average rate of $35.0 \mathrm{~m} / \mathrm{h}$. The average "net" ROP in sediment was $\sim 23 \mathrm{~m} / \mathrm{h}$ (including connection time). We continued drilling in basement to $2943.0 \mathrm{mbrf}$ ( $275.2 \mathrm{mbsf}$ ). The ROP for the $181 / 2$ inch bit in basement (first $8 \mathrm{~m}$ ) was $3.6 \mathrm{~m} / \mathrm{h}$ using a WOB of $\sim 15,000 \mathrm{lb}$. An additional $2 \mathrm{~m}$ of basement was then drilled with the underreamer penetrating the top of basement, placing the depth of the 20 inch hole at 2935.0 mbrf ( $267.2 \mathrm{mbsf})$. The actual ROP for the 2 $\mathrm{m}$ of basement drilled with the 20 inch underreamer was $\sim 1.3 \mathrm{~m} / \mathrm{h}$ using a reduced WOB of 10,000$12,000 \mathrm{lb}$. Other notable drilling parameters were rotation $=60-70 \mathrm{rpm}$, two pumps at $80 \mathrm{spm}$ each, and pump pressure $=1450-1475$ psi.

We then raised the bit to 2910.0 mbrf (242.2 mbsf), set back the top drive, and continued up to 2707.0 mbrf (39.2 mbsf). While lowering back into the hole, we began to take weight at 2906.0 mbrf (238.2 mbsf). The top drive was picked up, and we continued to wash and ream the hole at $2906.0 \mathrm{mbrf}$ (238.2 mbsf) and from 2910.0 mbrf (241.2 mbsf) to 2943.0 mbrf (275.2 mbsf). There was no fill encountered at TD.

We swept the hole with $50 \mathrm{bbl}$ of sepiolite mud and then made another wiper trip to 2900.0 mbrf (232.2 
mbsf) and back to TD. We checked the hole condition at that point by lowering the drilling assembly without pump or rotation until encountering a ledge at 2935.0 mbrf (267.2 mbsf). This was $<1.0 \mathrm{~m}$ below our target depth for the 16 inch casing shoe of 267.5 mbsf and was considered too close for comfort. We therefore elected to drill an additional $1.0 \mathrm{~m}$ of hole into basement. With the $181 / 2$ inch hole depth now at 2944.0 mbrf (276.2 mbsf) and the 20 inch hole depth at 2936.0 mbrf (268.2 mbsf), we again swept the hole with $50 \mathrm{bbl}$ of sepiolite mud and proceeded to conduct one last hole inspection to $2900.0 \mathrm{mbrf}$ (232.2 mbsf) and back to TD without rotation or circulation. This time, the hole was deemed in acceptable condition for 16 inch casing deployment.

The hole was swept a final time with $50 \mathrm{bbl}$ of sepiolite mud and then displaced with another $304 \mathrm{bbl}$ of sepiolite prior to retrieving the drill string. When the drill string was recovered, the underreamer arms were still in the expanded position. We were unable to retract the arms. The underreamer and drill bit assembly was laid out by $0615 \mathrm{~h}$ on 11 July.

\section{Deploying and cementing 16 inch casing}

By drilling the upper $3.0 \mathrm{~m}$ of basement with the underreamer assembly, we eliminated the need for another drill string round trip to deploy the bicentered bit assembly. Therefore, our attention turned to making up and deploying the 16 inch casing string. A total of 19 joints of 16 inch casing $(75 \mathrm{lb} / \mathrm{ft}$; K-55; range 3 ) were made up with a cementing float shoe on the bottom and a standard 16 inch casing hanger on the top. The special 16 inch seal bore pup joint was not used, however, because of insufficient clearance (0.015 inch per side) with the $103 / 4$ inch seal sub assembly designed to mate with the seal bore hanger.

To enhance our chances of successfully landing the casing hanger, we amended our operating procedures. We made up a single joint of drill pipe to the bottom of the cementing manifold. In this way, we hoped to speed up the process of adding the cementing manifold to the drill string later. It was during this time, with the circulation pumps shut down, that, based on previous experience, we were most vulnerable to packing of the hole annulus and the attendant problems with getting the casing string moving downhole once again.

The casing string was lowered to the seafloor, the camera system was deployed, and Hole U1301B was reentered for the second time at $1620 \mathrm{~h}$ on 11 July. After picking up the top drive, the casing was lowered into open hole and the casing hanger landed without incident at $1800 \mathrm{~h}$. Latch engagement was verified with 15,000 lb of overpull. The 16 inch casing shoe was subsequently cemented in place with
$18 \mathrm{bbl}$ of $15.2 \mathrm{ppg}$ cement at a $270.9 \mathrm{mbsf}$. The casing running tool was released with $3 \frac{1 / 4}{4}$ turns to the right, and the drill string/cementing manifold were thoroughly flushed with seawater prior to retrieval.

After recovering and detorquing the casing running tool, the underreamer was placed in the rotary table.

\section{Drilling $143 / 4$ inch hole in basement for $103 / 4$ inch casing}

At $0130 \mathrm{~h}$ on 12 July, we began making up the $143 / 4$ inch tricone drilling assembly. A five-stand BHA was run so that we could keep the top of the $81 / 4$ inch drill collars inside casing and out of open hole. In this way, we minimized our chances of getting stuck while drilling the 143/4 inch diameter hole.

Hole U1301B was reentered for the third time at $0700 \mathrm{~h}$ on $12 \mathrm{July}$, and by $1030 \mathrm{~h}$ the float shoe and cement were drilled out and the hole was cleaned up to TD at $2944.0 \mathrm{mbrf}$ ( $276.2 \mathrm{mbsf}$ ). At $1030 \mathrm{~h}$, we began drilling the $143 / 4$ inch hole in basement required for the 103/4 inch casing string.

Basement drilling was conducted using a new Varel 143/4 inch ETD617 tricone drill bit (SN174706) jetted with three number 20 nozzles. The first $50.0 \mathrm{~m}$ of basement drilling was achieved in $13.5 \mathrm{~h}$ at an average "net" drilling rate (including connection time) of $3.7 \mathrm{~m} / \mathrm{h}$. The actual ROP through this section varied from as much as 6.0 to $<1.0 \mathrm{~m} / \mathrm{h}$ (see Fig. $\mathbf{F 9}$ in the "Expedition 301 summary" chapter). Drilling was uneventful until reaching 327.2 mbsf. While picking up to make a connection, the driller noted $20,000 \mathrm{lb}$ of overpull and significantly elevated pump pressures. It appeared that the hole had packed off. The driller continued to fight hole problems including loss of rotation, loss of circulation, overpull, and elevated pump pressure for the next $>11 \mathrm{~h}$. Finally, at $1130 \mathrm{~h}$ on 13 July, the hole appeared to be stabilized and forward progress continued. By $1530 \mathrm{~h}$, the hole had been advanced to the target depth of 3018.0 mbrf (350.2 mbsf), or $85.0 \mathrm{~m}$ into basement.

The hole was swept multiple times with sepiolite mud, and we continued to wash and ream the hole until we were comfortable that hole stability was adequate for casing deployment. By $0215 \mathrm{~h}$ the morning of 14 July, the bit was back on board ship and preparations for running the $10^{3} / 4$ inch casing string began.

\section{First attempt at installing 103/4 inch casing}

Twenty nine joints of $103 / 4$ inch casing $(40.5 \mathrm{lb} / \mathrm{ft}$; K55; range 3 ) were made up, along with a cementing float shoe and the $103 / 4$ inch casing hanger. Total string length was $342.50 \mathrm{~m}$. The casing running tool was made up and lowered to the seafloor. The cam- 
era was deployed, and Hole U1301B was reentered for the fourth time at $1140 \mathrm{~h}$ on 14 July. The casing was lowered to $2964.0 \mathrm{mbrf}$, and the top drive was picked up. The casing was washed to $3002.0 \mathrm{mbrf}$ (334.2 mbsf) without incident. After picking up the cementing manifold, we found we could not pass 3002.0 mbrf. Nearly $7 \mathrm{~h}$ were spent attempting to move the casing further downhole, but all efforts were in vain. The string was entirely free above 3000.0 mbrf but could not be moved any further down the hole. At $1930 \mathrm{~h}$, we abandoned our efforts to install the casing, laid out the cementing manifold, and retrieved the casing string. There were no problems or indications of drag or overpull identified while pulling the casing upward through an open hole. By $0530 \mathrm{~h}$ on 15 July, the $10^{3 / 4}$ inch casing string had been disassembled and stored away in the riser hold.

\section{Reaming of $14 \%$ inch hole in basement}

A 14\%/4 inch tricone bit and five-stand drilling BHA was assembled and lowered to the seafloor. Reentry number 5 was made into Hole U1301B in short order, and at $1015 \mathrm{~h}$ on 15 July we began to lower the bit to 2965.0 mbrf, where the top drive was picked up. The bit was washed to $2998.0 \mathrm{mbrf}$ (330.2 mbsf) before encountering any significant resistance. At that depth, the driller noted that he was meeting resistance (taking weight). The next $6 \mathrm{~h}$ was spent washing, reaming, and pumping multiple sepiolite mud sweeps to clean and condition the hole once again from 2998.0 mbrf to TD at 3018.0 mbrf. By $2000 \mathrm{~h}$ on 15 July, we were comfortable with the shape the hole was in. We then pulled the pipe back up into the 16 inch casing shoe and waited $1 \mathrm{~h}$ for the hole to equilibrate. No overpull or drag was encountered during the trip up to the casing shoe, which was a good sign. At $2130 \mathrm{~h}$, we began lowering the pipe slowly to TD with minimal pump (30 spm) and no rotation. At TD, we swept the hole one final time with $50 \mathrm{bbl}$ of sepiolite mud and pulled out of the hole. No significant resistance was encountered, and we felt certain that the last remaining vestiges of problem spots had been removed. By $0500 \mathrm{~h}$ on 16 July, the bit was on deck and we began making up the $10 \frac{3}{4}$ inch casing string for the second time.

\section{Second attempt at deploying 103/4 inch casing}

The same casing string consisting of 29 joints of $103 / 4$ inch (40.5 lb/ft; K-55; range 3) casing was made up, along with a cementing float shoe and the $103 / 4$ inch casing hanger. The total string length was the same as that deployed during the first attempt $(342.50 \mathrm{~m})$.
The DQ running tool was made up, and the casing was deployed via the drill string. The vibrationisolated television (VIT) camera was installed, and Hole U1301B was reentered for the sixth time at $1425 \mathrm{~h}$ on 16 July. The casing was run in hole to $2964.5 \mathrm{mbrf}$, and the top drive was picked up. Lowering continued to $\sim 3005 \mathrm{~m}$, where minor resistance was met. The casing was encouraged to move down another meter by increasing the pump stroke. The cementing manifold with a pre-made-up drill pipe single was made up and the cementing hose was connected.

This new technique worked well, and mud pump circulation was shut down for only $2 \mathrm{~min}, 55 \mathrm{~s}$. With the manifold in the string, we resumed lowering casing and landed the casing hanger at $1615 \mathrm{~h}$ on 16 July. Proper latch engagement was verified with $15,000 \mathrm{lb}$ of overpull. The $103 / 4$ inch casing shoe was cemented at $346.1 \mathrm{mbsf}$ with $32 \mathrm{bbl}$ of $15.2-15.8 \mathrm{ppg}$ cement. Heavier cement was pumped at the shoe. The cement was displaced with the rig mud pumps, the cementing dart was released, and the SSR plug was landed with 500 psi. The pressure was vented at the standpipe manifold, and a check for backflow proved negative. The casing running tool was released with $3 \frac{1}{4}$ turns of right-hand rotation, and it was raised to 2657.0 mbrf. After flushing and laying out the cementing manifold, we set back the top drive and recovered the camera. Prior to retrieving the drill string, the drilling line was serviced (slip and cut). The pipe trip was completed while the ship moved to Hole 1026B. A positioning beacon (SN 2193; $14.0 \mathrm{kHz} ; 208 \mathrm{db}$ ) was deployed at $2356 \mathrm{~h}$, and by $0045 \mathrm{~h}$ on $17 \mathrm{July}$, the casing running tool was detorqued and laid out, ending operations in Hole U1301B for now.

\section{Transit to/from Site 1026}

Before continuing further operations at Site U1301, we decided to move over to Hole 1026B to remove a mini-reentry cone installed in the top of the existing CORK. See "Operations" in the "Site 1026" chapter for a detailed description of these operations. We conducted the $1.08 \mathrm{~km}$ transit to and from Hole 1026B in DP mode while retrieving the drill string.

\section{Return to Site U1301}

\section{Depth measurement check in Holes U1301A and U1301B}

The first operation during this occupation of Hole U1301B was to drill out the $10^{3 / 4}$ inch casing shoe, the SSR plug/dart assembly, and any remaining cement. A 978 inch tricone drill bit was made up to a three-stand BHA and lowered to the seafloor. 
Prior to reentry into Hole U1301A, we decided to conduct a thorough depth check in both Holes U1301A and U1301B. Using the drill string pipe tally and the camera system, we visually verified the seafloor depth, the depth for the top of the cuttings mound (at a single location), and the depth to the top rim of the installed reentry cones. By taking these measurements simultaneously over a $30 \mathrm{~min}$ period, we minimized tidal effects (Fig. F6), giving us accurate depth references for each hole as well as accurate comparison depths between holes. These data were important in accessing whether the final resting locations of the reentry cones were likely to present future ROV or submersible accessibility problems to the CORK head instrumentation bays. The results of these depth measurements are given in Tables T2 and T3. It was determined that both reentry cone rims were below the seafloor. Because of the buildup of cuttings above the top of the Hole $\mathrm{U} 1301 \mathrm{~B}$ reentry cone, the CORK to be installed in this hole would have to be raised $2.0 \mathrm{~m}$ prior to installation. Later in the expedition, we received a helicopter transfer with the required equipment to extend the height of the CORK head.

\section{Hole U1301A \\ Drilling out $10^{3 / 4}$ inch casing shoe}

With the depth measurement exercise completed, Hole U1301A was reentered for the seventh time at $1940 \mathrm{~h}$ on 17 July 2004 . The camera was recovered back on board ship while the pipe was lowered into the hole run and the top drive was picked up. The float shoe was drilled out in $45 \mathrm{~min}$, and the bit was then lowered without rotation and without circulation to see how much unrestricted depth of hole was available. Tag depth was recorded at $2963.5 \mathrm{mbrf}$ with $15,000 \mathrm{lb}$ of weight set down. This equates to 296.2 mbsf, which is $34.0 \mathrm{~m}$ into basement or 19.1 $\mathrm{m}$ below the $103 / 4$ inch casing shoe. The $97 / 8$ inch drilling assembly was retrieved, and at $0315 \mathrm{~h}$ on 18 July, the bit and bit sub were laid out and we began preparing for hydrologic (packer) testing.

\section{Hydrologic (packer) testing}

A packer testing BHA was assembled consisting of a clean-out bit, an $8 \frac{1}{4}$ inch, $10 \mathrm{ft}$ long drill collar pup, the TAM International packer assembly with a $5 \mathrm{ft}$ element, eight $8 \frac{1}{4}$ inch drill collars, and a TDC. This BHA was lowered and the camera/sonar system was deployed. Prior to reentry and offset from the reentry cone, a drill pipe wiper pig was pumped through the drill string to wipe out any rust or corrosion residue remaining; this was to ensure that any residue would not interfere with the hydrologic testing. Hole U1301A was reentered for the eighth time at $0901 \mathrm{~h}$ on 18 July. After recovering the camera, lowering pipe to 2941.0 mbrf, and picking up the top drive, the packer assembly was positioned inside the last (shoe) joint of 103/4 inch casing ( $2941.0 \mathrm{mbrf})$. A packer setting go-devil was deployed, and $1 \mathrm{~h}$ was spent recording a hydrostatic baseline pressure. At $1200 \mathrm{~h}$ on $18 \mathrm{July}$, the packer was inflated with 1000 psi pressure, and 10,000 lb of weight was set down on the packer to keep it from creeping uphole. Another $1 \mathrm{~h}$ was used standing by for a formation baseline pressure, and at $1300 \mathrm{~h}$ a series of constant-rate injection tests were conducted into the formation. Injection testing was completed at $2330 \mathrm{~h}$, at which time the packer was deflated and the wireline was lowered to recover the packer go-devil. The drill string was retrieved back on the rig floor by $0730 \mathrm{~h}$ on 19 July.

\section{Hole U1301A CORK installation}

The final configuration of the CORK installed in Hole U1301A is shown in Figure F7.

After rigging up for running 41/2 inch casing, three 6 m long "slotted" pup joints were made up with a casing bull plug on the bottom. The bull plug had a bar welded across the face to prevent any instruments from passing out the bottom of the $4 \frac{1}{2}$ inch casing string should the instrument string fail. The slots (cut with a plasma cutter) were put in the casing pups to allow free flow of formation fluids through the lower part of the instrumentation string. The landing sub was made up, along with a single $4 \frac{1}{2}$ inch casing packer. Three miniscreens were installed at the approximate center of the slotted casing joints ( $\sim 10 \mathrm{~m}$ below the packer). Another four miniscreens were installed immediately below the packer. By $1200 \mathrm{~h}$, the lower ends of the umbilical lines were connected. The umbilical for this installation was left over from Leg 196. The Hole U1301A CORK used $278 \mathrm{~m}$ of umbilical, and $234 \mathrm{~m}$ of the Leg 196 umbilical remains on the drum for possible future use. The next $8 \mathrm{~h}$ were spent making up 18 joints of $4 \frac{1}{2}$ inch casing and two $6 \mathrm{~m}$ long pup joints, strapping umbilical lines to the casing, installing casing centralizers ( 2 per joint; 48 total), making up the CORK running tool to the CORK head assembly, connecting the packer inflation hose from the running tool to the head, and making up the remaining BHA required for the deployment. The BHA consisted of the CORK running tool, five $8 \frac{1}{4}$ inch drill collars, a TDC, and the usual two stands of $5 \frac{1}{2}$ inch transition drill pipe.

The assembly was lowered into the moonpool, where a bent valve handle was replaced and a single osmotic sampler was attached. The moonpool doors were opened, and the large camera/sonar sleeve was 
test fitted over the CORK head to ensure that there would be no interference passing over it when the time came for the camera to be lowered down the end of the $4 \frac{1}{2}$ inch casing for reentry. At $2000 \mathrm{~h}$ on 19 July 2004, we began lowering the CORK assembly to the seafloor. The camera was deployed, and at 0045 h on 20 July, Hole U1301A was reentered for the ninth time. The casing was lowered until just before landing into the $103 / 4$ inch casing, and the top drive was picked up.

\section{CORK head identification}

The CORK head deployed in Hole U1301A had a wide black stripe painted circumferentially near the top of the structure just below the lugs used for engaging the CORK running tool. In the middle of the large black stripe was a small white stripe.

\section{Deployment of CORK osmotic sampler/ thermistor string}

At $0245 \mathrm{~h}$, we began making up the internal OsmoSampler/thermistor instrument string. This consisted of a lower sinker bar, four osmotic samplers, a lower "gravity plug" seal sub, a section of $3 / 8$ inch Spectra rope with two thermistors installed, another sinker bar, another section of Spectra rope, and an upper "gravity plug" seal sub. The assembly was deployed at the rig floor by using two sheaves, two tuggers, and a series of rope "grippers" that were systematically braided onto the Spectra rope and then removed prior to entry into the drill pipe. Once made up, the entire ( $294 \mathrm{~m}$ long) assembly was lowered through the pipe and down inside the CORK using the core winch with a special sinker bar assembly consisting of three sets of wireline jars installed in series. A special "weakened" shear pin was installed in the overshot. Once landed in the CORK head, the instrument string was released by jarring and severing the shear pin. The sinker bar assembly was recovered, and a packer setting go-devil was dropped down the drill string. This go-devil was used in the past as a backup way of inflating the $4 \frac{1}{2}$ inch casing packer should the seals in the CORK running tool "stinger" fail to seal properly. At $0745 \mathrm{~h}$, after activating the $A H C$, the CORK head was landed in the $10^{3} / 4$ inch casing hanger. The $4 \frac{1}{2}$ inch casing packer was inflated with 600 psi pump pressure, and this pressure was held for $30 \mathrm{~min}$. The camera was recovered, and preparations began for deployment of the ROV/submersible platform.

\section{Deployment of ROV/submersible platform}

The ROV/submersible platform used in Hole U1301A was of the older design. It was made up of gray plate steel with holes cut in it to aid in the passage of water through the structure during deployment. This platform is distinctively different than the newer design deployed in Hole U1301B. The new platforms, although they are also gray in color, are made up of steel grating material and are not solid metal. One quadrant of the Hole U1301A platform was outlined with a black paint stripe to give the DP operators a directional orientation reference. On the surface of the platform there were two opposing black squares painted with white numbers "1301A."

The ROV/submersible platform was moved into the moonpool, and final assembly (bolting/welding) was completed. A newly designed mechanical platform deployment tool (see Fig. F7 in the "Site 1026" chapter) was made up to the platform, and the assembly was deployed on the logging line via the new Schlumberger heave-compensated logging winch. In the past, the platforms were deployed using the logging line and a wire rope bridle attached to an acoustic release. Once landed, the platform was released by lowering a portable transducer over the side of the ship and sending a release command sequence to the subsea release system. The new mechanical system is designed to release the platform automatically as the deployment tool encounters the top of the CORK running tool. At $1400 \mathrm{~h}$ on 20 July, the platform reached the CORK; however, the weight of the platform was not released. When the winch operator picked up, he had $1300 \mathrm{lb}$ of overpull. The cable was slacked off a second time, and once again the winch operator picked up. This time, with a few hundred pounds of overpull, the tool came free and the static hanging weight indicated that the platform had been released. Upon recovery, one of the three arms on the running tool had bent. Two arms released properly and the third apparently hung up momentarily, which was long enough to put that portion of the mechanism in a bind. In retrospect, we believe one of the arms was hammered into place during attachment to the platform, and this is likely the one that did not release cleanly. The platform deployment tool was repaired, and the next time it was used, more care was given to making sure that the three engagement arms were fitted to the platform with the necessary clearance for a less forceful release.

By $2400 \mathrm{~h}$ on 20 July, the platform deployment tool had been recovered and the camera was deployed to inspect the CORK installation. The installation appeared to be fine. The CORK running tool was quickly released, and the drill string was retrieved. The camera was recovered, and the coring line was deployed to recover the packer setting go-devil. To our surprise, the overshot contacted the packer set- 
ting go-devil at 1540 mbrf. Apparently, the go-devil never properly seated in the CORK running tool as it was supposed to. Although this was a backup mechanism, there was still some concern as to why the godevil hung up in the drill string. After taking measurements of the go-devil body, we found that the upper diameter of the tool measured a larger diameter than the drill pipe drift used in "rabbiting" our drill pipe to ensure a clear bore. The investigation is continuing as to why this go-devil was designed the way it was. It was not used for other CORK deployments during Expedition 301.

During the pipe trip, the ship was moved $36 \mathrm{~m}$ back to Hole U1301B, and by $2400 \mathrm{~h}$ on 20 July, all tools had been recovered, ending operations for Hole U1301A.

\section{Hole U1301B}

\section{Drilling out 103/4 inch casing shoe}

A 978 inch tricone bit and drilling BHA was assembled and lowered to the seafloor. After deploying the camera and spacing out the drill string, Hole U1301B was reentered for the seventh time at $0525 \mathrm{~h}$ on 21 July 2004. The pipe was lowered to bottom, the top drive was picked up, and the 103/4 inch casing shoe, SSR plug assembly, and remnant cement were drilled out. The rathole below the shoe appeared clean, and no fill was encountered. Once on bottom, we drilled another $1.0 \mathrm{~m}$ of new hole to provide some stabilization for the RCB core bit soon to follow. The hole was swept with $20 \mathrm{bbl}$ of sepiolite mud, and the drilling assembly was recovered back on board ship by 1530 h on 21 July.

\section{RCB coring in basement-first bit run}

The Hole 1301B coring summary is shown in Table T1. A 97/8 inch RCB (CC-7 style) coring bit was made up with a mechanical bit release (MBR) and the remaining subs associated with the RCB outer core barrel assembly. A six-stand BHA was made up and lowered to the seafloor. The unusual number of drill collars allowed us to reach an adequate depth (100$150 \mathrm{~m}$ ) on the first RCB bit run without exposing the top of the TDC to open and possibly unstable hole. Prior to reentry, the drilling line was serviced (slip and cut), and at $2215 \mathrm{~h}$ on 21 July, Hole U1301B was reentered for the eighth time.

After picking up the top drive, continuous RCB coring commenced at $0300 \mathrm{~h}$ on 22 July. Coring continued with variable parameters. Hole instability seemed to be associated with those portions of the hole where rapid penetration rates $(4-6 \mathrm{~m} / \mathrm{h})$ were encountered. Core recovery also decreased in these "brecciated" intervals, and the drilling torque be- came higher and erratic; however, we were able to clean up these problem sections of hole. In the more massive portions of basement, the ROP slowed down dramatically with progress in the $1.0-3.0 \mathrm{~m} / \mathrm{h}$ range. The first bit run continued until $0300 \mathrm{~h}$ on 25 July, when Core $15 \mathrm{R}$ was recovered. This core was excellent, with $9.6 \mathrm{~m}$ advanced and $4.92 \mathrm{~m}$ of fairly massive core recovered (recovery $=51.3 \%$ ). The ROP for Core $15 \mathrm{R}$ averaged $1.5 \mathrm{~m} / \mathrm{h}$, although major tidal influences ( $\pm 2 \mathrm{~m}$ per day) continued to complicate our drilling depth references (see Fig. F6). Total depth achieved to this point was $3121.0 \mathrm{mbrf}$ (453.2 mbsf). A total of $102.0 \mathrm{~m}$ was cored, with the first bit achieving a recovery of $31.41 \mathrm{~m}(30.8 \%)$ and requiring 53.0 total bit rotating hours. We decided to retrieve the bit at this time to be conservative and to help minimize chances of a bit failure that might junk the hole. Recovery probably could have been improved substantially by deploying barrels without core liners and by cutting half rather than full cores, but the scientists considered deep penetration to be of equal importance to good recovery.

A wiper trip was made back up to the $103 / 4$ inch casing shoe and then back to TD, where $\sim 7 \mathrm{~m}$ of fill was encountered. The fill easily washed away, and the hole was swept with another $30 \mathrm{bbl}$ of sepiolite mud.

\section{RCB coring in basement-second bit run}

Consideration had been given earlier to running a C4 core bit in lieu of another C-7 style. The C- 4 has a slightly longer tungsten carbide insert and might have achieved a slightly faster rate of penetration. Once the initial bit was recovered, however, that idea was abandoned. Although the bearings were in excellent condition, the cutting structure was not. All buttons were broken on the ID gage cutters, and there were broken, chipped, or missing teeth on all other rows. The bit was considered junk. Because of the large number of broken teeth on the first bit, it was considered unwise to run a bit with longer teeth. Therefore, another new C-7 core bit was made up to a rebuilt MBR. Another three drill collars were picked up, enabling us to run a seven-stand BHA. This allowed us to core up to $186 \mathrm{~m}$ beyond the $10^{3} / 4$ inch casing shoe without exposing the smaller-diameter TDC to open hole. With the first bit advancing to $107.1 \mathrm{~m}$ beyond the shoe, the longer BHA would now allow us to core another $79 \mathrm{~m}$. The pipe was lowered to bottom, and Hole U1301B was reentered for the ninth time.

While lowering the bit through the $103 / 4$ inch casing, the driller noted that there was an obstruction inside the $103 / 4$ inch casing at 2918.2 mbrf. Even setting down a weight of $30,000 \mathrm{lb}$, the bit would not pass this point. The top drive was picked up, and with 
only minimal rotation the bit passed through the spot with little problem. The driller picked up above the point and when he came down a second time, once again the interference was identified at exactly the same depth. We had not seen this phenomenon on either of our first two trips through the $103 / 4$ inch casing string (later on we would find that this was the lower portion of the $103 / 4$ inch casing that had backed off). Unable to do anything about the problem, we continued on to bottom washing and reaming from $3106.0 \mathrm{~m}$ to $3121.0 \mathrm{mbrf}$ (TD). The hole was swept once more with $50 \mathrm{bbl}$ of sepiolite mud, and the center bit was recovered.

At $0030 \mathrm{~h}$ on 26 July, we resumed RCB coring in basement. Coring proceeded well initially. Sepiolite mud sweeps (30 bbl) were pumped every connection. The hole appeared to be in good condition with no overpull or fill on bottom. Coring continued through Core 26R to $3186.8 \mathrm{mbrf}$ (519.0 mbsf). When picking up off bottom after cutting Core 26R, the driller noted 40,000 lb of overpull and high torque off bottom. The hole was swept with $30 \mathrm{bbl}$ of sepiolite, and the pipe was raised to $3157.0 \mathrm{mbrf}$ before recovering Core 26R. Because the torque remained high, we elected to take time for hole cleaning and conditioning. We conducted a wiper trip up to the $103 / 4$ inch casing shoe, noting overpulls of 50,000 and $30,000 \mathrm{lb}$ at 3101.0 and $3073.0 \mathrm{mbrf}$, respectively. The hole was washed and reamed back to the bottom, where $12 \mathrm{~m}$ of soft fill was easily circulated out. Drilling torque returned to normal, and at $2230 \mathrm{~h}$ on 28 July, we resumed RCB coring. By 0630 h on 29 July, we had advanced the hole to 3200.0 mbrf (532.2 mbsf). The hole was swept with $30 \mathrm{bbl}$ of sepiolite mud, Core 28R was recovered, and at $0815 \mathrm{~h}$, we began to retrieve the bit for our second bit change. During the pipe trip, the driller worked the pipe several times through the earlier identified trouble spot at 2918.2 mbrf (inside the 103/4 inch casing). The driller repeatedly raised and lowered pipe from above 2918.0 and down to 2924.0 mbrf (which was simply a convenient drill pipe connection) without incident. There was no indication of any residual problem in that area (see later problems with backed off $103 / 4$ inch casing). At $1530 \mathrm{~h}$ on $29 \mathrm{July}$, the bit was back on board and we began making preparations for making up the new coring BHA.

\section{RCB coring in basement-third bit run}

A new C-7 core bit was made up to another rebuilt MBR. An additional nine drill collars were picked up, enabling us to run a 10-stand BHA. This allowed us to advance the bit up to $268.5 \mathrm{~m}$ beyond the $10^{3 / 4}$ inch casing shoe without exposing the smaller-diameter TDC to open hole. With the current total depth at 3200.0 mbrf, we were able to core $\sim 83 \mathrm{~m}$ deeper with this third bit for a total of $\sim 350 \mathrm{~m}$ into basement. The pipe was lowered to the seafloor, and Hole U1301B was reentered for the tenth time. While lowering pipe inside the casing, the driller noted an obstruction at 2926.0 mbrf. This was $8 \mathrm{~m}$ lower than the previous encounter. The top drive was picked up, and the camera was recovered. The pipe was rotated through the obstruction in the casing without difficulty. As before, the torque above and below that point was normal and consistent. The location of the trouble spot had moved down from 2918.2 on the last (second) bit trip to 2926.0 mbrf. We speculated (incorrectly) that the casing string was deflected because of an irregular and/or deviated hole and that the drill collars/drill pipe tool joints had been wearing a hole/slot (on low side) in the side of the casing at that depth. Later, we determined that the lower part of the $103 / 4$ inch casing had backed off and dropped down. After running the rest of the way to bottom, the hole was swept with $50 \mathrm{bbl}$ of sepiolite mud and RCB coring was initiated. Coring continued until Core 36R was on deck at $1400 \mathrm{~h}$ on 31 July. We terminated coring, as we achieved the primary objectives of obtaining substantial penetration deeply into extrusive basement and we felt it was wise to save extra time to deal with any uncertainties associated with the remainder of the expedition objectives (this turned out to be a wise decision).

\section{Distress call}

During the last few hours of coring in Hole U1301B, the ship's radio officer picked up a distress call communication between the U.S. Coast Guard (USCG) and a sailing vessel. The sail boat, with six people on board, was located $\sim 31 \mathrm{nmi}$ to the west of the JOIDES Resolution and was taking on water. We advised the USCG of our time to recover drill pipe and reach the location of the emergency. We also offered the use of our helideck and helicopter fuel if they were required for rescue operations. The USCG out of Port Angeles, Washington (USA), was handling the situation. We were not requested to cease operations, and later information indicated that the vessel was not in danger of sinking and that its pumps (hand pumps and buckets) were keeping up with the ingress of water. Apparently, a powered bilge pump was not operational and the source of the leak was also unknown at the time. Ultimately, the USCG dispatched a fixed wing "Buffalo" aircraft to the scene and air dropped a pump to the sailboat. The vessel continued to its home port of Seattle, Washington (USA).

\section{Preparations for wireline logging}

With the cutting of Core 36R, the final depth of Hole U1301B was established at $3250.6 \mathrm{mbrf}$ ( $582.8 \mathrm{mbsf}$ ). This yielded an ultimate penetration below the base- 
ment contact of $317.6 \mathrm{~m}$. A wiper trip was made up to the $103 / 4$ inch casing shoe and back to TD. No problems were experienced with the wiper trip. Only $8 \mathrm{~m}$ of soft fill was identified on bottom, and this was easily circulated out with a $50 \mathrm{bbl}$ sepiolite mud sweep. The bit was pulled back up into the $103 / 4$ inch casing, and the earlier identified problem areas were checked by raising the bit past 2918.0 mbrf and lowering the bit down until it shouldered (took weight) at 2926.0 mbrf. As before, slight rotation with the top drive allowed the bit to pass and the string was free below this depth. The pipe trip out of the hole continued, and, once clear of the reentry cone, the ship was offset $20 \mathrm{~m}$ to the north. The shifting tool was lowered, and at $0130 \mathrm{~h}$ on 1 August, the bit was released from the drill string. The ship was positioned back over the hole, and at $0147 \mathrm{~h}$, Hole U1301B was reentered for the eleventh time. The drill string was tripped to $2933.0 \mathrm{mbrf}$ ( $265.2 \mathrm{mbsf}$ ), or slightly below the trouble spot inside the $103 / 4$ inch casing. The top drive was once again used to rotate past this point. At $0415 \mathrm{~h}$ on 1 August, we began rigging up the logging sheaves for wireline logging.

\section{Wireline logging}

The Schlumberger logging sheaves were rigged up, and at $0415 \mathrm{~h}$ on 1 August, we began rigging up the first logging tool suite.

\section{Triple combo}

The first tool string included the Logging Equipment Head-Mud Temperature (LEH-MT), Hostile Environment Natural Gamma Ray Sonde (HNGS), Hostile Environment Litho-Density Sonde (HLDS), Accelerator Porosity Sonde (APS), and SlimXtreme Array Induction Tool (QAIT). The first pass with this tool string reached a total depth of 3246 mbrf. The second pass reached a total depth of $3122 \mathrm{mbrf}$. The caliper arms were fully extended during the first pass at 3242 mbrf.

\section{Ultrasonic Borehole Imager}

The second tool string included the LEH-MT, Scintillation Gamma Ray Tool (SGT), General Purpose Inclinometer Tool (GPIT), and Ultrasonic Borehole Imager (UBI). The second tool string deployment required slow deployment speeds because of low tool string weight. An obstruction was encountered in the hole at 3096 mbrf. There were two passes in open hole from $\sim 3096$ to 3021 mbrf before repositioning the open-ended pipe at 2914 mbrf. Two passes were made to $\log$ the casing interval from 3021 mbrf to seafloor. The UBI data were used to attempt to confirm the length of the gap between the two backedoff sections of $10^{3} / 4$ inch casing.

\section{Formation MicroScanner-sonic}

The third tool string included the LEH-MT, SGT, Dipole Sonic Imager (DSI), GPIT, and FMS. The third tool string deployment stopped at 2900 mbrf for recording uphole and downhole acceleration with the AHC on and off. An overpull of $\sim 6000 \mathrm{lb}$ was detected at $\sim 3072$ mbrf during the second pass. After the deployment, the logging engineer had to cut off $150 \mathrm{ft}$ of Hi-T logging line and rehead the rope socket because of several kinks in the cable.

\section{Vertical seismic profile}

Even though the three-component Well Seismic Tool (WST-3) checked out several days prior to deployment, there were problems getting the tool to respond on deck prior to running in the hole. The backup single-channel WST was deployed instead. While running in the hole with this tool, the arms appeared to keep opening. The deployment took $2 \mathrm{~h}$ to reach the seafloor because of the tool's light weight. On several occasions, descent was stopped to close the arm. The initial deployment speed was $\sim 1000 \mathrm{ft} / \mathrm{h}$, and this increased to $7700 \mathrm{ft} / \mathrm{h}$ with depth. Based on caliper observations, three potential intervals were identified for WST stations. Clamping and data were recovered at depths of 3075, 3050, and 3025 mbrf. While pulling out of the hole, we slowed down to $\sim 2500 \mathrm{ft} / \mathrm{h}$ to allow the rig floor crew to work on the AHC and then subsequently increased the speed to $\sim 9000 \mathrm{ft} / \mathrm{h}$. At the rig floor, we noticed that the clamping arms were fully extended, although they had been previously closed before entering the pipe. In support of the VSP program, the generator injector (GI) gun was used. The gun configuration consisted of a 45 inch $^{3}$ generator volume, a 105 inch $^{3}$ injector chamber volume, and a total pressure of 2000 psi. Data were recorded at $1 \mathrm{~ms}$ sampling interval, and the monitoring hydrophone was attached to the GI gun, which was placed $2 \mathrm{~m}$ below sea level. The delay time used for all shots was $40 \mathrm{~ms}$, and the recording length was $5 \mathrm{~s}$ with a starting point at $600 \mathrm{~ms}$.

At $1500 \mathrm{~h}$ on 2 August, the logging sheaves were rigged down and the wireline logging program in Hole U1301B was completed.

\section{Transit from Hole U1301B to Hole 1026B for CORK replacement}

After the drill string was recovered and fifteen $81 / 4$ inch drill collars were laid out, we began the $1.08 \mathrm{~km}$ DP move to Site 1026 to install a CORK-II in Hole 1026B. For details of the CORK replacement in Hole 1026B, see "Operations" in the "Site 1026" chapter. 


\section{Transit from Hole 1026B to Hole U1301B}

After finishing the Hole 1026B CORK-II installation (1130 h on 5 August 2004), we moved the ship back to Hole U1301B in DP mode while retrieving the CORK running tool. Once the running tool was secured on deck, the drilling line was serviced (slipped and cut).

\section{Attempted remedial cementing of $103 / 4$ inch casing gap}

This reoccupation of Hole U1301B was to attempt remedial cementing of the $10^{3} / 4$ inch casing that had backed off while RCB coring. A custom cementing assembly was designed and fabricated on board the ship. This consisted of a "stabbing sub" fabricated from an old head sub with the square rotary connection shoulder machined to a $45^{\circ}$ taper, two stands of $81 / 4$ inch drill collars, an internally blanked-off head sub, a ported cementing sub fabricated from a 36 inch long $81 / 4$ inch drill collar pup with three torchcut $1 \frac{1 / 4}{4}$ inch diameter holes, and two additional $8 \frac{1}{4}$ inch drill collars. The remainder of the BHA was the typical TDC and two stands of 51/2 inch drill pipe. The custom cementing assembly was lowered to the seafloor, and Hole U1301B was reentered for the twelfth time. The pipe was lowered to $2925.3 \mathrm{~m}$, where the driller noted a weight decrease. Once again, this spot in the casing could not be passed without rotation. The top drive was picked up, and the pipe was rotated easily into the lower portion of the $103 / 4$ inch casing string. It should be noted that, based upon an inspection of the MBR recently pulled out of the hole after logging, the 103/4 inch casing string most likely backed off at the casing coupling, leaving the coupling at the top of the lower section of casing looking uphole. Once past the open section of casing, the pipe was lowered to the perceived depth of the $103 / 4$ inch casing shoe at $3019.0 \mathrm{mbrf}$. At that point, $15 \mathrm{bbl}$ of high-viscosity bentonite gel mud was displaced into the hole. This was intended to help "float" the later displaced cement and keep it from falling downhole and out of the desired position. Bentonite gel mud was used for this so that we could keep freshwater- rather than seawater-based mud in the hole. Once the mud was displaced, the pipe was pulled back uphole and positioned so that the "ported sub" was located at 2924 mbrf, or just a 1-2 $\mathrm{m}$ above the estimated depth of the backed-off casing coupling. A $6 \%$ mix of freshwater and bentonite gel mud was premixed and then mixed with class G cement to make up a $10 \mathrm{bbl}, 15$ ppg cement slurry. Once the bentonite-water combination was added to the cement, the mix became very thick and almost unpumpable. With the cementing units pumps straining, the slurry was eventually pumped into the pipe and displaced downhole with the rig pumps. The cement pill was preceded and followed by $10 \mathrm{bbl}$ of fresh drill water to help isolate the cement slurry from the seawater. Once the cement was displaced into position in the hole, the drill string was pulled up again and the "ported sub" was repositioned at 2954.0 mbrf (the top of the calculated cement plug). A drill pipe cementing wiper dart was then pumped to bottom, stopping in the blanked-off sub located below the "ported sub." The drill string was then flushed thoroughly with seawater. The BHA was spaced out for this exercise so that while waiting for the cement to cure we could leave at least one stand of drill collars inside the lower section of $103 / 4$ inch casing to try to keep it aligned with the upper portion of $10^{3 / 4}$ inch casing above. While standing by waiting for the cement to harden, we circulated slowly at $\sim 40 \mathrm{spm}$ and rotated the pipe slowly at 15-20 rpm. This was to ensure that we did not cement our BHA in the hole or at least could recognize if that began to happen. After waiting $7.75 \mathrm{~h}$, we pulled pipe to 2900.0 mbrf and set back the top drive. The remainder of the drill string was then retrieved, and the BHA was back on the rig floor at $1700 \mathrm{~h}$ on 6 August, completing the attempted remedial cementing operation. We then decided to conduct APC coring in Hole U1301C to give the cement additional time to harden.

\section{Hole U1301C}

\section{APC coring}

The Hole 1031C coring summary is shown in Table T1. A typical three-stand APC/XCB coring BHA was made up, and the $\mathrm{XCB} /$ center bit and APC core barrels were spaced out. The APC core barrels to be used were dressed with liners and core catchers, and the drill string was lowered to 2652.1 mbrf, where the top drive was picked up and the pipe was spaced out for spudding. An APC core barrel was deployed via the core line, and with the bit positioned at 2663.0 mbrf, Hole U1301C was spudded at $0010 \mathrm{~h}$ on $7 \mathrm{Au}-$ gust 2004. Core $1 \mathrm{H}$ recovered $5.08 \mathrm{~m}$, establishing a seafloor depth of 2667.4 mbrf. We cored the sediment section in Hole U1301C to collect high-quality APC samples for geochemical and microbiological studies. We cored continuously from the seafloor to 119.1 mbsf (Cores $1 \mathrm{H}$ through $13 \mathrm{H}$ ). After that, we alternately cored and drilled ahead without coring to ensure we had sufficient time to obtain samples from the deepest sediments. We penetrated a total of $265.3 \mathrm{~m}$, cored $166.8 \mathrm{~m}$, and recovered $143.29 \mathrm{~m}$ (86\%). We pushed the APC coring system beyond its routine operational limits to obtain APC cores from the deepest sediments above basement. Cores $15 \mathrm{H}$ and $16 \mathrm{H}$ extended from 178.1 to $197.1 \mathrm{mbsf}$ and re- 
covered $11.87 \mathrm{~m}$ (62\%). After drilling ahead to 235.8 mbsf, we took Cores $17 \mathrm{H}$ through $19 \mathrm{H}$ from 235.8 to 265.3 mbsf in the pelagic section just above basement. These cores recovered $24.19 \mathrm{~m}(85 \%)$ and terminated just decimeters above basement. The APC core barrels failed to achieve full stroke after Core $6 \mathrm{H}$; however, good quality core samples were still obtained; we raised the bit $\sim 1 \mathrm{~m}$ before shooting each core. The cores were heavily sampled for microbiological and geochemical studies on the catwalk. PFT was pumped continuously for all APC cores. Five temperature measurements were attempted (APCtemperature tool [APCT] and DVTP), but two of these yielded poor-quality data due to tool motion or because of being pushed into poorly consolidated formation sands. Upon completion of APC coring, a small cement plug was displaced at the base of the hole and the drill string was recovered back on board ship. By $1530 \mathrm{~h}$ on 8 August, the APC coring BHA was back on board and preparations began for drilling out the cement placed earlier in Hole U1301B.

\section{Hole U1301B}

\section{Drilling out cement and checking open hole depth}

After completing APC coring in Hole U1301C, we moved the ship in DP mode back to Hole U1301B. We planned to drill out the remedial cement displaced 2 days earlier. We hoped that our attempt to keep the cement in place across the $10^{3 / 4}$ inch casing gap was successful. After lowering a tricone drill bit and drilling BHA to the seafloor, we reentered Hole $\mathrm{U} 1301 \mathrm{~B}$ for the thirteenth time at $2125 \mathrm{~h}$ on $8 \mathrm{Au}-$ gust 2004. The bit was lowered without resistance until contacting the top of the lower section of $10^{3 / 4}$ inch casing at the predictable depth of $2926.0 \mathrm{mbrf}$. The camera was recovered, and the top drive was used to rotate slowly through this location and into the top of the lower casing section. As before, the entry into the lower casing was relatively easy and the remainder of the trip to total depth did not require any rotation. At no time was any cement contacted inside the casing string, so the assumption was that our remedial cement went the same way as all the others-down the hole and into the formation. The pipe was advanced to 3175.0 mbrf, which was considered adequate as an open hole depth check because there were no plans to exceed this depth with the any part of the CORK installation. The hole was swept one final time with $30 \mathrm{bbl}$ of sepiolite mud, the drill string was retrieved back on board at $0730 \mathrm{~h}$ on 9 August, and preparations for hydrologic (packer) testing began.

\section{Hydrologic (packer) testing}

The TAM packer BHA was assembled with a single packer element, and the surface circulation equipment was successfully pressure tested in preparation for packer slug and flow testing. The drill string was lowered to the seafloor, and Hole U1301B was reentered for the fourteenth time at $1310 \mathrm{~h}$ on 9 August. The pipe was advanced all the way to $3152.0 \mathrm{mbrf}$, placing the packer at the first set point of 3140.0 mbrf. No problems were experienced on the trip except for what has become the traditional rotation into the top of the lower $103 / 4$ inch casing string at 2926.0 mbrf. The first packer tests were conducted from 1745 h on 9 August until 0215 h on 10 August. The packer was then deflated, and the pipe was raised to the second packer test depth of 3110.0 mbrf. This second set of packer tests was completed at $0700 \mathrm{~h}$. The packer was again deflated, and the pipe was raised to the third packer test depth of 3085.0 mbrf. These packer tests were completed at $1200 \mathrm{~h}$, the packer was deflated, and the pipe was raised for a fourth and final time to the last packer set depth of 3047.0 mbrf. The last packer set was to check for a good packer seat only, and no flow testing was conducted at this depth. By $1400 \mathrm{~h}$ on 10 August, all packer work was completed and the packer go-devil was recovered. The top drive was set back and the pipe was recovered, clearing the seafloor at $1645 \mathrm{~h}$. By $2100 \mathrm{~h}$, all packer components were laid out on the rig floor. The packer element, after four successful inflation cycles, appeared to be in surprisingly good condition. The element had a few minor cuts and abrasions, and there was a slight memory (set) to the elastomer; however, there was no major damage identified. Based on the data recovered with the downhole digital gauges, all packer tests appeared to be successful.

\section{Deployment of CORK "test" casing string}

We decided that before assembling the entire CORK casing string, dual umbilicals, three packers, and head, we should run a test to ensure that the casing and bowspring centralizers could be coaxed across the gap in the $103 / 4$ inch casing and into the lower section. At $2100 \mathrm{~h}$ on 10 August, we began rigging up the $4 \frac{1}{2}$ inch casing running tools. The first order of business was to determine how much weight was required to compress the bowsprings on our new $4 \frac{1}{2}$ inch bowspring centralizers. A centralizer was testfitted inside our remaining 103/4 inch casing hanger with attached $10^{3} / 4$ inch casing pup joint by making up a centralizer to a single joint of $4 \frac{1}{2}$ inch casing. This was lowered into the hanger/pup assembly, which was secured at the center of the rotary table. The test was completed quickly, as the centralizer 
slid effortlessly into the casing, requiring only the weight of the $4 \frac{1}{2}$ inch casing joint. The $103 / 4$ inch casing hanger was laid out, and assembly of the remaining $4 \frac{1}{2}$ inch test casing string began. The test string consisted of a $4 \frac{1}{2}$ inch casing bull nose, two joints of $4 \frac{1}{2}$ inch casing (slick), one joint of $4 \frac{1}{2}$ inch casing with two bowspring centralizers installed $5 \mathrm{~m}$ apart (to emulate having a casing packer in between), two more joints of $4 \frac{1}{2}$ inch casing (slick), a single $4 \frac{1}{2}$ inch casing joint and $2 \mathrm{~m}$ long casing pup with spring centralizer installed over the connection, a crossover from the $4 \frac{1}{2}$ inch casing eight-round thread (short) to a $5 \frac{1}{2}$ internal flush (IF) thread, and a standard crossover sub from the $5 \frac{1}{2}$ IF thread to the $5 \frac{1}{2}$ full hole thread on the 5 inch drill pipe. The casing crossover was fabricated by boring out a retired saver sub to accept a $4 \frac{1}{2}$ inch casing coupling and welding it inside and out. Welding was conducted with a pup joint installed in the coupling so as not to warp the coupling out of round. Once made up, the test string was lowered on the end of 5 inch drill pipe. The 5 inch pipe was used so as to more closely emulate the characteristics of the $4 \frac{1}{2}$ inch casing string to be deployed with the real CORK assembly. Hole U1301B was reentered for the fifteenth time at $0435 \mathrm{~h}$ on 11 August. The test string was lowered to $2888 \mathrm{mbrf}$, and the top drive was picked up. The string was then lowered to 2926 mbrf, where several attempts were made to pass into the lower section of separated $103 / 4$ inch casing. No progress was made using only up and down motion of the string. The top drive was then rotated very slowly, and the string was worked up and down. It was interesting that the top drive would stall out without any WOB registering. Only very low torque was allowed to build up for fear of overtorquing the relatively weak eight-round casing connections. Once into the lower section of $103 / 4$ inch casing, the end of the test string was advanced to 3002 mbrf, placing the $4 \frac{1}{2}$ inch casing test string and drill pipe crossover fully into the lower $10^{1 / 2}$ inch casing. The test string was then pulled back through the trouble zone and pulled back up to the surface. The seafloor was cleared at $0840 \mathrm{~h}$, and by $1315 \mathrm{~h}$ on 11 August, the casing test string was rigged down and the drill crew serviced the drill line (slip and cut).

\section{Initial deployment of CORK assembly}

Deployment of the Hole U1301B CORK assembly was the most complex and arduous of the expedition. The CORK assembly consisted of a $4 \frac{1}{2}$ inch casing bull plug with a 4 inch ID, two joints of slotted $4 \frac{1}{2}$ inch casing (slick) with Teflon shrink tubing installed over $30 \mathrm{ft}$ of casing and couplings, one $4 \frac{1}{2}$ inch casing packer (number 1) with three mini- screens installed directly below, two bowspring centralizers installed below the packer and one bowspring stabilizer installed above the packer, a gravity plug landing sub, two joints of $4 \frac{1}{2}$ inch casing, one $4 \frac{1}{2}$ inch casing packer (number 2) with three bowspring centralizers installed as on packer number 1 , four joints of $4 \frac{1}{2}$ inch casing, one $4 \frac{1}{2}$ inch casing packer (number 3) with bowspring stabilizers installed as on packers number 1 and number 2, 32 joints of $4 \frac{1}{2}$ inch casing, and the CORK head. Note that 28 bowspring centralizers were installed over the first $215 \mathrm{~m}$ (18 joints) of $4 \frac{1}{2} 2$ inch casing. Teflon stabilizers (three each) were used on the nineteenth and twentieth casing joints. A total of 44 fixed stabilizers were used on casing joints numbers 21-40 to $470.6 \mathrm{~m}$. A special new umbilical was deployed along with a special fabricated microbiology hose. In addition, the CORK running tool was modified with a special lockout (shear pin) ring that requires 4000$6000 \mathrm{lb}$ of down force before the J-tool will function and release. The numerous packers, complex umbilical, and microbiology hose connections, the special bowspring centralizers, the centralizer locking rings, the welding of the centralizers to prevent rotation, and the 40 joints of $4 \frac{1}{2}$ inch casing led to an overall CORK assembly time of $22.25 \mathrm{~h}$ and required the assistance of numerous technicians and crew members; it took nearly three times longer than anticipated. At $1330 \mathrm{~h}$ on 12 August, we began lowering the CORK assembly, and Hole U1301B was reentered for the sixteenth time at $1630 \mathrm{~h}$ on 12 August. We then carefully lowered the assembly into the hole. The camera system was left down until the first packer was safely through the level of the reentry cone's throat. It was then pulled up above the CORK head so as to not risk losing the camera system should a failure occur in the casing string being deployed (as ended up happening). As we continued to lower the CORK, it appeared that the CORK casing, bull nose, casing packers, and bowspring centralizers passed easily through the gap in the $10^{3 / 4}$ inch casing without incident. No rotation of the pipe was required. After picking up the top drive an additional joint of drill pipe was added to the drill string, placing the end of the CORK casing string at 3157 mbrf. This was $\sim 12 \mathrm{~m}$ short of landing the CORK wellhead.

\section{Open hole depth check with wireline sinker bar assembly}

Because the OsmoSampler/thermistor string was destined to be deployed beyond the $4 \frac{1}{2}$ inch casing shoe (bull nose) into open hole, we decided to conduct an open hole depth check using a wireline sinker bar (2.125 inch outer diameter) string. The sinker bars were rigged up and lowered into the pipe 
at $2015 \mathrm{~h}$ on 12 August for this routine depth check. To our surprise, the sinker bars would not pass 2665 mbrf (seafloor at $\sim 2667$ mbrf). After repeated attempts to lower the wireline past this point, we decided to lower the camera system back down over the CORK head to assess the situation. Once the seafloor and reentry cone came into view, we were greeted by a horrifying sight. A good portion of the $4 \frac{1}{2}$ inch casing, umbilical, and so on, was piled up around the reentry cone; one end of the $4 \frac{1}{2}$ inch casing string with attached umbilicals could be seen extending from the throat of the reentry cone and draping over the outside edge. Another end of casing could be seen sticking up out of the seafloor sediment adjacent to the reentry cone. It was immediately apparent that one or more casing failures had occurred, leaving more than half of the deployed casing strewn about on the seafloor. With nothing else to be gained we retrieved the camera system and drill string. The CORK head was recovered with nothing attached to the lower end, and by $0600 \mathrm{~h}$ on 13 August it was laid out. One of the casing failures had occurred right at the coupling to the head itself. A portion of the pin thread from the last joint of $4 \frac{1}{2}$ inch casing was broken off inside the coupling and was recovered with the head. After review, it became apparent that this particular failure was because of excessive bending.

\section{Seafloor inspection of reentry cone and seafloor}

A short inspection BHA made up of a reentry cleanout bit and the transition stand of drill collars (two $8 \frac{1}{4}$ inch drill collars and one TDC) was made up and lowered to the seafloor along with the camera system. At $1015 \mathrm{~h}$ on 13 August, we began to survey the aftermath of the $4 \frac{1}{2}$ inch casing failure(s). One joint of $4 \frac{1}{2}$ inch casing with umbilicals still attached was observed extending out of the reentry cone throat and was draped over the edge of the cone. We followed this section out $\sim 30 \mathrm{~m}$ from the reentry cone until we identified what appeared to be the end. Another joint with a visibly identifiable plastic (polyethylene) centralizer was seen lying directly adjacent and tangential to the outside edge of the reentry cone. Yet another joint of $4 \frac{1}{2}$ inch casing was observed sticking up out of the seafloor in close proximity to the Hole U1301A reentry cone. As part of our survey, we moved $36 \mathrm{~m}$ back over to Hole U1301A and assured ourselves that the Hole U1301A CORK was still all right. Our best analysis of the failure at this time is that a bowspring stabilizer either hung up momentarily in the throat of the reentry cone/casing hanger area or a buildup of friction from the multiple bowspring stabilizers deployed caused the $4 \frac{1}{2}$ inch casing to buckle above the seafloor. This led to the failure of one or more $4 \frac{1}{2}$ inch casing connections. The umbilical still appeared to be attached and acted as a tension member holding many, if not all, of the joints together. We confirmed that the end of the $4 \frac{1}{2}$ inch casing string had not yet reached the gap in the $103 / 4$ inch casing string, so that was ruled out as a possible cause. Our review of the rig instrumentation data remains inconclusive, and we have not yet been able to determine at what point in time the failure occurred, nor have we identified why we were not able to see the weight loss $(\sim 15,000 \mathrm{lb})$ that should have been associated with the failure. One explanation may be that the joints failed sequentially, and only small increments of weight were lost at a time. With the driller adding a stand of drill pipe at the same time, the gradual weight loss may have been partially masked. Analysis of the $1 \mathrm{~s}$ rig instrumentation data is ongoing, but it is clear that future CORK casing strings should be sufficiently weighted at the bottom to pull the casing into the hole. After satisfying ourselves that we had seen enough, we began to recover the seafloor survey BHA and simultaneously designed/fabricated a wall-hook-style fishing tool to be used in an attempt to drag the $4 \frac{1}{2}$ inch casing, umbilicals, packers, and so on out of the hole.

\section{Fishing $4 \frac{1}{2}$ inch casing string}

A wall-hook-style fishing tool was fabricated from 11/4 inch steel plate (Fig. F8) and welded to the same "jetting" sub used in fishing the aluminum reentry funnel in Hole 1026B earlier in the expedition. The new "rig-fabricated" fishing tool was made up to the transition string of drill collars (two 81/4 inch drill collars and one TDC). We tested how it would work on a $4 \frac{1}{2}$ casing pup joint on the rig floor. The fishing assembly was lowered to the seafloor. This time, the top drive was not picked up so that once the fish was engaged the driller would not have to lower the pipe to remove the top drive. Instead, torque to engage the casing body was provided by roughnecks using rig floor chain tongs. The first few attempts to engage the casing were unsuccessful when the driller could not get the hook underneath the bow in the casing. Ultimately, the casing was engaged at a spot just outside of the reentry cone rim. The entire time to hook the fish was $<30 \mathrm{~min}$. Estimates of the length of casing inside the reentry cone/casing varied from 200 to $250 \mathrm{~m}$, so the drill pipe was raised to $>300 \mathrm{~m}$ above the seafloor. The ship was then offset $300 \mathrm{~m}$ west of Holes U1301A and U1301B. The pipe was lowered back to the seafloor, and another $30 \mathrm{~min}$ and $300 \mathrm{~A}$ of top drive torque were required to release the fishing tool from the casing string. Large amounts of casing and umbilical and a casing packer were identified piled up on the seafloor. The entire release operation 
required $\sim 30 \mathrm{~min}$. With the fish gone, the ship was moved back over the Hole U1301B coordinates and we were pleased to see that only a single joint of $4 \frac{1}{2}$ inch casing was sticking out of the seafloor adjacent to the reentry cone. Apparently, nearly the entire CORK string was dragged $300 \mathrm{~m}$ to the west of the operating area. The reentry cone appeared free of any obstacles. Satisfied that we had accomplished our goal, the pipe was retrieved along with the fishing BHA and the camera, and by $0600 \mathrm{~h}$ on $14 \mathrm{Au}-$ gust, the fishing assembly was laid out.

\section{Open hole depth check}

A used $97 / 8$ tricone drill bit was made up to a threestand BHA and lowered to the seafloor, and Hole U1301B was reentered for the eighteenth time at $1030 \mathrm{~h}$ on 14 August. The pipe was lowered into the hole without any difficulty until reaching 2926 mbrf. Once again, the top drive had to be picked up to rotate the pipe slightly and the bit dropped through into the lower section of $103 / 4$ inch casing. Once through the casing gap, the pipe was lowered without rotation or circulation, and 3245 mbrf was achieved by $1300 \mathrm{~h}$ without resistance. Total depth of the hole was 3250 mbrf; however, we stopped just shy of that depth to save the time of having to make up another stand of drill collars. A depth of 3245 mbrf was a more than adequate open hole depth check, as this depth was well below anything that would be deployed as part of the CORK installation. The bit was retrieved and back on board at $1800 \mathrm{~h}$ on 14 August. Preparations then began for the second deployment attempt of the U1301B CORK assembly.

\section{Assembly of second Hole U1301B CORK}

To avoid the problem that caused our first attempted CORK installation to fail, we elected to add a significant amount of weight to the bottom of the $4 \frac{1}{2} \mathrm{inch}$ casing string. This would be analogous to the BHA or drill collars that are run at the end of the drill string to keep from putting the drill pipe into compression. Compression, or "buckling," is what led to the failure of the $4 \frac{1}{2}$ inch casing string during the first deployment in Hole U1301B. The CORK string had not been heavy enough for the driller to be able to tell if the string was going downhole or was hung up somewhere and the casing was buckling instead. The CORK for Hole U1301B consisted of the following: $4 \frac{1}{2}$ inch bull nose welded to the end of a stub of 5 inch drill pipe (1.97 m long), crossover sub, one $8 \frac{1}{4}$ inch drill collar (with zip lift groove), two $3.05 \mathrm{~m}$ long $81 / 4$ inch drill collar pup joints, one $4.58 \mathrm{~m}$ long $\times 81 / 4$ inch drill collar pup joint (with zip lift groove), one $8 \frac{1}{4}$ inch drill collar, two crossover subs, and one rig-fabricated crossover sub. The zip lift drill collars and two $3 \mathrm{~m}$ long drill collar pup joints were junk recovered with the Hole 1026B CORK and were drifted prior to use. This $32.5 \mathrm{~m}$ long CORK BHA added more than $10,000 \mathrm{lb}$ of weight to the end of the $4 \frac{1}{2}$ inch casing string and provided a much-needed aid to the driller while deploying the CORK. With the CORK BHA assembled, we began making up the CORK casing string. The first casing packer was made up to the rig-fabricated crossover sub at the top of the CORK BHA. This was followed by the landing sub (for the lower gravity plug) and the first joint of $4 \frac{1}{2}$ inch casing. This allowed us to lower the casing packer into the moonpool area, where four miniscreens were installed below the packer, and these were protected by installing a bowspring centralizer. The Expedition 301 umbilical and the microbiology hose (Tefzel) were then both attached to the top of the first casing packer. The umbilical and hose were run simultaneously off their respective reels by using a wheel sheave for the hose and a banana sheave for the umbilical. Both sheaves were hung from the support beams directly below the rig floor rotary table. The next step was to make up two additional joints of $4 \frac{1}{2}$ inch casing followed by the second casing packer. Another four miniscreens were installed below the second casing packer, and after making up the microbiology hose and umbilical connections, we attached our final bowspring centralizer. This was once again installed directly below the packer to help protect the miniscreens and to provide a smooth transition and guide for the 8 inch diameter packer element. Another 31 joints of $4 \frac{1}{2}$ inch casing were assembled while the umbilical and microbiology hose were deployed along side. The umbilical and hose were made fast to the casing by stainless steel banding placed approximately every $2 \mathrm{~m}$. This was also the case for the casing joints installed below and between the casing packers. Once the $4 \frac{1}{2}$ inch casing had been run, we changed out the elevator bales and picked up the CORK-II wellhead for Hole U1301B. The running tool was engaged by sliding it horizontally onto the CORK head while the latter was restrained within the confines of the pipe stabber. The end of the CORK head was prevented from moving by holding it with the pipe racker skate. The CORK wellhead/running tool assembly was picked up vertically with the drawworks, and we began to make up the lower connection to the top joint of $4 \frac{1}{2}$ inch casing. It was here that we realized that during the previous aborted deployment the lower end of the CORK body (made from $4 \frac{1}{2}$ inch casing) was slightly bent. This caused the head to wobble during make up and made it extremely difficult to make up the fine eight-round casing thread without cross threading. After several attempts, the thread was made up tight, and the connection was welded out 
top and bottom for added insurance. At this point, the master bushings were pulled from the rotary table and the CORK wellhead was lowered into the moonpool area, where the final umbilical and microbiology hose connections were made up. A stand of drill collars was made up to the top of the CORK running tool, and we then test-drifted the osmotic sampler sinker bar through the assembly to ensure that the bend in the CORK body would not interfere with the deployment of the instrument string later. Multiple packer inflation hoses were installed from the CORK running tool to the top of the CORK wellhead, and three osmotic samplers were installed on the CORK head. During installation of the samplers, a final plumbing inspection was conducted and it was noticed that one piece of tubing had been cut too short and had pulled away from the fitting. Approximately $1.25 \mathrm{~h}$ was required to cut a new piece of tubing and complete the plumbing. This included picking up the CORK head so all others could be checked. All were judged to be all right, and we began to deploy the CORK assembly at $1430 \mathrm{~h}$ on 15 August.

\section{Deployment of CORK (second attempt)}

The drill string and camera were lowered to the seafloor, and at $1745 \mathrm{~h}$ on 15 August, Hole U1301B was reentered for the nineteenth time. The CORK was lowered to $2926 \mathrm{mbrf}$, where the bottom of the $10^{3} / 4$ inch casing gap was tagged at the usual depth. The string was picked back up approximately one single $(\sim 9.5 \mathrm{~m})$, and the AHC was engaged. At the rig floor, the pipe was marked off in four quadrants so that we could keep track of its rotational orientation. The string was then lowered a second time, once again tagging the top of the casing coupling. The pipe was raised and lowered twice. Each time the pipe was rotated $1 / 4$ turn using chain tongs. On the third attempt, the nose of the CORK BHA slipped inside the lower backed-off 103/4 inch casing and the driller quickly continued to lower away to prevent pulling the pipe out on an up heave. This marked the first time that we had been able to pass into the lower casing section without having to use the top drive at $\sim 50 \mathrm{rpm}$. Use of top drive rotation at any speed would have been extremely risky during the CORK deployment because it would have been quite easy to inadvertently unlatch the running tool and drop the entire assembly prematurely. In case we did have to use some top drive rotation, a special modification to the running tool was made. This consisted of a shear ring that would lock the tool and prevent rotation until at least $6000 \mathrm{lb}$ of download was applied. Although we felt this would help to mitigate some of the risk involved with using the top drive, we were all very much relieved that we were able to cross the casing gap without using the top drive. The next anxious moment was when the first casing packer crossed the gap. Although we felt reasonably confident that the bowspring centralizers installed below each casing packer would guide the packers into the lower casing, we were still a bit apprehensive. These feelings soon passed when both casing packers crossed the gap without difficulty. The CORK string was advanced to 3165 mbrf, which was within 11.8 $\mathrm{m}$ of landing the CORK head, and at $2230 \mathrm{~h}$ on 15 August, we paused to run an open hole wireline depth check in preparation for deploying the thermistor/osmotic sampler instrument string.

\section{Deployment of CORK instrument string}

A sinker bar string was lowered through the CORK slowly at $\sim 25 \mathrm{~m} / \mathrm{min}$ so as not to inadvertently inflate the casing packers. The casing packers have check valves at the top that are set at a cracking pressure of 350 psi. Any pressure over this amount could have initiated packer inflation. The open hole depth check was terminated at 3200 mbrf, which was well below the depth to which the CORK instrument string was to be deployed. The sinker bars were recovered, and at $0230 \mathrm{~h}$ on 16 August, we began assembling the Hole U1301B instrument string. This string was longer than the others deployed earlier in the expedition in Holes U1301A and 1026B. The same technique was used as was described for those earlier holes; however, it took a little longer. By 0545 $\mathrm{h}$, we had completed the assembly and began deploying the instrument string using the core line. This time, a speed of $20 \mathrm{~m} / \mathrm{min}$ was used so as not to float the lightweight Spectra (Tefzel) line or lowweight $(60 \mathrm{lb})$ sinker bar. At $0845 \mathrm{~h}$, we reached what we thought was the landing point. After multiple attempts at jarring off, we decided we had better recover the instrument string and inspect the Spectra rope. It was feared that the lightweight (neutrally buoyant) line could get underneath the upper gravity plug during the jarring operation and either become cut or prevent proper seating of the plug. The instrument string was brought back to the ship, and a thorough inspection indicated that everything was all right. A longer piece of hose was put around the Spectra rope at the very top to stiffen the line and prevent the ability of the line to double back on itself. An inspection of the "weak" shear pin in the overshot assembly found that the pin had sheared through one shear plane; however, the other shear plane (the pin is in double shear) had tried to shear through the thicker portion of the pin rather than the weakened portion. It was determined that this occurred because the pin was not centered properly when installed in the overshot. The shear pins were replaced and the instrument string was deployed 
again. The gravity plugs were landed and the overshot was sheared off at $1415 \mathrm{~h}$. By $1545 \mathrm{~h}$, the wireline was out of the hole and preparations began for advancing the CORK wellhead the remaining $11.8 \mathrm{~m}$ to the landing seat.

\section{Final landing of CORK}

With the AHC engaged, the Hole U1301B CORK head was advanced the final distance and landed at $1600 \mathrm{~h}$ on 16 August. The final $11.8 \mathrm{~m}$ of advancement was carefully made. Several times the CORK acted as though it was setting down against a ledge, and each time the weight dropped off and the string began to advance again. A few minutes were taken to study the camera image and assure ourselves that the wellhead was resting in the proper location. We then pressured up the drill string to 1000 psi and proceeded to inflate the two casing packers. This process was expected to take a while because the packer penetrations were only single $3 / 8$ inch lines. While retrieving the camera system, we maintained the 1000 psi pressure on the system to ensure that we had full expansion of the packers. With the CORK landed, the middle of each packer was located at $3140.0 \mathrm{mbrf}$ (472.2 mbsf), or $207.0 \mathrm{~m}$ into basement, and 3096.8 mbrf (429.0 mbsf), or $163.8 \mathrm{~m}$ into basement, respectively (Fig. F9). We bled off the pressure to the packers at $1700 \mathrm{~h}$, and at $1715 \mathrm{~h}$ on 16 August, we prepared to deploy the ROV platform.

\section{Deployment of Hole U1301B ROV platform}

The ROV platform was modified for this installation to allow for reentry and displacing cement into the reentry cone (Fig. F10). Spotting cement into the reentry cone was intended to hopefully seal off the throat of the cone in the vicinity of the stacked casing hangers. This was deemed necessary because of our inability to install the 16 inch to $103 / 4$ inch casing hanger seal (due to a design flaw) and because the separated and uncemented $10^{3 / 4}$ inch casing allowed connectivity to the seafloor. This negated the hydraulic seal required for the long-term studies. The platform was also deployed differently in this hole. For the first time ever, the mechanical delivery system affectionately known as "Lula" (because of its resemblance to a lunar lander) was rigged below the camera frame. This negated the need to use the logging line and saved numerous hours in rigging. It took $30 \mathrm{~min}$ to attach Lula to the CORK platform and another $30 \mathrm{~min}$ to rig the VIT sleeve to Lula. The platform was lowered through the moonpool and lowered at a winch speed of $\sim 30 \mathrm{~m} / \mathrm{min}$. The platform appeared to be rock stable during the deployment, and a picture-perfect simultaneous release of the three arms was witnessed in real time using the camera. By $2130 \mathrm{~h}$, we had recovered and rigged down Lula, and we ran the camera back to bottom to review the installation and unlatch the CORK running tool. Lula had to be recovered before this operation because of the slings used in rigging the deployment tool to the VIT sleeve. There was too much danger of snagging something on the CORK head if we tried to lower down far enough to adequately observe the unlatching process. By $2230 \mathrm{~h}$, the camera was back down at the seafloor and we inspected the third and final successful CORK installation for Expedition 301. The running tool shear ring was not noticeable, and the unlatching process proceeded without incident. Prior to recovering the drill string, a few minutes were taken to get a good look at the top of the $4 \frac{1}{2}$ inch casing joint that was protruding out of the seabed directly adjacent to the Hole U1301B reentry cone. This was considered a potential hazard to future ROV or submersible operations, and we planned to fish this pipe out and deposit it at the same place as the rest of the casing string $\sim 300 \mathrm{~m}$ west of Hole U1301B. The casing appeared to have a coupling facing up, and this provided us with the information we needed to build the appropriate fishing tool (Fig. F11). The drill string was then tripped back to the surface, where the CORK running tool was removed.

\section{Cementing CORK head inside reentry cone}

At $0415 \mathrm{~h}$ on 17 August, a cementing diverter pipe was made up to the end of the drill string transition pipe. It was lowered into the opening in the Hole U1301B CORK-II ROV platform (Fig. F10) at $0900 \mathrm{~h}$ on 17 August. This was the twentieth and final reentry of Hole U1301B. Fifteen barrels of high-viscosity bentonite gel mud was displaced into the reentry cone, and this was followed immediately with $9 \mathrm{bbl}$ of cement. This was the last of the cement that we had on board. The drill string was pulled out of the ROV platform, and a drill string wiper dart was pumped down the drill string. The pipe was thoroughly flushed, and by $1430 \mathrm{~h}$ on 17 August, the drill string was back and the cement diverter tool had been laid out.

\section{Fishing $4 \frac{1}{2}$ inch casing joint}

A rig-fabricated fishing tool was fashioned (Fig. F11) from the hook tool used earlier to remove the aluminum reentry funnel from the top of the Hole 1026B CORK. A smaller insert was welded in to allow us to catch the coupling on the top of the $4 \frac{1}{2}$ inch casing joint. After making up the fishing tool, the pipe was run back to bottom and within 30 min the fishing tool was engaged on the fish and the casing joint was pulled out of the seafloor. The ship was offset 
$300 \mathrm{~m}$ west, and the joint was deposited on the seafloor with the other failed $4 \frac{1}{2}$ inch casing.

\section{ROV/submersible hazard survey surrounding Holes U1301A and U1301B}

With the fishing operation successfully concluded, we conducted a hazard survey with the camera system to identify any potential hazards that might pose a risk to future ROV or submersible operations at the site. A $100 \mathrm{~m} \times 100 \mathrm{~m}$ area was searched, along with two $200 \mathrm{~m}$ long approach paths from the north and the east. At $2300 \mathrm{~h}$ on 17 August 2004, the survey was completed, and by $0415 \mathrm{~h}$ on 18 August, the drill string had been recovered back on board ship. While recovering the drill string, the ship was offset 20 m east of Hole U1301C to take the final cores of Expedition 301.

\section{Hole U1301D}

Hole U1301D was APC cored to recover sediment from an interval that had not been cored in Hole U1301C. We offset the ship $20 \mathrm{~m}$ to the east of Hole U1301C, lowered an APC/XCB BHA to the seafloor, and started drilling ahead at $1600 \mathrm{~h}$ on 18 August 2004. We drilled without coring from the seafloor to 120.0 mbsf using an XCB center bit. Cores $1 \mathrm{H}$ through $6 \mathrm{H}$ were taken from 120.0 to $177.0 \mathrm{mbsf}$ and recovered $42.12 \mathrm{~m}$ (74\%). PFT was pumped during all of the coring operations. We stopped coring once the depth objective was reached. The bit was retrieved and back on board at $0600 \mathrm{~h}$ on 19 August, and we began securing the ship for the transit to Astoria, Oregon.

\section{Transit from Hole U1301D to Astoria, Oregon}

The transit to Astoria began at $0900 \mathrm{~h}$ on 19 August 2004. The ship arrived at the pilot station outside the Columbia River bar at 0400 h on 19 August. Expedition 301 ended in Astoria, Oregon, with the first line ashore at $0700 \mathrm{~h}$ on 20 August.

\section{Lithostratigraphy}

\section{Sediment coring}

Holes U1301C and U1301D were discontinuously APC cored to $265.3 \mathrm{mbsf}$, recovering fine- to coarsegrained turbidites and hemipelagic clay. This is virtually the same sedimentary section that was cored in Holes $1026 \mathrm{~A}$ and $1026 \mathrm{C}$ during Leg $168,1-2 \mathrm{~km}$ to the north along the same buried basement ridge. Resampling much of the same sedimentary interval during Expedition 301 was justified because APC cor- ing had not previously penetrated below $~ 100$ mbsf in this area, and we wished to collect high-quality samples for microbiological and geochemical analyses, especially close to the sediment/basement interface and the underlying crustal aquifer.

Time constraints prevented continuous coring of the complete sedimentary section in Holes U1301C and U1301D, but much of the interval that was cored yielded excellent recovery and high-quality samples (Fig. F12). Exceptions to this rule included Cores $301-\mathrm{U} 1301 \mathrm{C}-5 \mathrm{H}, 13 \mathrm{H}$, and $16 \mathrm{H}$ and Cores 301$\mathrm{U} 1301 \mathrm{D}-1 \mathrm{H}$ and $2 \mathrm{H}$ (recovery $=30 \%-40 \%$ ), where coarse sand prevented complete penetration of the APC barrel. In addition, an aggressive whole-round sampling program (for microbiological and geochemical analyses) removed a substantial fraction of recovered core from the catwalk, preventing description or other analyses of these intervals.

Hole U1301C is located $100 \mathrm{~m}$ north-northeast of Hole U1301B (Fig. F1). Sediment thickness in Hole U1301B was $265.2 \mathrm{~m}$, and Hole U1301C reached approximately the same depth (cored to $265.3 \mathrm{mbsf}$; recovered to $262.9 \mathrm{mbsf}$ ). As described later in this section, there is good reason to believe that coring penetrated essentially the complete sedimentary section in Hole U1301C.

Hole U1301D is located $20 \mathrm{~m}$ east of Hole U1301C (Fig. F1). Hole U1301D was cored only within the interval between 120 and 177 mbsf during the last 20 $\mathrm{h}$ of Expedition 301 operations. Because this coring was done at the end of the expedition and we had a short transit to port, sediments recovered from Hole U1301D were described rapidly and were subjected to minimal analysis on the ship.

Silt- and clay-rich cores from Site U1301 are of exceptionally high quality, even from depths below 250 mbsf, because we used the APC rather than the $\mathrm{XCB}$ or RCB. In contrast, cores recovered from sandy and gravely intervals are generally of poorer quality and often include intervals within which there was complete resuspension and settling of particles. Because of discontinuous coring, irregular recovery, and extensive whole-round sampling, we were unable to determine well-constrained lithologic boundaries for the primary stratigraphic units at Site U1301.

Based on the cores available for description, we defined two stratigraphic units from Hole U1301C: Unit I is a turbidite sequence, and Unit II is a hemipelagic clay sequence (Fig. F12). The true boundary between Units I and II occurs within the noncored interval between 197.1 and 235.8 mbsf; its approximate location may be inferred from its equivalent depth in nearby Hole U1026C (216.1 mbsf). 


\section{Stratigraphic units}

\section{Unit I}

Intervals: Sections 301-U1301C-1H-1, $0 \mathrm{~cm}$, through $2 \mathrm{H}-6,50 \mathrm{~cm}$, and 301-U1301-2H-6, $50 \mathrm{~cm}$, through 16H-CC, $5 \mathrm{~cm}$

Depth: 0-235.8 mbsf

Lithology: turbidite sequence

Unit I is composed of distal turbidite sequences and is $\sim 220 \mathrm{~m}$ thick. It is divided into two Subunits (IA and IB) on the basis of changes in dominant lithology (Fig. F12; Table T4). Upward-fining sequences were observed throughout the recovered intervals of Unit I. We do not distinguish turbidites and debris flows as previously described for Hole 1026C (Shipboard Scientific Party, 1997) because (1) the division between dense turbidite and debris flows is arbitrary and (2) coarser-grained sections of the sequence were often disturbed during coring, preventing accurate assessment of grain size distributions.

Five lithologies were identified in Unit I: (1) dark greenish gray hemipelagic clay (Fig. F13), (2) finely laminated silt and clay with normal size grading (Fig. F14A), (3) fine- to medium-grained sands with normal size grading (Fig. F14B), (4) massive, thick, medium-grained sand beds (Fig. F15A), and (5) granule beds (Fig. F15B, F15C). Based on the presence of graded bedding and parallel laminations within the silt and sand beds, they are identified as turbidites, in which layers Ta and $\mathrm{Tb}$ of the Bouma sequence are identified. Unfortunately, it was not possible to recognize finer structures (e.g., cross-lamination and flute casts), perhaps in part because of coring disturbance. Smear slide observations indicate that the sand layers in Unit I are composed of quartz, plagioclase, green amphibole, pyroxene, magnetite, pyrite, and other opaque mineral grains (Figs. F16, F17).

The subunits defined at Site U1301 differ somewhat from those defined at Site 1026 during Leg 168. This results mainly from differences in coring techniques and recovery during the two expeditions. Coring was continuous during Leg 168, but the RCB was used below $100 \mathrm{mbsf}$, resulting in underrepresentation of poorly consolidated, coarse-grained intervals. Discontinuous APC coring during Expedition 301 bypassed some depth intervals and recovered coarsegrained sediments from other intervals, but may also have resulted in an overrepresentation of sand and gravel due to "flow in."

\section{Subunit IA (0-13.1 mbsf)}

Subunit IA predominantly consists of thinly bedded hemipelagic clay layers interbedded with silty and fine-grained sandy turbidites (Fig. F13). The greenish gray sediment in the upper portion of Subunit I contains well-preserved diatoms and silicoflagellates (Fig. F16). No bioturbation was observed within the turbidites or hemipelagic clay.

\section{Subunit IB (13.1-235.8 mbsf)}

Subunit $1 \mathrm{~B}$ is a coarse- to fine-grained sequence of thinly bedded to massive bedded turbidites and clay layers (Fig. F12). The top boundary for this subunit is located where clay is no longer the dominant lithology, and the bottom of this subunit is located at the first appearance of the hemipelagic clay of Unit II. There are several 5-6 m thick intervals within this subunit where clay is the dominant lithology, but silt, sandy silt, silty sand, and sand are generally more abundant. This subunit also contains several gravel layers.

The shallowest part of Subunit IB (13.1-56.7 mbsf) was recovered in Hole U1301C and contains thinly bedded clay, silty clay, sandy clay, silt, clayey silt, sandy silt, clayey sand, silty sand, and sandy interbeds, generally arranged in fining-upward sequences. There are a few intervals within which clay or sand are the dominant lithology, with individual layer thicknesses of tens of centimeters to $\sim 1 \mathrm{~m}$, but thinner layers having a mixture of grain sizes are more common. Many of the thin silt and clay laminations within this part of the section contain poorly preserved microfossils and rare wood fragments (Fig. F13).

The central part of Subunit IB (56.7-109.6 mbsf) was recovered from Hole U1301C and is composed of more massive sand layers with thin silty and clayey interlayers. There is a small interval composed mainly of clay (74.6-79.9 mbsf), but this interval includes sandy interbeds. The rest of this part of Subunit IB is composed mainly of $1-20 \mathrm{~m}$ thick graded sand-silt beds (Fig. F14). Thick sand intervals $(>10$ $\mathrm{m})$ were recovered at 56.7-74.6 mbsf and 81.1-109.6 mbsf. The true thicknesses of many these sand beds is likely to be considerably less than what is represented in the recovered core because of "flow-in" during coring. Intervals containing soupy, unconsolidated sand having no internal structures are particularly suspect.

The depth interval 109.6-130.1 mbsf was poorly represented by cores recovered from Hole U1301C. Cores $301-\mathrm{U} 1301 \mathrm{C}-13 \mathrm{H}$ and $14 \mathrm{H}$ failed to penetrate significantly into hard layers, and the rest of the interval in this hole was drilled without coring. Core 301-U1301C-14H recovered material only in the core catcher, comprising well-sorted, subrounded granules, and the core catcher from Core $13 \mathrm{H}$ contained similar material. The granules include serpentinite, green amphibolite, quartzite, felsic volcanic, calcare- 
ous sandstone, and shallow-water shell fragments (Fig. F15). We initially considered defining a new subunit on the basis of this lithology, but subsequent coring in Hole U1301D demonstrated that the very coarse intervals recovered in Cores 301-U1301C-13H and $14 \mathrm{H}$ represented only a small fraction of the sedimentary section.

The depth interval 120.0-177.0 mbsf was cored in Hole U1301D, and we recovered primarily sandy and silty turbidites, clay, and occasional gravel layers. Thin fine-sand layers are commonly spaced at 20-50 $\mathrm{cm}$ intervals within clay beds. These sand, silt, and clay layers are compositionally similar to those found higher in the section.

The depth interval 178.1-197.1 mbsf was cored in Hole U1301C, once again recovering mainly thin bedded turbidites having a range of grain sizes. Section 301-U1301C-15H-5 has a $20 \mathrm{~cm}$, light yellowish gray clay bed that contains microfossils (foraminifers and diatoms). It is the palest lithology recovered from Hole U1301C. This clay bed was deposited during a time at which there was little continentderived sedimentation. The depth interval 197.1235.8 mbsf was not cored.

\section{Unit II}

Interval: Section 301-U1301-17H-1, $0 \mathrm{~cm}$, through $19 \mathrm{H}-\mathrm{CC}, 3 \mathrm{~cm}$

Depth: 235.8-265.3 mbsf

Lithology: hemipelagic clay sequence

The lowermost 30-40 m of the sedimentary section overlying basaltic basement consists of homogeneous hemipelagic dark greenish gray clay (Fig. F18). Very thin $(<2 \mathrm{~cm})$ fine sand layers are present in the upper portion of Unit II and are of similar composition to the thin sand layers in Unit I. Chlorite and iron oxide form a small proportion of the clay, and fine-grained organic matter was also identified (Fig. F17). There are rare carbonate nodules or pipes and siliceous concretions within this unit, which is slightly bioturbated. No basement rocks were recovered from below Unit II.

\section{Completeness of sediment section recovered from Hole U1301C}

Although we do not know the exact depth of basement below Hole U1301C, there are three good indications that we sampled the deepest part of the sedimentary sequence. First, seismic data show sediment cover in the vicinity of Hole U1031B of $290 \mathrm{~ms}$, whereas the uppermost basement reflector in Hole $\mathrm{U} 1301 \mathrm{C}$ is found at $280 \mathrm{~ms}$ below the seafloor (Fig. F3). Sediment thickness was $265.2 \mathrm{~m}$ in Hole U1301B, and Hole U1301C penetrated to $265.3 \mathrm{mbsf}$ (core recovery extending to $262.9 \mathrm{mbsf}$ ), consistent with the sediment thicknesses indicated by seismic data.

Second, we recovered a hemipelagic unit at the base of Hole U1301C (Unit II) that was at least $27 \mathrm{~m}$ thick; only $12 \mathrm{~m}$ of the equivalent unit was recovered in nearby Hole 1026C. The basal hemipelagic clay unit was $40 \mathrm{~m}$ thick at Site 1027, located above a buried basement trough $2.2 \mathrm{~km}$ to the east, and experience from Leg 168 shows that this unit is typically considerably thinner over basement highs. It is unlikely that Unit II is significantly thicker than the $27 \mathrm{~m}$ that was recovered.

Finally, geochemical data from pore fluids squeezed from the sediments of Unit II show that these fluids are (essentially) geochemically identical to those at the base of Hole 1026C and to Baby Bare outcrop vent and seep fluids, particularly with regard to major elements (see "Biogeochemistry"). Pore fluids recovered from the base of Hole U1301C are in geochemical equilibrium with the underlying basement; we see no evidence for significant gradients in major element fluid composition that would suggest a substantial missing sediment section. There were differences in the fluid chemistry of Hole 1026C and U1301C samples for some trace elements and metals, but this discrepancy results mainly from differences in coring and sample handing techniques (see "Biogeochemistry").

Collectively, these observations and inferences suggest that there is no more than 1-2 $\mathrm{m}$ of additional sediment below the base of the cored interval of Hole U1301C, and, in fact, we may have recovered the deepest sediment in this location.

\section{Deformation}

Five of the cores (301-U1301C-15H through 19H) have distorted and brecciated zones at the top of Section 1 . These zones contain mud/clay clasts within a disrupted muddy matrix, along with granules and pebbles similar to those observed in cores from Subunit IC (Fig. F19). Some clay clasts have well-developed slickenlines. These are not considered to be primary deformation structures and instead relate to a change in the APC coring method toward the bottom of the hole. To increase the distance of APC penetration into the deep, compacted sediments, the piston core was pulled back slightly from its previous maximum penetration depth and given a "running start" into the sediment (see "Operations"). The brecciation of the upper $80 \mathrm{~cm}$ of the lowermost cores may be a result of the APC impact, with granules probably falling in from above. No primary deformation structures are described in Hole U1301C. 


\section{Igneous and metamorphic petrology}

Basement was cored from 351.2 to 582.8 mbsf (86.0 to $317.6 \mathrm{~m}$ into basement in Hole U1301B). The 69.1 $\mathrm{m}$ of recovered core consisted of (1) basalt-hyaloclastite breccia, (2) aphyric to highly phyric pillow basalts, and (3) massive basalts. Eight units were defined on the basis of changes in lava morphology, rock texture, and phenocryst grain size, as summarized in Figure F20 and Table T3 in the "Methods" chapter. Pillow lava units (Units 1, 3, 5, 7, and 8) were subdivided based on changes in phenocryst mineralogy and abundances. Massive lava units (Units 2, 4, and 6) were subdivided into individual cooling units based on the presence of chilled margins.

\section{Lithologic units}

\section{Pillow basalts and basalt-hyaloclastite breccias}

\section{(Units 1, 3, 5, 7, and 8)}

Pillow basalt was the most abundant rock type recovered from Hole U1301B. Pillow lavas were identified by the presence of curved glassy chilled margins, oblique to the vertical axis of the core, with perpendicular radial cooling cracks (Fig. F21). An almost complete section through a single pillow was recovered in interval 301-U1301B-4R-3 (Piece 1, 0-45 cm) (Fig. F22), indicating that the pillows are at least $0.5 \mathrm{~m}$ in diameter. The pillow fragments have dominantly hypocrystalline textures with a cryptocrystalline to microcrystalline groundmass. They are aphyric or sparsely to highly plagioclase \pm clinopyroxene \pm olivine phyric. Observed basalt textures vary from hyalophitic (typically with sheaf-spherultic or plumose textures) to glomeroporphyritic, seriate, and intersertal. A small number of samples contain groundmass plagioclase crystals that display a weak pilotaxitic texture. The pillows are sparsely vesicular, containing $1 \%-5 \%$ round gas vesicles, and are slightly to moderately altered. Alteration includes interstitial groundmass replacement, vesicle fill, vein formation (with associated alteration halos), and complete replacement of olivine phenocrysts.

The subdivision of pillow Unit 7 (Fig. F20) was based on changes in grain size and phenocryst abundance. For example, Subunit 7A is sparsely to moderately plagioclase and olivine phyric, Subunit 7B is moderately to highly phyric and also contains clinopyroxene, and Subunit 7C is aphyric to moderately plagioclase, clinopyroxene, and olivine phyric.

Intervals 301-U1301B-1R-1 (Pieces 1-7, 0-57 cm) and 35R-1 (Piece 10, $81 \mathrm{~cm}$ ) to 35R-2 (Piece 7, $52 \mathrm{~cm}$ ) consist of basalt-hyaloclastite breccia and are defined as Subunits 1A and 8A, respectively (Fig. F23). These thin breccias ( $<1 \mathrm{~m}$ of recovered core) are composed of clasts that are similar to the underlying basalt, some with glassy margins. Given the low recovery, it is not possible to determine the relationship between the hyaloclastite portions and underlying lavas or, specifically, whether they are part of the same cooling unit. Subunits $1 \mathrm{~B}$ and $8 \mathrm{~B}$ are also thin, each representing $<1 \mathrm{~m}$ of recovered core, and lack the definitive curved glassy margins characteristic of pillow lavas. These subunits could be interpreted as either pillow flows or sheet flows (possibly with brecciated tops; Subunits $1 \mathrm{~A}$ and $8 \mathrm{~A}$, respectively), and are therefore simply described as basalt lavas. Because the relationships between the basalt-hyaloclastite breccia and the underlying basalt lavas are not established, they have not been divided into separate units. Given the possibility that Subunits $1 \mathrm{~B}$ and $8 \mathrm{~B}$ are pillow lavas, the underlying pillow basalts are also included in Units 1 and 8 as Subunits 1C and $8 \mathrm{C}$, respectively.

\section{Massive basalts (Units 2, 4, and 6)}

Massive basalt Units 2, 4, and 6 were recovered from Cores 301-U1301B-11R through 14R, 15R, and 18R, respectively (Fig. F20). They were classified as massive basalts because they consist of continuous sections of $\sim 0.5-4.4 \mathrm{~m}$ of similar lithology, which increases in grain size toward the center of the flow (Fig. F24). Some massive flows have upper and/or lower planar glassy chilled margins. High recovery, up to $100 \%$ in Core 301-U1301B-12R, allows individual lava flows or cooling units to be distinguished (Subunits 2A, 2B, 4A, 4B, and 4C).

Mineralogically, the massive lavas are very similar to the sparsely to moderately phyric pillow basalts containing plagioclase, olivine, and clinopyroxene as phenocryst as well as groundmass phases. However, they are predominantly fine grained and hypocrystalline to holocrystalline, with seriate intersertal to intergranular subophitic textures. The massive basalts are sparsely to highly vesicular, with an average of $1 \%-5 \%$ round gas vesicles, up to $3 \mathrm{~mm}$ in diameter. The vesicles are generally concentrated in the upper portions of the flows, but Unit 6 has a distinct 20 $\mathrm{cm}$ wide vesicular band in its center in interval 301U1301B-18R-2 (Piece 2, 75-95 cm), which is $\sim 15 \%$ vesicles (Fig. F24). The massive flows are slightly to moderately altered and exhibit similar alteration styles to the pillow basalts: vesicle fill, vein formation (and the development of associated alteration halos), and the complete replacement of olivine phenocrysts. However, the massive basalts contain fewer fractures and veins than the pillow basalts, allowing better core recovery and the retrieval of individual pieces up to $94 \mathrm{~cm}$ long (e.g., interval 301-U1301B18R-3 [Piece 2, 31-125 cm]). 


\section{Igneous petrology}

The basaltic rocks recovered from Hole U1301B are divided into three types as described above (basalthyaloclastite breccia, pillow lavas, and massive basalts), and 55 samples were selected for petrographic analysis. Table $\mathbf{T} 5$ summarizes the abundances and morphologies of the phenocryst and groundmass minerals present within representative samples.

\section{Aphyric and sparsely to highly phyric pillow basalts}

The pillow lavas from Hole U1301B vary from aphyric to highly phyric basalts. Subunits $1 \mathrm{C}, 7 \mathrm{~A}$, and $7 \mathrm{C}$ consist of sparsely to moderately phyric glassy to microcrystalline basalts, with between $\sim 1 \%$ and $12 \%$ phenocrysts, whereas Units 3 and 5 and Subunits 7B and $8 \mathrm{C}$ are moderately to highly phyric glassy to microcrystalline basalts with $\sim 5 \%-20 \%$ phenocrysts. Plagioclase is the most abundant phenocryst phase $(2 \%-15 \%)$, with clinopyroxene $(1 \%-5 \%)$ and olivine pseudomorphs $(<5 \%)$ also present in most of the phyric samples.

These lavas typically have hyalophitic to intersertal and intergranular textures (Fig. F25). Hyalophitic zones display sheaf-spherulitic textures, with occasional occurrences of plumose and honeycomb groundmass. Additionally, some thin sections also contain regions with glassy to variolitic and glomeroporphyritic textures, with several different textures often observed across a single thin section. A weak to strong plagioclase pilotaxitic texture was identified within the groundmass of some hypocrystalline-intersertal samples (e.g., Sample 301-U1301B-16R-1 [Piece 2, 8-10 cm]) (Fig. F25).

\section{Massive basalt}

The massive basalts of Units 2, 4, and 6 are sparsely to moderately plagioclase \pm clinopyroxene \pm olivine phyric $(<15 \%$ phenocrysts). The groundmass grain size varies significantly from the glassy to cryptocrystalline flow margins to the fine-grained flow interiors. Texturally, the central portions of the massive flows are predominantly intersertal to intergranular or seriate, whereas the margins are dominantly hyalophitic (Fig. F25). Some samples display glomeroporphyritic to subophitic textures.

\section{Basalt-hyaloclastite}

Basalt-hyaloclastite breccia was recovered within intervals 301-U1301B-1R-1 (Pieces 1-7, 0-57 cm) and 35R-1 (Piece 10, $81 \mathrm{~cm}$ ), which comprise Subunits 1A and $8 \mathrm{~A}$, respectively, to 35R-2 (Piece 7, $52 \mathrm{~cm}$ ) (Fig. F23). These breccias consist of glassy shards and angular to subangular clasts of aphyric and plagioclase phyric basalt set within a clay matrix. The breccia is variably clast and matrix supported. The matrix is predominantly dark gray to black clay (saponite) and phillipsite, with altered glass shards and calcium carbonate. Basalt clasts are typically $0.5-6 \mathrm{~cm}$, and glassy shards are generally $<1 \mathrm{~cm}$ in length. The basaltic clasts appear similar in hand specimen to other sparsely phyric basalts from Hole U1301B and are bordered by $2-6 \mathrm{~mm}$ black alteration halos. Several of the basalt clasts in the Subunit 1A breccia have curved chilled margins that are glassy to cryptocrystalline and aphyric with trace plagioclase microlites, similar to those of pillow margins. The basalt fragments in the Subunit 8A breccia are more angular, sparsely plagioclase phyric, and lack glassy margins. Vesicles within the clasts are filled by pale brown and granular saponite \pm iron oxyhydroxides, similar to those observed in other basalt samples from Hole U1301B.

\section{Phenocryst phases Plagioclase}

Plagioclase phenocrysts are $<4.5 \mathrm{~mm}$ (average $=1-2$ $\mathrm{mm}$ ) and typically comprise $<15 \%$ of pillow basalts and $<10 \%$ of massive lavas. They are euhedral to subhedral elongate and stubby laths, with rare skeletal or quench plagioclase crystals. The plagioclase phenocrysts occur singly and in mono- and polymineralic glomeroporphyritic clots (plagioclase \pm pyroxene \pm olivine) (Fig. F26). Simple to oscillatory zoning is common, and there is a sparse to dense abundance of glass inclusions in the cores of some plagioclase phenocrysts. Plagioclase is generally fresh and occasionally stained by secondary clays or replaced by saponite along cracks, cleavage planes, or crystal edges.

\section{Olivine}

Olivine is a common phenocryst phase observed in most thin sections as a pseudomorph, with an average abundance of $2 \%-3 \%$. Olivine phenocrysts $(<5.5$ $\mathrm{mm}$; commonly $0.7-1 \mathrm{~mm}$ ) have been completely replaced by a variety of secondary hydrothermal alteration phases and are identified by their euhedral to subhedral crystal morphology and their textural relationships to surrounding minerals. The olivine is pseudomorphed by granular to fibrous saponite \pm celadonite \pm iddingsite \pm calcium carbonate \pm opaque minerals.

\section{Pyroxene}

Pyroxene (<5.5 mm; commonly $0.5-1.0 \mathrm{~mm})$ is present in almost all thin sections, with an average abundance of $\sim 3 \%$. It is typically subhedral to euhedral forming stubby to short prismatic or round crystals and often displays simple basal twinning. The 
majority of crystals have a subhedral morphology and occur as solitary phenocrysts, intergrown with plagioclase, or within polymineralic glomeroporphyritic clots with plagioclase and olivine (Fig. F26). In some of the holocrystalline fine-grained basalts, the pyroxene partially encloses euhedral feldspar laths in a subophitic manner.

\section{Groundmass}

The groundmass of basalts from Hole U1301B is hypocrystalline to holocrystalline. The groundmass minerals are the same as those present as phenocrysts, but modal abundances vary between samples. Plagioclase occurs as microlaths, microlites, and quench crystals and is the most abundant groundmass crystalline phase, comprising $2 \%-35 \%$ of pillow lavas and $40 \%-60 \%$ of the holocrystalline central portions of the massive lava flows. Euhedral to skeletal microcrysts of olivine (average original abundance $=2 \%$ ), subhedral to anhedral clinopyroxene (less than $\sim 30 \%$ in pillow lavas and $7 \%-35 \%$ in massive flows), and trace amounts of opaque minerals are also present. Plagioclase microcrysts in some thin sections exhibit a subparallel to pilotaxitic texture. Fresh olivine was only identified as microlites within the fresh glass of some chilled margins (Fig. F27).

The remainder of the groundmass (up to 95\% in pillow lavas and $<55 \%$ in central portions of massive lavas) consists of a cryptocrystalline mesostasis that displays hyalophitic (sheaf-spherulitic to honeycomb) to intersertal textures (Fig. F25). Mesostasis textures are variable within a single sample, but basalts from different units of the same lithology exhibit the same range of textures. Primary magmatic opaque minerals are disseminated throughout the mesostasis, forming small $(<0.02 \mathrm{~mm})$, granular, euhedral to subhedral solitary grains. The mesostasis exhibits patchy alteration and is variably replaced by secondary hydrothermal clays (saponite and celadonite), disseminated pyrite, and iron oxyhydroxide.

Almost all basalt samples are sparsely vesicular, with $1 \%-3 \%$ vesicles in most samples. The majority of vesicles are round and are $0.05-3 \mathrm{~mm}$ in diameter. The upper portions of massive flows are typically particularly vesicular, with up to $7 \%$ vesicles that are $<5 \mathrm{~mm}$ in diameter. However, the central portion of the Unit 6 massive flow contains a $20 \mathrm{~cm}$ wide highly $(\sim 15 \%)$ vesicular band in the interval 301U1301B-18R-2 (Piece 2, 75-95 cm) (Fig. F24). The majority of vesicles have been partially to completely filled by mono- to polymineralic secondary assemblages, which include saponite, celadonite, iron oxyhydroxides, hematite, pyrite, and carbonate. Many of the vesicles display sequential concentric fills that are described in more detail in "Basement alteration." In some samples, vesicles are partially to completely filled with mesostasis, with some vesicles having a geopetal fill (for example, Sample 301U1301B-15R-1 [Piece 14, 118-129 cm]).

\section{Hard rock geochemistry}

Forty-four representative basalt samples from Hole U1301B were analyzed for major and trace elements on the JY2000 inductively coupled plasma-atomic emission spectrometer (ICP-AES). Effort was taken to collect the freshest material from the cores of rock pieces in order to obtain a downhole record of primary magmatic compositions. Rocks with thin fresh glassy margins and altered samples will be analyzed postcruise. Loss on ignition (LOI) values are variable, with some samples losing $<1 \mathrm{wt} \%$ (with the exception of a hyaloclastite sample [Unit 8B] that loses 2.6 $\mathrm{wt} \%$ ) but the majority gaining $0-1.7 \mathrm{wt} \%$. We report the data without an LOI correction factor (Table T6).

During the seven shipboard ICP-AES runs, withinrun reproducibility was assessed based on multiple analyses of BAS-148 and BAS-206, basaltic standards from ODP Legs 148 and 206, respectively (Table T12 in the "Methods" chapter). Precision on the JY2000 was typically $<4 \%$ for major elements and $<10 \%$ for trace elements, although for elements with nearbackground concentrations, the analytical error is artificially high and the actual analytical error is much better than suggested by the numbers. However, Ni and $\mathrm{Ba}$ were reproducible only to $<30 \%-40 \%$ and are reported in the data table but should be used only with caution.

\section{Results}

Hole U1301B penetrated $230 \mathrm{~m}$ of basement, which primarily consisted of slightly to highly olivine-clinopyroxene-plagioclase phyric pillow basalts, with three massive flow units. The chemical compositions of the basalts are shown in Table T6. All of them are normal depleted MORB, with $\mathrm{MgO}=6.48-8.10 \mathrm{wt} \%$, $\mathrm{Fe}_{2} \mathrm{O}_{3}=8.73-12.89$ wt $\%, \mathrm{Mg} \#=52.4 \%-65.8 \%, \mathrm{Cr}=$ 47-272 ppm, and $\mathrm{Zr}=91-178 \mathrm{ppm}$. Figure F28 is a plot of $\mathrm{TiO}_{2}(\mathrm{wt} \%)$ versus $\mathrm{Zr}$ (ppm) for all the analyzed samples; the good correlation indicates that all the Hole U1301B basalts have the same source. Figure F29 shows all the measured major and trace elements plotted against the $\mathrm{Mg \#}(\mathrm{Mg} / \mathrm{Mg}+\mathrm{Fe}) \cdot \mathrm{CaO}$ and $\mathrm{Al}_{2} \mathrm{O}_{3}$ show a weak correlation with Mg\#; however, when viewed as a total batch, the majority of elements show no significant variation with $\mathrm{Mg \#}$.

Figure F30 shows the variation in $\mathrm{Mg \#}$ and major and trace elements with depth. The most significant

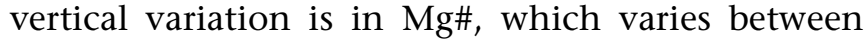


units (Fig. F30). Massive flows have the lowest Mg\#, $54.8 \%$ and $52.4 \%$ in Units 2 and 4, respectively. The $\mathrm{Mg \#}$ is highest (65.8\%) toward the base of Unit 7 and decreases to $59.9 \%$ upward through this $\sim 80 \mathrm{~m}$ thick pillow lava unit. Values within the upper thick pillow lava unit (Unit 1) are much more uniform (average $=62.5 \%$, with no obvious decrease up through the unit. The incompatible trace elements ( $\mathrm{Sr}, \mathrm{Y}, \mathrm{Zr}$, and $\mathrm{Nb}$ ) all show similar variations with depth, increasing slightly down through Unit 1 , and are most abundant in massive lava flows. Subunit $7 \mathrm{~B}$ has lower concentrations of incompatible trace elements than Subunits 7A and 7C; this may reflect the high phenocryst content of these pillow lavas. Other elements do not show systematic behavior downhole.

\section{Basement alteration}

All of the basement rocks recovered from Hole U1301B have undergone alteration. Most pieces are slightly to moderately altered, with secondary minerals (1) lining or filling vesicles and cavities, (2) filling fractures and veins and present in adjacent alteration halos, (3) replacing phenocrysts, and (4) replacing interstitial mesostasis and glass (Fig. F31). The alteration and vein logs (see "Site U1301 alteration log" and "Site U1301 vein log" in "Core Descriptions") quantify these different alteration types in hand specimen, on a piece-by-piece scale. Thin section observations indicate that the degree of alteration varies from $\sim 5 \%$ to $25 \%$, excluding the hyaloclastite breccia, which is $\sim 60 \%$ altered (Table T5). The freshest rocks are the interior cores of most pieces, which have a dark gray, saponitic background alteration. Fresh olivine occurs only as microphenocrysts in some glass margins, and elsewhere is completely replaced by clay minerals.

\section{Secondary minerals}

Secondary minerals were identified primarily on the basis of hand specimen descriptions, and specific secondary minerals are not generally distinguished in the vein and alteration logs. Observations were calibrated by thin section observations by X-ray diffraction (XRD) for six samples (five veins and a matrix of the hyaloclastite breccia) (Table T7).

Clay minerals are the most abundant secondary minerals and are the principal constituent of all four styles of alteration (vesicle fill, vein fill, phenocryst replacement, and background mesostasis alteration). The clay minerals were distinguished primarily on the basis of color in hand specimen and by their optical properties in thin section. Saponite is the most abundant of the clay minerals, identified in every thin section. It occurs as cryptocrystalline granular or fibrous aggregates and varies in color from black to dark greenish brown to pale blue in hand specimen and tan-brown to olive-green in thin section. Saponite lines or fills vesicles, is the most common olivine phenocryst replacement, occurs in mono- and polymineralic veins, replaces mesostasis and glassy margins, and forms the matrix of the hyaloclastite breccia. Celadonite, bright blue-green in hand specimen and bright green in thin section, also fills vesicles and veins and replaces olivine phenocrysts and mesostasis. However, celadonite is typically restricted to the alteration halos, frequently occurring as intergrowths with saponite and/or iron oxyhydroxide.

Iddingsite, a mixture of clay minerals and iron oxyhydroxide, is the second most abundant alteration product identified in Hole U1301B cores, producing a characteristic red-orange or reddish brown color in both hand specimen and thin section. It fills veins and vesicles, stains primary minerals, and is intergrown with the clays that replace olivine.

Calcium carbonate was observed in only six cores, filling vesicles and veins, and as a minor component of the basalt-hyaloclastite breccia matrix. Secondary pyrite was observed lining vesicles, as fine grains within saponite vesicle linings, with saponite \pm calcium carbonate in veins, and as disseminated fronts bounding some alteration halos. Zeolites (analcime and phillipsite) were tentatively identified by XRD in Samples 301-U1301B-1R-1 (Piece 15, 121-124 cm) and 18R-4 (Piece 7, 132-136 cm) in veins as well as the matrix of the hyaloclastite breccia.

\section{Basalt-hyaloclastite breccia}

The basalt-hyaloclastite breccias recovered in Cores 301-U1301B-1R and 35R are moderately to highly altered. The glass shards and basalt clasts are partially to completely replaced by green saponite and minor calcium carbonate and zeolite. Basalt clasts generally have altered glass margins or alteration halo rims and are freshest in the center (Fig. F23). XRD of the breccia matrix from Sample 301-U1301B-35R-1 (Piece 15, 112-118 cm) indicates the zeolite identified in the saponitic matrix is phillipsite.

\section{Vesicle filling}

Basalts from Hole U1301B are sparsely to moderately vesicular, containing $0.05-3.0 \mathrm{~mm}$ (commonly $0.1-$ $0.5 \mathrm{~mm}$ ) round vesicles. Almost all vesicles are partially or completely filled by one or more secondary minerals (saponite, celadonite, iron oxyhydroxide, hematite, pyrite, carbonate, and, possibly, zeolites). The type and sequence of filling is interpreted as a sensitive record of successive changes in the chemical microenvironments affecting the host rock. Vesicle fillings vary systematically, depending on whether 
the vesicles are in the alteration halos, transitional zones, or the less altered, gray interiors. Microscopic examples are shown in Figure F32. In the slightly altered gray rock interiors vesicles are either empty or lined/filled with fibrous to granular saponite. The vesicles within alteration halos (black, green, and brown) are filled with mono- or polymineralic assemblages that include saponite, celadonite, iron oxyhydroxide, hematite, pyrite, and carbonate. The particular vesicle filling assemblage reflects the secondary mineralogy of the halo, discussed below.

In many cases, these minerals form concentric fills, with the mineral-sequence varying in and between samples. In some cases, early fibrous saponite is followed by iron oxyhydroxide, hematite, or celadonite, although other samples contain saponite-filled vesicles that are lined with celadonite, indicating variable alteration sequences. The vesicles within the massive basalts are typically lined with fibrous saponite or fibrous saponite with microgranular pyrite. Rare, small vesicles ( $<0.5 \mathrm{~mm}$ diameter) adjacent to pyrite-bearing veins are filled with pyrite. Some of the vesicles within massive flows contain calcium carbonate; these vesicles are lined with carbonate \pm pyrite, with an inner fibrous carbonate layer or radial/coarse crystalline carbonate fill (e.g., Sample 301-U1301B-18R-2 [Piece 2, 75-95 cm]). The carbonate is always the innermost vesicle-filling mineral, indicating that it is a later stage alteration product.

\section{Veins}

A total of 2301 veins were identified in the core recovered from Hole U1301B, with an average frequency of 31 veins/m of recovered core (Table T8). Saponite is the most abundant vein-filling mineral, present in $98 \%$ of the veins. Iron oxyhydroxide was documented in 1010 of the veins, equivalent to $44 \%$ of the total in the core, typically occurring with saponite. Celadonite was identified in only 93 of the veins, equivalent to $4 \%$ of the total in the core, typically occurring with iron oxyhydroxide \pm saponite. Pyrite was observed in 59 veins $(2.6 \%$ of the total in the core) and is typically associated with saponite. Calcium carbonate was observed in only 38 veins (1.6\% of the total in the core), with saponite \pm pyrite. Two zeolite-bearing veins were identified by XRD (Table T7). Examples of the different vein types, in thin section, are given in Figure F33. The majority of veins described in samples from Hole U1301B are flanked by alteration halos.

Clay-bearing veins are ubiquitous in the rocks recovered from Hole U1301B and vary in width from 10 $\mu \mathrm{m}$ to $6 \mathrm{~mm}$ (average $=0.2 \mathrm{~mm}$ ). The maximum width of the simple dark green saponite veins is 2 $\mathrm{mm}$. These predominantly narrow veins are prolific in pillow fragments, with saponite filling many of the radial cooling cracks along pillow margins. Iron oxyhydroxide- and celadonite-bearing clay veins vary in width from $10 \mu \mathrm{m}$ to $6 \mathrm{~mm}$, and average 0.2 $\mathrm{mm}$. They are most common in the pillow lavas (Units 1, 3, 5, 7, and 8). However, the most spectacular iron oxyhydroxide-bearing vein occurs in a massive lava flow, spanning the interval 301-U1301B15R-1 (Pieces 10 and 11, 70-97 cm). This vein is 6 $\mathrm{mm}$ wide with a $10-25 \mathrm{~mm}$ wide alteration halo (Fig. F34). Goethite and minor celadonite were identified within this vein by XRD (Samples 301-U1301B-15R1 [Piece 11, 121-124 cm] and 15R-1 [Piece 11, 87-89 $\mathrm{cm}]$ ).

Calcium carbonate-bearing veins were documented only in Cores 301-U1301B-1R, 4R, 5R, 11R, 12R, 18R, and $35 \mathrm{R}$, and they are restricted to the massive flows (Table T8). Carbonate veins vary in width from 0.1 to $2 \mathrm{~mm}$ and average $0.3 \mathrm{~mm}$. The veins are typically lined with a thin layer of saponite \pm pyrite, with blocky to fibrous carbonate spanning the gap (Fig. F33). The carbonate-bearing veins are generally not flanked by alteration halos.

\section{Alteration halos}

The rocks throughout Hole U1301B exhibit a pervasive dark gray background alteration with saponite replacing mesostasis and olivine phenocrysts and lining vesicles, but many pieces also contain differently colored alteration halos. The halos border rock fragments and flank $56 \%$ of the veins. The relative proportions of background alteration and halos are described in Table T6 in the "Methods" chapter. In hand specimen, alteration halos are generally associated with saponite, iron oxyhydroxide, and celadonite-bearing veins.

The alteration halos termed "black" range in color from very dark gray to dark green to black and flank $54 \%$ of the veins in Hole U1301B (e.g., Fig. F31). The black halos range in width from 1 to $30 \mathrm{~mm}$, but the majority are $3-12 \mathrm{~mm}$ wide. The percentage of secondary minerals is similar or slightly greater than in the adjacent dark gray host rock (5\%-15\% secondary minerals), but the mineralogy is distinct, with celadonite typically present in addition to saponite. These minerals have a similar distribution to the saponite in the background alteration, replacing mesostasis and olivine phenocrysts and lining vesicles (Fig. F35). Approximately half of the halos described as black in the alteration log contain vesicles filled with a mixture of iron oxyhydroxide and saponite or celadonite (e.g., Fig. F36) that give the halos an orange or greenish tinge, depending on the vesicularity of the rock. Because the iron oxyhydroxide is primarily restricted to the vesicles, these halos are still 
termed black, but a note of which halos contain iron oxyhydroxide-filled vesicles is made in the vein log where they are described as "mixed." A narrow band $(\sim 0.1 \mathrm{~mm})$ of disseminated secondary pyrite separates the black halo of saponite + iron oxyhydroxide veins from the adjacent dark gray host rock in three cases: intervals 301-U1301B-5R-2 (Piece 11, 80-102 $\mathrm{cm}$ ), 18R-2 (Piece 2, 80-102 cm), and 18R-3 (Piece 2, 79-80 cm) (e.g., Fig. F37).

Rarely, brown and green halos were described. The green halos, 2-35 mm wide, are mineralogically similar to the black alteration halos but have a greater percentage of secondary minerals (up to $25 \%$ saponite + celadonite), which impart a stronger green color to the rock. Brown alteration halos, ranging from 2 to $12 \mathrm{~mm}$ in width, are associated with only $0.2 \%$ of the veins described from Hole U1301B. The orange-red-brown coloration of these halos results from the filling of vesicles and fractures and the staining of primary minerals with iron oxyhydroxides (Fig. F35). Six "multi" halos with impressive color zonation were also observed. These halos consist of two or three different-colored halos, most commonly an inner brown halo and outer black halo, or with a transitional green zone separating the two (Fig. F38). In such cases the outer black and inner brown halos are mineralogically similar to those described above, and the transitional zone contains minor iron oxyhydroxides with celadonite and saponite, although there is a variation in the modal compositions of the different zones between samples.

\section{Spatial variations}

Although all samples recovered from Hole U1301B have undergone some alteration, there is a significant variation in alteration style and intensity between the identified lithologic units. The pillow lavas (Units 1, 3, 5, 7, and 8) contain between 25 and 36 veins/m recovered core (Table $\mathrm{T} 8$ ); because the most fractured material is likely to be lost during coring, this is considered a minimum estimate of the actual vein density. The principal vein-filling minerals in these units are saponite, iron oxyhydroxides, and celadonite. In contrast, the massive lavas (Units 2, 4, and 6) contain between 14 and 18 veins/ $\mathrm{m}$ in recovered core, with up to $95 \%$ and $100 \%$ recovery in Cores 301-U1301B-18R and 12R.

Low-temperature seafloor basalt alteration is often described in terms of two contrasting styles: oxidative and nonoxidative (Laverne et al., 1996; Teagle et al., 1996). Iron oxyhydroxides and celadonite are characteristic of oxidative alteration, and saponite and sulfides are indicative of nonoxidative alteration. This may account for the differences in the alteration styles observed at Site U1301 because the pillow basalts provide a highly fractured permeable aquifer for circulation of oxidative evolved seawater and consequently have an oxidative alteration assemblage, whereas the massive flows are less permeable, allowing limited fluid circulation that results in less oxidative alteration.

\section{Basement structures}

Basalts from Hole U1301B were cut during different episodes by veins and fractures of various origins. They include fractures formed during eruption (such as the radial cooling cracks of pillow lavas), hydrothermal alteration (such as veins), later tectonic fractures (such as shear veins), and those that have been induced during coring.

The dips of 647 veins and fractures were measured in the recovered cores from Hole U1301B. Four types of fractures were distinguished in the cores: (1) veins flanked by alteration halos (termed haloed veins), (2) veins not flanked by alteration halos but filled with secondary minerals (termed nonhaloed veins), (3) shear veins with slickenfibers (microfaults with contemporaneous displacement and secondary mineral growth), and (4) microveins ( $<0.05 \mathrm{~mm}$ wide) that are only identifiable in thin sections.

Haloed veins were the most frequently observed structures in rocks from Hole U1301B. The radial cracks observed perpendicular to some chilled pillow margins also have associated alteration halos that are often truncated by perpendicular (pillow marginparallel) haloed veins. Nonhaloed veins were identified in the massive lavas and some pillow lava pieces and represent $\sim 30 \%$ of the vein structures documented in Table T8.

Shear veins or faults were identified in three of the recovered pieces (e.g., Sample 301-U1301B-23R-2 [Piece 18, 139-149 cm]). These are always steeply dipping structures and have calcite slickenfibers or overlapping fibers. It is not possible to determine the offset across the shear veins, as they occur on the sides of pieces for which the adjoining pieces were not recovered. However, the fibers define a steeply plunging lineation with asymmetrical calcite crystals, indicating contemporaneous dip-slip motion and calcite precipitation. This extensional style of deformation may relate to regional normal faulting.

Microveins ( $<0.05 \mathrm{~mm}$ wide) were identified in several thin sections. They are filled with the same minerals as the macroscopic veins observed in hand specimen: saponite, iron oxyhydroxide, and celadonite. They have pinch and swell, curved, and anastomosing structures.

Figure F39 shows the distribution of measured fracture dips and indicates a general progressive increase 
in occurrence with increasing dip angle. Slight bimodal peaks are identified at $55^{\circ}-65^{\circ}$ and $80^{\circ}-90^{\circ}$, which include $>70 \%$ of the total of counted veins. Fractures and veins are not uniformly distributed through Hole U1301B and occur more frequently (per meter of recovered core) in the pillow lava units relative to the massive lava units (Fig. F40). However, shallow and deep pillow lava units (e.g., Units 1 and 7) show similar distributions of vein and fracture dips. Histograms of vein/fracture dip for haloed structures are compared to those of nonhaloed veins in the massive and pillow lavas (Fig. F41) and indicate that massive and pillow lavas have similarly dipping fractures. Haloed fractures in massive flows and pillow lavas are predominantly steeply dipping, with frequency increasing with dip angle. The nonhaloed fractures have a more uneven distribution of orientations, with peaks at $15^{\circ}-30^{\circ}, 50^{\circ}-65^{\circ}$, and $80^{\circ}-90^{\circ}$ within massive flows and at $20^{\circ}-35^{\circ}$ and $80^{\circ}-85^{\circ}$ in pillow lavas. The expected sampling bias during coring is toward horizontal structures that are more likely to be intersected by a vertical hole. The observed predominance of steeply dipping haloed veins is therefore interpreted to reflect the actual distribution of fracture orientations in the basement at Site U1301.

Hand specimen observations indicate that the sequence of structure formation in rocks from Hole U1301B is (1) formation of radial cooling cracks perpendicular to pillow margins, (2) formation of vertical cracks with associated hydrothermal alteration halos during seafloor spreading/normal faulting, and (3) development of younger fractures without halos. The observed dominance of vertical, extensional related structures is consistent with the location of Site U1301 on an abyssal, normal-faulted basement high.

\section{Paleomagnetism}

There were several objectives for paleomagnetic measurements at Site U1301. For the sedimentary section, the goal was simply to characterize magnetism within the cores for the initial reports. In the igneous section, one goal was to measure the variation in magnetic directions, which may result from several sources, including geomagnetic secular variation, magnetic reversals, and tectonic processes in the crust. Another goal was to look at variations in magnetic characteristics, which may result from differences in basalt composition or alteration.

\section{Sedimentary section}

There are two limitations on the usefulness of paleomagnetic measurements from the sedimentary section of Site U1301: lithology and age. The section did not promise good paleomagnetic results because the sediments consist of a mix of hemipelagic mud, sand turbidites, silt turbidites, and sandy debris flow deposits with mud clasts (Shipboard Scientific Party, 1997) (see "Lithostratigraphy"). All but the hemipelagic mud are poor candidates for producing good paleomagnetic data. In part, this is because coarsegrained sediments are poor paleomagnetic recorders; also, coarse-grained sediments are difficult to core, frequently resulting in less than complete cores, often with liquefaction and redeposition during coring and recovery. Another problem is that the section was not continuously cored, which breaks the continuity of the record and makes interpretation more difficult. Furthermore, most of the section is $<1 \mathrm{Ma}$ in age, so no significant change in paleomagnetic inclination owing to plate motion should have occurred and only one magnetic reversal, at the base of the Brunhes Chron, is to be expected. Finally, the cores were not oriented using the Tensor tool because of time constraints. The actual measurements lived up (or down, as the case may be) to expectations.

Measurements were made with the pass-through cryogenic magnetometer at $5 \mathrm{~cm}$ intervals on all archive-half core sections that appeared to have intact stratigraphy. Many sand cores appeared to have liquefied and settled inside the core liner; these were not measured. In addition to the natural remanent magnetization (NRM), the cores were also measured after alternating-field (AF) demagnetization at 10, 20, 30, and $40 \mathrm{mT}$ levels.

Initial NRM measurements typically showed steep inclination values, approaching $90^{\circ}$, with consistent declinations near $0^{\circ}$. This situation is typical of cores that are overprinted with a drill string induced isothermal remanent magnetization and sidewall core deformation (Acton et al., 2002). AF demagnetization produced data that appear less affected. With paleomagnetic inclinations plotted versus depth (Fig. F42), it can be seen that most measurements give positive inclinations around $40^{\circ}-80^{\circ}$, with considerable scatter. This result is consistent with the expectation that the entire sedimentary section was deposited during the Brunhes Chron. Scattered negative inclinations and other inclinations near zero are likely spurious data points caused by internal core deformation, rather than actual reversed or transitional field directions. However, near the bottom of the hole, in Core $301-\mathrm{U} 1301 \mathrm{C}-17 \mathrm{H}$, is a zone of consistent negative inclinations that may indicate reversed polarity at the top of the Matuyama Chron. This finding is consistent with ages of sediments determined from prior drilling, which suggest that the Brunhes/Matuyama boundary should occur around 
200 mbsf (Shipboard Scientific Party, 1997). Given the poor stratigraphic control, high paleomagnetic data scatter, and poor continuity, it is impossible to know whether this apparent reversed section is a true record of the paleomagnetic field.

NRM intensities of Hole U1301C sediments are quite high for sediments, with values as high as $1.7 \mathrm{~A} / \mathrm{m}$ (Fig. F43). The lowest reliable NRM intensity is $2.1 \times$ $10^{-2} \mathrm{~A} / \mathrm{m}$, so the intensity range is relatively small, covering only about two orders of magnitude. The strong intensities are likely a result of the sediment sources, which include the Columbia River basalts and Cascade volcanics, and are therefore rich in magnetic minerals. The high scatter in intensities plotted versus depth are probably the result of the sediment transport mechanisms, which are episodic, high energy, and unlikely to produce uniform sediments.

\section{Igneous section}

Because the igneous section was rotary cored, producing generally small, often unoriented pieces, whole igneous core sections were not measured with the pass-through cryogenic magnetometer. This produces a situation where the magnetic fields of several small, variously oriented rock fragments can combine within the $30 \mathrm{~cm}$ sensing region of the passthrough magnetometer and result in spurious measurements. Instead, measurements were made on 286 discrete samples (Table T9). Most samples were 6-10 $\mathrm{cm}^{3}$ cubes cut from working-half core rock pieces with straight sides that indicate vertical orientation. In all, 158 cube samples were measured, including 23 samples taken by physical properties scientists, which were used to increase the number of paleomagnetic data points. To keep from affecting the physical properties of these samples, magnetic cleaning was restricted to AF demagnetization. Additional data were derived by measuring oriented pieces borrowed from the archive-half cores (128 total samples). Archive-half samples were irregular in volume and shape because cutting or modifying the archive rock pieces was not permitted. All such samples had straight vertical sides, indicating vertical orientation, and the sample volumes were $\sim 50-200$ $\mathrm{cm}^{3}$. Such irregular pieces are not often used in paleomagnetic studies because of concern that the irregular shapes may affect the accuracy of measurements rendered by the magnetometer. However, these measurements were considered useful in the current study because the recovery was often low and measurements were possible on many pieces that were either sampled by other investigators in the working half or were unsuitable for sampling because of fractures and cracks. Because these rock pieces are part of an archive, heating was not permitted, so AF demagnetization was used.

Most AF demagnetization was done using the cryogenic magnetometer's inline AF coils. The usual routine was to use $5 \mathrm{mT}$ steps from 10 to $50 \mathrm{mT}$, with an additional step at $60 \mathrm{mT}$. For thermal demagnetization, $50^{\circ} \mathrm{C}$ steps were used from $100^{\circ}$ or $150^{\circ} \mathrm{C}$ up to $350^{\circ}-375^{\circ} \mathrm{C}$, with $25^{\circ} \mathrm{C}$ steps up to $500^{\circ}-550^{\circ} \mathrm{C}$. The top end of the thermal demagnetization as well as the beginning of $25^{\circ} \mathrm{C}$ steps was changed slightly during the course of the study, depending on prior results. Characteristic remanent magnetization (ChRM) directions (i.e., the magnetization believed to be the thermal remanent magnetization [TRM] acquired initially upon cooling of the igneous rocks) was determined for each sample by examining orthogonal vector plots of demagnetization steps and looking for a consistent direction showing univectorial decay toward the plot origin. If such a vector was found, its mean direction was calculated using a least-squares line fit (principal component analysis [PCA]) of Kirschvink (1980).

NRM values for the igneous samples range from 1.33 to $60.81 \mathrm{~A} / \mathrm{m}$ (Table T9), values consistent with other young ocean crustal basalts (e.g., Johnson et al., 1996). Demagnetization results showed that many samples have the ubiquitous steep, downwarddirected overprint that is usually attributed to an isothermal remanent magnetization imparted by the drill string (Acton et al., 2002). This remagnetization does not significantly affect all samples but probably inflates NRM values for those with low-coercivity magnetic grains.

Orthogonal vector plots show that Hole U1301B basalts have a complex set of demagnetization behaviors (Fig. F44). Some samples have simple, single magnetizations, consisting of the ChRM only, which shows univectorial decay to the orthogonal vector plot origin (Fig. F44B). Some others have similar ChRM with a variable amount of steep, downwarddirected overprint, likely a result of exposure to high magnetic fields in the drill string and coring equipment (Fig. F44A, F44C, F44E, F44F). With many samples, however, the magnetization appears to have several components and complex demagnetization curves are common. Some samples appear to carry a high-coercivity magnetization that is not easily removed by AF demagnetization. Indeed, many such samples show low demagnetization step vectors converging on the origin, only to veer away at the highest steps (Fig. F44D). Furthermore, with thermal demagnetization, many samples do not stabilize on a stable ChRM direction until high temperatures, in excess of $450^{\circ}-500^{\circ} \mathrm{C}$ (Fig. F44E). 
Thermal demagnetization curves suggest that the complex demagnetization data may result from the samples having several different types of magnetic grains. In Figure F45, curve A shows a sample magnetization that is not reduced significantly until high temperature is applied. The trajectory of this curve and its rapid decay to near zero at $550^{\circ} \mathrm{C}$ is consistent with relatively pure magnetite. Curve $\mathrm{C}$ shows a sample whose magnetization is nearly gone by $300^{\circ} \mathrm{C}$, consistent with impure magnetite (i.e., containing titanium in its crystal lattice) or another mineral with a lower Curie temperature. Curve B has two plateaus, implying two different populations of magnetic grains with different Curie temperatures. Curve $\mathrm{D}$ shows an increase in magnetization between $200^{\circ}$ and $250^{\circ} \mathrm{C}$, which is a characteristic of the mineral pyrrhotite, a metastable iron sulfide that becomes more magnetic upon heating in that range, but whose magnetization is destroyed upon heating to $300^{\circ} \mathrm{C}$ (Thompson and Oldfield, 1986). In sum, the magnetizations of Hole U1301B basalt samples are variable and appear to be the result of several types of magnetic grains. This should come as little surprise because the basalts show extensive evidence of variable hydrothermal alteration (see "Igneous and metamorphic petrology").

An initial plot of ChRM inclination values versus depth (Table T9) showed considerable scatter, thought to result from including samples with poorly defined magnetizations. To distinguish between more and less reliable sample magnetizations, the samples were grouped by their demagnetization behavior. The most reliable samples are those that show consistent, univectorial decay toward the origin of an orthogonal vector plot. These were labeled A1 for the most consistent samples and A2 for those with fewer consistent steps or higher scatter between demagnetization steps (see Table T9). Samples that displayed univectorial decay, but with ChRM vectors that did not converge directly on the origin, were labeled class B. Those samples that were close to converging on the orthogonal vector plot origin were labeled B1, but those that missed significantly were labeled B2 (Table T9). Samples whose magnetizations veered away from the orthogonal vector plot origin at high demagnetization steps were labeled class C, with those that passed close to the origin labeled C1 and those that missed by a wide margin or trended away labeled C2. Samples with irregular, inconsistent demagnetization steps were labeled class D. Classes A1 and A2, considered the most reliable, compose $\sim 57 \%$ of the samples. Classes B1 and C1, those that were close to ideal univectorial behavior, are another $14 \%$. Samples in classes B2, C2, and D were considered too unreliable for inclusion in magnetic field inclination interpretations.
Even when unreliable samples are removed, the plot of inclination versus depth still shows considerable scatter, especially in the lower part of the cored section (Fig. F46). In the section of the hole covered by Cores 301-U1301B-1R to $15 \mathrm{R}$ ( $\sim 350$ to $\sim 450 \mathrm{mbsf}$ ), inclination values cluster, with most samples giving values between $30^{\circ}$ and $70^{\circ}$ (Fig. F46). From Core 301-U1301B-16R and downward, many samples give similar inclination values but many others yield lower inclinations. In addition, many samples produced negative inclinations. Below 450 mbsf, 29 samples have negative inclinations, whereas only 5 occur above that depth (Fig. F46). Many of the recovered core pieces are small, so it is likely that a few negative inclinations reflect accidental inversion of core pieces during handling. However, the large number below $450 \mathrm{mbsf}$ is too many to be explained simply by such mishaps. Furthermore, the direction of the low-coercivity, downward-pointing overprint, probably imparted by the drill string, should point upward if a sample were inverted. Though inconclusive for some samples without much overprint, virtually all of those with steep overprints and negative inclinations have a downward-pointing overprint. Thus, the likeliest conclusion is that most of the negative inclinations reflect the true magnetization direction of the rocks.

How could the rocks become magnetized with a negative inclination? Magnetic reversals are an obvious possibility; however, this is an untenable explanation because the negative-inclination samples are interspersed with positive-inclination samples in many places. One would have to postulate a multitude of short periods of magnetic field reversal or an uncharacteristically long time of basalt emplacement that would include millions of years of reversal record. Neither fits with current knowledge of the recent geomagnetic reversal record or crustal formation. Whatever causes these samples to have negative inclinations must be specific to the rocks themselves.

Given that constraint, two other possibilities are remagnetization or self-reversal. Self-reversal is a process through which basalts of certain compositions record a magnetization direction that is opposite to that of the prevailing geomagnetic field (Verhoogen, 1956). Although self-reversal is thought to be relatively rare, occurring in a restricted range of maghemite compositions, recent research suggests it may be more prevalent than normally regarded (Doubrovine and Tarduno, 2004). Without further tests, this possibility cannot be ruled out. Curiously, of nine sets of matched samples from the same rock pieces, three give negative magnetizations through thermal demagnetization and positive inclinations through AF demagnetization (Fig. F44A, F44E; Samples 301U1301B-30R-1, 98-100 cm, and 30R-1, 99-101 cm). 
All of these are comparisons of working-half core cube samples with archive-half irregular samples, so the possibility of accidental sample inversion during handling cannot be ruled out.

Remagnetization can occur through heating or chemical changes within a rock that changes the magnetic minerals. Although alteration changes the magnetic minerals in most crustal basalts (e.g., Johnson et al., 1996), usually the new magnetization has the same direction as the old as long as the remagnetization occurs rapidly. However, a reversed magnetization could occur if the alteration and magnetic mineral replacement occurs during a period of time with an opposite magnetic polarity. This seems the most likely explanation for Hole U1301B samples because geologic observations indicate extensive hydrothermal alteration (see "Igneous and metamorphic petrology") and because shipboard paleomagnetic studies point to multiple magnetization components as well as the presence of pyrrhotite in some samples. Pyrrhotite is a mineral that is a common byproduct of the dissolution of magnetic minerals, such as magnetite, and the conversion of the iron into iron sulfide minerals (Thompson and Oldfield, 1986).

If the remagnetization interpretation is correct, then the negative inclinations show zones where greater alteration has occurred. Looking at Figure F46, it appears that most samples with negative inclinations occur in two depth bands. The upper one spans 460 to 500 mbsf (Fig. F46), and the lower spans from $\sim 515$ mbsf to the bottom core at $\sim 577$ mbsf. It is difficult to determine whether the apparent gap between the two zones is real or an artifact of core recovery. Interestingly, the negative inclinations in the upper band have lower absolute values $\left(10^{\circ}-40^{\circ}\right)$, whereas those in the lower band are generally higher (up to $\sim 80^{\circ}$ ). This difference could be explained by the two sections having been remagnetized at different times, when the magnetic field was reversed, but at different inclinations owing to magnetic field secular variation. Another indicator that supports two bands of more intense alteration is the stratigraphic positions of unreliable samples (Fig. F46). Although poor-quality samples are scattered throughout the entire igneous section, there are clusters of them around 470-510 mbsf and 550-560 mbsf. The clustering of these samples partly results from sampling bias, but they also reflect zones where samples with poor quality occur in greater abundance. The overall implication of these arguments is that the upper part of the section has experienced less magnetic alteration, whereas the lower has been more affected, with perhaps two zones in the lower part of the section in which the greatest alteration has occurred.
Interestingly, the inclinations that are from apparently reliable samples give inclinations that tend to be shallower than expected for the latitude of the site (dashed lines, Fig. F46). This is true even when the expected inclination is corrected to account for the fact that the average inclination derived from azimuthally unoriented core samples is less than the true inclination (Cox and Gordon, 1984). The actual geocentric axial dipole inclination (expected value) for Site U1301 is $66.5^{\circ}$. However, applying the correction for inclination-only data bias reduces the expected value only to $64.2^{\circ}$. The average inclination of the samples above $450 \mathrm{mbsf}$, where the apparent remagnetization has been least, is only $55.7^{\circ}$, a difference of nearly $9^{\circ}$. The cause of this discrepancy is unclear and requires further research.

\section{Biogeochemistry}

Site U1301, with a depth to basement of $265 \mathrm{mbsf}$, lies along a buried basement ridge paralleling the Endeavor segment of the Juan de Fuca Ridge axis. Two basement exposures lie along this ridge near Site U1301: Baby Bare outcrop, located $\sim 6 \mathrm{~km}$ to the south-southwest, and Mama Bare outcrop, located $\sim 8 \mathrm{~km}$ north-northeast (see "Geologic context"). At Baby Bare outcrop, hydrothermal springs have been sampled, revealing a highly altered and warm fluid that circulates within basaltic basement (e.g., Mottl et al., 1998; Wheat et al., 2002). The source for this altered fluid is seawater, which is inferred to enter basement $52 \mathrm{~km}$ to the south-southwest at Grizzly Bare outcrop, another basaltic formation located along the same basement ridge (Wheat et al., 2000, 2002; Fisher et al., 2003). This along-strike pattern of hydrothermal circulation through the crust provides a potential habitat for a diverse biosphere not only within basaltic basement but also in the deepest sediments within a transitional environment between diagenetic- and water-rock-dominated chemical gradients.

Compositions of hydrothermal fluids within basaltic basement along this ridge between Baby Bare outcrop and Mama Bare outcrop have been documented extensively by sampling fluids directly from springs, boreholes, and surficial pore waters in zones of focused upflow (e.g., Wheat and Mottl, 2000; Wheat et al., 2000, 2002, 2004). Estimates of the composition of basaltic formation fluids were attempted using basal pore water gradients during Leg 168; however, fluids could have been affected by sampling artifacts caused by changes in pressure, temperature, and redox state. Potential artifacts have been determined for the major ions in seawater (Wheat et al., 2004). Concentrations for many trace elements are compro- 
mised by exposing the sediments to oxygen during pore fluid extraction. The introduction of oxygen to the sample creates the potential for reduced iron to oxidize and precipitate, affecting a variety of elements that coprecipitate and adsorb onto iron oxides. The sediment sampling and pore water extraction during Expedition 301 differed from that during Leg 168 in two important ways. First, we used an APC system to collect the sediment cores rather than the XCB or RCB systems. Second, to minimize potential artifacts caused by oxidation, whole-round sediment samples were placed into the squeezer within a nitrogen atmosphere. We report chemical data from 38 pore water samples, 45 gas headspace samples, and 30 solid-phase samples that were analyzed during IODP Expedition 301.

\section{Results}

\section{Pore water analyses}

Due to operational and time constraints, the sediment column in Hole U1301C was not continuously cored. At the end of the expedition we had some extra time, so we returned to Site U1301 to fill the gaps in the section (Hole U1301D). The results presented in this section integrate the data from Holes U1301C and U1301D (Table T10; Figs. F47, F48, F49, F50). For comparison, we also present pore fluid compositions from Leg 168 Site 1026 and spring fluid compositions from Baby Bare outcrop (Shipboard Scientific Party, 1997; Mottl et. al, 2000; Wheat and Mottl, 2000). Before selecting whole-round samples for pore water extraction, great care was taken to ensure that the samples consisted mostly of a fine-grained matrix whenever possible. One sample (301-U1301C$5 \mathrm{H}-2, \quad 0-40 \mathrm{~cm})$ consisted of sediment that was mostly mud in the lower section and mostly sand in the upper section. Both sections were squeezed and denoted as mud and sand in the table, respectively. Chemical analyses of these two samples are nearly identical. Sample 301-U1301C-19H-1, 110-150 cm, was a slurry of drilling fluids and sediment and was clearly altered by drilling. Data from this sample are not shown in the figures.

The majority of pore water chemical depth profiles from Site U1301 are similar to those from Site 1026. As observed in numerous DSDP and ODP holes drilled to basaltic basement, there are distinct biogeochemical zones identified on the basis of steep geochemical gradients at the seawater/sediment and sediment/basement interfaces. The gradients are particularly well defined in the dissolved sulfate, manganese, and iron profiles (Fig. F50). For example, sulfate concentrations decline from a seawater value of $28 \mathrm{mmol} / \mathrm{kg}$ at the sediment surface to $\sim 0.4 \mathrm{mmol} /$ $\mathrm{kg}$ at $\sim 57$ mbsf. At Site U1301, sulfate concentrations remain near zero to a depth of $\sim 125$ mbsf and then increase again to $\sim 16 \mathrm{mmol} / \mathrm{kg}$ at $263 \mathrm{mbsf}$. This downhole pattern of sulfate concentrations indicates active sulfate reduction at depths of $\sim 50$ and $\sim 125$ mbsf and diffusive sources from bottom seawater and the basaltic formation fluid, respectively, as is the case at Site 1026. Concentrations of dissolved barium are high in between these depths (Fig. F50). The downhole pattern of methane concentrations (Fig. F50) indicates that methane is created at depths of 80-110 mbsf and diffuses to the overlying and underlying zones of active sulfate reduction.

Alkalinity, chlorinity, and ammonium profiles are also nearly identical at Sites 1026 and U1301 and have end-member compositions that approach those of spring fluids from Baby Bare outcrop at the sediment/basement interface. However, there are several significant differences in the profiles from these two sites for the minor elements, most notably for dissolved iron. Data from Site U1301 show a maximum iron concentration of $133 \mu \mathrm{mol} / \mathrm{kg}$, compared to $14.8 \mu \mathrm{mol} / \mathrm{kg}$ at Site 1026 . This highlights the importance of squeezing the sediment within a nitrogen atmosphere. Other differences between chemical profiles from Sites U1301 and 1026 exist for Mn, B, $\mathrm{Sr}$, and Li. For these elements, the upper portion of the profiles are identical but differences occur within the basal sediments. These differences are likely caused by differences in composition (see "Lithostratigraphy") and not sampling artifacts, as was the case for iron. Although these elements are highly reactive within the sediment section, they do not rapidly oxidize like $\mathrm{Fe}$, nor do they coprecipitate with Fe.

The carbon content of the pore water increases in the uppermost $40 \mathrm{~m}$ of sediment, reaching a maximum at $47 \mathrm{mbsf}$ with values of $43.5 \mathrm{mmol} / \mathrm{kg}$ dissolved total carbon (TC), $24.3 \mathrm{mmol} / \mathrm{kg}$ dissolved inorganic carbon (IC), and $19.1 \mathrm{mmol} / \mathrm{kg}$ dissolved organic carbon (OC) (Table T10; Fig. F47). From 179 mbsf to the bottom of the hole at $260 \mathrm{mbsf}$, dissolved carbon concentrations are very low, ranging $0.57-1.79 \mathrm{mmol} / \mathrm{kg} \mathrm{TC}, 0.01-0.76 \mathrm{mmol} / \mathrm{kg} \mathrm{IC}$, and $0.4-1.4 \mathrm{mmol} / \mathrm{kg}$ OC. The concentration profiles of TC, IC, and OC show the same trend as the alkalinity profile, which increases from bottom seawater of 2.5 $\mathrm{mmol} / \mathrm{kg}$ to a maximum of $31.6 \mathrm{mmol} / \mathrm{kg}$ at 31.3 mbsf and then decreases to concentrations of $\sim 0.33$ $\mathrm{mmol} / \mathrm{kg}$ (Fig. F47).

\section{Gas analyses}

Results from headspace gas analyses are listed in Table T11 and illustrated in Figure F50. At Site U1301, the depth profile of methane varies inversely with sulfate and indicates the presence of two sulfate/ 
methane interfaces. Methane concentrations are low in the upper part of the sediment but increase sharply in the depth interval between 60 and 70 mbsf and reach a maximum at 111 mbsf. At and below $132 \mathrm{mbsf}$, concentrations of methane are near 0 $\mathrm{mmol} / \mathrm{kg}$. Here, a second, deep sulfate/methane interface occurs. Higher molecular weight hydrocarbon gases were not detected in samples from Site U1301.

The highest methane concentrations occur within the interval where sulfate is nearly depleted. This relationship is consistent with a methane source from microbiological production. Typically, substantial concentrations of methane are not produced until the dissolved sulfate concentration drops below 1-2 $\mathrm{mmol} / \mathrm{kg}$, which is close to the threshold value of $0.5 \mathrm{mmol} / \mathrm{kg}$ sulfate generally thought necessary for the accumulation of methane (Whiticar et al., 1994). Methane that diffuses out from the methane production zone is oxidized at the sulfate/methane interface by a consortium of archaea and sulfate-reducing bacteria (Boetius et al., 2000). The disappearance of almost all of the methane at the depths of sulfate depletion indicates that most of this methane is likely consumed by anaerobic methane oxidation. Consequently, methane concentrations remain low in zones without active methanogenesis.

\section{Sediments}

At Site U1301, the solid phase of the cored sediments has relatively low organic carbon, nitrogen, and hydrogen contents (Table T12; Fig. F51). Organic carbon contents are highest close to the sediment/water interface $(0.9 \mathrm{wt} \%)$ but decrease rapidly and fluctuate around $0.3 \mathrm{wt} \%$ throughout the sediment column. Total nitrogen averages $\sim 0.04 \mathrm{wt} \%$ and has a depth trend similar to organic carbon. In general, calculated atomic $\mathrm{C} / \mathrm{N}$ ratios vary around a mean value of 7.7, which indicates organic matter of marine origin. However, there are some deviations from this general trend. $\mathrm{C} / \mathrm{N}$ values increase in discrete sediment layers and reach values of up to 19.6 and 37.3 at sediment depths of 34.6 and 56.7 mbsf, respectively. These higher $\mathrm{C} / \mathrm{N}$ ratios indicate significant input of terrestrial organic matter, likely a result of turbidite deposition. Overall, these findings agree well with previous observations at Site 1026 (Shipboard Scientific Party, 1997).

Throughout most of the cored sediment, inorganic carbon contents are low, with corresponding $\mathrm{CaCO}_{3}$ values ranging from 0.75 to $5.7 \mathrm{wt} \%$ (Table T12; Fig. F51). Nonetheless, we find distinct layers with highly elevated carbonate contents below the postulated lower zone of anaerobic methane oxidation.
$\mathrm{CaCO}_{3}$ values increase to $7.6 \mathrm{wt} \%$ at $184 \mathrm{mbsf}$ and reach $1.5 \mathrm{wt} \%$ at the sediment/basement interface. Both carbonate peaks coincide with elevated carbonate levels found at Site 1026 below the lower zone of anaerobic methane oxidation and at the sediment/ basement interface (Fig. F49).

\section{Discussion}

Calculated compositions of fluids within uppermost basement derived from pore water chemical gradients in basal sediments from Expedition 301, in the absence of external sources or sinks, should equal those measured in spring fluid from Baby Bare outcrop and borehole fluids from Site 1026 (Wheat et al., 2004). There is interest in the basal gradients for determining fluxes to and from the sediment for elements and chemical species that are important to microbial processes. Examples of chemical species that can be utilized by microbial life are sulfate, iron, manganese, silicate, and phosphate. Fluids flowing past Baby Bare outcrop continue to undergo reaction in the basement and are exposed to diffusive exchange with the overlying sediment before arriving at Site U1301. We can use the calculated diffusive gradient for a range of ions to model the average fluid flux through the upper basement. Deviations from the modeled flux should be caused by reactions, either inorganic or microbially mediated, thus providing estimates for microbial consumption rates within the deep biosphere.

The chemical compositions for the major ions in pore waters at the base of the sediment column in Hole U1301C agree with measurements made from borehole fluids from Site 1026 and spring fluids from Baby Bare outcrop. Concentrations of $\mathrm{Na}, \mathrm{K}, \mathrm{Ca}$, and $\mathrm{Mg}$ in the deepest sample differ by $<7 \mathrm{mmol} / \mathrm{kg}$ from those measured at Baby Bare springs. Sulfate and chlorinity concentrations in the deepest samples are even closer to those of Baby Bare springs- 1.7 and $0.1 \mathrm{mmol} / \mathrm{kg}$, respectively. One of the hopes for these data and interpretations is to obtain better estimates for the composition of minor and trace elements in the formation fluid. Initial interpretations for $\mathrm{Si}$, ammonium, and $\mathrm{Mn}$ are consistent with a better approximation to the spring and borehole compositions compared with those from Site 1026. In contrast, other basal gradients of minor elements from Site U1301 (e.g., Sr and Li) point to different values.

Evidence of microbial activity at the sediment/basement interface is consistent with elevated concentrations of Fe and Mn near this interface. For example, in the deepest sample concentrations of dissolved iron increase to $9.8 \mu \mathrm{mol} / \mathrm{kg}$ and concentrations of dissolved $\mathrm{Mn}$ rise to values $>150 \mu \mathrm{mol} / \mathrm{kg}$. The ob- 
served gradients are much higher than those recorded from Site 1026, probably a result of differing sampling techniques. In contrast, sulfate gradients from both sites appear to be similar in profile and demonstrate the existence of a deep zone of anaerobic methane oxidation and sulfate reduction that is maintained by sulfate diffusion from sulfate-rich hydrothermal fluids from the sediment/basement interface.

\section{Microbiology}

Site U1301 lies on a sediment-buried basement ridge on the eastern flank of the Juan de Fuca Ridge. The basement at this location hosts vigorously connecting hydrothermal fluid from the crust that enters the overlying sediment. This presents an opportunity to investigate microbial communities in distinct biogeochemical zones within the sediment column as well as within igneous basement. The Expedition 301 microbiology program was designed to collect sediment and igneous rock samples to attempt cultivation of indigenous microbes, study phylogenetic diversity, estimate the total and active microbial population densities, quantify microbial biomass, measure potential rates of microbial metabolism, and investigate microbial alteration of primary igneous minerals.

\section{Sediment microbiology}

The lithology and geochemical/thermal gradients of the sediment section at Site U1301 (Holes U1301C and U1301D) are nearly identical to those at Site 1026 , which is located only $1-2 \mathrm{~km}$ north and has been characterized previously (Shipboard Scientific Party, 1997). Site U1301 has two sulfate-methane transition zones at $\sim 30-50$ and $\sim 100-120$ mbsf. Sulfate reduction is the dominant terminal electronaccepting process of organic matter remineralization above and below the two transition zones, whereas methanogenesis is the dominant terminal electronaccepting process of organic matter remineralization between the two transition zones. Sulfate in the upper part of the sediment column comes from ocean bottom seawater, whereas sulfate in the lower part diffuses up from young hydrothermal crustal fluids (altered seawater). The two sulfate transition zones are exposed to different temperatures $\left(\sim 15^{\circ}\right.$ and $\sim 40^{\circ} \mathrm{C}$ ). The geochemistry of the upper zone is influenced by water column processes (e.g., photosynthetic primary production, deposition of turbidites, or volcanic ash), whereas that of the lower zone is additionally controlled by the composition of hydrothermal fluids that flow within the uppermost oceanic crust. The differences in thermal and geochemi- cal conditions between the zones make for an interesting comparison of their respective microbial communities. Because of operational and time constraints, the sediment section at Site U1301 was not continuously cored in Hole U1301C. Near the end of the expedition, we had time to return to the site to fill a gap in Hole U1301D. However, microbiological samples from Hole U1301D were only collected, processed, and preserved for shore-based analyses. In addition to the dual sulfate-methane transition zones at Site U1301, the sediment/basement interface at $\sim 265$ mbsf is where basaltic oceanic crust inundated by warm, electron-acceptor-rich fluid $\left(\sim 64^{\circ} \mathrm{C} ; \sim 15\right.$ $\mathrm{mM} \mathrm{SO}_{4}{ }^{2-}$ ) meets organic matter-and, hence, electron-donor-rich sediment. These conditions are likely to support high microbial activity and biomass. Moreover, the sediment column at Site U1301 has a wide temperature range $\left(\sim 2^{\circ}-64^{\circ} \mathrm{C}\right)$, making it well suited for the study of microbial community composition and activity along temperature gradients in deep-sea sediments. The lithologic heterogeneity with sharp interfaces between layers (e.g., between hemipelagic clay and turbidite sand) allows us to study changes in microbial communities across different lithologies.

\section{Sample preparation and distribution}

Samples were taken as listed in Table T13. Nineteen APC sediment cores were taken over the depth interval of 0-265.3 mbsf in Hole U1301C. We obtained samples from all cores except 301-U1301C-14R, which had poor recovery. The majority of cores (14) were taken above 130 mbsf. Additional cores were obtained from the middle (180-198 mbsf) and bottom (238-265 mbsf) of the hole. Additional coring was conducted in Hole U1301D over 120-177 mbsf.

\section{Estimates of contamination with drilling fluid}

We measured PFT concentrations along cross-sectional transects in cores. Three general locations were sampled: (1) the exterior adjacent to core liner, (2) halfway between the core liner and the center of the core, and (3) the center of the core. For each location, duplicate samples from opposite sides of the core were taken and their PFT concentrations averaged. Contamination was generally low, averaging for all cores at $0.23,0.03$, and $0.02 \mu \mathrm{L} / \mathrm{g}$ for the exterior, halfway, and center, respectively (Fig. F52), and ranging $0-2.12,0-0.30$, and $0-0.39 \mu \mathrm{L} / \mathrm{g}$ for individual samples in the exterior, halfway, and center, respectively (Table T14). PFT was absent in measurable amounts from 9 of the 23 samples analyzed and could only be detected in 12,10 , and 4 of the samples from the exterior, halfway, and center, respectively (Table T14). Direct cell counts estimated an av- 
erage of $1.85 \times 10^{7} \pm 0.26 \times 10^{7}$ cells/L for surface seawater (drilling fluid). Based on this mean, contamination with cells from seawater ranged 0-39.1 cells $/ g$ (mean $=4.3 \pm 10.1$ cells $/ g$ ) in the exterior part of each core, $0-5.5$ cells $/ g$ (mean $=0.6 \pm 1.3$ cells $/ g$ ) in the halfway part of each core, and $0-7.1$ cells/g (mean $=0.4 \pm 1.5$ cells $/ g$ ) in the center part of each core (Table T14). Total cell counts, conducted in parallel for each sample (see "Total cell counts," below), were used to estimate ratios of contaminant to indigenous cells. Ratios ranged from 0 to $114.6 \times$ $10^{-9}\left(\right.$ mean $\left.=21.4 \times 10^{-9} \pm 36.1 \times 10^{-9}\right)$ in the exterior part of each core, 0 to $19.7 \times 10^{-9}$ (mean $=3.2 \times 10^{-9} \pm$ $\left.5.9 \times 10^{-9}\right)$ in the halfway part of each core, and 0 to $17.4 \times 10^{-9}\left(\right.$ mean $\left.=1.2 \times 10^{-9} \pm 3.8 \times 10^{-9}\right)$ in the center part of each core (Table T14). This is a conservative estimate because PFT molecules have high volatility and a much smaller size than bacterial molecules, so they are likely to diffuse and hence penetrate cores much faster than contaminant cells.

We examined potential relationships between drilling fluid contamination and variables such as core depth (mbsf), location within the core, and lithology (sand versus clay). Our data suggested no relationship between drilling fluid contamination and core depth or lithology (Table T14). In contrast, although our data set is small and biased toward shallow sediments, there appears to be a relationship between contamination and sample location within a core: four out of five samples from the first section of each core (Cores 301-U1301C-1H, 5H, 11H, 12H, and $19 \mathrm{H})$ and eight out of eleven samples from the second section of each core (Cores $1 \mathrm{H}, 3 \mathrm{H}, 6 \mathrm{H}, 7 \mathrm{H}, 8 \mathrm{H}$, $9 \mathrm{H}, 10 \mathrm{H}, 13 \mathrm{H}, 15 \mathrm{H}, 16 \mathrm{H}$, and $18 \mathrm{H}$ ) were contaminated. By contrast, none of the three samples from the third section of each core (Cores 301-U1301C$2 \mathrm{H}, 4 \mathrm{H}$, and $19 \mathrm{H}$ ) were measurably contaminated, and only one of the two samples from the fourth and fifth sections of each core (Cores $17 \mathrm{H}, 18 \mathrm{H}$, and 19H) was measurably contaminated (Table T14).

\section{Total cell counts}

We obtained a vertical depth profile of prokaryotic cells from 24 sediment samples (code $=$ AODC; Table T15) by direct counts of fixed, acridine orangestained cells. The cell numbers were counted independently by two shipboard microbiologists to balance individual counting biases. Cells were detectable at all depths analyzed. Staining alone with acridine orange or the alternative fluorescent dye DAPI did not provide satisfactory results. Samples from surface sediments in particular contained high amounts of diatom ooze, which emitted a strong fluorescent signal after staining (Fig. F53). To improve our ability to distinguish cells from background, we prepared several dilutions and used the one that optimized the signal-to-noise ratio prior to counting cells (Fig. F54).

Total cell counts decreased slightly with depth, from near-surface concentrations of $7.5 \times 10^{8}$ to concentrations of $1.8 \times 10^{7}$ cells $/ \mathrm{cm}^{3}$ at $248 \mathrm{mbsf}$. Overall, the profile of microbial cell densities (Fig. F55) followed a similar trend as for other ODP sites (Parkes et al., 1994). Our cell counts over the upper $70 \mathrm{~m}$ were slightly higher than those reported for Site 1026 during Leg 168 (Mather and Parkes, 2000). One sample (Section 301-U1301C-19R-1; 259 mbsf) was judged as an outlier: cell counts were much higher than in samples from surrounding locations. Examination of PFT (Table T14) and geochemical data indicated strong contamination of this sample.

Although microscopic examination only provides rough estimates of microbial diversity, we were able to distinguish morphotypes along the depth profile (Table T15). Tiny coccoid-shaped cells dominated throughout the sediment column. Numbers of rodshaped cells fluctuated strongly. Aggregates of up to 30 microbial cells were detected in four horizons between 63 and 90 mbsf.

Interestingly, an increase in cell numbers was observed near the sediment/basement interface. This increase in biomass may be supported by upward flux of electron acceptors from hydrothermal fluids in the underlying basement. Lowest cell densities of $1.8 \times 10^{7}$ to $4.1 \times 10^{7}$ cells $/ \mathrm{cm}^{3}$ were observed in the zone where hydrothermally introduced sulfate was almost depleted (240-252 mbsf). Sulfate may play an important role as an electron acceptor in the deepest zone of the sediment column and stimulate microbial growth. The continuous increase in cell numbers from $7.5 \times 10^{7}$ to $2.3 \times 10^{8}$ cells $/ \mathrm{cm}^{3}$ near the basement (256-262 mbsf) supports this interpretation and provides an example of how the deep biosphere may be fueled by hydrothermal fluids.

\section{Cultivation experiments}

Geochemical analyses indicate the occurrence of methanogenesis and sulfate reduction within the sediment column, yet nothing is known about the identity and respective metabolism of microbes present. We performed cultivation experiments during Expedition 301 using three different approaches. In total, 1000 enrichment cultures of indigenous microorganisms were inoculated on board.

In the first approach, samples from inner parts of cores (from a total of 25 horizons; described as CLTI in Table T13) were used. Cultivation media were designed to target (1) methanogens, (2) sulfate reducers, (3) hydrogen/sulfur oxidizers, and (4) fermenters 
(see "Microbiology" in the "Methods" chapter). Slurries were made by mixing $25 \mathrm{~cm}^{3}$ of sample with $50 \mathrm{~mL}$ of synthetic seawater containing $0.05 \%(\mathrm{w} / \mathrm{v})$ sodium sulfide under an $\mathrm{N}_{2}$ atmosphere $(200 \mathrm{kPa})$. Aliquots of $500 \mu \mathrm{L}$ from these slurries were inoculated in tubes containing $3 \mathrm{~mL}$ of medium and incubated at $20^{\circ}, 37^{\circ}, 55^{\circ}, 70^{\circ}$, and $85^{\circ} \mathrm{C}$. The total number of enrichments was 336. The remainder of slurries were stored at $4^{\circ} \mathrm{C}$ for shore-based studies. In addition, using Mono medium (see "Microbiology" in the "Methods" chapter) as an inoculum, $25 \mathrm{~cm}^{3}$ aliquots of sediment samples were incubated at different temperatures: (1) sample codes 4-2, 8-2, 11-1, $12-1$, and $13-2$ at $20^{\circ} \mathrm{C}$; (2) sample code $15-2$ at $37^{\circ} \mathrm{C}$; (3) sample code $17-4$ at $55^{\circ} \mathrm{C}$; and (4) sample codes $18-2,19-1,19-2,19-4$, and $19-5$ at $70^{\circ} \mathrm{C}$ (for more information see "Microbiology" in the "Methods" chapter).

A second cultivation approach was performed on samples from 11 depth intervals (sample code BERT; Table T13). Samples were taken from the innermost part of whole-round cores and transferred to three series of sterile $100 \mathrm{~mL}$ flasks. Two series were flushed with nitrogen, one of which additionally contained a mild reducing agent. The third series was flushed with a mixture of $80 \%$ hydrogen and $20 \%$ carbon dioxide. Samples will serve as inocculi for further shore-based cultivation experiments. Onboard cultivation was performed in Mono medium (see "Microbiology" in the "Methods" chapter) under oxic and anoxic conditions at room temperature. Sediment samples from the 11 depth intervals were cultivated in gradient cultures, dilution series in test tubes, and most probable number (MPN) enrichment series in microtiter plates (see "Microbiology" in the "Methods" chapter). The total number of enrichments was 372 cultures. One week after sampling, growth was detected only in some of the aerobic enrichments.

In a third approach (sample code DNASS; Table T13), samples were collected from the center part of each core with a $60 \mathrm{~mL}$ syringe and stored for shore-based deoxyribonucleic acid (DNA) extraction. Samples for cultivation were taken along the inner edges of the remaining part of the core and transferred immediately to sterile $50 \mathrm{~mL}$ serum bottles under constant flushing with $\mathrm{N}_{2}$. Bottles were sealed with butyl rubber stoppers, and a slight overpressure was applied. Finally, $2-3 \mathrm{~mL}$ of sulfide-reduced $\left(2 \mathrm{mM} \mathrm{Na}_{2} \mathrm{~S}\right)$ artificial seawater was added to each of the bottles. The bottles were kept refrigerated and returned to shore for further cultivation experiments. From each core, $3 \mathrm{~cm}^{3}$ of sediment was collected with a $3 \mathrm{~mL}$ syringe and transferred to a $50 \mathrm{~mL}$ serum bottle containing $30 \mathrm{~mL}$ of Met3-medium (see Table T13 in the "Meth- ods" chapter). The bottles were shaken vigorously until the sediment was evenly distributed. These slurries were used as an inoculum in cultivation experiments. Enrichments targeting methanogens were made from all sampled cores. From the last three cores sampled (Cores 301-U1301C-17R through 19R), additional enrichments selecting for sulfur reducers and chemolithotrophic nitrate reducers were started. Incubation temperatures were $5^{\circ}, 20^{\circ}, 37^{\circ}$, $55^{\circ}$, and $70^{\circ} \mathrm{C}$, corresponding to known in situ temperatures at Site 1026. A total of 44 enrichment cultures were inoculated using this cultivation approach.

None of the anaerobically incubated enrichments showed growth during Expedition 301. The incubation time was probably too short for most of the microorganisms to grow. All shipboard microbiologists will continue the incubation experiments on shore. Additional enrichments will be started that will focus on cultivation of methanogens and homoacetogens at different temperature and substrate treatments and measure potential rates of methanogenesis (sample codes = CULT-L and AODC). We expect anaerobically incubated enrichments to start showing signs of growth within weeks after end of expedition.

\section{Basalt microbiology}

Previous studies of basaltic rock obtained by ODP drilling have suggested a potentially extensive microbial biosphere in oceanic crust (Giovannoni et al., 1996; Fisk et al., 1998). Microscopic observations and nucleic acid staining indicated low densities of cells in basaltic rocks within volcanic glass and along fractures (Fisk et al., 1998). To date, there are no extensive studies on microbes inhabiting ocean crustal basalt. No cultured members exist, and nothing is known about phylogenetic diversity or microbial metabolism.

\section{Total cell counts}

We counted total cell numbers in samples fixed in $60 \%$ ethanol and containing (1) small pieces of basalt and (2) basalt that had been crushed to powder. Unfortunately, the material itself showed a high amount of cell-like structures (small crystals and needles) with high fluorescent signals. Even after testing a variety of dilutions that had been filtered and stained, it was impossible to distinguish cells because of the background fluorescence.

\section{Estimates of contamination with drilling fluid}

We measured PFT concentrations on rock exteriors and interiors. PFT measurements were conducted on 
15 rock samples, each from a different core. PFT was detected in all but one sample (Section 301-U1301B33R-1). To remove PFT, and thus potential microbial contaminants, from rock surfaces, we washed rocks twice in sterile bags containing sterile saline solution (ultrananopure deionized $\mathrm{H}_{2} \mathrm{O}$ and $3 \% \mathrm{NaCl}$ ) and flamed rocks using a propane torch until the exterior was completely dry. We then took samples from the rock interior. To compare PFT removal, we measured PFT content in pieces of (1) untreated rock exterior, (2) $2 \times$ washed rock exterior, (3) $2 \times$ washed + flamed rock exterior, and (4) rock interior (Table T16; Fig. F56). Our PFT removal method was highly effective for the 14 samples with measurable PFT concentrations: on average $83 \%$ of PFT was removed via washing, and 99\% was removed after additional flaming. PFT content of the rock interior was as low as on the outside after flaming (Fig. F56). In 4 of the 14 rock samples where PFT was detectable on the outside, no PFT was measured in the interior. In the 9 rock samples with measurable PFT values, drilling fluid contamination estimated from PFT concentrations ranged from 0.003 to $0.081 \mu \mathrm{L} / \mathrm{g}$. Based on acridine orange direct cell counts during this cruise, microbial cell concentrations in surface seawater (drilling fluid) were on the order of $1.85 \times 10^{7} \pm 0.26^{3} \times 10^{7}$ cells/L. This equates to $0.1-1.5$ contaminant cells/g basalt in our samples. Contamination of basalt with microbes from drilling fluid therefore appears to be very low. Unfortunately, due to the difficulty of quantifying densities of basalt-inhabiting microbes, we could not compare numbers of contaminant cells to densities of indigenous cells. Nonetheless, contamination of rock interiors with drilling fluid is so low that it probably is insignificant and even low compared to the minute but inevitable contamination during the "aseptic" handling process of samples.

\section{Cultivation experiments}

Using slurries or rock pieces, we inoculated $\sim 300$ test tubes in 12 different growth media at five different temperatures $\left(20^{\circ}, 37^{\circ}, 55^{\circ}, 70^{\circ}\right.$, and $85^{\circ} \mathrm{C}$; see "Microbiology" in the "Methods" chapter). After 2 weeks of incubation, we observed cell growth in several culture media ( $<10 \%$ of total cultures) (Table T17). We obtained cells that could grow at near in situ temperature, potentially suggesting successful enrichment of indigenous microbes from the warm, shallow basalt aquifer (Table T17). Microscopic observations of DAPI-stained cells revealed coccoidshaped cells attached to iron sulfide particles. These particles were part of the growth medium. Curiously, in these enrichments no cells were found in association with basalt particles (Fig. F57). Considering the chemical composition of the Mono medium (see "Microbiology" in the "Methods" chapter), these microorganisms probably grow with the provided substrates as carbon sources and ferrous iron as an electron donor. In other enrichments at room temperature, we found anaerobic mesophilic microbes, likely to be fermenters and/or heterotrophic sulfate reducers. There are three conceivable explanations for the retrieval of mesophilic strains: microbes might be (1) derived from sediment above basement, (2) contaminants imported by drilling fluid, or (3) relics transferred to the basaltic oceanic crust by hydrothermal circulation. Further physiological and phylogenetic characterizations of retrieved microbes will be performed as part of shore-based studies. We will compare the results from culture experiments to the results obtained from culture-independent molecular analyses.

\section{Physical properties}

Physical property measurements provide indications of lithology, texture, and degree of alteration. Shipboard measurements of physical properties are used to help correlate data from downhole logging with those from cored sections to provide additional insight on the physical state of the section. Data also provide context that aids in the interpretation of other information such as microbiological and biogeochemical results. The sediment section at Site U1301 was cored using the APC in Holes U1301C and U1301D. The basement section was cored using the RCB in Hole U1301B. The following sections describe the results of the shipboard analyses for both the sediment and basement sections.

\section{Hole U1301C}

Nineteen APC sediment cores were obtained over a depth interval of 0-265.3 mbsf in Hole U1301C, with the majority (16) taken in lithologic Unit I (0$13.1 \mathrm{mbsf}$ ) and the remainder taken from Unit II (Fig. F58A). The section was not continuously cored because of time and operational constraints and because an essentially identical section was cored at Site 1026 during Leg 168. At the end of the expedition, we returned to Site U1301 to core the interval 120-177 mbsf in Hole U1301D. However, no physical property measurements were made from this last set of cores because of the short transit time at the end of the expedition. Physical property measurements were made on whole cores (multisensor track and thermal conductivity), split cores ( $P$-wave velocity and shear strength), and discrete samples (moisture and density [MAD] properties); data are presented in Table T18. 
In an effort to assess potential sampling bias, each sample was classified as clay, sand, or mixed lithology. This nomenclature may not correspond precisely to the lithologic description of the section (see "Lithostratigraphy") but is correct at the scale of physical property samples. Table T19 shows the percentage of sand in the total thickness of the described section (excluding whole-round samples collected from the catwalk) and also shows the percentage of measurements that were made in sand layers. This demonstrates that measurements of thermal conductivity, $P$-wave velocity, MAD properties (bulk density, grain density, and porosity), and shear strength are all biased toward an oversampling of clay layers, suggesting that a weighted averaging scheme should be employed when characterizing overall conditions throughout the cored interval. However, it should also be noted that recovery was incomplete in many cores, cores containing sand are often highly disturbed, we did not core the sections continuously, and many whole-round sections were removed for microbiology. Thus, even if we had made physical property measurements in each recovered lithology according to its fractional representation in the cores, there would still be an unquantifiable bias in the data set.

\section{Multisensor track}

\section{Magnetic susceptibility}

Magnetic susceptibility ranged from $44 \times 10^{-6}$ to $3460 \times 10^{-6}$ SI units (Fig. F58B), with large spikes in the data set corresponding to sand layers of turbidite sequences and lower values corresponding to silt and clay layers. The highest values were measured in a series of interbedded turbidites recovered in Cores 301U1301C-6H and 7H over an interval of $12 \mathrm{~m}$ beginning at 45 mbsf and likely result from the presence of magnetite grains (see "Lithostratigraphy"). Figure F59 displays the variability within a typical 1.5 $\mathrm{m}$ section of interbedded sand and clay recovered from Subunit IB (Section 301-U1301C-3H-5), along with colocated magnetic susceptibility and bulk density data. Magnetic susceptibility is initially low in the uppermost clay layer and increases with depth through a $\sim 50 \mathrm{~cm}$ thick turbidite layer. Oscillations in the record correspond to thin interbedded layers of sand and clay. The variations in the magnetic susceptibility record are tracked nicely by those in the bulk density record, where low- and high-density layers correspond to clay and sand, respectively. Similar profiles of magnetic susceptibility and bulk density are seen deeper in Subunit IB (Fig. F60) over a longer, $7 \mathrm{~m}$ thick portion of Cores 301-U1301C-8H and $9 \mathrm{H}$. Magnetic susceptibility is initially near 1000 $\times 10^{-6} \mathrm{SI}$ in the sand layer near the top of the core, before dropping and oscillating through a $1.5 \mathrm{~m}$ thick interbedded sequence, and attaining a constant low value of $\sim 250 \times 10^{-6}$ SI throughout the underlying clay layer. As with Section 301-U1301C-3H5 , the bulk density record displays a similar pattern. Magnetic susceptibility decreases both in magnitude and variability across the transition from Unit I to Unit II (dropping from $560 \times 10^{-6} \pm 318 \times 10^{-6}$ SI to $\left.280 \times 10^{-6} \pm 95 \times 10^{-6} \mathrm{SI}\right)$, along with the shift from sand (containing magnetite) to hemipelagic clay lithology.

\section{Natural gamma radiation}

Although pore volume may have an effect on the natural gamma radiation (NGR) signal where emissions from NGR-producing elements are low, the porosity in Hole U1301C varied by less than a factor of two $(\sim 50 \%-80 \%)$, whereas the NGR data varied by one order of magnitude (5-50 cps) (Fig. F58E). In general, NGR counts were higher in clay than in sand, resulting from the higher content of radioactive isotopes in the clay. The highest values were obtained from a $5 \mathrm{~m}$ thick clay layer in Cores 301U1301C-9H and 10H (Figs. F58E, F60). The resolution of the NGR data is lower than that of the other MST instruments (measurements every $15 \mathrm{~cm}$, as opposed to $2.5 \mathrm{~cm}$ ), so the pattern does not show the same degree of variability in the thinly interbedded sand and clay zones (Fig. F59).

\section{Gamma ray attenuation density}

The bulk density of the core is estimated by gamma ray attenuation (GRA). Results vary by as much as $15 \%$ between GRA and MAD property samples within the highly porous clay layers at depths $<100$ mbsf, whereas the difference is smaller for less porous layers deeper within the section (Fig. F58C). In general, the data show a systematic increase in bulk density with depth from $\sim 1.5$ to $2 \mathrm{~g} / \mathrm{cm}^{3}$ in the upper $75 \mathrm{~m}$ of the section, below which they scatter around a mean value of $\sim 2 \mathrm{~g} / \mathrm{cm}^{3}$ (Fig. F58C).

\section{$\boldsymbol{P}$-wave logger}

The $P$-wave logger (PWL) showed anomalous results and ceased to operate beginning with Core 301U1301C-4H and was not repaired in time for use on any further sections. The limited data obtained over the interval of $0-24$ mbsf are loosely consistent with velocity data obtained using the $P$-wave sensor (PWS) system on split cores (Fig. F58F).

\section{Moisture and density properties}

A total of 78 discrete $10 \mathrm{~cm}^{3}$ samples were collected immediately after splitting of cores for the determi- 
nation of MAD properties and were classified as being predominantly either clay, sand, or mixed lithology.

Bulk density of the clay layers increases systematically from $1.4 \mathrm{~g} / \mathrm{cm}^{3}$ at the seafloor to $\sim 2 \mathrm{~g} / \mathrm{cm}^{3}$ at a depth of 100 mbsf and correlates with a 30\% decrease in porosity over the same depth interval (Fig. F58C, F58I). The porosity of sand layers remains relatively constant at $\sim 40 \%$ to a depth of 115 mbsf. Analysis of trends at greater depth is precluded by the discontinuous core. Bulk density values from clay lithologies recovered in Cores 301-U1301C-15H through $19 \mathrm{H}$ vary slightly about a mean of $1.9 \mathrm{~g} /$ $\mathrm{cm}^{3}$. The bulk density of sand layers is relatively consistent at $2.0 \pm 0.1 \mathrm{~g} / \mathrm{cm}^{3}$, with the exception of a highly variable zone located within Subunit IB at 79-82 mbsf. Grain density is remarkably consistent at $2.8 \pm 0.1 \mathrm{~g} / \mathrm{cm}^{3}$ regardless of depth or lithology. The higher than expected grain density could be attributable to pyrite, which has a grain density of $\sim 5$ $\mathrm{g} / \mathrm{cm}^{3}$.

\section{Thermal conductivity}

Thermal conductivity data were collected at a frequency of at least one measurement per section, with additional data acquired in some turbidite layers and in sections bracketing regions where downhole temperature tools (APCT and DVTP) were used. A total of 238 discrete measurements were made at 88 different locations on whole cores using the fullspace needle probe configuration. Each sample location was classified as being either clay, sand, or mixed. In order to estimate the degree of uncertainty in any single value, multiple measurements were made at each sampling location. Thermal conductivity was strongly controlled by lithology, with values for clay being significantly lower than values for sand, averaging $1.12 \pm 0.12$ and $1.53 \pm 0.19 \mathrm{~W} / \mathrm{m} \cdot \mathrm{K}$, respectively. Values of mixed lithology span the range in between (Fig. F61A; Table T18). A systematic increase of thermal conductivity is apparent in the upper $100 \mathrm{mbsf}$, where thermal conductivity increases from $\sim 0.9$ to $\sim 1.2 \mathrm{~W} / \mathrm{m} \cdot \mathrm{K}$, whereas the porosity of clay layers decreases concurrently from $>80 \%$ to $\sim 50 \%$. The observed relationship between thermal conductivity and porosity suggests that thermal conductivity varies consistently with porosity only within the clay layers (Fig. F61B).

We calculate a range of potential matrix thermal conductivities by employing a geometric mean mixing model (e.g., Woodside and Messmer, 1961) and estimate matrix thermal conductivities ranging from 1.3 to $6.0 \mathrm{~W} / \mathrm{m} \cdot \mathrm{K}$. A matrix thermal conductivity of $\sim 2.5 \mathrm{~W} / \mathrm{m} \cdot \mathrm{K}$ was calculated for clay lithologies, which is $\sim 1 \mathrm{~W} / \mathrm{m} \cdot \mathrm{K}$ less than those estimated by
Shipboard Scientific Party (1997) for Hole 1026A located $<2 \mathrm{~km}$ north northeast along the same buried basement ridge as Hole U1301C.

Thermal conductivity drops at $\sim 100$ mbsf from $\sim 1.25$ to $1.05 \mathrm{~W} / \mathrm{m} \cdot \mathrm{K}$ (Fig. F58G), concurrent with a lithologic change from medium-coarse massive sand to gravel, consistent with a similar decrease seen at Sites 1026 and 1027. Below 200 mbsf, thermal conductivity varies little with depth within the hemipelagic clay recovered in Cores 301-U1301C-17H, 18H, and $19 \mathrm{H}$, having a mean value of $1.16 \mathrm{~W} / \mathrm{m} \cdot \mathrm{K}$.

\section{P-wave velocity}

A total of 107 measurements of $P$-wave velocity were made on split sections using the Hamilton Frame PWS3 contact probe system. Cracking of lithified sediments precluded the acquisition of reliable velocities by the $\mathrm{z}$ - and $\mathrm{y}$-axis transducers in sediments from deeper than $\sim 35$ mbsf, but $\mathrm{x}$-axis velocities (perpendicular to the cut face) were successfully measured using a noninvasive transducer pair. The digitally recorded distance between the PWS3 transducers was found to be in error, and postprocessing corrections were applied to all $\mathrm{x}$-axis velocity data by simply correcting for the actual sample thickness and recalculating the correct velocity as

$$
\begin{array}{r}
v=\left[\left(m \times d_{\text {meas }}+b\right)-\Delta x_{\text {liner }}\right] / \\
{\left[\Delta t_{\text {meas }}-\left(\Delta x_{\text {liner }} / \Delta v_{\text {liner }}\right)-\Delta t_{\text {delay }}\right]}
\end{array}
$$

where

$v \quad=$ the correct velocity;

$t_{\text {meas }}=$ the measured traveltime;

$d_{\text {meas }}=$ the original recorded transducer separation,

$m \quad$ = the slope of the regression line defining the correct transducer separation;

$b \quad=$ the intercept of the regression line defining the correct transducer separation;

$x_{\text {liner }}=$ the thickness of the core liner;

$v_{\text {liner }}=$ the seismic velocity of the core liner; and

$t_{\text {delay }}=$ the instrument electronic delay (Fig. F62A; see caption for variable values and equation reference).

Data were classified by lithology (clay, sand, or mixed), and are shown in Figure F58F.

Velocity values range from $\sim 1480$ to $1780 \mathrm{~m} / \mathrm{s}$ over the $265 \mathrm{~m}$ drilled interval, with an increase of $\sim 10 \%$ occurring within the uppermost 50 mbsf (Fig. F62B). Velocities measured in clay lithologies consistently display a lesser degree of variability than those measured in sand and also display a systematic increase with depth. Mobilization and redeposition of sand layers in turbidite sequences during coring precludes determining a statistically significant trend with depth for sandy units. We evaluate the degree of ani- 
sotropy by comparing horizontal and vertical velocities where the vertical spacing between measurements is $<5 \mathrm{~m}$ and find no significant directional preference (Fig. F62C).

\section{Undrained shear strength}

A total of 46 shear strength measurements were made on split cores immediately after splitting using either a handheld Torvane device or a pocket penetrometer (Fig. F58H). The strength of the sediment determined which instrument was used. Measured ranges were 0-184 $\mathrm{kPa}$ for the Torvane and 86-221 $\mathrm{kPa}$ for the penetrometer. Three different adapters are available for the Torvane, and the strength of the sediment determined which adapter was used. Measurements needed to be converted to account for the size of the adapter and to change the units from kilograms per square centimeter into kilopascals (1.96 for the large adapter, 9.81 for the medium adapter, and 24.52 for the small adapter). In addition to the unit conversion, penetrometer readings were divided by 2 because the penetrometer is calibrated as an unconfined compression test equal to twice the undrained shear strength.

Most measurements were carried out on clayey material, and only a few measurements were made on sand. Values measured on sand are consistently lower than values measured on clayey material, probably because they are less consolidated and sand has been resuspended. Values of shear strength range from 1 to $221 \mathrm{kPa}$. In the upper part of the section (above $120 \mathrm{mbsf}$ ), shear strength increases with depth, most likely because of consolidation of the sediment caused by the increase of the effective stress. Consolidation in the upper part of the hole is confirmed by MAD measurements, which show an increase in bulk density and decrease in porosity with depth.

\section{Hole U1301B}

Physical property measurements in the basement section (Hole U1301B) included magnetic susceptibility measured on every section using the MST and discrete measurements of thermal conductivity, $P$ wave velocity, and MAD properties (bulk density, dry density, grain density, wet density, wet weight, dry weight, porosity, and void ratio) (Fig. F63; Table T20). Sampling frequency for the discrete samples was generally one per section, with extra samples collected where there were visibly significant changes in lithology, alteration, or texture of the core.

\section{Magnetic susceptibility}

Whole sections were run through the MST after the core liner was split, with sampling resolution set at 1 $\mathrm{cm}$ regardless of section continuity. Magnetic susceptibility was as great as $\sim 4000 \times 10^{-6}$ SI, with the highest values corresponding to massive lava flows recovered in Cores 301-U1301B-13R, 15R, and 18R, which were located at $\sim 430,445$, and 472 mbsf, respectively (Fig. F63A, F63B). Other lithologies (pillow lava and hyaloclastite) generally yield values $<2000 \times 10^{-6} \mathrm{SI}$, partly due to highly fractured layers and poor core recovery leading to large discontinuous sections, both of which act to reduce the magnetic susceptibility. No effort was made to correct for incomplete filling of the core liner or for discontinuous rock that is characteristic of this formation or to correct for voids due to the removal of whole-round sections for microbiological analysis (Fig. F64).

\section{Thermal conductivity}

A total of 365 individual measurements were made on 68 basalt samples over the interval of 351.2 to 576.3 mbsf (Fig. F63C; Table T20), with samples being chosen based on size, continuity, and absence of fractures or veins. A minimum length of $6 \mathrm{~cm}$ was required to achieve full contact between the sample and the thermal conductivity probe. Thermal conductivity measured on samples with lengths $\leq 6 \mathrm{~cm}$ tended to be slightly lower than the overall average, suggesting a bias due to small sample size. These values are plotted as open squares on Figure F63C. By making three to six individual measurements on each sample, we are able to evaluate the reliability of each point measurement by including error bars of $1 \sigma$.

Thermal conductivity values ranged from 1.17 to $1.84 \mathrm{~W} / \mathrm{m} \cdot \mathrm{K}$ (average $=1.70 \pm 0.10 \mathrm{~W} / \mathrm{m} \cdot \mathrm{K}$ ) over the depth range of 351.2-576.3 mbsf. Measurements were made on samples having varying lithology, porosity, and degrees of alteration; there is no statistically significant change in thermal conductivity with depth. Values $>1.75 \mathrm{~W} / \mathrm{m} \cdot \mathrm{K}$ consistently came from large massive samples ( $>6 \mathrm{~cm}$ in length), recovered in either massive flows or pillow basalts. The lowest values of 1.17 and $1.37 \mathrm{~W} / \mathrm{m} \cdot \mathrm{K}$ correspond to the two hyaloclastite samples from Cores 301U1301B-1R and 35R at depths of 351.2 and 564.7 mbsf, respectively. This suggests that recovery and sampling biases toward unfractured basalt skew the data toward higher values and likely provide an upper bound on the effective thermal conductivity of uppermost basement in this region.

\section{$P$-wave velocity}

A total of 106 discrete samples were initially collected from oriented cores for measurement of $P$ wave velocity, with roughly half being shared with the paleomagnetism group. Unlike samples collected 
for MAD property analysis, those collected for paleomagnetic investigation were not carefully cut and polished to ensure that the cut faces were flat and parallel. More than $95 \%$ of the samples were cut as 2 $\mathrm{cm} \times 2 \mathrm{~cm} \times 2 \mathrm{~cm}$ minicubes, allowing two horizontal velocities to be measured in addition to the vertical velocity. Only where lithology or structure precluded cutting of a minicube were round minicores collected, allowing $P$-wave measurement in one direction.

Following initial processing, the PWS3 transducer pair was found to be out of calibration. Samples shared with the paleomagnetism group that had not been heated were remeasured, along with those collected initially for $P$-wave determination only, reducing the overall sample number from 166 to 106 (Janus database run numbers 3512-3803). Compressional velocities were measured on 94 samples in the $\mathrm{x}$-direction (perpendicular to the half-cutting surface), 92 samples in the y-direction (parallel to the half-cutting surface), and 105 samples in the z-direction (vertical). The assignment of $\mathrm{x}$ - and $\mathrm{y}$-directions is arbitrary because basalt cores cannot be oriented in azimuth.

Velocity values ranged from a minimum of $3940 \mathrm{~m} / \mathrm{s}$ to a maximum of $5750 \mathrm{~m} / \mathrm{s}$ (Fig. F63D) (average = $5130 \pm 280 \mathrm{~m} / \mathrm{s}$ ). This average value is more than regional values determined using seismic reflection techniques (Rohr, 1994) and is consistent with shipboard sample values from Leg 168 (Shipboard Scientific Party, 1997). Velocities measured on samples used for paleomagnetism analysis tend to display a slightly higher degree of variability (due to the cutting/polishing differences stated previously), but mean values are generally consistent with those samples prepared for MAD property measurements. The lowest velocity was measured on a highly vesicular sample recovered from Core 301-U1301B-18R, located within a massive flow unit at a depth of $\sim 475$ mbsf. Additional samples recovered from the same lithologic unit include velocities as great as $\sim 5500$ $\mathrm{m} / \mathrm{s}$, demonstrating a high degree of heterogeneity. There is no statistically significant overall velocity trend with depth, although it appears that $P$-wave velocity may be locally reduced in areas of higher porosity or greater alteration and fracturing (discussed below). A comparison of horizontal velocity with vertical velocity for paleomagnetic and MAD property samples displays no anisotropy (Fig. F65).

\section{MAD properties}

A total of 83 discrete samples were collected from Hole U1301B for the determination of MAD properties (Fig. F63E, F63F, F63G). More than 95\% of the samples were cut as minicubes and were also used for velocity measurements, with the remainder consisting of nonoriented minicores or rock fragments with a minimum size of $\sim 5 \mathrm{~cm}^{3}$.

Bulk density spanned the range 1.86-3.03 g/ $\mathrm{cm}^{3}$ (average $=2.75 \pm 0.13 \mathrm{~g} / \mathrm{cm}^{3}$ ) (Fig. F63E). Grain density exhibited a similar distribution of $2.23-3.11 \mathrm{~g} / \mathrm{cm}^{3}$ (average $\left.=2.86 \pm 0.09 \mathrm{~g} / \mathrm{cm}^{3}\right)$ (Fig. F63F). The lowest values of both grain and bulk density were made in a highly brecciated hyaloclastite sample recovered from Core 301-U1301B-1R at 351.2 mbsf, whereas the highest density comes from the top of Core $14 \mathrm{R}$ at the boundary between a massive and pillow flow at 432 mbsf. Low values were also measured in a hyaloclastite flow recovered in Core 301-U1301B$35 \mathrm{R}$ from $\sim 562$ mbsf. Porosity values span the range $1.9 \%-30.3 \%$ (average $=5.8 \% \pm 3.5 \%$ ) (Fig. F63G). The strong heterogeneity of fractured crystalline rock is displayed by a single sequence recovered in Core 301-U1301B-18R at $\sim 472$ mbsf, where density and porosity are as variable over the $9 \mathrm{~m}$ thick massive section as they are over the entire $225 \mathrm{~m}$ cored interval from Cores 301-U1301B-2R through 36R.

Porosity values are inversely correlated with grain density, with minimum porosity values generally measured where grain densities were highest (Fig. F66A). Additionally, grain density variability decreases with decreasing porosity, possibly resulting from infilling of vesicles, fractures, and microcracks with precipitates and alteration minerals, as a result of basement alteration. Similar correlations between porosity and grain density were shown by Busch et al. (1992), Broglia and Moos (1988), and Carlson and Herrick (1990).

Similarly, seismic velocity and porosity are inversely correlated (Fig. F66B), which may be due in part to formation porosity but may also be an artifact of sample cracking and other core damage. The effect of decreasing grain density, which may be inferred to be a proxy for increasing basement alteration, on seismic velocity is shown in Figure F66C. Seismic velocity displays a loose positive correlation with grain density, with the majority of velocities decreasing from $>5500$ to $\sim 4750 \mathrm{~m} / \mathrm{s}$ while grain density decreases from $\sim 3.0$ to $\sim 2.7 \mathrm{~g} / \mathrm{cm}^{3}$.

\section{Thermal measurements}

Determining conductive heat flow through sediments at Site U1301 was an important part of the Expedition 301 plan to assess hydrogeologic conditions in basement. It was shown with data collected during and after Leg 168 that temperatures in upper basement in Holes 1026B and 1027C are identical to within a few degrees. These two holes are separated by $2.2 \mathrm{~km}$, and the top of basement in Hole $1027 \mathrm{C}$ is 
significantly deeper than that in Hole 1026B (see the "Expedition 301 summary" chapter). Upper basement temperatures would be considerably greater in Hole 1027C than in Hole 1026B if conditions were purely conductive. The upper basement temperature in Hole 1026C, located $1 \mathrm{~km}$ north of Hole 1026B, is somewhat cooler but still relatively consistent with other basement temperatures in the Second Ridge area. The measurement program in Hole U1301C, located $0.9 \mathrm{~km}$ south of Hole $1026 \mathrm{~B}$, was intended to determine whether nearly isothermal basement conditions extended this far south.

\section{Temperature measurements}

Two attempts to determine in situ temperatures in Hole U1301C were made with the APCT tool, and three attempts were made with the DVTP. Results are summarized in Table T21. The tools were held $10 \mathrm{~m}$ above mudline for $10 \mathrm{~min}$ during all deployments, to check bottom water temperature and intertool calibration, before measuring sediment temperatures. The first APCT tool measurement during Core 301U1301C-3H yielded what appears to be a clean record, although close inspection reveals evidence of probe motion during the first $150 \mathrm{~s}$ following tool penetration (Fig. F67A). The data are well fit by the standard cooling model, giving an extrapolated equilibrium temperature of $10.4^{\circ} \mathrm{C}$ (Fig. F67B). The deployment with Core 301-U1301C-5H initially appeared to be less reliable. The record indicates that the tool moved repeatedly during the first $200 \mathrm{~s}$ following penetration (Fig. F67A). The fit to the analytical model is only fair, and the extrapolated equilibrium temperature is $11.5^{\circ} \mathrm{C}$ (Fig. F67B).

APC penetration was incomplete in deeper cores and pull-out tension reached $60,000 \mathrm{lb}$, so we ended the APCT tool measurement program and switched over to the DVTP. The first DVTP deployment followed collection of Core 301-U1301C-9H. The temperature record indicates that there was considerable tool motion during the first $200 \mathrm{~s}$ and additional motion throughout the rest of the record, but the data are still usable (Fig. F68A). Interestingly, fitting of extremely early time and late time data to the analytical model yields essentially the same equilibrium temperature, $21.0^{\circ} \mathrm{C}$ (Fig. F68B). The DVTP was deployed again following collection of Core 301U1301C-14H. This core barrel did not stroke out completely, so prior to DVTP deployment the hole was advanced $3.0 \mathrm{~m}$. Unfortunately, the DVTP failed to penetrate the undisturbed formation and the data collected are not usable (Fig. F68A). The DVTP was deployed a final time after collection of Core 301U1301C-19H. The hole was advanced $1.0 \mathrm{~m}$ immedi- ately prior to DVTP deployment to avoid pressing the tool into fill. The temperature record shows motion throughout the first $400 \mathrm{~s}$ after penetration, but the data stabilize near a maximum temperature of $58.2^{\circ} \mathrm{C}$. Not surprisingly, fitting the late-time data to the equilibration model yields the same temperature.

\section{Data interpretation}

A plot of temperature versus depth in Hole U1301C shows that most of the data are consistent with a linear gradient of $0.228^{\circ} \mathrm{C} / \mathrm{m}$ (Fig. F69A). This gradient was estimated from three subseafloor temperature values (Cores 301-U1301C-5H, 9H, and $17 \mathrm{H}$ ) and a bottom water temperature of $1.88^{\circ} \mathrm{C}$. This is the bottom water temperature determined during heat flow surveys prior to Expedition 301, and it is consistent with measurements made just above mudline with the APCT tool. The DVTP gave bottom water temperatures $0.05^{\circ} \mathrm{C}$ lower, and all DVTP values have been shifted to account for this difference. Uncertainties in estimated equilibrium temperatures are based on the fit of the data to the models used for extrapolation, using a reasonable range of sediment thermal conductivities (Table T21). Thermal conductivity is notoriously variable in turbidites, and it is difficult to determine the true value at the exact location of tool penetration for both the APCT tool and the DVTP. Uncertainties in equilibrium sediment temperatures are smaller than the symbols shown in the thermal gradient plot (Fig. F69A).

The equilibrium temperature from APCT tool deployment in Core 301-U1301C-3H is anomalously warm relative to the gradient suggested by the other data. There is a history of APCT tool equilibrium values being inconsistent with those determined with the DVTP (for example, see fig. 58A of Shipboard Scientific Party, 1997), but it is surprising that the measurement of Core 301-U1301C-5H is more consistent with DVTP data than of Core 301-U1301C-3H because the latter data appear to be less influenced by tool motion (Fig. F67A).

Because core recovery was limited and biased in Hole U1301C, we do not have a representative set of thermal conductivity data for the sediment section. Considerably more data were collected at nearby Sites 1026 and 1027, but even these data were likely biased by incomplete, selective recovery. Davis et al. (1999) adjusted thermal conductivity data collected during Leg 168 based on sediment thickness (determined during drilling) and seafloor heat flow (determined during predrilling site surveys with short probes). They used observed thermal conductivities to derive a thermal resistance $\left(R_{z}\right)$ versus depth $(z)$ 
function, a third-order polynomial, and then linearly shifted this function to force the equilibrium temperatures determined during drilling to yield the seafloor heat flow. The function derived for Sites 1026 and 1027 is

$$
R_{z}=0.701 z+6.18 \times 10^{-4} z^{2}-7.95 \times 10^{-7} z^{3},
$$

where $R_{\mathrm{z}}$ is in $\mathrm{m}^{2} \cdot \mathrm{K} / \mathrm{W}$ and depth is in meters. We use this same function for calculation of heat flow in Hole U1301C.

Heat flow in Hole U1301C is $280 \mathrm{~mW} / \mathrm{m}^{2}$ (Fig. F69B). This value is lower than that determined in Holes $1026 \mathrm{~A}$ or $1026 \mathrm{C}$, to the north, but is consistent with basement being roughly isothermal and sediment being thicker in Hole U1301C. The extrapolated temperature at the top of basement in Hole $\mathrm{U} 1301 \mathrm{C}$ (estimated to be at $265 \mathrm{mbsf}$ ) is $62^{\circ} \mathrm{C}$, essentially the same value estimated for Hole 1026C and slightly lower than the value estimated in open Hole 1026B. Thus, the thermal data from Hole U1301C suggest that isothermality of uppermost basement temperatures extends along $2 \mathrm{~km}$ of the buried basement ridge, from Hole $1026 \mathrm{C}$ in the north to Hole U1301C in the south.

\section{Packer experiments Hole U1301A}

The drill string packer was deployed in single-element mode in casing in Hole U1301A to assess the permeability of upper basement between the base of casing (14.9 $\mathrm{m}$ into basement) and the bottom of open hole. Inflation of the packer within the open hole was precluded by poor hole conditions and the large diameter of the hole, which was drilled with a $14 \% / 4$ inch bit. The packer was positioned at $267 \mathrm{mbsf}$, $10 \mathrm{~m}$ above the casing shoe (Fig. F70), and the ship's mud pump was used for all operations. The experiments were conducted after the pipe trip to drill out the cement at the 103/4 inch casing shoe and a check of open hole depth without rotation or circulation (see "Operations"). The depth check had indicated an obstruction at a depth of $34 \mathrm{~m}$ into basement, compared to total drilled depth of $107.5 \mathrm{~m}$ into basement. Given that the depth check was made without rotation or circulation, we assume that the obstruction was incomplete and that the hydraulically tested interval comprises the $92.6 \mathrm{~m}$ section between casing and total drilled depth. However, an alternate interpretation is also possible: that the only interval open to the hydrologic testing was the $18.7 \mathrm{~m}$ between casing and the depth reached during the depth check.

Two Geophysical Research Corporation Model ERPG-300 electronic pressure gauges (SN 78743 and
78745) were deployed in the packer go-devil. Their records of pressures and internal gauge temperatures are shown in Figure F71. After the go-devil landed but before the packer was inflated, hydrostatic baseline pressure was recorded for $1 \mathrm{~h}$. Then the packer was inflated at $1000 \mathrm{psi}(6.9 \mathrm{MPa})$, after which the sealed-hole pressure baseline was recorded for $1 \mathrm{~h}$. A series of five constant-rate injection tests was conducted at $15 \mathrm{spm}$ (equivalent to $5 \mathrm{gpm}$ or $0.3 \mathrm{~L} / \mathrm{s}$ ) for $30 \mathrm{~min}, 30 \mathrm{spm}$ for $45 \mathrm{~min}, 50 \mathrm{spm}$ for $1 \mathrm{~h}, 75 \mathrm{spm}$ for $2 \mathrm{~h}$, and $100 \mathrm{spm}$ for $1 \mathrm{~h}$. Following each period of injection, the pressure recovery was monitored for a period of the same duration as the respective pumping time. The last three injection tests were of longer duration than any attempted previously in DSDP or ODP and were intended to investigate to greater radial distance into the formation than previous packer experiments in upper oceanic basement.

The pressure records from the two gauges (Fig. F71), which had been recalibrated by the manufacturer just before Expedition 301, are offset by $\sim 15 \mathrm{kPa}$ because the depths of the sensing points differed by $\sim 1.5 \mathrm{~m}$. During periods of no pumping, the records show strong trends in the baseline readings (pressures increasing with time) that we interpret as transient recovery effects from the thermal perturbations to near-borehole fluid densities due to circulation during prior drilling operations. Owing to the timing of these operations and the depth of penetration of the hole into an overpressured setting, these trends are stronger than any observed in previous packer experiments in other crustal holes. They are also opposite in sign to the additional transient thermal perturbations induced by the pumping of cool fluids into the formation during the injection tests themselves. Because of the masking effects of these opposing thermal effects, the pressure rises recorded during the injection tests do not conform to behavior commonly seen during injection testing (in the limit, linear with log time). Thus, full interpretation of these tests will require correction to the recorded pressures for the two kinds of thermal perturbations to borehole fluid densities and pressures, calculations that may require careful numerical modeling.

During the injection tests, the magnitudes of the responses recorded by gauge 78745 were greater than those recorded by gauge 78743 , despite the fact that gauge 78745 was installed in the shallower, somewhat more isolated position in the go-devil. The difference in gauge response cannot be explained easily, but may be partly a result of hydrodynamic effects during the relatively high volume pumping combined with relatively low signal level in terms of response from the highly permeable formation. Although the uncorrected pressure data do not conform to ideal behavior, preliminary shipboard in- 
terpretations for all but the first injection test at the lowest rate were made using Glover's formula (Snow, 1968), which applies to the case in which the pressure rise on injection reaches a nearly steady state value. We used the abrupt pressure drop at the end of injection as an approximation to the nearly steady state pressure rise achieved during injection. The results (using the signals from either gauge) indicate a permeability on the order of $3 \times 10^{-11}$ to $5 \times 10^{-11} \mathrm{~m}^{2}$ when averaged over the $92.6 \mathrm{~m}$ basement section drilled below casing. This preliminary value lies between indications of (1) lower permeability at shorter length scales from shorter-duration Leg 168 packer experiments in Holes 1026B and 1027C and (2) higher permeability at much larger scales on the same ridge flank from earlier CORK observations and thermal modeling. Thus, preliminary indications are that the results are consistent with and complement previous reports of a spatial scale effect of permeability of uppermost basement on the flank of the Juan de Fuca Ridge (Becker and Fisher, 2000; Becker and Davis, 2003).

\section{Hole U1301B}

In Hole U1301B, the drill string packer was successfully inflated in single-element mode at three positions in open hole that were chosen primarily on the basis of caliper and density information from the wireline logs. In sequence, the three packer seats were at 472 mbsf (3140 mbrf), $442 \mathrm{mbsf}$ (3110 mbrf), and 417 mbsf (3085 mbrf). In contrast to Hole U1301A, conditions in Hole U1301B were excellent (aside from the gap in the $103 / 4$ inch casing string above the tested interval), and the hole was open to the full drilled depth of $582.6 \mathrm{mbsf}$, or $317.6 \mathrm{~m}$ into basement. The inflation/test sequence was designed to determine the permeability of upper basement at deeper levels than tested in Hole U1301A, for one of the few assessments of the depth variation of upper basement permeability in the ocean crust. More specifically, the test sequence was conducted to allow (1) direct measurement of the bulk permeabilities of three zones of upper basement between those inflation depths and the bottom of open hole and (2) indirect assessment of the permeabilities of the thinner zones between inflation depths by taking differences of transmissivities calculated for the larger zones measured directly. At the conclusion of the hydrologic testing program, the packer was also successfully inflated shallower in the hole for a brief test of the suitability of a likely seat for the CORK packers at 3047 mbrf, or 379 mbsf.

The same ERPG-300 electronic pressure gauges used earlier were deployed in the packer go-devil, and the ship's mud pump was used for all operations. The records of gauge pressure and internal temperature for 78745 are shown in Figure F72. After the go-devil landed at the first inflation depth but before the packer was inflated, hydrostatic baseline pressure was recorded for $1 \mathrm{~h}$. Then the packer was inflated at $\sim 1000$ psi $(6.9 \mathrm{MPa})$, after which the sealed-hole pressure baseline was recorded for $1 \mathrm{~h}$. At the first inflation depth, a single slug test was conducted, but this decayed rapidly and only constant-rate injection tests were conducted thereafter at all inflation depths. Under the expectation that permeabilities deeper in basement in Hole U1301B would be less than those in the shallower basement section in Hole U1301A, lower rates of injection were used in Hole U1301B: 11, 20, and $30 \mathrm{spm}$ for the inflation at $472 \mathrm{mbsf}$ and 15 and $30 \mathrm{spm}$ for the inflations at 442 and 417 mbsf. Injection periods were all $1 \mathrm{~h}$, and each was followed by a $1 \mathrm{~h}$ period of pressure recovery.

As in Hole U1301A, the pressure records from the two recently recalibrated gauges were offset by $\sim 15$ $\mathrm{kPa}$ because the depths of the sensing points differed by $\sim 1.5 \mathrm{~m}$. Also as in Hole U1301A, the magnitudes of responses recorded by the two gauges differed significantly, despite the relative consistency of the hydrostatic reference readings. When the gauges were recovered from the testing in Hole U1301B, the screened carrier for the gauge showing lower-magnitude response (78743) was observed to be fouled with rust particles, and it is inferred that this may have attenuated the gauge response. This carrier also held the same gauge for the testing in Hole U1301A, during which that gauge also recorded a lower-magnitude relative response. Thus, the record from gauge 78745 is considered a more reliable indicator of actual borehole pressure response during the testing in both Holes U1301A and U1301B.

During periods of no pumping, some of the records show trends in the baseline readings like those seen in Hole U1301A (pressures increasing with time) that we interpret as transient recovery effects from the thermal perturbations to near-borehole fluid densities due to circulation during prior drilling operations. However, the effect was less significant in Hole U1301B than in Hole U1301A, with the exception of the intermediate inflation depth of 442 mbsf. Again, full interpretation of these tests will require correction to the recorded pressures for the thermal perturbations to borehole fluid densities and pressures, calculations that may require careful numerical modeling.

Nevertheless, the uncorrected pressure data conform to ideal behavior much better in Hole U1301B, partly because the thermal perturbation effects were less and also because lower injection rates were used 
in Hole U1301B. As for Hole U1301A, preliminary shipboard interpretations were made using Glover's formula (Snow, 1968), using the nearly instantaneous pressure drops at the ends of injection periods as approximations to the near steady-state pressure rises achieved during injection. The results suggest permeabilities on the order of $1 \times 10^{-11} \mathrm{~m}^{2}$ for the three zones tested, spanning 152-317.6 $\mathrm{m}$ into basement. This preliminary value is less than the $3 \times$ $10^{-11}$ to $5 \times 10^{-11} \mathrm{~m}^{2}$ suggested for the shallower basement interval in Hole U1301A. If borne out by more complete analysis, the preliminary processing would suggest only a slight reduction of permeability of upper basement with depth at Site U1301 and a thicker zone of highly permeable uppermost basement than interpreted at the older ridge flank sites (ODP Sites 504 and 896) in 6 Ma crust on the Costa Rica Rift (Becker, 1996).

\section{Wireline logging}

\section{Hole U1301B}

A wiper trip was completed throughout open hole before the start of the wireline logging operations. The hole was circulated with $50 \mathrm{bbl}$ of sepiolite mud, which was not displaced, and the pipe was pulled out of the hole so that the bit could be dropped on the seafloor. Wireline logging operations required $35.25 \mathrm{~h}$ beginning at $0415 \mathrm{~h}$ on 1 August. The wireline logging operations consisted of four tool string deployments in the following order (Table T22):

1. The triple combo tool string consisting of an LEHMT cable head with sensors for measuring spontaneous potential (SP), temperature, and tension; the HNGS; the HLDS; the APS; and the QAIT.

2. The UBI tool string consisting of the LEH-MT with sensors for measuring SP, temperature, and tension; the Scintillation Gamma Ray Tool (SGT); the GPIT; and the UBI.

3. The FMS-sonic tool string consisting of the LEHMT with sensors for measuring SP, temperature, and tension, the SGT; the DSI; the GPIT; and the FMS.

4. The WST string.

\section{First deployment: triple combo string}

The drill pipe was set in casing at a depth of 265.2 mbsf (2933 mbrf), which is below the depth in casing where we had problems passing the bit during reentry (257.8 mbsf; 2925.6 mbrf). During the rig-up, a grounding cable was connected from the winch unit to the drill pipe to serve as the contact for the surface electrode that was used for SP measurements. The tool string was then assembled and run in the hole at $2500 \mathrm{~m} / \mathrm{h}$.
A downgoing log was recorded, starting before reaching seafloor to a total depth of 578.2 mbsf (3246 mbrf), where $\sim 4 \mathrm{~m}$ of fill at the bottom of the hole was encountered, and the APS minitron source was put in standby mode $50 \mathrm{~m}$ above total depth and before commencing the first uphole log. Two uphole logs were then recorded, with the first pass recording from 578.2 to $298 \mathrm{mbsf}$ ( $2965.3 \mathrm{mbrf}$ ) and the second pass recording from $454.2 \mathrm{mbsf}$ (3122 mbrf) to past seafloor on the way back to the rig floor. The caliper arm was opened at $574.2 \mathrm{mbsf}$ (3242 mbrf) during first uphole log, and a caliper check was done inside the casing to confirm the calibration but was closed before entering the drill pipe. Once the first uphole log was finished, the APS minitron was shut down after closing the caliper arm inside the casing, and it was put in standby mode $50 \mathrm{~m}$ above the total depth of the second uphole log. The second uphole logging pass was planned to repeat a section of the borehole that was measured during the first pass for quality control purposes. Caliper measurements showed that the upper $50 \mathrm{~m}$ of the open hole was enlarged and irregular, so a larger interval was chosen for the repeat pass to ensure that data were collected over a depth interval that included good borehole conditions. No problems were encountered during either pass.

\section{Second deployment: UBI tool string}

Operations began by picking up the top drive because this would allow us to raise the drill string while logging so that we could image a section of $103 / 4$ inch casing that was thought to either have a hole in it or to have separated from the rest of the casing. This procedure required us to break and reconnect the wireline torpedo connection. We lowered the tool string at $400 \mathrm{~m} / \mathrm{h}$ because it was so light but increased the speed to $\sim 2500 \mathrm{~m} / \mathrm{h}$ as cable weight increased. An obstruction was found in the hole at 428.2 mbsf (3096 mbrf). Several attempts to get past the obstruction by running down the tool string at different speeds failed, and we decided to $\log$ the open hole and casing above this depth.

The open hole interval (428.2-346.1 mbsf) was logged with two full passes. The second pass stopped at 353.2 mbsf (3021 mbrf) to change the data acquisition configuration of the UBI to casing mode, the pipe was raised to a depth of $246.2 \mathrm{mbsf}$ ( $2914 \mathrm{mbrf}$ ), and data were recorded inside the casing and up to seafloor. The tool was returned to the surface without incident, although some cable speed fluctuations were observed in the winch unit during the tool deployment. Variations in tool acceleration during acquisition were $\pm 1 \mathrm{~m} / \mathrm{s}^{2}$. 


\section{Third deployment: FMS-sonic tool string}

Rig-up was completed and the tool string was deployed through the pipe at $\sim 2500 \mathrm{~m} / \mathrm{h}$. The deployment was stopped at $232.2 \mathrm{mbsf}$ (2900 mbrf) to check operation of the new wireline heave compensator (WHC). Surface and downhole acceleration measurements were recorded with the surface moonpool instrumentation and the GPIT, respectively. The station consisted of $15 \mathrm{~min}$ with the WHC on and 15 min with the WHC off. At the conclusion of the WHC station, the tool string was lowered into the open hole to begin logging operations.

The first pass reached nearly the same depth as the UBI deployment, 427.2 mbsf (3095 mbrf). Several attempts were made to go past the hole obstruction, but they all failed and logging operations began from this depth. Cable speed fluctuations were also observed throughout most of the deployment as during the UBI deployment. The first pass continued into the $103 / 4$ inch casing to check the caliper calibrations, and the tool string was then lowered to the bottom of the unobstructed interval to begin the second pass.

A brief indication of low overpull $(\sim 340 \mathrm{lb})$ was recorded during the second pass at $\sim 404.2$ mbsf (3072 mbrf), and shortly thereafter, one FMS caliper (C2) began to behave erratically. After the second pass, operations in the open hole were finished, the calipers were closed, and data acquisition was stopped shortly before entering the $10^{3 / 4}$ inch casing shoe. The DSI was reconfigured to the cement bond mode to look at the bottom of the casing shoe and the gap in the casing, and the pipe was raised to $242.2 \mathrm{mbsf}$ (2910 mbrf). The caliper arms were opened inside the $103 / 4$ inch casing at $268.2 \mathrm{mbsf}$ (2936 mbrf) to check caliper $\mathrm{C} 2$, and this caliper read 4 inches, whereas $\mathrm{C} 1$ read $\sim 10$ inches. The tool string was pulled up past the casing gap.

Once above the casing gap, the caliper arms were closed and the tool string was brought to the end of the pipe, where it became stuck. The tool string was lowered back inside the casing, and the caliper arms were opened and closed once again. The tool string was brought back inside the end of pipe, and once again it became stuck. A maximum of $7800 \mathrm{lb}$ was pulled to try to get the tool string free, and after failing, the pipe was lowered several meters in case there was an obstruction in the casing that may have impeded the tool's motion. At this time, the tool string was wedged and partially sticking out of the end of the drill pipe with no ability to move in or out. We then began pumping for several minutes followed by a series of hard pulls in the range of $6500-7800 \mathrm{lb}$. After several iterations of this technique, the tool string began to move inside the pipe and was finally retrieved to the surface. We spent $\sim 2 \mathrm{~h}$ trying to get the tool string past the end of the drill pipe. When the tool string was recovered on the rig floor, the FMS C2 caliper had lost part of the imaging pad, the outer cover of the caliper that serves as a housing for the pad wiring, and the arm expansion springs.

Preliminary observations suggest that during the second pass and while still in the open hole, the tool string probably hit a ledge or otherwise damaged the upper joint of the $\mathrm{C} 2$ and the closing mechanism. This caused the arm to show erratic responses and prevented complete closure. In addition, the lower $50 \mathrm{~m}$ of cable was kinked. We cut and reterminated the cable and prepared a new rope socket for the next deployment.

\section{Fourth deployment: WST tool string (vertical seismic profile)}

The original logging plan included use of the WST-3 for obtaining a zero-offset VSP. However, when we powered up the WST-3 on deck, it did not respond, even though a deck check 2 days earlier did not show any problems. The clamping arms were opened and closed several times using the manual control box, but the tool did not respond once power was supplied. After the unsuccessful attempts, the WST-3 was replaced with the WST. The WST powered up on deck and all diagnostic checks were positive. The Schlumberger winch unit was used for the WST data acquisition.

Rig-up procedures began after sunrise with several observers in place for compliance with the IODP marine mammal policy. The procedure included a $1 \mathrm{~h}$ observation period prior to the use of the seismic source, where the mate on watch and the marine mammal observers on the aft end of the ship began observations. Observations continued throughout the duration of the seismic experiment, and no marine mammals were sighted within the $700 \mathrm{~m}$ safety zone. After the initial observation period, the "soft start" procedure began with the seismic source being fired at $30 \mathrm{~s}$ intervals starting at a pressure of $500 \mathrm{psi}$ and gradually increasing the pressure to the "operational" pressure of 2000 psi over a $30 \mathrm{~min}$ period.

A GI seismic source consisting of a 45 inch $^{3}$ generator chamber volume and a 105 inch $^{3}$ injector chamber volume was used for the experiment. The generator produced the primary pulse, while the injector controlled the oscillation of the bubble produced by the generator. The GI seismic source was operated at 2000 psi air pressure with a time delay between the generator and injector shots of $40 \mathrm{~ms}$. The GI seismic source was deployed using the JOIDES Resolution portside crane number 3 and suspended with a floating buoy at a depth of $2 \mathrm{~m}$ below the sea surface (Fig. 
F73). The seismic source was located $14.6 \mathrm{~m}$ from the ship, and the length between the GI seismic source and the center of the moonpool was $44 \mathrm{~m}$. The overthe-side monitoring hydrophone was placed $2.3 \mathrm{~m}$ below the GI seismic source, and we confirmed that the source wavelet had minimum phase. After each shot, $5 \mathrm{~s}$ was recorded with a starting point of 600 $\mathrm{ms}$ and a sampling rate of $1 \mathrm{~ms}$.

The WST took $2 \mathrm{~h}$ to reach the seafloor because of the tool's light weight. On several occasions, we stopped to close the clamping arm, as we suspected that it opened periodically during descent. The initial downgoing speed was $\sim 305 \mathrm{~m} / \mathrm{h}$ and increased to $\sim 2350 \mathrm{~m} / \mathrm{h}$ with depth. Based on caliper observations from previous logging runs, three potential intervals were identified for WST stations. These were at 407.2 mbsf (3075 mbrf), $382.2 \mathrm{mbsf}$ (3050 mbrf), and 357.2 mbsf (3025 mbrf). Shots were taken at all three approximate depths, and details are presented in Table T22.

The experiment concluded at $1150 \mathrm{~h}$ on 2 August, when fog covered the area and poor visibility did not allow us to monitor the $700 \mathrm{~m}$ radius stipulated in the marine mammal policy. The tool's retrieval speed was slowed down to $\sim 760 \mathrm{~m} / \mathrm{h}$ to allow the rig floor crew to work on the AHC system, after which we increased the speed to $\sim 2740 \mathrm{~m} / \mathrm{h}$. Once the tool was back on the rig floor, we noticed that the clamping arms were fully extended, although they had been closed before entering the pipe.

\section{Depth shifting of logs}

Depth shifts begin with the selection of a reference (base) $\log$ (usually the total gamma ray log from the run with the greatest vertical extent and no sudden changes in cable speed), and features in equivalent logs from other runs are aligned by eye. The depth adjustments that are required to bring the match log in line with the base log are applied to all the other data sets from the same tool string.

Proper depth shifting of wireline logging depths relative to pipe depths was essential both to achieve scientific goals and to assess the state of the $103 / 4$ inch casing string, as described below. Local tides during Expedition 301 created ambiguity as to relative depths for all measurements, with typical uncertainties of 1-3 m (see "Operations" and Fig. F6). In addition, because of uncertainty as to the depth of the $103 / 4$ inch casing shoe, we could not use this as a depth reference from which we could "hang" wireline logging data.

There are two other targets that offered potential wireline logging depth references: the seafloor and the sediment/basement interface. However, data ac- quired across the seafloor resulted from logging through the drill string and a reentry cone, so data from this interval are of poor quality. Depth matching between logging passes across this interval was difficult because of the low gamma radiation levels and general lack of significant features in the gamma ray logs that could be matched. The natural gamma ray record across the sediment/basement contact proved to be more useful, with caliper logs used for additional interlog comparison. Drilling data (penetration rate and torque) suggested that the sediment/ basement interface was located at 265 mbsf (2933 mbrf), and this coincided with an abrupt (local) decrease in natural gamma radiation as detected with the FMS tool string. Caliper logs from the triple combo and FMS strings suggested that these two strings were matching within $1 \mathrm{~m}$ of each other, with the FMS string being $\sim 1 \mathrm{~m}$ deeper. Based on these observations and the relatively short logged interval, differential depth matching, which includes stretching and squeezing the depth scale to line up common features, was not done and only block shifts were applied.

Some common features could be identified in the caliper logs-for example, the base of a zone where the hole widened (404 mbsf) and the base of the 103/4 inch casing (352 mbsf). As shown in Table T22, depth shifts were applied to align these log features with each other, to match the step in gamma ray in the casing logs to the sediment/basement interface at 2933 mbrf (268 mbsf) and to fit the driller's seafloor depth of 2667.8 mbrf. All logging depths discussed in the rest of this report have been depth shifted accordingly.

\section{Logging data used to assess $103 / 4$ inch casing geometry}

We had two casing depth "targets" we hoped to identify using the various logging tools. First, we intended to identify the depth of the $103 / 4$ inch casing shoe. This was originally cemented into place at 346 mbsf (3014 mbrf), but it was possible that the lower section of casing had slipped downward after cementing if the casing had parted somewhere in the middle of the string. Second, we hoped to identify the dimensions and geometry of a suspected gap in the casing that was responsible for obstructing the drill pipe during previous operations (see "Operations") at 250-258 mbsf (2918-2926 mbrf). Even taking into account uncertainties associated with local tides (1-3 m), the variations in the depth of the obstruction in casing suggested that the gap had changed shape over time.

Results from the triple combo and FMS strings were relatively consistent with regard to the depth of the 
$103 / 4$ inch casing shoe, but these results were inconsistent with results from the UBI tool. The caliper logs from the triple combo tool string and the FMS tool string demonstrate convincingly that the casing shoe is located at $352 \mathrm{mbsf}$ (3020 mbrf). UBI data suggest that the casing shoe is located at $357 \mathrm{mbsf}$ (3025 mbrf), $11 \mathrm{~m}$ deeper than originally placed and $7 \mathrm{~m}$ deeper than the $143 / 4$ inch rat hole. The casing shoe depth indicated by the triple combo and FMS calipers makes more sense operationally than that indicated by the UBI tool, since the former places the casing shoe just $2 \mathrm{~m}$ deeper than the $143 / 4$ inch rat hole. For these reasons, we place the depth of the casing shoe based on logging data at 352 mbsf (3020 mbrf).

Data collected with the FMS and UBI tool strings also can be used to assess the geometry of the $10^{3 / 4}$ inch casing gap, but unfortunately results from both tools are inconsistent with operational data. Both the FMS and UBI tools suggest that the base of the casing gap is located at $263 \mathrm{mbsf}$ ( $2931 \mathrm{mbrf}$ ), whereas repeated trips across the gap with the drill string indicate that the primary obstruction, interpreted to be the top of the lower section of casing, is located at $258 \mathrm{mbsf}$ (2926 mbrf), a difference of $5 \mathrm{~m}$. Interestingly, this difference is the same as that found for the casing shoe, comparing the triple combo and FMS calipers to the UBI tool. Because the most likely explanation for the casing gap is separation at a casing joint, we can use the known lengths of casing joints to determine the most likely geometry for the gap. With the $103 / 4$ inch casing shoe placed at 352 mbsf (3020 mbrf), based on caliper logs described above, the bottom of the $103 / 4$ inch casing gap should be at $257-$ 258 mbsf (2925-2926 mbrf), consistent with the location of the obstruction determined repeatedly with the drill pipe. Both the FMS and UBI tools place the top of the casing gap at 252 mbsf (2920 mbrf), and this depth is inconsistent with consideration of casing joint lengths and the estimated depth of the $103 / 4$ inch casing hanger. The most reliable indicators suggest that the casing gap is $\sim 5-6 \mathrm{~m}$ thick. It remains unclear why the FMS and UBI tools indicate a greater gap thickness $(\sim 10-11 \mathrm{~m})$ and a downward shift of the base of the gap.

\section{Results and data quality}

The quality of wireline logging data was assessed by evaluating whether logged values are reasonable for the lithologies encountered, by checking consistency between different passes of the same tool, and by correspondence between logs affected by the same formation property (e.g., the resistivity log should show similar features to the sonic velocity $\log$ ). Gamma ray logs recorded through BHA and drill pipe should be used only qualitatively because of signal attenuation and noise. A wide ( $>12$ inch) and/or irregular borehole affects most recordings, particularly those that require eccentralization and a good contact with the borehole wall (HLDS and APS). Hole diameter was recorded by the hydraulic caliper on the HLDS tool (LCAL) and by the calipers on the FMS tool (C1 and C2). The triple combo was the only tool string that could be lowered to the bottom of Hole U1301B. Good repeatability was observed between the main and repeat passes from 450 to $350 \mathrm{mbsf}$, particularly for measurements of neutron porosity, density, and photoelectric factor. The caliper arm from the HLDS shows that the borehole is almost in gauge below $\sim 464$ mbsf but very irregular and oversized between 352 and 464 mbsf, reaching >18 inches between 395 and 405 mbsf (Fig. F72). The sonic velocity logs contain minor intervals of poorquality data but are mostly reliable in sections where the borehole is not enlarged.

\section{Electrical resistivity measurements}

A total of 15 electrical resistivity curves were obtained with the QAIT. These resistivity profiles represent five different depths of investigation into the formation $(10,20,30,60$, and 90 inches) and three different vertical resolutions (1, 2, and $4 \mathrm{ft}$ ). Some of the resistivity curves show small spikes of high electrical resistivity values reaching up to $1950 \Omega \mathrm{m}$; however, most of the resistivity values within the basement range between 0.3 and $150 \Omega \mathrm{m}$. Among the set of resistivity curves, the 10 inch depth of investigation curves show lower electrical resistivity values than the other resistivity curves of the same vertical resolution. Despite some scattering within the data, most curves follow similar trends. For example, there is remarkably little variation in formation electrical resistivity with depth (Fig. F74). Interestingly, the shorter-spaced log (AF-10) suggests a systematic increase in resistivity with depth through the logged interval.

\section{Neutron porosity measurements}

Neutron porosity values show a large range from $4 \%$ to $100 \%$. Neutron porosity values are particularly high above $~ 462$ mbsf, where the borehole is enlarged, and are lower in the bottommost part of the hole, where values are mostly between $5 \%$ and $20 \%$. The latter values are closer to porosities measured on core samples, which range from $2 \%$ to $9 \%$ and have a mean value of 5\% (see "Physical properties"). High neutron porosity values measured above 462 mbsf can be attributed either to the tool losing contact with the borehole wall, the high degree of frac- 
turing, or the presence of clays in veins, hydrous vesicle fillings, or altered groundmass (see "Igneous and metamorphic petrology").

\section{Density and photoelectric factor}

Density values range from 1.23 to slightly more than $3.00 \mathrm{~g} / \mathrm{cm}^{3}$ over the entire section of the open hole. Below 462 mbsf, density values are between 2.5 and $3.0 \mathrm{~g} / \mathrm{cm}^{3}$ and close to the range of values measured on core samples, which average $2.78 \pm 0.08 \mathrm{~g} / \mathrm{cm}^{3}$ (see "Physical properties"), except for some local intervals that may be associated with fractures. Above 460 mbsf, density values are lower because of the irregular and enlarged shape of the borehole. Photoelectric factor values range between 0.89 and $6.69 \mathrm{~b} / \mathrm{e}^{-}$. Values tend to be higher below $462 \mathrm{mbsf}$ than in the shallower section.

\section{Gamma ray measurements}

Gamma ray measurements in basaltic oceanic crust are typically low (e.g., Bartetzko et al., 2001; Barr et al., 2002). Total gamma ray values (HSGR) obtained with the triple combo tool string range from 5.3 to 13.2 gAPI. Potassium values are low, with values between 0 and $0.48 \mathrm{wt} \%$. Thorium and uranium values are mostly between 0 and $1 \mathrm{ppm}$.

\section{Spontaneous potential measurements}

Values of spontaneous potential from the main triple combo logging run vary between -170 and $24 \mathrm{mV}$. Values increase within the enlarged borehole sections and decrease within more massive intervals. Particularly low values are observed above $378 \mathrm{mbsf}$, which is above the strongly oversized interval from 380 to 390 mbsf.

\section{Sonic velocity measurements}

Shipboard slowness time coherence analyses were used for estimating $P$ - and $S$-wave velocities by correlating digital waveform signals recorded at each receiver. $P$-wave velocities obtained with the DSI range from 4000 to $6000 \mathrm{~m} / \mathrm{s}$ and correlate well with the average laboratory velocity measurements of $\sim 5300$ $\mathrm{m} / \mathrm{s}$ obtained from core samples (Fig. F75). $S$-wave velocities range from 2000 to $3000 \mathrm{~m} / \mathrm{s}$ (Fig. F75). However, several sections have anomalously high or low velocities, especially below $385 \mathrm{mbsf}$, where both $P$ - and $S$-wave velocities are low because the borehole is enlarged and irregular. Estimation of accurate velocities within those sections will require postcruise processing. At this point, it is difficult to identify significant trends of $P$ - and $S$-wave velocity with depth and lithology.

\section{Seismic velocity measurements}

Recorded waveforms from the VSP experiment with the WST at 402.2 mbsf (shots 91-94) are too noisy for analysis. The first five waveforms at $413.6 \mathrm{mbsf}$ (shots 72-76) are also noisy and could not be used for analysis. At these stations, the WST may have slipped along the borehole.

The waveforms at each of the good stations were stacked (Fig. F76A), and a traveltime was determined from the first breaks (Orcutt, Schultz, Davies, et al., 2003). In some instances, it is difficult to determine the first break, so we also used the median of the first break for each stacked trace to determine interval velocities (Fig. F76B). The gradient of the traveltime first break used to estimate an interval velocity produced a result of $\sim 5220 \mathrm{~m} / \mathrm{s}$, whereas the median yielded an interval velocity of $4990 \mathrm{~m} / \mathrm{s}$. Core sample and sonic logging measurements show a slightly higher range of velocities, and the difference may reflect the different scales of core measurements, sonic logs, and seismic experiments.

\section{Lithostratigraphic correlations}

Except for the enlarged borehole sections, most measurements do not show statistically significant variations. This may result from the lithology primarily consisting of pillow basalts throughout the logged interval (see "Igneous and metamorphic petrology"). Overall, 21 logging units were identified using mainly density, porosity, and photoelectric effect profiles obtained with the triple combo over the entire open hole section (Fig. F74). Most of the units are characterized by massive sections bounded by fractured or brecciated intervals (Fig. F74). In the narrower borehole intervals, massive flow of Units 2, 4 , and 6 can also be identified in the downhole logs as slight increases in electrical resistivity, low neutron porosity, and high density values (Fig. F74). Pillow basalt Subunit $1 \mathrm{C}$ and Units 3 and 5 coincide with the enlarged borehole intervals above 462 mbsf. Pillow basalt Unit 7 is located at a depth interval with narrower borehole dimensions. This unit is characterized by low neutron porosity and high density values with small spikes of high neutron porosity and low density that may be caused by fracturing. The slight increase in gamma ray values below 515 mbsf may be caused by slightly higher alteration within Subunit 7C, which is the only depth interval with highly altered rocks identified in the cores. Typical secondary minerals in this interval are saponite, iron hydroxides, and celadonite (see "Igneous and metamorphic petrology"). Celadonite may contain potassium and thus increase the gamma ray values. The two intervals of basalt-hyaloclastite breccia of 
Subunits $1 \mathrm{~A}$ and $8 \mathrm{~A}$ cannot be identified in the downhole measurements, consistent with the subunits being very thin.

\section{Borehole images}

Acoustic and microresistivity borehole images were acquired with the UBI and FMS, respectively. The initial quality of both sets of images is poor for two main reasons. The section of the borehole that was imaged is characterized by washouts and irregularities that hinder the acquisition of high-resolution images. In addition, the new heave compensating system (hardware and software) used during Expedition 301 may have not worked properly.

Preliminary examination of the data suggests that there could be depth discrepancies associated with the acceleration data that were collected with the GPIT. The compensated depth data are calculated from a time-indexed data file that uses cable speed for its conversion. Cable speeds fluctuated during the deployments, although it was difficult to assess if these were normal fluctuations because the cable drum is supposed to rotate frontward and backward to compensate for the ship's motion. A 30 min heave compensating station was performed at the beginning of the FMS/DSI tool string deployment and evaluated postcruise in an attempt to understand the compensator's behavior. These and subsequent postcruise tests revealed that the hardware was working properly, but the software was not. It does not appear that postexpedition processing will help to improve the quality of borehole imaging data.

\section{Hole completion}

CORK observatory deployment operations during Expedition 301 are described in considerable detail in "Operations," and CORK designs and final configurations are described by Fisher et al. (this volume). In the remainder of this section, we provide an overview of CORK operations and configuration in Holes U1301A and U1301B.

\section{Hole U1301A}

Hole U1301A was drilled using a 14\% inch tricone bit to a TD of $369.7 \mathrm{mbsf}, 107.5 \mathrm{~m}$ into basement. This was originally intended to be the deeper of two basement holes drilled during Expedition 301, but after two unsuccessful attempts to install a long $103 / 4$ inch casing string, we made Hole U1301A a shallower basement completion and installed the first CORK of the expedition (see "Operations"). We reconfigured the $10^{3 / 4}$ inch casing string to extend to $277.1 \mathrm{mbsf}, 14.9 \mathrm{~m}$ into basement. Once the casing was emplaced and cemented, we drilled out the casing shoe and checked the final depth of the 143/4 inch hole. Resistance was encountered at $296.2 \mathrm{mbsf}$ (34.0 $\mathrm{m}$ into basement), so this became the maximum depth to which $4 \frac{1}{2}$ inch CORK casing could be run (Fig. F77).

The CORK system installed in Hole U1301A included a single monitoring interval. The large diameter of the borehole precluded setting a CORK packer in open hole, so the packer was set near the bottom of the $103 / 4$ inch casing. Slotted $4 \frac{1}{2}$ inch casing was extended below the packer element to 291.8 mbsf so that OsmoSamplers and temperature sensors could be installed and protected for future recovery (Fisher et al., this volume).

We used surplus umbilical from Leg 196, comprising a single $1 / 2$ inch packer inflation line, six $1 / 4$ inch pressure-monitoring and sampling lines, and one $1 / 8$ inch sampling line. The $1 / 4$ inch and $1 / 8$ inch lines were run through the packer and ended in small wire-wrapped screens. Four of the screens attached to $1 / 4$ inch lines were attached to the $4 \frac{1}{2}$ inch casing just below the packer element, and the remaining screens and lines were terminated roughly in the middle of the $4 \frac{1}{2}$ inch slotted casing (Fig. F77).

The pass-through across the $103 / 4$ inch casing seal that was not plumbed to a formation sampling or monitoring line was connected to a three-way valve and manifold at the wellhead for future installation of pressure-monitoring instrumentation. This plumbing will allow monitoring of fluid pressure below the casing seal and above the packer element, to evaluate system integrity. All valves in the wellhead were left open during deployment to prevent air from being trapped in the sampling and monitoring lines. An OsmoSampler was attached to one of the fluid-sampling manifolds for short-term collection of fluids during the initial few weeks of borehole equilibration.

After we deployed the CORK system from the ship and reentered Hole U1301A, the CORK body was held a few meters above the cone so that we could deploy the instrument string. The Hole U1301A instrument string included four OsmoSampler packages. The uppermost OsmoSampler contains a copper coil for gas sampling. The next OsmoSampler contains microbiological incubation substrate. The third OsmoSampler has Teflon tubing for fluid sampling and rare earth tracer injection. The final OsmoSampler includes a module for acid injection into the sampling line to prevent precipitation of metal compounds. There is a single self-contained temperature logger in each of the OsmoSamplers $(3.7 \mathrm{~m}$ apart), and two additional temperature instruments were installed $2.5 \mathrm{~m}$ and $7.5 \mathrm{~m}$ above the bottom 
plug (Fig. F77). Thus, temperature monitoring in Hole U1301A extends across $\sim 24.2 \mathrm{~m}$ of upper basement. A 1 inch rod was welded across the opening in the bottom of the $4 \frac{1}{2}$ inch casing to prevent the OsmoSamplers from being lost through the plug if the line that holds these instruments breaks.

Instrument string deployment went smoothly, and the CORK was set in the cone and the packer was inflated in the casing. The submersible/ROV platform was assembled in the moonpool and lowered onto the CORK by wireline and released. We went back down with the camera to check the landing platform prior to releasing the CORK running tool. The platform appeared to be properly deployed, so we released from the CORK head, ending seafloor operations in Hole U1301A.

\section{Hole U1301B}

Hole U1301B was drilled to a total depth of 582.8 mbsf, $318 \mathrm{~m}$ into basement. The last $232 \mathrm{~m}$ were drilled and cored with a 97/8 inch tricone RCB bit. Large sections of the upper $100 \mathrm{~m}$ of open hole were washed out, whereas the lower $130 \mathrm{~m}$ of open hole was generally to gauge (see "Wireline logging"). Several potential CORK packer seats were identified in the upper $100 \mathrm{~m}$ of open hole, and we planned to isolate the upper and lower parts of the open hole for monitoring. We did not consider setting one of the CORK packers in $103 / 4$ inch casing because we were not confident that there was a good cement seal between this casing and the formation, potentially leaving the annulus between the $103 / 4$ inch and 16 inch casing open all the way to the seafloor. In addition, this would have resulted in isolation of a basement zone that overlapped with that isolated below the CORK in Hole U1301A, just $36 \mathrm{~m}$ away.

After completing all other operations in Hole U1301B, we initially deployed a CORK system with three casing packers, with the intent of setting all three in open hole. However, the CORK casing system became stuck in the $103 / 4$ inch casing, or in the throat of the reentry cone, and most of the casing, packers, and umbilical for this system were laid out onto the seafloor around the cone, with an unknown amount remaining in the $10^{3} / 4$ inch casing (see "Operations"). We believe that the CORK casing became stuck because it was too light in weight, particularly because the spring-centralizers (added to assist with passage through a break in the $103 / 4$ inch casing) created excessive friction in the $103 / 4$ inch casing.

Fortunately, we were able to fish all of the junked CORK casing and umbilical from the cone and surrounding seafloor, and we used components originally intended for the CORK in Hole 1027C to fabri- cate another CORK installation for Hole U1301B. We were ultimately successful in deploying this second CORK system.

The final Hole U1301B CORK system included two casing packers set in open hole at depths of 428.8 and 472.0 mbsf (163.6 and $206.8 \mathrm{~m}$ subbasement [msb], respectively) (Fig. F78). The lowermost packer element isolates the deepest $\sim 120$ m of Hole U1301B, whereas this and the shallowest packer isolate a $42 \mathrm{~m}$ thick interval within the transition between shallower and deeper parts of the hole. Based on caliper and other wireline log responses, it appears that the upper $100 \mathrm{~m}$ of the hole has formation properties associated with the most brecciated and rubbly parts of basement. In contrast, the lower $120 \mathrm{~m}$ of the hole appears to be more massive, although it still appears to have relatively high bulk permeability (see "Packer experiments"). The Hole U1301B CORK system also includes an upper monitored interval, comprising uppermost basement and the entire 103/4 inch and 16 inch casing strings below the cone. It should be possible to assess the quality of the hydrogeologic seal at the seafloor using the pressure monitoring line into this uppermost interval. The upper zone includes no fluid sampling, but this interval is sampled in nearby Hole U1301A.

The Hole U1301B CORK system included an umbilical containing nine separate lines: a single $1 / 2$ inch packer inflation line, four $1 / 4$ inch pressure-monitoring and sampling lines, and four $1 / 8$ inch sampling lines. A separate $1 / 2$ inch Tefzel (Teflon variant) microbiological sampling line was run to the deepest monitored zone. Four small intake screens were deployed below each of the packer elements.

The bottom of the CORK installation was considerably different from that originally planned. We had hoped to minimize the amount of metal below the deepest packer to reduce contamination and its influence on fluid and microbiological sampling and incubation. However, we learned from the first (attempted) CORK deployment in Hole U1301B that it is essential to put enough weight at the bottom of the CORK casing string to pull the system into the hole, particularly when the long casing string is completely unsupported in the water column above the reentry cone. For this reason, we deployed $35 \mathrm{~m}$ of drill collars and crossovers below the lower packer, including $\sim 10,000 \mathrm{lb}$ of metal. We put plastic heat shrink tubing on the end of the lower CORK packer casing joint, above the first drill collar, to help isolate the titanium intake screen from the contaminating influence of the underlying stainless steel.

As with other CORK deployments during Expedition 301, all sampling and monitoring valves were left open on deployment to make sure that no air was 
trapped in the lines. These valves will be closed during a ROV visit to the CORK 3 weeks after Expedition 301. Three OsmoSamplers were attached at the wellhead for short-term collection of fluids in the isolated basement zones during the initial few weeks of CORK equilibration. Two of these were recovered during the ROV visit, but the third remains in place to continue sampling fluids during the first year of borehole recovery. This sampler will be replaced when other samplers are deployed by submersible in summer 2005.

Once the CORK system was deployed most of the way into Hole U1301B, we deployed the internal string of temperature loggers, OsmoSamplers, and microbiological substrate. Because we knew that we would not be deploying a new CORK in Hole 1027C during Expedition 301, we deployed extra instruments in Hole U1301B. The downhole sensor and sampling string included 14 autonomous temperature loggers and six OsmoSamplers packages, including two microbiological growth packages (Fig. F78). Temperature monitoring extends from $\sim 1 \mathrm{~m}$ below top of basement to $\sim 263 \mathrm{~m}$ into basement, with typical sensor spacing of $\sim 20-25 \mathrm{~m}$. All of the downhole OsmoSamplers and microbiology growth systems have their intake lines extending beyond the bottom of the $4 \frac{1}{2}$ inch CORK casing system, in open hole.

The uppermost OsmoSampler contains a copper coil for gas sampling. The next OsmoSampler contains microbiological substrate in flow cells. The third OsmoSampler has Teflon tubing for fluid sampling and additional microbiological substrate. The fourth OsmoSampler includes a module for acid injection into the sampling line, to prevent precipitation of metal compounds, and microbiological substrate. The fifth OsmoSampler is injecting rare earth element tracers, and the final OsmoSampler module is configured for acid addition. There is a stainless steel sinker bar at the bottom of the sensor and sampling string. Three of the OsmoSamplers contain autonomous temperature loggers (Fig. F78).

Preparation and deployment of the instrument string went smoothly, although we had to replace the shear pin in the plug-setting tool when the first one failed to release the top plug. After release of the instruments, the CORK was set in the cone and the packers were inflated. The submersible/ROV platform was assembled in the moonpool and lowered onto the CORK by wireline and then released. We watched the platform being deployed and confirmed that it was properly seated on the cone.

The submersible/ROV platform had been modified to allow us to cement the Hole U1301B CORK into place in an effort to seal the annulus between $103 / 4$ inch and 16 inch casing strings. We tripped the pipe back to the ship and made up a cementing BHA, and then returned to the seafloor and "reentered" the cone through the hole in the landing platform. We pumped a plug of bentonite mud followed immediately by the last cement left on the ship.

Final operations around Hole U1301B included a fishing trip to remove a piece of CORK casing from the initial deployment that was sticking vertically from the seafloor and might have posed a hazard to submersible and ROV operations. This piece of casing was pulled from the seafloor and deposited 300 $\mathrm{m}$ west of Hole U1301B, in the same pile where the rest of the CORK casing had been deposited. We conducted a camera survey of a $100 \mathrm{~m} \times 100 \mathrm{~m}$ box around Holes U1301A and U1301B and two $200 \mathrm{~m}$ long swaths to the east and north of the holes that could be used as approach corridors during submersible or ROV operations. We found no other items on the seafloor that might pose a hazard for future operations.

\section{References}

Acton, G.D., Okada, M., Clement, B.M., Lund, S.P., and Williams, T., 2002. Paleomagnetic overprints in ocean sediment cores and their relationship to shear deformation caused by piston coring. J. Geophys. Res., 107. doi:10.1029/2001JB000518

Barr, S.R., Révillion, S., Brewer, T.S., Harvey, P.K., and Tarney, J., 2002. Determining the inputs to the Mariana Subduction Factory: using core-log integration to reconstruct basement lithology at ODP Hole 801C. Geochem., Geophys., Geosyst., 3(11). doi:10.1029/2001GC000255

Bartetzko, A., Pezard, P., Goldberg, D., Sun, Y.-F., and Becker, K., 2001. Volcanic stratigraphy of DSDP/ODP Hole 395A: an interpretation using well-logging data. Mar. Geophys. Res., 22:111-127. doi:10.1023/ A:1010359128574

Becker, K., 1996. Permeability measurements in Hole 896A and implications for the lateral variability of upper crustal permeability at Sites 504 and 896. In Alt, J.C., Kinoshita, H., Stokking, L.B., and Michael, P.J. (Eds.), Proc. ODP, Sci. Results, 148: College Station, TX (Ocean Drilling Program), 353-363.

Becker, K., and Davis, E.E., 2003. New evidence for age variation and scale effects of permeabilities of young oceanic crust from borehole thermal and pressure measurements. Earth. Planet. Sci. Lett., 210(3-4):499-508. doi:10.1016/S0012-821X(03)00160-2

Becker, K., and Fisher, A.T., 2000. Permeability of upper oceanic basement on the eastern flank of the Juan de Fuca Ridge determined with drill-string packer experiments. J. Geophys. Res., 105:897-912. doi:10.1029/ 1999JB900250

Blum, P., 1997. Physical properties handbook: a guide to the shipboard measurement of physical properties of deep-sea cores. ODP Tech. Note, 26 [Online]. Available 
from World Wide Web: <http://www-odp.tamu.edu/ publications/tnotes/tn26/INDEX.HTM $>$.

Boetius, A., Ravenschlag, K., Schubert, C.J., Rickert, D., Widdel, F., Gieseke, A., Amann, R., Jørgensen, B.B., Witte, U., and Pfannkuche, O., 2000. A marine microbial consortium apparently mediating the anaerobic oxidation of methane. Nature (London, U. K.), 407:623626. doi:10.1038/35036572

Broglia, C., and Moos, D., 1988. In-situ structure and properties of 110-Ma crust from geophysical logs in DSDP Hole 418A. In Salisbury, M.H., Scott, J.H., et al., Proc. ODP, Sci. Results, 102: College Station, TX (Ocean Drilling Program), 29-47.

Busch, W.H., Castillo, P.R., Floyd, P.A., and Cameron, G., 1992. Effects of alteration of physical properties of basalts from the Pigafetta and East Mariana basins. In Larson, R.L., Lancelot, Y., et al., Proc. ODP, Sci. Results, 129: College Station, TX (Ocean Drilling Program), 485499.

Carlson, R.L., and Herrick, C.N., 1990. Densities and porosities in the oceanic crust and their variations with depth and age. J. Geophys. Res., 95:9153-9170.

Cox, A.V., and Gordon, R.G., 1984. Paleolatitudes determined from paleomagnetic data from vertical cores. Rev. Geophys. Space Phys., 22:47-72.

Davis, E.E., Chapman, D.S., Wang, K., Villinger, H., Fisher, A.T., Robinson, S.W., Grigel, J., Pribnow, D., Stein, J., and Becker, K., 1999. Regional heat-flow variations across the sedimented Juan de Fuca Ridge eastern flank: constraints on lithospheric cooling and lateral hydrothermal heat transport. J. Geophys. Res., 104:1767517688. doi:10.1029/1999JB900124

Davis, E.E., Villinger, H., MacDonald, R.D., Meldrum, R.D., and Grigel, J., 1997. A robust rapid-response probe for measuring bottom-hole temperatures in deep-ocean boreholes. Mar. Geophys. Res., 19:267-281. doi:10.1023/ A:1004292930361

Doubrovine, P.V., and Tarduno, J.A., 2004. Self-reversed magnetization carried by titanomaghemite in oceanic basalts. Earth Planet. Sci. Lett., 222:959-969. doi:10.1016/j.epsl.2004.04.009

Fisher, A.T., Davis, E.E., Hutnak, M., Spiess, V., Zühlsdorff, L., Cherkaoui, A., Christiansen, L., Edwards, K.M., MacDonald, R., Villinger, H., Mottl, M.J., Wheat, C.G., and Becker, K., 2003. Hydrothermal recharge and discharge across $50 \mathrm{~km}$ guided by seamounts on a young ridge flank. Nature (London, U. K.), 421:618-621. doi:10.1038/nature01352

Fisk, M.R., Giovannoni, S.J., and Thorseth, I.H., 1998. Alteration of oceanic volcanic glass: textural evidence of microbial activity. Science, 281:978-980. doi:10.1126/ science.281.5379.978

Giambalvo, E.R., Fisher, A.T., Martin, J.T., Darty, L., and Lowell, R.P., 2000. Origin of elevated sediment permeability in a hydrothermal seepage zone, eastern flank of the Juan de Fuca Ridge, and implications for transport of fluid and heat. J. Geophys. Res.,105:913-928. doi:10.1029/1999JB900360

Giovannoni, S.J., Fisk, M.R., Mullins, T.D., and Furnes, H., 1996. Genetic evidence for endolithic microbial life col- onizing basaltic glass/seawater interfaces. In Alt, J.C., Kinoshita, H., Stokking, L.B., and Michael, P.J. (Eds.), Proc. ODP, Sci. Results, 148: College Station, TX (Ocean Drilling Program), 207-214.

Horai, K., and Von Herzen, R.P., 1985. Measurement of heat flow on Leg 86 of the Deep Sea Drilling Project. In Heath, G.R., Burckle, L.H., et al., Init. Repts. DSDP, 86: Washington (U.S. Govt. Printing Office), 759-777.

Johnson, H.P., Van Patten, D.A., and Sager, W.W., 1996. Age-dependent variation in the magnetization of seamounts. J. Geophys. Res., 101:13701-13714. doi:10.1029/96JB00537

Kirschvink, J.L., 1980. The least-squares line and plane and the analysis of palaeomagnetic data. Geophys. J. R. Astron. Soc., 62:699-718.

Laverne, C., Belarouchi, A., and Honnorez, J., 1996. Alteration mineralogy and chemistry of the upper oceanic crust from Hole 896A, Costa Rica Rift. In Alt, J.C., Kinoshita, H., Stokking, L.B., and Michael, P.J. (Eds.), Proc. ODP, Sci. Results, 148: College Station, TX (Ocean Drilling Program), 151-170.

Mather, I.D., and Parkes, R.J., 2000. Bacterial profiles in sediments of the eastern flank of the Juan de Fuca Ridge, Sites 1026 and 1027. In Fisher, A., Davis, E.E., and Escutia, C. (Eds.), Proc. ODP, Sci. Results, 168: College Station, TX (Ocean Drilling Program), 161-165.

Mottl, M.J., Wheat, C.G., Baker, E., Becker, N., Davis, E., Feely, R., Grehan, A., Kadko, D., Lilley, M., Massoth, G., Moyer, C., and Sansone, F., 1998. Warm springs discovered on 3.5 Ma oceanic crust, eastern flank of the Juan de Fuca Ridge. Geology, 26:51-54. doi:10.1130/00917613(1998)026<0051:WSDOMO>2.3.CO;2

Mottl, M.J., Wheat, C.G., Monnin, C., and Elderfield, H., 2000. Data report: Trace elements and isotopes in pore water from Sites 1023 through 1032, eastern flank of the Juan de Fuca Ridge. In Fisher, A., Davis, E.E., and Escutia, C. (Eds.), Proc. ODP, Sci. Results, 168: College Station, TX (Ocean Drilling Program), 105-115.

Orcutt, J.A., Schultz, A., Davies, T.A., et al., 2003. Proc. ODP, Init. Repts., 203 [CD-ROM]. Available from: Ocean Drilling Program, Texas A\&M University, College Station TX 77845-9547, USA.

Parkes, R.J., Cragg, B.A., Bale, S.J., Getliff, J.M., Goodman, K., Rochelle, P.A., Fry, J.C., Weightman, A.J., and Harvey, S.M., 1994. Deep bacterial biosphere in Pacific Ocean sediments. Nature (London, U. K.), 371:410-413. doi:10.1038/371410a0

Rohr, K., 1994. Inverse of seismic velocities in upper oceanic crust and hydrothermal circulation in the Juan de Fuca plate. Geophys. Res. Lett., 21(19):2163-2166. doi:10.1029/94GL01913

Shipboard Scientific Party, 1997. Rough basement transect (Sites 1026 and 1027). In Davis, E.E., Fisher, A.T., Firth, J.V., et al., Proc. ODP, Init. Repts., 168: College Station, TX (Ocean Drilling Program), 101-160.

Snow, D.T., 1968. Rock fracture spacings, openings, and porosities. J. Soil Mech. Found. Div., Am. Soc. Civ. Eng. Proc., 94:73-91.

Spinelli, G.A., Zühlsdorff, L., Fisher, A.T., Wheat, C.G., Mottl, M., Spiess, V., and Giambalvo, E.R., 2004. Hydrothermal seepage patterns above a buried basement 
ridge, eastern flank of the Juan de Fuca Ridge. J. Geophys. Res., 109. doi:10.1029/2003JB002476

Teagle, D.A.H., Alt, J.C., Bach, W., Halliday, A.N., and Erzinger, J., 1996. Alteration of upper ocean crust in a ridge-flank hydrothermal upflow zone: mineral, chemical, and isotopic constraints from Hole 896A. In Alt, J.C., Kinoshita, H., Stokking, L.B., and Michael, P.J. (Eds.), Proc. ODP, Sci. Results, 148: College Station, TX (Ocean Drilling Program), 119-150.

Thompson, R., and Oldfield, F., 1986. Environmental Magnetism: London (Allen and Unwin).

Verhoogen, J., 1956. Ionic ordering and self-reversal in impure magnetites. J. Geophys. Res., 61:201-209.

Wheat, C.G., and Mottl, M., 2000. Composition of pore and spring waters from Baby Bare: global implications of geochemical fluxes from a ridge flank hydrothermal system. Geochim. Cosmochim. Acta, 64:629-642. doi:10.1016/S0016-7037(99)00347-6

Wheat, C.G., Elderfield, H., Mottl, M.J., and Monnin, C., 2000. Chemical composition of basement fluids within an oceanic ridge flank: implications for along-strike and across-strike hydrothermal circulation. J. Geophys. Res., 105(6):13437-13448. doi:10.1029/2000JB900070
Wheat, C.G., Jannasch, H.W., Kastner, M., Plant, J.N., DeCarlo, E.H., and Lebon, G., 2004. Venting formation fluids from deep-sea boreholes in a ridge flank setting: ODP Sites 1025 and 1026. Geochem., Geophys., Geosyst., 5(8). doi:10.1029/2004GC000710

Wheat, C.G., Mottl, M., and Rudnicki, M., 2002. Trace element and REE composition of a low-temperature ridgeflank hydrothermal spring. Geochim. Cosmochim. Acta, 66:3693-3705. doi:10.1016/S0016-7037(02)00894-3

Whiticar, M.J., Faber, E., Whelan, J.K., and Simoneit, B.R.T., 1994. Thermogenic and bacterial hydrocarbon gases (free and sorbed) in Middle Valley, Juan de Fuca Ridge, Leg 139. In Mottl, M.J., Davis, E.E., Fisher, A.T., and Slack, J.F. (Eds.), Proc. ODP, Sci. Results, 139: College Station, TX (Ocean Drilling Program), 467-477.

Woodside, W., and Messmer, J.H., 1961. Thermal conductivity of porous media in unconsolidated sands. J. Appl. Phys., 32:1688-1699. doi:10.1063/1.1728419

Publication: 31 October 2005 MS 301-106 
Figure F1. Maps of the area around Site U1301. A. Map of Second Ridge area, showing approximate locations of ODP (blue dots) and IODP (red dot) holes. Papa Bare outcrop, Mama Bare outcrop, and Baby Bare outcrop are basement outcrops, shown as closely spaced yellow contours. Area of dashed box is shown in B. B. Track chart of seismic lines around Site U1301 collected during the 2000 ImageFlux expedition (Zühlsdorff et al., this volume). Parts of Lines GeoB00-466 and GeoB00-468 (thick dashed lines) are shown in Figures F2 and F3.
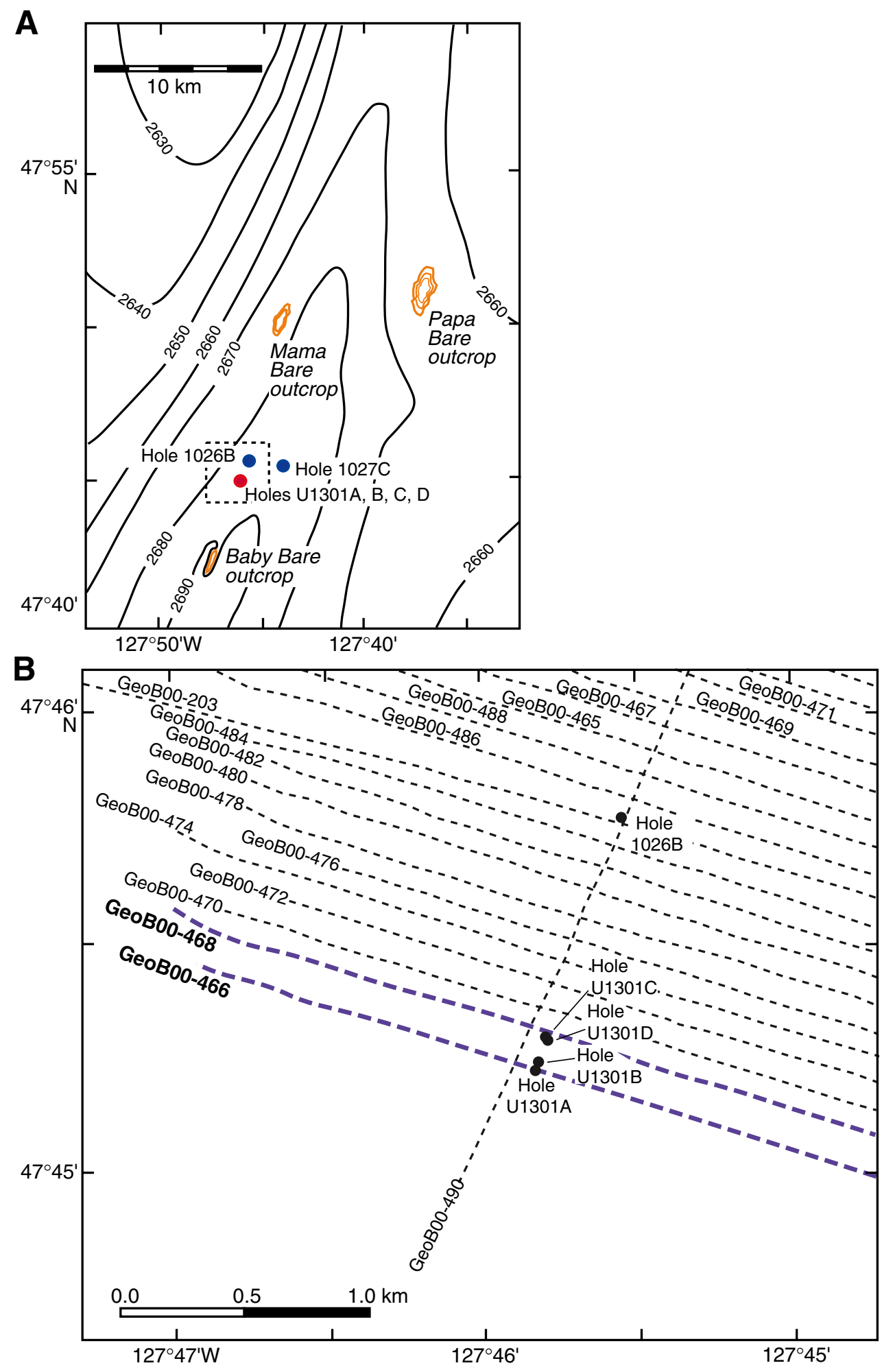
Figure F2. Seismic Line GeoB00-466 across Second Ridge and Site U1301. Sediment structures and the sediment/basement interface are clearly visible. Site U1301 is located over the peak of a buried basement ridge, adjacent to a high-angle normal fault, near the western edge of a major Pleistocene distributary channel for turbidites. Please see additional discussion in Zühlsdorff et al. (this volume). Arrow indicates location of Hole U1301A and approximate projection of Holes U1301B, U1301C, and U1301D onto this seismic profile. Details from this profile and an adjacent seismic line are shown in Figure F3, including approximate penetration depths for individual holes.

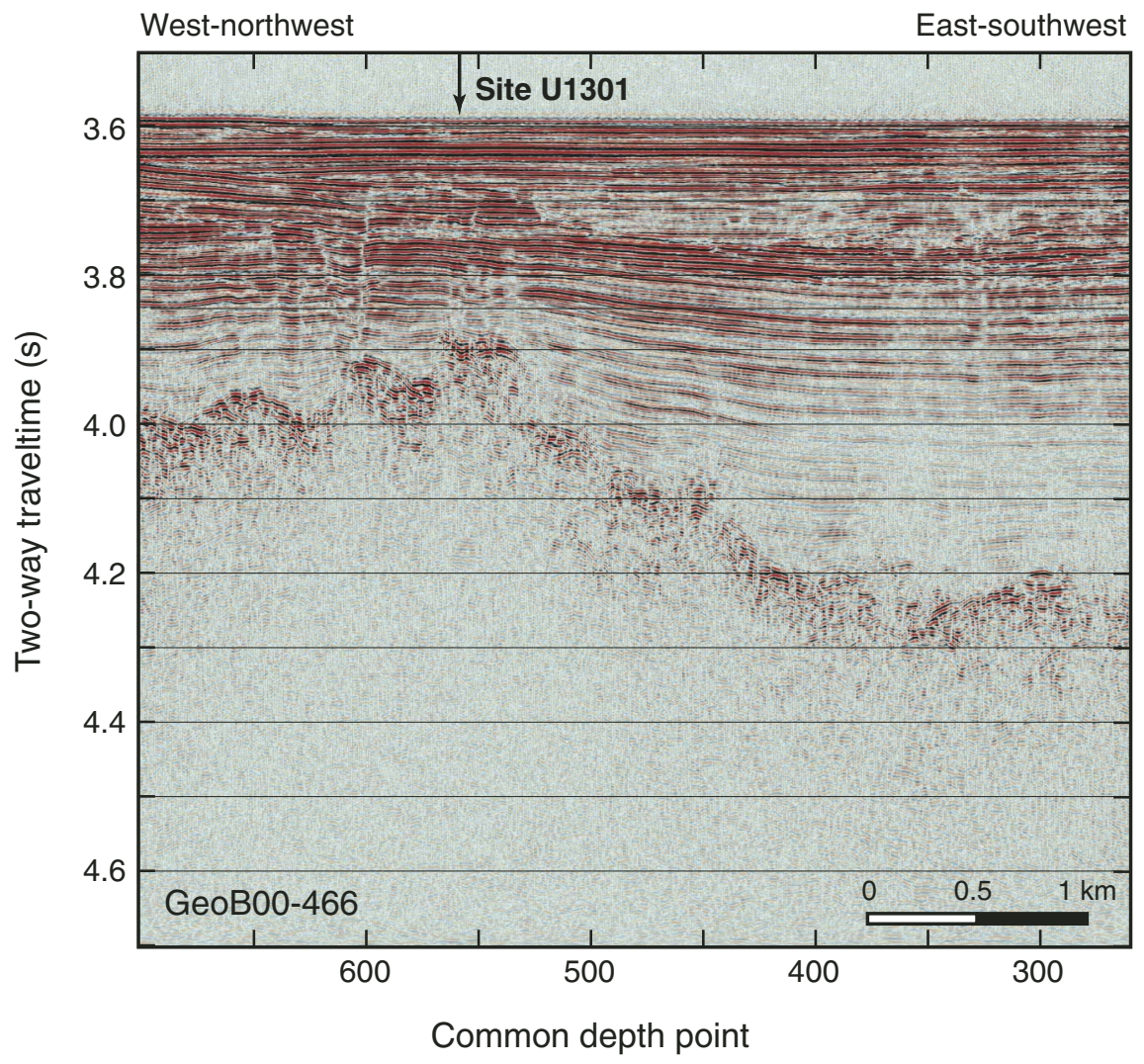


Figure F3. Expanded segments of seismic lines across Site U1301. Basement in both images is clearly visible as bright events at 2.9 s two-way traveltime. A. Line GeoB00-466 across Holes U1301A and U1301B. Thin vertical lines indicate approximate depths of penetration, assuming an uppermost basement seismic velocity of 5 $\mathrm{km} / \mathrm{s}$ (see "Wireline logging"). Hole U1301A is on common depth point (CDP) 557 as indicated by the arrow, whereas Hole U1301B is located $36 \mathrm{~m}$ north northeast of the seismic line and projects onto the same CDP. B. Line GeoB00-468 across Holes U1301C and U1031D. The closest approach to Hole U1301C is at CDP 390, and the closest approach to Hole U1301D is CDP 388. Thin vertical lines indicate depths of penetration.

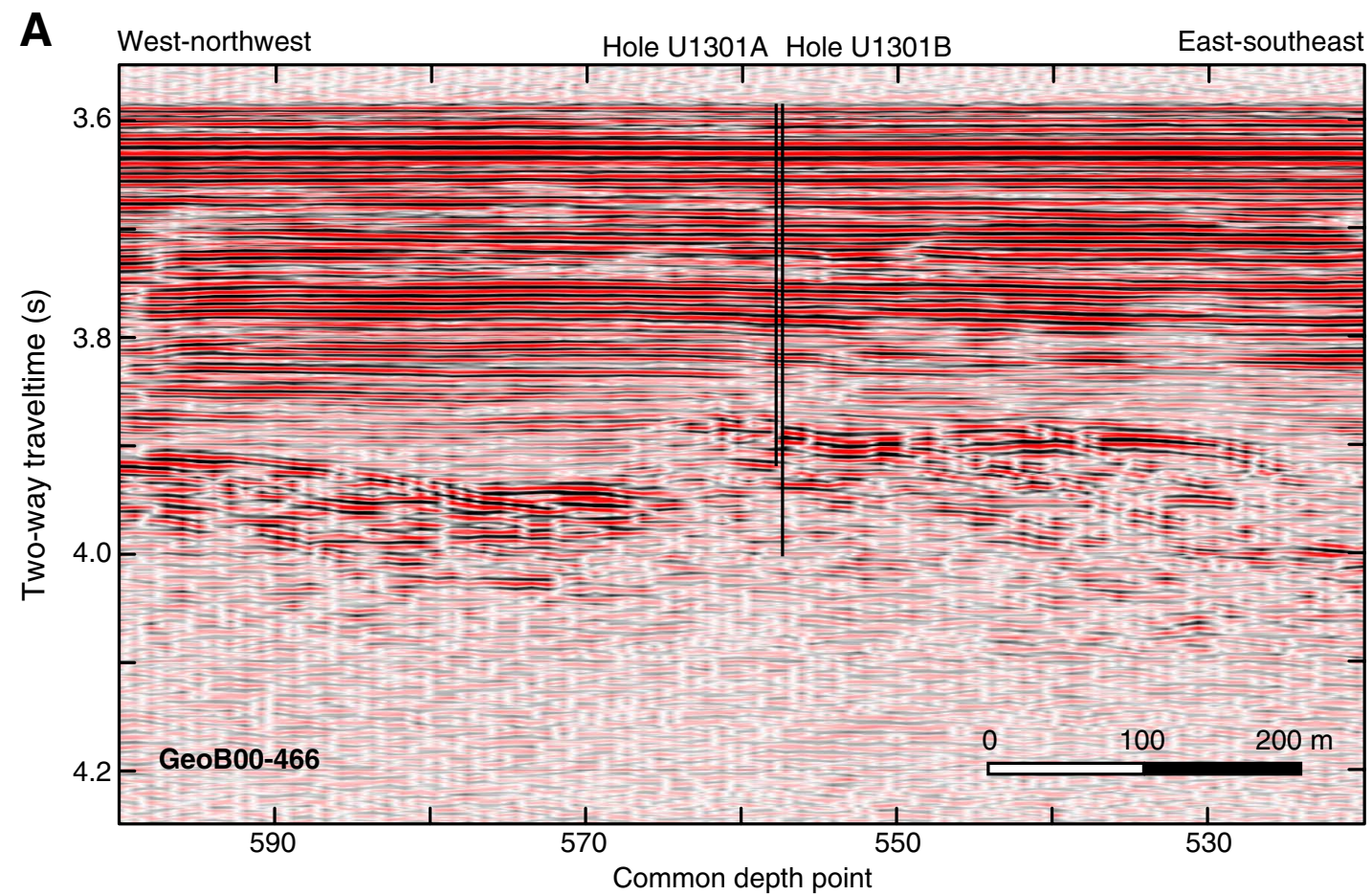

B West-northwest Hole U1301C Hole U1301D East-southeast

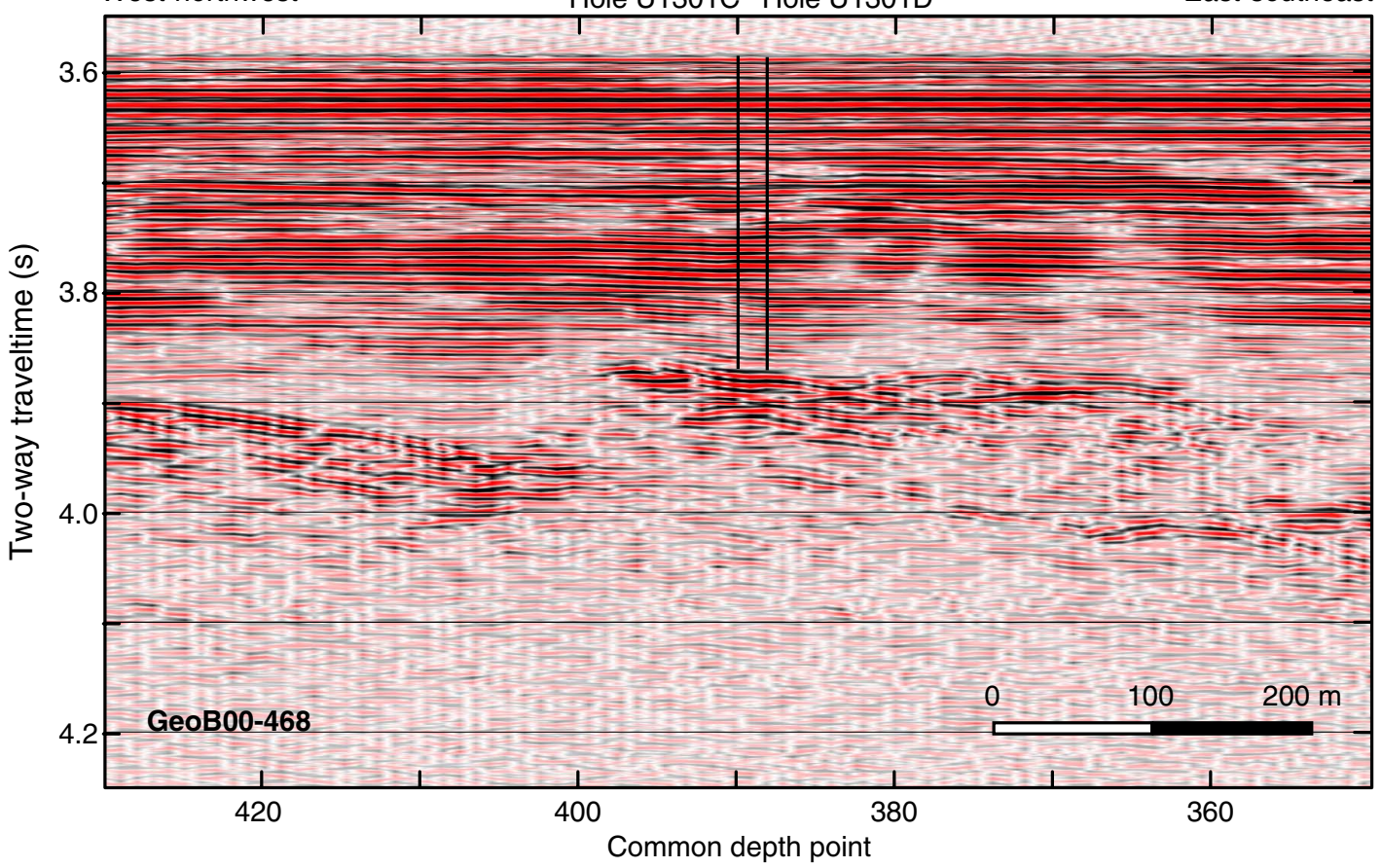


Figure F4. Hole U1301A reentry cone.

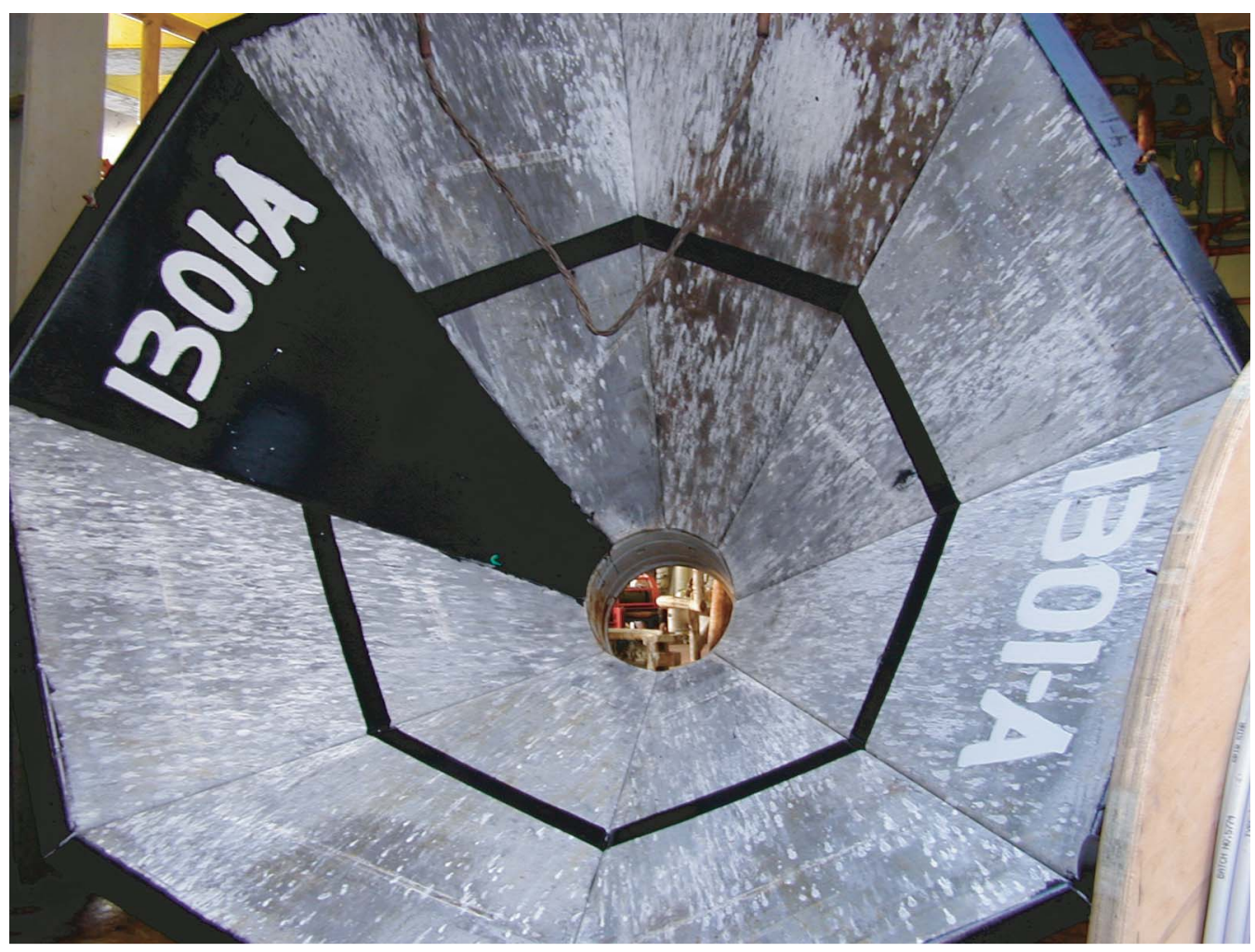


Figure F5. Hole U1301B reentry cone.

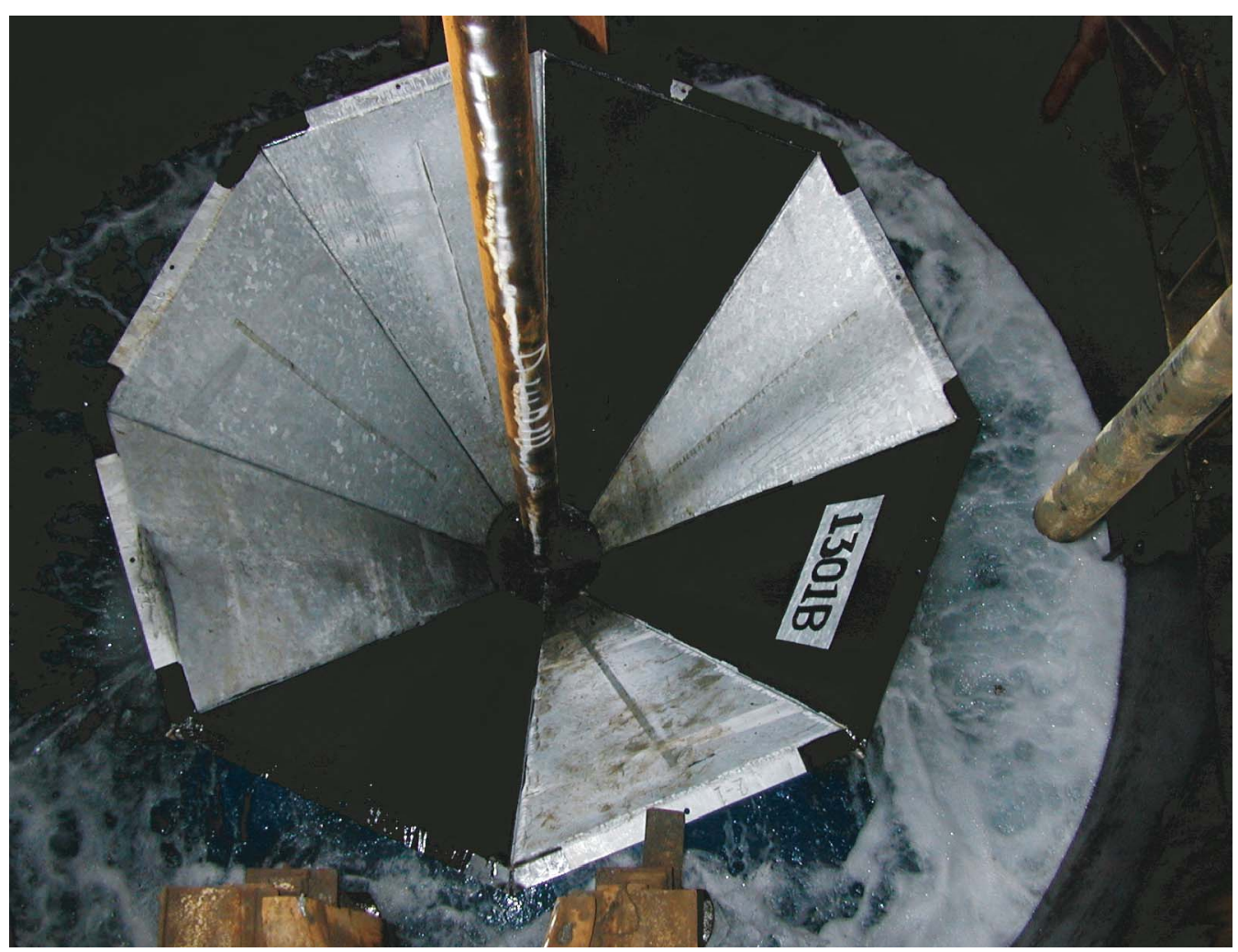


Figure F6. Calculated tides for the duration of Expedition 301 (top) and for a 1 day period (27 July 2004; bottom). Times shown are Universal Time Coordinated (UTC); ship local time is UTC -7.

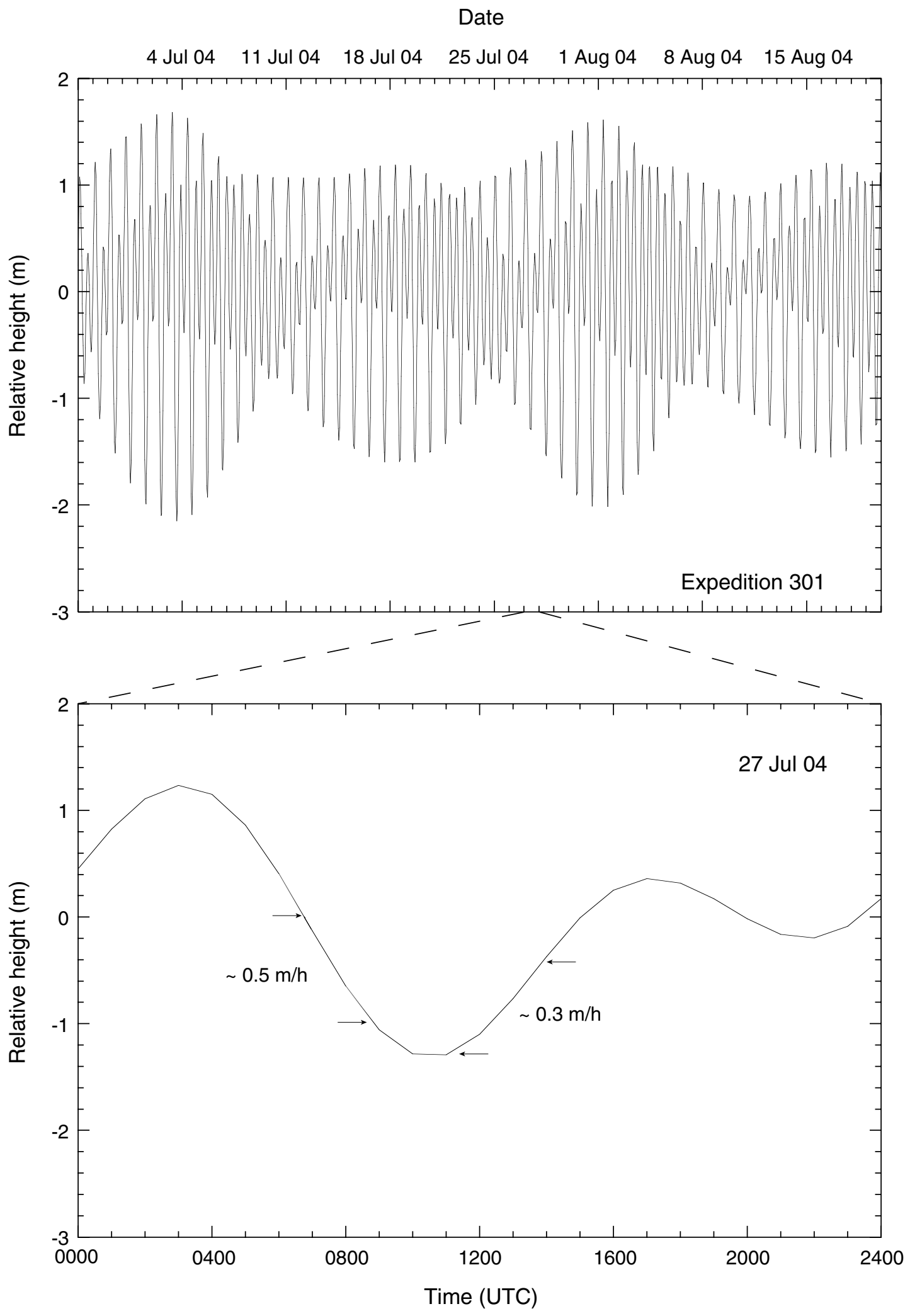


Figure F7. Schematic showing the Hole U1301A reentry cone and borehole casing (right), CORK borehole completion (center), and the instrument string deployed through the $4 \frac{1}{2}$ inch casing (left). ROV $=$ remotely operated vehicle. TAM $=$ TAM International. Osmo $=$ OsmoSampler.

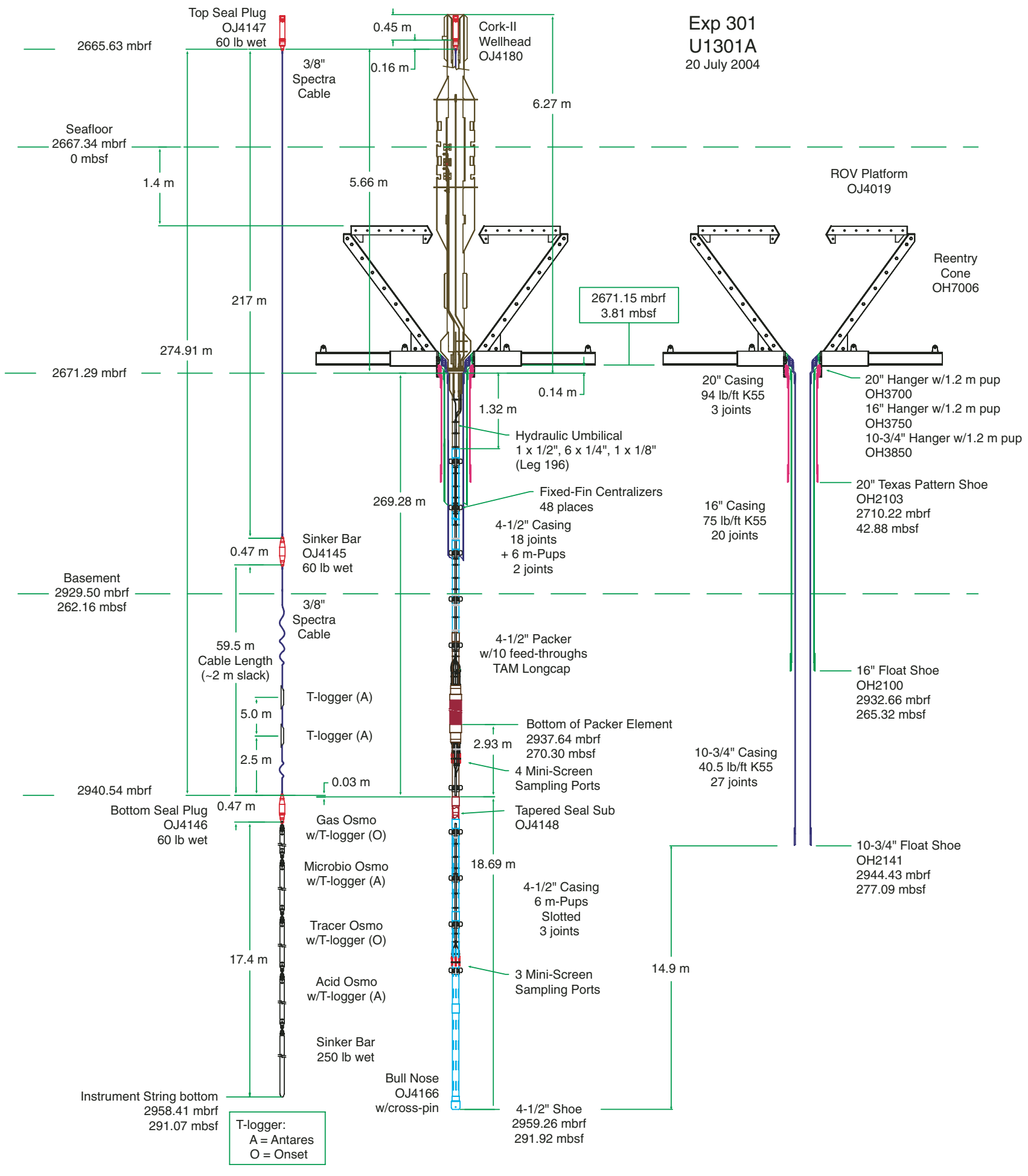


Figure F8. Fishing tool fabricated to retrieve the failed $4 \frac{1}{2}$ inch casing from inside the reentry cone and casing of Hole U1301B.

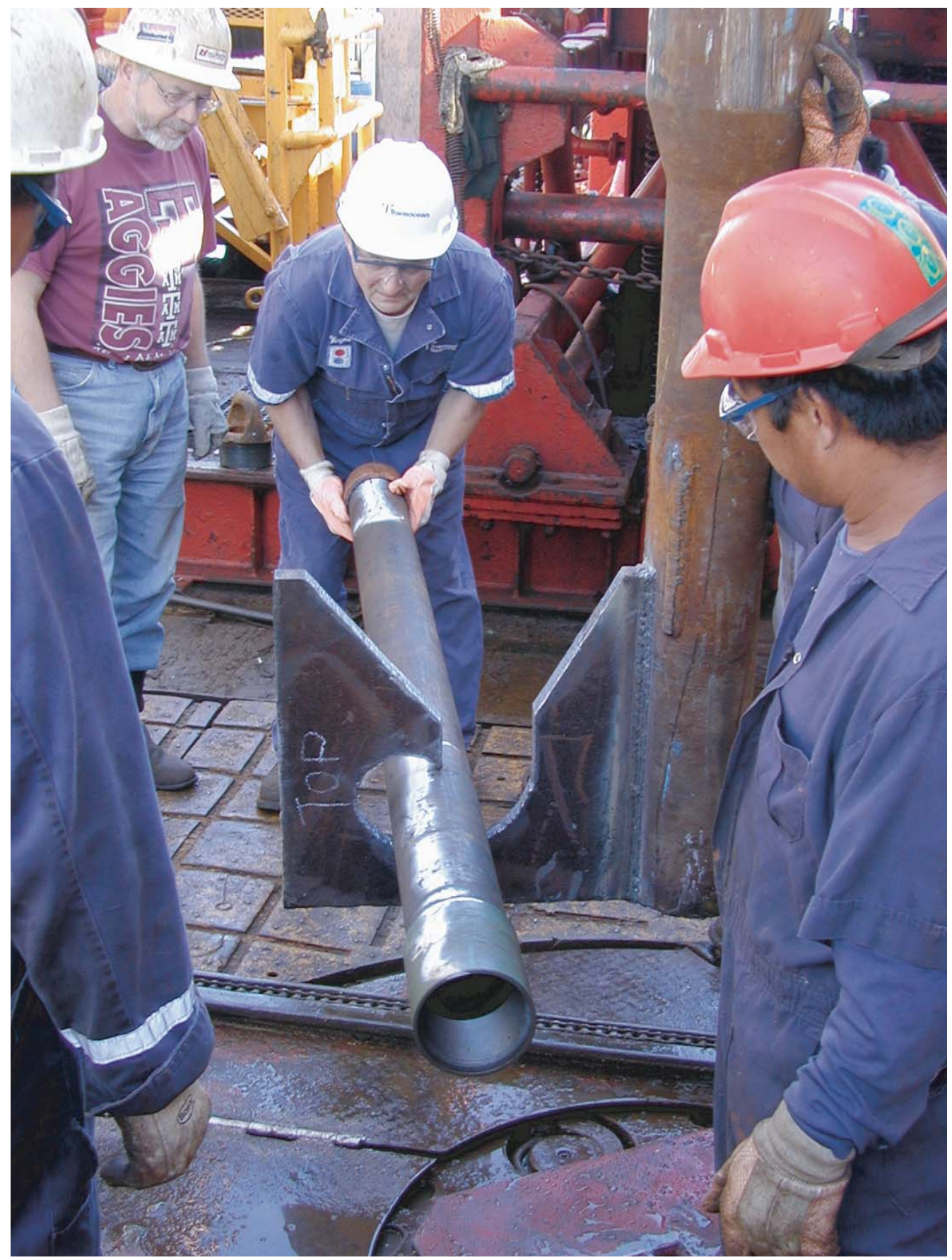


Figure F9. Schematic showing the Hole U1301B reentry cone and borehole casing (right), CORK borehole completion (center), and the instrument string deployed through the $4 \frac{1}{2} \mathrm{inch}$ casing (left). ROV $=\mathrm{remotely}$ operated vehicle. TAM = TAM International. Osmo = OsmoSampler.

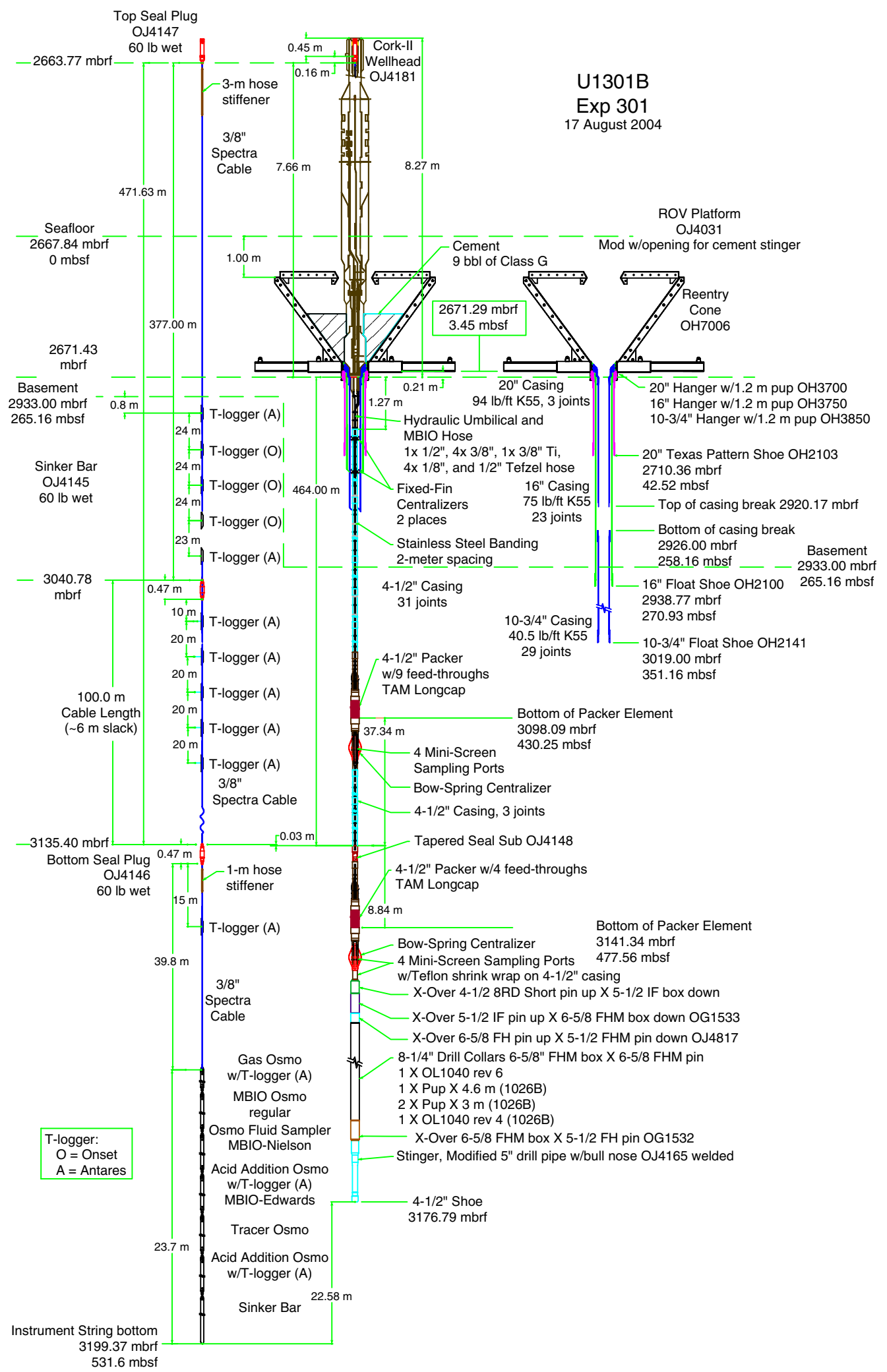


Figure F10. Hole U1301B ROV/submersible platform being prepared for deployment in the moonpool. We used the VIT subsea camera/sonar system to deploy the platform.

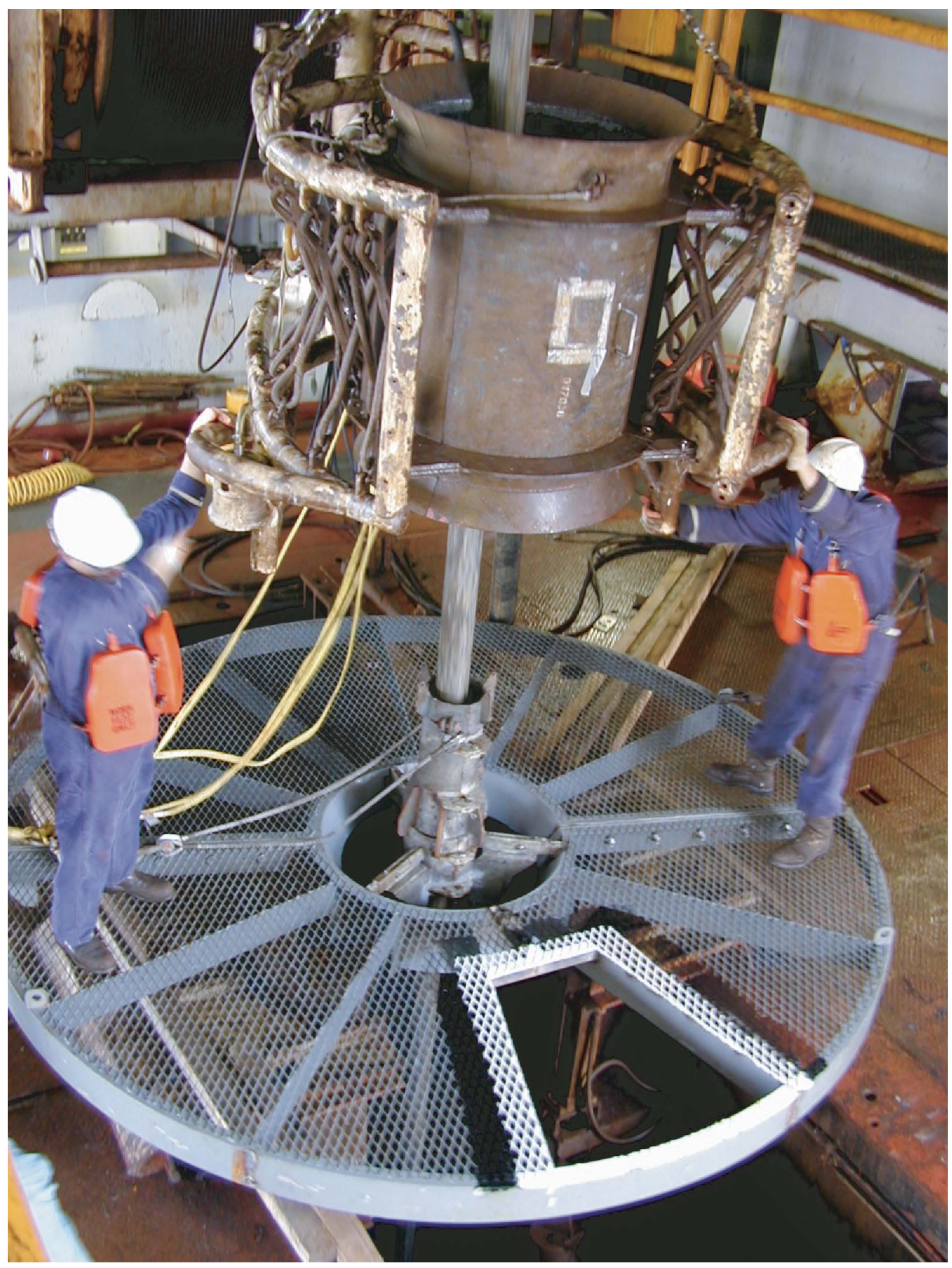


Figure F11. After finishing installing the Hole U1301B CORK, we used this fishing tool to remove a joint of failed $4 \frac{1}{2}$ inch casing that was sticking out of the seafloor near the Hole U1301B reentry cone. Once this was completed, we conducted a camera survey to verify that Hole U1301B and U1301A areas were free of any obstructions.

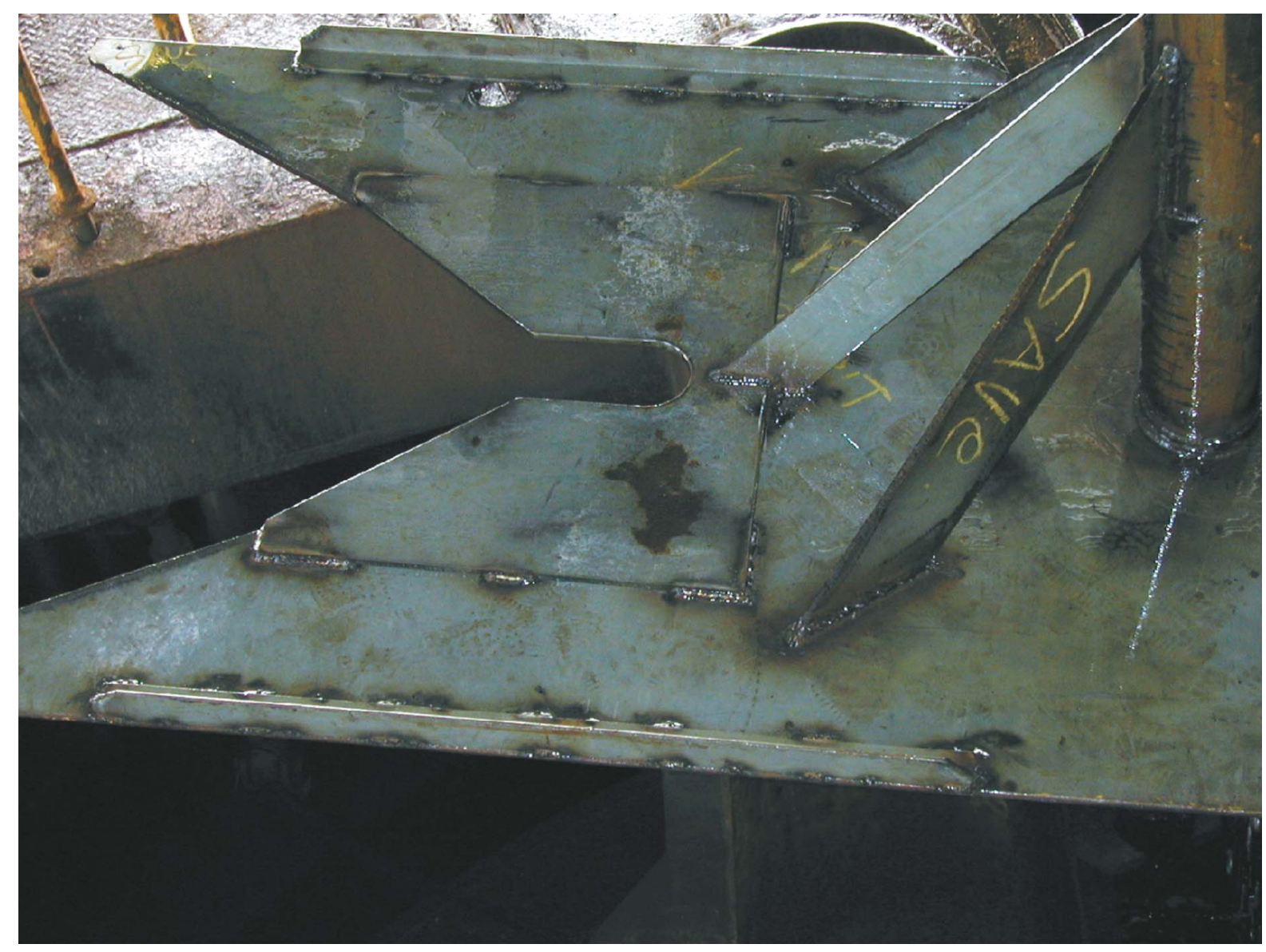


Figure F12. Lithologic and summary stratigraphic columns for sediment cores from Holes U1301C and U1301D. The core recovery is indicated graphically by horizontal black bars in the recovery column. Basaltic basement was not cored. TD = total depth.

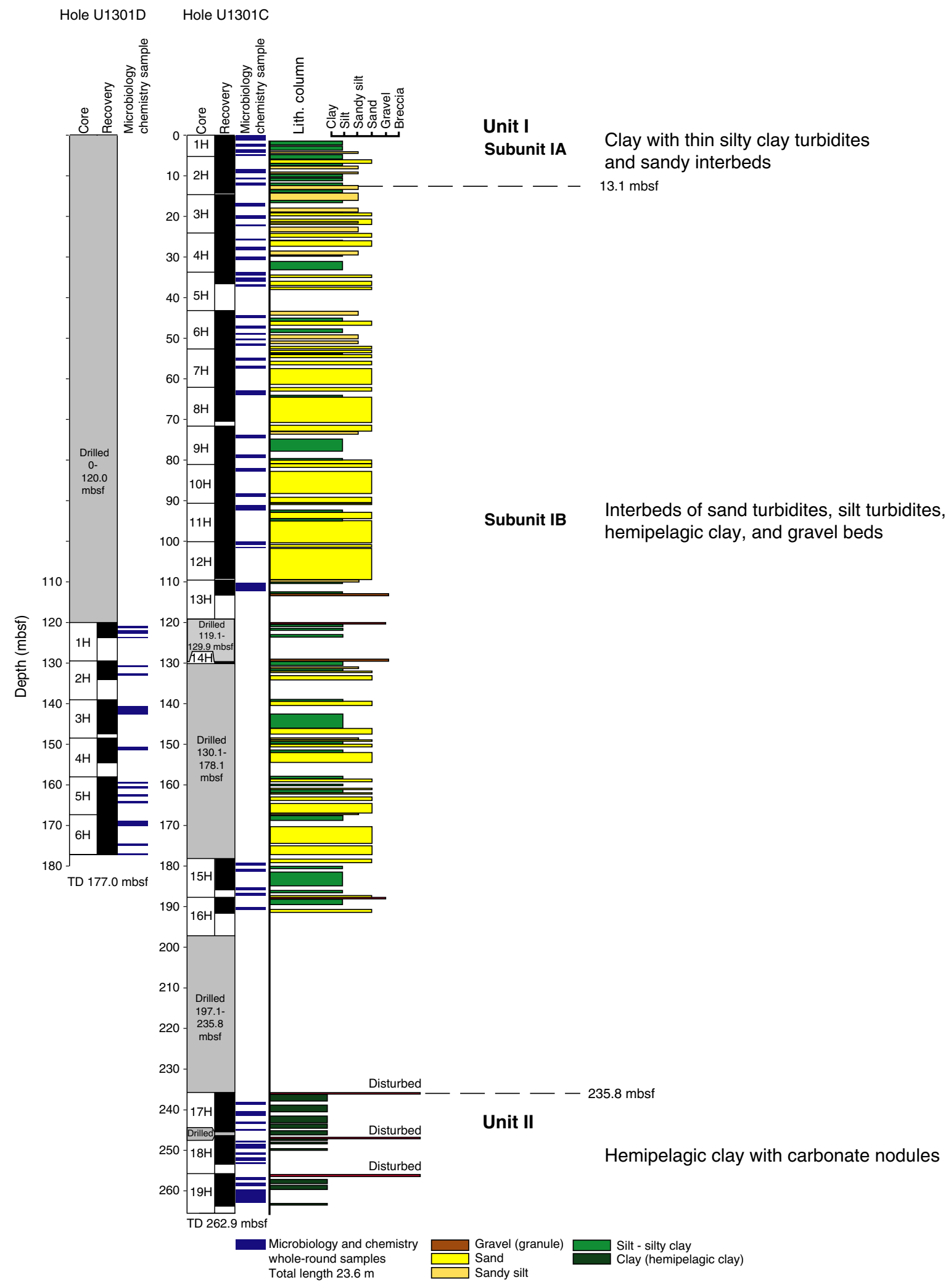


Figure F13. Hemipelagic clay layers in Unit I. A. Homogeneous dark greenish gray clay with rare bioturbation from the top of Subunit IB (interval 301-U1301C-9H-4, 100-120 cm). Thin, gray, fine sand laminations are partially preserved. B. The center of Subunit ID is homogeneous greenish gray clay and is the only occurrence of this lighter colored microfossil-bearing clay (interval 301-U1301C-15H-5, 6-20 cm). C. The center of Subunit IB consists of interbedded clay and fine-graded sand, with wood fragments (interval 301-U1301C-9H-4, $115-120 \mathrm{~cm})$.

$\mathbf{A}_{\mathrm{cm}}$

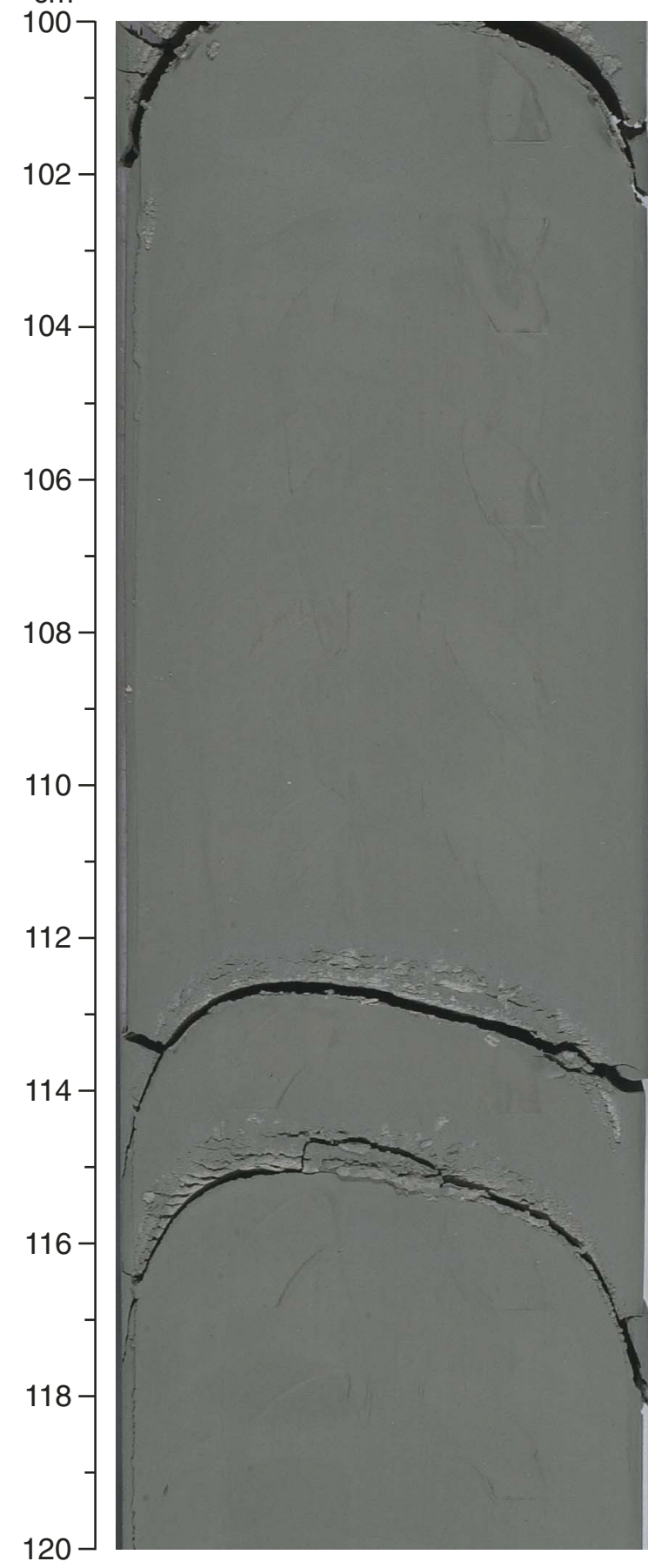

B

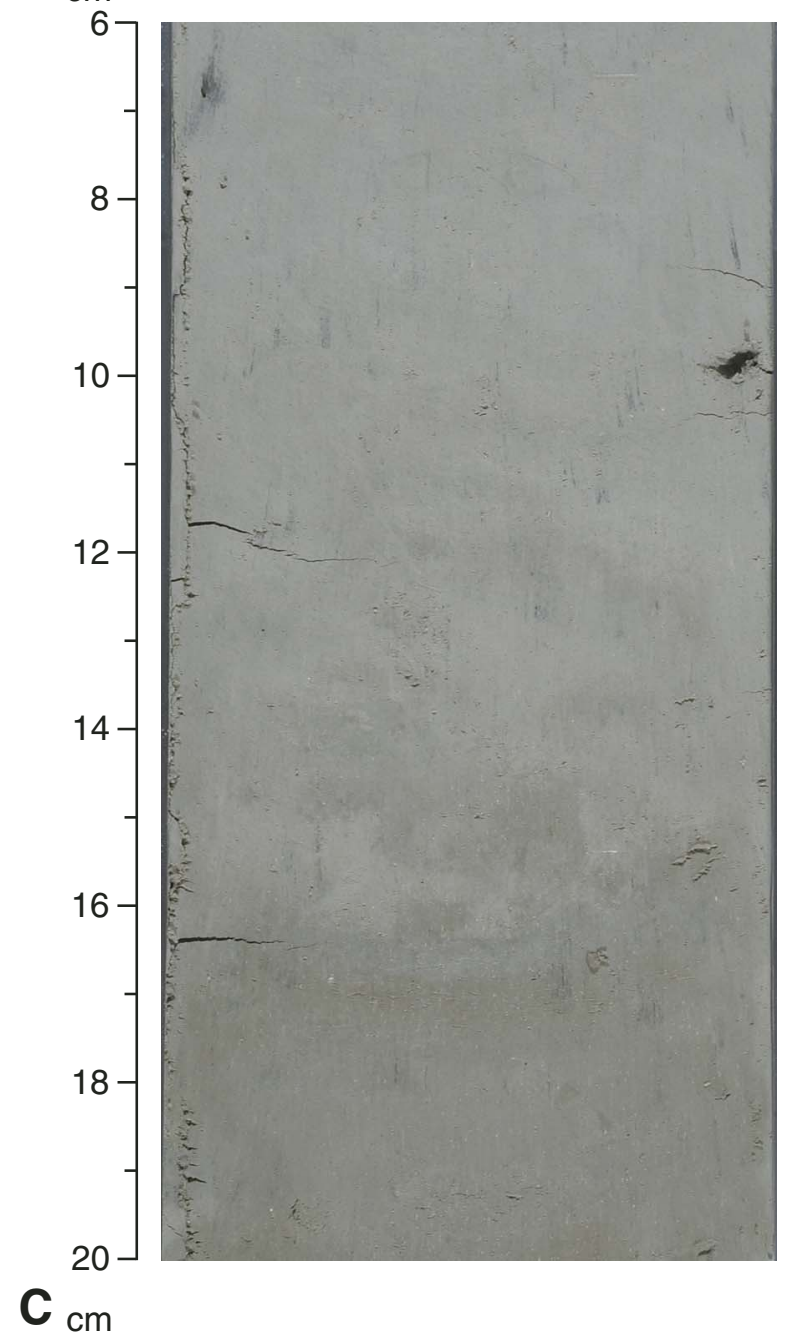

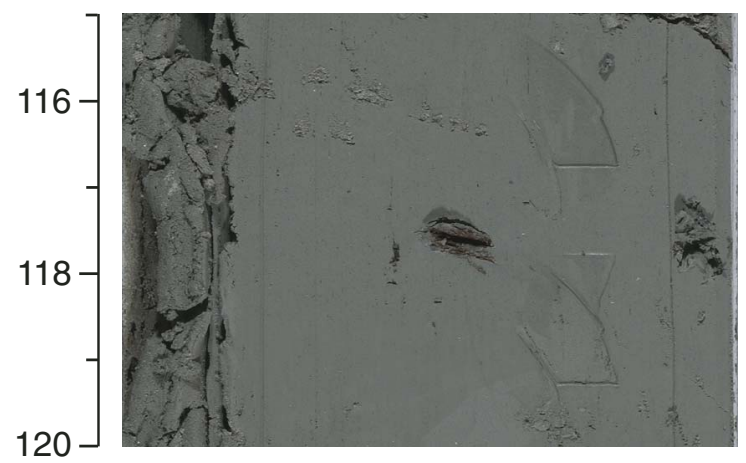


Figure F14. Thin graded hemipelagic clay and thick graded beds with normal size grading from fine sand to clay from the middle of Subunit IB. A. Laminations $(1-2 \mathrm{~cm})$ of dark greenish gray silty clay and light greenish gray fine sand (interval 301-U1301C-9H-2, 40-50 cm). B. A $10 \mathrm{~cm}$ thick graded sand to silt bed, with no bioturbation (interval 301-U1301C-9H-1, 50-70 cm).

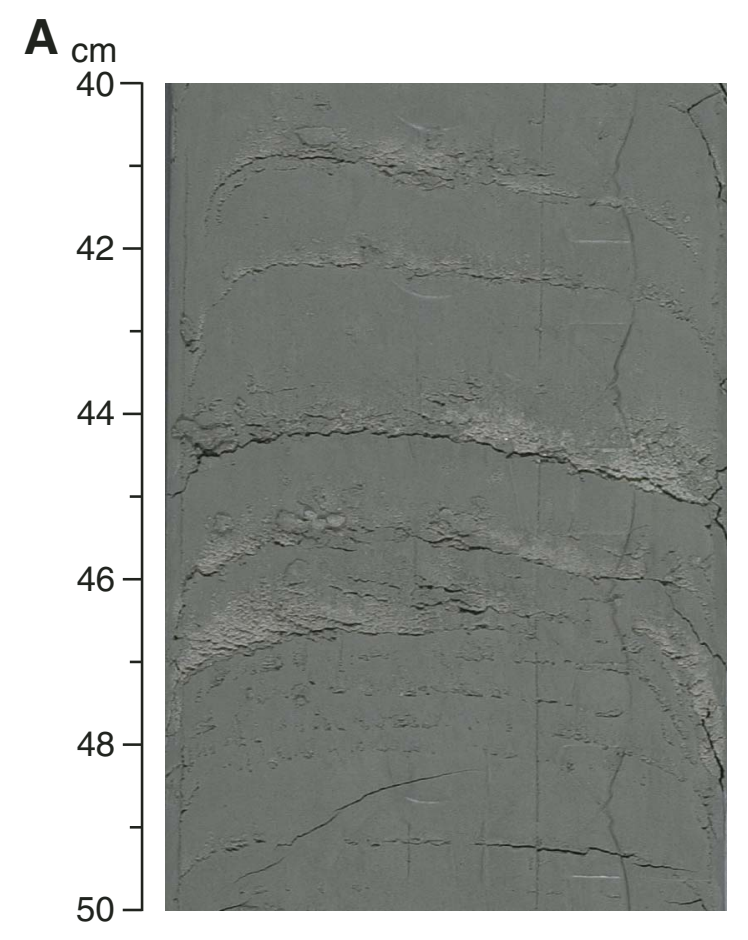

$\mathbf{B}_{\mathrm{c}}$

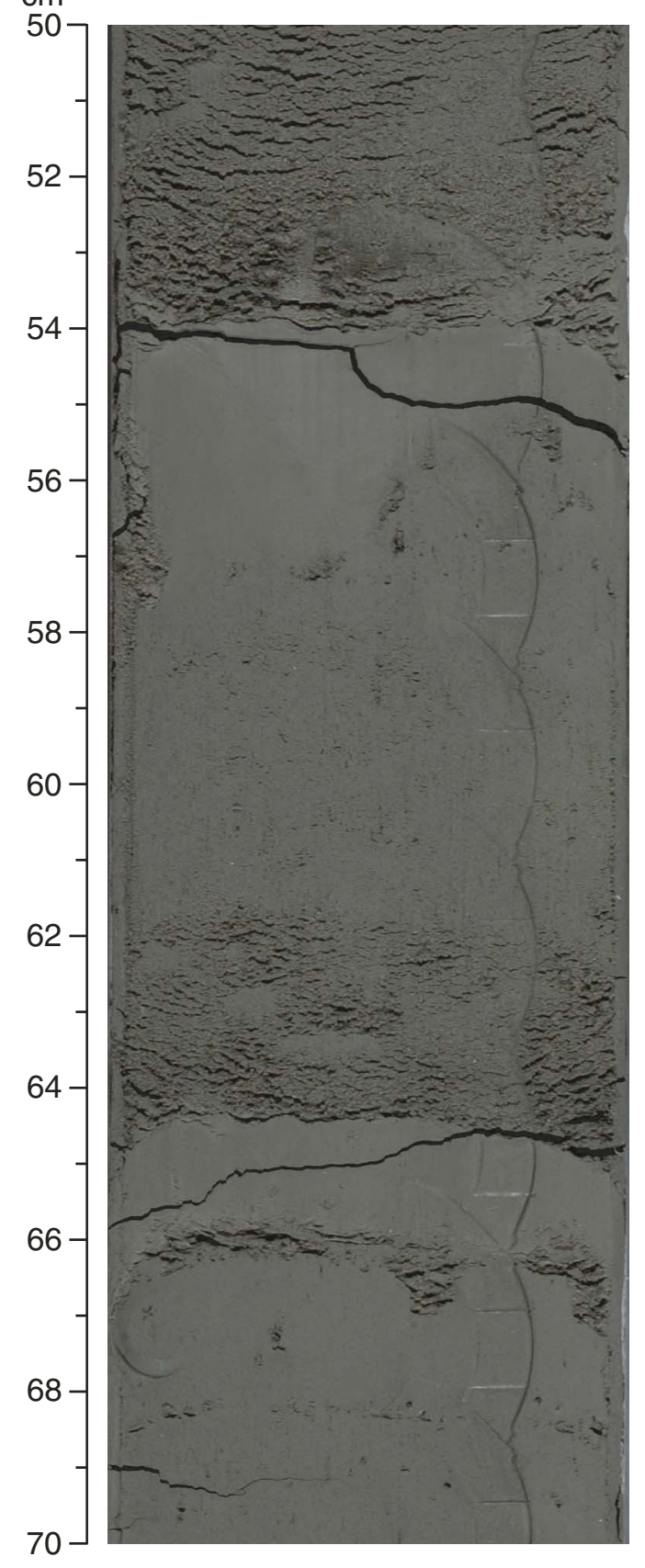


Figure F15. Thick massive sand bed in Subunit IB. A. Coarse sand from an $\sim 10 \mathrm{~m}$ thick bed (interval 301U1301C-11H-6, 110-120 cm). B. Granule layer within Subunit IB (interval 301-U1301C-13H-CC, 5-10 cm). C. Washed granules from the same interval as in B. The granules consist of subrounded grains of green metamorphic grains (possibly amphibolite or serpentinite), white felsic volcanics, calcareous sandstone, and shallow-water shell fragments in a matrix of soupy clay (interval 301-U1301C-13H-CC, 9-11 cm).

A

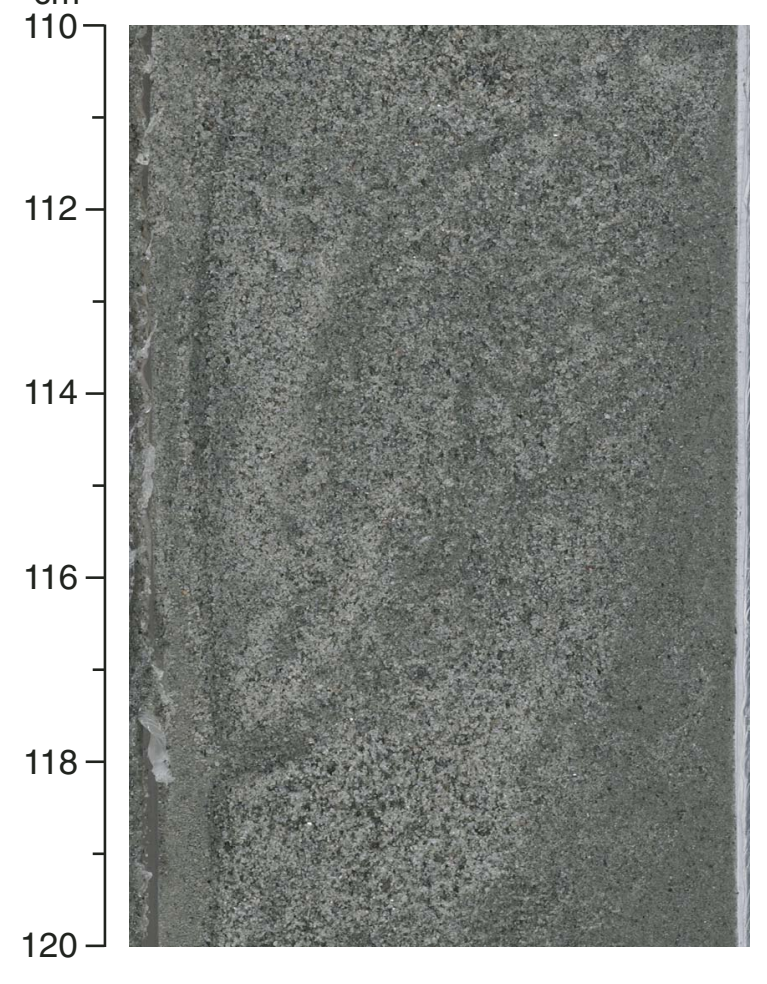

C

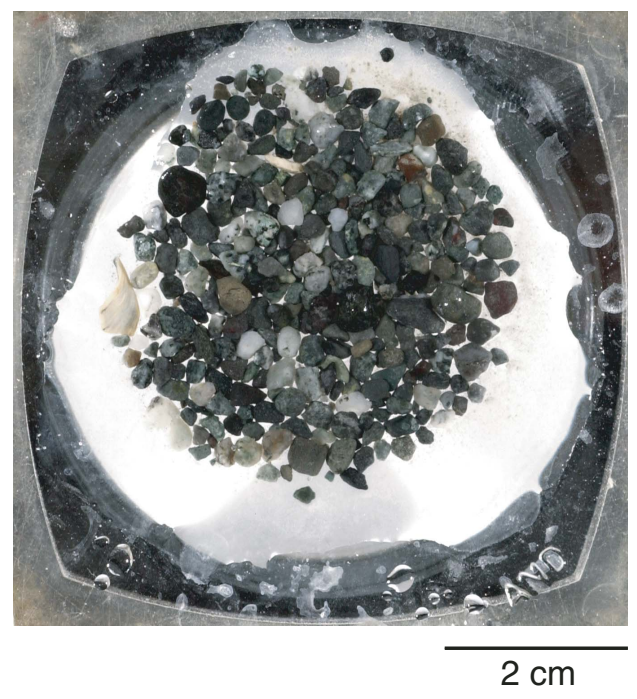

$\mathbf{B}_{\mathrm{cm}}$

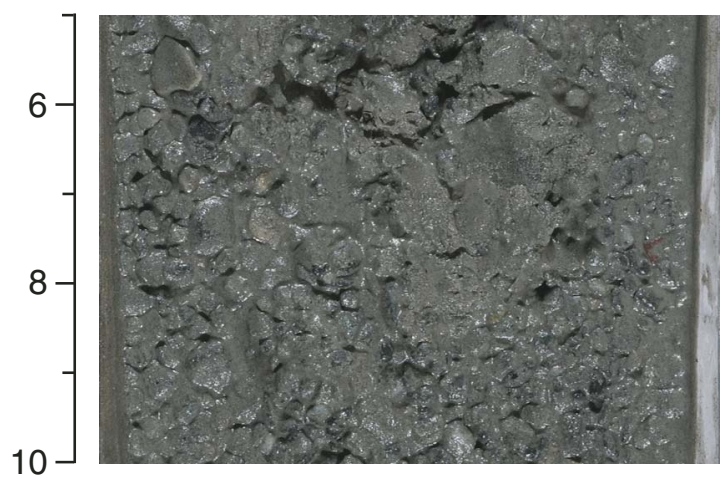


Figure F16. A. Biogenic clay from Subunit IA with clay minerals, fine quartz, diatoms, sponge spicules, and silicoflagellates (Sample 301-U1301C-1H-3, $10 \mathrm{~cm}$ ) (field of view [FOV] $=0.7 \mathrm{~mm}$ ). B. Very fine sand in Subunit I, which contains quartz, plagioclase, green amphibole, calcite, iron oxide, and opaque minerals (Sample 301$\mathrm{U} 1301 \mathrm{C}-4 \mathrm{H}-2,10 \mathrm{~cm})(\mathrm{FOV}=0.7 \mathrm{~mm})$.

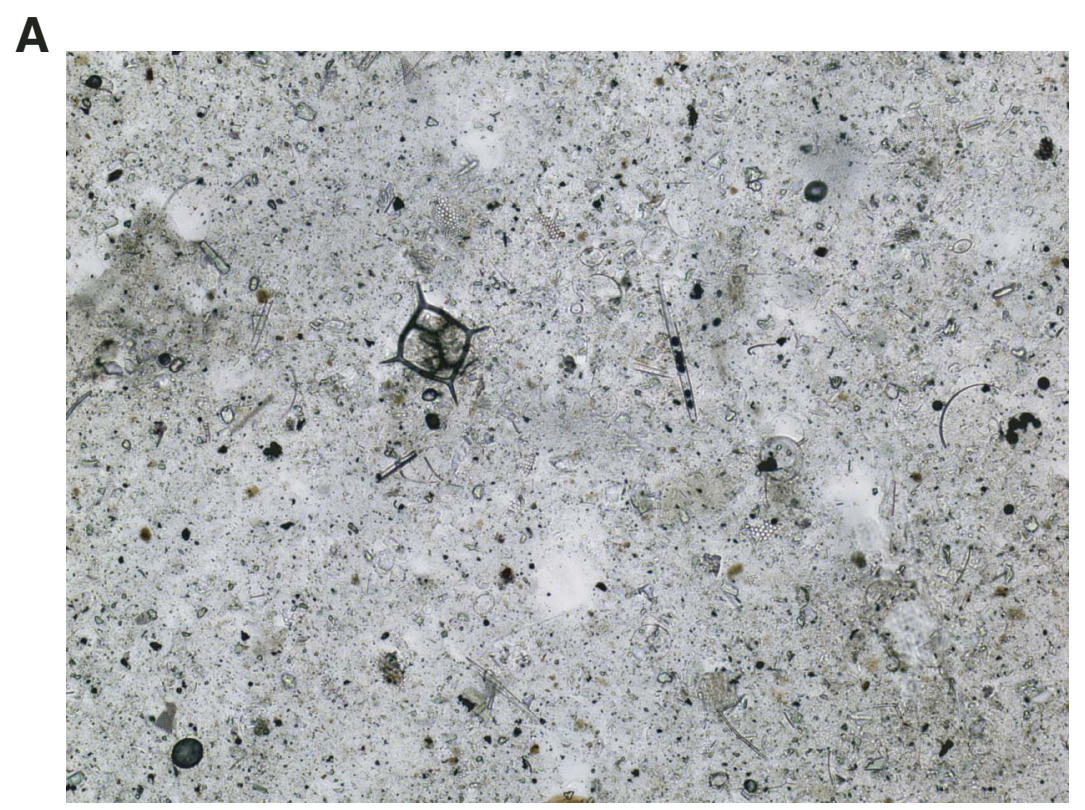

B

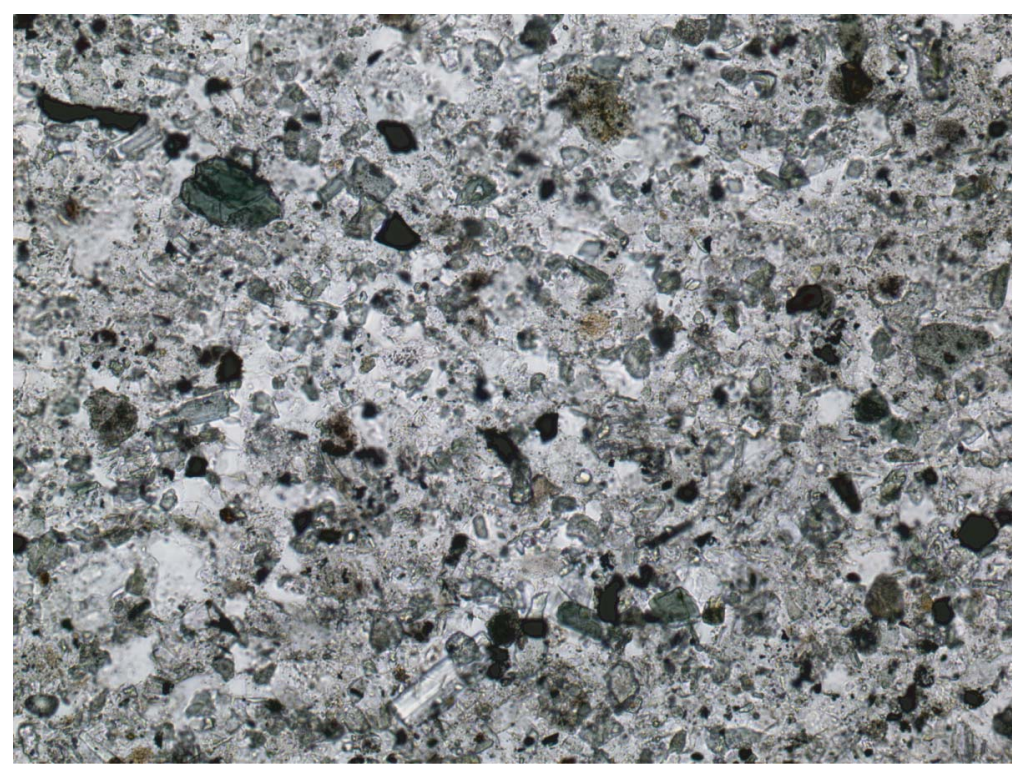


Figure F17. A. Fine- to medium-grained sand from Subunit IB with well-sorted subangular grains of quartz, plagioclase, amphibole, opaque minerals, and epidote (Sample 301-U1301C-6H-3, $60 \mathrm{~cm}$ ) (field of view [FOV] $=1.4 \mathrm{~mm})$. B. Hemipelagic clay from Unit II, which consists of clay minerals with very fine grains of organic matter (Sample U1301C-17H-4, $125 \mathrm{~cm})(\mathrm{FOV}=0.7 \mathrm{~mm})$.

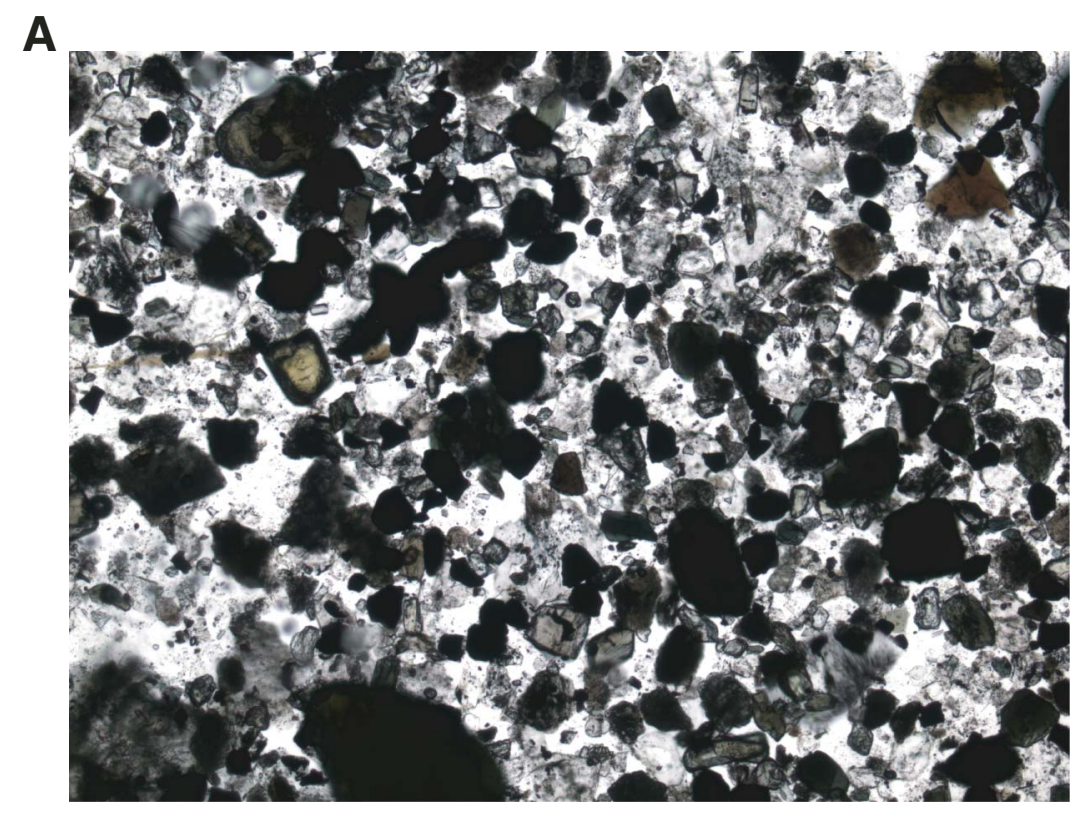

B

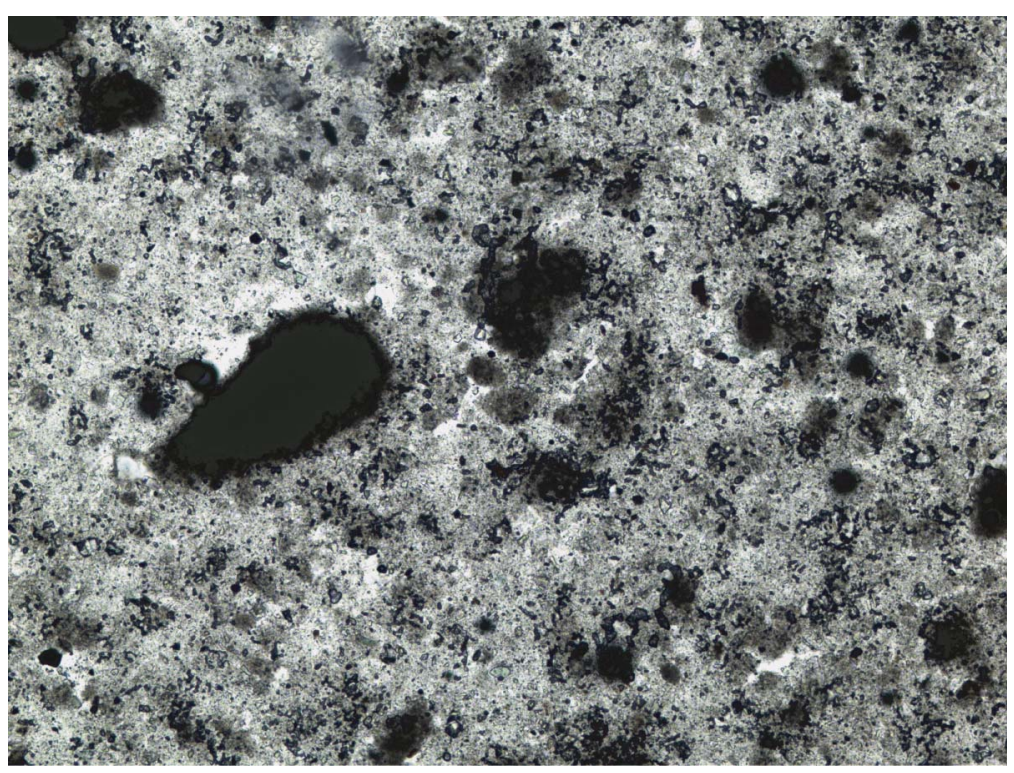


Figure F18. Hemipelagic clay from Unit II. A. Dark greenish gray clay with rare bioturbation (interval 301U1301C-17H-4, 123-130 cm). The white patches are carbonate rich and contain very fine black organic matter. B. Dark greenish gray clay with a disk-shaped siliceous concretion (interval 301-U1301C-17H-CC, 1-8 $\mathrm{cm})$.

$\mathbf{A}_{\mathrm{cm}}$

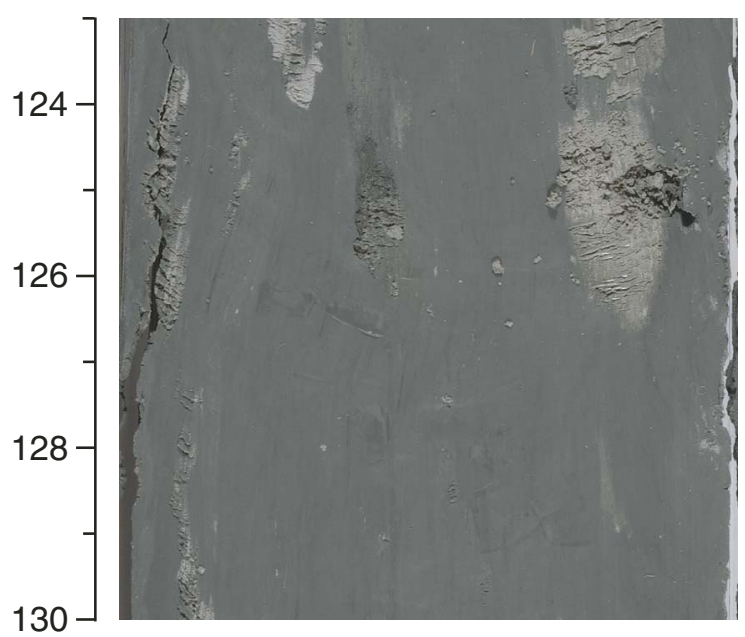

$\mathbf{B}_{\mathrm{cm}}$

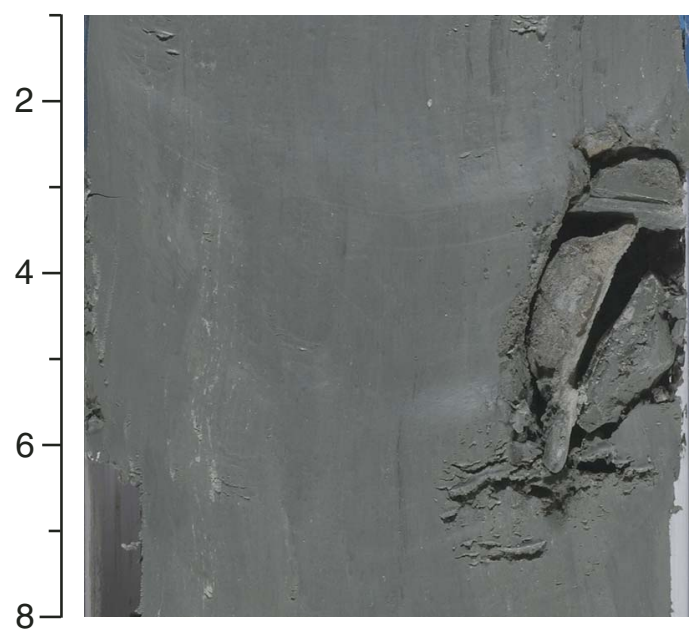


Figure F19. Disrupted and brecciated mud with granules and pebbles in the upper part of Cores 301-U1301C$15 \mathrm{H}$ to $19 \mathrm{H}$. A. Disrupted mud with granules (interval 301-U1301C-16H-1, 10-25 cm). B. Clay matrix-supported breccia with granules and mud clasts (interval 301-U1301C-17H-1, 10-20 cm). C. Matrix-supported breccia with granules and mud clasts. Mud clasts contain well-preserved slicken surfaces and microfractures (interval 301-U1301C-18H-1, 27-31 cm). D. Washed granules from the brecciated zone at the top of Core $15 \mathrm{H}$, which include green metamorphic grains (amphibolite or serpentinite?), white felsic volcanics, and calcareous sandstone and are similar to those from Section 301-U1301C-13H-CC (Fig. F18).

$\mathbf{A}_{\mathrm{cm}}$

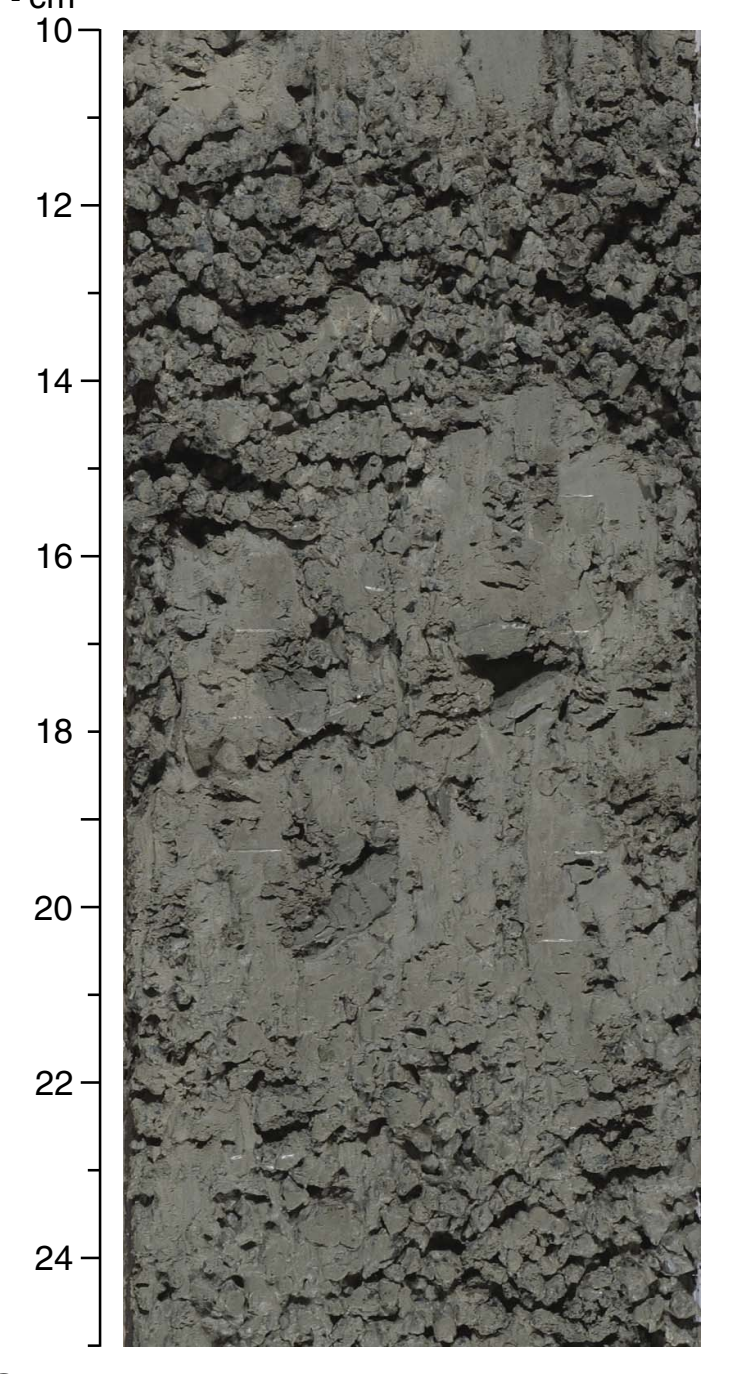

C

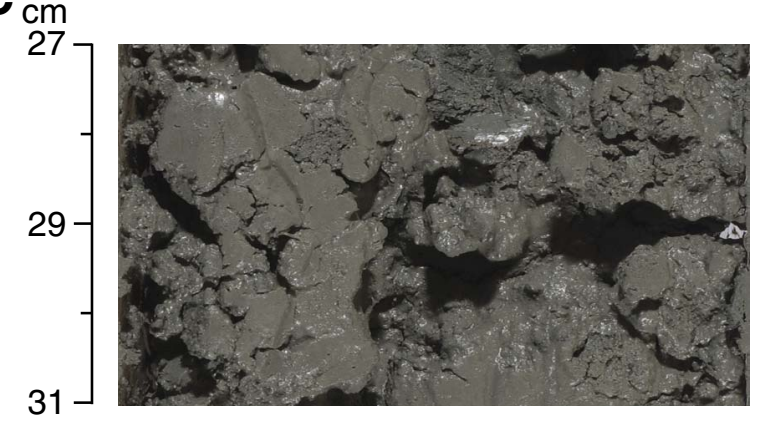

$\mathbf{B}_{\mathrm{cm}}$

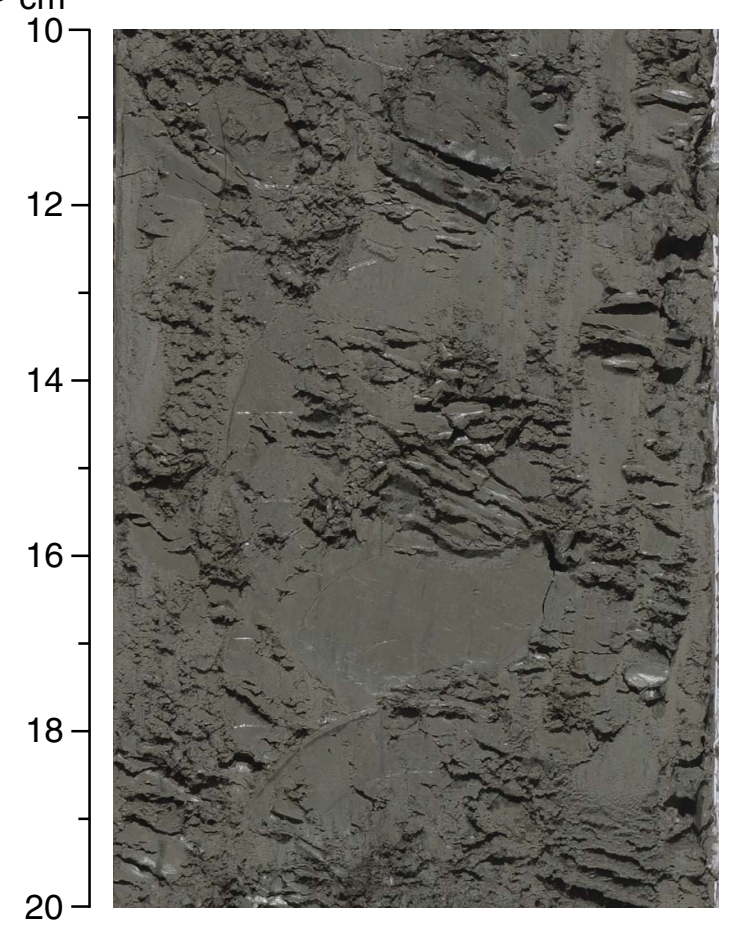

D

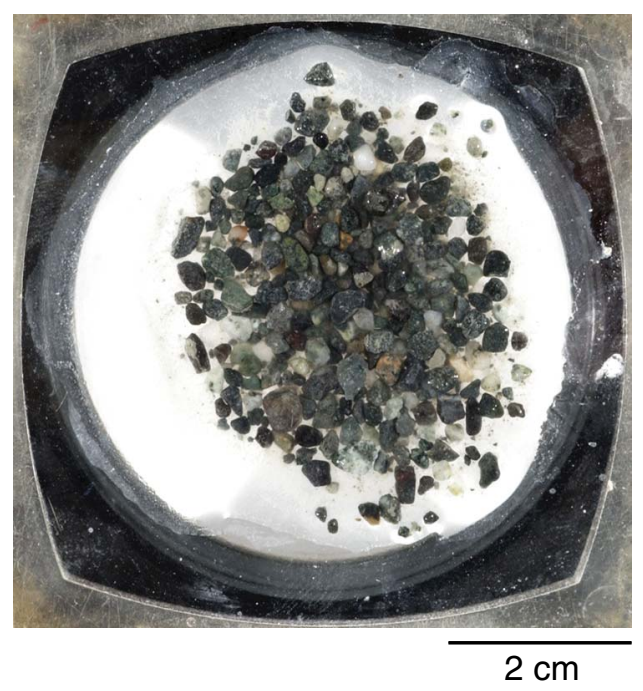


Figure F20. Lithostratigraphic log for Hole U1301B. Core recovery is indicated graphically by horizontal black bars in the recovery column. Maximum groundmass grain size, phenocryst type and abundance, the degree of alteration, and the principal secondary mineralogy in each unit are summarized. TD = total depth.

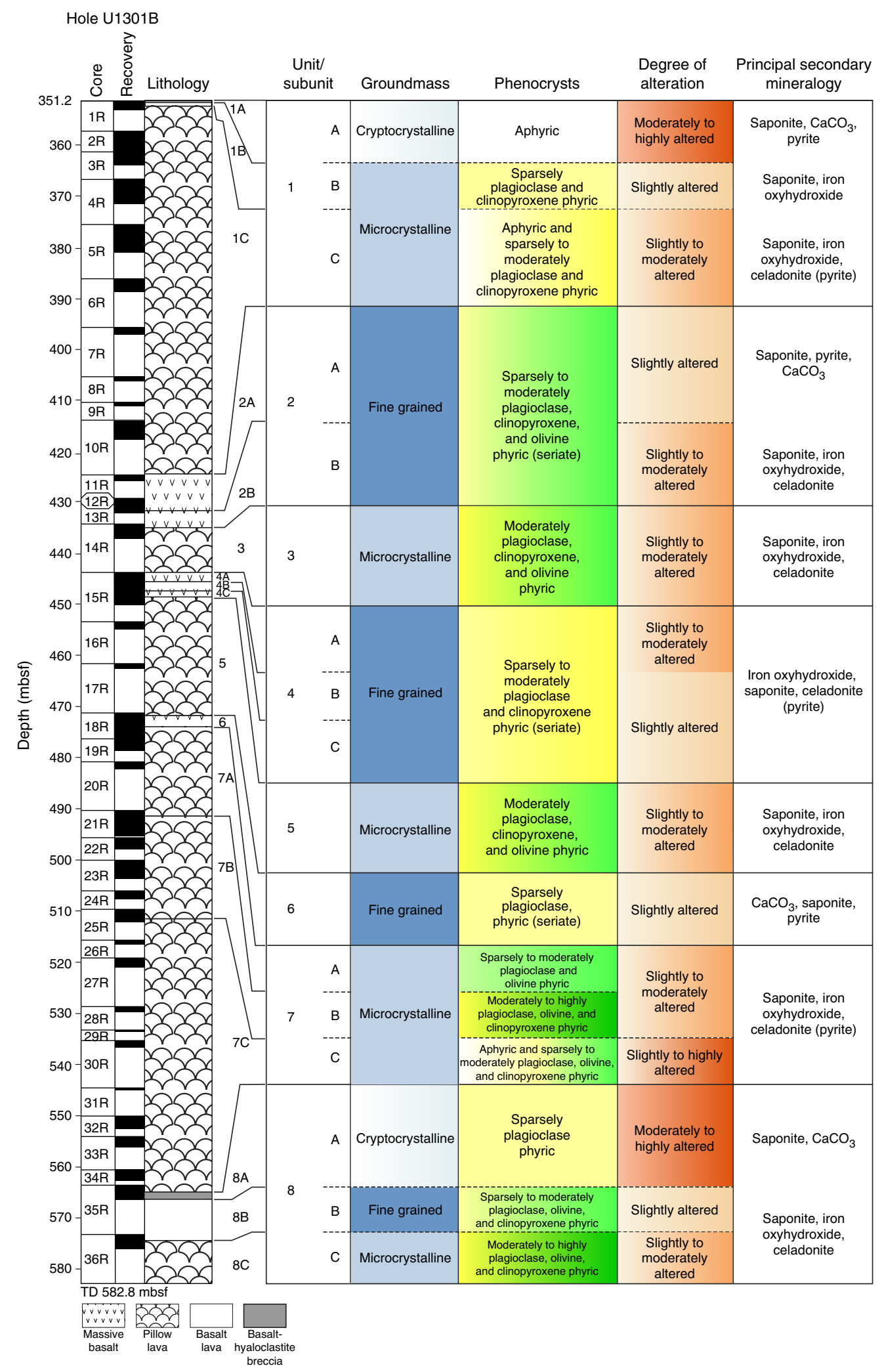


Figure F21. Pillow fragments. A. Curved glassy margin with concentric and radial cooling cracks (interval 301-U1301B-24R-1 [Piece 4, 18-37 cm]). B. Glassy chilled margin that separates two pillows (interval 301U1301B-26R-1 [Piece 7, 34-47 cm]).

$\mathbf{A}_{\mathrm{cm}}$

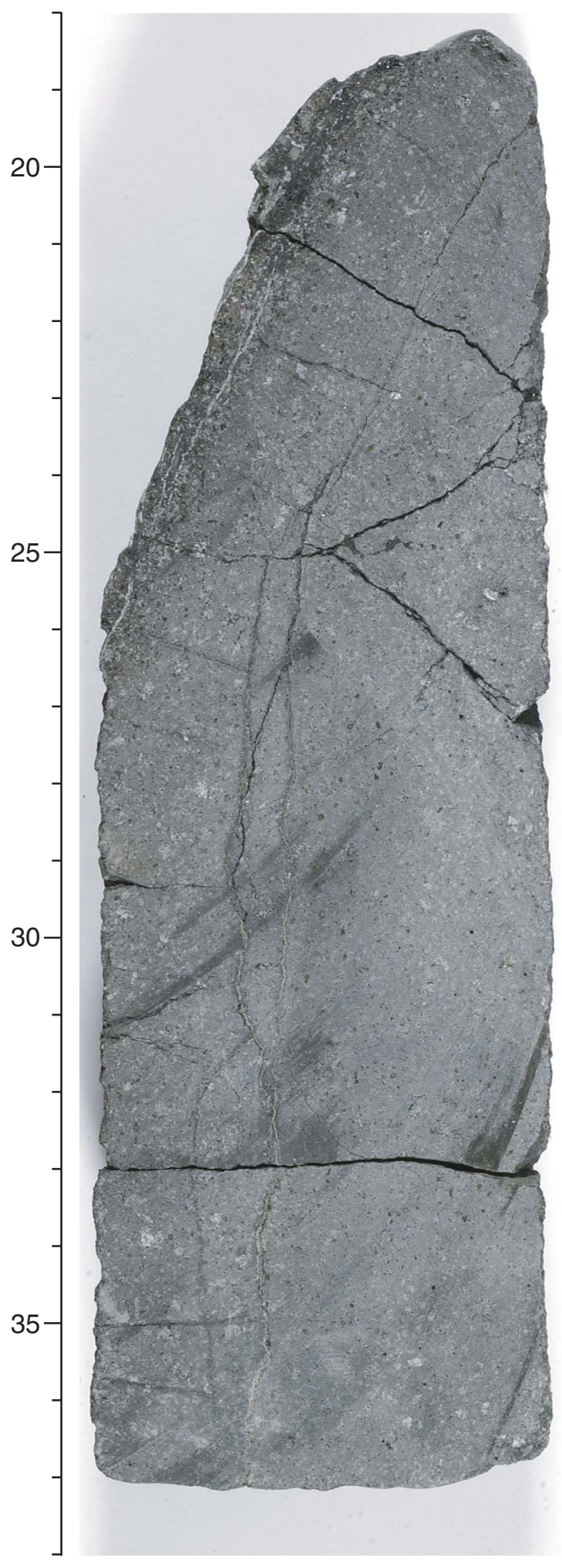

$\mathbf{B}_{\mathrm{cm}}$

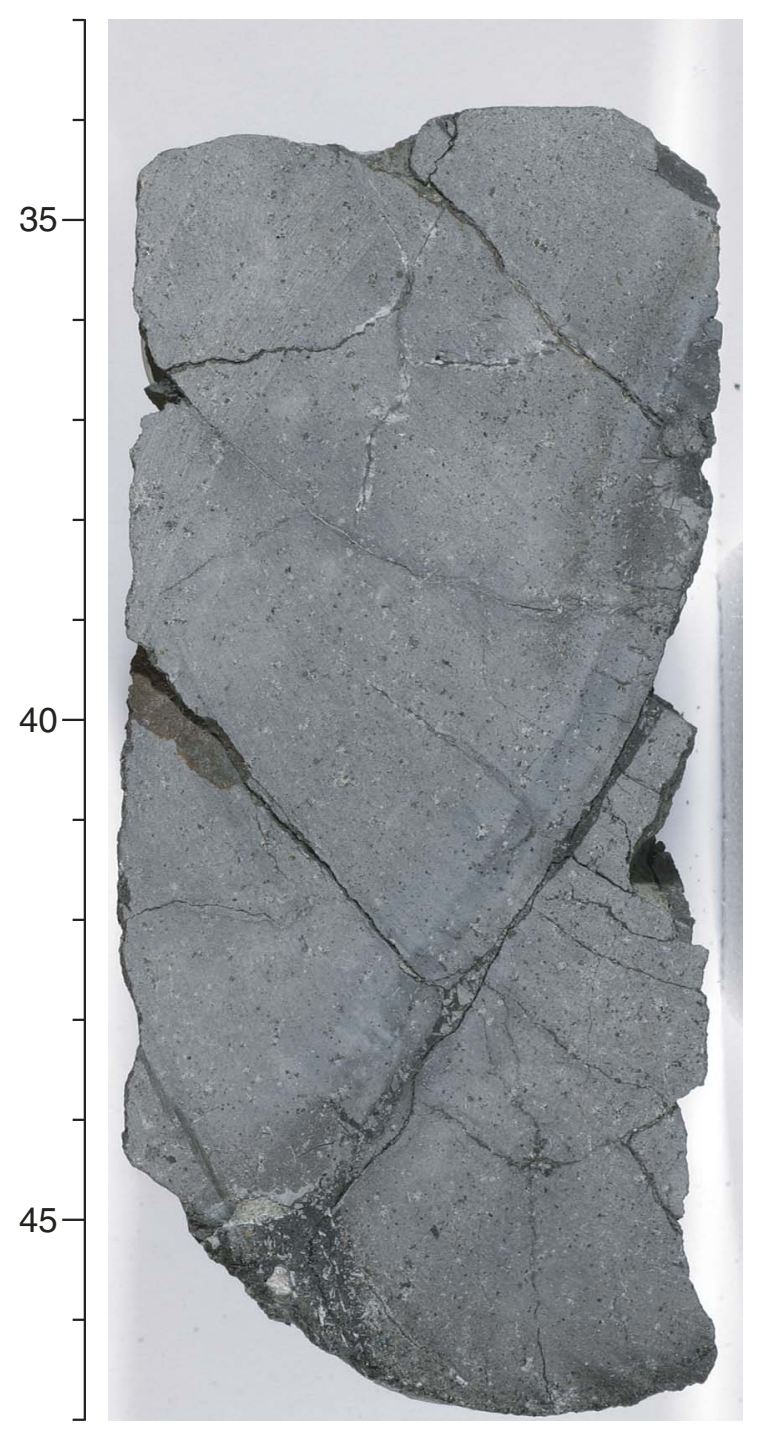


Figure F22. An almost complete section through a single pillow lava. The pillow has a planar upper glassy chilled margin and a convex lower glassy chilled margin and is at least $50 \mathrm{~cm}$ in diameter (interval 301U1301B-4R-3 [Pieces 1-2, 0-46 cm]).

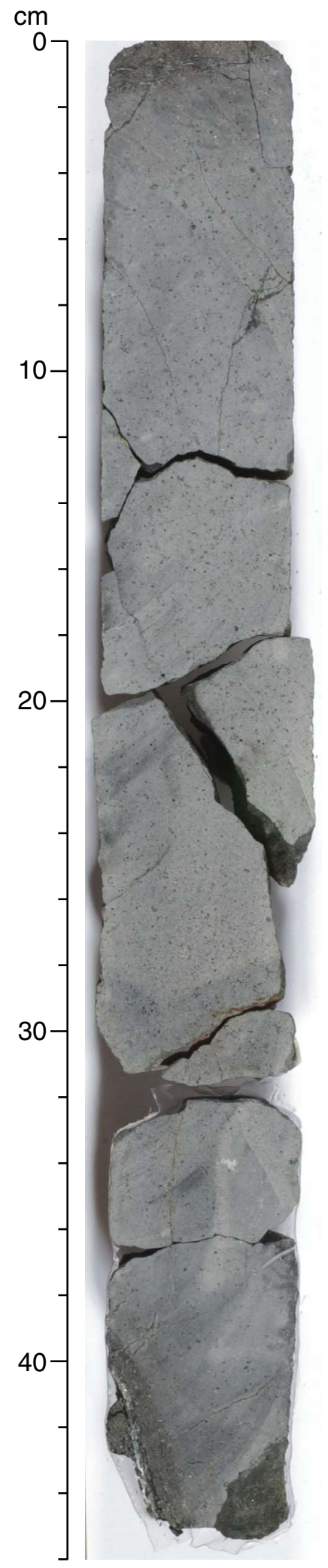


Figure F23. A. Subunit 1A basalt-hyaloclastite breccia, which consists of variably altered basalt and glass clasts in a saponitic matrix. White minerals in the matrix are calcium carbonate and zeolite (interval 301-U1301B1R-1 [Piece 2, 4-18 cm]). B. Subunit 8A basalt-hyaloclastite breccia, which consists of angular basalt clasts and glass shards in saponitic matrix (interval 301-U1301B-35R-1 [Piece 13, 99-106 cm]).

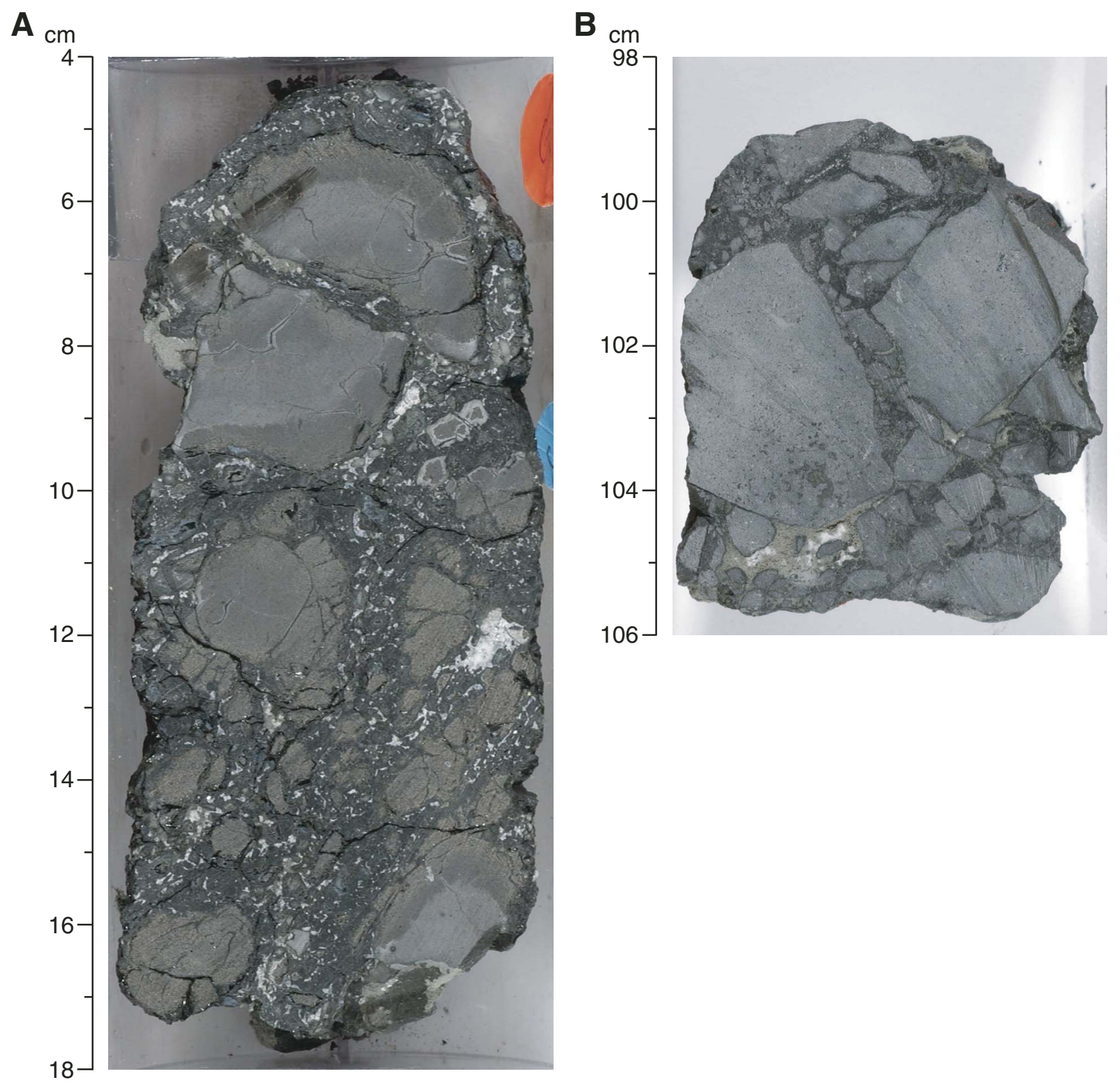


Figure F24. Highly vesicular central portion of a massive lava flow (interval 301-U1301B-18R-2, 70-100 cm). The core is cut by several saponite \pm calcium carbonate veins, and vesicles are lined/filled by saponite and carbonate.

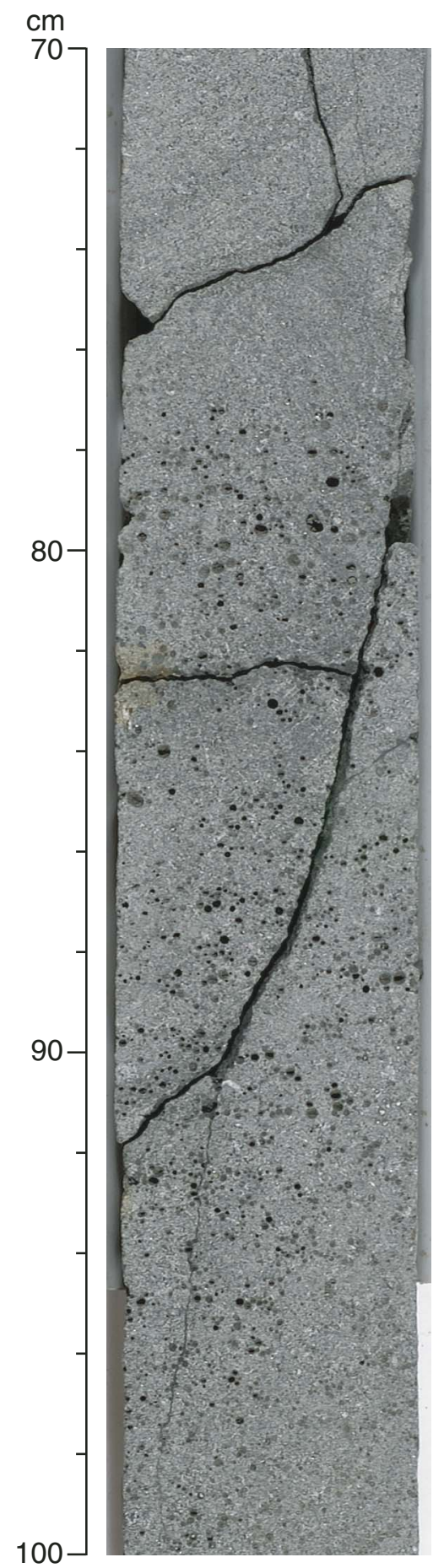


Figure F25. Typical mineral assemblages, abundances, and groundmass textures within basalts from Hole U1301B. A, B. Spherultic, hyalophitic groundmass (Sample 301-U1301B-26R-1 [Piece 7, 41-43 cm]) (field of view $[\mathrm{FOV}]=1.4 \mathrm{~mm}$ ); (A) plane-polarized light, (B) cross-polarized light. C, D. Intersertal, seriate texture (Sample 301-U1301B-32R-2 [Piece 2, 123-125 cm]) (FOV = $5.5 \mathrm{~mm})$; (C) plane-polarized light, (D) cross-polarized light. E. Pilotaxitic groundmass plagioclase (Sample 301-U1301B-16R-1 [Piece 2, 8-10 cm]); plane-polarized light $(\mathrm{FOV}=5.5 \mathrm{~mm})$. F. Intergranular fine-grained massive basalt (Sample 301-U1301B-18R-4 [Piece 1, $17-19 \mathrm{~cm}])$; plane-polarized light $(\mathrm{FOV}=5.5 \mathrm{~mm})$.

A

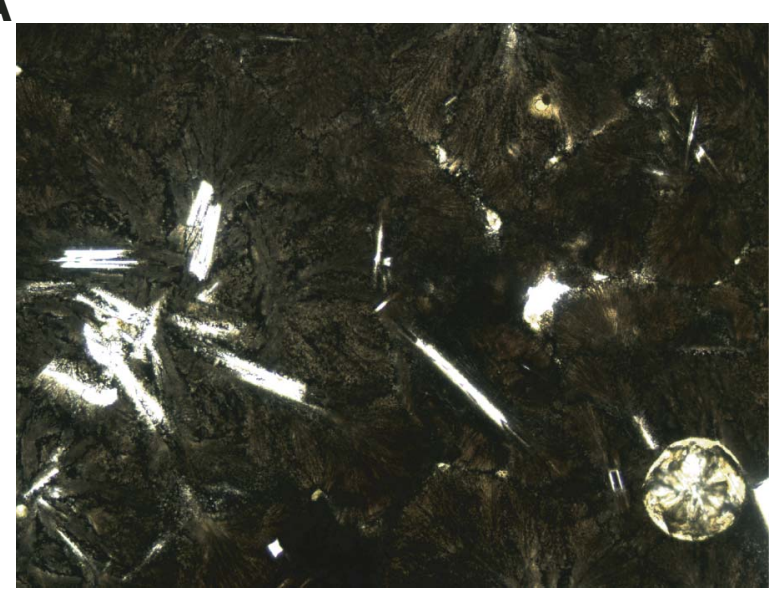

C

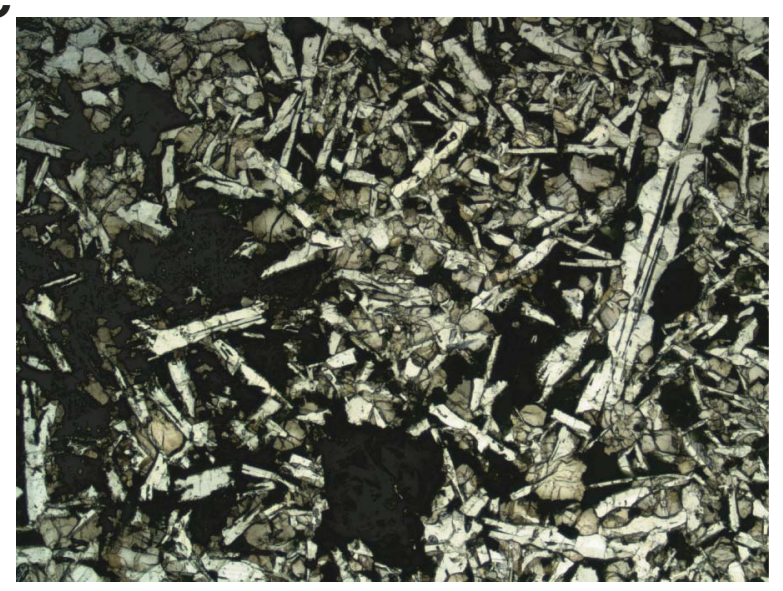

E

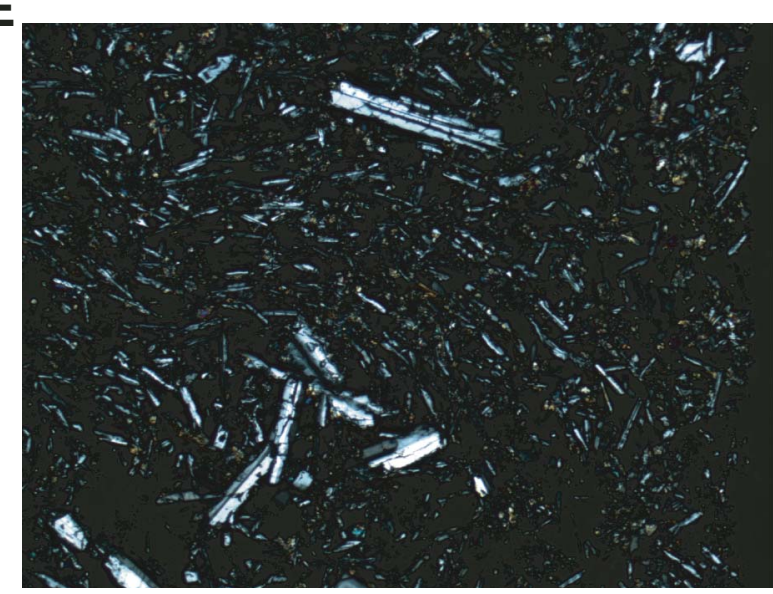

B

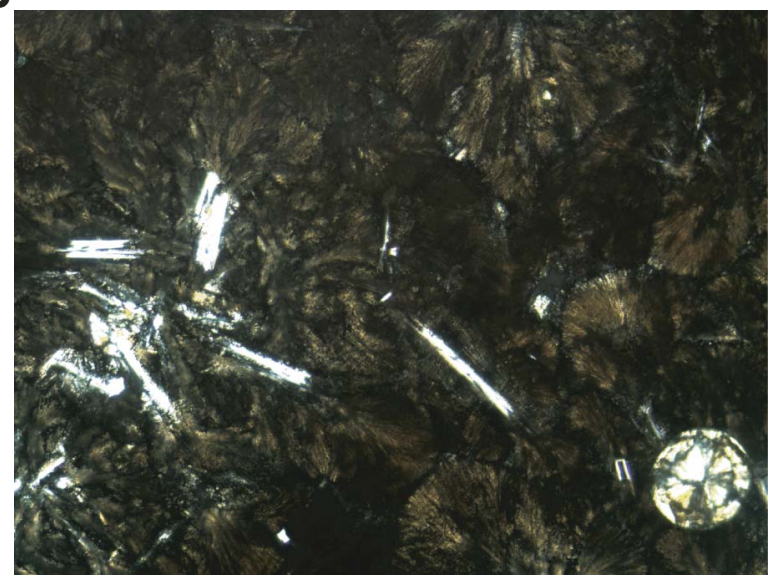

D

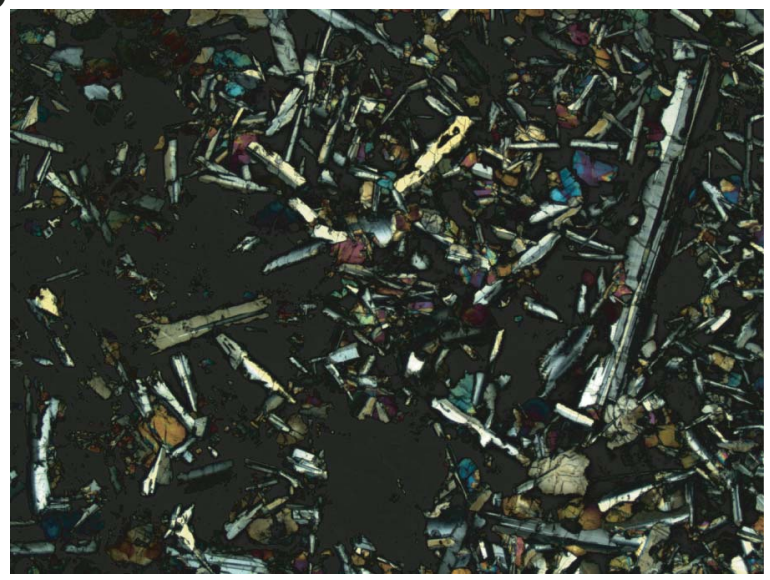

F

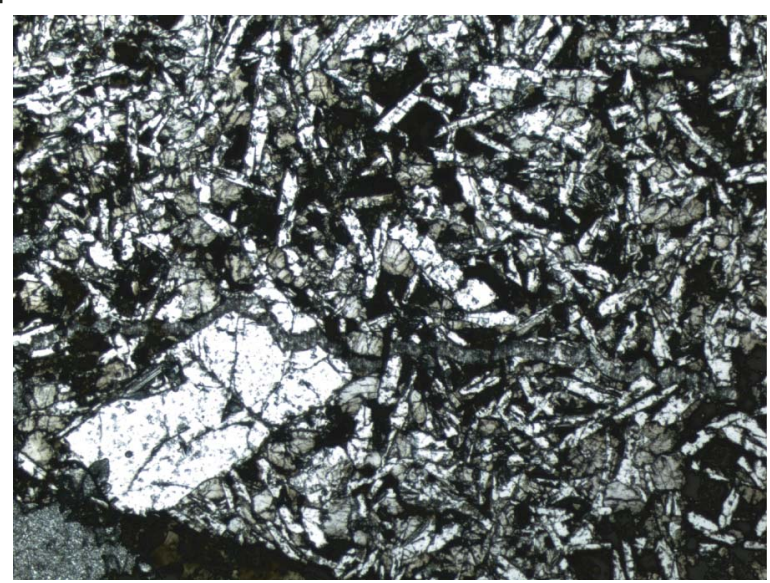


Figure F26. Glomeroporphyritic clots (Sample 301-U1301B-21R-2 [Piece 17, 126-128 cm]) (field of view = 2.75 $\mathrm{mm}$ ). A, B. Clinopyroxene-plagioclase glomeroporphyritic clots; (A) plane-polarized light, (B) cross-polarized light. C. Clinopyroxene-plagioclase and olivine (completely replaced by brown saponite)-plagioclase glomeroporphyritic clots (plane-polarized light).

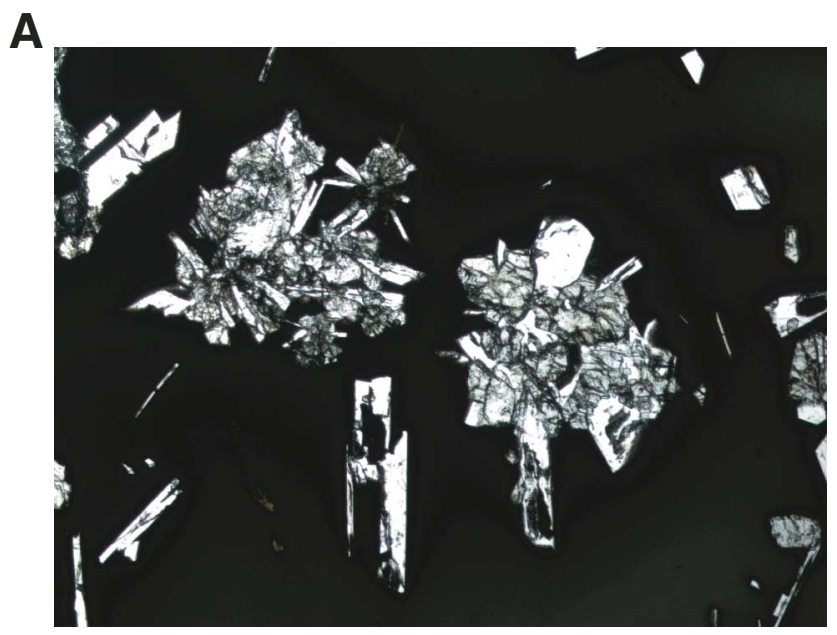

B

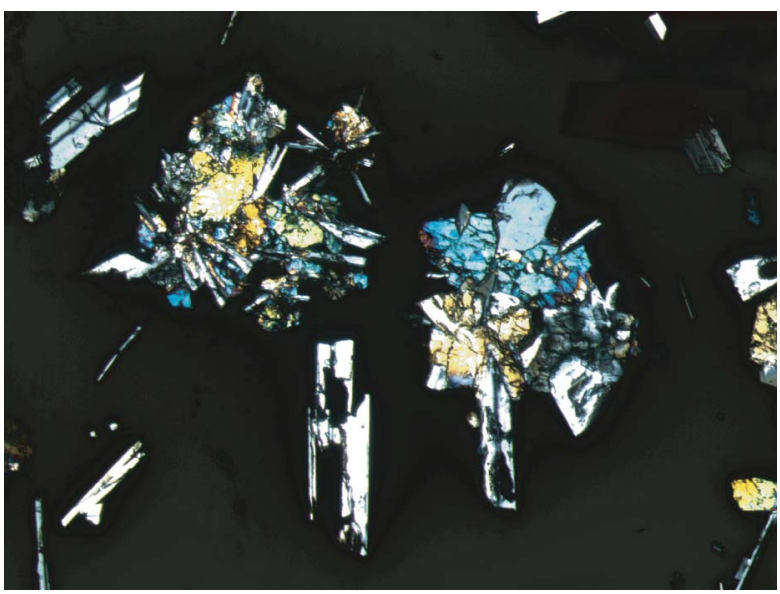

C

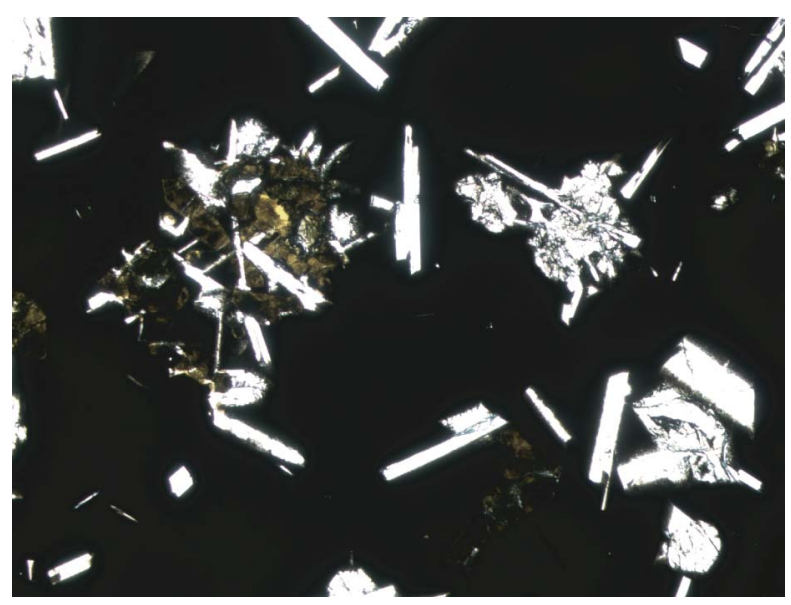


Figure F27. Fresh and partially replaced (by saponite) olivine microlites in the fresh glass portion of a pillow margin (Sample 301-U1301B-4R-3 [Piece 13, 138-140 cm]) (field of view $=2.75 \mathrm{~mm}$ ). A. Plane-polarized light. B. Cross-polarized light.
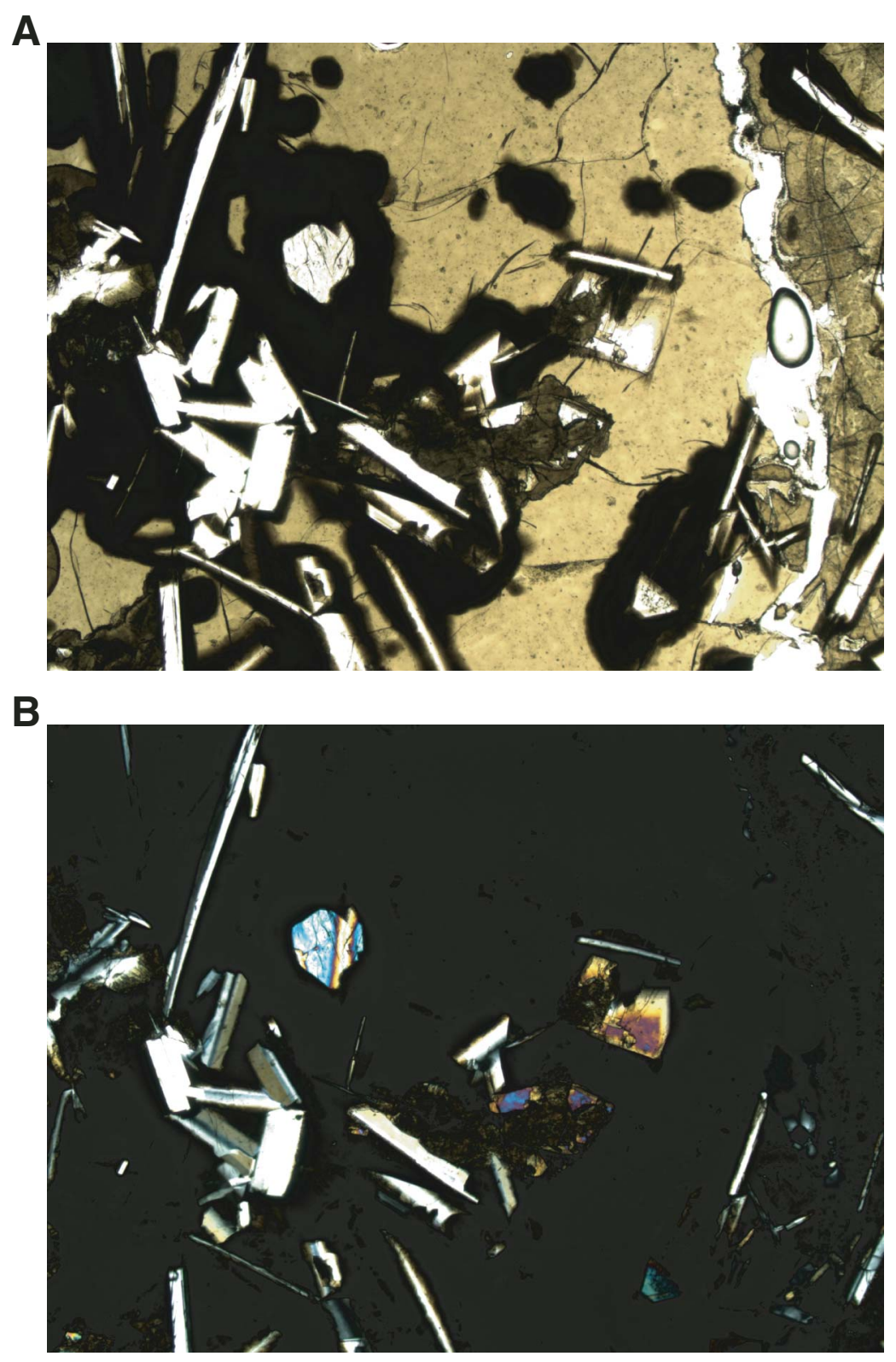
Figure F28. Plot of $\mathrm{TiO}_{2}$ versus $\mathrm{Zr}$ abundance for all shipboard ICP-AES hard rock analyses.

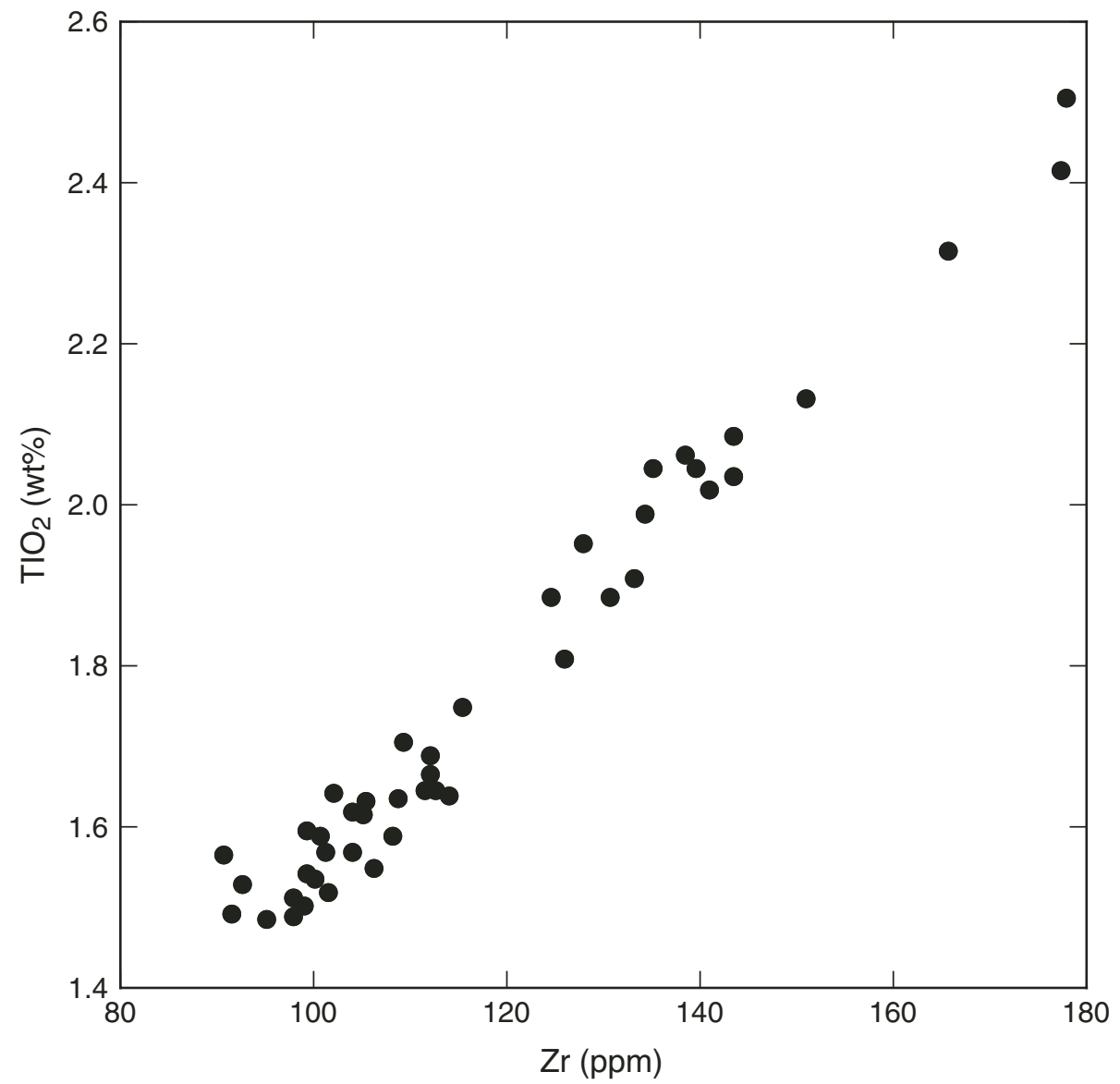


Figure F29. Plots of elemental abundance versus Mg\# for all shipboard ICP-AES hard rock analyses. (Continued on next page.)
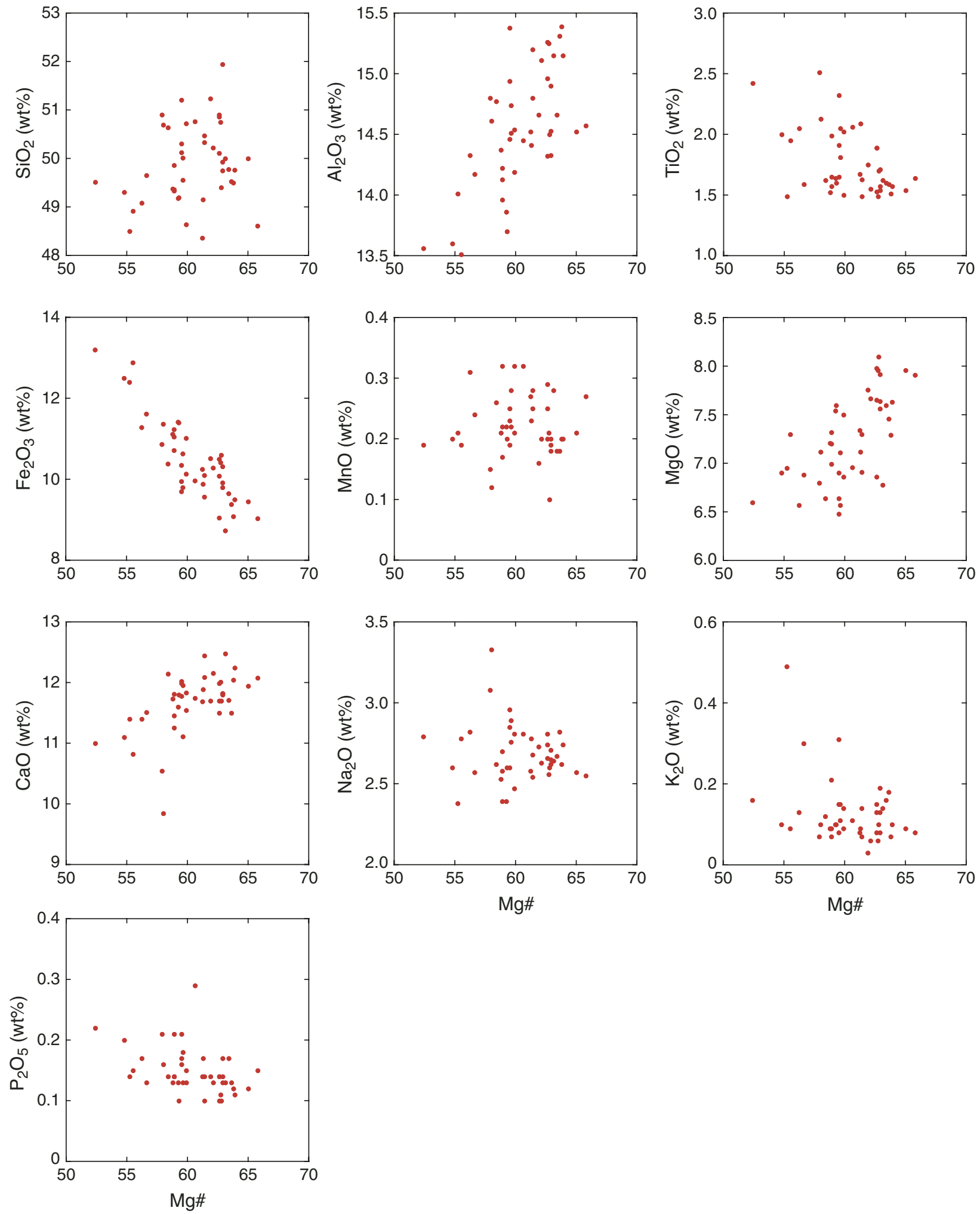
Figure F29 (continued).
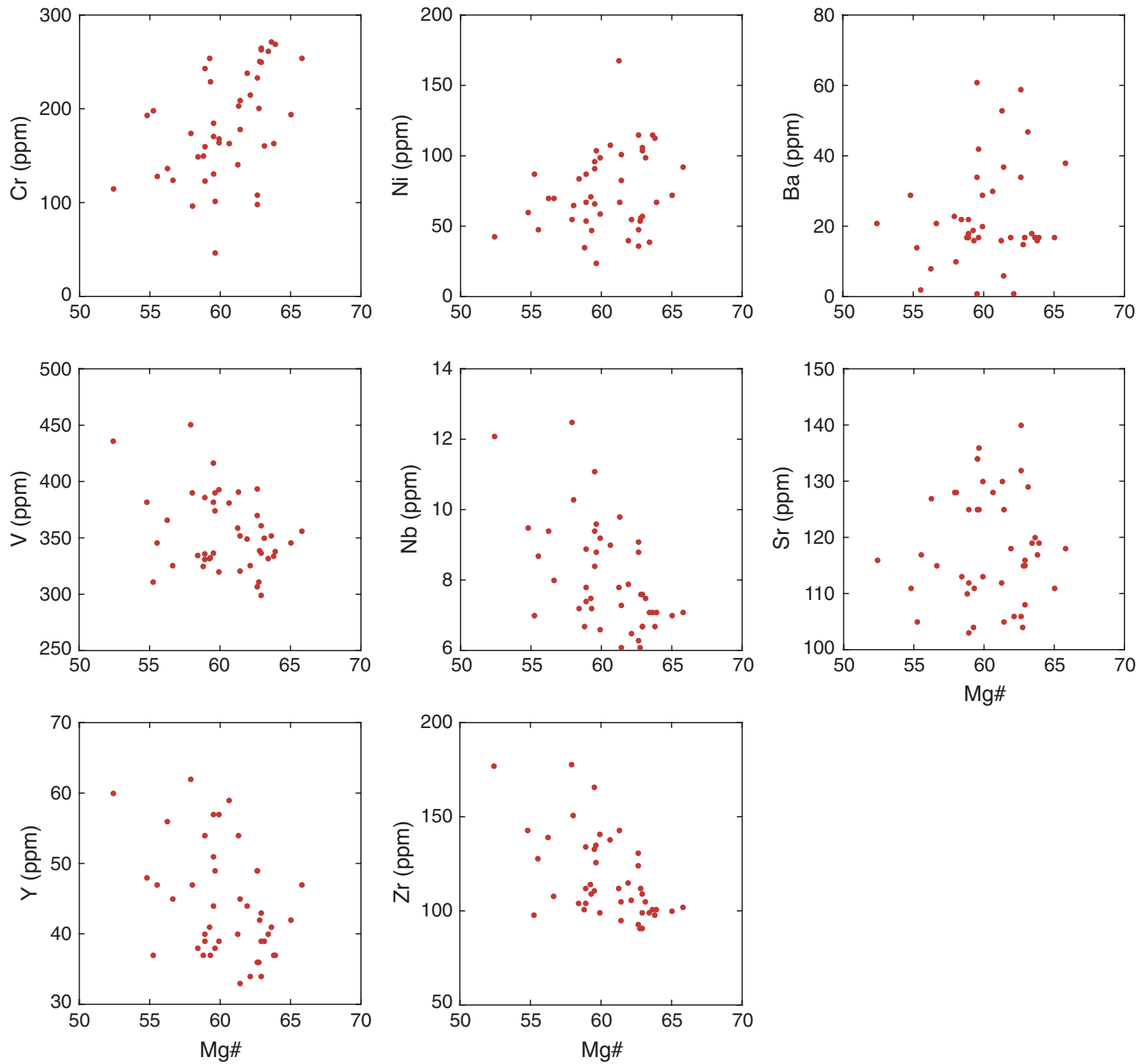
Figure F30. Plots of shipboard ICP-AES analyses versus depth, with igneous stratigraphy and units for comparison (Continued on next three pages).

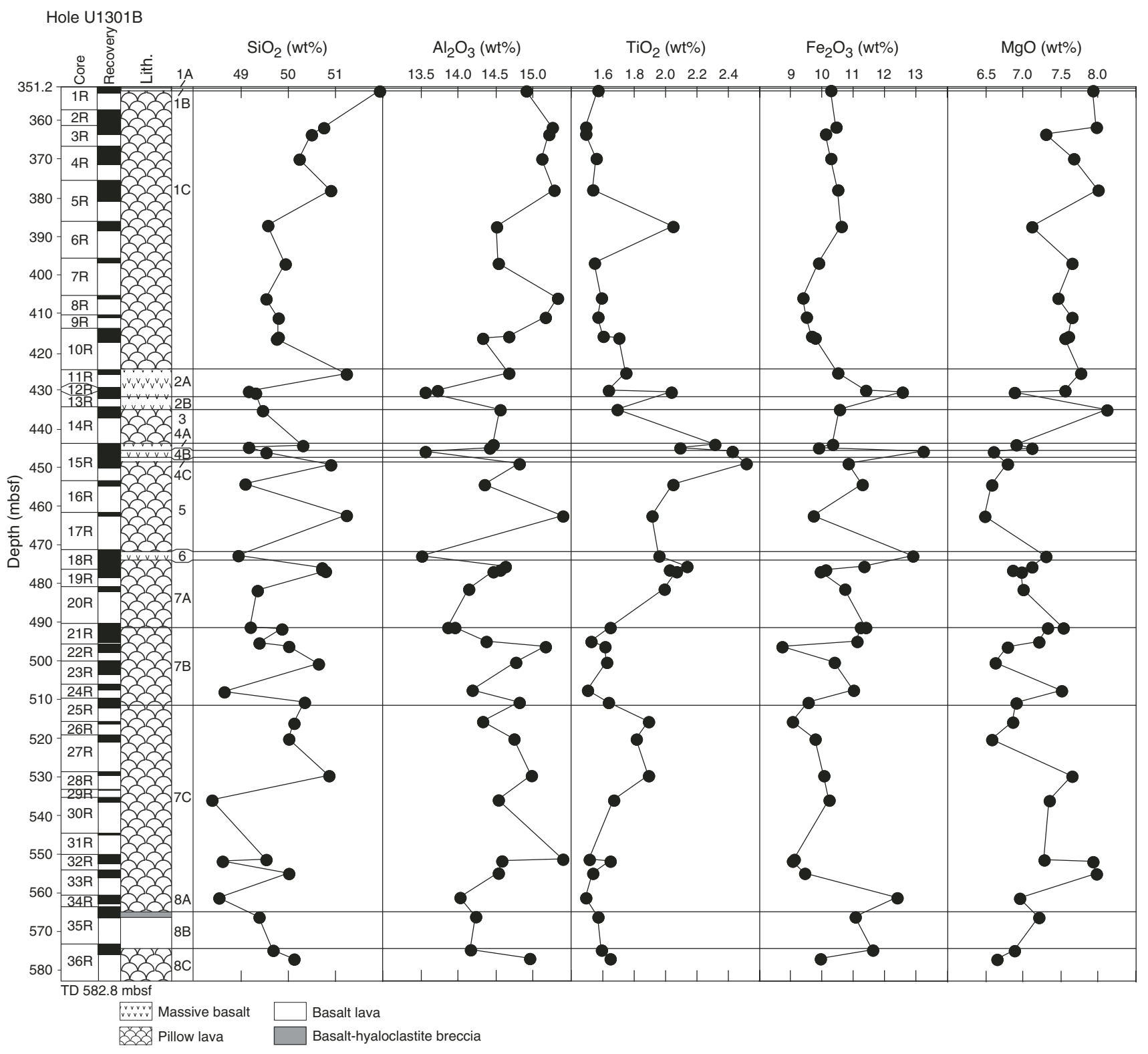


Figure F30 (continued).

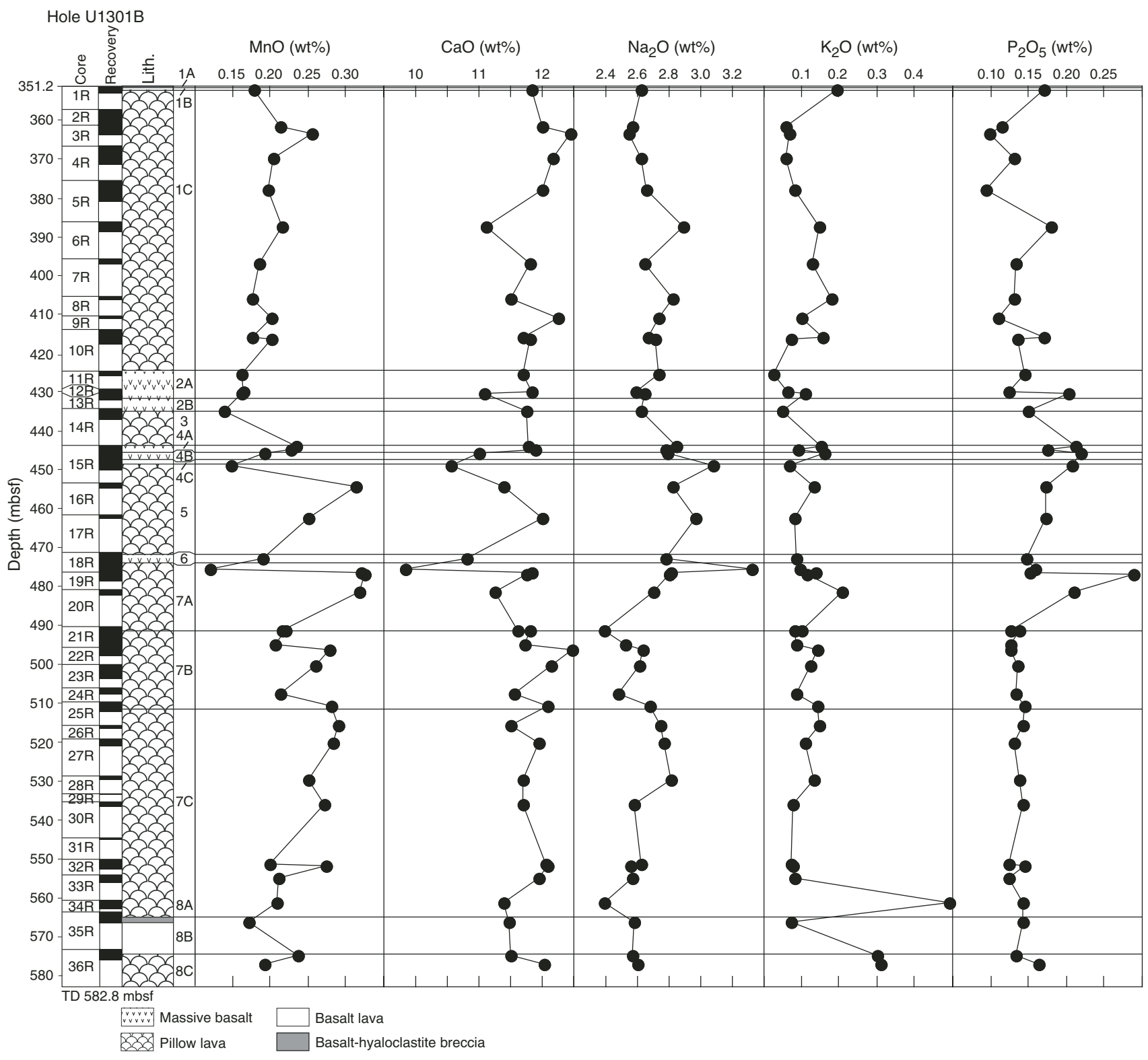


Figure F30 (continued).

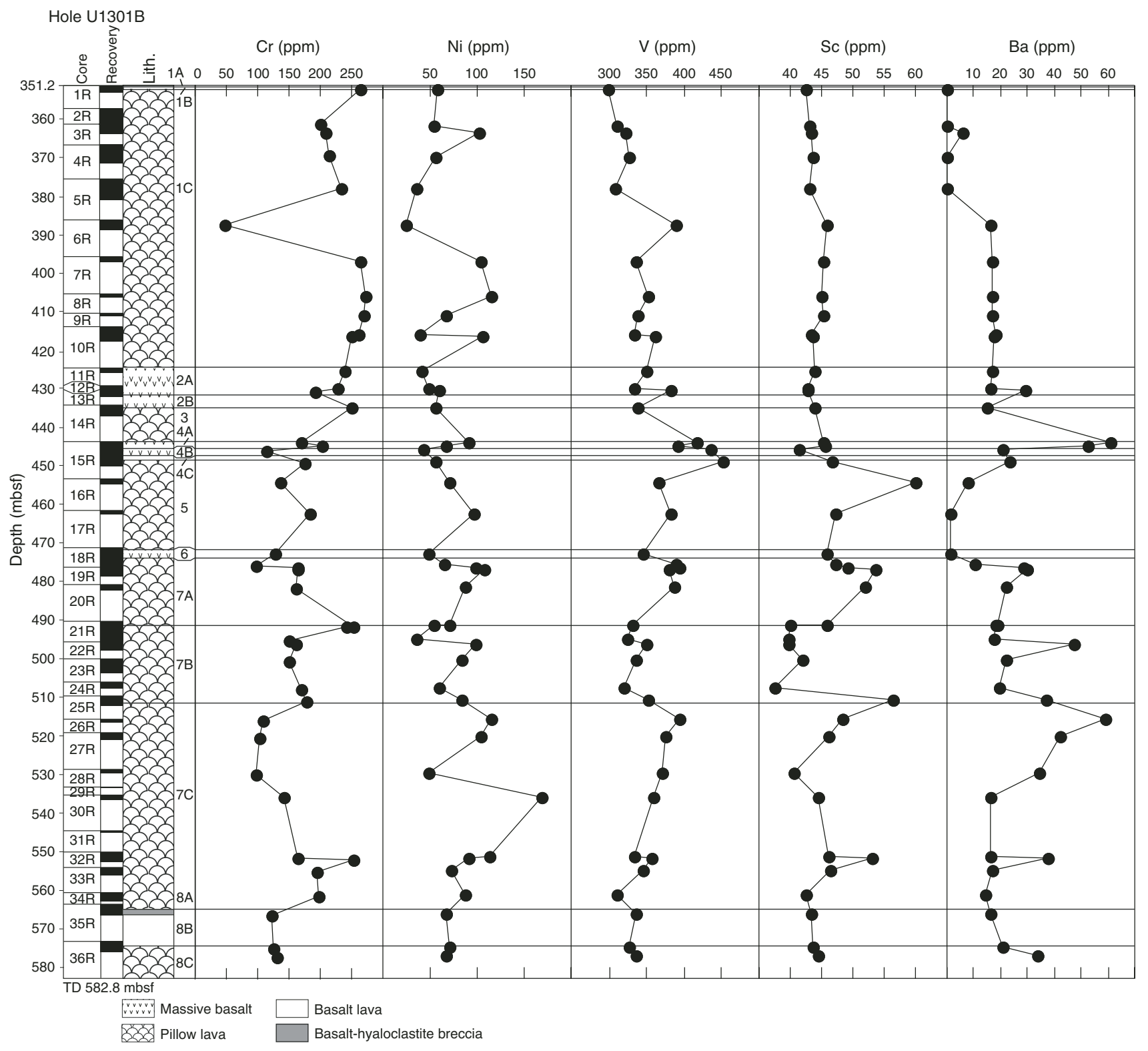


Figure F30 (continued).

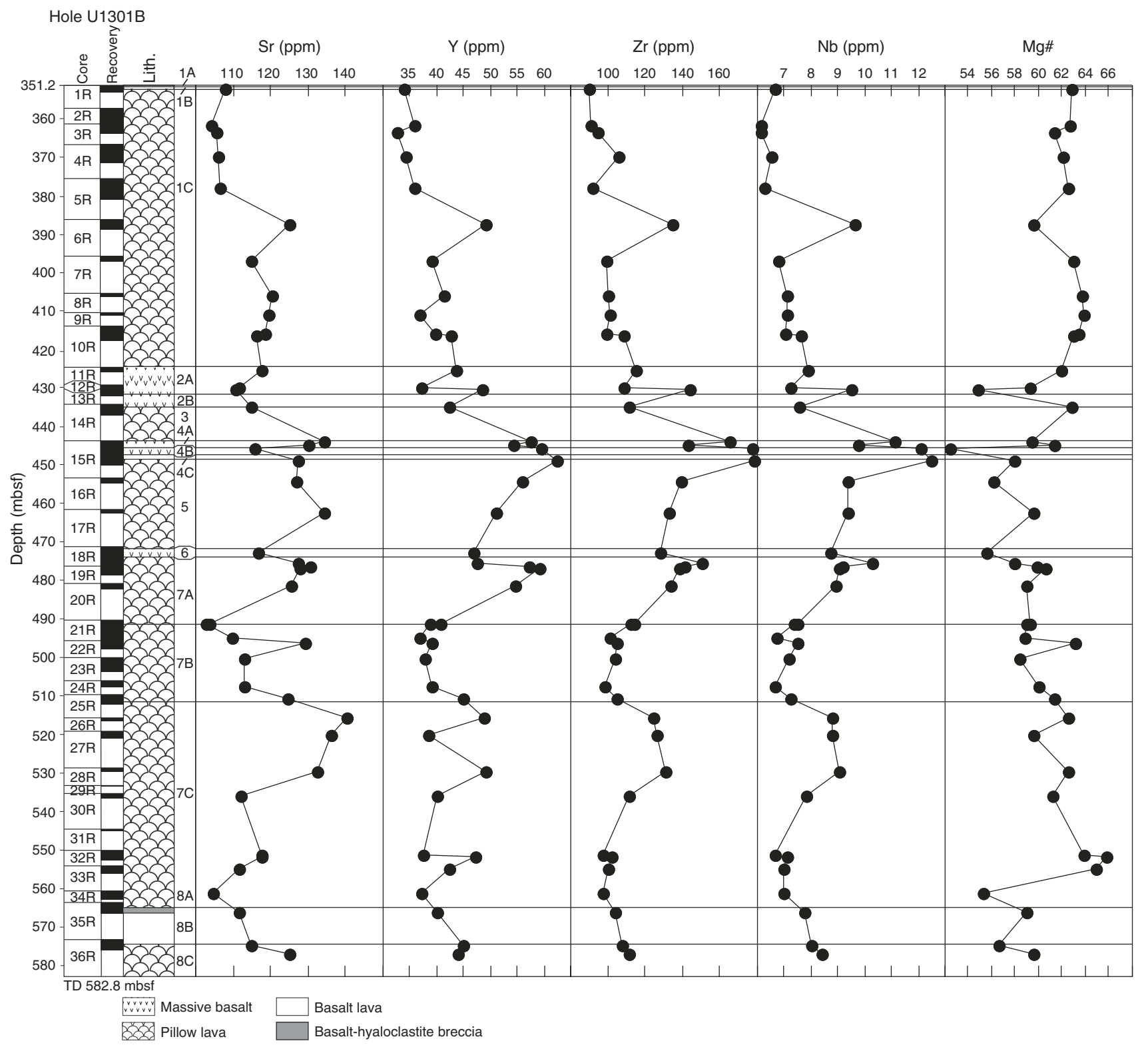


Figure F31. Veins with black alteration halos. A. Saponite vein is flanked by a black alteration halo (interval 301-U1301B-1R-1 [Piece 8, 58-64 cm]). B. Dark gray background alteration with saponite-filled vesicles, cut by an iron oxyhydroxide vein with a black alteration halo (interval 301-U1301B-1R-1 [Piece 15, 118-124 cm]) (photograph is of a wet surface).
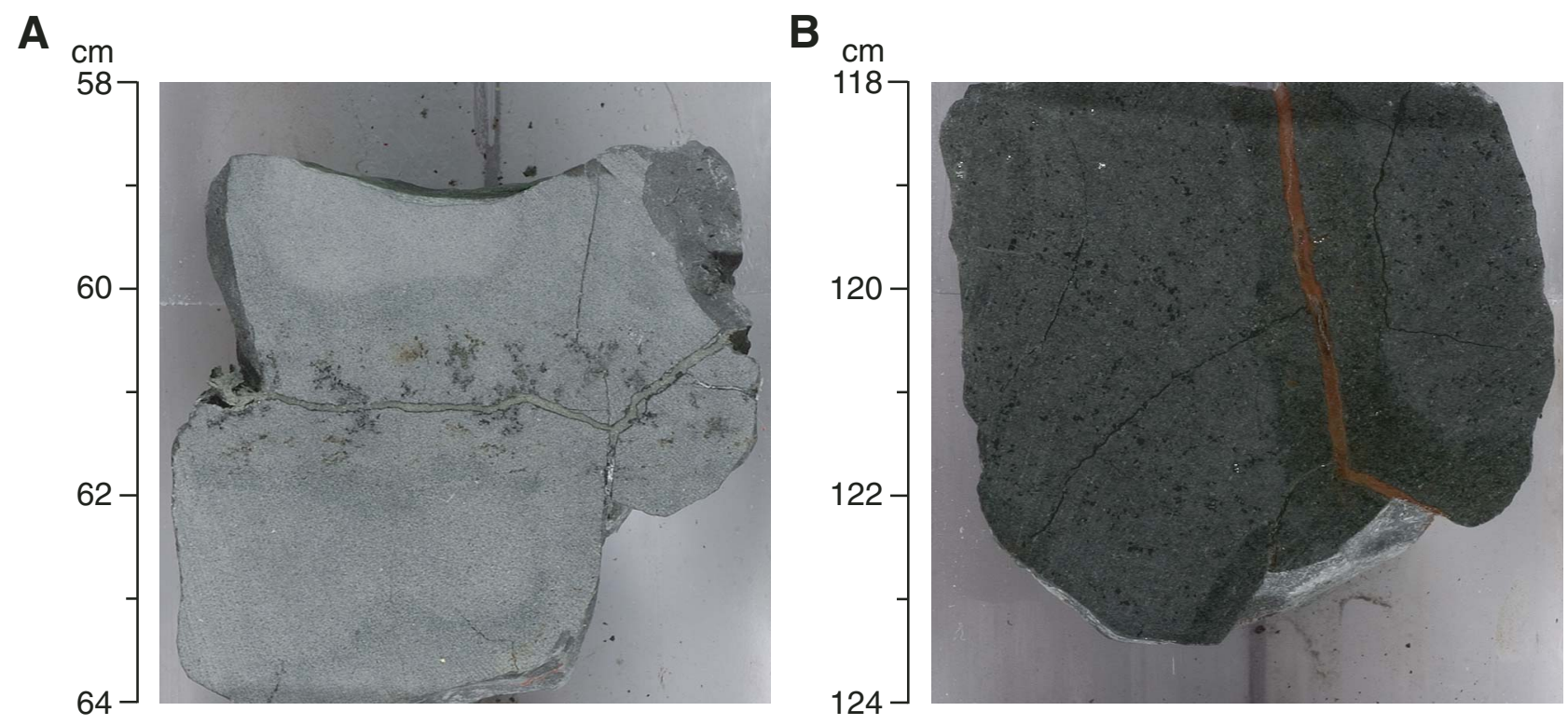
Figure F32. Filled vesicles. A. Vesicles lined with celadonite followed by fibrous saponite (upper right) and saponite followed by celadonite (upper left) (Sample 301-U1301B-7R-1 [Piece 17, 108-110 cm]); plane-polarized light (field of view $[\mathrm{FOV}]=1.4 \mathrm{~mm}$ ). B. Vesicle filled with a mixture of saponite and celadonite, iron oxyhydroxide, and celadonite in the center (Sample 301-U1301B-23R-3 [Piece 4, 21-24 cm]); cross-polarized light $(\mathrm{FOV}=0.7 \mathrm{~mm})$. C. Vesicles with saponite lining (upper left), celadonite followed by saponite lining (upper right), and iron oxyhydroxide fill (lower right) (Sample 301-U1301B-14R-3 [Piece 11, 90-92 cm]); plane-polarized light $(\mathrm{FOV}=5.5 \mathrm{~mm})$. D. Mesostasis and saponite-filled vesicle (Sample 301-U1301B-15R-1 [Piece 16, $143-145 \mathrm{~cm}])$; plane-polarized light $(\mathrm{FOV}=5.5 \mathrm{~mm})$.

A

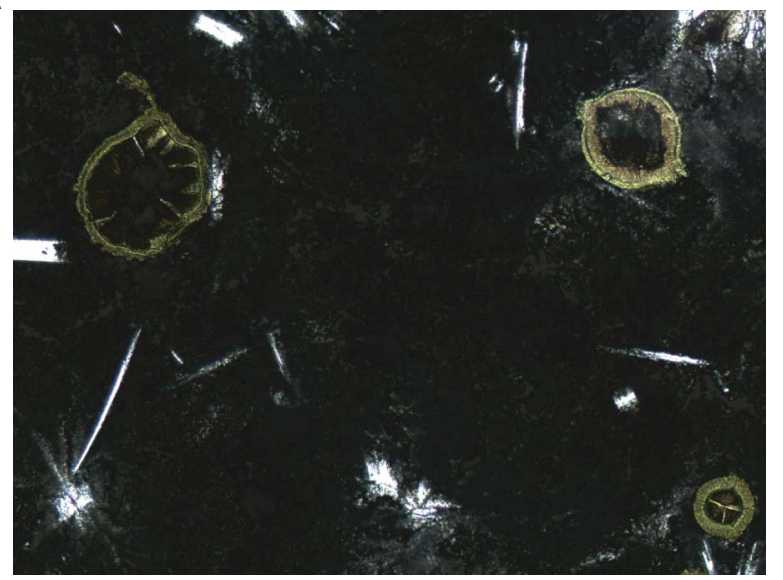

C

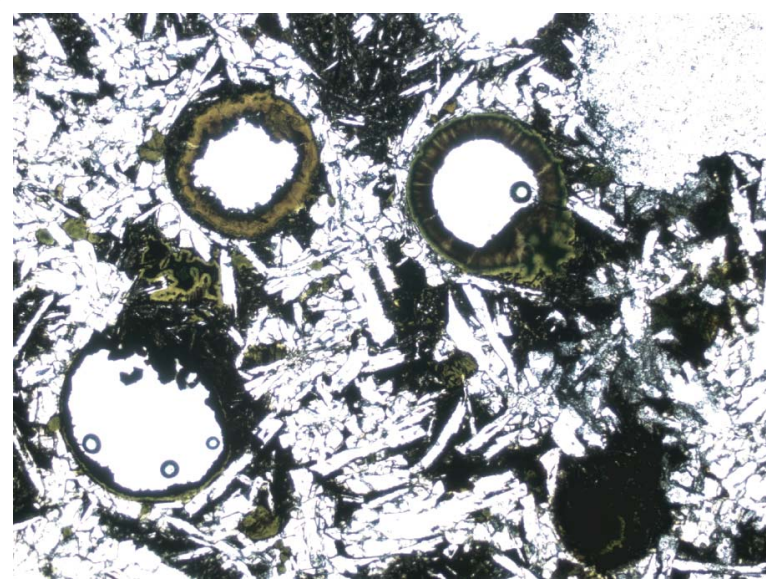

B

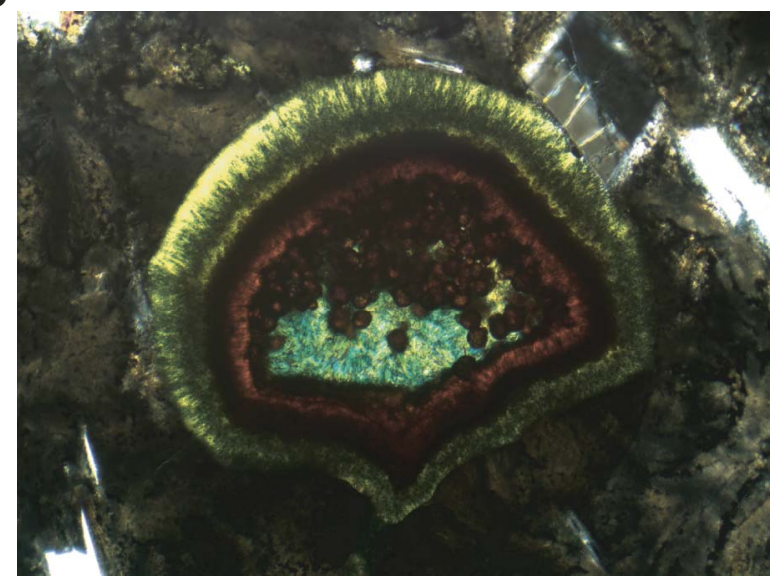

D

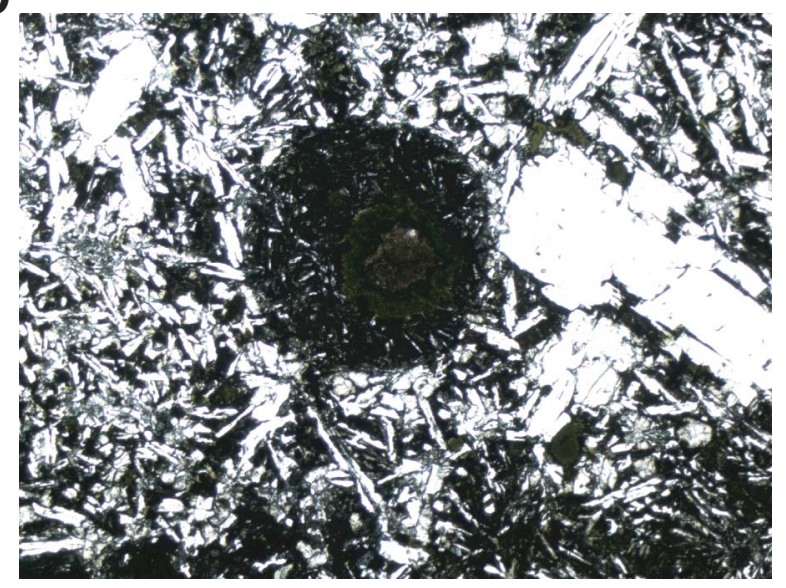


Figure F33. An assortment of veins from Hole U1301B basalts. A. Microvein of saponite (10-20 $\mu \mathrm{m}$ wide), with saponite filling the adjacent vesicles and replacing olivine phenocryst (Sample 301-U1301B-36R-1 [Piece 4, 29-32 cm]); plane-polarized light (field of view $[\mathrm{FOV}]=5.5 \mathrm{~mm}$ ). B. Iron oxyhydroxide and saponite vein, $1.5 \mathrm{~mm}$ wide (Sample 301-U1301B-1R-1 [Piece 15, 118-121 cm]); plane-polarized light (FOV $=5.5 \mathrm{~mm})$. C, D. Micrometer-wide calcium carbonate vein, with saponite lined walls, cutting through plagioclase phenocrysts and the intergranular ground mass (Sample 301-U1301B-18R-4 [Piece 1, 17-19 cm]); (C) plane-polarized light $(\mathrm{FOV}=5.5 \mathrm{~mm})$, (D) close-up of the fibrous carbonate vein; cross-polarized light $(\mathrm{FOV}=1.4 \mathrm{~mm})$. E. Saponite, iron oxyhydroxide, and celadonite vein (1 mm wide) (Sample 301-U1301B-4R-1 [Piece 9, 62-63 $\mathrm{cm}]$ ); plane-polarized light $(\mathrm{FOV}=5.5 \mathrm{~mm})$.

A

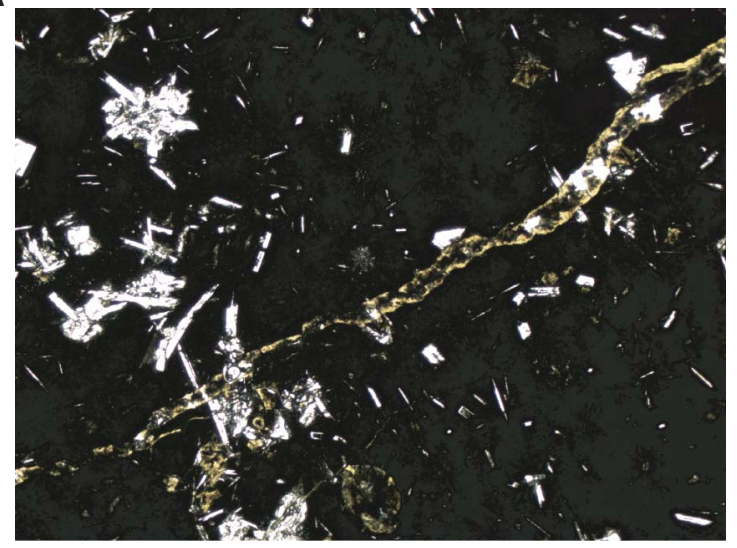

C

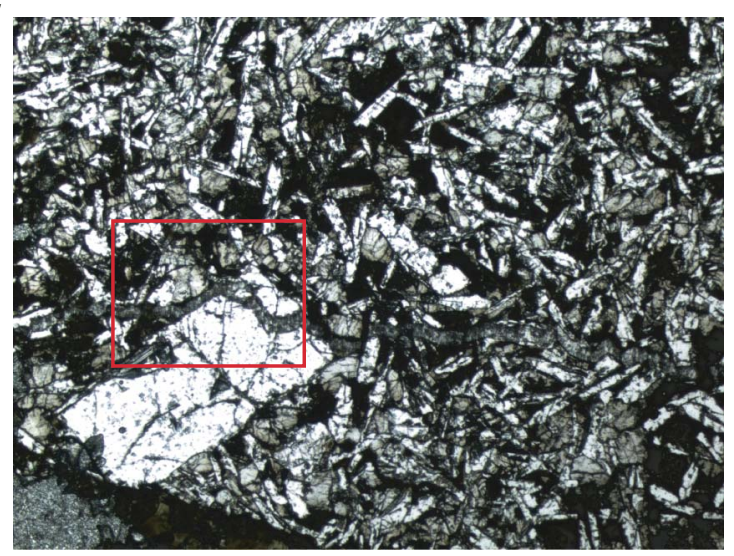

E

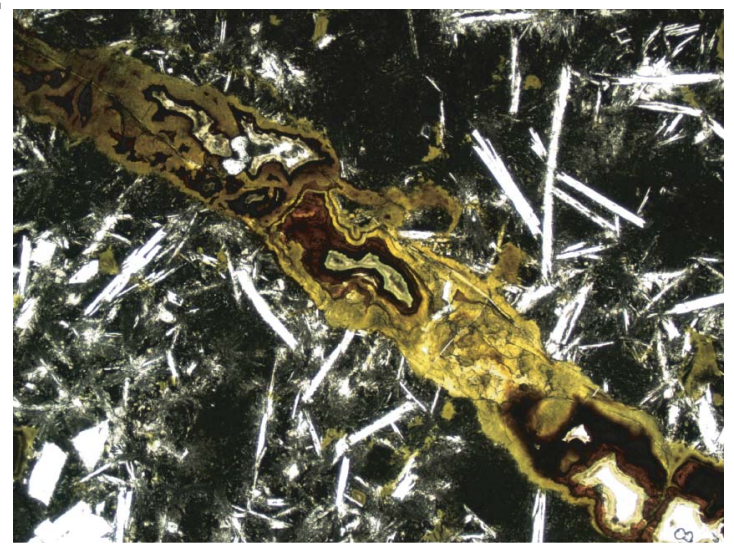

B

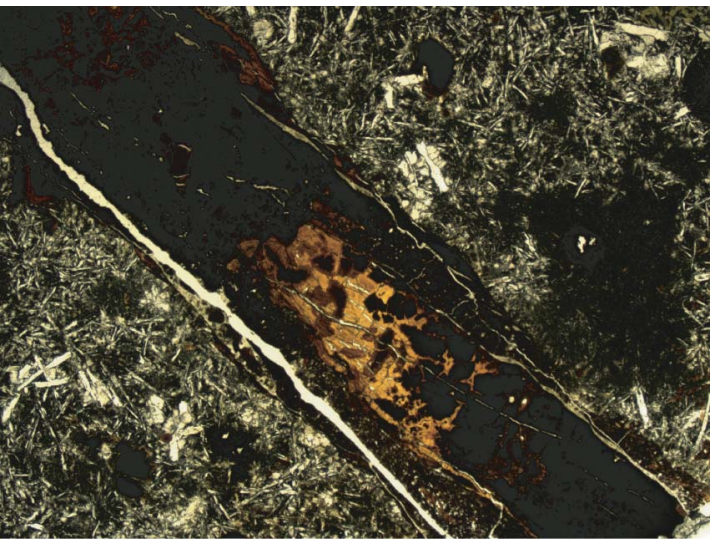

D

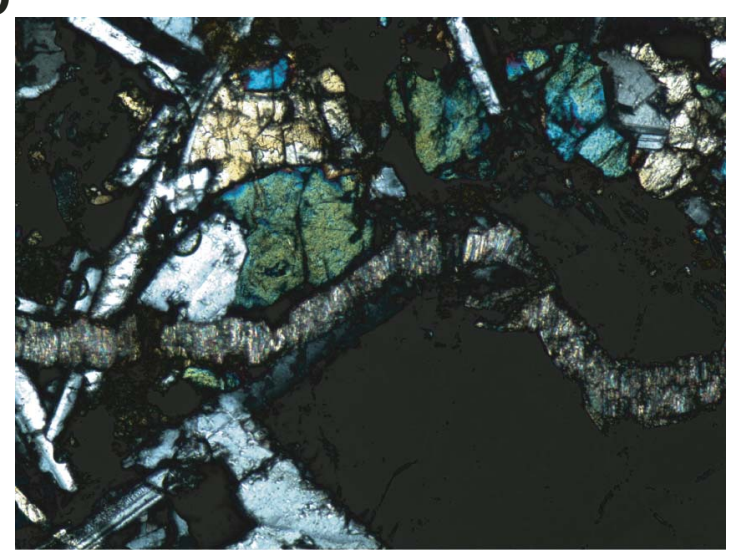


Figure F34. An impressive $6 \mathrm{~mm}$ wide goethite and celadonite vein with a patchy green, brown, and black multi-alteration halo (interval 301-U1301B-15R-1 [Pieces 10, 11, 70-96 cm]). (Photograph is of a wet surface.)

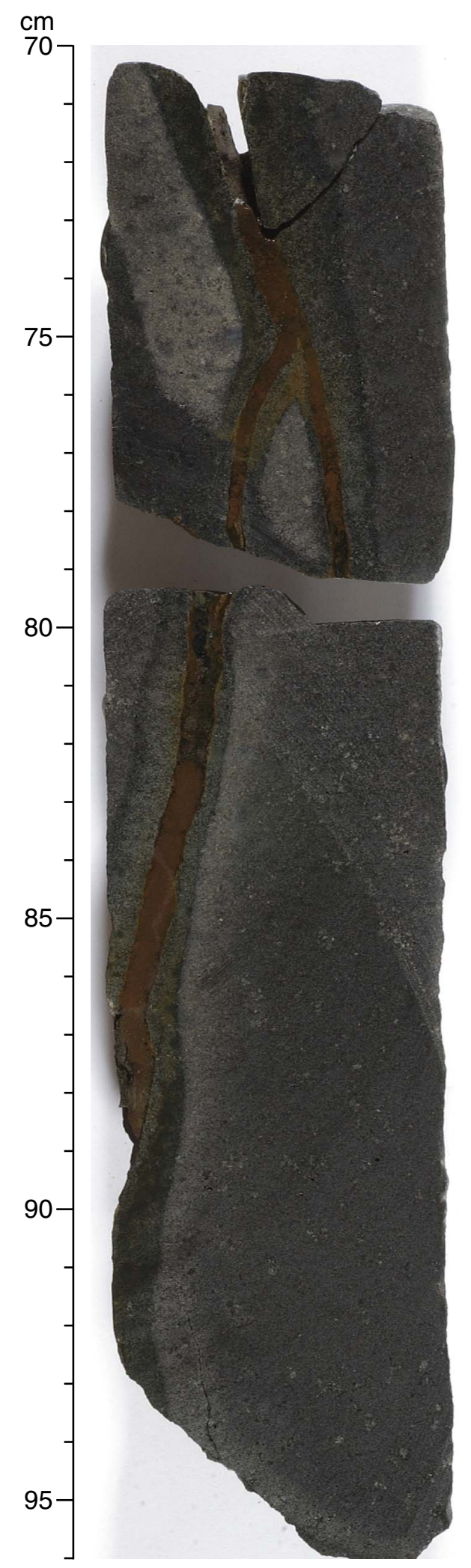


Figure F35. Alteration halos in plane-polarized light. A. Background saponitic alteration of the nonhalo portion (Sample 301-U1301B-30R-1 [Piece 21, 103-106 cm]). Saponite fills vesicles and replaces the mesostasis and olivine phenocrysts (field of view $[\mathrm{FOV}]=2.75 \mathrm{~mm}$ ). B. Saponite replaces euhedral olivine crystals in the nonhalo portion (Sample 301-U1301B-33R-1 [Piece 22, 117-119 cm]) (FOV = 1.4 mm). C. Saponite followed by celadonite replaces euhedral olivine phenocrysts and fills vesicles in the halo-nonhalo transition zone (Sample 301-U1301B-27R-2 [Piece 6, 38-40 cm]) (left half of field of view), and celadonite filling vesicles/ replacing olivine in the green halo portion (lower right field of view; FOV $=1.4 \mathrm{~mm}$ ). D. Celadonitic green halo in the lower left corner of the field of view, and background saponite alteration in the upper right corner (Sample 301-U1301B-32R-1 [Piece 13, 78-80 cm]). The fill of the micrometer-wide microvein changes from celadonitic to saponitic outside the halo $(\mathrm{FOV}=5.5 \mathrm{~mm})$. E. Background saponitic alteration (left field of view) and iron oxyhydroxide-bearing brown halo (right field of view) in Sample 301-U1301B-15R-4 (Piece 6, $66-68 \mathrm{~cm}$ ), with microvein fill changing across the transition (FOV $=5.5 \mathrm{~mm}$ ).

A

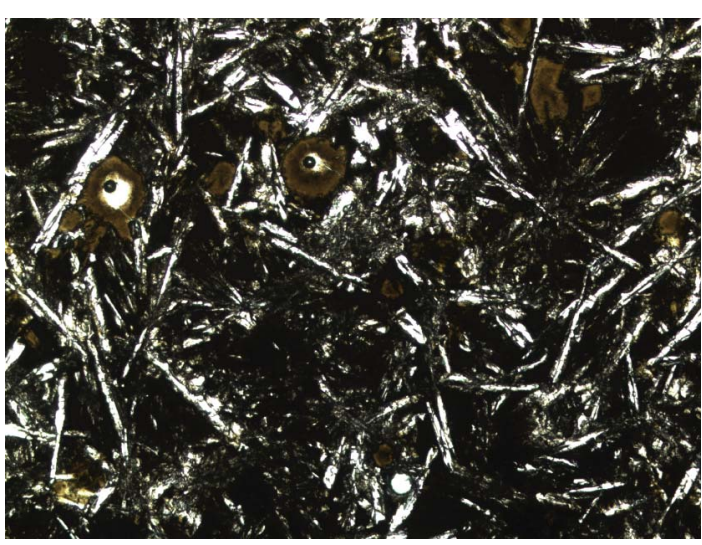

C

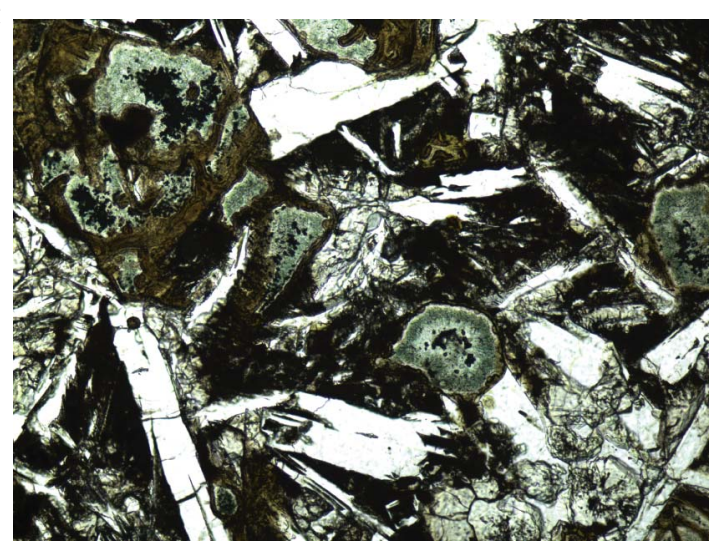

$\mathbf{E}$

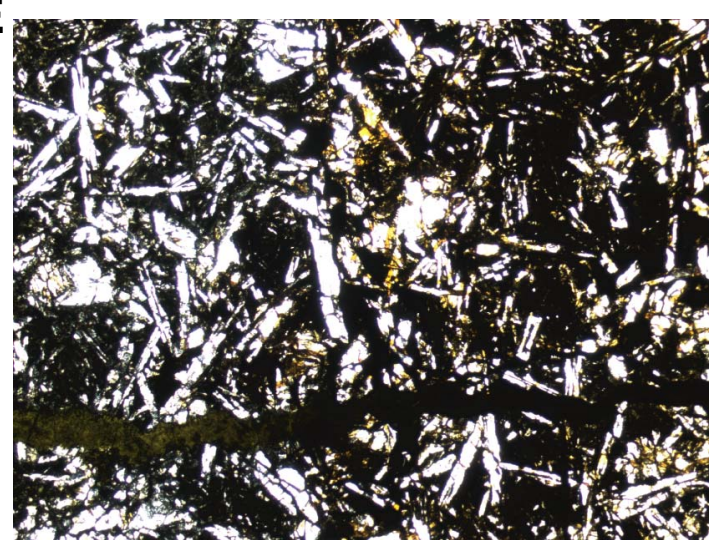

B

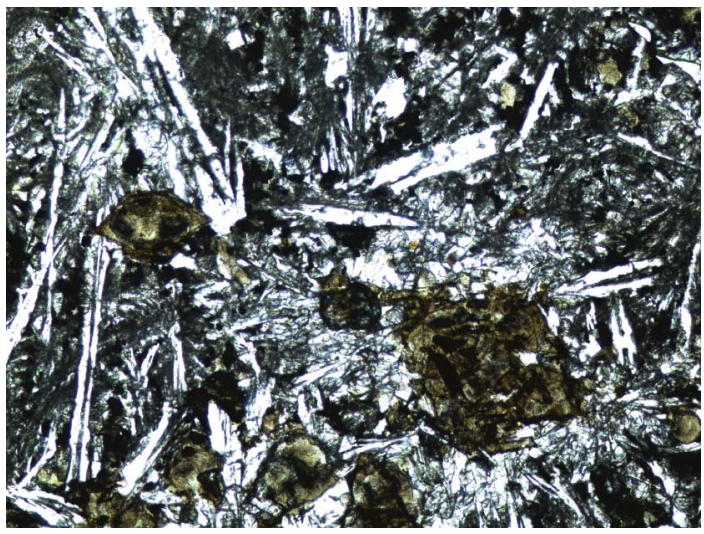

D

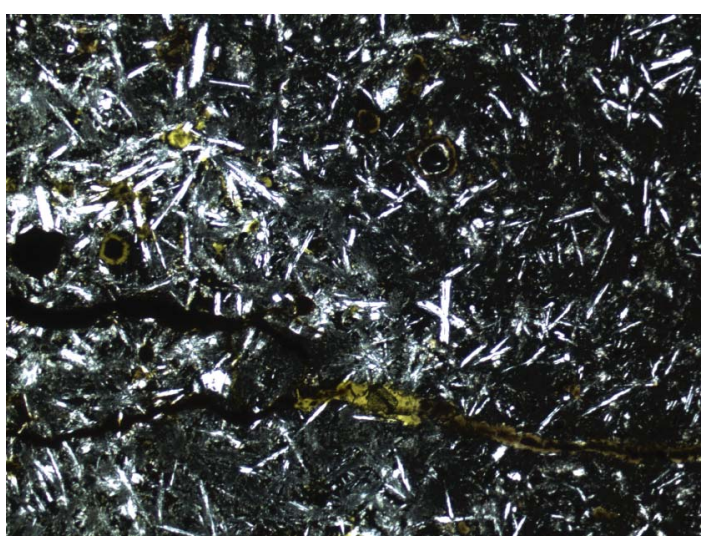


Figure F36. "Mixed" alteration halos. A. $10 \mathrm{~mm}$ wide black halo with sparse iron oxyhydroxide filled vesicles (interval 301-U1301B-21R-3 [Piece 7, 51-60 cm]). B. Moderately vesicular interval containing a $20 \mathrm{~mm}$ wide black halo in which vesicles are filled with iron oxyhydroxide (interval 301-U1301B-14R-1 [Piece 7, 42-49 $\mathrm{cm}]$ ). (Photographs are of wet surfaces.)

$\mathbf{A}_{\mathrm{cm}}$

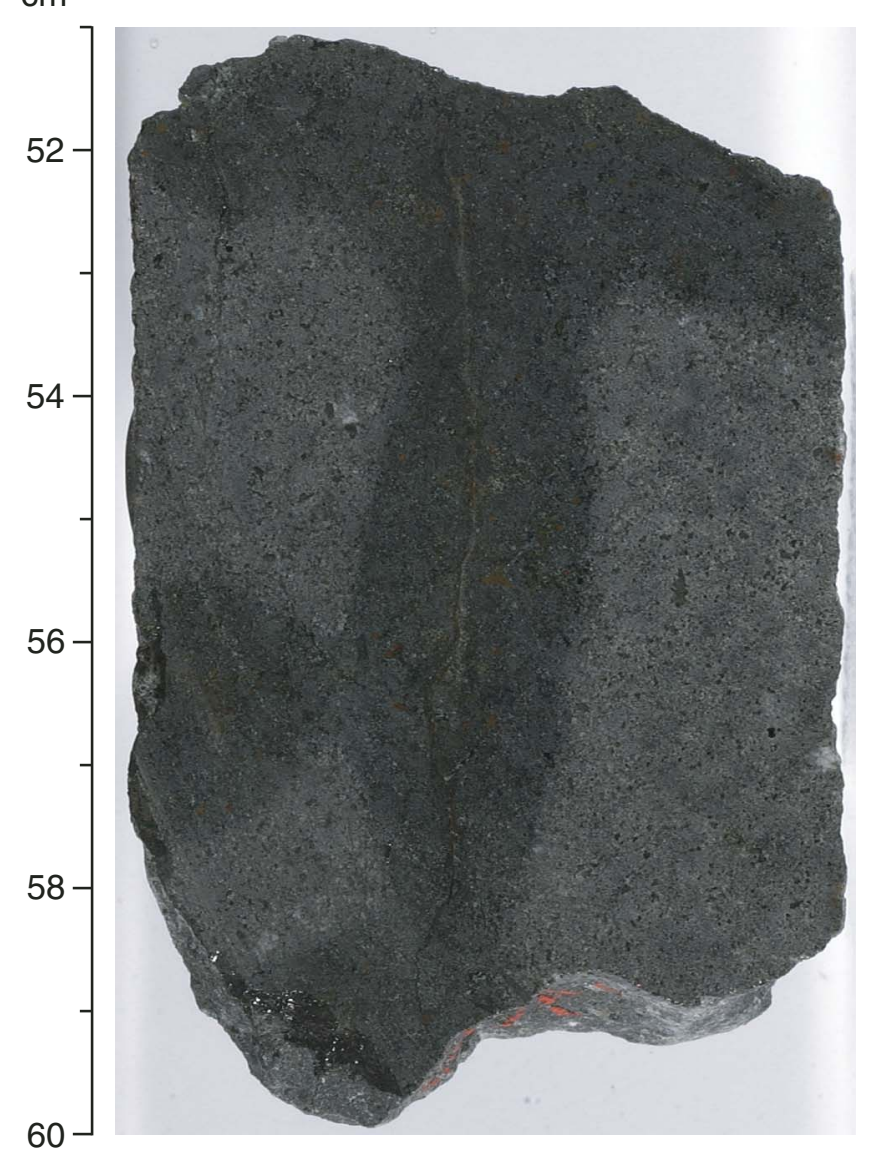

B

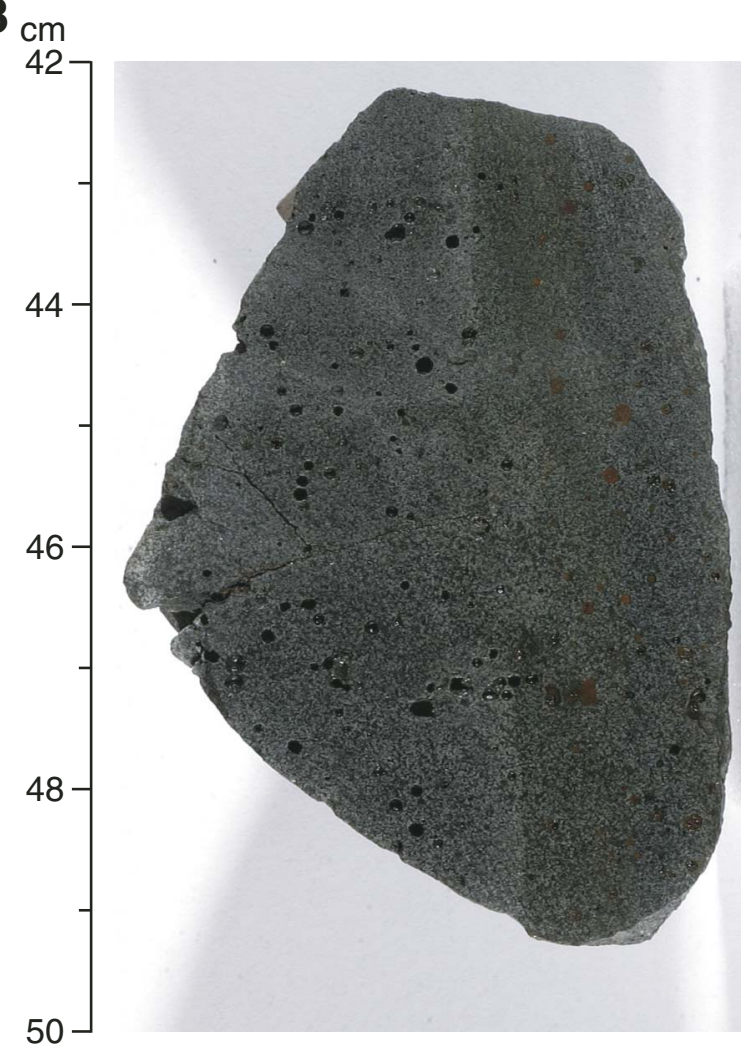


Figure F37. Disseminated pyrite front separating the green halo (lower field of view) from the background saponitic alteration (upper field of view) (Sample 301-U1301B-14R-1 [Piece 11, 90-92 cm]). A. Reflected light (field of view $[\mathrm{FOV}]=2.75 \mathrm{~mm}$ ). B. The red lines indicate the position of the pyrite front; the celadonitic alteration of the green halo can be seen below it; plane-polarized light (FOV $=5.5 \mathrm{~mm}$ ).

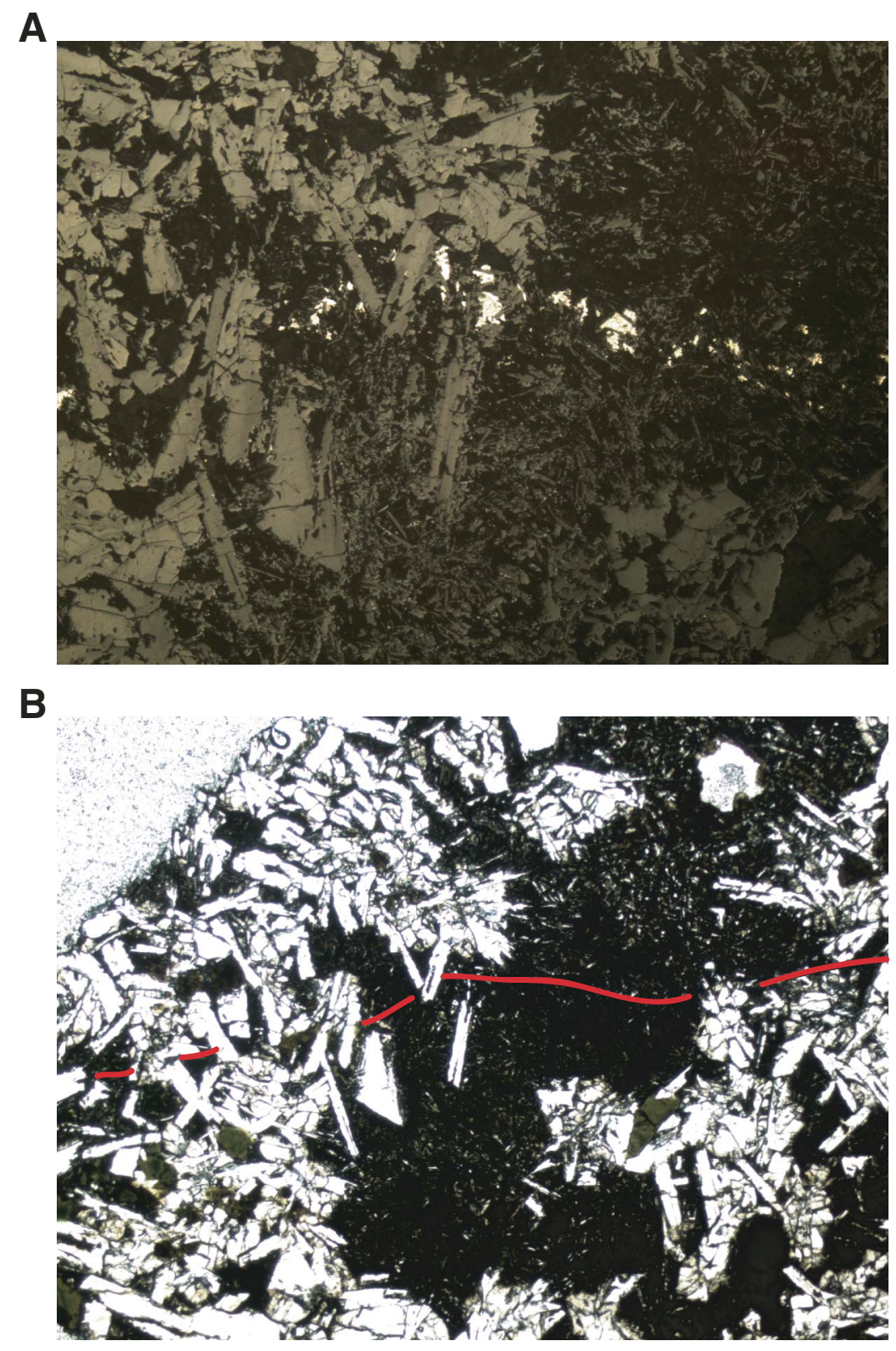


Figure F38. "Multi" halos (photographs of wet rock surfaces). A. A $15 \mathrm{~mm}$ wide multihalo with a $10 \mathrm{~mm}$ brown zone, a $2 \mathrm{~mm}$ yellow transitional zone, and a $3 \mathrm{~mm}$ black zone (interval 301-U1301B-15R-4 [Piece 6, 64-73 cm]). B. A 10-20 mm wide multihalo with a $5 \mathrm{~mm}$ red-brown, a $5 \mathrm{~mm}$ yellow, and $5 \mathrm{~mm}$ black zones (interval 301-U1301B-33R-1 [Piece 22, 105-122 cm]). The halo encroaches into the fresher rock interior along the small fractures.

$\mathbf{A}_{\mathrm{cm}}$

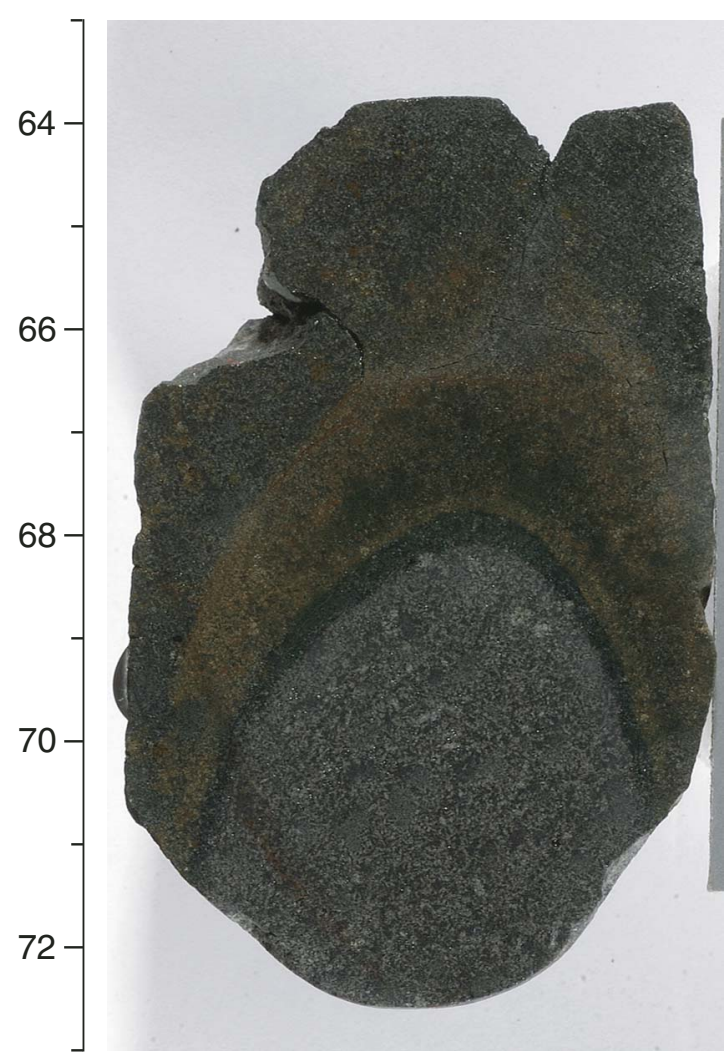

B

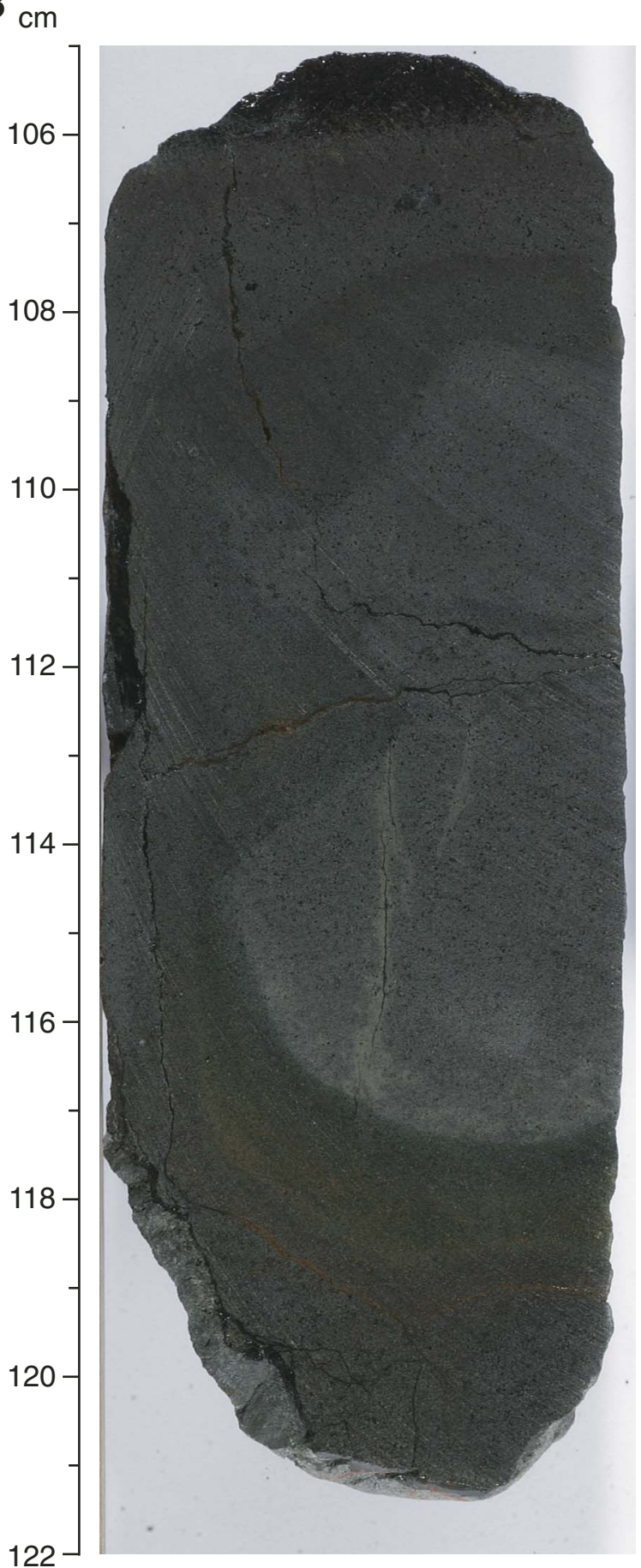


Figure F39. Orientations of all measured veins and fractures in rocks from Hole U1301B. A. Poles of veins and fractures on a lower hemisphere equal angle project. Structures are orientated using the reference frame (see Figs. F9 and F10 in the "Methods" chapter). B. Distribution of true dip angles for all measured veins and fractures.

A

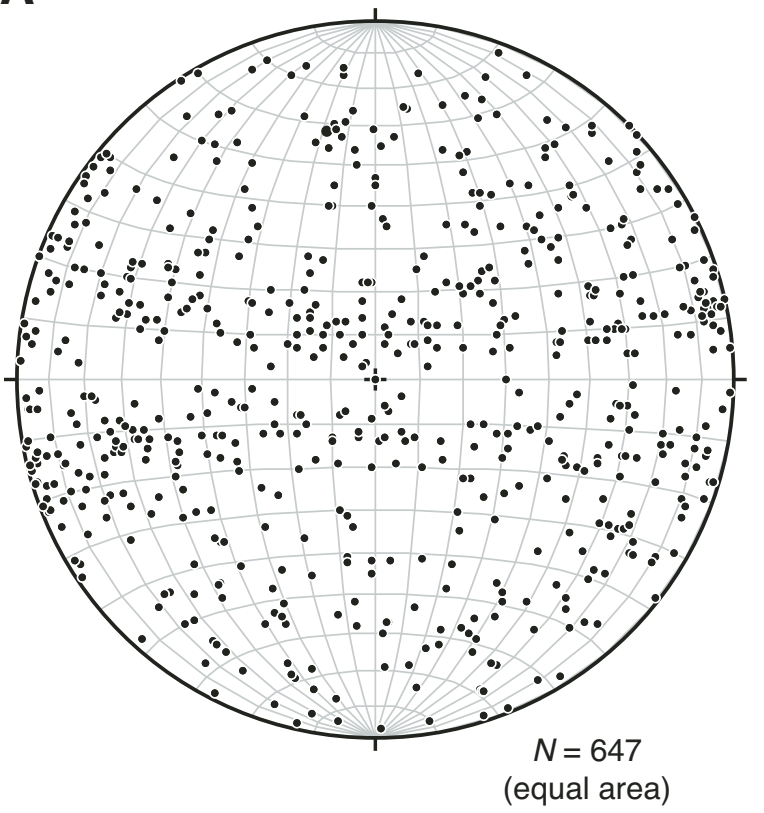

B

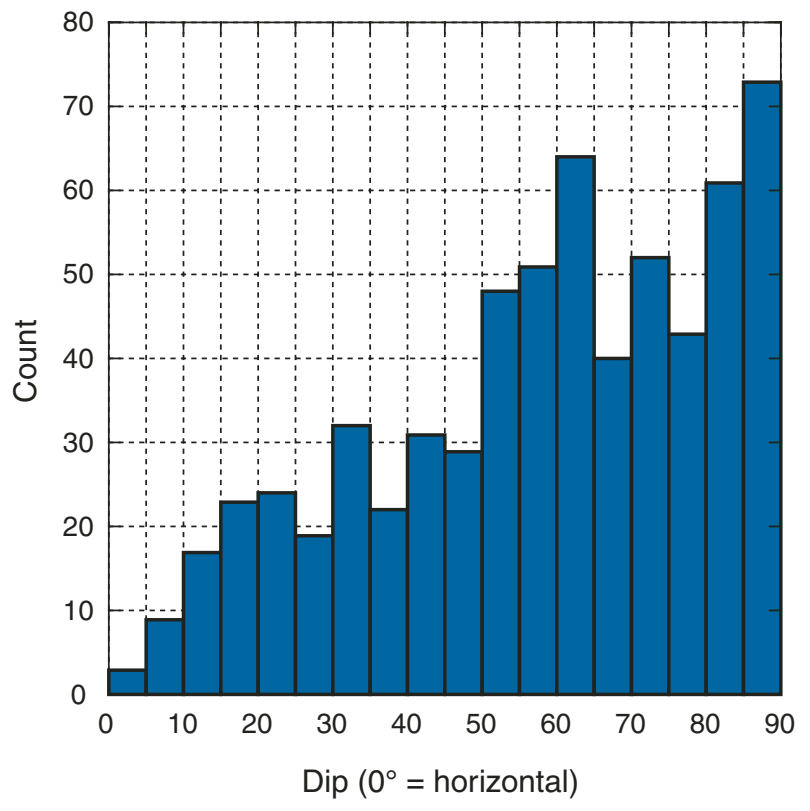


Figure F40. Distribution of true dip orientations of veins and fractures for lithologic units defined for rocks recovered from Hole U1301B.

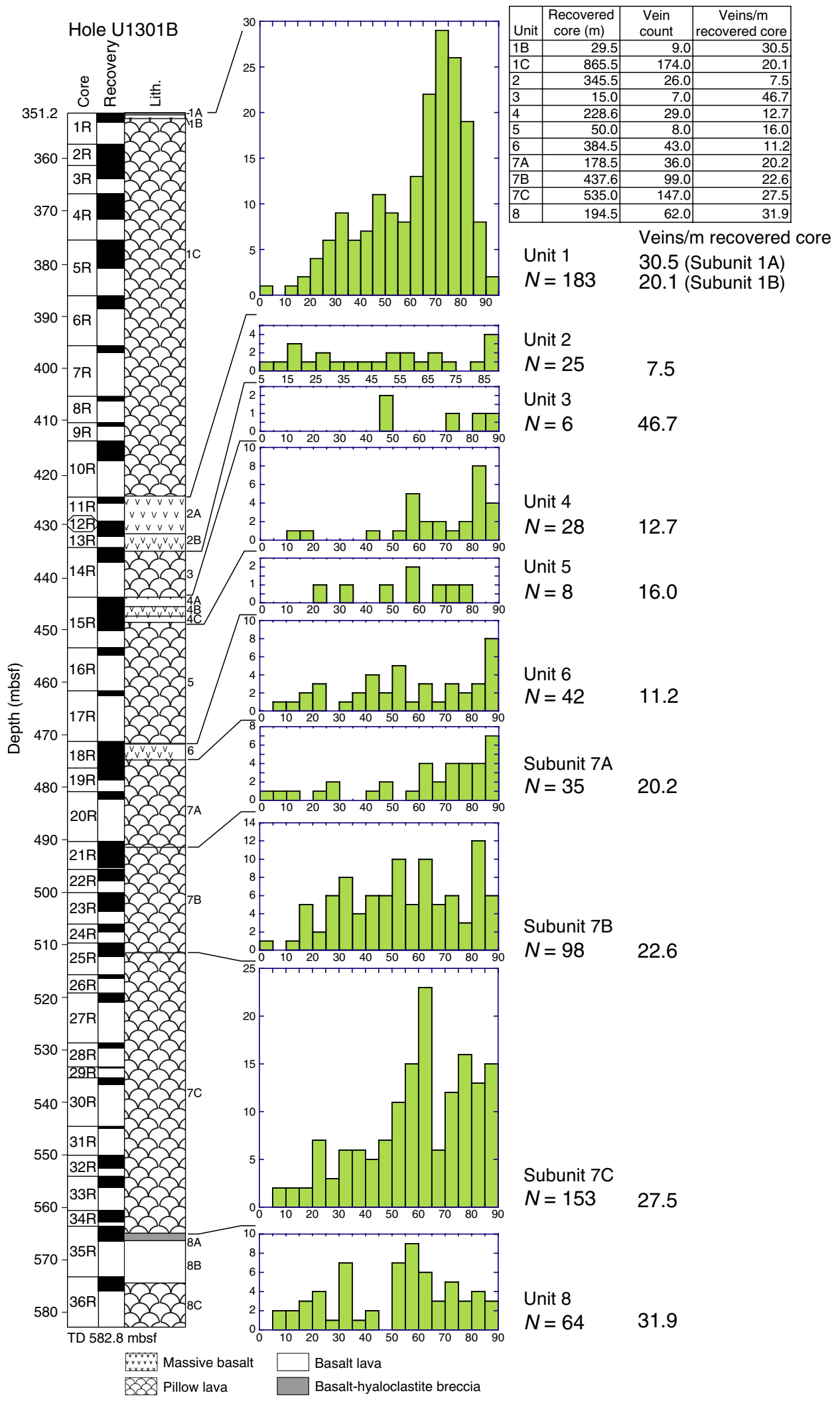


Figure F41. Comparative histograms showing the distribution of dips for haloed and nonhaloed veins and fractures in massive and pillow lava units.
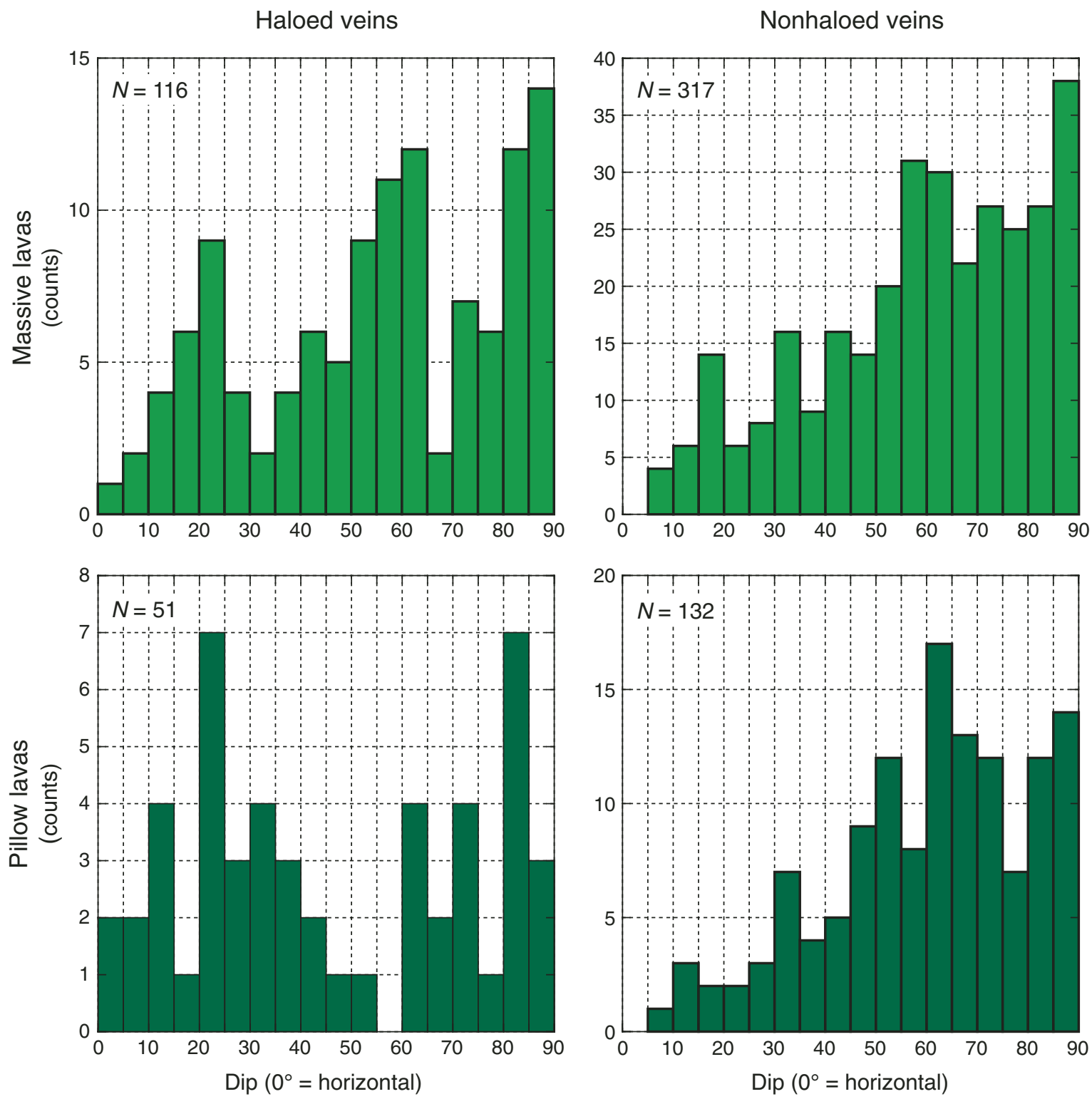
Figure F42. Paleomagnetic inclination data from Hole U1301C archive-half core sections after AF demagnetization to $40 \mathrm{mT}$ plotted versus depth. Column at left shows core boundaries and core recovery.

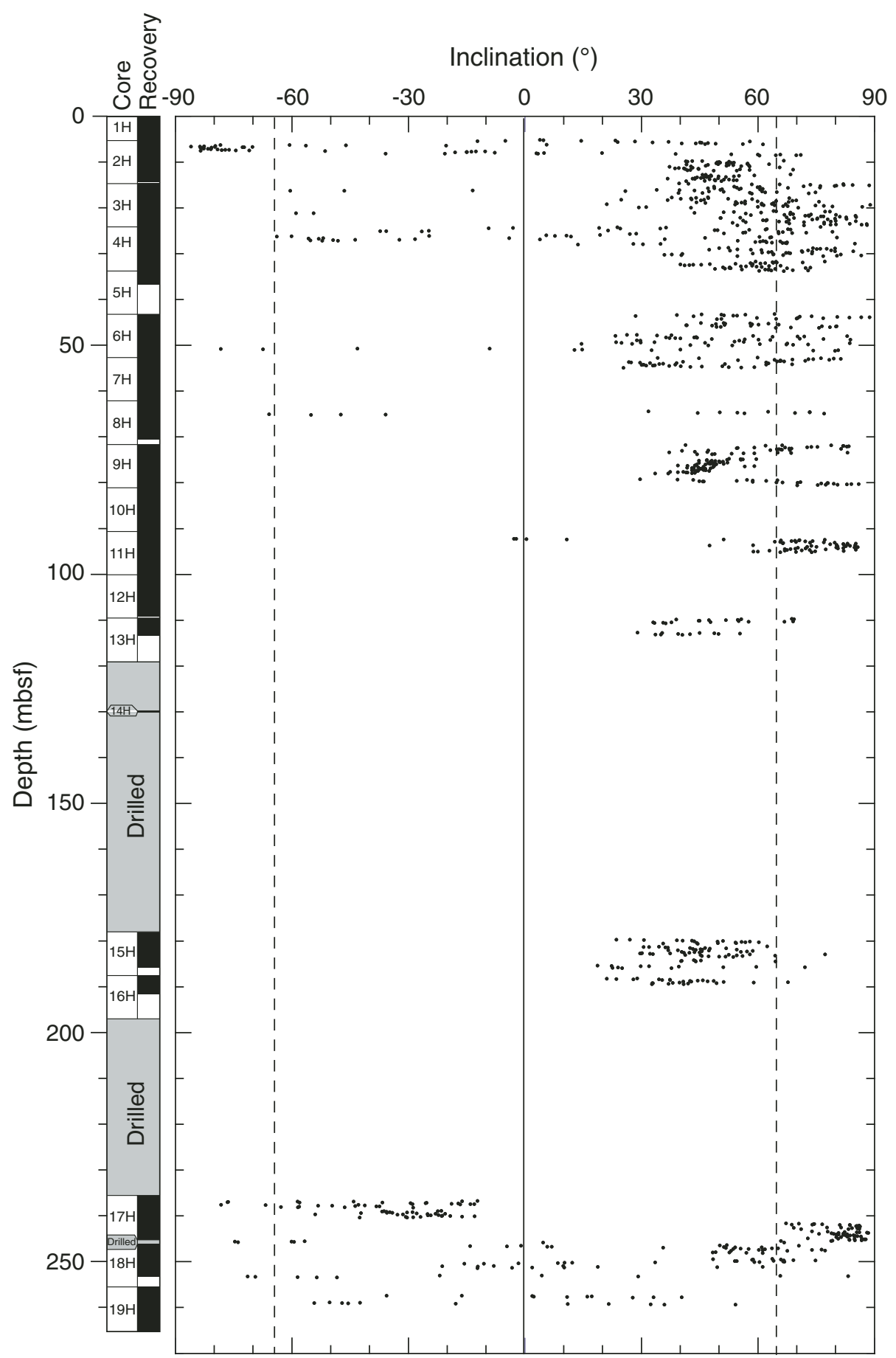


Figure F43. Natural remanent magnetization intensity measurements from Hole U1301C archive-half core sections plotted versus depth. Column at left shows core boundaries and recovery.

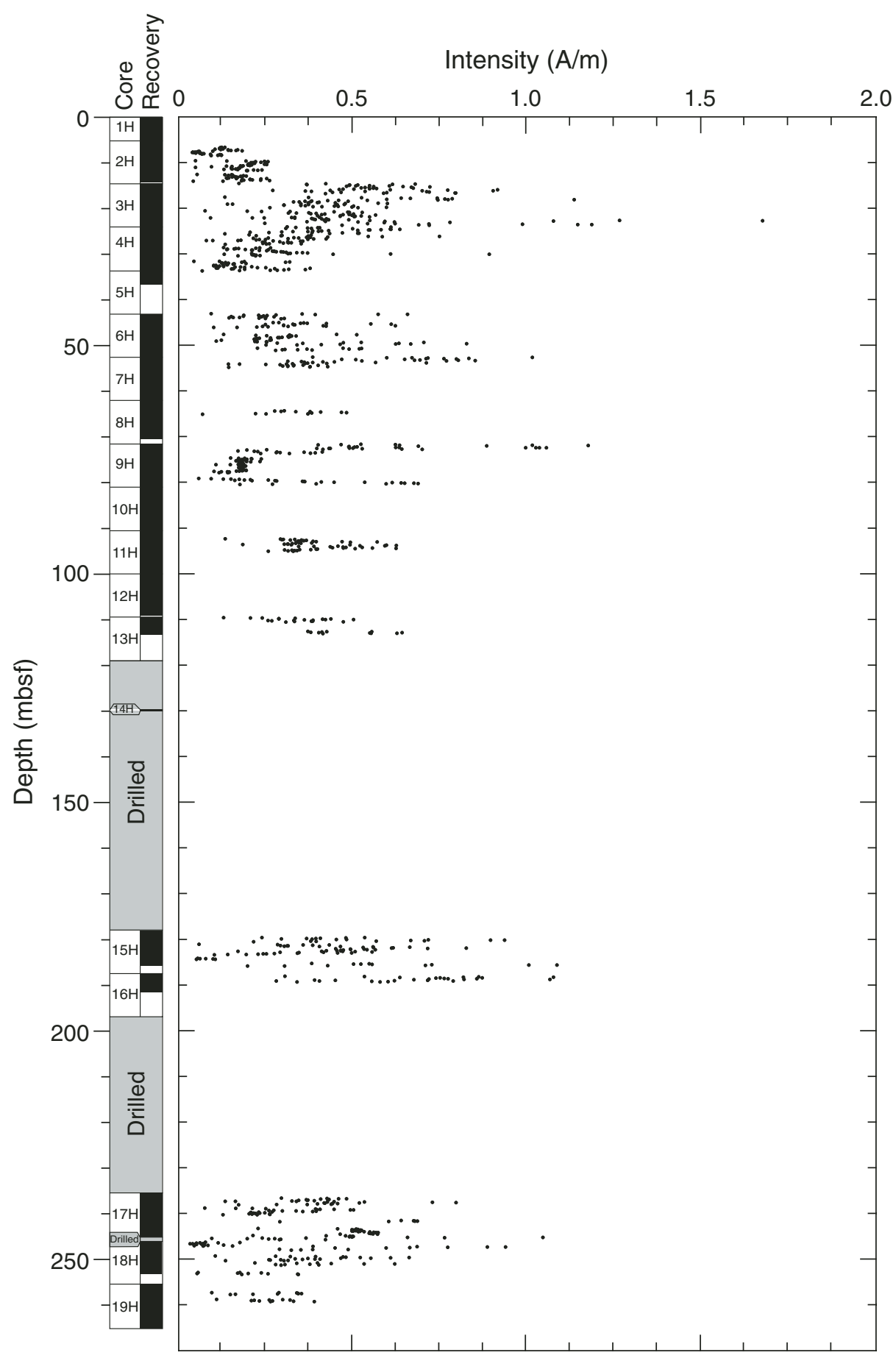


Figure F44. Orthogonal vector plots of selected igneous rock samples from Hole U1301B. Points represent successive vector endpoints during progressive, stepwise alternating field (AF) and thermal demagnetization. Small numbers give the field strength for AF demagnetization (in mT; A-D) or the temperature for thermal demagnetization (in ${ }^{\circ} \mathrm{C}$; E, F). A. AF demagnetization showing simple univectorial decay toward the plot origin. Note that the natural remanent magnetization (NRM) shows a steep, downward-directed overprint. B. AF demagnetization showing univectorial decay from a sample with a high coercivity. Note there is no apparent NRM overprint. Inset shows reduction of magnetization strength with increasing field. C. AF demagnetization of a sample with low coercivity. Note the rapid reduction of magnetization within first several AF steps. Inset shows the reduction in magnetization intensity with increasing AF field strength, for comparison with $B$. D. Enlargement of orthogonal vector plot for a sample with a high-coercivity component that causes the demagnetization path to veer away from the origin of the plot. E, F. Thermal demagetization of two samples showing eventual univectorial decay toward plot origin. Both samples display a downward overprint on the NRM. The sample in E shows a reversal of magnetization sign with the characteristic remanent magnetization having a negative sign. Interestingly, this sample is from the same piece as the AF demagnetized sample in A, which has a different characteristic magnetization sign. The reason for this difference is not known.

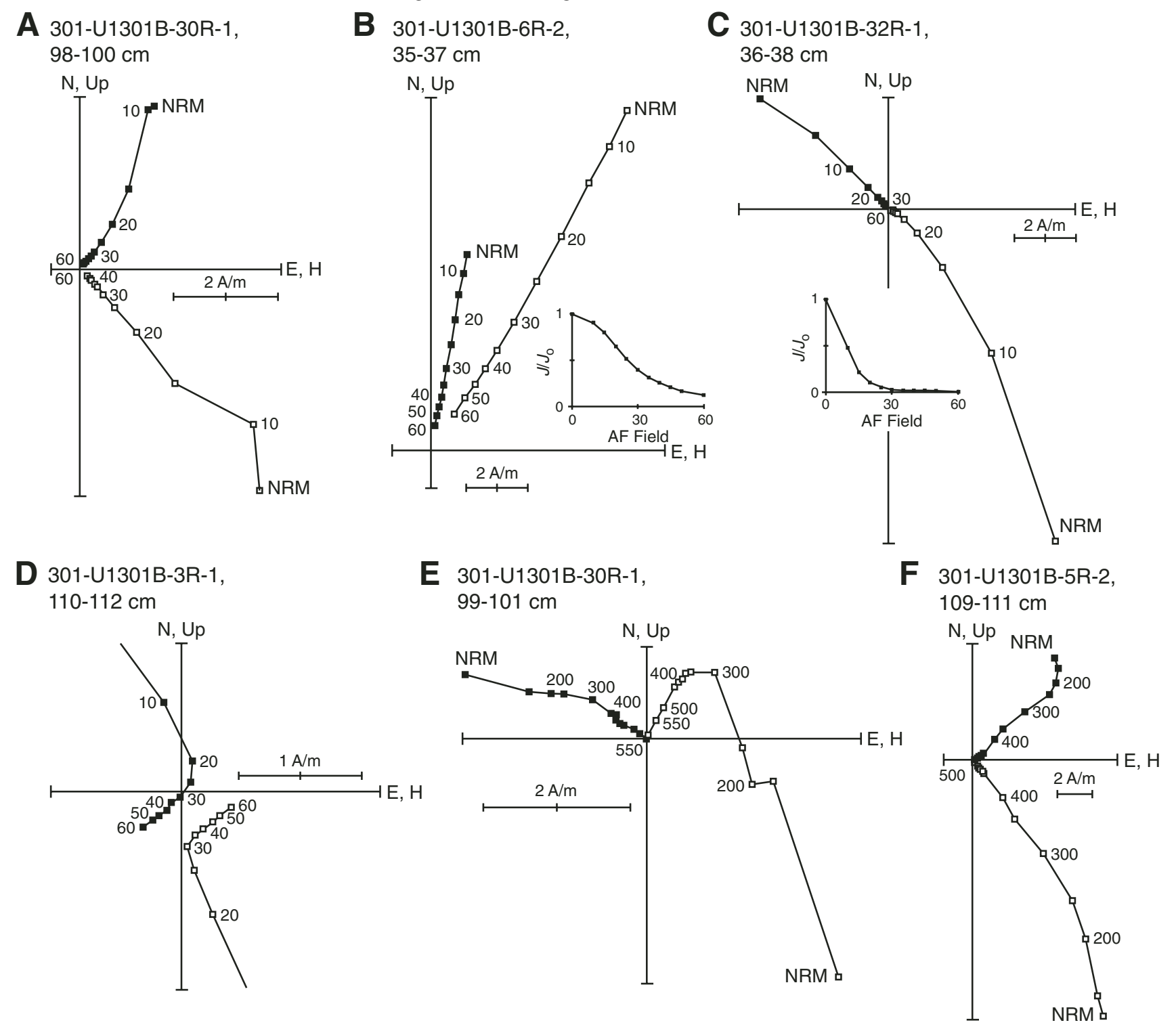


Figure F45. Plot showing the reduction of magnetization intensity of four samples during thermal demagnetization, each sample having a different behavior. A. Sample 301-U1301B-34R-2, 26-28 cm, maintains high magnetization strength until high temperature, at which point the magnetization falls off rapidly with increasing temperature. B. Sample 301-U1301B-20R-1, 47-49 cm, shows two magnetization plateaus, one at low temperature and one a higher temperature. C. Sample 301-U1301B-4R-4, 45-47 cm, displays significant demagnetization at low temperature. D. Sample 301-U1301B-30R-1, 63-65 cm, shows an increase in magnetization between $200^{\circ}$ and $250^{\circ} \mathrm{C}$, probably indicative of the presence of the magnetic mineral pyrrhotite.

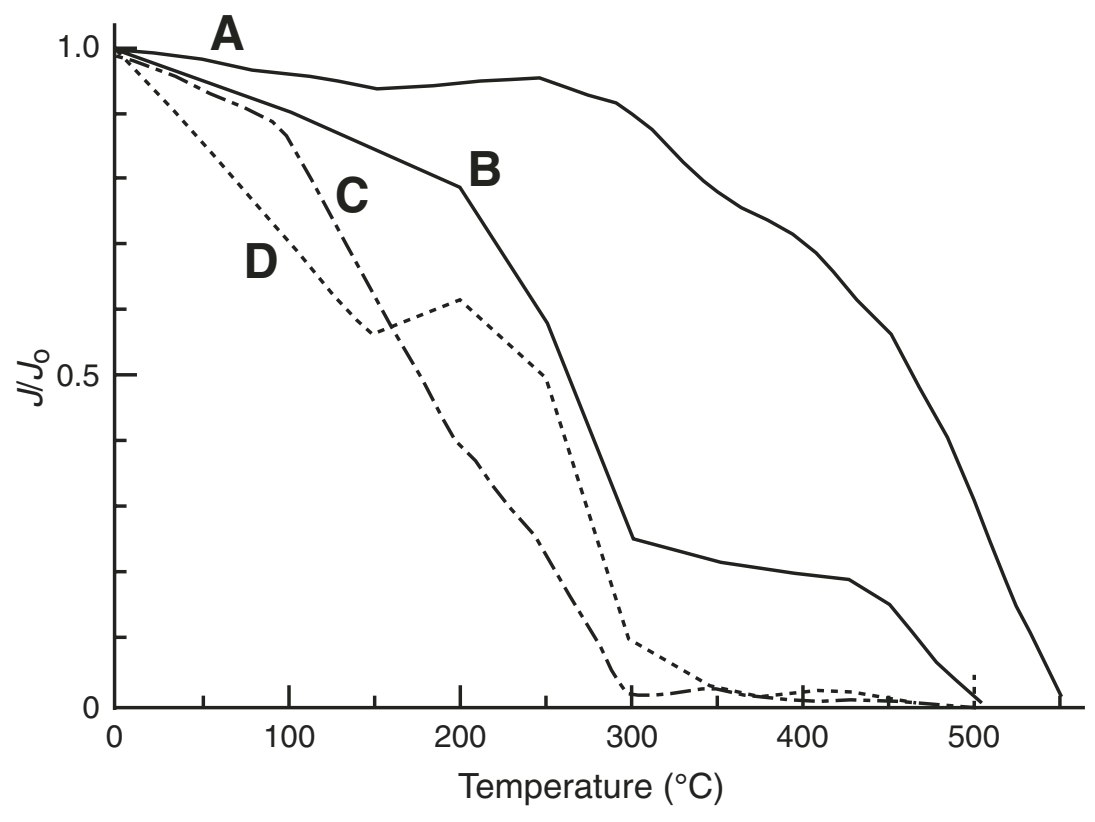


Figure F46. Characteristic remanent magnetization inclination values from Hole U1301B igneous samples. Dashed vertical lines show expected geocentric axial dipole inclination for the site $\left(64^{\circ}=\right.$ normal polarity; $-64^{\circ}$ $=$ reversed polarity), corrected for bias expected from averaging azimuthally unoriented samples (Cox and Gordon, 1984). Open circles $=$ thermally demagnetized samples, solid symbols $=$ samples that were demagnetized with the AF method. Solid circles = standard paleomagnetic cube samples, solid diamonds = measurements from archive-half core pieces, solid triangles = samples that were taken by physical property scientists for velocity measurements. Column at left shows core depths and recovery, with the numbers being the core numbers. Horizontal ticks on the $0^{\circ}$ axis at the middle of the plot show the stratigraphic positions of samples that produced results deemed to be unreliable, with one tick per sample.

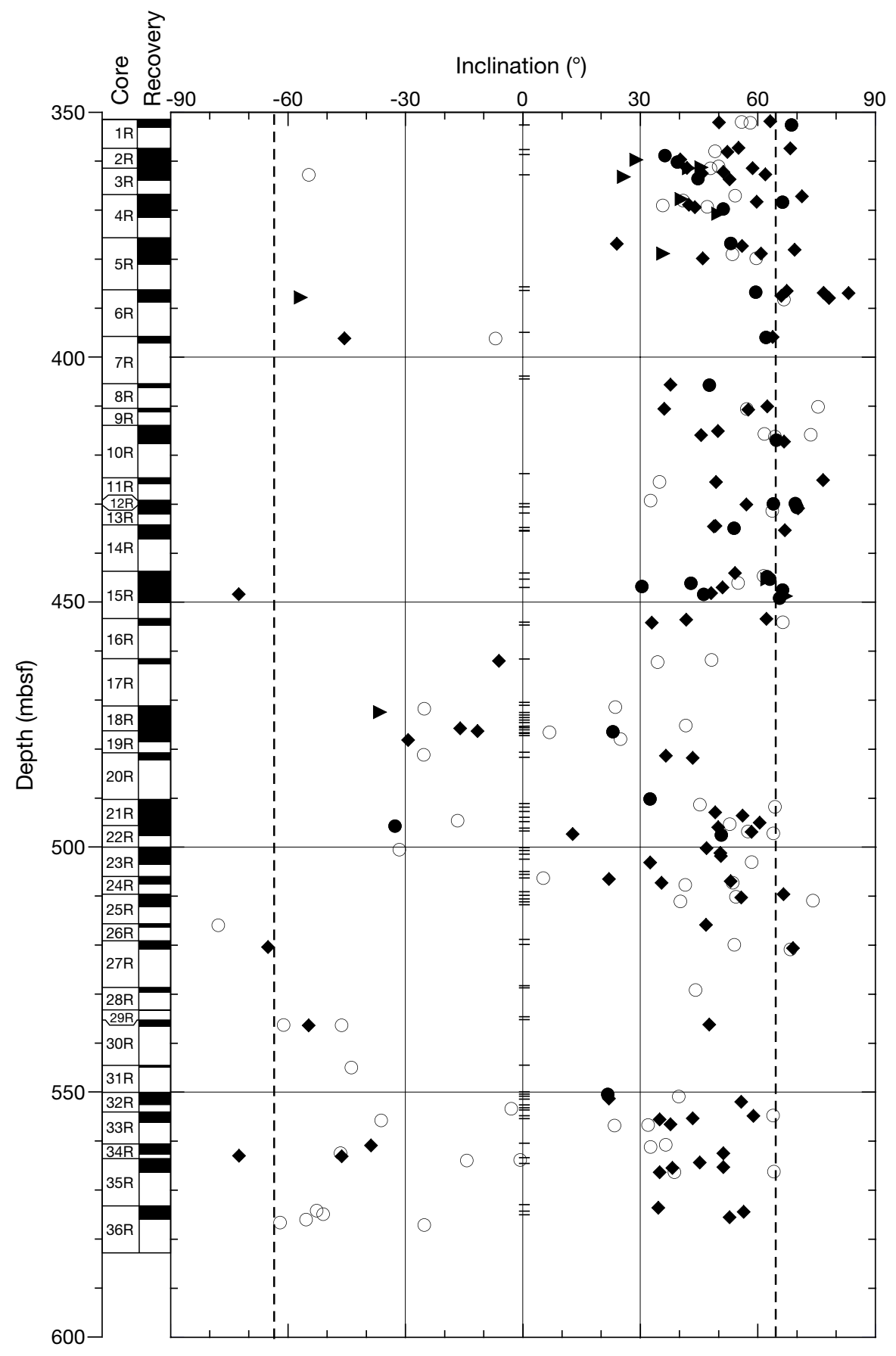


Figure F47. Composition of pore waters from Holes U1301C and U1301D, Site 1026, and Baby Bare springs—nutrients and early diagenesis. A. $\mathrm{pH}$, ammonium, phosphate, silicate. (Continued on next page.)

A

$\mathrm{pH}$

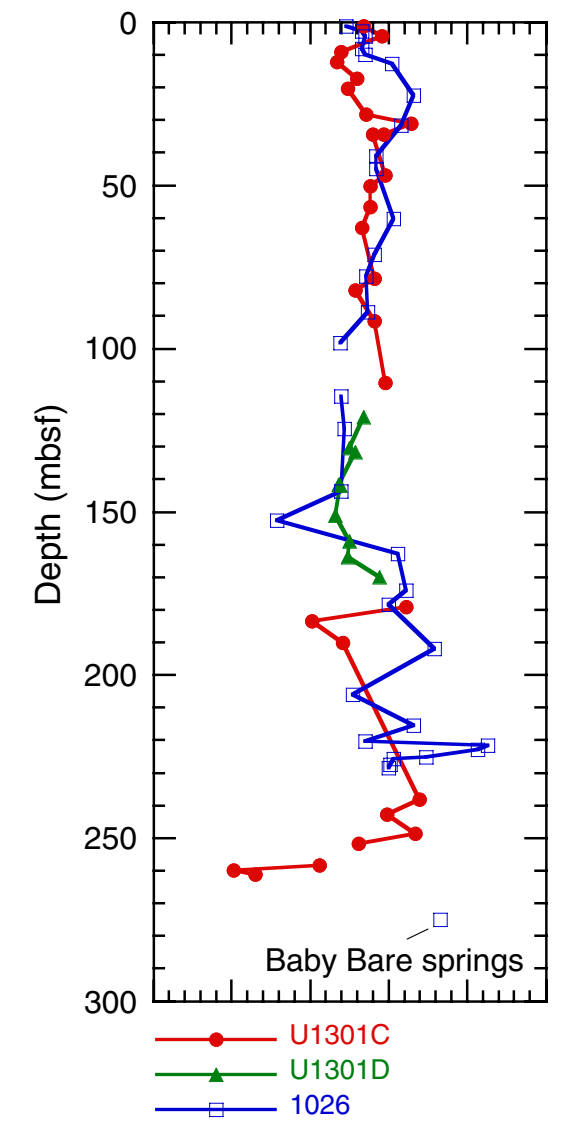

$\mathrm{PO}_{4}(\mu \mathrm{mol} / \mathrm{kg})$

$\begin{array}{lllllll}0 & 10 & 20 & 30 & 40 & 50 & 60\end{array}$

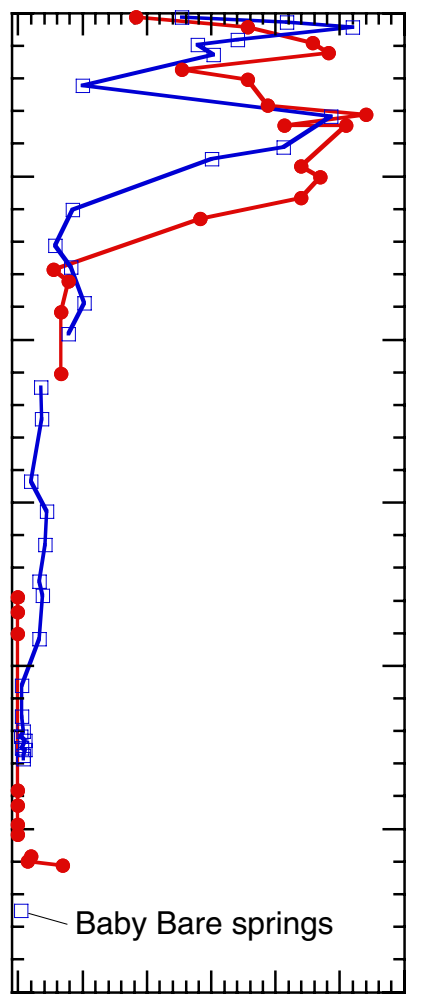

$\mathrm{Si}(\mu \mathrm{mol} / \mathrm{kg})$

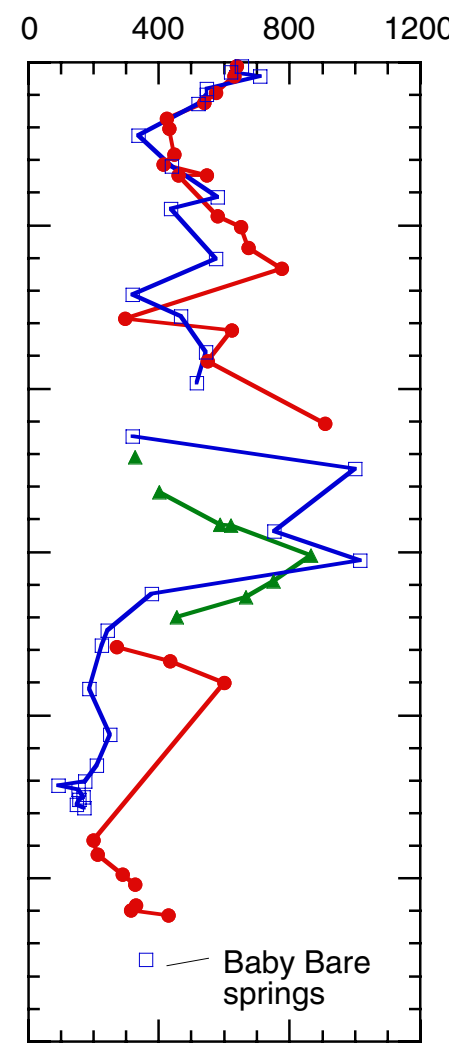


Figure F47 (continued). B. Total dissolved carbon (TC), dissolved inorganic carbon (IC), dissolved organic carbon (OC), alkalinity.

B

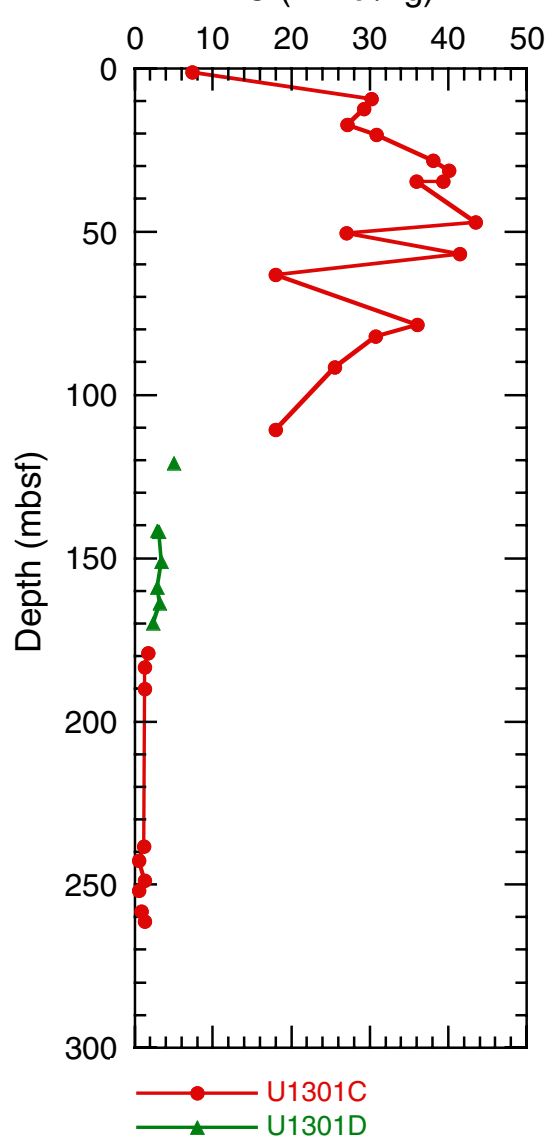

IC $(\mathrm{mmol} / \mathrm{kg})$

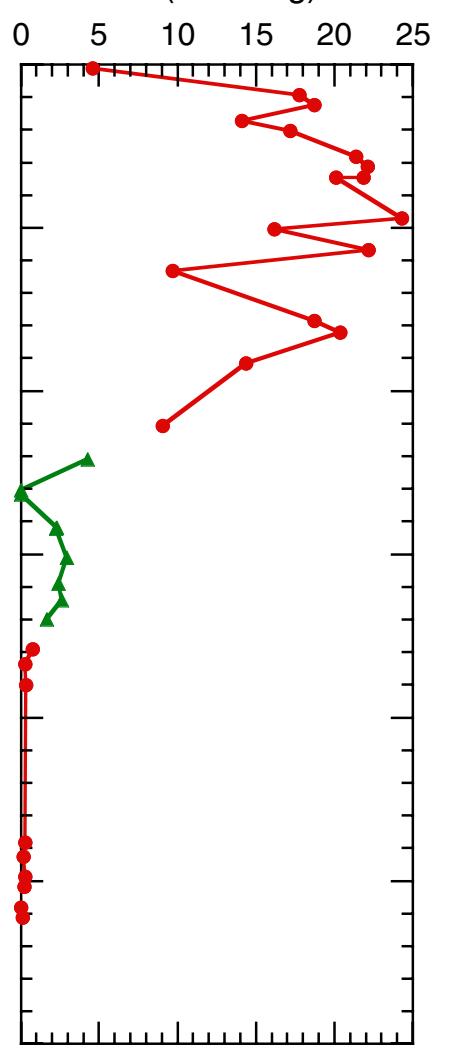

$\mathrm{OC}(\mathrm{mmol} / \mathrm{kg})$

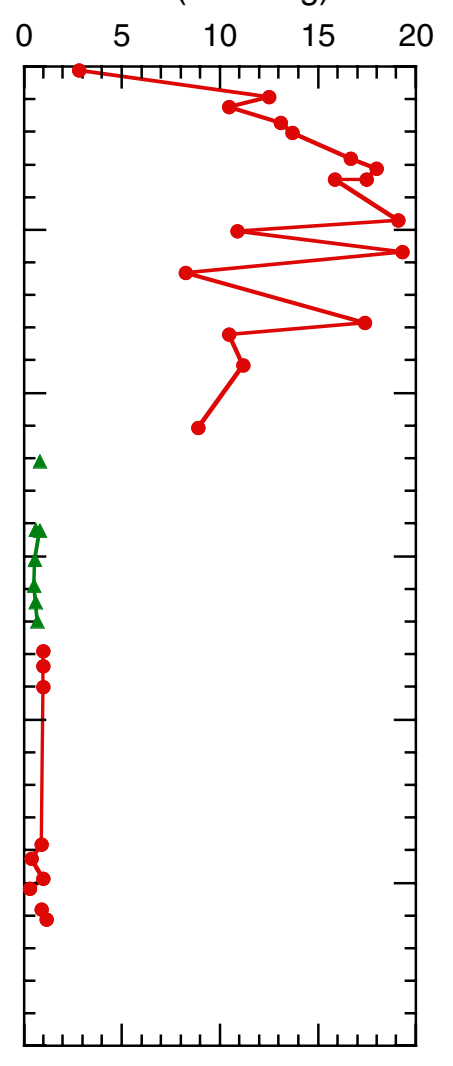

Alkalinity $(\mathrm{mmol} / \mathrm{kg})$

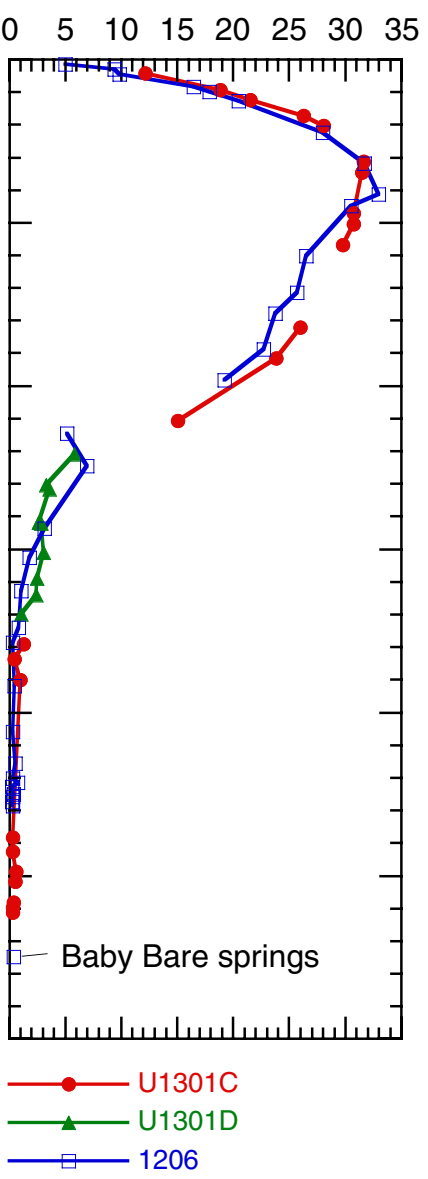


Figure F48. Composition of pore waters from Holes U1301C and U1301D, Site 1026, and Baby Bare springs—major ions: Ca and Mg, K, Cl, and $\mathrm{Na}$.

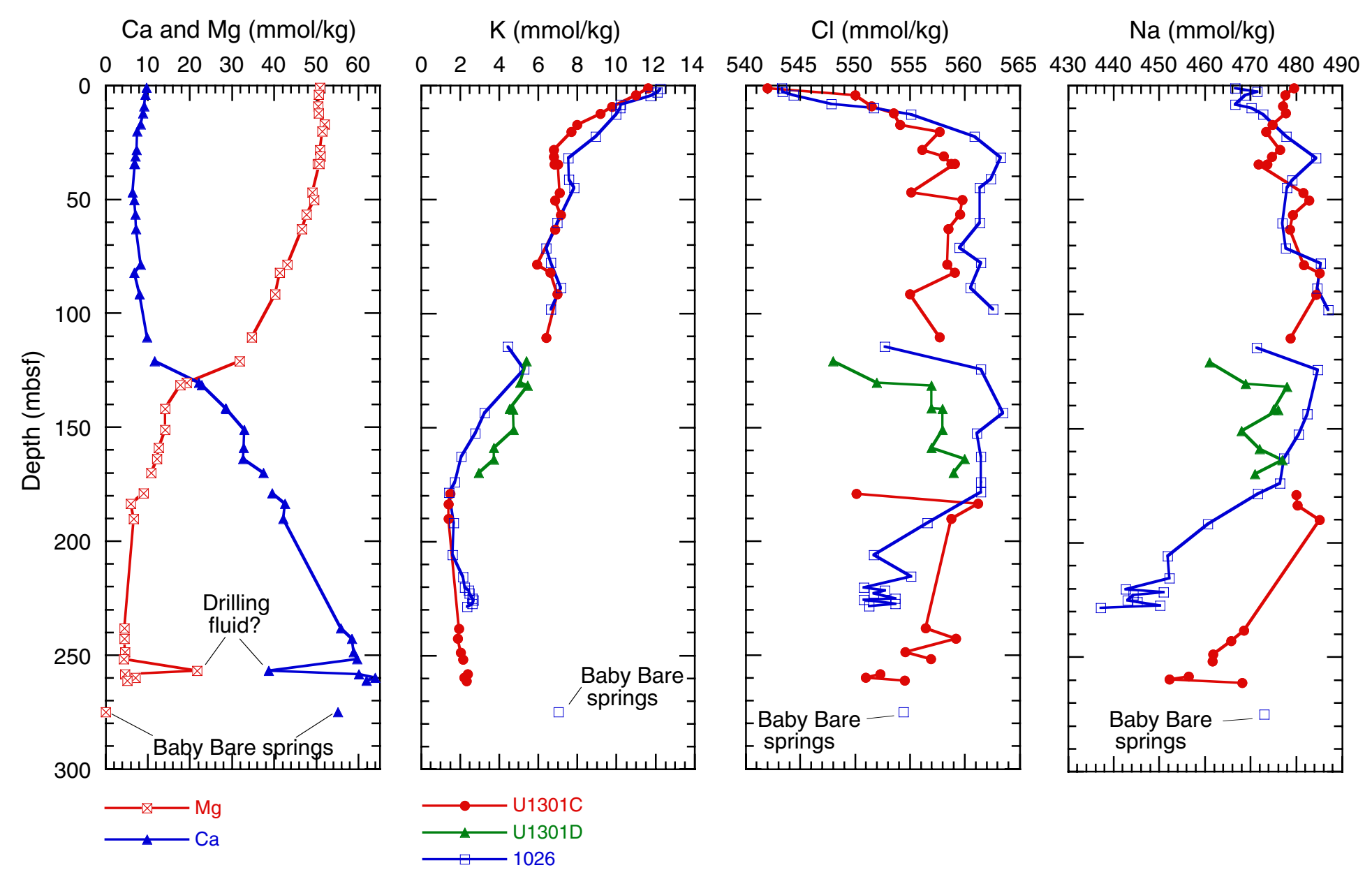


Figure F49. Composition of pore waters from Holes U1301C and U1301D, Site 1026, and Baby Bare springs—minor ions: Fe, Mn, Sr, and B.
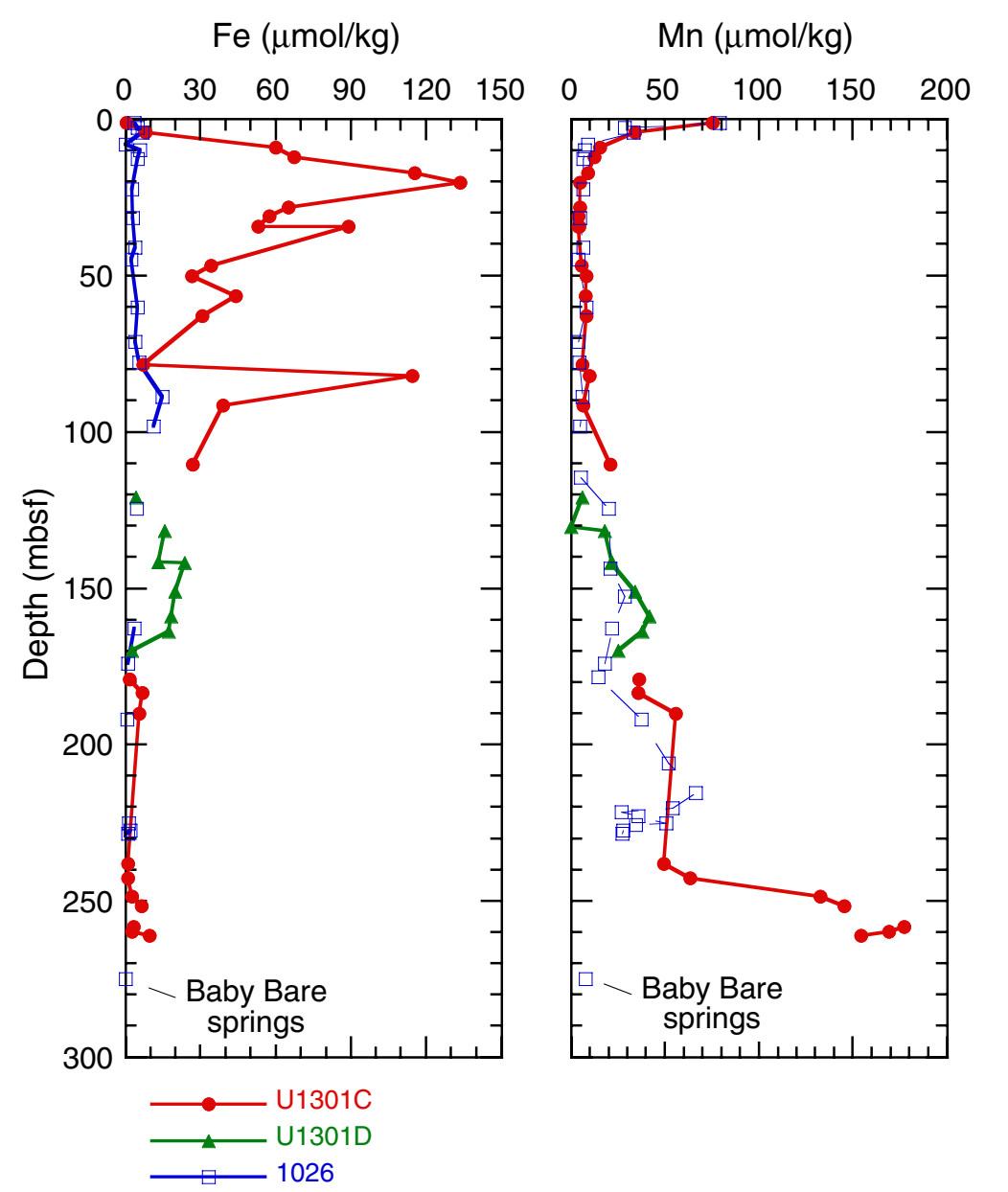

$\mathrm{Sr}(\mu \mathrm{mol} / \mathrm{kg})$

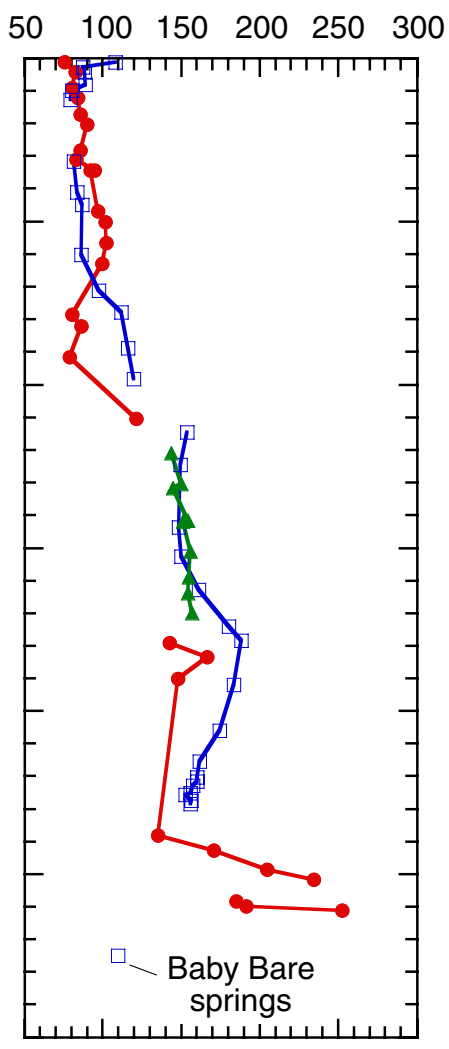

$\mathrm{B}(\mu \mathrm{mol} / \mathrm{kg})$

100200300400500600700

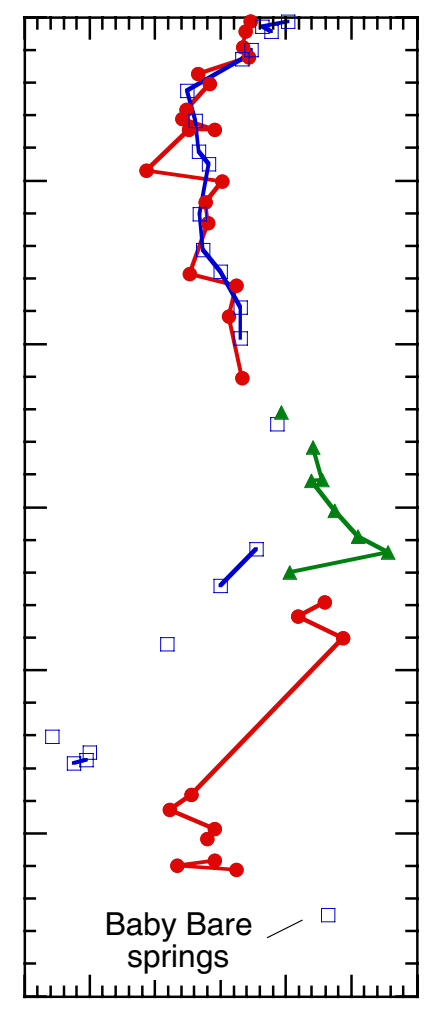


Figure F50. Composition of pore waters from Holes U1301C and U1301D, Site 1026, and Baby Bare springsmethane, sulfate, and barium.

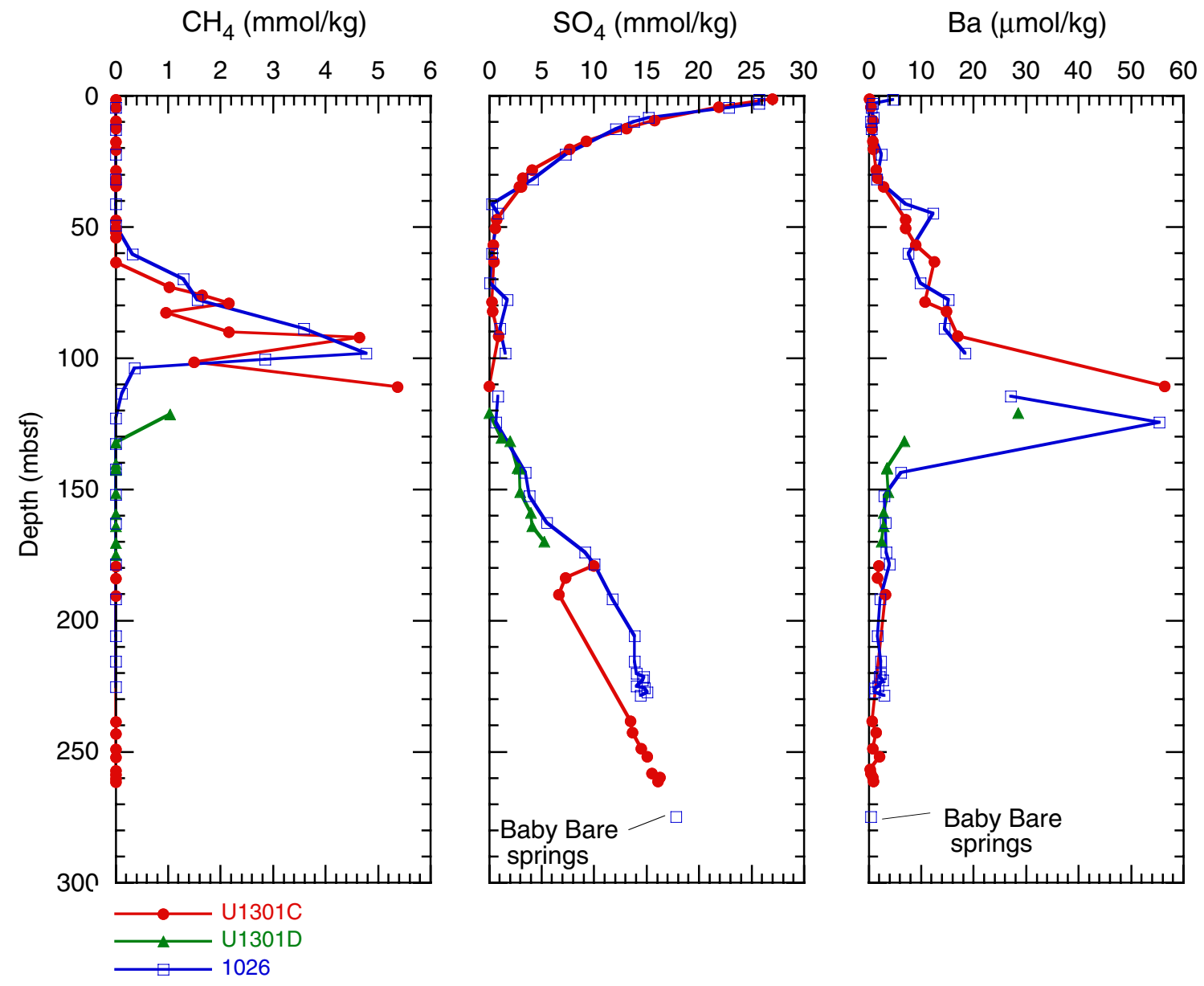


Figure F51. Composition of the solid phase in sediments from Hole U1301C and Site 1026-organic carbon, $\mathrm{C} / \mathrm{N}$ ratio, and calcium carbonate.

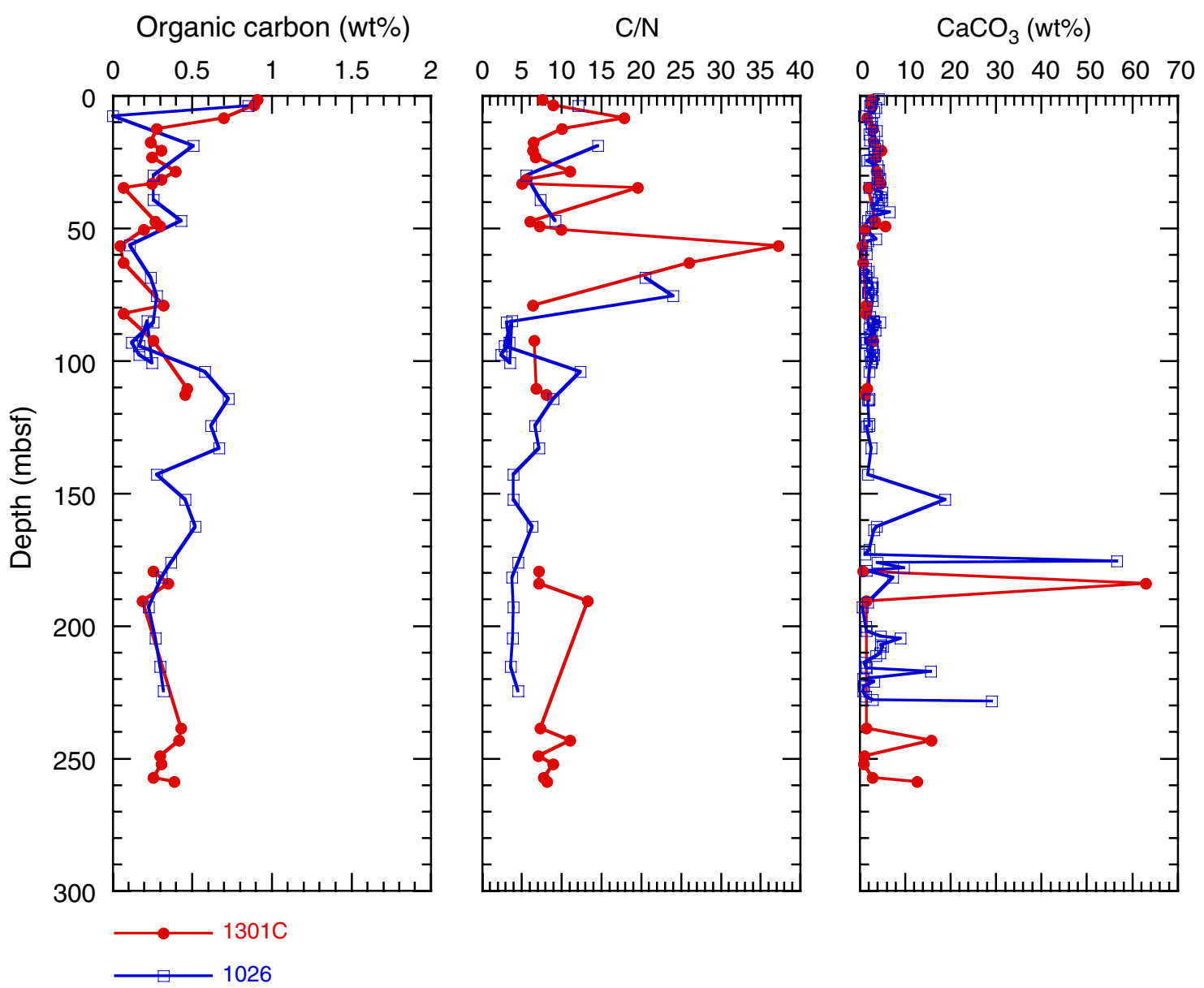


Figure F52. Drilling fluid contamination of a sample from Section 301-U1301C-13H-2 as estimated from PFT concentrations in exterior core, adjacent to core liner (exterior), halfway between core liner and center (halfway), and core center (center). This is a representative sample showing typical data. Data for all 23 samples are summarized on Table T14.

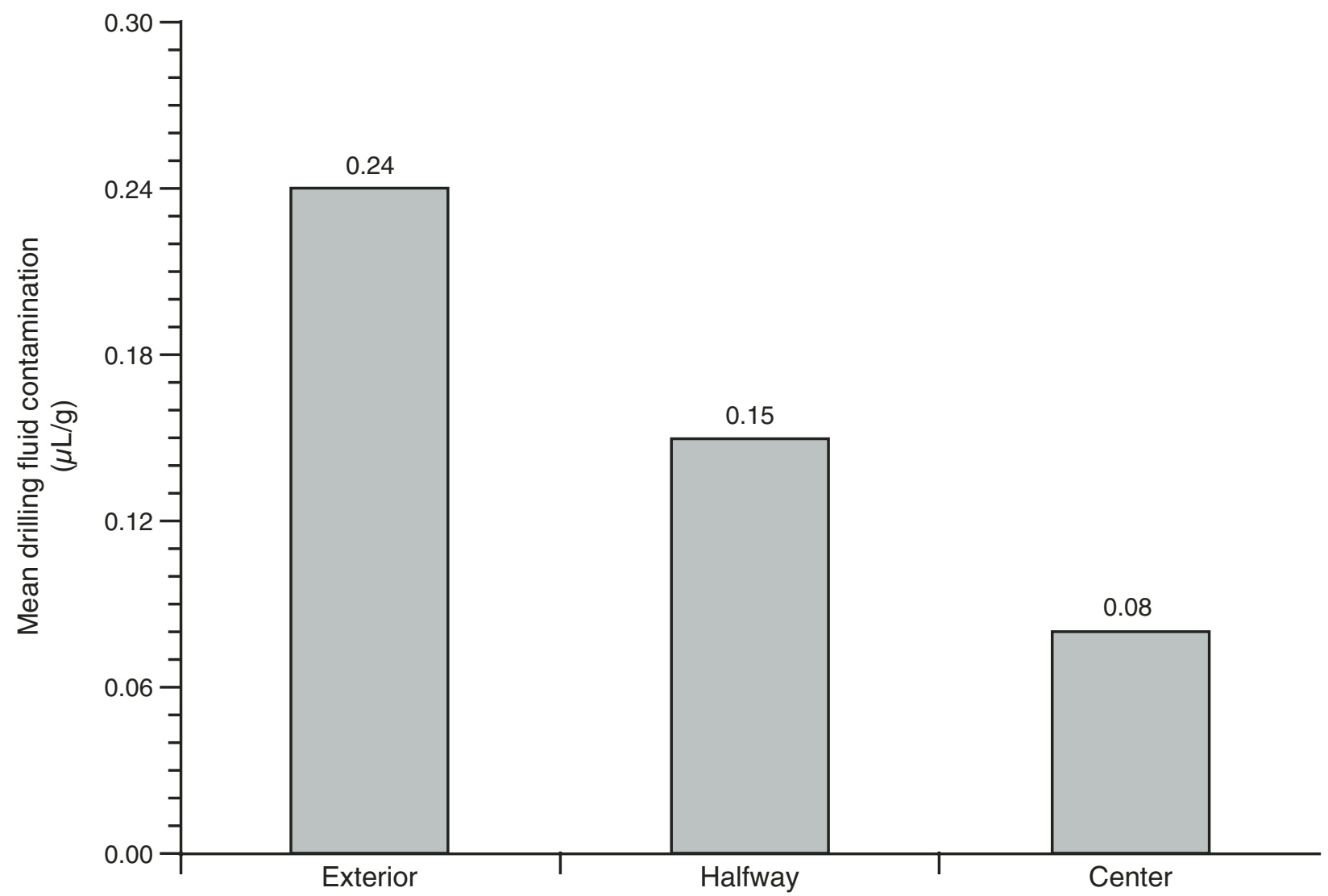


Figure F53. Microscopic image of acridine orange-stained sediment slurry ( $0.2 \mathrm{mbsf})$. The high numbers of diatom fragments create high background fluorescence (red arrows) and make detection of microbial cells (yellow arrows) almost impossible.

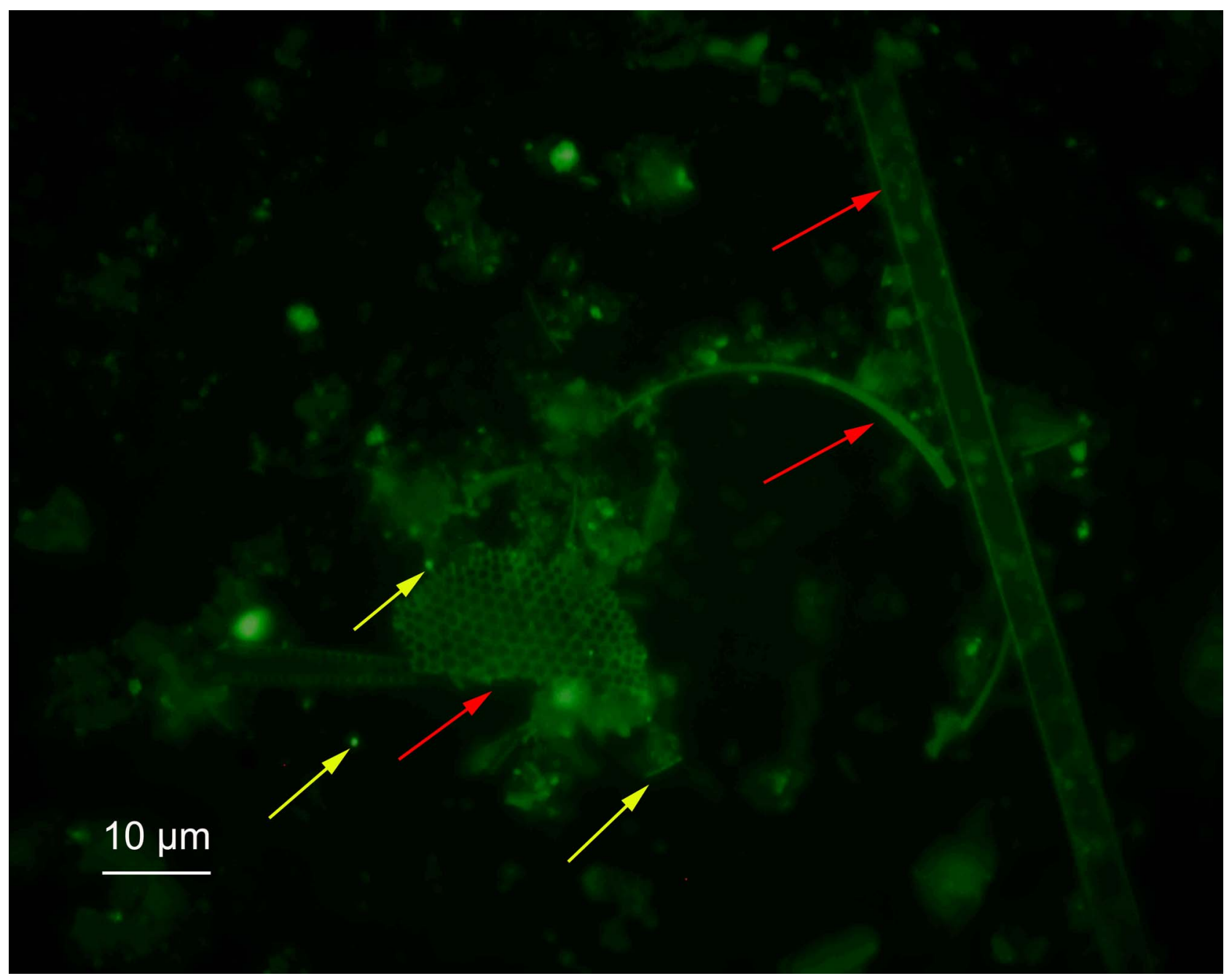


Figure F54. Microscopic image of acridine orange-stained sediment slurry (45 mbsf) after ultrasonication and sedimentation of particulate matter. Microbial cells (yellow arrows) can be distinguished from other particles.

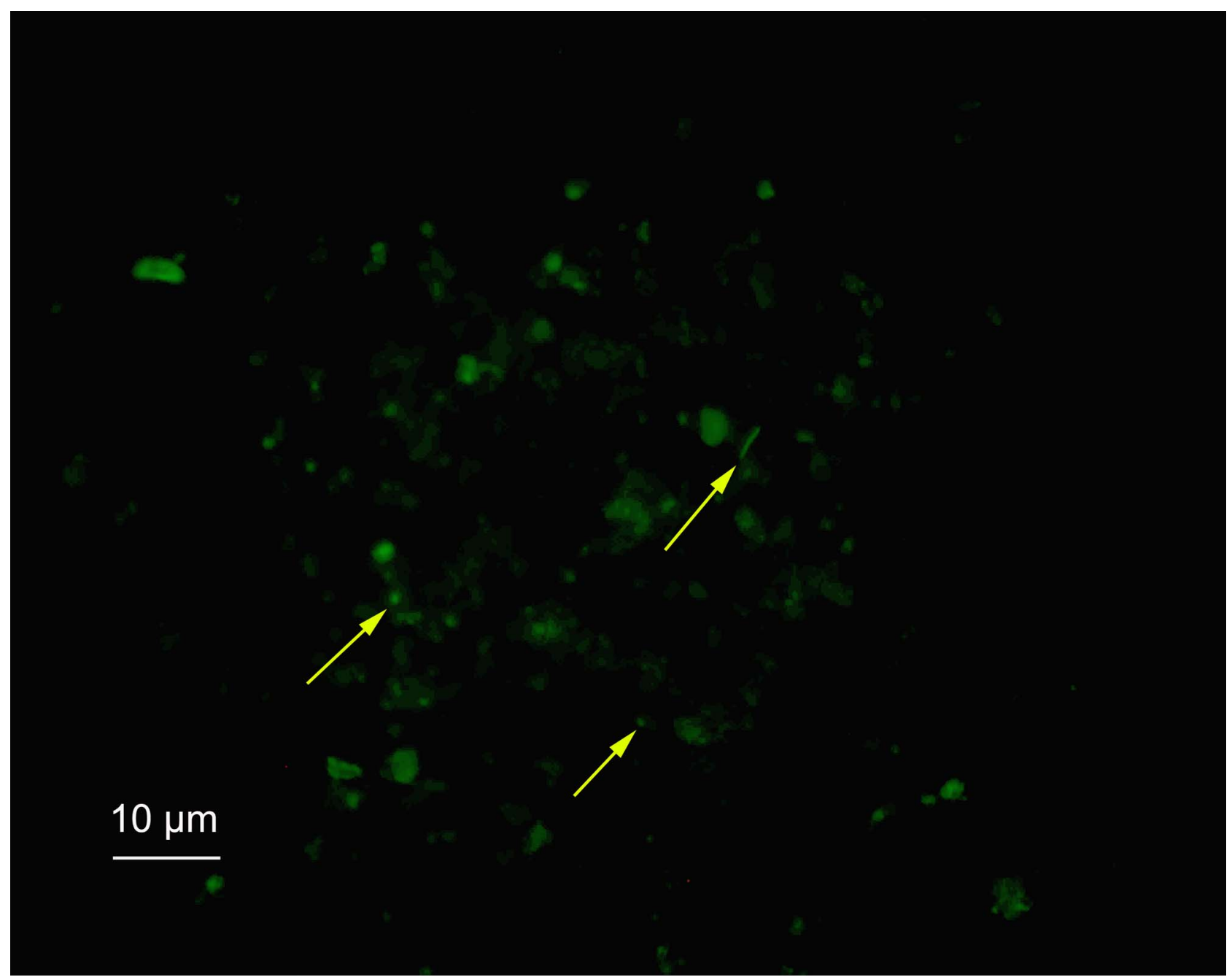


Figure F55. Profile of microbial cell counts through the sediment column of Hole U1301C. Cell numbers were determined by the AODC technique and were independently counted by two shipboard scientists. The dashed lines indicate areas of no core recovery. The open circle was judged as an outlier after consulting geochemical data and PFT measurements.

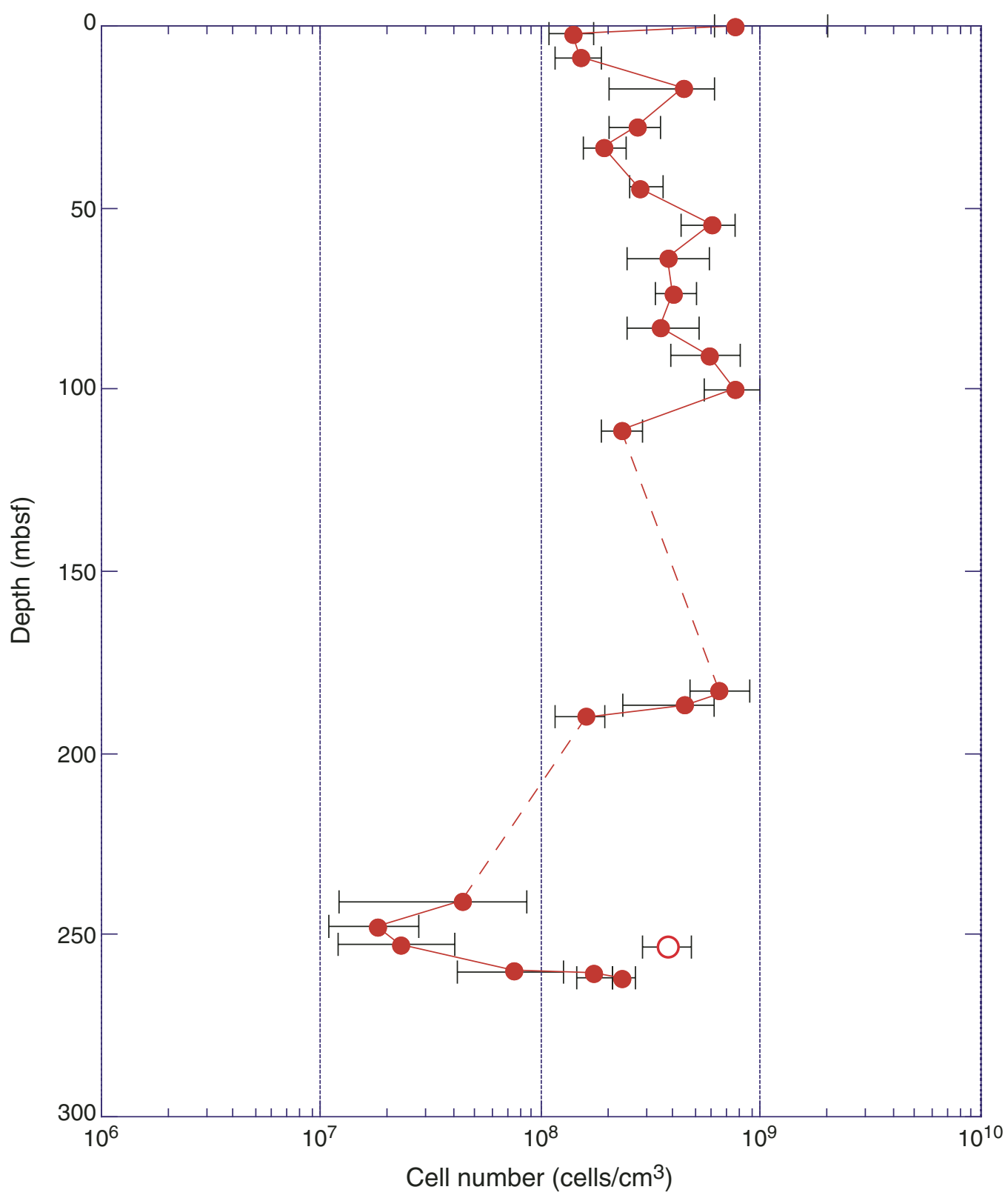


Figure F56. Drilling fluid contamination for a sample from Section 301-U1301B-5R-1 as estimated from PFT concentrations in the untreated exterior, $2 \times$ washed exterior, $2 \times$ washed + flamed exterior, and interior of rocks. Values given above each column indicate measured PFT concentration after treatment. This sample was the most contaminated sample of the 14 measured samples (see Table T16) and demonstrates the effectiveness of our treatments.

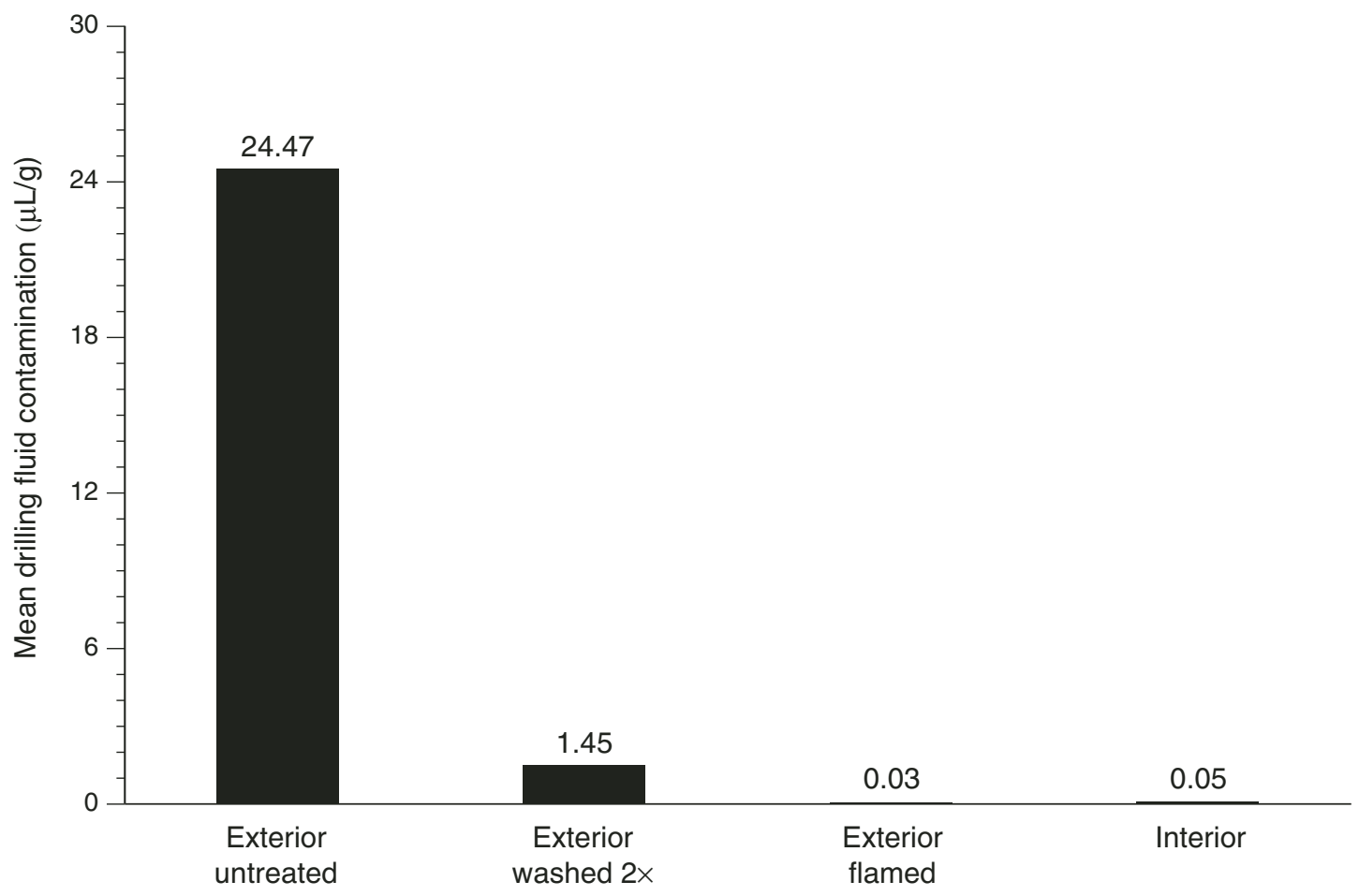


Figure F57. Microscopic image of DAPI-stained cells from a growing enrichment culture of a basaltic rock sample (Section 301-U1301B-IR-2; 350 mbsf) (sample code: MBSTE). Enrichment is prepared in Mono medium at $70^{\circ} \mathrm{C}$ under anaerobic conditions. Coccoid-shaped microorganisms (blue) are attached to iron sulfide particles.
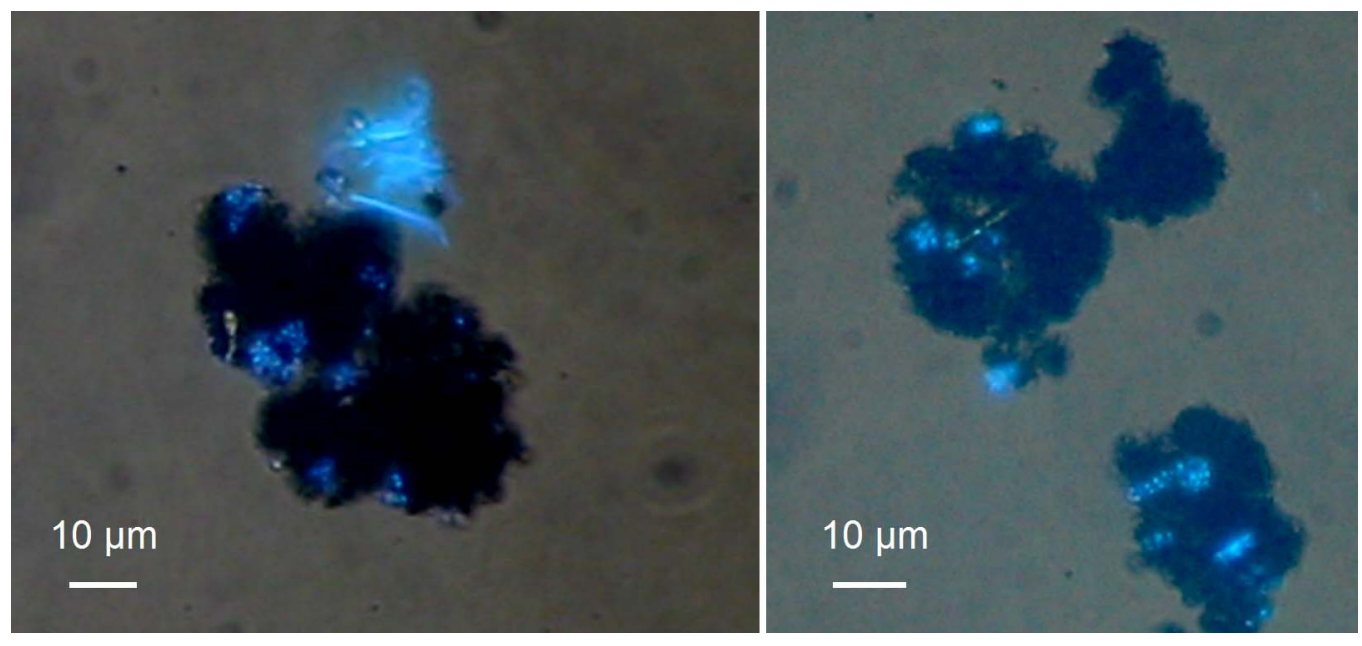
Figure F58. Physical and moisture and density (MAD) property data collected from Hole U1301C. A. Depth, core number, amount recovered, and brief description of overall lithology. B. Magnetic susceptibility. C. MAD and gamma ray attenuation (GRA) bulk density. D. MAD grain density. E. Natural gamma ray (NGR). TD = total depth. (Continued on next page.)

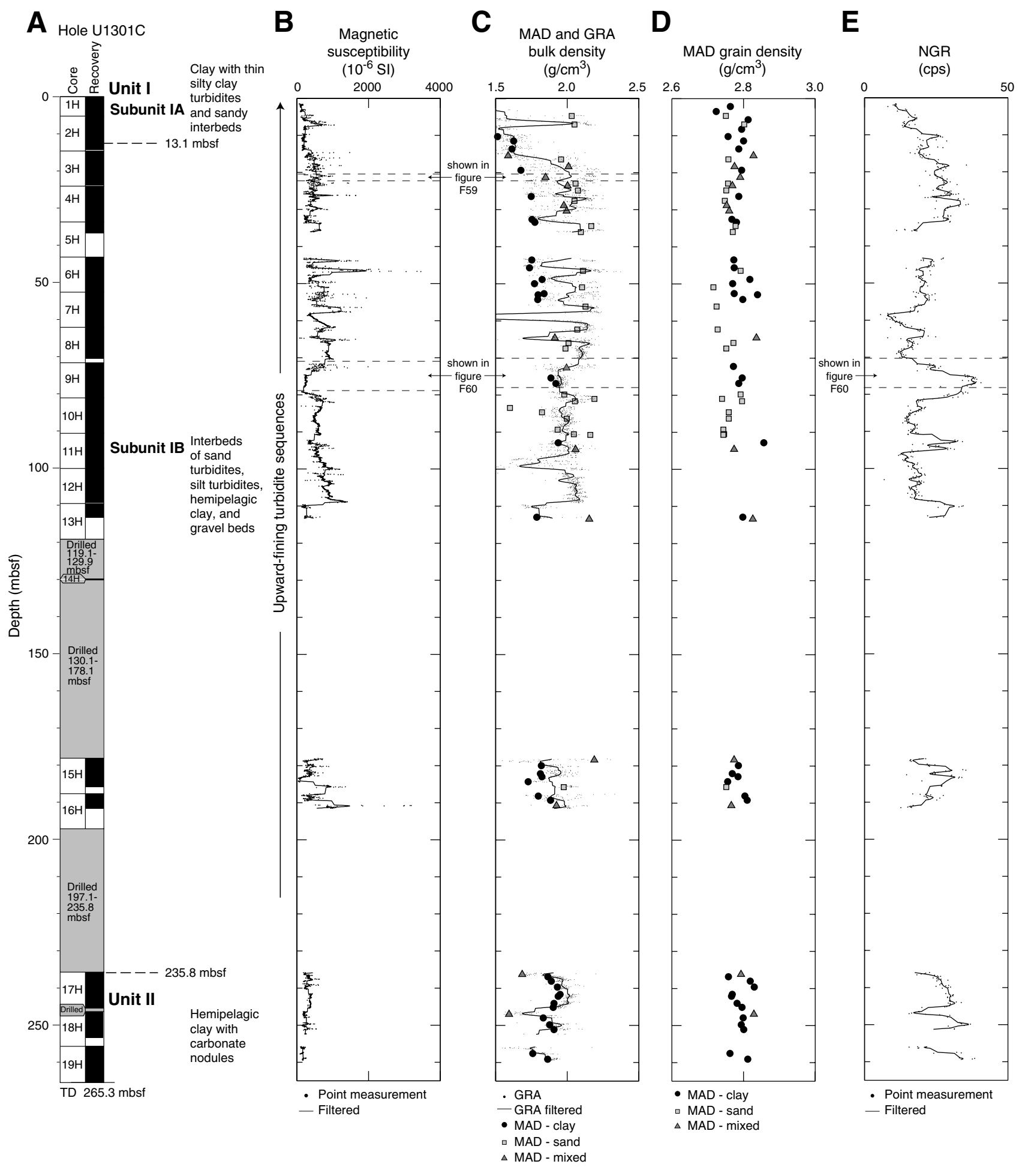


Figure F58 (continued). F. Compressional velocity (also see Fig. F62A). G. Thermal conductivity. Error bars of one standard deviation are shown when larger than symbol. H. Shear strength. I. Porosity. PWL $=P$-wave logger.

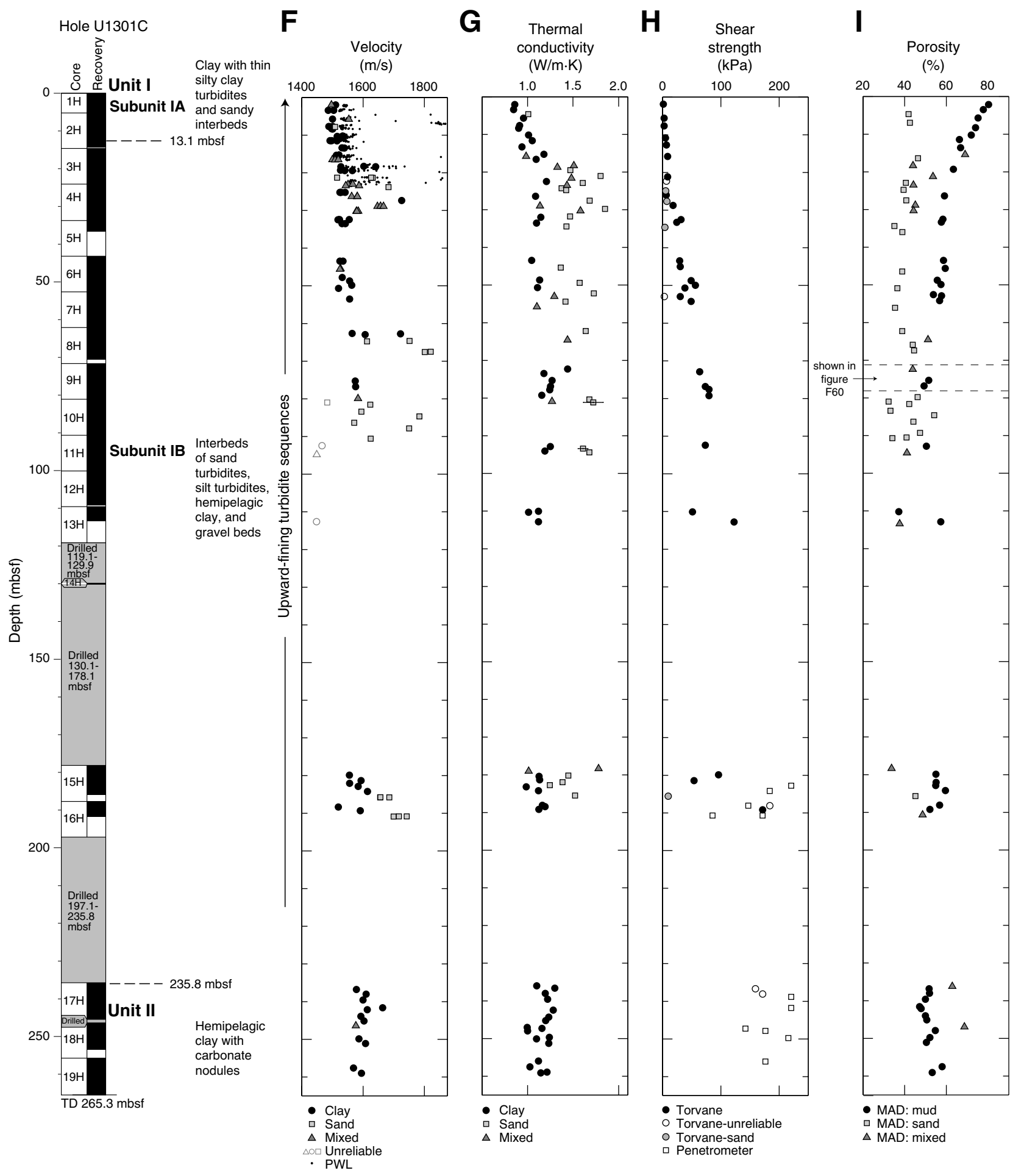


Figure F59. Magnetic susceptibility and gamma ray attenuation (GRA) and moisture and density (MAD) bulk density data measured on a typical $1.5 \mathrm{~m}$ core from Subunit $1 \mathrm{~A}$.

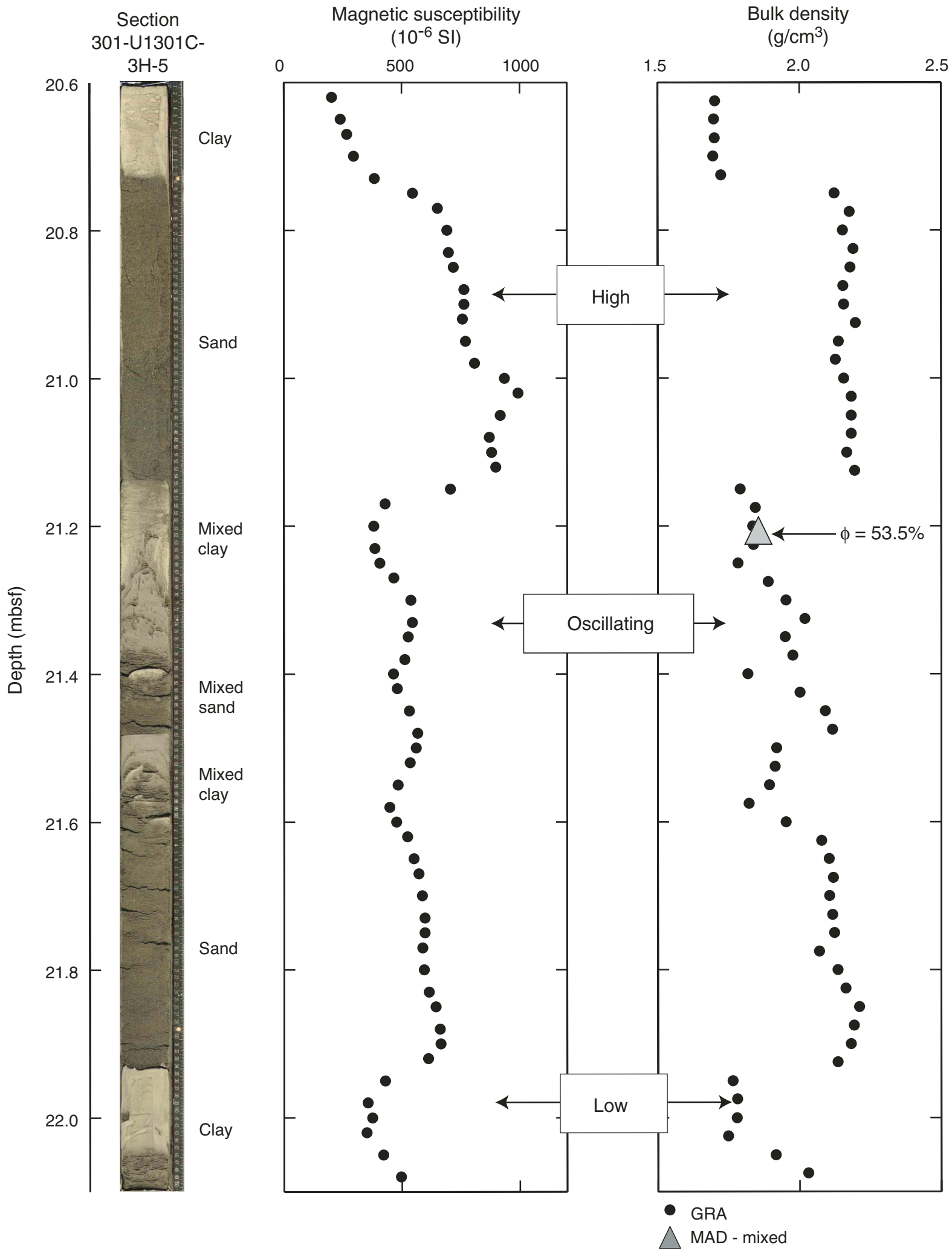


Figure F60. Magnetic susceptibility, gamma ray attenuation (GRA) and moisture and density (MAD) bulk density, MAD porosity, and natural gamma ray (NGR) data from a $7 \mathrm{~m}$ thick sequence from Subunit IB. mbio = microbiological whole-round sample taken.
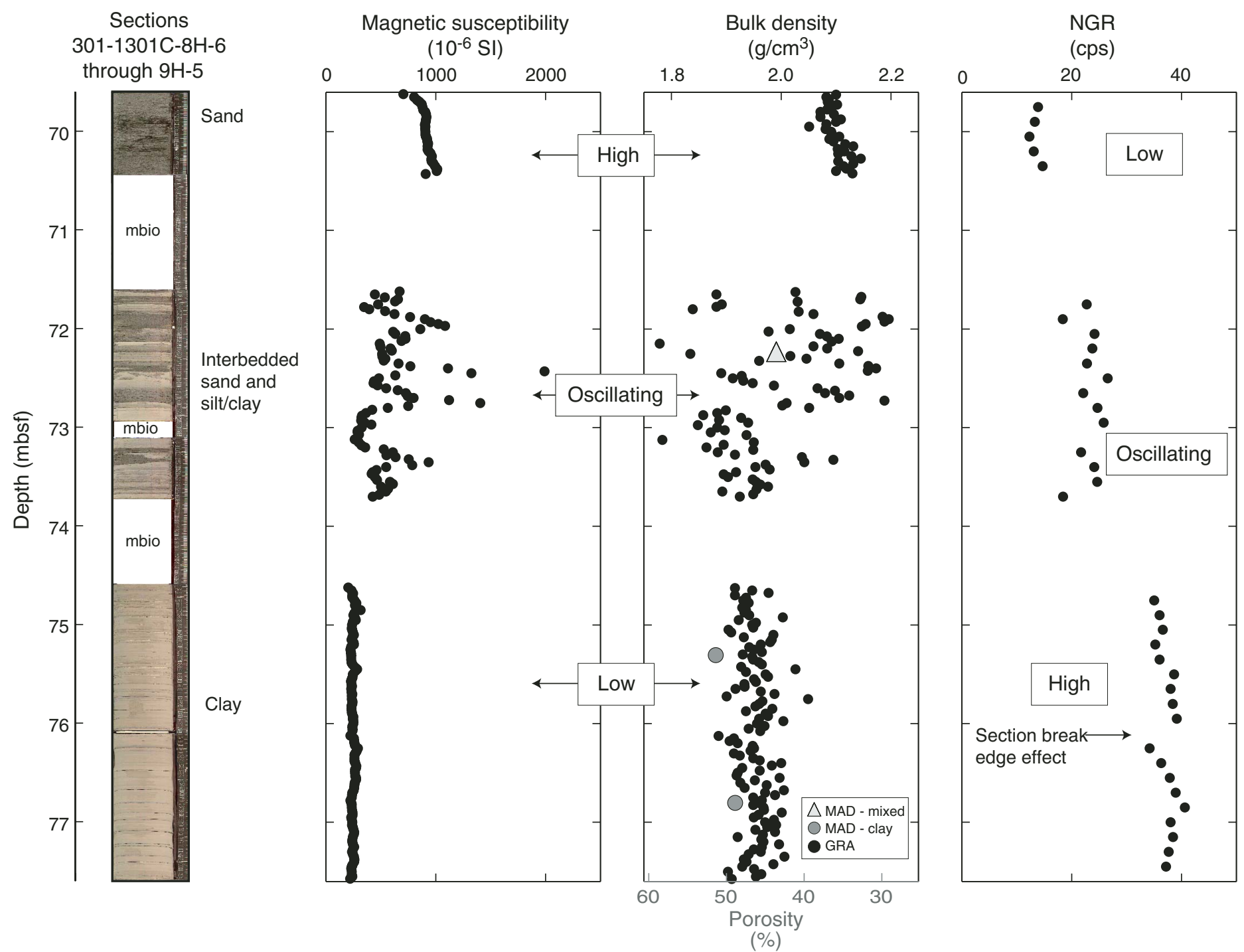
Figure F61. A. Histograms of thermal conductivity, showing a bimodal distribution based on lithology and sampling bias toward clay layers. B. Observed relationship between thermal conductivity and porosity.
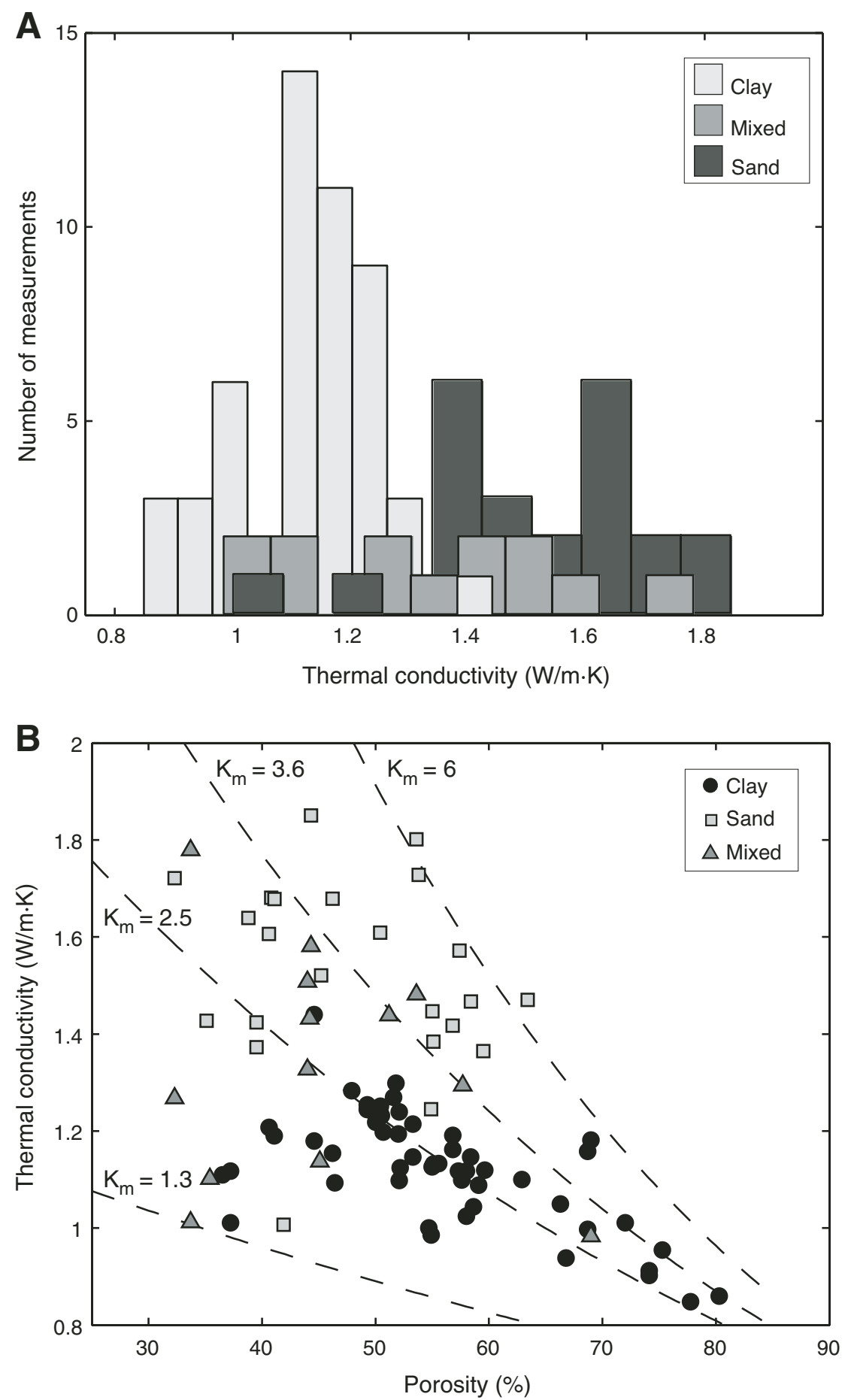
Figure F62. A. Correction for velocity error (see Blum, 1997, for equation). All variables are from Janus database. B. Seismic velocity measured on split cores, showing an increase of $10 \%$ within the upper $100 \mathrm{mbsf}$. C. Evaluation of seismic anisotropy, showing no directional preference. PWS3 = $P$-wave sensor 3 .
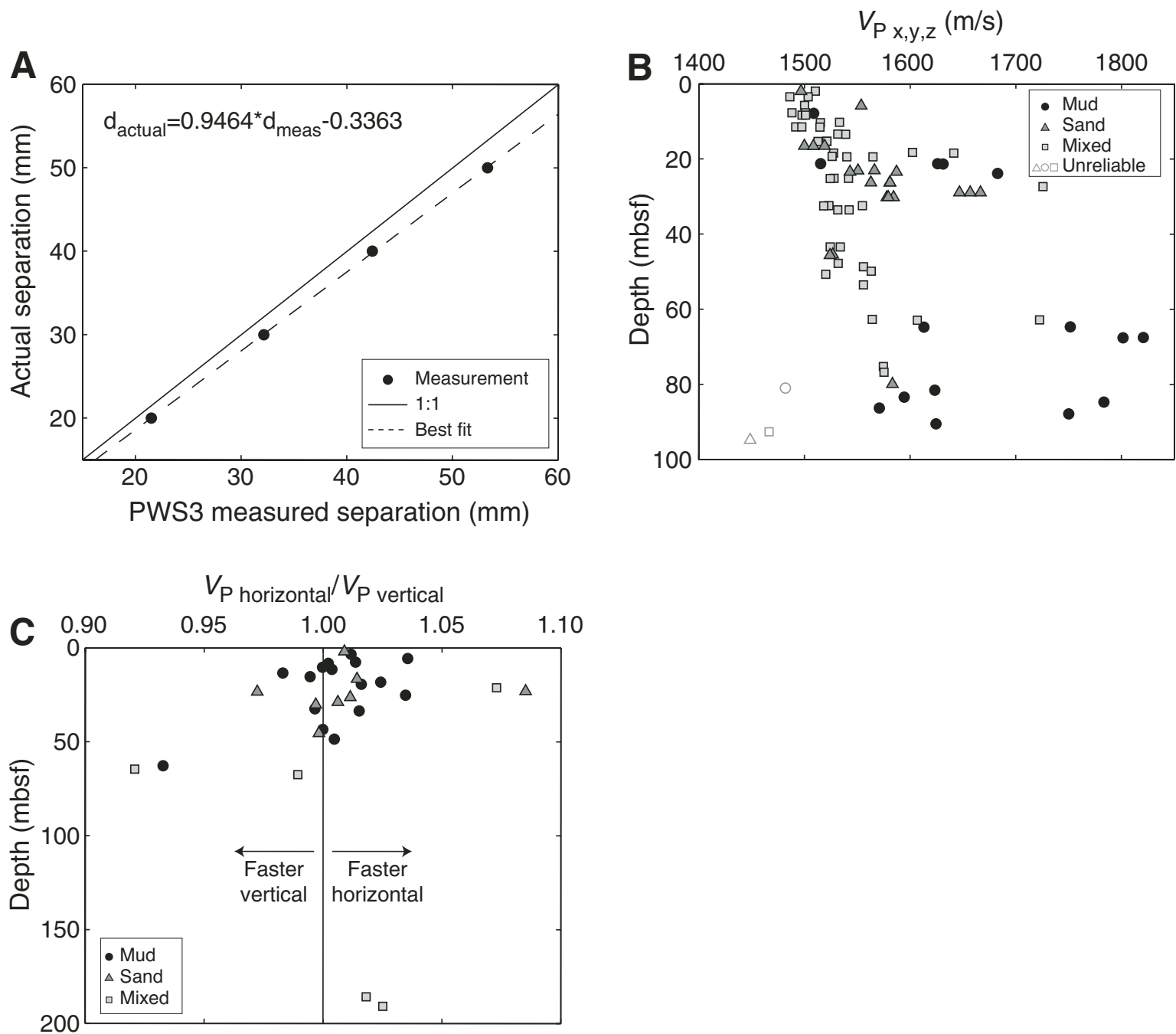
Figure F63. Summary plots for physical properties from the basement section of Hole U1301B. A. Core recovery, showing core number, portion recovered, and lithologic units. B. Magnetic susceptibility sampled at $1 \mathrm{~cm}$ intervals within the recovered sections. C. Thermal conductivity (see text for justification). Error bars denote 1 $\sigma$. The two lowest values correspond to hyaloclastite samples. D. Compressional $P$-wave velocity of samples collected for moisture and density (MAD) and paleomagnetic analysis. Velocities of paleomagnetic samples consistently demonstrate a wider range of values than those measured on MAD samples, which is likely attributable to nonparallel faces on the paleomagnetic samples (see text for details). TD = total depth. (Continued on next page.)

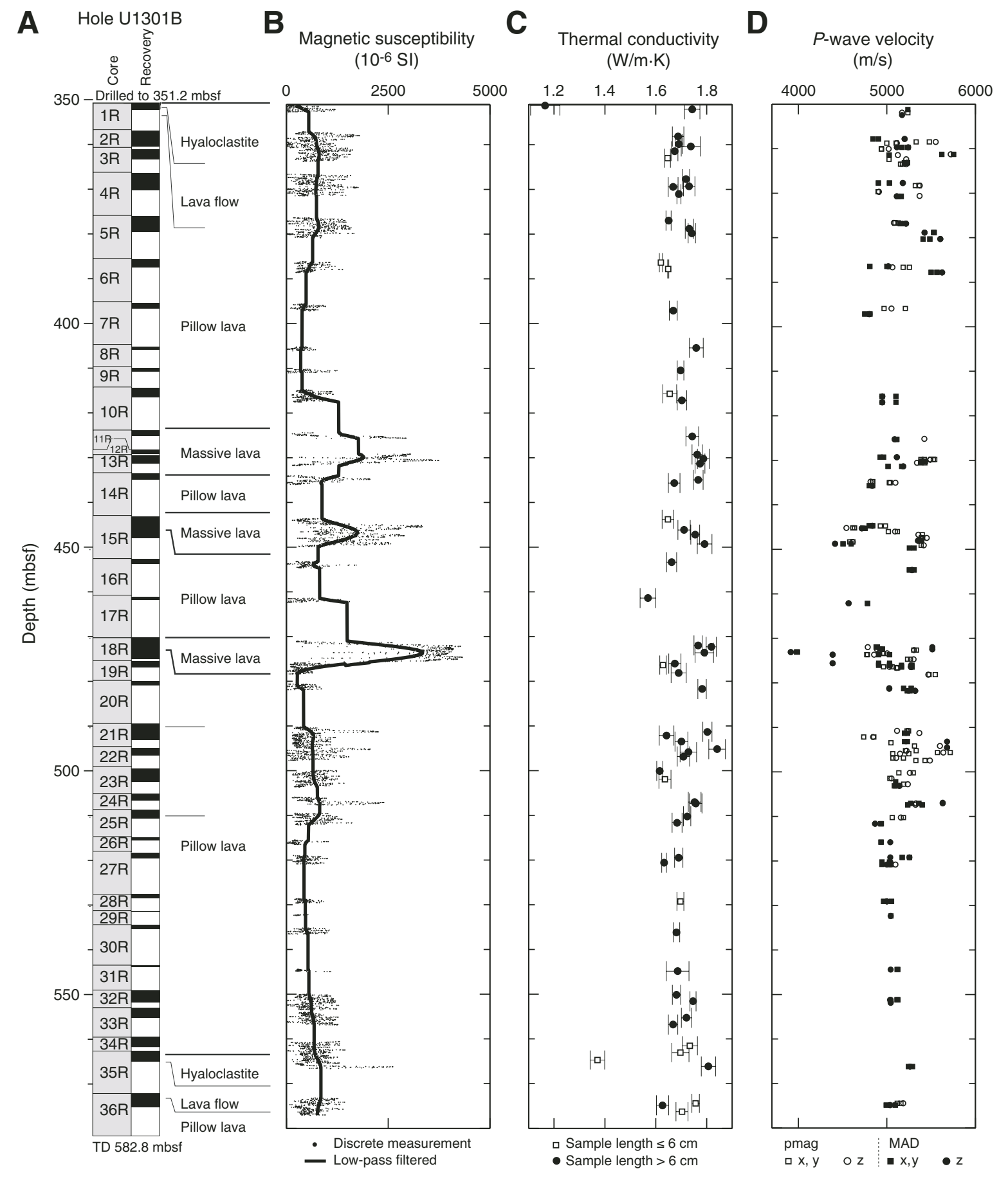


Figure F63 (continued). E. Bulk density of MAD samples, with the low value at $\sim 352$ mbsf corresponding to a highly brecciated sample. F. Grain density is shown, with the lowest value of $\sim 2.2 \mathrm{~g} / \mathrm{cm}^{3}$ corresponding to a brecciated sample at a depth of $\sim 352$ mbsf. G. The same brecciated sample yields the highest porosity value (almost 30\%), and a second highly porous sample ( 13\%) was recovered at a depth of $\sim 565$ mbsf.

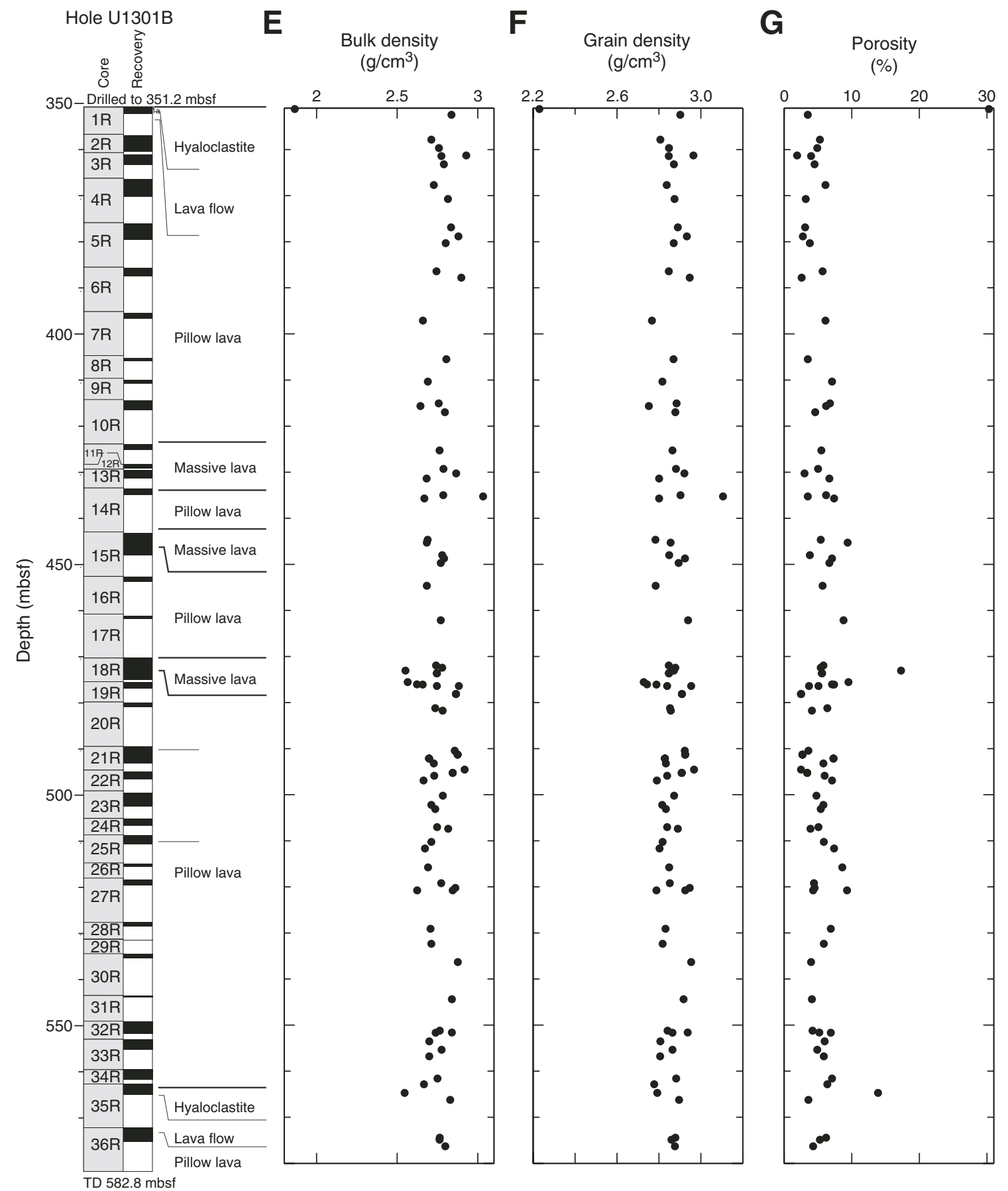


Figure F64. Magnetic susceptibility for Section 301-U1301B-4R-3 (369.39-370.89 mbsf), showing the high degree of variability characteristic of the discontinuous and fractured core recovered in Hole U1301B. The lowest values shown correspond to $\sim 6 \mathrm{~cm}$ wide gaps where whole-round sections have been removed, whereas the highest values correspond to more massive sections of rock. Magnetic susceptibility is reduced at the ends of the section as well as at the interfaces between noncontinuous pieces.

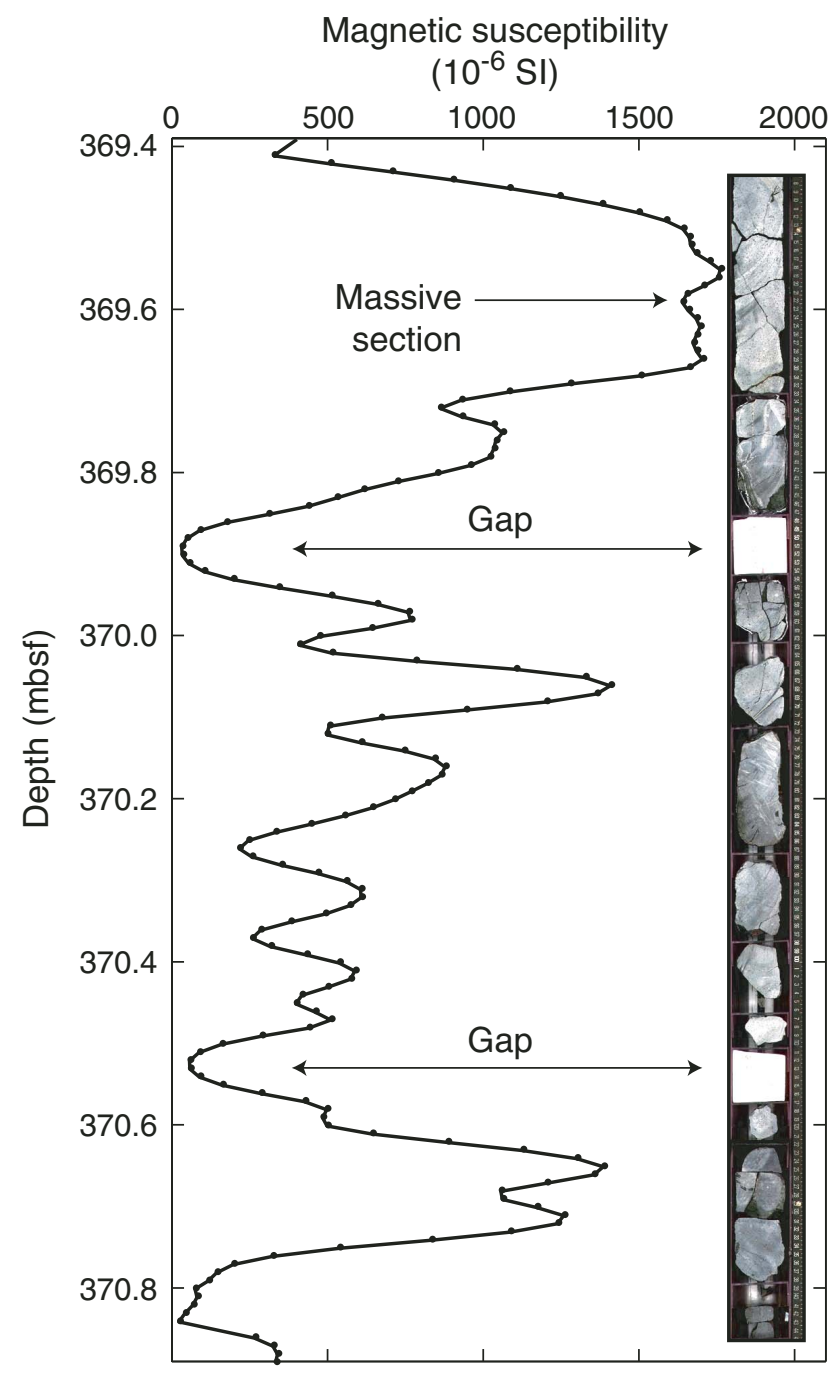


Figure F65. Comparison of horizontal and vertical velocities for paleomagnetic and MAD samples. The solid line indicates equal horizontal and vertical velocity.

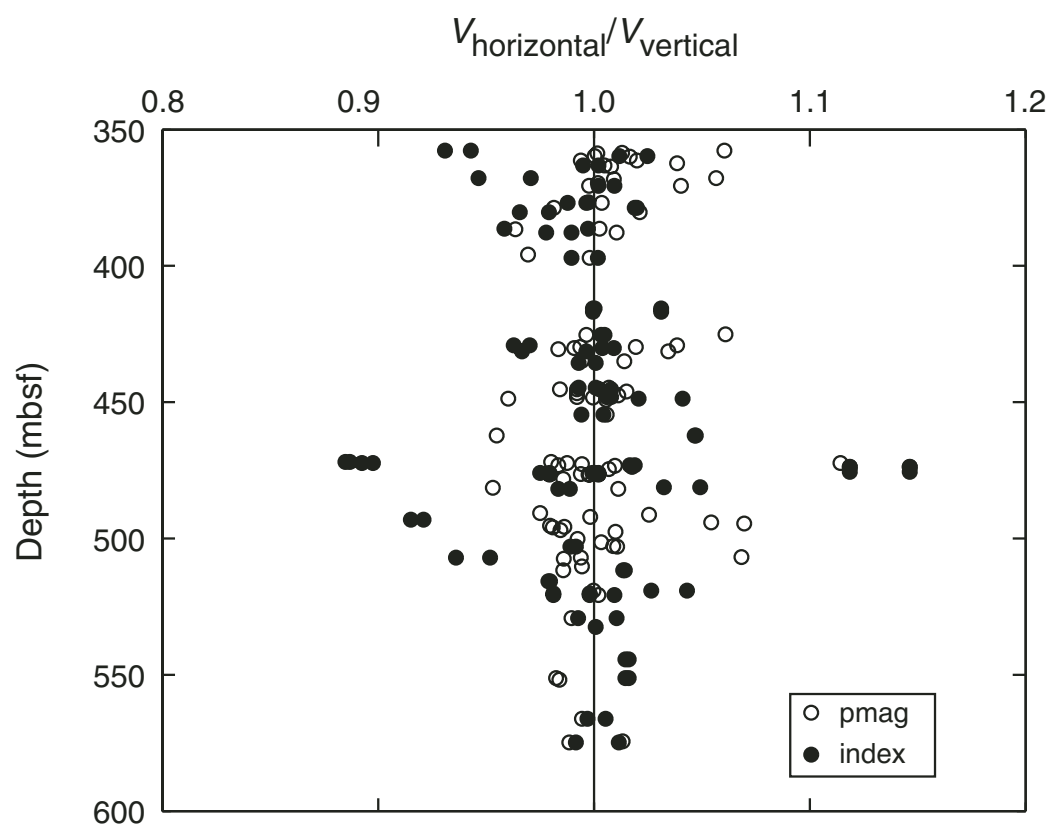


Figure F66. Crossplots of physical property data, derived from samples used for MAD property determination. For illustrative purposes, only z-axis $P$-wave velocity is compared-horizontal velocities yield virtually identical results. In all cases, alteration (on a sample scale) will tend to decrease compressional wave velocity. A. Negative correlation between porosity and bulk density. As porosity decreases, the variability in bulk density for samples with similar porosities also decreases, likely resulting from variations in alteration and mineral precipitation within the open pore spaces. B. Strong inverse correlation between porosity and grain density. The variability in vertical velocity also decreases with decreasing porosity. C. Correlation between compressional velocity and grain density, showing a slight positive trend.
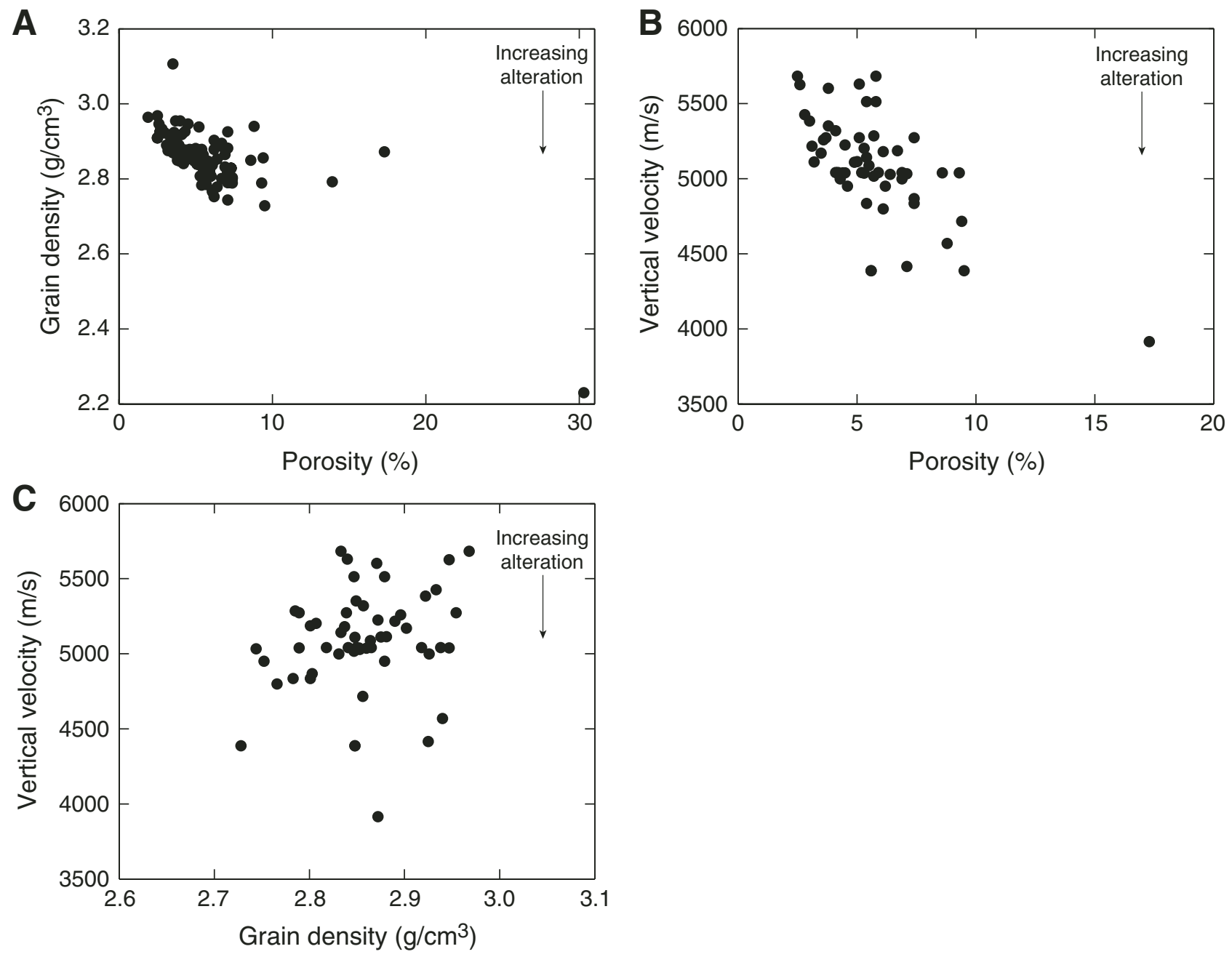
Figure F67. Temperature versus time and interpreted equilibrium temperatures for Hole U1301C deployments (Cores 301-U1301C-3H and 5H) of the APCT tool. A. Temperature versus time, shifted to show time since tool penetration. Small vertical bars indicate the range of data used in subsequent analyses of equilibrium temperatures. B. Plots of temperature versus the theoretical decay function for the APCT tool, based on a one-dimensional radial model of tool cooling (Horai and Von Herzen, 1985). As time goes to infinity, the function goes to zero, so the temperature intercept indicates the predicted equilibrium temperature.

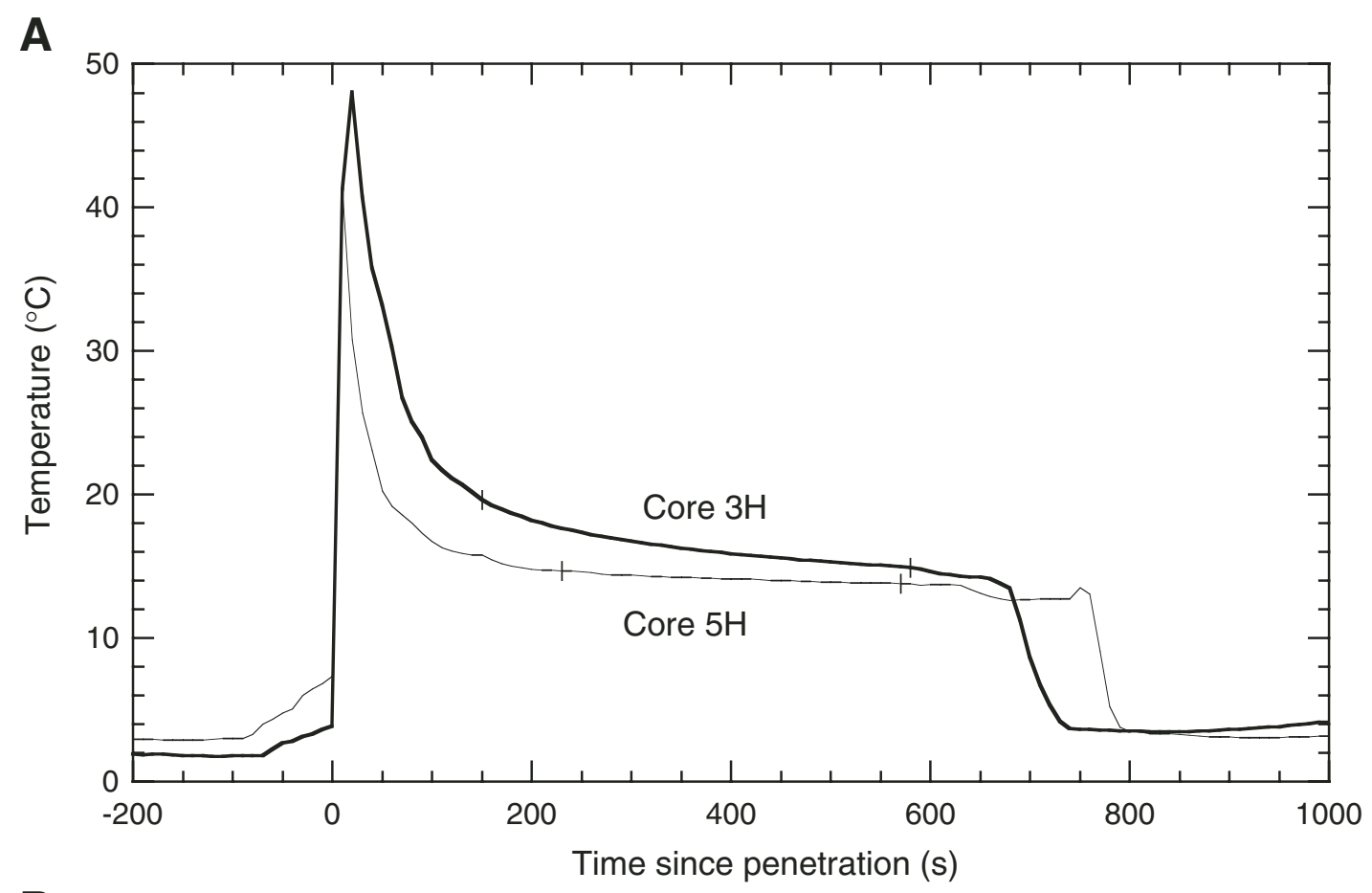

B

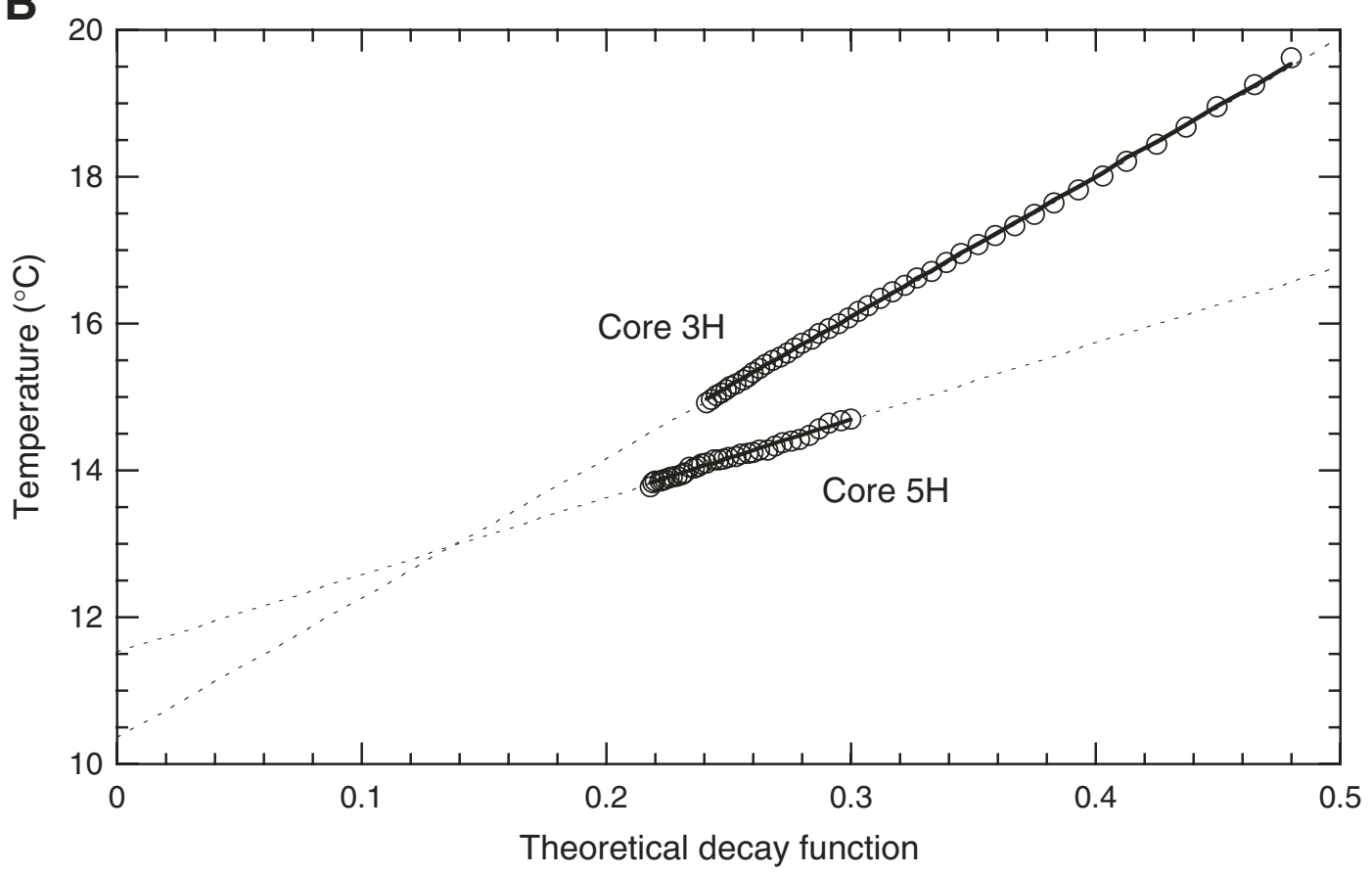


Figure F68. Temperature versus time and interpreted equilibrium temperatures for Hole U1301C deployments of the DVTP. A. Temperature versus time, shifted to show time since tool penetration. Small vertical bars indicate the range of data used in subsequent analyses of equilibrium temperatures. The data from deployment in Core 301-U1301C-14H indicate that the tool did not penetrate into undisturbed formation. These data cannot be used to estimate an equilibrium temperature. B. Plots of temperature versus the theoretical decay function for the DVTP, based on numerical model of tool cooling (Davis et al., 1997). As time goes to infinity, the function goes to zero, so the temperature intercept indicates the predicted equilibrium temperature. Two different data segments were analyzed for deployment in Core 301-U1301C-9H, and they yield the same equilibrium temperature.
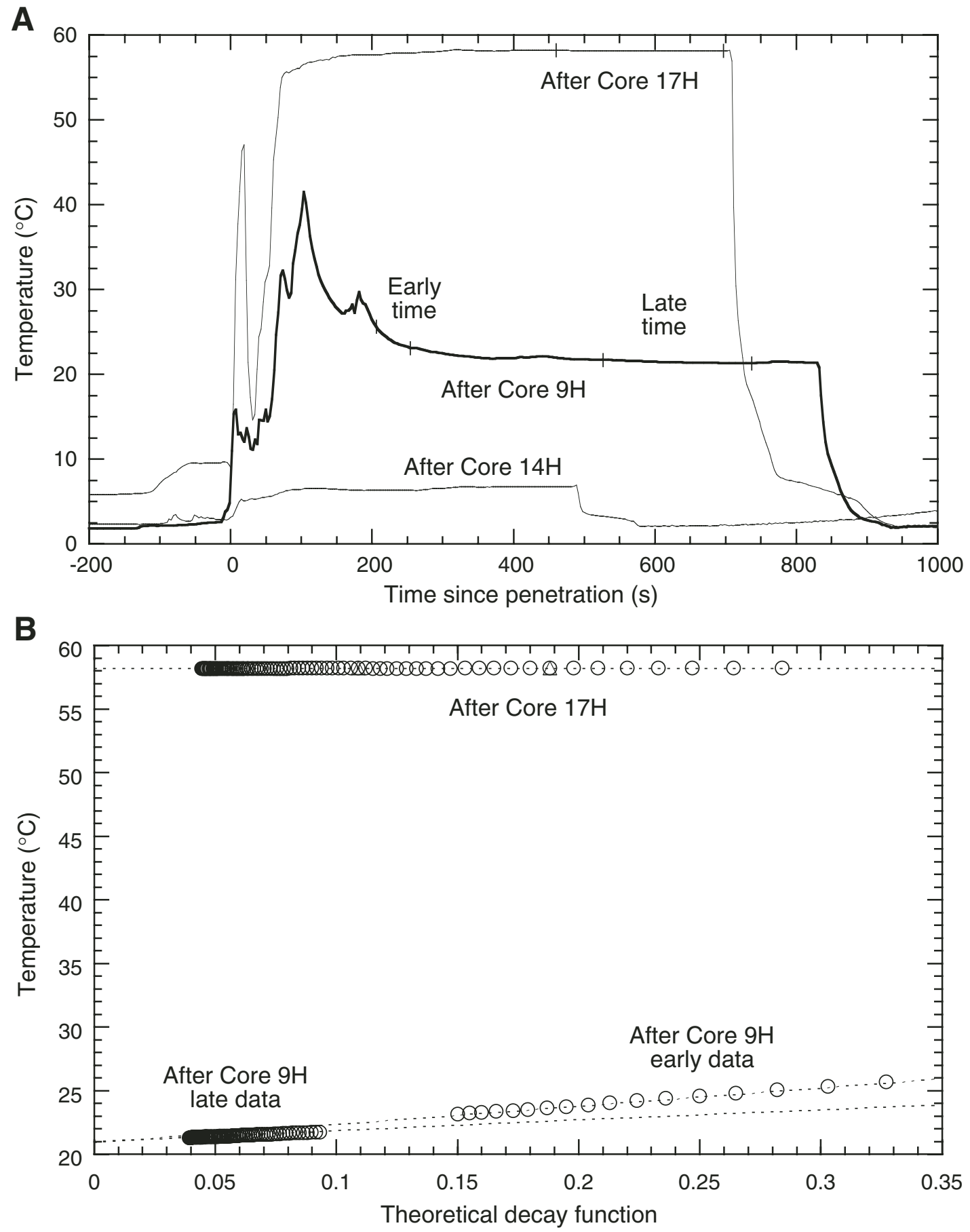
Figure F69. Thermal gradient and heat flow plots. A. Temperatures versus depth in Hole U1301C. Solid squares are from deployments used to derive the gradient by linear regression (dashed line), $0.228^{\circ} \mathrm{C} / \mathrm{m}$. The value at $Z=0$ is bottom water. The open square is from the APCT tool deployment in Core 301-U1301C-3H and was not used in the analysis. Estimated uncertainties in equilibrium values are smaller than the symbols used to plot the data. B. "Bullard" plot of temperature versus thermal resistance. The slope of the dashed line indicates heat flow of $280 \mathrm{~mW} / \mathrm{m}^{2}$.
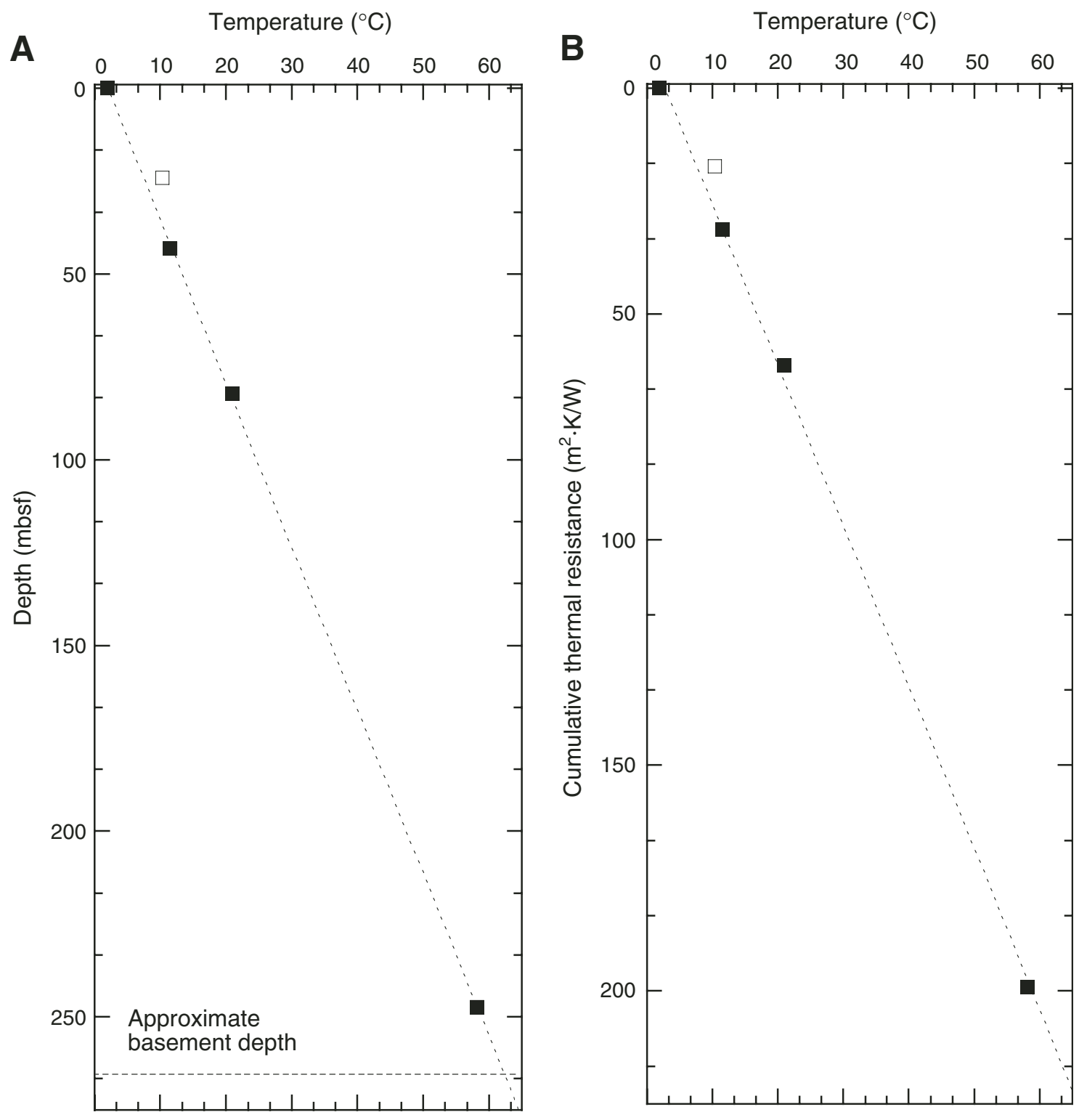
Figure F70. Drawing (not to scale) of downhole configuration of packer experiments conducted in Hole U1301A. TD = total depth.

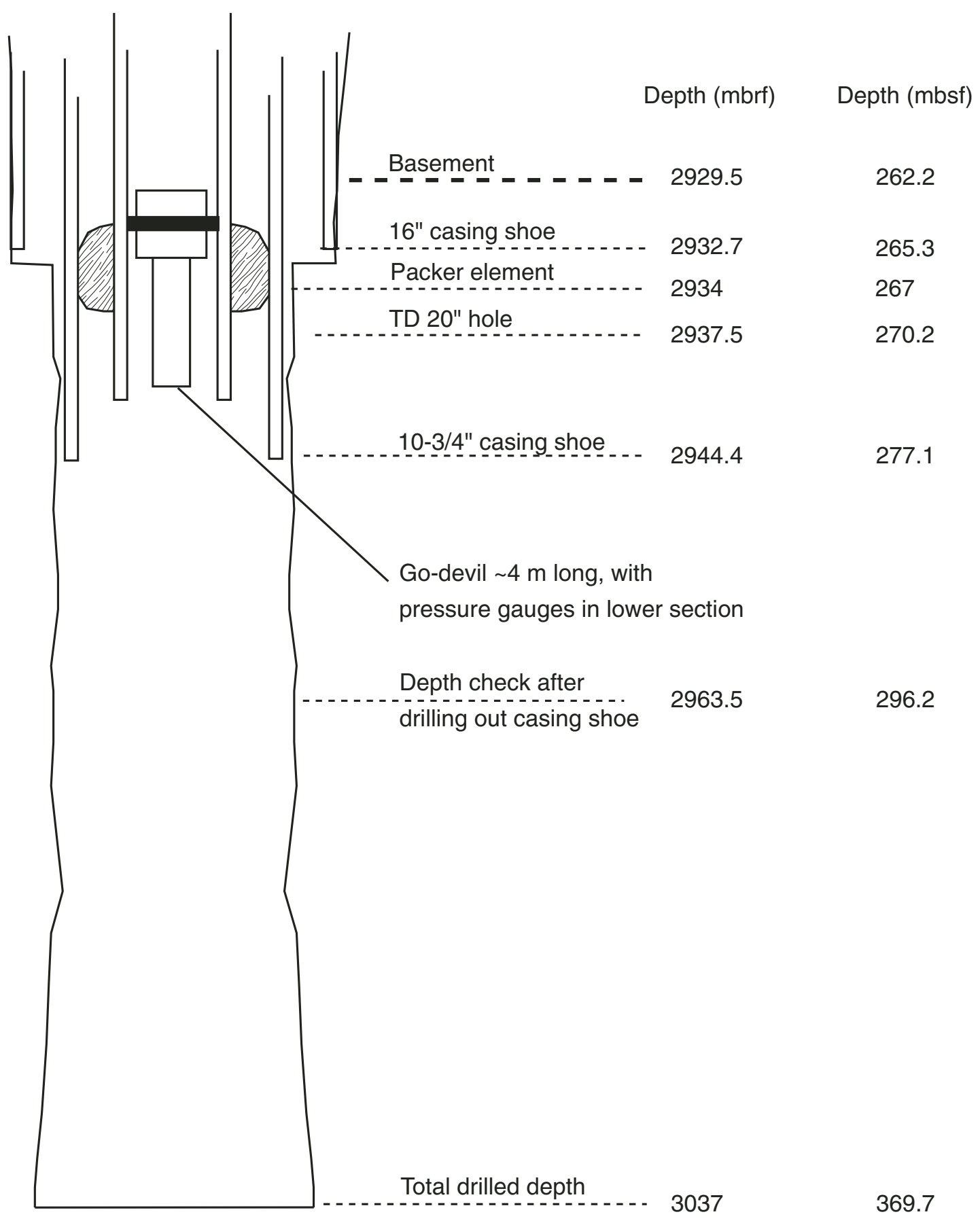


Figure F71. Pressure and temperature records collected with downhole electronic gauges during packer experiments in Hole U1301A.

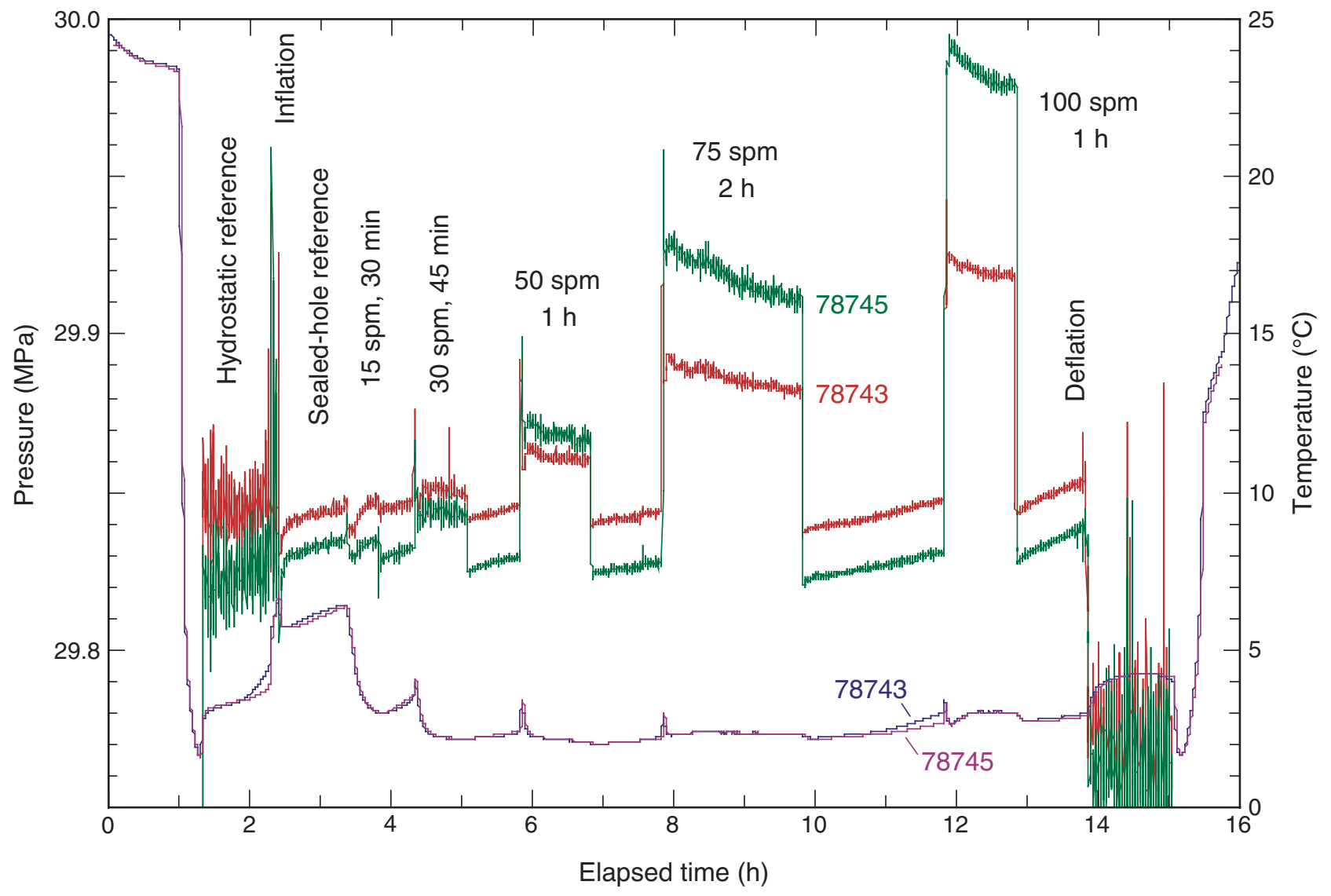


Figure F72. Pressure and temperature records collected with downhole electronic gauge SN 78745 during packer experiments in Hole U1301B. A. Record for the overall test sequence. B. Expanded view of test sequence at 472 mbsf. (Continued on next page.)

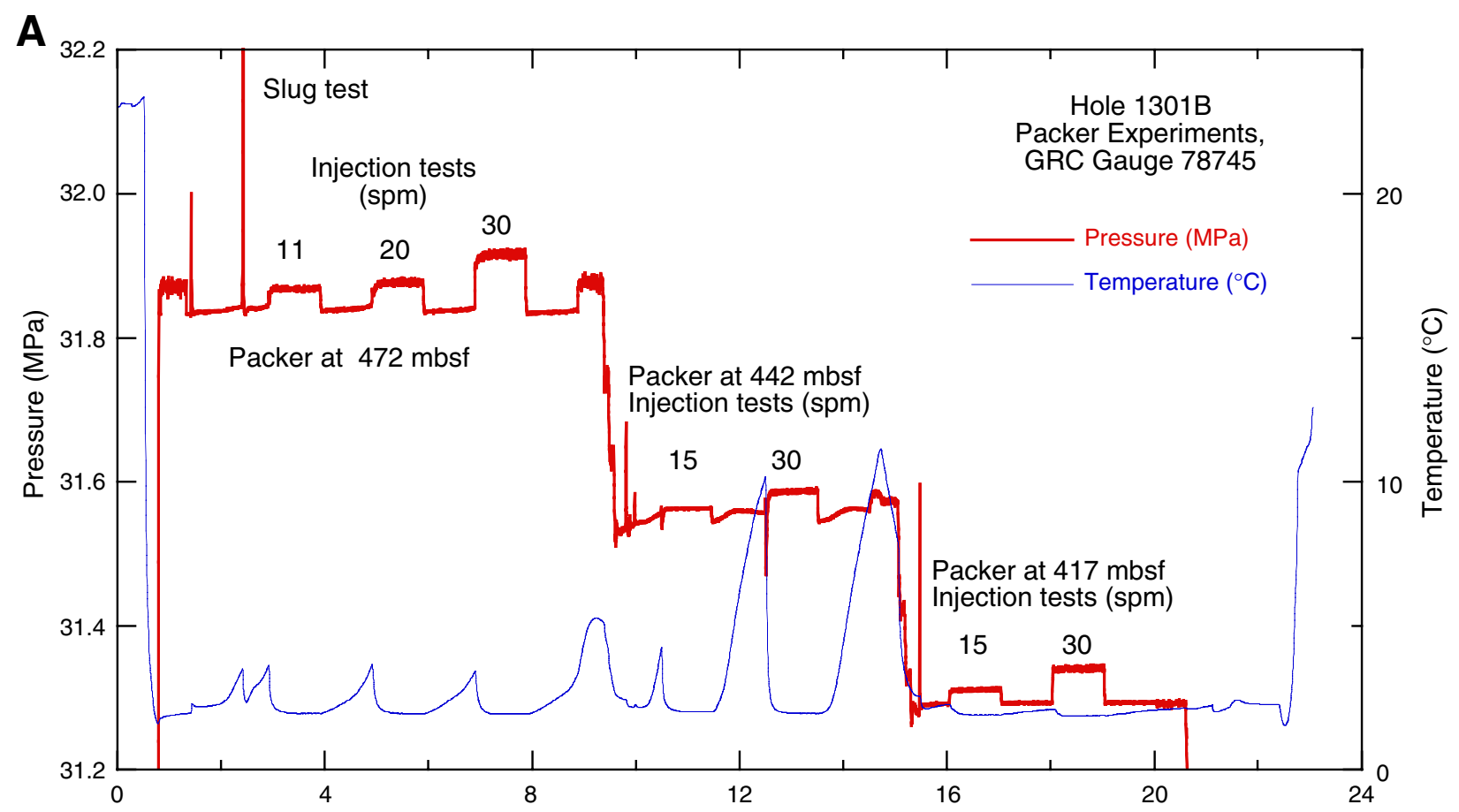

B

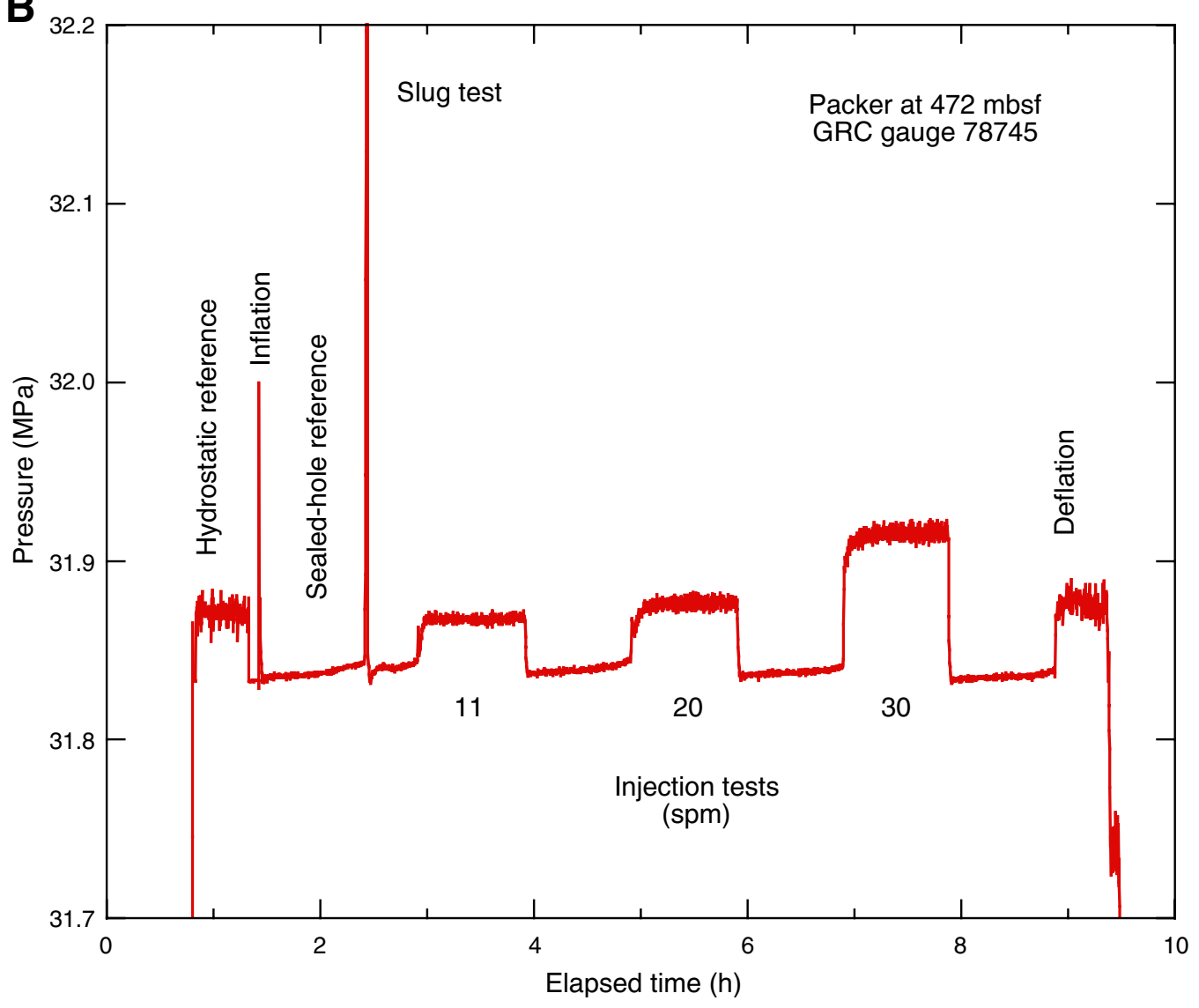


Figure F72 (continued). C. Expanded view of sequence at 442 and 417 mbsf.

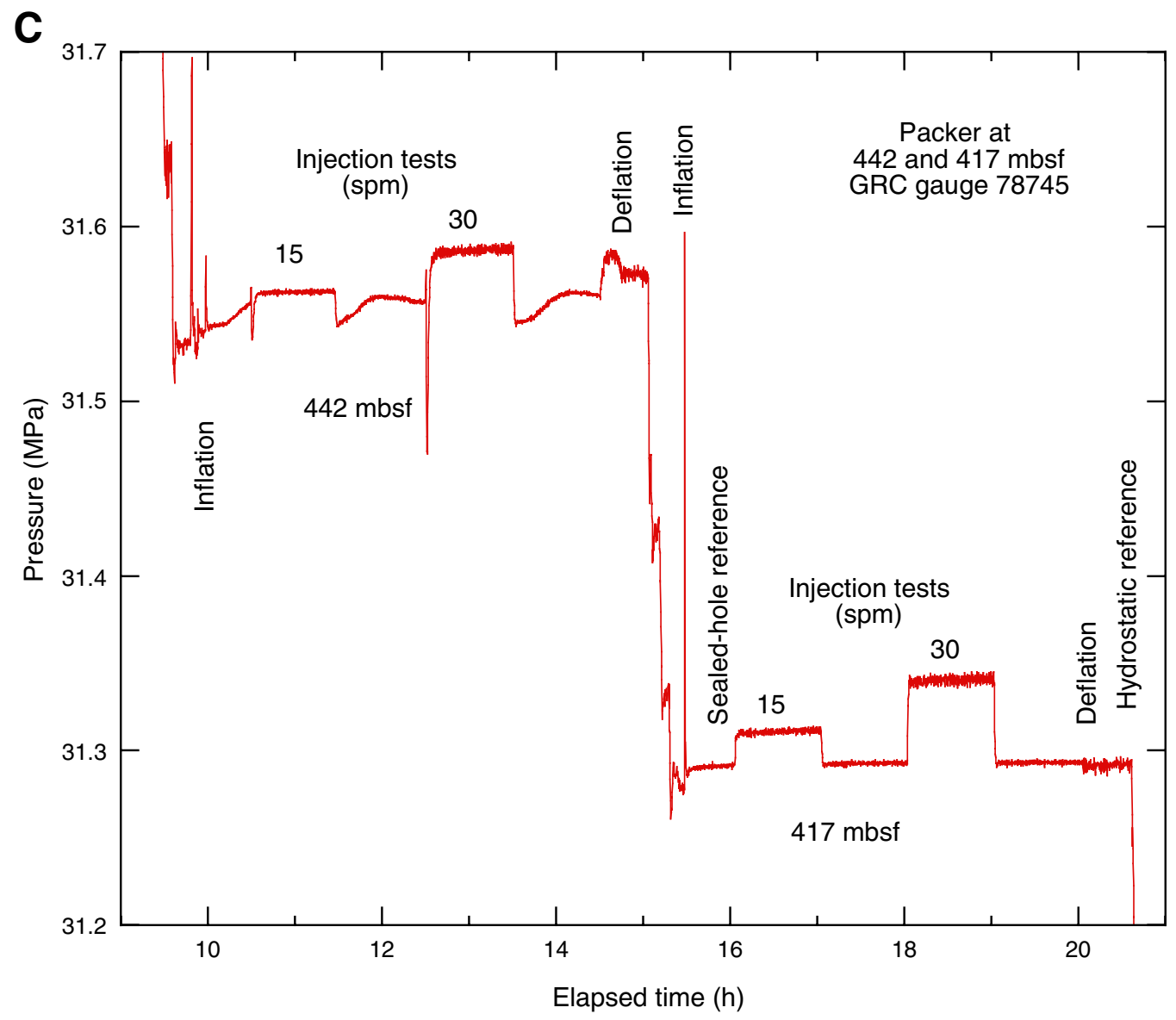


Figure F73. Geometric configuration of the GI seismic source deployment with respect to the JOIDES Resolution.
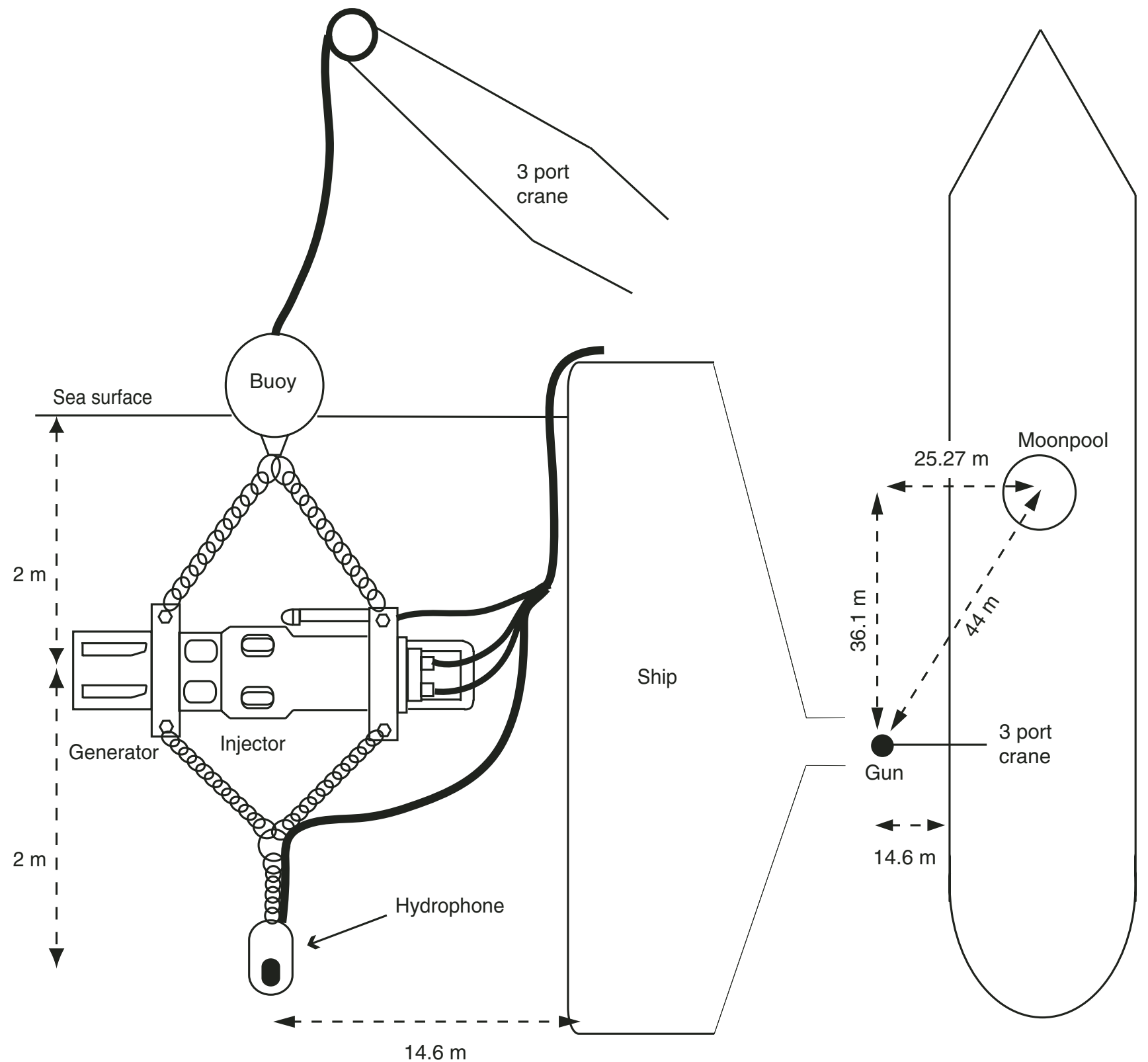
Figure F74. Results of triple combo tool string measurements from Hole U1301B. The left panels show the core reference with core recovery and principal lithologic units as derived from core descriptions. For electrical resistivity measurements, only curves of $4 \mathrm{ft}$ vertical resolution with different penetration ( $\mathrm{AF} 10=10$ inches and $\mathrm{AF} 90=90$ inches penetration) are shown. Dots and diamonds in the neutron porosity and density panels represent shipboard measurements on core samples. Logging units are represented by white, yellow, and purple shading: yellow = more massive intervals, white $=$ mostly fractured intervals, and purple shading $=$ position of massive basalts of Units 2,4 , and 6 . SP $=$ spontaneous potential. Legend for lithology can be found in "Lithostratigraphy."

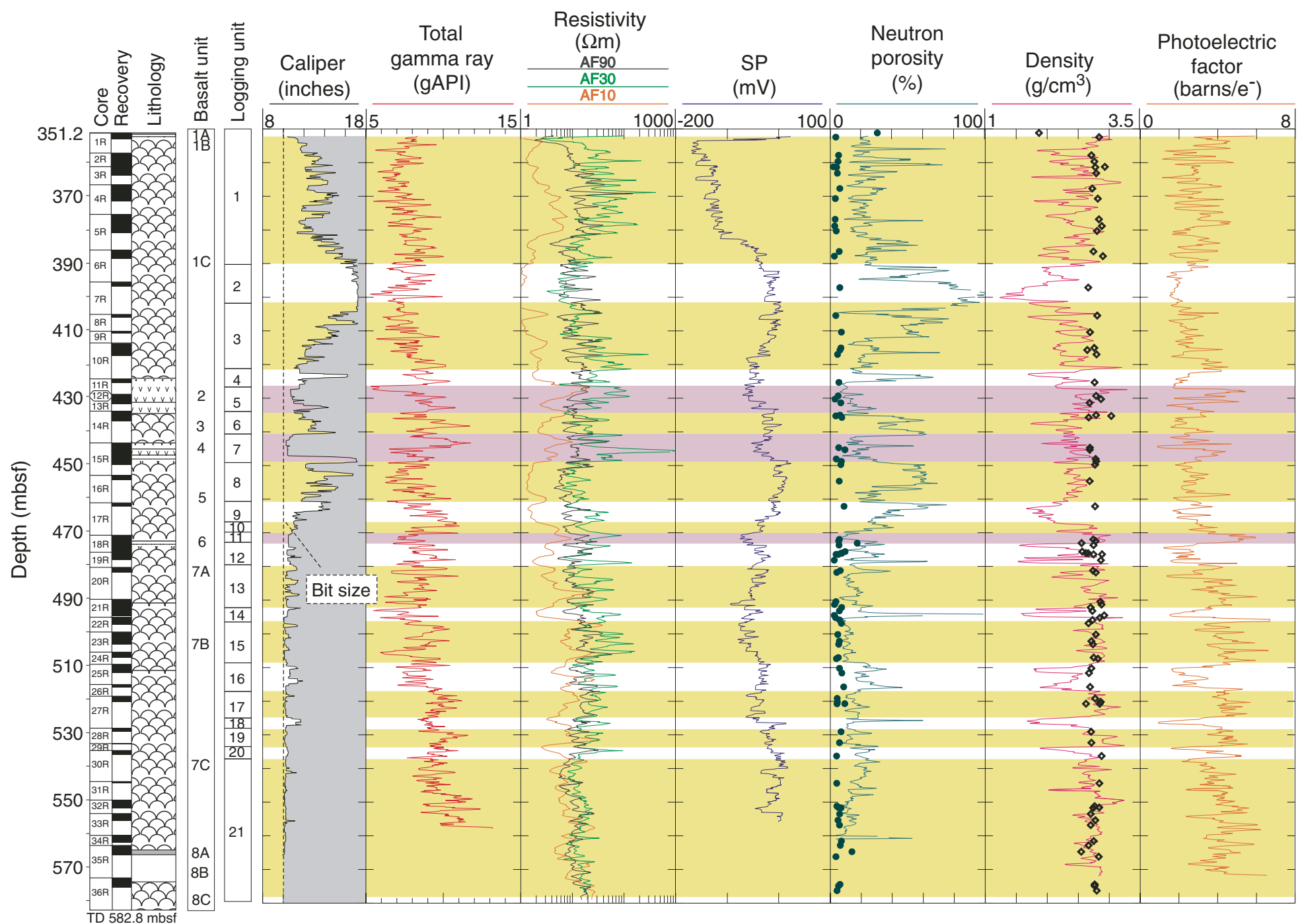


Figure F75. Results from the FMS-sonic tool string measurements in Hole U1301B. The left panels show the core reference with core recovery and principal lithologic units as defined from core descriptions. Data are from the first FMS-sonic tool string pass. Black dots in the $P$-wave velocity panel represent discrete measurements on core samples. The right panel shows the density log from the triple combo for comparison.

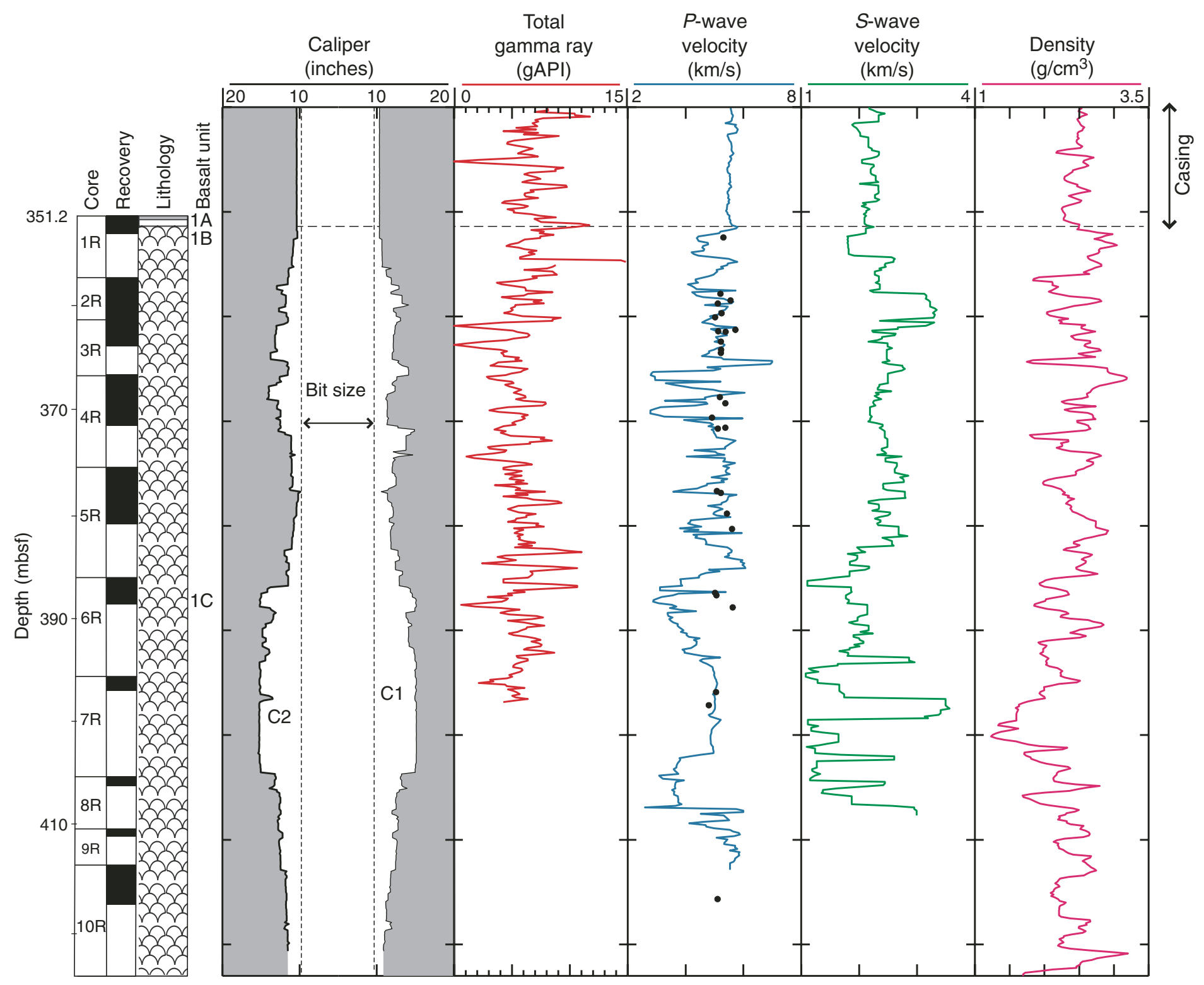


Figure F76. (A) WST stacked waveforms and (B) determination of interval velocities for the $100 \mathrm{~m}$ section of open hole that was logged.

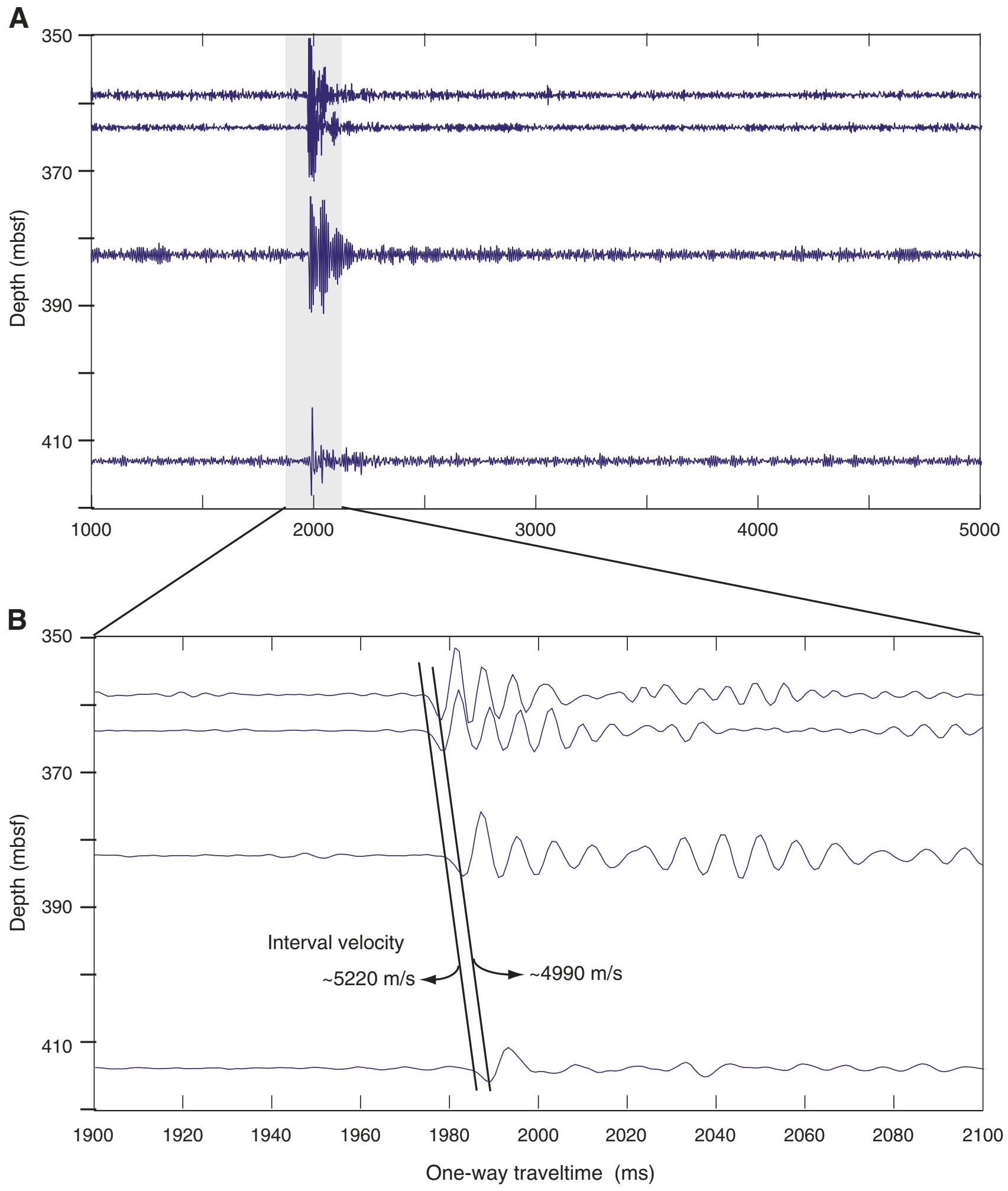


Figure F77. Drawing showing observatory completion in Hole U1301A. Positions and geometries of OsmoSamplers (OS), temperature loggers (T), and intake screens are highly idealized. TD = total depth, MBIO = microbiology. Please see more detailed drawings and discussion in the "Operations" chapter and in Fisher et al. (this volume).

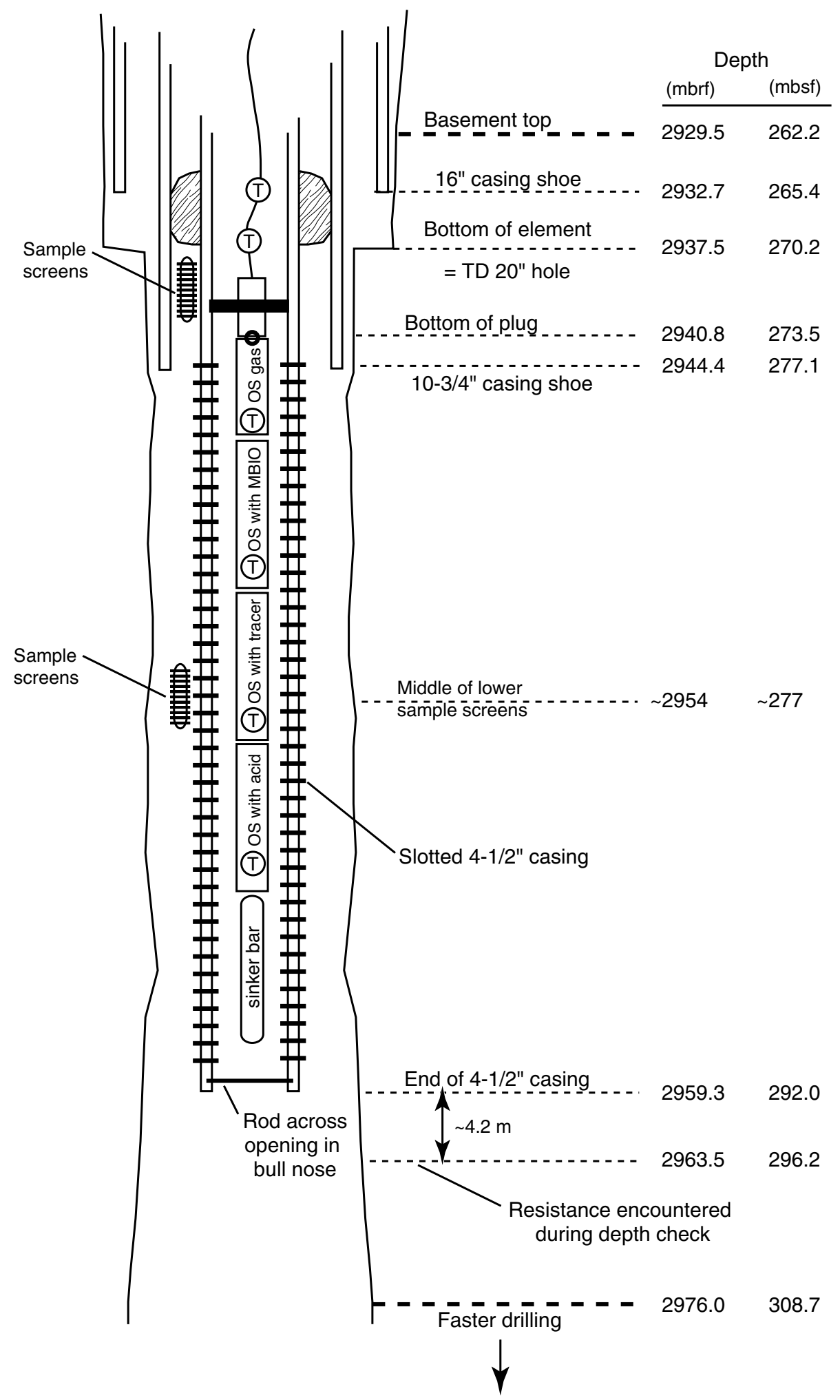


Figure F78. Drawing showing observatory completion in Hole U1301B. Positions and geometries of OsmoSamplers (OS), temperature loggers (T), and intake screens are highly idealized. Only 6 of the 14 autonomous temperature loggers deployed in Hole U1301B are shown in this drawing. Depths of temperature loggers above the bottom plug are approximate because of slack in the able. Please see more detailed drawings and discussion in the "Operations" chapter and in Fisher et al. (this volume).

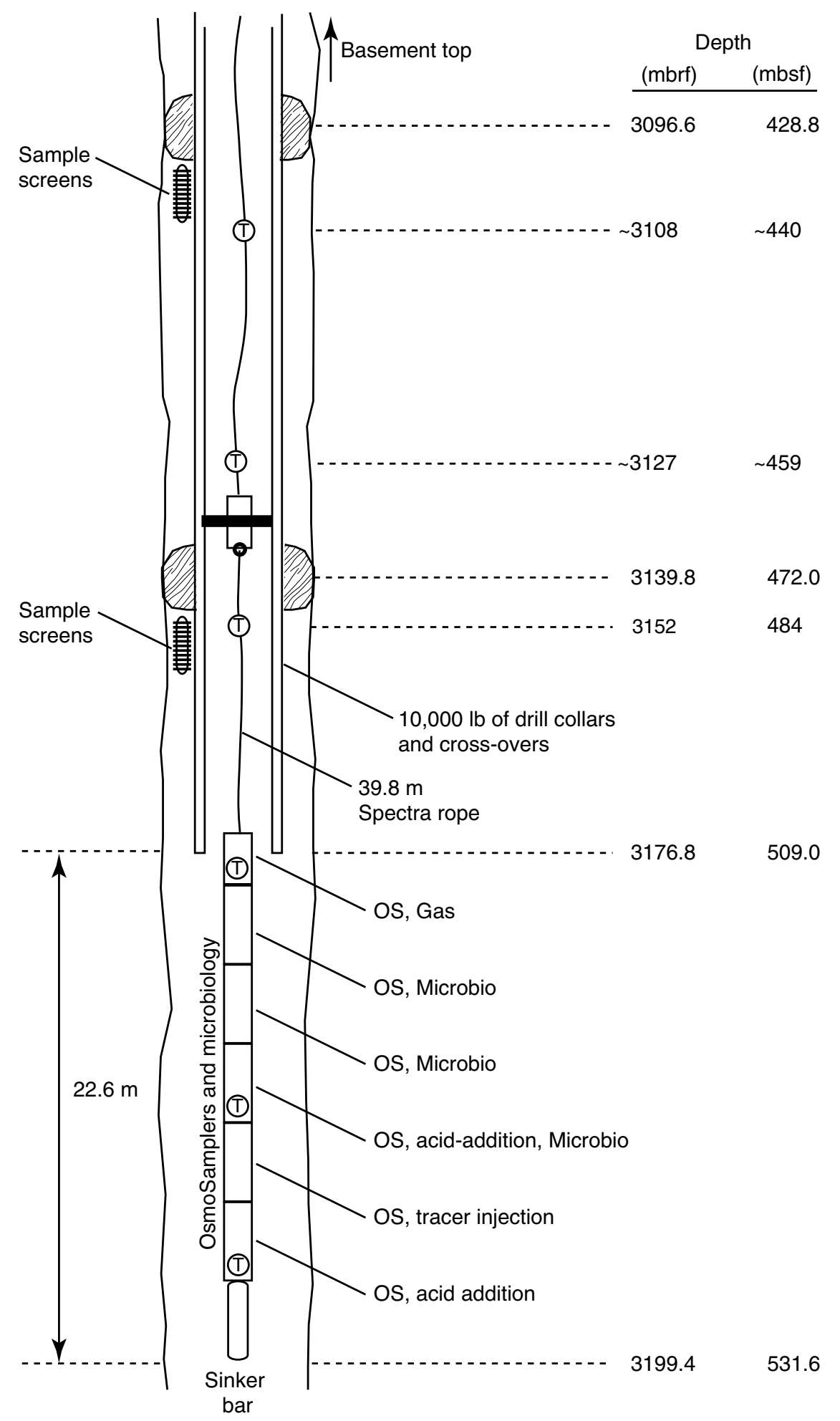


Table T1. Site U1301 operations and coring summary. (See table notes. Continued on next two pages.)

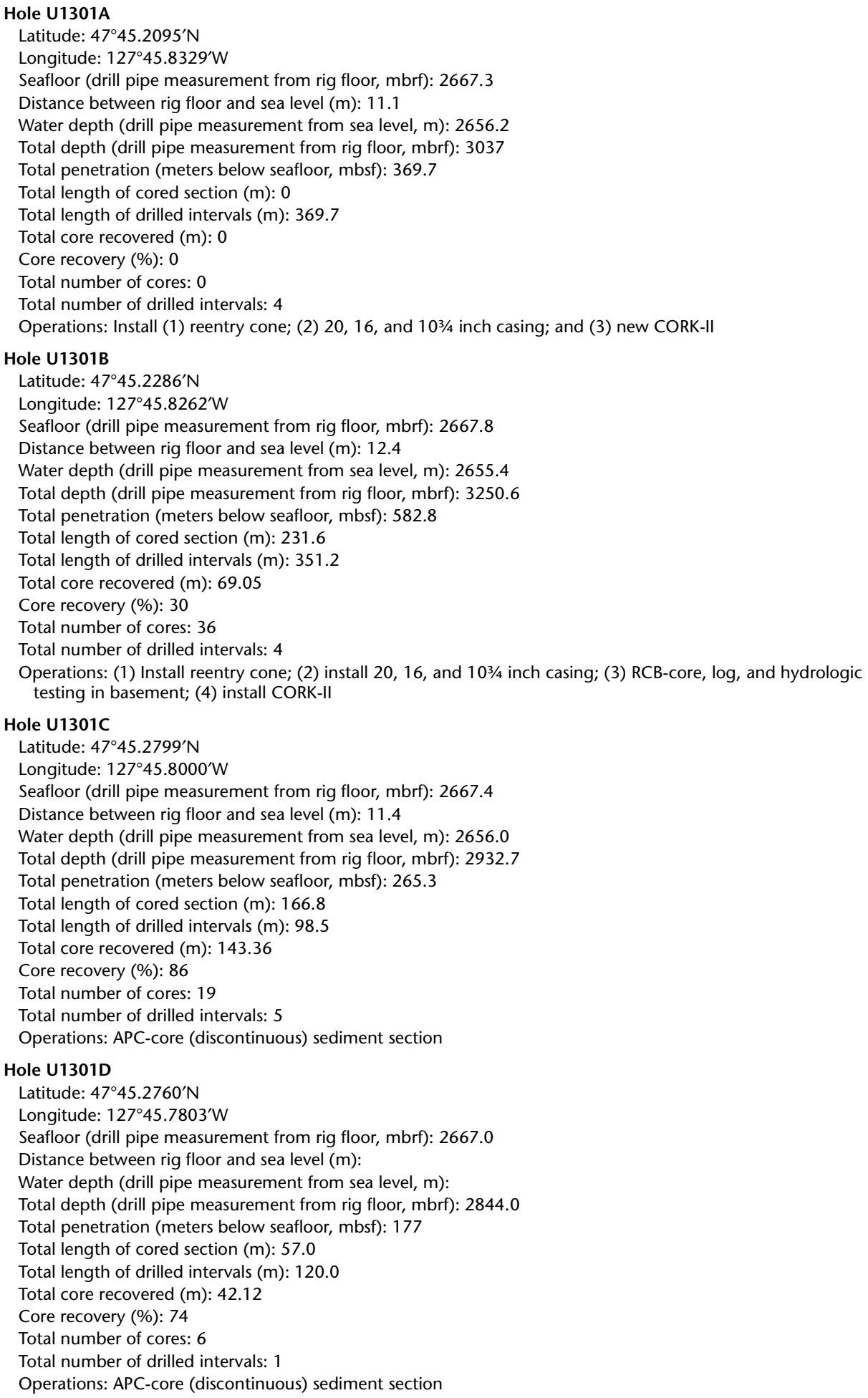


Table T1 (continued).

\begin{tabular}{|c|c|c|c|c|c|c|c|c|}
\hline \multirow[b]{2}{*}{ Core } & \multirow{2}{*}{$\begin{array}{l}\text { Date } \\
\text { (2004) }\end{array}$} & \multirow{2}{*}{$\begin{array}{l}\text { Local time } \\
\text { (h) }\end{array}$} & \multicolumn{2}{|c|}{ Depth (mbsf) } & \multicolumn{2}{|c|}{ Length $(\mathrm{m})$} & \multirow{2}{*}{$\begin{array}{l}\text { Recovery } \\
\text { (\%) }\end{array}$} & \multirow[b]{2}{*}{ Comment } \\
\hline & & & Top & Bottom & Cored & Recovered & & \\
\hline \multicolumn{9}{|c|}{ 310-U1301B- } \\
\hline $1 \mathrm{R}$ & $22 \mathrm{Jul}$ & 535 & 351.2 & 357.1 & 5.9 & 1.50 & 25 & PFT \\
\hline $2 \mathrm{R}$ & $22 \mathrm{Jul}$ & 1240 & 357.1 & 361.1 & 4.0 & 3.51 & 88 & PFT \\
\hline $3 \mathrm{R}$ & $22 \mathrm{Jul}$ & 1620 & 361.1 & 366.6 & 5.5 & 2.29 & 42 & PFT \\
\hline $4 \mathrm{R}$ & $22 \mathrm{Jul}$ & 2325 & 366.6 & 376.3 & 9.7 & 3.76 & 39 & PFT \\
\hline $5 \mathrm{R}$ & $23 \mathrm{Jul}$ & 525 & 376.3 & 386.0 & 9.7 & 3.53 & 36 & PFT \\
\hline $6 \mathrm{R}$ & $23 \mathrm{Jul}$ & 1125 & 386.0 & 395.6 & 9.6 & 1.80 & 19 & PFT \\
\hline $7 \mathrm{R}$ & $23 \mathrm{Jul}$ & 1530 & 395.6 & 405.2 & 9.6 & 1.20 & 13 & PFT \\
\hline $8 \mathrm{R}$ & $23 \mathrm{Jul}$ & 1950 & 405.2 & 410.2 & 5.0 & 0.62 & 12 & PFT \\
\hline $9 \mathrm{R}$ & $23 \mathrm{Jul}$ & 2215 & 410.2 & 414.8 & 4.6 & 0.75 & 16 & PFT \\
\hline $10 \mathrm{R}$ & 24 Jul & 405 & 414.8 & 424.4 & 9.6 & 2.07 & 22 & \\
\hline $11 \mathrm{R}$ & 24 Jul & 840 & 424.4 & 428.9 & 4.5 & 1.19 & 26 & \\
\hline $12 \mathrm{R}$ & 24 Jul & 1145 & 428.9 & 429.9 & 1.0 & 1.00 & 100 & \\
\hline $13 \mathrm{R}$ & $24 \mathrm{Jul}$ & 1545 & 429.9 & 434.0 & 4.1 & 1.85 & 45 & \\
\hline $14 \mathrm{R}$ & $24 \mathrm{Jul}$ & 1950 & 434.0 & 443.6 & 9.6 & 1.42 & 15 & PFT \\
\hline $15 \mathrm{R}$ & $25 \mathrm{Jul}$ & 315 & 443.6 & 453.2 & 9.6 & 4.92 & 51 & \\
\hline $16 \mathrm{R}$ & $26 \mathrm{Jul}$ & 335 & 453.2 & 461.4 & 8.2 & 1.12 & 14 & \\
\hline $17 R$ & $26 \mathrm{Jul}$ & 700 & 461.4 & 471.0 & 9.6 & 0.70 & 7 & PFT \\
\hline $18 \mathrm{R}$ & $26 \mathrm{Jul}$ & 1415 & 471.0 & 476.1 & 5.1 & 4.83 & 95 & \\
\hline $19 \mathrm{R}$ & $26 \mathrm{Jul}$ & 1640 & 476.1 & 480.6 & 4.5 & 1.33 & 30 & \\
\hline $20 \mathrm{R}$ & $26 \mathrm{Jul}$ & 2200 & 480.6 & 490.2 & 9.6 & 0.94 & 10 & PFT \\
\hline $21 \mathrm{R}$ & $27 \mathrm{Jul}$ & 500 & 490.2 & 495.4 & 5.2 & 3.69 & 71 & \\
\hline $22 \mathrm{R}$ & $27 \mathrm{Jul}$ & 840 & 495.4 & 499.9 & 4.5 & 1.70 & 38 & \\
\hline $23 \mathrm{R}$ & $27 \mathrm{Jul}$ & 1815 & 499.9 & 505.9 & 6.0 & 2.99 & 50 & PFT \\
\hline $24 \mathrm{R}$ & $27 \mathrm{Jul}$ & 2300 & 505.9 & 509.5 & 3.6 & 1.50 & 42 & \\
\hline $25 \mathrm{R}$ & $28 \mathrm{Jul}$ & 605 & 509.5 & 515.5 & 6.0 & 1.90 & 32 & \\
\hline $26 \mathrm{R}$ & $28 \mathrm{Jul}$ & 830 & 515.5 & 519.0 & 3.5 & 0.72 & 21 & PFT \\
\hline $27 \mathrm{R}$ & $29 \mathrm{Jul}$ & 345 & 519.0 & 528.6 & 9.6 & 1.25 & 13 & \\
\hline $28 \mathrm{R}$ & $29 \mathrm{Jul}$ & 800 & 528.6 & 532.2 & 3.6 & 0.89 & 25 & \\
\hline $29 \mathrm{R}$ & $30 \mathrm{Jul}$ & 600 & 532.2 & 535.2 & 3.0 & 0.15 & 5 & PFT \\
\hline $30 \mathrm{R}$ & $30 \mathrm{Jul}$ & 1000 & 535.2 & 544.4 & 9.2 & 1.02 & 11 & PFT \\
\hline $31 R$ & $30 \mathrm{Jul}$ & 1435 & 544.4 & 550.0 & 5.6 & 0.38 & 7 & \\
\hline $32 \mathrm{R}$ & $30 \mathrm{Jul}$ & 1815 & 550.0 & 554.0 & 4.0 & 2.73 & 68 & \\
\hline $33 R$ & $31 \mathrm{Jul}$ & 150 & 554.0 & 560.6 & 6.6 & 2.21 & 33 & PFT \\
\hline $34 \mathrm{R}$ & $31 \mathrm{Jul}$ & 420 & 560.6 & 563.6 & 3.0 & 2.23 & 74 & \\
\hline $35 \mathrm{R}$ & $31 \mathrm{Jul}$ & 1135 & 563.6 & 573.2 & 9.6 & 2.34 & 24 & \\
\hline \multirow[t]{2}{*}{$36 \mathrm{R}$} & 31 Jul & 1400 & 573.2 & 582.8 & 9.6 & 3.02 & 31 & PFT \\
\hline & & & \multicolumn{2}{|c|}{ Cored totals: } & 231.6 & 69.05 & 30 & \\
\hline \multicolumn{9}{|c|}{ 301-U1301C- } \\
\hline $1 \mathrm{H}$ & 7 Aug & 30 & 0.0 & 5.1 & 5.1 & 5.08 & 100 & PFT \\
\hline $2 \mathrm{H}$ & 7 Aug & 200 & 5.1 & 14.6 & 9.5 & 9.15 & 96 & PFT \\
\hline $3 \mathrm{H}$ & 7 Aug & 300 & 14.6 & 24.1 & 9.5 & 9.30 & 98 & PFT, APCT \\
\hline $4 \mathrm{H}$ & 7 Aug & 350 & 24.1 & 33.6 & 9.5 & 9.79 & 103 & PFT \\
\hline $5 \mathrm{H}$ & 7 Aug & 525 & 33.6 & 43.1 & 9.5 & 3.01 & 32 & PFT, APCT \\
\hline $6 \mathrm{H}$ & 7 Aug & 630 & 43.1 & 52.6 & 9.5 & 9.94 & 105 & PFT \\
\hline $7 \mathrm{H}$ & 7 Aug & 800 & 52.6 & 62.1 & 9.5 & 9.82 & 103 & PFT \\
\hline $8 \mathrm{H}$ & 7 Aug & 840 & 62.1 & 71.6 & 9.5 & 8.35 & 88 & PFT \\
\hline $9 \mathrm{H}$ & 7 Aug & 925 & 71.6 & 81.1 & 9.5 & 9.90 & 104 & PFT, DVTP at $81.1 \mathrm{mbsf}$ \\
\hline $10 \mathrm{H}$ & 7 Aug & 1145 & 81.1 & 90.6 & 9.5 & 9.96 & 105 & PFT \\
\hline $11 \mathrm{H}$ & 7 Aug & 1235 & 90.6 & 100.1 & 9.5 & 9.79 & 103 & PFT \\
\hline $12 \mathrm{H}$ & 7 Aug & 1315 & 100.1 & 109.6 & 9.5 & 9.16 & 96 & PFT \\
\hline \multirow{2}{*}{$13 \mathrm{H}$} & 7 Aug & 1400 & 109.6 & 119.1 & 9.5 & 3.85 & 41 & PFT \\
\hline & & ***Dilled $\mathrm{n}$ & thout c & ring from & 19.1 to 1 & $29.9 \mathrm{mbsf**}$ & & PFT \\
\hline $14 \mathrm{H}$ & 7 Aug & 1545 & 129.9 & 130.1 & 0.2 & 0.20 & 100 & PFT \\
\hline & & ** Drilled $\mathrm{w}$ & thout c & ring from & 30.1 to 1 & $33.1 \mathrm{mbsf}^{* *}$ & & PFT, DVTP at $133.1 \mathrm{mbsf}$ \\
\hline & & ${ }^{* * * *}$ Drilled $\mathrm{w}$ & thout c & ring from & 33.1 to 1 & $78.1 \mathrm{mbsf}^{* *}$ & & PFT \\
\hline $15 \mathrm{H}$ & 7 Aug & 2130 & 178.1 & 187.6 & 9.5 & 7.88 & 83 & PFT \\
\hline $16 \mathrm{H}$ & 7 Aug & 2215 & 187.6 & 197.1 & 9.5 & 3.99 & 42 & PFT \\
\hline & & ${ }^{*}$ Drilled $\mathrm{w}$ & thout c & ring from & 97.1 to 2 & $35.8 \mathrm{mbsf**}$ & & PFT \\
\hline $17 \mathrm{H}$ & 8 Aug & 215 & 235.8 & 245.3 & 9.5 & 9.99 & 105 & PFT \\
\hline & & ***Drilled $\mathrm{n}$ & thout c & ring from & 45.3 to 2 & $46.3 \mathrm{mbsf}^{* *}$ & & PFT, DVTP at $246.3 \mathrm{mbsf}$ \\
\hline $18 \mathrm{H}$ & 8 Aug & 605 & 246.3 & 255.8 & 9.5 & 7.08 & 75 & PFT \\
\hline $19 \mathrm{H}$ & 8 Aug & 815 & 255.8 & 265.3 & 9.5 & 7.12 & 75 & PFT \\
\hline & & & Co & ed totals: & 166.8 & 143.36 & 86 & \\
\hline
\end{tabular}


Table T1 (continued).

\begin{tabular}{|c|c|c|c|c|c|c|c|c|c|}
\hline \multirow[b]{2}{*}{ Core } & \multirow{2}{*}{$\begin{array}{l}\text { Date } \\
(2004)\end{array}$} & \multirow{2}{*}{$\begin{array}{l}\text { Local time } \\
\text { (h) }\end{array}$} & \multicolumn{2}{|c|}{ Depth (mbsf) } & \multicolumn{2}{|c|}{ Length $(\mathrm{m})$} & \multirow{2}{*}{$\begin{array}{l}\text { Recovery } \\
\text { (\%) }\end{array}$} & \multirow{2}{*}{\multicolumn{2}{|c|}{ Comment }} \\
\hline & & & Top & Bottom & Cored & Recovered & & & \\
\hline \multicolumn{10}{|c|}{ 301-U1301D- } \\
\hline \multicolumn{10}{|c|}{${ }^{* \star * \star *}$ Drilled without coring from 0.0 to $120.0 \mathrm{mbsf}^{\star \star * \star *}$} \\
\hline $1 \mathrm{H}$ & 18 Aug & 2000 & 120.0 & 129.5 & 9.5 & 3.82 & 40 & PFT & \\
\hline $2 \mathrm{H}$ & 18 Aug & 2050 & 129.5 & 139.0 & 9.5 & 4.52 & 48 & PFT & \\
\hline $3 \mathrm{H}$ & 18 Aug & 2145 & 139.0 & 148.5 & 9.5 & 8.50 & 89 & PFT & \\
\hline $4 \mathrm{H}$ & 18 Aug & 2230 & 148.5 & 158.0 & 9.5 & 5.55 & 58 & PFT & \\
\hline $5 \mathrm{H}$ & 18 Aug & 2335 & 158.0 & 167.5 & 9.5 & 9.97 & 105 & PFT & \\
\hline $6 \mathrm{H}$ & 19 Aug & 30 & 167.5 & 177.0 & 9.5 & 9.76 & 103 & PFT & \\
\hline \multicolumn{5}{|c|}{ Cored totals: } & 57.0 & 42.12 & 74 & & \\
\hline
\end{tabular}

Notes: Ship local time is UTC - 7. PFT = perfluorocarbon fluid tracers added to drill fluid for microbiologic contamination testing. Temperature measurements indicated by tool acronym: Advanced Piston Corer Temperature (APCT) tool or Davis-Villinger Temperature Probe (DVTP). APC $=$ advanced piston corer, $\mathrm{RCB}=$ rotary core barrel.

Table T2. Hole U1301A final formation and casing depth measurements.

\begin{tabular}{|c|c|c|c|c|}
\hline \multirow[b]{2}{*}{ Description } & \multicolumn{4}{|c|}{ Official (final) depths (m) } \\
\hline & $\begin{array}{l}\text { Below rig } \\
\text { floor }\end{array}$ & $\begin{array}{l}\text { Below } \\
\text { seafloor }\end{array}$ & $\begin{array}{c}\text { Into } \\
\text { basement }\end{array}$ & $\begin{array}{l}\text { Below base } \\
\text { of reentry } \\
\text { cone }\end{array}$ \\
\hline \multicolumn{5}{|l|}{ Formation data: } \\
\hline Seafloor & 2667.34 & - & - & -3.81 \\
\hline Top of cuttings & 2667.80 & - & - & -3.35 \\
\hline Basement & 2929.50 & 262.16 & - & 258.35 \\
\hline \multicolumn{5}{|l|}{ Hole depth data: } \\
\hline 20 inch diameter hole & 2937.50 & 270.16 & 8.00 & 266.35 \\
\hline $18 \frac{1}{2}$ inch diameter hole & 2939.20 & 271.86 & 9.70 & 268.05 \\
\hline $143 / 4$ inch diameter hole (TD) & 3037.00 & 369.66 & 107.50 & 365.85 \\
\hline \multicolumn{5}{|l|}{ Reentry cone installation data: } \\
\hline Top (rim) of reentry cone & 2668.74 & 1.40 & - & -2.41 \\
\hline Mud skirt (base) & 2671.15 & 3.81 & - & 0.00 \\
\hline \multicolumn{5}{|l|}{ Casing shoe data: } \\
\hline 20 inch casing shoe & 2710.22 & 42.88 & - & 39.07 \\
\hline 16 inch casing shoe & 2932.66 & 265.32 & 3.16 & 261.51 \\
\hline $103 / 4$ inch casing shoe & 2944.43 & 277.09 & 14.93 & 273.28 \\
\hline
\end{tabular}

Notes: Negative numbers represent distance above the base of the reentry cone. TD $=$ total depth. $-=$ not applicable or meaningful. 
Table T3. Hole U1301B final formation and casing depth measurements.

\begin{tabular}{|c|c|c|c|c|}
\hline \multirow[b]{2}{*}{ Description } & \multicolumn{4}{|c|}{ Official (final) depths (m) } \\
\hline & $\begin{array}{l}\text { Below rig } \\
\text { floor }\end{array}$ & $\begin{array}{l}\text { Below } \\
\text { seafloor }\end{array}$ & $\begin{array}{c}\text { Into } \\
\text { basement }\end{array}$ & $\begin{array}{l}\text { Below base } \\
\text { of reentry } \\
\text { cone }\end{array}$ \\
\hline \multicolumn{5}{|l|}{ Formation data: } \\
\hline Seafloor & 2667.84 & - & - & -3.45 \\
\hline Top of cuttings & 2666.80 & - & - & -4.49 \\
\hline Basement & 2933.00 & 265.16 & - & 261.71 \\
\hline \multicolumn{5}{|l|}{ Hole depth data: } \\
\hline 20 inch diameter hole & 2936.00 & 268.16 & 3.00 & 264.71 \\
\hline $18 \frac{1}{2}$ inch diameter hole & 2944.00 & 276.16 & 11.00 & 272.71 \\
\hline $143 / 4$ inch diameter hole (TD) & 3018.00 & 350.16 & 85.00 & 346.71 \\
\hline $9 \%$ inch diameter drilled hole & 3019.00 & 351.16 & 86.00 & 347.71 \\
\hline 97/8 inch diameter cored hole (TD) & 3250.60 & 582.76 & 317.60 & 579.31 \\
\hline \multicolumn{5}{|l|}{ Reentry cone installation data: } \\
\hline Top (rim) of reentry cone & 2668.84 & 1.00 & - & -2.45 \\
\hline Mud skirt (base) & 2671.29 & 3.45 & - & 0.00 \\
\hline \multicolumn{5}{|l|}{ Casing shoe data: } \\
\hline 20 inch casing shoe & 2710.36 & 42.52 & - & 39.07 \\
\hline 16 inch casing shoe & 2938.77 & 270.93 & 5.77 & 267.48 \\
\hline Bottom of $10^{3 / 4}$ inch casing "gap" & 2920.17 & 252.33 & -12.83 & 248.88 \\
\hline Top of 103/4 inch casing "gap" & 2926.00 & 258.16 & -7.00 & 254.71 \\
\hline Original $103 / 4$ inch casing shoe & 3013.91 & 346.07 & 80.91 & 342.62 \\
\hline Final $103 / 4$ inch casing shoe & 3019.00 & 351.16 & 86.00 & 347.71 \\
\hline Estimated gap in $10^{3 / 4}$ inch casing string & 5.83 & & & \\
\hline
\end{tabular}

Notes: Negative numbers represent distance above the base of the reentry cone. A $103 / 4$ inch casing coupling backed off between joints number 8 and 9. Bottom of casing "gap" at 2926.0 mbrf documented by numerous tags; shoe depth was calculated from this. Top of $103 / 4$ casing gap at 2920.2 mbrf calculated from casing tally. $-=$ not applicable or meaningful.

Table T4. Summary of lithologic units and boundaries, Hole U1301C.

\begin{tabular}{|c|c|c|c|c|c|}
\hline Unit & Subunit & Lithology & Core, section, interval $(\mathrm{cm})$ & $\begin{array}{l}\text { Unit interval } \\
\text { (mbsf) }\end{array}$ & $\begin{array}{l}\text { Unit thickness } \\
\text { (m) }\end{array}$ \\
\hline & & & 301-U1301C- & & \\
\hline I & A & Hemipelagic clay, silt, and sandy turbidites & $1 \mathrm{H}-1,0$, to $2 \mathrm{H}-6,50$ & $0-13.1$ & 13.1 \\
\hline I & B & Sand turbidites, silt turbidites, gravel, and hemipelagic clay & $2 \mathrm{H}-6,50$, to $16 \mathrm{H}-\mathrm{CC}, 5$ & $13.1-235.8$ & 222.7 \\
\hline II & & Hemipelagic clay with carbonate nodules & $17 \mathrm{H}-1,0$, to $19 \mathrm{H}-\mathrm{CC}, 3$ & $235.8-265.3$ & 29.5 \\
\hline
\end{tabular}

Notes: The core interval is between the first and last appearance of the unit within the recovered cores. The unit interval is the interval between the first appearance of a unit in the recovered core and the appearance of a different unit below, although the actual lithologic transition may occur within a drilled interval in some cases. Unit thicknesses are calculated from the unit intervals. 
Table T5. Summary of the phenocryst and groundmass minerals present in representative thin sections for the different basalt units, Hole $1301 \mathrm{~B}$. (Continued on next page.)

\begin{tabular}{|c|c|c|c|c|c|c|c|}
\hline \multirow{2}{*}{$\begin{array}{l}\text { Hole: } \\
\text { Core, section, interval }(\mathrm{cm}) \text { : }\end{array}$} & \multicolumn{6}{|c|}{ 301-U1301B- } & \multirow[b]{2}{*}{ 18R-2, 92-94 } \\
\hline & $1 \mathrm{R}-1,14-18$ & 1R-1, 118-121 & $2 \mathrm{R}-1,4-8$ & $12 \mathrm{R}-1,31-33$ & $15 R-4,66-68$ & $16 \mathrm{R}-1,83-85$ & \\
\hline Depth (mbsf): & 351.20 & 351.20 & 357.10 & 428.90 & 448.10 & 453.20 & 472.30 \\
\hline Basalt unit: & $1 \mathrm{~A}$ & 1B & $1 \mathrm{C}$ & $2 \mathrm{~A}$ & $4 \mathrm{C}$ & 5 & 6 \\
\hline Rock type: & Breccia & Massive basalt & Pillow basalt & Massive basalt & Massive basalt & Pillow basalt & Massive basalt \\
\hline Texture: & Brecciated & Intersertal & Hyalophitic & Intersertal & Intersertal & Intersertal & Intergranular \\
\hline Maximum groundmass grain size: & Clay to pebbles & Microcrystalline & Microcrystalline & Fine grained & Fine grained & Microcrystalline & Fine grained \\
\hline Vesicles (\%): & NA & 2 & 2.3 & 2.7 & Trace & 2.7 & 13.3 \\
\hline \multicolumn{8}{|l|}{ Phenocrysts: } \\
\hline Plagioclase (\%) & - & 3 & 1.2 & 3.1 & 3 & 5.4 & 3.7 \\
\hline Morphology & Euhedral & Euhedral to subhedral & Euhedral to subhedral & Euhedral to subhedral & Euhedral to subhedral & Euhedral to subhedral & Euhedral to subhedral \\
\hline Size range $(\mathrm{mm})$ & - & $0.4-1.4$ & $1.2-2.0$ & $1.2-2.5$ & $0.7-2.8$ & $0.2-4.5$ & $1.2-2.5$ \\
\hline Olivine (\%) & - & Trace & 0.5 & 3.6 & 3 & 3 & 1.2 \\
\hline Morphology & - & Euhedral to subhedral & Euhedral to subhedral & Euhedral to subhedral & Euhedral to subhedral & Euhedral to subhedral & Euhedral to subhedral \\
\hline Size range $(\mathrm{mm})$ & - & $0.2-0.5$ & $1-1.5$ & $0.8-1.6$ & $0.5-1.0$ & $0.5-1.0$ & $0.6-1.2$ \\
\hline Clinopyroxene (\%) & - & 1 & 0.8 & 1.2 & 1 & 3.4 & - \\
\hline Morphology & - & Anhedral & Euhedral to anhedral & Euhedral to anhedral & Euhedral to anhedral & Euhedral to anhedral & - \\
\hline Size range $(\mathrm{mm})$ & - & $0.2-0.5$ & $1.5-2.5$ & $0.8-2.2$ & $0.4-1$ & $0.5-1.0$ & - \\
\hline Total phenocryst (\%): & & 4 & 2.5 & 7.9 & 7 & 11.8 & 4.9 \\
\hline \multicolumn{8}{|l|}{ Groundmass: } \\
\hline Plagioclase (\%) & Trace & 38 & 15.5 & 34.2 & 37 & 28.3 & 32.9 \\
\hline Morphology & Euhedral & Euhedral to subhedral & Euhedral to subhedral & Euhedral to subhedral & Euhedral to subhedral & Euhedral to subhedral & Euhedral to subhedral \\
\hline Size range $(\mathrm{mm})$ & $<0.2$ & $<0.4$ & $<0.8$ & $<1.0$ & $<0.5$ & $<0.8$ & $<1.0$ \\
\hline Olivine (\%) & - & Trace & 1.6 & 12.5 & Trace & 5 & 17.4 \\
\hline Morphology & - & Euhedral to subhedral & Euhedral to subhedral & Euhedral to subhedral & Euhedral to subhedral & Euhedral to subhedral & Euhedral to subhedral \\
\hline Size range $(\mathrm{mm})$ & - & $<0.2$ & $<0.8$ & $<0.8$ & $<0.5$ & $<0.4$ & $<1.0$ \\
\hline Clinopyroxene (\%) & - & 20 & 3.3 & 35.5 & 10 & 19.6 & 31 \\
\hline Morphology & - & Anhedral & Euhedral to anhedral & Anhedral & Anhedral & Anhedral & Anhedral \\
\hline Size range $(\mathrm{mm})$ & - & $<0.2$ & $<0.8$ & $<0.6$ & $<0.4$ & $<0.5$ & $<0.8$ \\
\hline Mesostasis (\%): & - & 36 & 74.8 & 7.2 & 46 & 32.6 & 1.7 \\
\hline
\end{tabular}

Note: $\mathrm{NA}=$ not applicable,$-=$ not observed. 


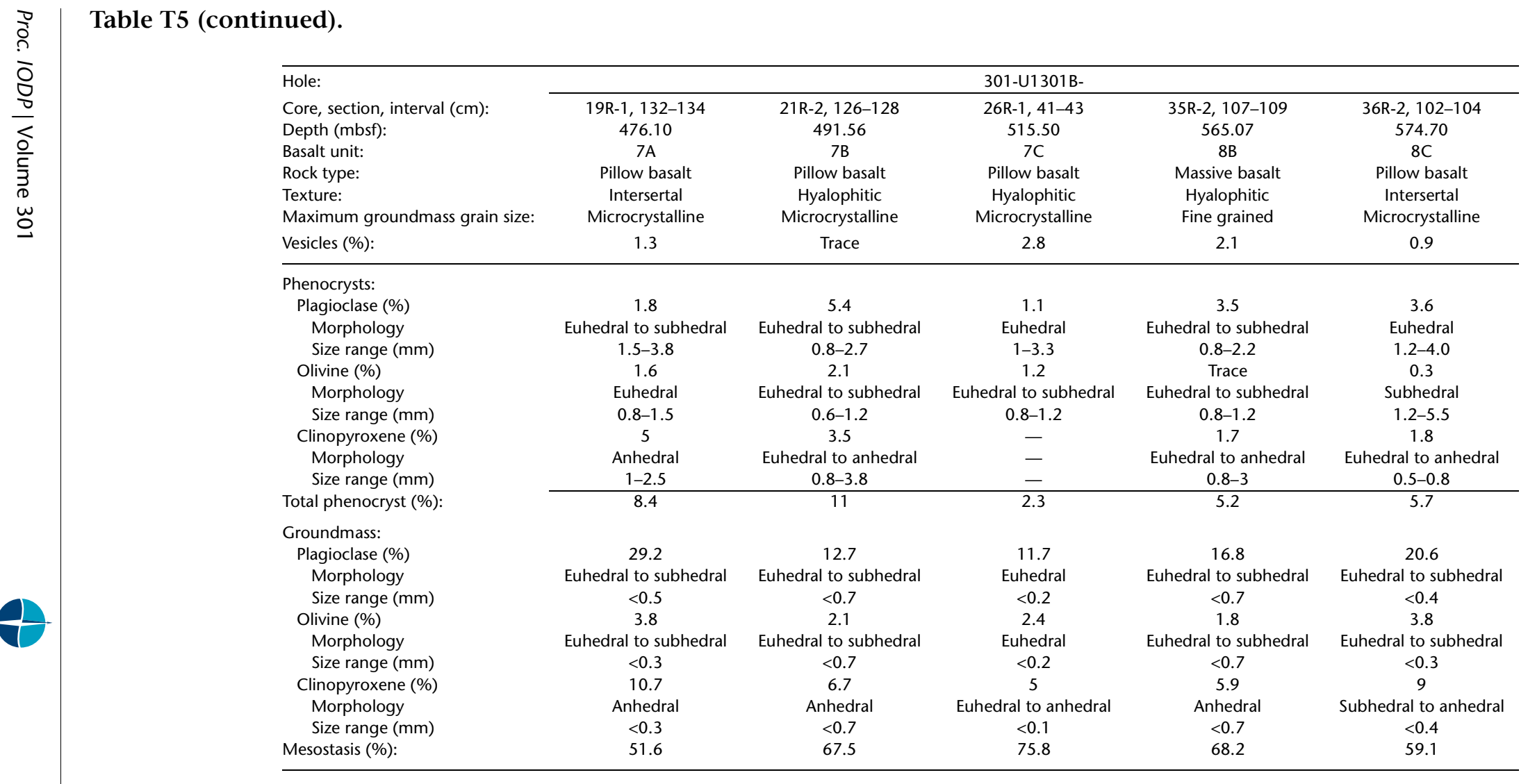


Table T6. Shipboard ICP-AES analyses, Hole U1301B. (Continued on next two pages).

\begin{tabular}{|c|c|c|c|c|c|c|c|c|c|c|c|c|c|c|c|c|c|}
\hline Hole: & & & & & & & & & 01-U130 & & & & & & & & \\
\hline $\begin{array}{l}\text { Core, section, } \\
\text { interval }(\mathrm{cm}) \text { : }\end{array}$ & $\begin{array}{l}\text { 1R-1, } \\
96-98\end{array}$ & $\begin{array}{c}2 \mathrm{R}-3 \\
145-147\end{array}$ & $\begin{array}{c}3 \mathrm{R}-2, \\
101-103\end{array}$ & $\begin{array}{c}4 \mathrm{R}-3 \\
16-18\end{array}$ & $\begin{array}{c}5 \mathrm{R}-2 \\
2-4\end{array}$ & $\begin{array}{c}\text { 6R-1 } \\
117-122\end{array}$ & $\begin{array}{c}\text { 7R-1, } \\
117-119\end{array}$ & $\begin{array}{l}8 \mathrm{R}-1 \\
59-61\end{array}$ & $\begin{array}{l}9 \mathrm{R}-1 \\
68-70\end{array}$ & $\begin{array}{c}\text { 10R-1, } \\
101-103\end{array}$ & $\begin{array}{c}10 \mathrm{R}-2, \\
7-9\end{array}$ & $\begin{array}{l}11 \mathrm{R}-1, \\
79-81\end{array}$ & $\begin{array}{l}12 \mathrm{R}-1, \\
99-101\end{array}$ & $\begin{array}{l}13 \mathrm{R}-1, \\
50-52\end{array}$ & $\begin{array}{l}14 \mathrm{R}-1, \\
70-72\end{array}$ & $\begin{array}{l}15 \mathrm{R}-1, \\
29-31\end{array}$ & $\begin{array}{l}\text { 15R-1, } \\
92-94\end{array}$ \\
\hline Piece: & $12 \mathrm{D}$ & 17B & 10 & 1B & 1 & 19 & 19 & 9 & 10 & 12 & $2 \mathrm{~A}$ & $14 \mathrm{~A}$ & $3 \mathrm{E}$ & $5 B$ & 10 & 4 & 11 \\
\hline Unit/Subunit: & 1B & $1 \mathrm{C}$ & $1 \mathrm{C}$ & $1 \mathrm{C}$ & $1 C$ & $1 \mathrm{C}$ & $1 \mathrm{C}$ & $1 \mathrm{C}$ & $1 \mathrm{C}$ & $1 C$ & $1 \mathrm{C}$ & $2 \mathrm{~A}$ & $2 \mathrm{~A}$ & $2 \mathrm{~A}$ & $2 \mathrm{~B}$ & 3 & $4 \mathrm{~A}$ \\
\hline Depth (mbsf): & 352.16 & 361.49 & 363.61 & 369.55 & 377.82 & 387.17 & 396.77 & 405.79 & 410.88 & 415.81 & 416.32 & 425.19 & 429.89 & 430.4 & 434.7 & 443.89 & 444.52 \\
\hline ICP-AES run: & 1 & 1 & 1 & 1 & 1 & 2 & 2 & 2 & 2 & 2 & 2 & 2 & 3 & 3 & 3 & 3 & 3 \\
\hline Major element & ide (wt\%) & & & & & & & & & & & & & & & & \\
\hline $\mathrm{SiO}_{2}$ & 51.95 & 50.75 & 50.47 & 50.22 & 50.90 & 49.55 & 49.93 & 49.53 & 49.76 & 49.78 & 49.75 & 51.24 & 49.2 & 49.3 & 49.4 & 50.31 & 49.16 \\
\hline $\mathrm{Al}_{2} \mathrm{O}_{3}$ & 14.90 & 15.25 & 15.20 & 15.11 & 15.26 & 14.51 & 14.53 & 15.31 & 15.15 & 14.66 & 14.33 & 14.66 & 13.7 & 13.6 & 14.5 & 14.46 & 14.41 \\
\hline $\mathrm{TiO}_{2}$ & 1.57 & 1.49 & 1.49 & 1.55 & 1.53 & 2.05 & 1.54 & 1.59 & 1.57 & 1.60 & 1.71 & 1.75 & 1.6 & 2.0 & 1.7 & 2.32 & 2.09 \\
\hline $\mathrm{Fe}_{2} \mathrm{O}_{3}$ & 10.31 & 10.42 & 10.10 & 10.28 & 10.50 & 10.63 & 9.91 & 9.39 & 9.50 & 9.65 & 9.80 & 10.52 & 11.4 & 12.5 & 10.6 & 10.35 & 9.88 \\
\hline $\mathrm{MgO}$ & 7.92 & 7.96 & 7.30 & 7.67 & 7.98 & 7.11 & 7.64 & 7.46 & 7.63 & 7.60 & 7.56 & 7.76 & 7.6 & 6.9 & 8.1 & 6.90 & 7.12 \\
\hline $\mathrm{MnO}$ & 0.18 & 0.21 & 0.25 & 0.20 & 0.20 & 0.22 & 0.19 & 0.18 & 0.20 & 0.18 & 0.20 & 0.16 & 0.2 & 0.2 & 0.1 & 0.23 & 0.23 \\
\hline $\mathrm{CaO}$ & 11.82 & 12.01 & 12.44 & 12.16 & 11.99 & 11.11 & 11.82 & 11.50 & 12.25 & 11.71 & 11.80 & 11.70 & 11.8 & 11.1 & 11.7 & 11.78 & 11.89 \\
\hline $\mathrm{Na}_{2} \mathrm{O}$ & 2.62 & 2.56 & 2.54 & 2.63 & 2.66 & 2.89 & 2.65 & 2.82 & 2.74 & 2.67 & 2.71 & 2.73 & 2.6 & 2.6 & 2.6 & 2.85 & 2.78 \\
\hline $\mathrm{K}_{2} \mathrm{O}$ & 0.19 & 0.06 & 0.07 & 0.06 & 0.08 & 0.15 & 0.13 & 0.18 & 0.10 & 0.16 & 0.08 & 0.03 & 0.1 & 0.1 & 0.1 & 0.15 & 0.09 \\
\hline $\mathrm{P}_{2} \mathrm{O}_{5}$ & 0.17 & 0.11 & 0.10 & 0.13 & 0.10 & 0.18 & 0.13 & 0.13 & 0.11 & 0.17 & 0.14 & 0.14 & 0.1 & 0.2 & 0.1 & 0.21 & 0.17 \\
\hline Totals: & 101.63 & 100.83 & 99.97 & 100.01 & 101.19 & 98.40 & 98.46 & 98.09 & 99.02 & 98.17 & 98.07 & 100.69 & 98.2 & 98.6 & 99.0 & 99.57 & 97.81 \\
\hline Trace elements & pm): & & & & & & & & & & & & & & & & \\
\hline $\mathrm{Cr}$ & 263 & 201 & 209 & 215 & 233 & 47 & 265 & 272 & 269 & 262 & 250 & 238 & 229 & 193 & 251 & 171 & 203 \\
\hline $\mathrm{Ni}$ & 57 & 54 & 101 & 55 & 36 & 24 & 104 & 115 & 67 & 39 & 106 & 40 & 47 & 60 & 56 & 91 & 67 \\
\hline $\mathrm{v}$ & 299 & 311 & 321 & 326 & 307 & 390 & 337 & 352 & 338 & 332 & 361 & 349 & 333 & 382 & 339 & 417 & 391 \\
\hline Sc & 43 & 43 & 43 & 44 & 43 & 46 & 45 & 45 & 45 & 43 & 44 & 44 & 43 & 43 & 44 & 45 & 45 \\
\hline $\mathrm{Ba}$ & -1 & -1 & 6 & 1 & -1 & 17 & 17 & 17 & 17 & 18 & 17 & 17 & 16 & 29 & 15 & 61 & 53 \\
\hline $\mathrm{Sr}$ & 108 & 104 & 105 & 106 & 106 & 125 & 115 & 120 & 119 & 119 & 116 & 118 & 111 & 111 & 115 & 134 & 130 \\
\hline $\mathrm{Y}$ & 34 & 36 & 33 & 34 & 36 & 49 & 39 & 41 & 37 & 40 & 43 & 44 & 37 & 48 & 42 & 57 & 54 \\
\hline $\mathrm{Zr}$ & 91 & 91 & 95 & 106 & 93 & 135 & 99 & 101 & 101 & 99 & 109 & 115 & 109 & 143 & 112 & 166 & 143 \\
\hline $\mathrm{Nb}$ & 6.7 & 6.1 & 6.1 & 6.5 & 6.3 & 9.6 & 6.7 & 7.1 & 7.1 & 7.1 & 7.6 & 7.9 & 7.2 & 9.5 & 7.6 & 11.1 & 9.8 \\
\hline LOI (wt\%) & -0.5 & -1.2 & -1.2 & 0.1 & -1.3 & -1.3 & -0.5 & -0.1 & -0.7 & 0.4 & -0.4 & 0.0 & -0.3 & -0.3 & 0.0 & 0.0 & -0.2 \\
\hline $\mathrm{Mg \#}$ & 62.9 & 62.7 & 61.4 & 62.1 & 62.6 & 59.6 & 62.9 & 63.6 & 63.9 & 63.4 & 62.9 & 61.9 & 59.3 & 54.8 & 62.8 & 59.5 & 61.3 \\
\hline
\end{tabular}

Notes: ICP-AES = inductively coupled plasma-atomic emission spectrometry. $\mathrm{Mg} \#=(\mathrm{MgO} / 40.305) /\left[(\mathrm{MgO} / 40.305)+0.9 \times 2 \times\left(\mathrm{Fe}_{2} \mathrm{O}_{3} / 159.694\right)\right] \times 100$. 


\begin{tabular}{|c|c|c|c|c|c|c|c|c|c|c|c|c|c|c|c|c|c|}
\hline \multirow{2}{*}{$\begin{array}{l}\text { Hole: } \\
\text { Core, section, } \\
\text { interval }(\mathrm{cm}) \text { : }\end{array}$} & \multicolumn{17}{|c|}{ 301-U1301B- } \\
\hline & $\begin{array}{l}15 R-2, \\
63-65\end{array}$ & $\begin{array}{l}15 R-4, \\
84-87\end{array}$ & $\begin{array}{l}16 \mathrm{R}-1 \\
81-83\end{array}$ & $\begin{array}{l}\text { 17R-1, } \\
76-78\end{array}$ & $\begin{array}{l}18 \mathrm{R}-2, \\
21-23\end{array}$ & $\begin{array}{l}18 \mathrm{R}-4 \\
68-69\end{array}$ & $\begin{array}{c}\text { 18R-4, } \\
135-137\end{array}$ & $\begin{array}{l}19 \mathrm{R}-1 \\
49-50\end{array}$ & $\begin{array}{l}20 \mathrm{R}-1 \\
80-82\end{array}$ & $\begin{array}{c}\text { 21R-1, } \\
101-103\end{array}$ & $\begin{array}{c}\text { 21R-1, } \\
103-105\end{array}$ & $\begin{array}{l}21 \mathrm{R}-4, \\
48-50\end{array}$ & $\begin{array}{l}22 \mathrm{R}-1 \\
54-56\end{array}$ & $\begin{array}{l}23 \mathrm{R}-1 \\
37-39\end{array}$ & $\begin{array}{l}24 \mathrm{R}-2 \\
37-39\end{array}$ & $\begin{array}{c}\text { 25R-1, } \\
113-115\end{array}$ & $\begin{array}{l}26 \mathrm{R}-1, \\
26-28\end{array}$ \\
\hline Piece: & 3 & 8 & 13 & 15 & $1 \mathrm{C}$ & $2 \mathrm{~A}$ & 7 & 6 & 13 & $13 \mathrm{E}$ & $13 \mathrm{E}$ & 7 & 7 & 6 & 5 & 17 & 6 \\
\hline Unit/Subunit: & 4B & 4C & 5 & 5 & 6 & 6 & $7 \mathrm{~A}$ & $7 \mathrm{~A}$ & $7 \mathrm{~A}$ & $7 \mathrm{~A}$ & $7 \mathrm{~A}$ & $7 \mathrm{~B}$ & $7 \mathrm{~B}$ & $7 \mathrm{~B}$ & $7 \mathrm{~B}$ & $7 \mathrm{~B}$ & 7C \\
\hline Depth (mbsf): & 445.73 & 448.94 & 454.01 & 462.16 & 472.51 & 475.56 & 476.23 & 476.59 & 481.4 & 491.21 & 491.23 & 494.97 & 495.94 & 500.27 & 507.59 & 510.63 & 515.76 \\
\hline ICP-AES run: & 3 & 3 & 4 & 4 & 4 & 4 & 4 & 4 & 4 & 5 & 5 & 5 & 5 & 5 & 5 & 6 & 6 \\
\hline \multicolumn{18}{|c|}{ Major element oxide (wt\%): } \\
\hline $\mathrm{SiO}_{2}$ & 49.51 & 50.91 & 49.09 & 51.21 & 48.92 & 50.69 & 50.72 & 50.77 & 49.33 & 49.18 & 49.86 & 49.37 & 50.00 & 50.64 & 48.64 & 50.34 & 50.11 \\
\hline $\mathrm{Al}_{2} \mathrm{O}_{3}$ & 13.56 & 14.80 & 14.33 & 15.38 & 13.51 & 14.61 & 14.54 & 14.45 & 14.13 & 13.86 & 13.96 & 14.37 & 15.15 & 14.77 & 14.19 & 14.80 & 14.32 \\
\hline $\mathrm{TiO}_{2}$ & 2.42 & 2.51 & 2.05 & 1.91 & 1.95 & 2.13 & 2.02 & 2.06 & 1.99 & 1.64 & 1.65 & 1.52 & 1.62 & 1.62 & 1.50 & 1.63 & 1.89 \\
\hline $\mathrm{Fe}_{2} \mathrm{O}_{3}$ & 13.20 & 10.86 & 11.29 & 9.70 & 12.89 & 11.36 & 10.13 & 9.97 & 10.72 & 11.41 & 11.23 & 11.11 & 8.73 & 10.39 & 11.02 & 9.56 & 9.05 \\
\hline $\mathrm{MgO}$ & 6.60 & 6.80 & 6.57 & 6.48 & 7.30 & 7.12 & 6.86 & 6.96 & 6.99 & 7.54 & 7.32 & 7.21 & 6.78 & 6.64 & 7.50 & 6.91 & 6.86 \\
\hline $\mathrm{MnO}$ & 0.19 & 0.15 & 0.31 & 0.25 & 0.19 & 0.12 & 0.32 & 0.32 & 0.32 & 0.22 & 0.22 & 0.21 & 0.28 & 0.26 & 0.21 & 0.28 & 0.29 \\
\hline $\mathrm{CaO}$ & 11.00 & 10.55 & 11.40 & 11.99 & 10.82 & 9.84 & 11.83 & 11.75 & 11.26 & 11.60 & 11.81 & 11.73 & 12.48 & 12.14 & 11.55 & 12.09 & 11.50 \\
\hline $\mathrm{Na}_{2} \mathrm{O}$ & 2.79 & 3.08 & 2.82 & 2.96 & 2.78 & 3.33 & 2.81 & 2.81 & 2.70 & 2.39 & 2.39 & 2.53 & 2.64 & 2.62 & 2.47 & 2.68 & 2.74 \\
\hline $\mathrm{K} 2 \mathrm{O}$ & 0.16 & 0.07 & 0.13 & 0.08 & 0.09 & 0.10 & 0.14 & 0.11 & 0.21 & 0.10 & 0.09 & 0.09 & 0.14 & 0.12 & 0.09 & 0.14 & 0.15 \\
\hline \multirow{2}{*}{$\mathrm{P}_{2} \mathrm{O}_{5}$ Totals: } & 0.22 & 0.21 & 0.17 & 0.17 & 0.15 & 0.16 & 0.15 & 0.29 & 0.21 & 0.13 & 0.14 & 0.13 & 0.13 & 0.14 & 0.13 & 0.14 & 0.14 \\
\hline & 99.65 & 99.93 & 98.17 & 100.14 & 98.60 & 99.45 & 99.52 & 99.50 & 97.85 & 98.07 & 98.67 & 98.25 & 97.95 & 99.33 & 97.31 & 98.59 & 97.06 \\
\hline \multicolumn{18}{|c|}{ Trace elements (ppm): } \\
\hline $\mathrm{Cr}$ & 115 & 174 & 137 & 185 & 128 & 97 & 164 & 163 & 160 & 254 & 243 & 150 & 161 & 149 & 168 & 178 & 108 \\
\hline $\mathrm{Ni}$ & 43 & 55 & 70 & 96 & 48 & 65 & 99 & 108 & 87 & 71 & 54 & 35 & 99 & 84 & 59 & 83 & 115 \\
\hline $\mathrm{v}$ & 436 & 451 & 366 & 382 & 346 & 390 & 393 & 381 & 386 & 332 & 331 & 325 & 350 & 335 & 320 & 352 & 394 \\
\hline Sc & 41 & 47 & 60 & 47 & 46 & 47 & 49 & 53 & 52 & 46 & 40 & 40 & 40 & 42 & 37 & 56 & 48 \\
\hline $\mathrm{Ba}$ & 21 & 23 & 8 & 1 & 2 & 10 & 29 & 30 & 22 & 19 & 18 & 17 & 47 & 22 & 20 & 37 & 59 \\
\hline $\mathrm{Sr}$ & 116 & 128 & 127 & 134 & 117 & 128 & 130 & 128 & 125 & 104 & 103 & 110 & 129 & 113 & 113 & 125 & 140 \\
\hline $\mathrm{Y}$ & 60 & 62 & 56 & 51 & 47 & 47 & 57 & 59 & 54 & 41 & 39 & 37 & 39 & 38 & 39 & 45 & 49 \\
\hline $\mathrm{Zr}$ & 177 & 178 & 139 & 133 & 128 & 151 & 141 & 138 & 134 & 114 & 112 & 101 & 105 & 104 & 99 & 105 & 124 \\
\hline $\mathrm{Nb}$ & 12.1 & 12.5 & 9.4 & 9.4 & 8.7 & 10.3 & 9.2 & 9.0 & 8.9 & 7.5 & 7.4 & 6.7 & 7.5 & 7.2 & 6.6 & 7.3 & 8.8 \\
\hline LOI (wt\%) & 0.1 & 0.1 & -0.8 & -1.1 & -0.4 & -0.2 & -1.0 & -0.4 & -0.6 & -0.8 & -0.4 & -1.1 & -1.7 & -1.6 & -1.0 & -1.1 & -0.9 \\
\hline $\mathrm{Mg \#}$ & 52.4 & 57.9 & 56.2 & 59.5 & 55.5 & 58.0 & 59.9 & 60.6 & 58.9 & 59.2 & 58.9 & 58.8 & 63.1 & 58.4 & 59.9 & 61.4 & 62.6 \\
\hline
\end{tabular}




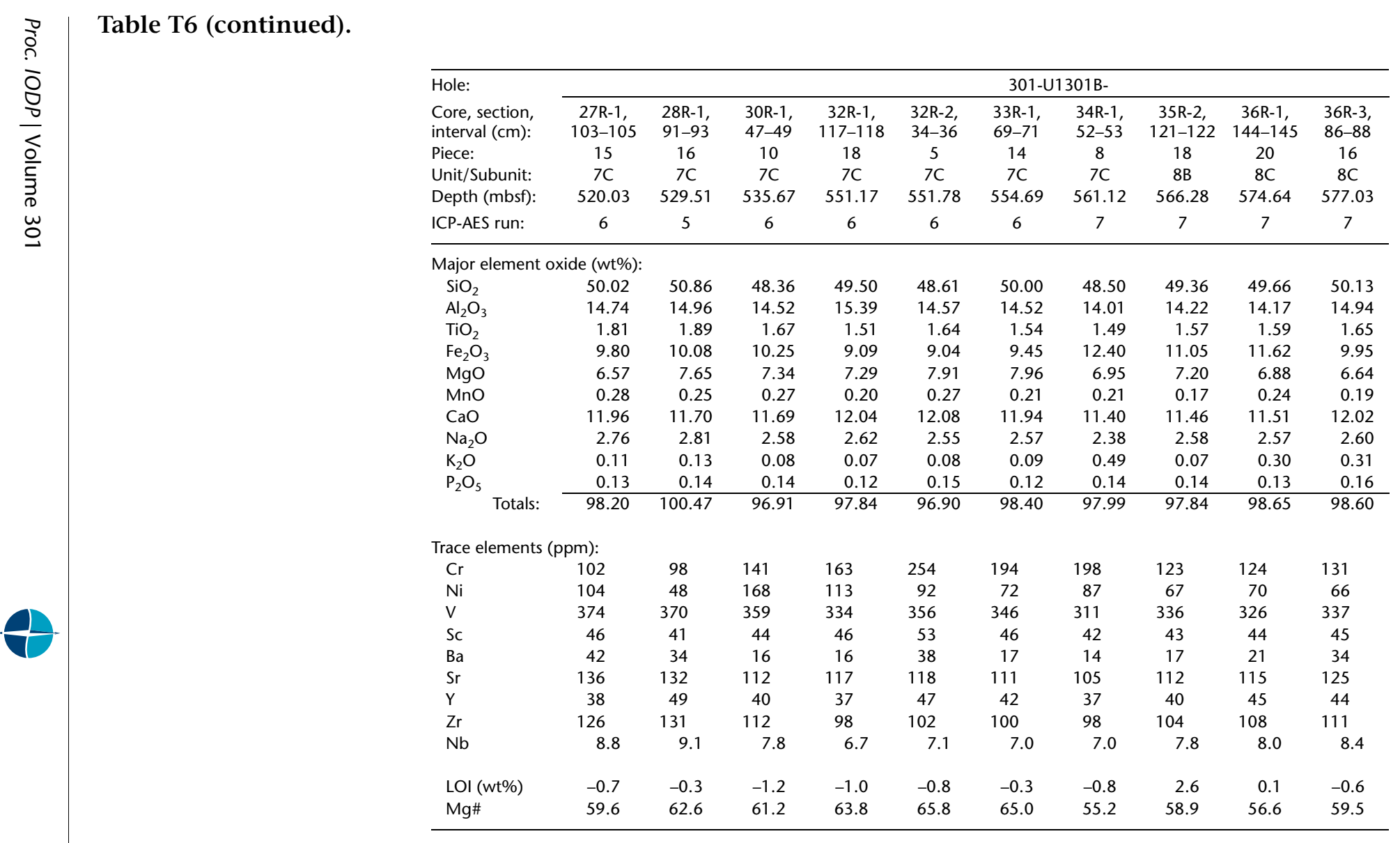


Table T7. Summary of X-ray diffraction results, Hole U1301B.

\begin{tabular}{|c|c|c|c|c|}
\hline $\begin{array}{l}\text { Core, section, } \\
\text { interval }(\mathrm{cm})\end{array}$ & $\begin{array}{l}\text { Depth } \\
\text { (mbsf) }\end{array}$ & Piece & Mode of occurrence & Secondary minerals identified \\
\hline \multicolumn{5}{|l|}{ 301-U1301B- } \\
\hline $1 \mathrm{R}-1,121-124$ & 351.20 & 15 & Vein & Clay (saponite?), goethite, hematite, celadonite, analcime(?) \\
\hline $3 R-1,33-36$ & 361.10 & 4 & Vein & Clay (saponite?) \\
\hline $15 R-1,87-89$ & 443.60 & 11 & Vein & Geothite, celadonite(?) \\
\hline $18 \mathrm{R}-4,132-136$ & 474.88 & 7 & Vein & Phillipsite(?) \\
\hline $21 \mathrm{R}-2,125-126$ & 491.56 & 17 & Vein & Clay (saponite?), celadonite(?), analcime(?) \\
\hline $24 \mathrm{R}-1,0-2$ & 505.90 & 1 & Vein & Clay (saponite?) \\
\hline $35 R-1,112-118$ & 563.60 & 15 & Hyaloclastite matrix & Clay (saponite?), phillipsite(?) \\
\hline
\end{tabular}

Table T8. Summary of the veins measured in the different lithologic units, Hole U1301B.

\begin{tabular}{llcccl}
\hline Unit & $\begin{array}{c}\text { Lava } \\
\text { morphology }\end{array}$ & $\begin{array}{c}\text { Number of } \\
\text { veins } \\
\text { logged }\end{array}$ & $\begin{array}{c}\text { Core } \\
\text { recovered } \\
(\mathrm{m})\end{array}$ & $\begin{array}{c}\text { Veins/m } \\
\text { recovered } \\
\text { core }\end{array}$ & \multicolumn{1}{c}{$\begin{array}{c}\text { Principal } \\
\text { vein minerals }\end{array}$} \\
\hline 1 & Pillow & 765 & 21.86 & 35 & Sap, FeOx, cel \\
2 & Massive & 64 & 4.54 & 14.1 & Sap, py, CC, FeOx \\
3 & Pillow & 24 & 0.92 & 26.1 & Sap, FeOx, cel \\
4 & Massive & 84 & 4.76 & 17.6 & FeOx, sap, cel \\
5 & Pillow & 54 & 2.18 & 24.8 & Sap, FeOx, cel \\
6 & Massive & 80 & 4.39 & 18.2 & CC, sap, py \\
7 & Pillow & 1057 & 29.38 & 35.8 & Sap, FeOx, cel (Py) \\
8 & Pillow & 173 & 5.21 & 33.2 & Sap, FeOx, cel \\
\cline { 3 - 5 } & & 2301 & 73.2 & 33.2 & \\
\hline
\end{tabular}

Note: sap = saponite, $\mathrm{FeOx}=$ iron oxyhydroxide, $\mathrm{cel}=$ celdaonite, $\mathrm{CC}=$ calcium carbonate, $\mathrm{py}=$ pyrite. 
Table T9. Paleomagnetic data from the igneous section, Hole U1301B. (See table notes. Continued on next four pages.)

\begin{tabular}{|c|c|c|c|c|c|c|c|c|}
\hline $\begin{array}{l}\text { Core, section, } \\
\text { interval }(\mathrm{cm})\end{array}$ & $\begin{array}{l}\text { Depth } \\
\text { (mbsf) }\end{array}$ & $\begin{array}{l}\text { NRM } \\
(\mathrm{A} / \mathrm{m})\end{array}$ & $\begin{array}{l}\text { PCA } \\
\left({ }^{\circ}\right)\end{array}$ & $\begin{array}{l}\text { Demag. } \\
\text { type }\end{array}$ & $N$ & $\begin{array}{l}\text { Demag. } \\
\text { steps } \\
\left(\mathrm{mT} /{ }^{\circ} \mathrm{C}\right)\end{array}$ & $\begin{array}{l}\text { MAD } \\
\left({ }^{\circ}\right)\end{array}$ & Qual. \\
\hline \multicolumn{9}{|l|}{ 301-U1301B- } \\
\hline 1R-1, 70 & 351.88 & 5.71 & 63.2 & $\mathrm{AF}$ & 5 & $15-35$ & 2.8 & $\mathrm{~A} 1$ \\
\hline 1R-1, 72 & 351.90 & 4.51 & 56.0 & TH & 5 & $300-475$ & 2.2 & $\mathrm{~A} 1$ \\
\hline $1 \mathrm{R}-1,87$ & 352.07 & 4.16 & 50.1 & $\mathrm{AF}$ & 4 & $25-40$ & 2.1 & A1 \\
\hline 1R-1, 92 & 352.12 & 8.22 & 58.2 & TH & 5 & $300-475$ & 1.6 & $\mathrm{~A} 1$ \\
\hline $1 \mathrm{R}-1,120$ & 352.40 & 4.71 & 72.7 & $\mathrm{AF}$ & 4 & $15-25$ & 0.9 & $\mathrm{C} 2$ \\
\hline $1 \mathrm{R}-1,130$ & 352.50 & 12.59 & 68.7 & $\mathrm{AF}$ & 7 & $20-50$ & 1.6 & $\mathrm{~A} 1$ \\
\hline $2 \mathrm{R}-1,17$ & 357.27 & 4.72 & 55.1 & $\mathrm{AF}$ & 6 & $25-50$ & 4.0 & $\mathrm{~A} 1$ \\
\hline $2 \mathrm{R}-1,30$ & 357.40 & 3.16 & 68.3 & $\mathrm{AF}$ & 5 & $30-50$ & 1.9 & A1 \\
\hline $2 \mathrm{R}-1,73$ & 357.83 & 6.90 & 39.3 & $\mathrm{AF}$ & 5 & $20-40$ & 1.8 & $\mathrm{C} 2$ \\
\hline $2 \mathrm{R}-1,79$ & 357.89 & 6.81 & 49.2 & $\mathrm{TH}$ & 5 & $300-475$ & 4.6 & A2 \\
\hline $2 \mathrm{R}-1,100$ & 358.10 & 3.18 & 52.2 & $\mathrm{AF}$ & 4 & $35-50$ & 2.1 & $\mathrm{~A} 1$ \\
\hline $2 \mathrm{R}-1,137$ & 358.47 & 11.06 & 39.3 & $\mathrm{AF}$ & 8 & $20-60$ & 0.9 & $\mathrm{C} 2$ \\
\hline $2 \mathrm{R}-2,22$ & 358.76 & 7.68 & 36.4 & $\mathrm{AF}$ & 7 & $20-50$ & 2.1 & A1 \\
\hline $2 \mathrm{R}-2,110$ & 359.64 & 3.00 & 40.2 & $\mathrm{AF}$ & 5 & $30-50$ & 1.3 & $\mathrm{~A} 1$ \\
\hline $2 \mathrm{R}-2,115$ & 359.69 & 9.75 & 29.0 & $\mathrm{AF}$ & 6 & $15-40$ & 1.2 & $\mathrm{~A} 1$ \\
\hline $2 \mathrm{R}-3,3$ & 360.07 & 8.05 & 39.6 & AF & 4 & $25-40$ & 3.4 & $\mathrm{C} 1$ \\
\hline $2 \mathrm{R}-3,95$ & 360.99 & 7.02 & 50.1 & TH & 7 & $350-550$ & 9.3 & A2 \\
\hline $2 \mathrm{R}-3,123$ & 361.27 & 12.57 & 45.6 & $\mathrm{AF}$ & 6 & $20-50$ & 1.0 & $\mathrm{~A} 1$ \\
\hline $3 R-3,130$ & 361.34 & 2.95 & 41.9 & $\mathrm{AF}$ & 5 & $30-50$ & 1.7 & A1 \\
\hline $3 \mathrm{R}-1,24$ & 361.34 & 8.09 & 48.0 & TH & 3 & $300-450$ & 4.9 & $\mathrm{~A} 1$ \\
\hline $3 R-1,30$ & 361.40 & 4.41 & 58.7 & $\mathrm{AF}$ & 5 & $20-40$ & 1.4 & $\mathrm{~A} 1$ \\
\hline $3 \mathrm{R}-1,31$ & 361.41 & 6.90 & 42.4 & $\mathrm{AF}$ & 6 & $15-40$ & 0.4 & A1 \\
\hline $3 R-1,112$ & 362.22 & 3.88 & 51.2 & $\mathrm{AF}$ & 6 & $25-50$ & 0.7 & $\mathrm{~A} 1$ \\
\hline $3 \mathrm{R}-1,130$ & 362.40 & 8.70 & 49.2 & $\mathrm{AF}$ & 5 & $15-35$ & 0.7 & B2 \\
\hline $3 R-1,135$ & 362.45 & 4.80 & 45.7 & $\mathrm{AF}$ & 6 & $25-50$ & 0.9 & $\mathrm{~A} 1$ \\
\hline $3 R-2,10$ & 362.70 & 3.79 & 61.9 & $\mathrm{AF}$ & 5 & $30-50$ & 1.9 & $\mathrm{~A} 1$ \\
\hline $3 R-2,12$ & 362.72 & 11.49 & -54.6 & TH & 5 & $250-450$ & 0.5 & $\mathrm{~A} 1$ \\
\hline $3 R-2,58$ & 363.18 & 10.00 & 25.8 & $\mathrm{AF}$ & 6 & $20-50$ & 0.5 & $\mathrm{~A} 1$ \\
\hline $3 \mathrm{R}-2,88$ & 363.48 & 10.37 & 44.8 & $\mathrm{AF}$ & 5 & $20-40$ & 0.4 & A1 \\
\hline $3 \mathrm{R}-2,107$ & 363.67 & 5.60 & 52.8 & $\mathrm{AF}$ & 5 & $30-50$ & 0.5 & A1 \\
\hline $4 \mathrm{R}-1,37$ & 366.97 & 11.74 & 54.3 & $\mathrm{TH}$ & 4 & $250-450$ & 0.1 & A1 \\
\hline $4 \mathrm{R}-1,55$ & 367.15 & 6.88 & 71.3 & $\mathrm{AF}$ & 4 & $35-50$ & 0.8 & $\mathrm{C} 1$ \\
\hline $4 \mathrm{R}-1,110$ & 367.70 & 9.98 & 40.5 & $\mathrm{AF}$ & 5 & $25-45$ & 1.3 & $\mathrm{~A} 1$ \\
\hline $4 \mathrm{R}-1,134$ & 367.94 & 8.59 & 41.0 & TH & 4 & $350-500$ & 10.0 & A2 \\
\hline $4 \mathrm{R}-2,20$ & 368.26 & 6.06 & 59.7 & AF & 4 & $40-60$ & 2.0 & $\mathrm{C} 1$ \\
\hline $4 \mathrm{R}-2,23$ & 368.29 & 10.70 & 66.4 & $\mathrm{AF}$ & 4 & $20-35$ & 1.1 & $\mathrm{~A} 1$ \\
\hline $4 \mathrm{R}-2,84$ & 368.90 & 4.45 & 42.4 & $\mathrm{AF}$ & 5 & $30-50$ & 0.6 & $\mathrm{~A} 1$ \\
\hline $4 \mathrm{R}-2,88$ & 368.94 & 9.41 & 35.8 & $\mathrm{TH}$ & 5 & $250-500$ & 1.8 & $\mathrm{~A} 1$ \\
\hline $4 \mathrm{R}-3,1$ & 369.40 & 3.58 & 43.9 & $\mathrm{AF}$ & 5 & $35-60$ & 1.5 & $\mathrm{~A} 1$ \\
\hline $4 R-3,25$ & 369.64 & 12.18 & 47.2 & $\mathrm{TH}$ & 4 & $300-500$ & 2.2 & $\mathrm{~A} 1$ \\
\hline $4 \mathrm{R}-3,27$ & 369.66 & 9.07 & 51.3 & $\mathrm{AF}$ & 6 & $25-60$ & 2.8 & $\mathrm{~A} 1$ \\
\hline $4 \mathrm{R}-3,64$ & 370.03 & 7.33 & 63.1 & $\mathrm{AF}$ & 5 & $30-50$ & 2.2 & B2 \\
\hline $4 \mathrm{R}-3,132$ & 370.71 & 14.61 & 49.9 & $\mathrm{AF}$ & 5 & $20-40$ & 1.7 & A1 \\
\hline $4 \mathrm{R}-4,45$ & 371.29 & 13.94 & 63.5 & $\mathrm{TH}$ & 4 & $200-400$ & 1.1 & B2 \\
\hline $5 R-1,37$ & 376.67 & 8.48 & 53.2 & $\mathrm{AF}$ & 6 & $25-60$ & 1.4 & $\mathrm{~A} 1$ \\
\hline $5 \mathrm{R}-1,57$ & 376.87 & 4.47 & 24.0 & $\mathrm{AF}$ & 4 & $40-60$ & 0.5 & $\mathrm{~A} 1$ \\
\hline $5 R-1,100$ & 377.30 & 2.08 & 56.0 & AF & 5 & $35-60$ & 2.7 & A1 \\
\hline $5 \mathrm{R}-2,27$ & 378.07 & 1.69 & 69.4 & $\mathrm{AF}$ & 5 & $30-50$ & 0.5 & A1 \\
\hline $5 R-2,104$ & 378.84 & 16.65 & 35.8 & $\mathrm{AF}$ & 6 & $30-50$ & 3.5 & $\mathrm{~A} 1$ \\
\hline $5 \mathrm{R}-2,105$ & 378.85 & 1.92 & 60.8 & $\mathrm{AF}$ & 5 & $35-60$ & 2.0 & $\mathrm{~A} 1$ \\
\hline $5 R-2,109$ & 378.89 & 16.49 & 53.6 & TH & 7 & $275-475$ & 1.9 & B1 \\
\hline $5 R-3,44$ & 379.74 & 28.52 & 59.7 & TH & 4 & $375-475$ & 12.6 & $\mathrm{~A} 1$ \\
\hline $5 R-3,55$ & 379.85 & 2.69 & 45.9 & $\mathrm{AF}$ & 5 & $35-60$ & 1.6 & $\mathrm{~A} 1$ \\
\hline 6R-1, 33 & 386.33 & 12.49 & 67.8 & TH & 5 & $150-350$ & 2.7 & B2 \\
\hline $6 \mathrm{R}-1,41$ & 386.41 & 15.96 & 81.9 & $\mathrm{AF}$ & 4 & $25-40$ & 1.5 & $\mathrm{C} 2$ \\
\hline $6 \mathrm{R}-1,48$ & 386.48 & 5.78 & 67.4 & $\mathrm{AF}$ & 3 & $45-60$ & 1.6 & B1 \\
\hline $6 \mathrm{R}-1,64$ & 386.64 & 12.53 & 59.6 & $\mathrm{AF}$ & 4 & $35-60$ & 2.4 & B1 \\
\hline $6 \mathrm{R}-1,86$ & 386.86 & 4.59 & 76.8 & $\mathrm{AF}$ & 4 & $30-45$ & 1.5 & B1 \\
\hline $6 \mathrm{R}-1,92$ & 386.92 & 4.81 & 83.2 & $\mathrm{AF}$ & 6 & $30-60$ & 1.7 & B1 \\
\hline $6 \mathrm{R}-2,4$ & 387.49 & 4.28 & 66.0 & $\mathrm{AF}$ & 5 & $35-60$ & 3.3 & $\mathrm{~A} 1$ \\
\hline $6 \mathrm{R}-2,35$ & 387.80 & 17.24 & -56.7 & $\mathrm{AF}$ & 5 & $35-60$ & 0.4 & $\mathrm{~A} 1$ \\
\hline $6 \mathrm{R}-2,44$ & 387.89 & 4.74 & 78.2 & $\mathrm{AF}$ & 5 & $35-60$ & 2.5 & A1 \\
\hline $6 \mathrm{R}-2,67$ & 388.12 & 10.22 & 66.8 & TH & 4 & $350-475$ & 1.2 & $\mathrm{~A} 1$ \\
\hline 7R-1, 29 & 395.89 & 14.67 & 62.2 & $\mathrm{AF}$ & 6 & $25-60$ & 0.9 & $\mathrm{C} 1$ \\
\hline $7 \mathrm{R}-1,30$ & 395.90 & 60.81 & 63.8 & $\mathrm{AF}$ & 6 & $30-60$ & 1.6 & $\mathrm{~A} 1$ \\
\hline $7 \mathrm{R}-1,52$ & 396.12 & 9.26 & -6.9 & TH & 4 & $150-275$ & 1.7 & $\mathrm{~A} 1$ \\
\hline
\end{tabular}


Table T9 (continued).

\begin{tabular}{|c|c|c|c|c|c|c|c|c|}
\hline $\begin{array}{l}\text { Core, section, } \\
\text { interval }(\mathrm{cm})\end{array}$ & $\begin{array}{l}\text { Depth } \\
\text { (mbsf) }\end{array}$ & $\begin{array}{l}\text { NRM } \\
(\mathrm{A} / \mathrm{m})\end{array}$ & $\begin{array}{c}\text { PCA } \\
\left({ }^{\circ}\right)\end{array}$ & $\begin{array}{c}\text { Demag. } \\
\text { type }\end{array}$ & N & $\begin{array}{l}\text { Demag. } \\
\text { steps } \\
\left(\mathrm{mT} /{ }^{\circ} \mathrm{C}\right)\end{array}$ & $\begin{array}{c}\text { MAD } \\
\left({ }^{\circ}\right)\end{array}$ & Qual. \\
\hline 7R-1, 57 & 396.17 & 6.68 & -45.6 & $\mathrm{AF}$ & 4 & $35-50$ & 3.5 & A1 \\
\hline $7 \mathrm{R}-2,4$ & 397.14 & 10.90 & 42.6 & $\mathrm{AF}$ & 4 & $40-60$ & 12.8 & $\mathrm{C} 2$ \\
\hline $8 \mathrm{R}-1,19$ & 405.39 & 6.90 & -59.7 & $\mathrm{AF}$ & 5 & $35-60$ & 1.8 & B2 \\
\hline $8 \mathrm{R}-1,43$ & 405.63 & 6.26 & 37.7 & $\mathrm{AF}$ & 6 & $30-60$ & 0.3 & $\mathrm{~A} 1$ \\
\hline $8 \mathrm{R}-1,44$ & 405.64 & 8.79 & 47.7 & $\mathrm{AF}$ & 6 & $30-60$ & 1.0 & A1 \\
\hline $8 \mathrm{R}-1,63$ & 405.83 & 5.78 & -2.8 & $\mathrm{AF}$ & 3 & $45-60$ & 1.9 & $\mathrm{C} 2$ \\
\hline $9 \mathrm{R}-1,30$ & 410.50 & 10.76 & 57.3 & $\mathrm{TH}$ & 4 & $425-500$ & 10.3 & A1 \\
\hline $9 \mathrm{R}-1,32$ & 410.52 & 4.69 & 36.1 & $\mathrm{AF}$ & 4 & $40-60$ & 2.9 & $\mathrm{~A} 1$ \\
\hline $9 \mathrm{R}-1,53$ & 410.73 & 8.03 & 57.6 & $\mathrm{AF}$ & 5 & $35-60$ & 0.4 & A1 \\
\hline $9 \mathrm{R}-1,63$ & 410.83 & 13.78 & 75.5 & $\mathrm{TH}$ & 5 & $400-500$ & 7.9 & $\mathrm{~A} 1$ \\
\hline $9 \mathrm{R}-1,63$ & 410.83 & 4.79 & 62.4 & AF & 4 & $30-45$ & 0.8 & A1 \\
\hline $10 \mathrm{R}-1,26$ & 415.06 & 6.18 & 49.8 & $\mathrm{AF}$ & 5 & $35-60$ & 0.7 & $\mathrm{~A} 1$ \\
\hline $10 \mathrm{R}-1,79$ & 415.59 & 9.11 & 61.8 & $\mathrm{TH}$ & 5 & $400-500$ & 8.7 & $\mathrm{~A} 1$ \\
\hline $10 \mathrm{R}-1,95$ & 415.75 & 6.05 & 73.6 & $\mathrm{TH}$ & 5 & $400-500$ & 5.7 & $\mathrm{~A} 1$ \\
\hline 10R-1, 131 & 416.11 & 13.04 & 64.5 & $\mathrm{TH}$ & 6 & $375-500$ & 4.5 & $\mathrm{~A} 1$ \\
\hline $10 \mathrm{R}-2,57$ & 416.82 & 14.02 & 64.8 & $\mathrm{AF}$ & 4 & $35-50$ & 1.5 & $\mathrm{~A} 1$ \\
\hline $10 \mathrm{R}-2,67$ & 415.92 & 4.73 & 45.5 & $\mathrm{AF}$ & 5 & $35-60$ & 1.1 & $\mathrm{C} 1$ \\
\hline 10R-2, 96 & 417.21 & 6.62 & 66.7 & $\mathrm{AF}$ & 4 & $40-60$ & 2.4 & $\mathrm{C} 1$ \\
\hline $11 \mathrm{R}-1,67$ & 425.07 & 5.14 & 76.7 & $\mathrm{AF}$ & 4 & $40-60$ & 1.2 & A1 \\
\hline $11 \mathrm{R}-1,68$ & 425.08 & 13.96 & 84.5 & $\mathrm{TH}$ & 4 & $425-500$ & 3.4 & B2 \\
\hline 11R-1, 94 & 425.34 & 34.41 & 35.0 & $\mathrm{TH}$ & 3 & $450-500$ & 6.3 & $\mathrm{~A} 1$ \\
\hline $11 \mathrm{R}-1,107$ & 425.47 & 5.36 & 49.3 & $\mathrm{AF}$ & 5 & $30-45$ & 1.5 & B1 \\
\hline $12 \mathrm{R}-1,27$ & 429.17 & 25.58 & 32.7 & $\mathrm{TH}$ & 6 & $300-500$ & 8.8 & $\mathrm{~A} 1$ \\
\hline $12 \mathrm{R}-1,91$ & 429.81 & 28.52 & 69.7 & $\mathrm{AF}$ & 6 & $30-60$ & 3.8 & $\mathrm{~A} 1$ \\
\hline $12 \mathrm{R}-1,93$ & 429.83 & 30.58 & 64.1 & $\mathrm{AF}$ & 6 & $30-60$ & 2.9 & A1 \\
\hline $13 \mathrm{R}-1,14$ & 430.04 & 6.06 & 57.1 & $\mathrm{AF}$ & 5 & $35-60$ & 2.7 & A1 \\
\hline $13 \mathrm{R}-1,22$ & 430.12 & 28.60 & 63.1 & $\mathrm{TH}$ & 4 & $400-475$ & 12.4 & B2 \\
\hline $13 R-1,68$ & 430.58 & 32.17 & 70.1 & $\mathrm{AF}$ & 5 & $30-50$ & 6.3 & A1 \\
\hline $13 \mathrm{R}-1,94$ & 430.84 & 2.80 & 70.3 & $\mathrm{AF}$ & 5 & $30-50$ & 1.1 & A1 \\
\hline $13 \mathrm{R}-2,5$ & 431.38 & 17.70 & 63.8 & $\mathrm{TH}$ & 4 & $350-450$ & 13.8 & $\mathrm{~A} 1$ \\
\hline $13 \mathrm{R}-2,14$ & 431.47 & 4.18 & 84.2 & $\mathrm{AF}$ & 3 & $40-50$ & 0.6 & $\mathrm{C} 2$ \\
\hline $13 \mathrm{R}-2,17$ & 431.50 & 1.33 & 47.5 & $\mathrm{AF}$ & 4 & $25-40$ & 15.1 & $\mathrm{D}$ \\
\hline $14 \mathrm{R}-1,26$ & 434.26 & 6.88 & 66.5 & $\mathrm{AF}$ & 4 & $30-45$ & 0.4 & B2 \\
\hline $14 \mathrm{R}-1,45$ & 434.45 & 4.75 & 49.2 & $\mathrm{AF}$ & 4 & $35-50$ & 8.7 & $\mathrm{C} 1$ \\
\hline $14 \mathrm{R}-1,55$ & 434.55 & 6.08 & 48.8 & $\mathrm{AF}$ & 5 & $30-50$ & 7.2 & A1 \\
\hline $14 \mathrm{R}-1,81$ & 434.81 & 25.51 & 54.0 & $\mathrm{AF}$ & 5 & $30-50$ & 4.8 & $\mathrm{~A} 1$ \\
\hline $14 \mathrm{R}-1,132$ & 435.32 & 13.73 & 77.6 & $\mathrm{TH}$ & 4 & $250-375$ & 1.4 & D \\
\hline $14 \mathrm{R}-1,133$ & 435.33 & 7.13 & 66.9 & AF & 3 & $45-60$ & 1.3 & $\mathrm{~A} 1$ \\
\hline $14 \mathrm{R}-1,142$ & 435.42 & 3.61 & 84.3 & $\mathrm{AF}$ & 4 & $35-50$ & 0.7 & B2 \\
\hline $15 R-1,45$ & 444.05 & 6.61 & 54.2 & AF & 4 & $35-50$ & 1.1 & A1 \\
\hline 15R-1, 94 & 444.54 & 11.58 & 61.6 & $\mathrm{TH}$ & 3 & $425-500$ & 5.0 & A1 \\
\hline $15 \mathrm{R}-1,108$ & 444.68 & 15.33 & 55.1 & $\mathrm{AF}$ & 4 & $35-50$ & 12.1 & B2 \\
\hline $15 \mathrm{R}-1,113$ & 444.73 & 16.83 & 62.5 & $\mathrm{AF}$ & 7 & $20-50$ & 1.8 & $\mathrm{~A} 1$ \\
\hline $15 \mathrm{R}-2,9$ & 445.19 & 27.40 & 63.2 & $\mathrm{AF}$ & 6 & $20-45$ & 5.2 & $\mathrm{~A} 1$ \\
\hline $15 \mathrm{R}-2,20$ & 445.30 & 23.98 & 62.4 & AF & 4 & $20-35$ & 8.3 & A1 \\
\hline 15R-2, 91 & 446.01 & 27.89 & 55.1 & $\mathrm{TH}$ & 6 & $350-475$ & 14.4 & $\mathrm{~A} 1$ \\
\hline $15 \mathrm{R}-2,93$ & 446.03 & 30.91 & 43.0 & AF & 5 & $30-50$ & 4.7 & A1 \\
\hline $15 \mathrm{R}-3,10$ & 446.70 & 24.62 & 30.5 & $\mathrm{AF}$ & 5 & $35-60$ & 3.7 & A1 \\
\hline $15 \mathrm{R}-3,22$ & 446.82 & 5.76 & 48.7 & $\mathrm{AF}$ & 3 & $35-45$ & 1.3 & $\mathrm{C} 2$ \\
\hline $15 \mathrm{R}-3,41$ & 447.01 & 5.26 & 51.0 & $\mathrm{AF}$ & 4 & $40-60$ & 0.6 & A1 \\
\hline 15R-3, 81 & 447.41 & 39.73 & 66.4 & $\mathrm{AF}$ & 5 & $35-60$ & 1.2 & $\mathrm{~A} 1$ \\
\hline $15 \mathrm{R}-3,144$ & 448.04 & 6.58 & 51.2 & $\mathrm{AF}$ & 4 & $30-45$ & 1.8 & B2 \\
\hline $15 R-4,5$ & 448.15 & 3.67 & 48.1 & $\mathrm{AF}$ & 5 & $35-60$ & 0.4 & B1 \\
\hline 15R-4, 21 & 448.31 & 23.39 & 46.3 & AF & 4 & $25-40$ & 9.2 & $\mathrm{~A} 1$ \\
\hline $15 \mathrm{R}-4,29$ & 448.39 & 3.30 & -72.6 & $\mathrm{AF}$ & 4 & $35-50$ & 3.0 & $\mathrm{~A} 1$ \\
\hline $15 R-4,65$ & 448.75 & 15.99 & 67.2 & $\mathrm{AF}$ & 5 & $20-45$ & 3.9 & $\mathrm{~A} 1$ \\
\hline 15R-4, 101 & 449.11 & 36.80 & 65.7 & $\mathrm{AF}$ & 4 & $40-60$ & 1.4 & $\mathrm{~A} 1$ \\
\hline 16R-1, 22 & 453.42 & 6.76 & 62.2 & $\mathrm{AF}$ & 3 & $35-45$ & 1.3 & B1 \\
\hline $16 \mathrm{R}-1,38$ & 453.58 & 7.14 & 41.7 & AF & 4 & $40-60$ & 2.2 & B1 \\
\hline 16R-1, 81 & 454.01 & 14.46 & 66.5 & $\mathrm{TH}$ & 4 & $425-500$ & 6.0 & A2 \\
\hline $16 \mathrm{R}-1,100$ & 454.20 & 3.91 & 32.9 & $\mathrm{AF}$ & 3 & $45-60$ & 3.4 & $\mathrm{~A} 1$ \\
\hline 16R-1, 107 & 454.27 & 3.90 & 62.7 & $\mathrm{AF}$ & 5 & $20-40$ & 2.0 & B2 \\
\hline 16R-1, 144 & 454.64 & 2.23 & 44.4 & $\mathrm{AF}$ & 4 & $30-45$ & 7.5 & $\mathrm{C} 2$ \\
\hline 17R-1, 32 & 461.72 & 3.19 & 48.3 & $\mathrm{TH}$ & 5 & $400-500$ & 8.9 & A1 \\
\hline $17 \mathrm{R}-1,58$ & 461.98 & 5.36 & -6.1 & AF & 4 & $40-60$ & 2.0 & A1 \\
\hline $17 \mathrm{R}-1,73$ & 462.13 & 7.47 & 75.6 & $\mathrm{AF}$ & 4 & $30-45$ & 19.3 & B2 \\
\hline $17 \mathrm{R}-1,76$ & 462.16 & 7.26 & 34.5 & $\mathrm{TH}$ & 6 & $375-500$ & 5.9 & $\mathrm{~A} 1$ \\
\hline $18 \mathrm{R}-1,34$ & 471.34 & 20.80 & 23.7 & $\mathrm{TH}$ & 5 & $400-500$ & 11.9 & A1 \\
\hline
\end{tabular}


Table T9 (continued).

\begin{tabular}{|c|c|c|c|c|c|c|c|c|}
\hline $\begin{array}{l}\text { Core, section, } \\
\text { interval }(\mathrm{cm})\end{array}$ & $\begin{array}{l}\text { Depth } \\
\text { (mbsf) }\end{array}$ & $\begin{array}{l}\text { NRM } \\
(\mathrm{A} / \mathrm{m})\end{array}$ & $\begin{array}{c}\text { PCA } \\
\left({ }^{\circ}\right)\end{array}$ & $\begin{array}{c}\text { Demag. } \\
\text { type }\end{array}$ & $N$ & $\begin{array}{l}\text { Demag. } \\
\text { steps } \\
\left(\mathrm{mT} /{ }^{\circ} \mathrm{C}\right)\end{array}$ & $\begin{array}{c}\text { MAD } \\
\left({ }^{\circ}\right)\end{array}$ & Qual. \\
\hline $18 \mathrm{R}-1,53$ & 471.53 & 5.43 & 7.5 & $\mathrm{AF}$ & 4 & $30-50$ & 3.5 & $\mathrm{C} 2$ \\
\hline $18 \mathrm{R}-1,65$ & 471.65 & 12.83 & -25.1 & $\mathrm{AF}$ & 4 & $425-500$ & 2.0 & $\mathrm{~A} 1$ \\
\hline 18R-1, 96 & 471.96 & 25.51 & & $\mathrm{AF}$ & & & & $\mathrm{C} 2$ \\
\hline $18 \mathrm{R}-2,13$ & 472.43 & 17.07 & -36.5 & $\mathrm{AF}$ & 5 & $20-40$ & 1.6 & $\mathrm{~A} 1$ \\
\hline $18 \mathrm{R}-2,24$ & 472.54 & 10.28 & 33.9 & $\mathrm{AF}$ & 4 & $35-50$ & 6.6 & B2 \\
\hline $18 \mathrm{R}-2,32$ & 472.62 & 30.02 & 67.7 & $\mathrm{AF}$ & 3 & $45-60$ & 7.1 & $\mathrm{D}$ \\
\hline $18 \mathrm{R}-2,78$ & 473.08 & 15.11 & & $\mathrm{AF}$ & & & & D \\
\hline $18 \mathrm{R}-2,108$ & 473.38 & 21.42 & & $\mathrm{AF}$ & & & & D \\
\hline $18 \mathrm{R}-3,44$ & 474.00 & 26.67 & & $\mathrm{TH}$ & & & & D \\
\hline $18 \mathrm{R}-3,112$ & 474.68 & 26.04 & & $\mathrm{AF}$ & & & & $\mathrm{D}$ \\
\hline 18R-4, 21 & 475.09 & 19.57 & 41.7 & $\mathrm{TH}$ & 3 & $475-525$ & 3.2 & A1 \\
\hline $18 \mathrm{R}-4,65$ & 475.53 & 9.78 & 30.7 & AF & 4 & $30-45$ & 7.9 & $\mathrm{C} 2$ \\
\hline $18 \mathrm{R}-4,71$ & 475.59 & 16.16 & & $\mathrm{AF}$ & & & & $\mathrm{C} 2$ \\
\hline $18 \mathrm{R}-4,84$ & 475.72 & 4.18 & -4.4 & $\mathrm{TH}$ & 3 & $450-500$ & 7.2 & $\mathrm{C} 2$ \\
\hline $18 \mathrm{R}-4,84$ & 475.72 & 5.83 & -16.0 & $\mathrm{AF}$ & 3 & $40-60$ & 10.5 & A1 \\
\hline $18 \mathrm{R}-4,115$ & 476.03 & 4.06 & & $\mathrm{AF}$ & & & & $\mathrm{C} 2$ \\
\hline $18 \mathrm{R}-5,5$ & 476.38 & 6.08 & 23.1 & $\mathrm{AF}$ & 5 & $35-60$ & 5.4 & B1 \\
\hline 19R-1, 21 & 476.31 & 8.88 & -11.6 & $\mathrm{AF}$ & 5 & $35-60$ & 0.5 & A1 \\
\hline $19 \mathrm{R}-1,32$ & 476.42 & 4.99 & 2.8 & $\mathrm{AF}$ & 4 & $40-60$ & 3.8 & $\mathrm{C} 2$ \\
\hline $19 \mathrm{R}-1,35$ & 476.45 & 2.78 & 6.9 & $\mathrm{TH}$ & 3 & $450-500$ & 2.7 & A1 \\
\hline $19 \mathrm{R}-1,47$ & 476.57 & 4.80 & 45.6 & $\mathrm{AF}$ & 3 & $30-40$ & 0.2 & B2 \\
\hline 19R-1, 51 & 476.61 & 2.67 & 57.5 & $\mathrm{AF}$ & 4 & $25-40$ & 1.9 & B2 \\
\hline $19 \mathrm{R}-1,105$ & 477.15 & 9.12 & & $\mathrm{AF}$ & & & & B2 \\
\hline 19R-2, 28 & 477.85 & 6.75 & 25.0 & $\mathrm{TH}$ & 4 & $400-475$ & 15.6 & A1 \\
\hline $19 \mathrm{R}-2,58$ & 478.15 & 4.49 & -29.3 & AF & 3 & $35-45$ & 0.5 & $\mathrm{C} 1$ \\
\hline $20 \mathrm{R}-1,23$ & 480.83 & 5.77 & 32.7 & $\mathrm{AF}$ & 3 & $30-40$ & 1.6 & $\mathrm{C} 2$ \\
\hline $20 \mathrm{R}-1,47$ & 481.07 & 12.78 & -25.2 & $\mathrm{TH}$ & 4 & $425-500$ & 3.8 & A1 \\
\hline 20R-1, 71 & 481.31 & 4.42 & 36.5 & AF & 4 & $40-60$ & 1.0 & $\mathrm{~A} 1$ \\
\hline $20 \mathrm{R}-1,72$ & 481.32 & 8.34 & & $\mathrm{AF}$ & & & & $\mathrm{C} 2$ \\
\hline 20R-1, 117 & 481.77 & 5.15 & 43.4 & $\mathrm{AF}$ & 3 & $30-40$ & 0.6 & $\mathrm{C} 1$ \\
\hline $21 \mathrm{R}-1,60$ & 490.80 & 12.31 & 32.6 & $\mathrm{AF}$ & 5 & $25-45$ & 1.8 & $\mathrm{~A} 1$ \\
\hline $21 \mathrm{R}-1,104$ & 491.24 & 29.82 & 45.3 & $\mathrm{TH}$ & 4 & $450-525$ & 2.7 & A1 \\
\hline $21 \mathrm{R}-2,14$ & 491.70 & 6.50 & 64.5 & $\mathrm{TH}$ & 3 & $475-525$ & 5.1 & A1 \\
\hline $21 \mathrm{R}-2,30$ & 491.86 & 5.36 & -61.6 & $\mathrm{AF}$ & 3 & $45-60$ & 2.1 & B2 \\
\hline $21 \mathrm{R}-2,62$ & 492.18 & 1.77 & & $\mathrm{AF}$ & & & & B2 \\
\hline $21 \mathrm{R}-2,99$ & 492.55 & 5.13 & & $\mathrm{TH}$ & & & & $\mathrm{D}$ \\
\hline $21 \mathrm{R}-2,136$ & 492.92 & 3.15 & 49.1 & AF & 3 & $35-45$ & 0.9 & A1 \\
\hline $21 \mathrm{R}-3,46$ & 493.45 & 5.51 & & $\mathrm{AF}$ & & & & B2 \\
\hline $21 \mathrm{R}-3,55$ & 493.54 & 3.34 & 56.1 & $\mathrm{AF}$ & 4 & $30-45$ & 1.1 & B1 \\
\hline $21 \mathrm{R}-3,118$ & 494.17 & 3.12 & 11.5 & AF & 4 & $40-60$ & 6.6 & B2 \\
\hline $21 \mathrm{R}-4,3$ & 494.52 & 8.00 & -16.6 & $\mathrm{TH}$ & 3 & $450-500$ & 7.2 & A1 \\
\hline $21 \mathrm{R}-4,49$ & 494.98 & 5.05 & 60.5 & $\mathrm{AF}$ & 4 & $40-60$ & 1.3 & $\mathrm{~A} 1$ \\
\hline $21 \mathrm{R}-4,71$ & 495.20 & 31.86 & 52.9 & $\mathrm{TH}$ & 5 & $425-525$ & 4.1 & A1 \\
\hline $22 \mathrm{R}-1,23$ & 495.63 & 15.86 & -32.6 & $\mathrm{AF}$ & 4 & $40-60$ & 3.4 & $\mathrm{~A} 1$ \\
\hline $22 \mathrm{R}-1,53$ & 495.93 & 3.55 & 49.9 & $\mathrm{AF}$ & 5 & $35-60$ & 0.7 & $\mathrm{~A} 1$ \\
\hline 22R-1, 96 & 496.36 & 11.16 & & $\mathrm{AF}$ & & & & B2 \\
\hline 22R-1, 107 & 496.47 & 5.65 & & AF & & & & B2 \\
\hline $22 \mathrm{R}-1,131$ & 496.71 & 11.74 & 57.6 & $\mathrm{TH}$ & 4 & $425-500$ & 5.2 & B1 \\
\hline $22 \mathrm{R}-2,5$ & 496.88 & 4.60 & 58.4 & $\mathrm{AF}$ & 5 & $35-60$ & 0.7 & $\mathrm{~A} 1$ \\
\hline $22 \mathrm{R}-2,26$ & 497.09 & 10.10 & 64.1 & $\mathrm{TH}$ & 3 & $475-525$ & 9.7 & A1 \\
\hline $22 \mathrm{R}-2,48$ & 497.31 & 11.16 & 12.7 & $\mathrm{AF}$ & 4 & $30-45$ & 1.0 & $\mathrm{~A} 1$ \\
\hline $22 \mathrm{R}-2,60$ & 497.43 & 7.95 & 50.8 & $\mathrm{AF}$ & 5 & $30-50$ & 2.0 & $\mathrm{~A} 1$ \\
\hline $23 \mathrm{R}-1,29$ & 500.19 & 7.11 & 46.9 & AF & 4 & $40-60$ & 1.9 & A1 \\
\hline $23 \mathrm{R}-1,50$ & 500.40 & 2.70 & -31.5 & $\mathrm{TH}$ & 5 & $425-525$ & 14.1 & $\mathrm{~A} 1$ \\
\hline $23 \mathrm{R}-1,66$ & 500.56 & 4.81 & 37.6 & $\mathrm{AF}$ & 3 & $45-60$ & 1.1 & B2 \\
\hline $23 \mathrm{R}-1,93$ & 500.83 & 4.48 & & $\mathrm{AF}$ & & & & B2 \\
\hline $23 \mathrm{R}-1,131$ & 501.21 & 5.81 & 50.4 & $\mathrm{AF}$ & 4 & $40-60$ & 2.5 & B1 \\
\hline $23 \mathrm{R}-2,10$ & 501.46 & 10.47 & & $\mathrm{AF}$ & & & & $\mathrm{C} 2$ \\
\hline $23 R-2,46$ & 501.82 & 5.62 & 50.6 & $\mathrm{AF}$ & 3 & $45-60$ & 4.3 & B1 \\
\hline $23 \mathrm{R}-2,141$ & 502.77 & 7.64 & & AF & & & & $\mathrm{C} 2$ \\
\hline $23 \mathrm{R}-3,8$ & 502.94 & 17.42 & 58.5 & $\mathrm{TH}$ & 4 & $425-500$ & 2.9 & A1 \\
\hline $23 \mathrm{R}-3,24$ & 503.10 & 8.47 & 32.5 & $\mathrm{AF}$ & 4 & $30-45$ & 1.1 & B1 \\
\hline $24 \mathrm{R}-1,13$ & 506.03 & 3.72 & 9.9 & $\mathrm{AF}$ & 4 & $35-50$ & 0.6 & B2 \\
\hline $24 \mathrm{R}-1,34$ & 506.24 & 7.14 & 5.3 & $\mathrm{TH}$ & 4 & $425-500$ & 25.7 & A1 \\
\hline $24 \mathrm{R}-1,59$ & 506.49 & 3.73 & 22.0 & AF & 3 & $35-45$ & 1.0 & $\mathrm{C} 1$ \\
\hline $24 \mathrm{R}-1,89$ & 506.79 & 5.19 & 32.0 & $\mathrm{AF}$ & 4 & $35-50$ & 2.4 & $\mathrm{C} 2$ \\
\hline $24 \mathrm{R}-1,103$ & 506.93 & 10.73 & 53.1 & AF & 4 & $35-50$ & 1.1 & A1 \\
\hline $24 \mathrm{R}-1,126$ & 507.16 & 30.43 & 53.7 & $\mathrm{TH}$ & 6 & $400-525$ & 10.2 & A1 \\
\hline
\end{tabular}


Table T9 (continued).

\begin{tabular}{|c|c|c|c|c|c|c|c|c|}
\hline $\begin{array}{l}\text { Core, section, } \\
\text { interval }(\mathrm{cm})\end{array}$ & $\begin{array}{l}\text { Depth } \\
\text { (mbsf) }\end{array}$ & $\begin{array}{l}\text { NRM } \\
(\mathrm{A} / \mathrm{m})\end{array}$ & $\begin{array}{c}\text { PCA } \\
\left({ }^{\circ}\right)\end{array}$ & $\begin{array}{c}\text { Demag. } \\
\text { type }\end{array}$ & N & $\begin{array}{l}\text { Demag. } \\
\text { steps } \\
\left(\mathrm{mT} /{ }^{\circ} \mathrm{C}\right)\end{array}$ & $\begin{array}{c}\text { MAD } \\
\left({ }^{\circ}\right)\end{array}$ & Qual. \\
\hline $24 \mathrm{R}-2,8$ & 507.30 & 3.00 & 35.4 & $\mathrm{AF}$ & 3 & $35-45$ & 2.6 & $\mathrm{~A} 1$ \\
\hline $24 \mathrm{R}-2,9$ & 507.31 & 32.91 & 51.1 & $\mathrm{TH}$ & 4 & $400-500$ & 17.6 & B2 \\
\hline $24 \mathrm{R}-2,37$ & 507.59 & 32.83 & 41.6 & $\mathrm{TH}$ & 3 & $475-525$ & 2.3 & $\mathrm{~A} 1$ \\
\hline $25 \mathrm{R}-1,11$ & 509.61 & 5.80 & 66.6 & $\mathrm{AF}$ & 4 & $35-50$ & 0.7 & B1 \\
\hline $25 \mathrm{R}-1,42$ & 509.92 & 3.21 & -51.9 & AF & 4 & $25-40$ & 0.9 & B2 \\
\hline $25 \mathrm{R}-1,54$ & 510.04 & 8.14 & 61.0 & $\mathrm{TH}$ & 3 & $475-525$ & 11.4 & B1 \\
\hline $25 \mathrm{R}-1,75$ & 510.25 & 4.46 & 55.8 & $\mathrm{AF}$ & 4 & $35-50$ & 2.5 & A1 \\
\hline $25 \mathrm{R}-1,110$ & 510.60 & 4.46 & 52.8 & $\mathrm{AF}$ & 3 & $35-45$ & 1.3 & $\mathrm{C} 2$ \\
\hline $25 \mathrm{R}-1,132$ & 510.82 & 15.32 & 74.2 & $\mathrm{TH}$ & 5 & $400-500$ & 3.9 & A1 \\
\hline $25 \mathrm{R}-2,6$ & 510.97 & 9.70 & 40.3 & $\mathrm{TH}$ & 3 & $475-525$ & 7.3 & $\mathrm{~A} 1$ \\
\hline $25 \mathrm{R}-2,55$ & 511.46 & 3.90 & 43.6 & AF & 3 & $35-45$ & 1.5 & B2 \\
\hline $25 \mathrm{R}-2,76$ & 511.67 & 6.08 & 50.9 & $\mathrm{AF}$ & 3 & $35-45$ & 0.8 & $\mathrm{C} 2$ \\
\hline $25 \mathrm{R}-2,97$ & 511.88 & 11.35 & -5.5 & $\mathrm{AF}$ & 3 & $35-45$ & 0.9 & B2 \\
\hline $26 \mathrm{R}-1,37$ & 515.87 & 4.36 & -77.7 & $\mathrm{TH}$ & 3 & $450-500$ & 4.8 & A1 \\
\hline $26 \mathrm{R}-1,37$ & 515.87 & 3.13 & 46.8 & $\mathrm{AF}$ & 4 & $30-45$ & 3.2 & A1 \\
\hline $27 \mathrm{R}-1,66$ & 519.66 & 4.49 & 67.2 & $\mathrm{AF}$ & 3 & $35-45$ & 0.2 & B2 \\
\hline $27 \mathrm{R}-1,68$ & 519.68 & 10.26 & & $\mathrm{AF}$ & & & & $\mathrm{C} 2$ \\
\hline 27R-1, 84 & 519.84 & 15.91 & 54.1 & $\mathrm{TH}$ & 3 & $475-525$ & 1.5 & A1 \\
\hline $27 \mathrm{R}-1,136$ & 520.36 & 6.75 & -65.1 & AF & 4 & $35-50$ & 0.9 & B1 \\
\hline $27 \mathrm{R}-2,4$ & 520.54 & 5.98 & 62.9 & $\mathrm{AF}$ & 3 & $35-45$ & 1.6 & $\mathrm{C} 2$ \\
\hline $27 \mathrm{R}-2,13$ & 520.63 & 6.12 & 69.0 & $\mathrm{AF}$ & 3 & $30-40$ & 0.5 & A1 \\
\hline $27 \mathrm{R}-2,26$ & 520.76 & 17.10 & 68.4 & $\mathrm{TH}$ & 4 & $425-500$ & 12.5 & A1 \\
\hline 28R-1, 19 & 528.79 & 8.40 & & $\mathrm{TH}$ & & & & $\mathrm{C} 2$ \\
\hline $28 \mathrm{R}-1,46$ & 529.06 & 16.31 & 44.2 & $\mathrm{TH}$ & 3 & $475-525$ & 5.9 & $\mathrm{~A} 1$ \\
\hline $28 \mathrm{R}-1,49$ & 529.09 & 6.33 & 66.3 & AF & 3 & $30-40$ & 0.7 & $\mathrm{C} 2$ \\
\hline $30 \mathrm{R}-1,47$ & 535.67 & 8.61 & 48.7 & AF & 4 & $40-60$ & 2.3 & B2 \\
\hline $30 \mathrm{R}-1,63$ & 535.83 & 4.66 & 63.2 & $\mathrm{TH}$ & 3 & $500-550$ & 19.1 & B2 \\
\hline $30 \mathrm{R}-1,98$ & 536.18 & 5.35 & 47.6 & $\mathrm{AF}$ & 4 & $35-50$ & 0.7 & A1 \\
\hline $30 \mathrm{R}-1,99$ & 536.19 & 4.22 & -61.0 & $\mathrm{TH}$ & 3 & $450-525$ & 0.9 & A1 \\
\hline 30R-1, 106 & 536.26 & 3.13 & -46.2 & $\mathrm{TH}$ & 3 & $500-550$ & 5.1 & A1 \\
\hline 30R-1, 116 & 536.36 & 7.59 & -54.7 & $\mathrm{AF}$ & 3 & $45-60$ & 2.3 & $\mathrm{~A} 1$ \\
\hline $31 \mathrm{R}-1,49$ & 544.89 & 3.18 & 52.9 & AF & 3 & $45-60$ & 7.2 & $\mathrm{C} 2$ \\
\hline $31 \mathrm{R}-1,51$ & 544.91 & 3.37 & -43.7 & $\mathrm{TH}$ & 3 & $500-550$ & 9.2 & A1 \\
\hline $32 \mathrm{R}-1,19$ & 550.19 & 2.64 & -8.3 & $\mathrm{AF}$ & 4 & $30-45$ & 1.4 & B2 \\
\hline $32 \mathrm{R}-1,36$ & 550.36 & 11.36 & 21.8 & AF & 4 & $40-60$ & 3.9 & $\mathrm{~A} 1$ \\
\hline $32 \mathrm{R}-1,81$ & 550.81 & 4.99 & 39.9 & $\mathrm{TH}$ & 3 & $475-550$ & 2.4 & A1 \\
\hline $32 \mathrm{R}-1,119$ & 551.19 & 3.66 & 55.4 & AF & 3 & $20-30$ & 3.2 & $\mathrm{C} 2$ \\
\hline $32 \mathrm{R}-1,129$ & 551.29 & 18.58 & 22.0 & $\mathrm{AF}$ & 3 & $35-45$ & 0.6 & $\mathrm{C} 1$ \\
\hline $32 \mathrm{R}-2,18$ & 551.62 & 5.28 & & $\mathrm{AF}$ & & & & $\mathrm{C} 2$ \\
\hline $32 \mathrm{R}-2,54$ & 551.98 & 5.84 & 55.8 & $\mathrm{AF}$ & 3 & $40-50$ & 0.2 & B1 \\
\hline $32 \mathrm{R}-2,83$ & 552.27 & 15.50 & -30.2 & $\mathrm{AF}$ & 3 & $40-50$ & 1.9 & B2 \\
\hline $32 \mathrm{R}-2,105$ & 552.49 & 8.71 & 60.0 & $\mathrm{TH}$ & 3 & $500-550$ & 43.1 & B2 \\
\hline $32 \mathrm{R}-3,4$ & 552.98 & 10.71 & -13.0 & $\mathrm{TH}$ & 3 & $450-525$ & 14.8 & $\mathrm{C} 2$ \\
\hline $32 \mathrm{R}-3,19$ & 553.13 & 5.09 & -2.5 & $\mathrm{AF}$ & 4 & $35-50$ & 2.1 & B2 \\
\hline $32 \mathrm{R}-3,33$ & 553.27 & 7.23 & -2.9 & $\mathrm{TH}$ & 3 & $500-550$ & 10.9 & A1 \\
\hline $33 \mathrm{R}-1,67$ & 554.67 & 2.40 & 64.0 & $\mathrm{TH}$ & 3 & $500-550$ & 7.4 & A1 \\
\hline $33 \mathrm{R}-1,83$ & 554.83 & 6.41 & 58.9 & AF & 3 & $30-40$ & 0.6 & B1 \\
\hline $33 \mathrm{R}-1,110$ & 555.10 & 15.56 & & $\mathrm{AF}$ & & & & $\mathrm{C} 2$ \\
\hline $33 \mathrm{R}-1,132$ & 555.32 & 3.53 & 43.4 & $\mathrm{AF}$ & 4 & $30-45$ & 1.7 & B1 \\
\hline $33 \mathrm{R}-2,7$ & 555.57 & 5.64 & 34.9 & $\mathrm{AF}$ & 3 & $40-50$ & 1.2 & A1 \\
\hline $33 \mathrm{R}-2,19$ & 555.69 & 6.16 & -36.1 & $\mathrm{TH}$ & 4 & $475-550$ & 9.7 & $\mathrm{~A} 1$ \\
\hline $33 \mathrm{R}-2,40$ & 555.90 & 2.17 & 78.5 & $\mathrm{AF}$ & 3 & $30-40$ & 1.4 & $\mathrm{C} 2$ \\
\hline $33 \mathrm{R}-2,105$ & 556.55 & 3.11 & 37.7 & AF & 4 & $40-60$ & 1.6 & B1 \\
\hline $33 \mathrm{R}-2,124$ & 556.74 & 5.44 & 23.5 & $\mathrm{TH}$ & 3 & $500-550$ & 1.5 & A1 \\
\hline $34 \mathrm{R}-1,3$ & 560.63 & 6.33 & 36.6 & $\mathrm{TH}$ & 5 & $425-550$ & 14.2 & A1 \\
\hline $34 \mathrm{R}-1,28$ & 560.88 & 7.96 & -38.8 & AF & 4 & $35-50$ & 1.1 & $\mathrm{C} 1$ \\
\hline $34 \mathrm{R}-1,49$ & 561.09 & 3.95 & 32.7 & $\mathrm{TH}$ & 3 & $500-550$ & 12.6 & $\mathrm{~A} 1$ \\
\hline $34 \mathrm{R}-1,80$ & 561.40 & 4.57 & 11.1 & $\mathrm{AF}$ & 3 & $35-45$ & 0.7 & B2 \\
\hline $34 \mathrm{R}-2,26$ & 562.36 & 4.16 & -46.5 & $\mathrm{TH}$ & 4 & $450-525$ & 4.5 & A1 \\
\hline $34 \mathrm{R}-2,35$ & 562.45 & 4.44 & 51.2 & AF & 3 & $40-50$ & 0.9 & B1 \\
\hline $34 \mathrm{R}-2,87$ & 562.97 & 4.64 & -72.5 & $\mathrm{AF}$ & 3 & $35-45$ & 1.5 & A1 \\
\hline $34 \mathrm{R}-2,98$ & 563.08 & 7.85 & -46.3 & $\mathrm{AF}$ & 4 & $30-45$ & 2.3 & A1 \\
\hline 34R-2, 119 & 563.29 & 9.10 & 11.5 & $\mathrm{TH}$ & 4 & $475-550$ & 5.3 & B2 \\
\hline $35 \mathrm{R}-1,16$ & 563.76 & 3.05 & -0.6 & $\mathrm{TH}$ & 4 & $475-550$ & 4.3 & B1 \\
\hline $35 \mathrm{R}-1,27$ & 563.87 & 7.61 & -14.2 & $\mathrm{TH}$ & 4 & $450-525$ & 14.2 & A1 \\
\hline $35 \mathrm{R}-1,54$ & 564.14 & 3.17 & -6.3 & AF & 3 & $40-50$ & 12.7 & $\mathrm{C} 2$ \\
\hline $35 \mathrm{R}-1,77$ & 564.37 & 7.17 & 45.2 & $\mathrm{AF}$ & 3 & $40-50$ & 1.3 & A1 \\
\hline $35 \mathrm{R}-2,20$ & 565.27 & 6.03 & 51.2 & $\mathrm{AF}$ & 3 & $35-45$ & 1.2 & $\mathrm{C} 1$ \\
\hline
\end{tabular}


Table T9 (continued).

\begin{tabular}{|c|c|c|c|c|c|c|c|c|}
\hline $\begin{array}{l}\text { Core, section, } \\
\text { interval }(\mathrm{cm})\end{array}$ & $\begin{array}{l}\text { Depth } \\
\text { (mbsf) }\end{array}$ & $\begin{array}{l}\text { NRM } \\
(\mathrm{A} / \mathrm{m})\end{array}$ & $\begin{array}{c}\text { PCA } \\
\left({ }^{\circ}\right)\end{array}$ & $\begin{array}{l}\text { Demag. } \\
\text { type }\end{array}$ & $N$ & $\begin{array}{c}\text { Demag. } \\
\text { steps } \\
\left(\mathrm{mT} /{ }^{\circ} \mathrm{C}\right)\end{array}$ & $\begin{array}{c}\text { MAD } \\
\left({ }^{\circ}\right)\end{array}$ & Qual. \\
\hline $35 \mathrm{R}-2,41$ & 565.48 & 5.07 & 38.2 & $\mathrm{AF}$ & 4 & $35-50$ & 1.3 & A1 \\
\hline 35R-2, 104 & 566.11 & 27.67 & 64.2 & $\mathrm{TH}$ & 4 & $450-550$ & 17.9 & $\mathrm{~A} 1$ \\
\hline $35 \mathrm{R}-2,118$ & 566.25 & 10.46 & 38.8 & $\mathrm{TH}$ & 3 & $475-525$ & 18.4 & A1 \\
\hline $35 \mathrm{R}-2,128$ & 566.35 & 5.30 & 34.9 & $\mathrm{AF}$ & 4 & $40-60$ & 2.2 & $\mathrm{~A} 1$ \\
\hline $35 \mathrm{R}-3,12$ & 566.61 & 21.16 & 32.1 & $\mathrm{TH}$ & 4 & $450-525$ & 17.5 & A1 \\
\hline $36 \mathrm{R}-1,30$ & 573.50 & 16.51 & 66.5 & $\mathrm{AF}$ & 4 & $40-60$ & 2.3 & $\mathrm{C} 2$ \\
\hline $36 \mathrm{R}-1,41$ & 573.61 & 7.00 & 34.6 & $\mathrm{AF}$ & 3 & $35-45$ & 2.7 & $\mathrm{C} 1$ \\
\hline $36 \mathrm{R}-1,90$ & 574.10 & 3.26 & -52.6 & $\mathrm{TH}$ & 5 & $450-550$ & 6.3 & $\mathrm{~A} 1$ \\
\hline $36 \mathrm{R}-1,124$ & 574.44 & 5.74 & 56.4 & $\mathrm{AF}$ & 3 & $35-45$ & 0.7 & B1 \\
\hline $36 \mathrm{R}-1,144$ & 574.64 & 6.09 & -19.9 & $\mathrm{TH}$ & 2 & $525-550$ & 7.5 & $\mathrm{C} 2$ \\
\hline $36 \mathrm{R}-2,8$ & 574.78 & 4.25 & -50.9 & $\mathrm{TH}$ & 3 & $500-550$ & 1.4 & $\mathrm{~A} 1$ \\
\hline $36 \mathrm{R}-2,85$ & 575.55 & 5.43 & 52.8 & $\mathrm{AF}$ & 3 & $35-45$ & 2.2 & B1 \\
\hline 36R-2, 101 & 575.71 & 8.19 & 53.9 & $\mathrm{AF}$ & 3 & $25-35$ & 1.7 & $\mathrm{C} 2$ \\
\hline $36 \mathrm{R}-2,122$ & 575.92 & 6.63 & -55.3 & $\mathrm{TH}$ & 4 & $475-550$ & 3.3 & $\mathrm{~A} 1$ \\
\hline $36 \mathrm{R}-3,36$ & 576.53 & 3.76 & -61.9 & $\mathrm{TH}$ & 3 & $500-550$ & 0.9 & $\mathrm{~A} 1$ \\
\hline $36 \mathrm{R}-3,85$ & 577.02 & 3.10 & -25.1 & $\mathrm{TH}$ & 4 & $450-550$ & 9.6 & A1 \\
\hline
\end{tabular}

Notes: $\mathrm{NRM}=$ natural remanent magnetization intensity. PCA = inclination of characteristic remanent magnetization determined by principal component analysis. Demag. type $=$ method of sample demagnetization. $\mathrm{AF}=$ alternating field, $\mathrm{TH}=$ thermal. $\mathrm{N}=$ number of demagnetization steps used for principal component fit. Demag. steps = demagnetization steps used for principal component analysis. MAD = maximum angle of deviation (error parameter; see Kirschvink, 1980). Qual. = subjective classification of demagnetization behavior. A1 = univectorial decay toward orthogonal vector $(\mathrm{OV})$ plot origin with low scatter, $\mathrm{A} 2=$ univectorial decay toward OV origin with higher scatter, $\mathrm{B} 1=$ univectorial decay, close to but not directly to OV origin, B2 = univectorial decay, but not close to OV origin, $\mathrm{C} 1=$ sample directions veer from OV origin at high demagnetization steps but trend close to origin, $\mathrm{C} 2$ = sample directions veer from OV origin at high demagnetization steps and trends away from OV origin, $\mathrm{D}=$ directions inconsistent. 
Table T10. Composition of pore waters, Hole U1301C. (Continued on next page.)

\begin{tabular}{|c|c|c|c|c|c|c|c|c|c|c|c|c|c|c|c|c|}
\hline \multirow{2}{*}{$\begin{array}{l}\text { Core, section, } \\
\text { interval }(\mathrm{cm})\end{array}$} & \multirow{2}{*}{$\begin{array}{l}\text { Depth } \\
\text { (mbsf) }\end{array}$} & \multirow[b]{2}{*}{$\mathrm{pH}$} & \multirow{2}{*}{$\begin{array}{c}\text { Alk } \\
(\mathrm{mmol} / \mathrm{kg})\end{array}$} & \multirow{2}{*}{$\begin{array}{l}\text { Salinity } \\
\text { (RI) }\end{array}$} & \multicolumn{6}{|c|}{ Cations and anions $(\mathrm{mmol} / \mathrm{kg})$} & \multicolumn{6}{|c|}{ Minor and trace elements $(\mu \mathrm{mol} / \mathrm{kg})$} \\
\hline & & & & & $\mathrm{Cl}$ & $\mathrm{Mg}$ & $\mathrm{Ca}$ & $\mathrm{Na}$ & $\mathrm{K}$ & $\mathrm{SO}_{4}$ & $\mathrm{PO}_{4}$ & $\mathrm{NH}_{4}$ & $\mathrm{Si}$ & $B$ & $\mathrm{Ba}$ & $\mathrm{Sr}$ \\
\hline \multicolumn{17}{|l|}{ 301-U1301C- } \\
\hline $1 \mathrm{H}-1,130-150$ & 1.3 & 7.84 & ND & 35 & 542.0 & 51.0 & 9.76 & 480 & 11.6 & 27.0 & 18.3 & 243 & 639 & 446 & 0.17 & 75.8 \\
\hline $1 \mathrm{H}-3,130-150$ & 4.3 & 7.96 & 12.16 & 37 & 550.0 & 50.7 & 9.46 & 478 & 11.0 & 21.9 & 35.7 & 595 & 632 & 438 & 0.45 & 82.6 \\
\hline $2 \mathrm{H}-3,130-150$ & 9.4 & 7.70 & 18.83 & 36 & 551.5 & 50.4 & 9.20 & 477 & 9.76 & 15.8 & 45.7 & 1100 & 576 & 434 & 0.86 & 80.6 \\
\hline $2 \mathrm{H}-5,130-150$ & 12.4 & 7.67 & 21.50 & 37 & 553.5 & 50.6 & 8.94 & 478 & 9.19 & 13.1 & 48.2 & 1430 & 541 & 444 & 0.78 & 84.3 \\
\hline $3 \mathrm{H}-2,130-150$ & 17.4 & 7.80 & 26.25 & 38 & 554.1 & 51.9 & 8.27 & 475 & 8.00 & 9.30 & 25.5 & 1600 & 426 & 366 & 0.83 & 86.2 \\
\hline $3 \mathrm{H}-4,130-150$ & 20.4 & 7.74 & 28.06 & 36 & 557.7 & 51.4 & 7.50 & 473 & 7.71 & 7.70 & 35.7 & 1670 & 432 & 383 & 0.97 & 90.1 \\
\hline $4 \mathrm{H}-3,130-150$ & 28.4 & 7.86 & ND & 36 & 556.1 & 50.9 & 7.38 & 477 & 6.79 & 4.10 & 38.8 & 1820 & 447 & 348 & 1.52 & 85.7 \\
\hline $4 \mathrm{H}-5,130-150$ & 31.3 & 8.14 & 31.62 & 36 & 558.1 & 51.1 & 7.14 & 475 & 6.80 & 3.20 & 54.1 & 1960 & 415 & 341 & 1.77 & 83.0 \\
\hline $5 \mathrm{H}-2$ mud, $0-40$ & 34.6 & 7.97 & ND & 36 & 558.8 & 50.3 & 6.83 & 474 & 6.83 & 2.90 & 41.4 & 2020 & 547 & 392 & 2.93 & 95.0 \\
\hline $5 \mathrm{H}-2$ sand, $0-40$ & 34.6 & 7.90 & 31.54 & 36 & 559.1 & 50.8 & 6.96 & 472 & 7.00 & 3.10 & 51.0 & 2140 & 461 & 351 & 2.90 & 92.4 \\
\hline $6 \mathrm{H}-3,110-150$ & 47.2 & 7.98 & 30.72 & 36 & 555.1 & 49.1 & 6.36 & 482 & 7.08 & 0.79 & 43.9 & 2000 & 581 & 287 & 7.11 & 97.2 \\
\hline $6 \mathrm{H}-5,110-150$ & 50.4 & 7.88 & 30.72 & 35 & 559.8 & 49.5 & 6.77 & 483 & 6.87 & 0.63 & 47.0 & 1830 & 651 & 403 & 7.11 & 102 \\
\hline $7 \mathrm{H}-3,110-150$ & 56.9 & 7.88 & 29.78 & 35 & 559.6 & 47.7 & 7.12 & 479 & 7.15 & 0.45 & 43.9 & 1710 & 675 & 378 & 9.09 & 102 \\
\hline $8 \mathrm{H}-1,110-150$ & 63.2 & 7.83 & ND & 36 & 558.5 & 46.5 & 7.30 & 479 & 6.87 & 0.51 & 28.3 & 1290 & 776 & 381 & 12.6 & 99.6 \\
\hline $9 \mathrm{H}-5,110-150$ & 78.7 & 7.91 & ND & 35 & 558.4 & 43.2 & 8.35 & 482 & 5.94 & 0.31 & 5.5 & 1230 & 297 & 353 & 10.9 & 80.7 \\
\hline $10 \mathrm{H}-1,110-150$ & 82.2 & 7.79 & 26.01 & 35 & 559.1 & 41.3 & 6.79 & 485 & 6.64 & 0.37 & 7.8 & 1530 & 623 & 425 & 14.9 & 86.5 \\
\hline $11 \mathrm{H}-1,110-150$ & 91.7 & 7.91 & 23.84 & 35 & 555.0 & 40.2 & 8.08 & 484 & 6.97 & 0.95 & 6.6 & 1590 & 550 & 413 & 17.1 & 79.2 \\
\hline $13 \mathrm{H}-1,110-150$ & 110.7 & 7.98 & 15.08 & 34 & 557.7 & 34.7 & 9.83 & 479 & 6.42 & ND & 6.6 & 1610 & 909 & 433 & 56.4 & 122 \\
\hline $15 \mathrm{H}-1,110-150$ & 179.2 & 8.11 & 1.314 & 34 & 550.1 & 9.11 & 39.5 & 480 & 1.49 & 10.0 & ND & 828 & 273 & 559 & 1.96 & 143 \\
\hline $15 \mathrm{H}-4,110-150$ & 183.7 & 7.51 & 0.529 & 34 & 561.2 & 6.06 & 42.6 & 480 & 1.43 & 7.30 & ND & 727 & 436 & 519 & 1.68 & 167 \\
\hline $16 \mathrm{H}-2,110-150$ & 190.2 & 7.71 & 0.972 & 34 & 558.8 & 6.64 & 42.2 & 485 & 1.42 & 6.70 & ND & 717 & 600 & 588 & 3.23 & 148 \\
\hline $17 \mathrm{H}-2,110-150$ & 238.4 & 8.20 & 0.313 & 36 & 556.4 & 4.46 & 55.9 & 469 & 1.95 & 13.5 & ND & 397 & 201 & 356 & 0.70 & 135 \\
\hline $17 \mathrm{H}-5,110-150$ & 242.9 & 7.99 & 0.331 & 37 & 559.2 & 4.51 & 58.4 & 466 & 1.90 & 13.7 & ND & 351 & 214 & 322 & 1.57 & 171 \\
\hline $18 \mathrm{H}-2,110-150$ & 248.9 & 8.17 & 0.667 & 36 & 554.6 & 4.65 & 58.9 & 462 & 2.04 & 14.5 & ND & 316 & 290 & 391 & 0.84 & 205 \\
\hline $18 \mathrm{H}-4,110-150$ & 251.9 & 7.81 & 0.572 & 36 & 556.9 & 4.44 & 59.7 & 462 & 2.16 & 15.1 & ND & 292 & 328 & 380 & 2.13 & 235 \\
\hline $19 \mathrm{H}-1,110-150$ & 256.9 & 7.94 & 1.091 & 35 & 521.2 & 21.8 & 38.7 & 444 & 3.93 & 22.2 & ND & 243 & 236 & 430 & 0.27 & 171 \\
\hline $19 \mathrm{H}-2,110-150$ & 258.4 & 7.56 & 0.416 & 36 & 552.3 & 4.64 & 60.1 & 456 & 2.40 & 15.5 & 2.0 & 263 & 330 & 391 & 0.51 & 185 \\
\hline $19 \mathrm{H}-3,110-150$ & 259.9 & 7.01 & 0.322 & 36 & 551.1 & 7.14 & 64.0 & 452 & 2.23 & 16.3 & 1.5 & 238 & 317 & 334 & 0.81 & 192 \\
\hline $19 \mathrm{H}-4,110-150$ & 261.4 & 7.15 & 0.363 & 36 & 554.5 & 5.21 & 62.0 & 468 & 2.33 & 16.1 & 6.9 & 246 & 430 & 425 & 1.03 & 253 \\
\hline \multicolumn{17}{|l|}{ 301-U1301D- } \\
\hline $1 \mathrm{H}-1,110-150$ & 121.1 & 7.84 & 5.82 & ND & 547.8 & 31.8 & 11.7 & 470 & 5.40 & 0.0 & ND & ND & 327 & 493 & 28.5 & 144 \\
\hline $2 \mathrm{H}-1,98-118$ & 130.48 & 7.75 & 3.31 & 34 & 551.5 & 19.2 & 22.1 & 474 & 5.09 & 1.2 & ND & ND & ND & ND & ND & 150 \\
\hline $2 \mathrm{H}-2,110-150$ & 131.78 & 7.79 & 3.64 & 34 & 557.2 & 17.7 & 22.8 & 483 & 5.47 & 2.0 & ND & ND & 401 & 542 & 6.84 & 145 \\
\hline $3 \mathrm{H}-2,132-150$ & 141.82 & 7.68 & 2.69 & 34 & 556.8 & 14.1 & 28.5 & 477 & 4.54 & 2.7 & ND & ND & 589 & 556 & 3.48 & 154 \\
\hline $3 \mathrm{H}-3,14-54$ & 142.14 & 7.69 & 2.89 & 34 & 558.0 & 14.1 & 28.7 & 480 & 4.73 & 2.9 & ND & ND & 620 & 540 & 3.51 & 151 \\
\hline $4 \mathrm{H}-2,110-150$ & 151.1 & 7.66 & 3.11 & 35 & 558.0 & 14.2 & 32.9 & 482 & 4.76 & 3.0 & ND & ND & 866 & 574 & 3.74 & 156 \\
\hline $5 \mathrm{H}-1,110-150$ & 159.1 & 7.75 & 2.53 & 35 & 556.9 & 12.6 & 32.8 & 481 & 3.73 & 4.0 & ND & ND & 751 & 611 & 2.98 & 155 \\
\hline $5 \mathrm{H}-5,0-40$ & 164 & 7.74 & 2.44 & 35 & 560.0 & 12.2 & 32.7 & 483 & 3.72 & 4.1 & ND & ND & 669 & 656 & 2.98 & 154 \\
\hline $6 \mathrm{H}-2,110-150$ & 170.1 & 7.94 & 1.10 & 35 & 558.8 & 10.8 & 37.4 & 476 & 2.96 & 5.3 & ND & ND & 454 & 506 & 2.58 & 157 \\
\hline
\end{tabular}

Notes: $\mathrm{RI}=$ refractive index, repeated in percent. $\mathrm{ND}=$ not determined. 


\begin{tabular}{|c|c|c|c|c|c|c|c|c|}
\hline & \multirow{2}{*}{$\begin{array}{l}\text { Core, section, } \\
\text { interval }(\mathrm{cm})\end{array}$} & \multirow{2}{*}{$\begin{array}{l}\text { Depth } \\
\text { (mbsf) }\end{array}$} & \multicolumn{3}{|c|}{ Minor and trace elements $(\mu \mathrm{mol} / \mathrm{kg})$} & \multicolumn{3}{|c|}{ Carbon $(\mathrm{mmol} / \mathrm{kg})$} \\
\hline & & & $\mathrm{Mn}$ & $\mathrm{Li}$ & $\mathrm{Fe}$ & Total & Inorganic & Organic \\
\hline & 301-U1301C- & & & & & & & \\
\hline & $1 \mathrm{H}-1,130-150$ & 1.3 & 75.4 & 19.2 & 0.5 & 7.4 & 4.6 & 2.84 \\
\hline & $1 \mathrm{H}-3,130-150$ & 4.3 & 34.1 & 16.8 & 8.2 & ND & ND & ND \\
\hline & $2 \mathrm{H}-3,130-150$ & 9.4 & 15.5 & 9.1 & 60.0 & 30.3 & 17.8 & 12.5 \\
\hline & $2 \mathrm{H}-5,130-150$ & 12.4 & 12.8 & 7.5 & 67.0 & 29.3 & 18.7 & 10.5 \\
\hline & $3 \mathrm{H}-2,130-150$ & 17.4 & 8.9 & 5.0 & 115 & 27.2 & 14.1 & 13.1 \\
\hline & $3 \mathrm{H}-4,130-150$ & 20.4 & 5.0 & 3.4 & 134 & 30.9 & 17.2 & 13.7 \\
\hline & $4 \mathrm{H}-3,130-150$ & 28.4 & 5.0 & 3.5 & 65.3 & 38.1 & 21.4 & 16.7 \\
\hline & $4 \mathrm{H}-5,130-150$ & 31.3 & 4.2 & 4.2 & 57.5 & 40.1 & 22.1 & 18.0 \\
\hline & $5 \mathrm{H}-2$ mud, $0-40$ & 34.6 & 4.3 & 4.7 & 53.0 & 39.4 & 21.9 & 17.5 \\
\hline & $5 \mathrm{H}-2$ sand, $0-40$ & 34.6 & 4.2 & 5.0 & 89.0 & 36.0 & 20.1 & 15.9 \\
\hline & $6 \mathrm{H}-3,110-150$ & 47.2 & 5.7 & 5.9 & 34.2 & 43.5 & 24.3 & 19.1 \\
\hline & $6 \mathrm{H}-5,110-150$ & 50.4 & 8.6 & 6.2 & 26.6 & 27.1 & 16.2 & 10.9 \\
\hline & $7 \mathrm{H}-3,110-150$ & 56.9 & 8.1 & 6.3 & 44.2 & 41.5 & 22.2 & 19.3 \\
\hline & $8 \mathrm{H}-1,110-150$ & 63.2 & 8.4 & 6.7 & 30.7 & 18.0 & 9.73 & 8.26 \\
\hline & $9 \mathrm{H}-5,110-150$ & 78.7 & 6.3 & 5.4 & 7.1 & 36.1 & 18.7 & 17.4 \\
\hline & $10 \mathrm{H}-1,110-150$ & 82.2 & 9.9 & 5.3 & 115 & 30.8 & 20.4 & 10.5 \\
\hline & $11 \mathrm{H}-1,110-150$ & 91.7 & 6.5 & 5.7 & 39.1 & 25.6 & 14.4 & 11.2 \\
\hline & $13 \mathrm{H}-1,110-150$ & 110.7 & 21.1 & 19.0 & 26.9 & 18.0 & 9.09 & 8.9 \\
\hline & $15 \mathrm{H}-1,110-150$ & 179.2 & 36.3 & 49.0 & 1.9 & 1.79 & 0.757 & 1.03 \\
\hline & $15 \mathrm{H}-4,110-150$ & 183.7 & 36.0 & 60.6 & 6.7 & 1.36 & 0.322 & 1.03 \\
\hline & $16 \mathrm{H}-2,110-150$ & 190.2 & 56.0 & 63.2 & 5.5 & 1.38 & 0.380 & 1.00 \\
\hline & $17 \mathrm{H}-2,110-150$ & 238.4 & 49.6 & 66.7 & 1.0 & 1.24 & 0.293 & 0.944 \\
\hline & $17 \mathrm{H}-5,110-150$ & 242.9 & 63.4 & 73.1 & 1.1 & 0.654 & 0.216 & 0.44 \\
\hline & $18 \mathrm{H}-2,110-150$ & 248.9 & 133 & 73.6 & 2.8 & 1.33 & 0.326 & 1.00 \\
\hline & $18 \mathrm{H}-4,110-150$ & 251.9 & 146 & 73.6 & 6.5 & 0.568 & 0.258 & 0.310 \\
\hline & $19 \mathrm{H}-1,110-150$ & 256.9 & 251 & 43.0 & 4.4 & 1.36 & 0.525 & 0.832 \\
\hline & $19 \mathrm{H}-2,110-150$ & 258.4 & 178 & 62.7 & 3.4 & 0.963 & 0.012 & 0.951 \\
\hline & $19 \mathrm{H}-3,110-150$ & 259.9 & 169 & 62.4 & 2.8 & ND & ND & ND \\
\hline & $19 \mathrm{H}-4,110-150$ & 261.4 & 155 & 70.8 & 9.8 & 1.36 & 0.163 & 1.19 \\
\hline & 301-U1301D- & & & & & & & \\
\hline & $1 \mathrm{H}-1,110-150$ & 121.1 & 6.38 & 24.6 & 4.23 & 5.10 & 4.29 & 0.82 \\
\hline & $2 \mathrm{H}-1,98-118$ & 130.48 & ND & 30.7 & ND & ND & ND & ND \\
\hline & $2 \mathrm{H}-2,110-150$ & 131.78 & 18.0 & 32.0 & 15.6 & ND & ND & ND \\
\hline & $3 \mathrm{H}-2,132-150$ & 141.82 & 21.8 & 41.3 & 13.2 & 2.94 & 2.32 & 0.63 \\
\hline & $3 \mathrm{H}-3,14-54$ & 142.14 & 21.5 & 41.3 & 23.7 & 3.12 & 2.29 & 0.82 \\
\hline & $4 \mathrm{H}-2,110-150$ & 151.1 & 34.3 & 46.8 & 20.0 & 3.51 & 2.94 & 0.57 \\
\hline & $5 \mathrm{H}-1,110-150$ & 159.1 & 41.7 & 49.5 & 18.3 & 2.98 & 2.44 & 0.54 \\
\hline & $5 \mathrm{H}-5,0-40$ & 164 & 37.9 & 51.0 & 17.3 & 3.25 & 2.64 & 0.62 \\
\hline & $6 \mathrm{H}-2,110-150$ & 170.1 & 25.2 & 55.8 & 2.73 & 2.38 & 1.69 & 0.69 \\
\hline
\end{tabular}


Table T11. Headspace composition data, Holes U1301C and U1301D.

\begin{tabular}{|c|c|c|c|}
\hline $\begin{array}{l}\text { Core, section, } \\
\text { interval }(\mathrm{cm})\end{array}$ & $\begin{array}{l}\text { Depth } \\
\text { (mbsf) }\end{array}$ & $\begin{array}{c}\mathrm{C}_{1} \text { in headspace } \\
\text { (ppmv) }\end{array}$ & $\begin{array}{c}\mathrm{CH}_{4} \text { in pore water } \\
(\mathrm{mmol} / \mathrm{kg})\end{array}$ \\
\hline \multicolumn{4}{|l|}{ 301-U1301C- } \\
\hline $1 \mathrm{H}-2,0-5$ & 1.5 & 2 & 0.001 \\
\hline $1 \mathrm{H}-4,0-5$ & 4.5 & 2 & 0.002 \\
\hline $2 \mathrm{H}-4,0-5$ & 9.6 & 2 & 0.001 \\
\hline $2 \mathrm{H}-5,0-5$ & 11.1 & 2 & 0.001 \\
\hline $2 \mathrm{H}-6,0-5$ & 12.6 & 2 & 0.001 \\
\hline $3 \mathrm{H}-3,0-5$ & 17.6 & 2 & 0.001 \\
\hline $3 \mathrm{H}-5,0-5$ & 20.6 & 3 & 0.001 \\
\hline $4 \mathrm{H}-4,0-5$ & 28.6 & 2 & 0.001 \\
\hline $4 \mathrm{H}-6,0-5$ & 31.6 & 2 & 0.001 \\
\hline $4 \mathrm{H}-7,0-5$ & 33.1 & 2 & 0.002 \\
\hline $5 \mathrm{H}-1,95-100$ & 34.6 & 2 & 0.002 \\
\hline $6 \mathrm{H}-4,0-5$ & 47.6 & 2 & 0.001 \\
\hline $6 \mathrm{H}-6,0-5$ & 50.6 & 2 & 0.002 \\
\hline $6 \mathrm{H}-7,0-5$ & 52.1 & 3 & 0.001 \\
\hline $7 \mathrm{H}-2,0-5$ & 54.1 & 2 & 0.001 \\
\hline $8 \mathrm{H}-2,0-5$ & 63.6 & 6 & 0.004 \\
\hline $9 \mathrm{H}-2,0-5$ & 73.1 & 1810 & 1.03 \\
\hline $9 \mathrm{H}-4,0-5$ & 76.1 & 2760 & 1.65 \\
\hline $9 \mathrm{H}-6,0-5$ & 79.1 & 3410 & 2.17 \\
\hline $10 \mathrm{H}-2,0-5$ & 82.6 & 1230 & 0.963 \\
\hline $10 \mathrm{H}-7,0-5$ & 90.1 & 3010 & 2.17 \\
\hline $11 \mathrm{H}-2,0-5$ & 92.1 & 7960 & 4.65 \\
\hline $12 \mathrm{H}-1,145-150$ & 101.6 & 1990 & 1.5 \\
\hline $13 \mathrm{H}-2,0-5$ & 111.1 & 6790 & 5.37 \\
\hline $15 \mathrm{H}-2,0-5$ & 179.6 & 6 & 0.003 \\
\hline $15 \mathrm{H}-5,0-5$ & 184.1 & 5 & 0.003 \\
\hline $16 \mathrm{H}-3,0-5$ & 190.6 & 4 & 0.002 \\
\hline $17 \mathrm{H}-3,0-5$ & 238.8 & 5 & 0.003 \\
\hline $17 \mathrm{H}-6,0-5$ & 243.3 & 6 & 0.003 \\
\hline $18 \mathrm{H}-3,0-5$ & 249.3 & 5 & 0.003 \\
\hline $18 \mathrm{H}-5,0-5$ & 252.3 & 4 & 0.003 \\
\hline $19 \mathrm{H}-2,0-5$ & 257.3 & 4 & 0.002 \\
\hline $19 \mathrm{H}-3,0-5$ & 258.8 & 4 & 0.002 \\
\hline $19 \mathrm{H}-4,0-5$ & 260.3 & 5 & 0.003 \\
\hline $19 \mathrm{H}-5,0-5$ & 261.8 & 5 & 0.003 \\
\hline \multicolumn{4}{|l|}{ 301-U1301D- } \\
\hline $1 \mathrm{H}-2,0-5$ & 121.5 & 1950 & 1.04 \\
\hline $2 \mathrm{H}-3,0-5$ & 132.2 & 11 & 0.006 \\
\hline $3 \mathrm{H}-2,0-5$ & 140.5 & 8 & 0.004 \\
\hline $3 \mathrm{H}-3,0-5$ & 142.0 & 5 & 0.003 \\
\hline $3 \mathrm{H}-3,69-74$ & 142.7 & 4 & 0.002 \\
\hline $4 \mathrm{H}-3,0-5$ & 151.5 & 5 & 0.003 \\
\hline $5 \mathrm{H}-2,0-5$ & 159.5 & 5 & 0.003 \\
\hline $5 \mathrm{H}-5,0-5$ & 164.0 & 4 & 0.002 \\
\hline $6 \mathrm{H}-3,0-5$ & 170.5 & 6 & 0.003 \\
\hline $6 \mathrm{H}-6,0-5$ & 175.0 & 4 & 0.002 \\
\hline
\end{tabular}


Table T12. Composition of the sediment solid phase, Hole U1301C.

\begin{tabular}{|c|c|c|c|c|c|c|c|}
\hline \multirow{2}{*}{$\begin{array}{l}\text { Core, section, } \\
\text { interval }(\mathrm{cm})\end{array}$} & \multirow{2}{*}{$\begin{array}{l}\text { Depth } \\
\text { (mbsf) }\end{array}$} & \multicolumn{3}{|c|}{ Carbon (wt\%) } & \multirow{2}{*}{$\begin{array}{c}\text { Total } \\
\text { nitrogen } \\
\text { (wt\%) }\end{array}$} & \multirow{2}{*}{$\begin{array}{c}\text { Total } \\
\text { hydrogen } \\
\text { (wt\%) }\end{array}$} & \multirow{2}{*}{$\begin{array}{l}\mathrm{C} / \mathrm{N} \\
\text { atomic } \\
\text { ratio }\end{array}$} \\
\hline & & Total & Inorganic & Organic & & & \\
\hline \multicolumn{8}{|l|}{ 301-U1301C- } \\
\hline $1 \mathrm{H}-2,2-3$ & 1.50 & 1.24 & 0.33 & 0.91 & 0.104 & 0.78 & 7.6 \\
\hline $1 \mathrm{H}-3,68-69$ & 3.68 & 1.21 & 0.32 & 0.89 & 0.085 & 0.92 & 9.0 \\
\hline $2 \mathrm{H}-3,41-42$ & 8.51 & 0.91 & 0.21 & 0.70 & 0.033 & 0.82 & 17.9 \\
\hline $2 \mathrm{H}-6,0-1$ & 12.60 & 0.65 & 0.37 & 0.28 & 0.024 & 0.62 & 10.1 \\
\hline $3 \mathrm{H}-3,3-4$ & 17.63 & 0.63 & 0.39 & 0.24 & 0.032 & 0.44 & 6.5 \\
\hline $3 \mathrm{H}-5,3-4$ & 20.63 & 0.89 & 0.58 & 0.31 & 0.041 & 0.68 & 6.4 \\
\hline $3 \mathrm{H}-7,7-8$ & 23.37 & 0.69 & 0.44 & 0.25 & 0.032 & 0.54 & 6.8 \\
\hline $4 \mathrm{H}-4,2-3$ & 28.62 & 0.85 & 0.45 & 0.40 & 0.030 & 0.42 & 11.1 \\
\hline $4 \mathrm{H}-6,1-2$ & 31.61 & 0.82 & 0.51 & 0.31 & 0.047 & 0.64 & 5.6 \\
\hline $4 \mathrm{H}-7,1-2$ & 33.11 & 0.82 & 0.57 & 0.25 & 0.042 & 0.62 & 5.1 \\
\hline $5 \mathrm{H}-1,99-100$ & 34.59 & 0.31 & 0.24 & 0.07 & 0.003 & 0.16 & 19.6 \\
\hline $6 \mathrm{H}-4,0-1$ & 47.60 & 0.69 & 0.42 & 0.27 & 0.038 & 0.64 & 6.1 \\
\hline $6 \mathrm{H}-5,0-1$ & 49.10 & 0.99 & 0.69 & 0.30 & 0.035 & 0.56 & 7.3 \\
\hline $6 \mathrm{H}-6,0-1$ & 50.60 & 0.36 & 0.16 & 0.20 & 0.017 & 0.25 & 10.0 \\
\hline 7H-3, 109-110 & 56.69 & 0.14 & 0.09 & 0.05 & 0.001 & 0.12 & 37.3 \\
\hline $8 \mathrm{H}-1,99-100$ & 63.09 & 0.17 & 0.10 & 0.07 & 0.002 & 0.12 & 26.1 \\
\hline $9 \mathrm{H}-6,15-16$ & 79.25 & 0.52 & 0.20 & 0.32 & 0.043 & 0.73 & 6.4 \\
\hline $10 \mathrm{H}-1,99-100$ & 82.09 & 0.24 & 0.17 & 0.07 & 0.000 & 0.10 & \\
\hline $11 \mathrm{H}-2,25-26$ & 92.35 & 0.63 & 0.37 & 0.26 & 0.033 & 0.48 & 6.6 \\
\hline $13 \mathrm{H}-1,97-98$ & 110.57 & 0.68 & 0.21 & 0.47 & 0.058 & 0.93 & 6.9 \\
\hline $13 \mathrm{H}-3,27-28$ & 112.87 & 0.61 & 0.15 & 0.46 & 0.049 & 0.76 & 8.1 \\
\hline $15 \mathrm{H}-2,0-1$ & 179.60 & 0.37 & 0.11 & 0.26 & 0.031 & 0.54 & 7.2 \\
\hline $15 \mathrm{H}-5,0-1$ & 184.10 & 7.93 & 7.58 & 0.35 & 0.041 & 0.37 & 7.2 \\
\hline $16 \mathrm{H}-3,0-1$ & 190.60 & 0.39 & 0.20 & 0.19 & 0.012 & 0.36 & 13.3 \\
\hline $17 \mathrm{H}-3,0-1$ & 238.80 & 0.62 & 0.19 & 0.43 & 0.050 & 0.89 & 7.4 \\
\hline $17 \mathrm{H}-6,0-1$ & 243.30 & 2.33 & 1.91 & 0.42 & 0.032 & 0.63 & 11.1 \\
\hline $18 \mathrm{H}-3,0-1$ & 249.30 & 0.44 & 0.14 & 0.30 & 0.036 & 0.85 & 7.1 \\
\hline $18 \mathrm{H}-5,0-1$ & 252.30 & 0.43 & 0.12 & 0.31 & 0.029 & 0.79 & 9.0 \\
\hline $19 \mathrm{H}-2,0-1$ & 257.30 & 0.62 & 0.36 & 0.26 & 0.029 & 0.72 & 7.8 \\
\hline $19 \mathrm{H}-3,0-1$ & 258.80 & 1.91 & 1.52 & 0.39 & 0.041 & 0.69 & 8.2 \\
\hline
\end{tabular}


Table T13. Microbiology sampling of sediment, Hole U1301C.

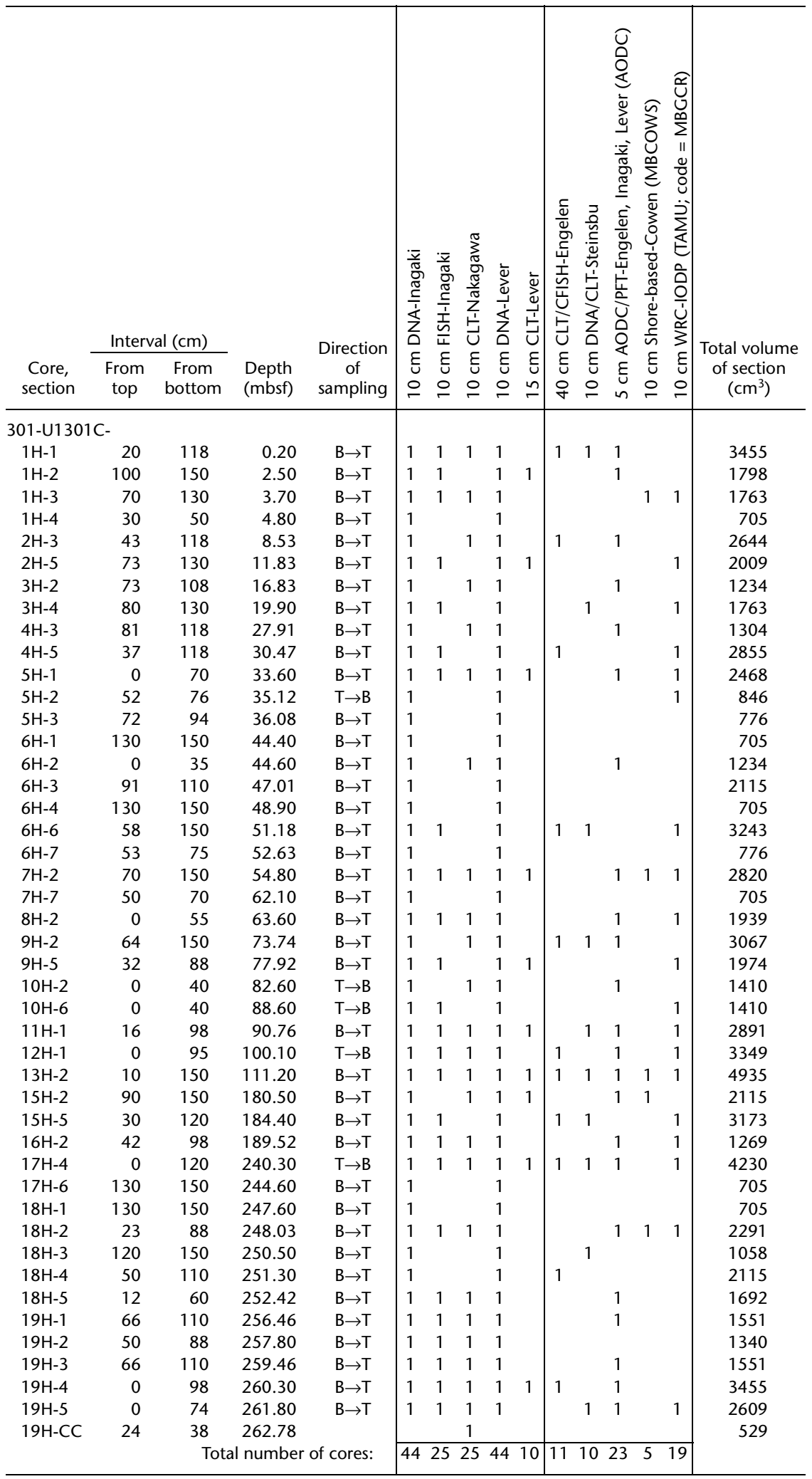

Notes: DNA = deoxyribonucleic acid, FISH = fluorescence in situ hybridization, CLT = cultivation, AODC = acridine orange direct count, PFT = perfluorocarbon tracer; MBCOWS = samples for geochemical and microbiological analyses (taken on behalf of shore-based scientists Cowen, Kenig, and Giovannoni); $M B G C R=$ samples taken for storage in the IODP Gulf Coast Repository. $T \rightarrow B=$ top to bottom; $B \rightarrow T=b o t t o m$ to top. 


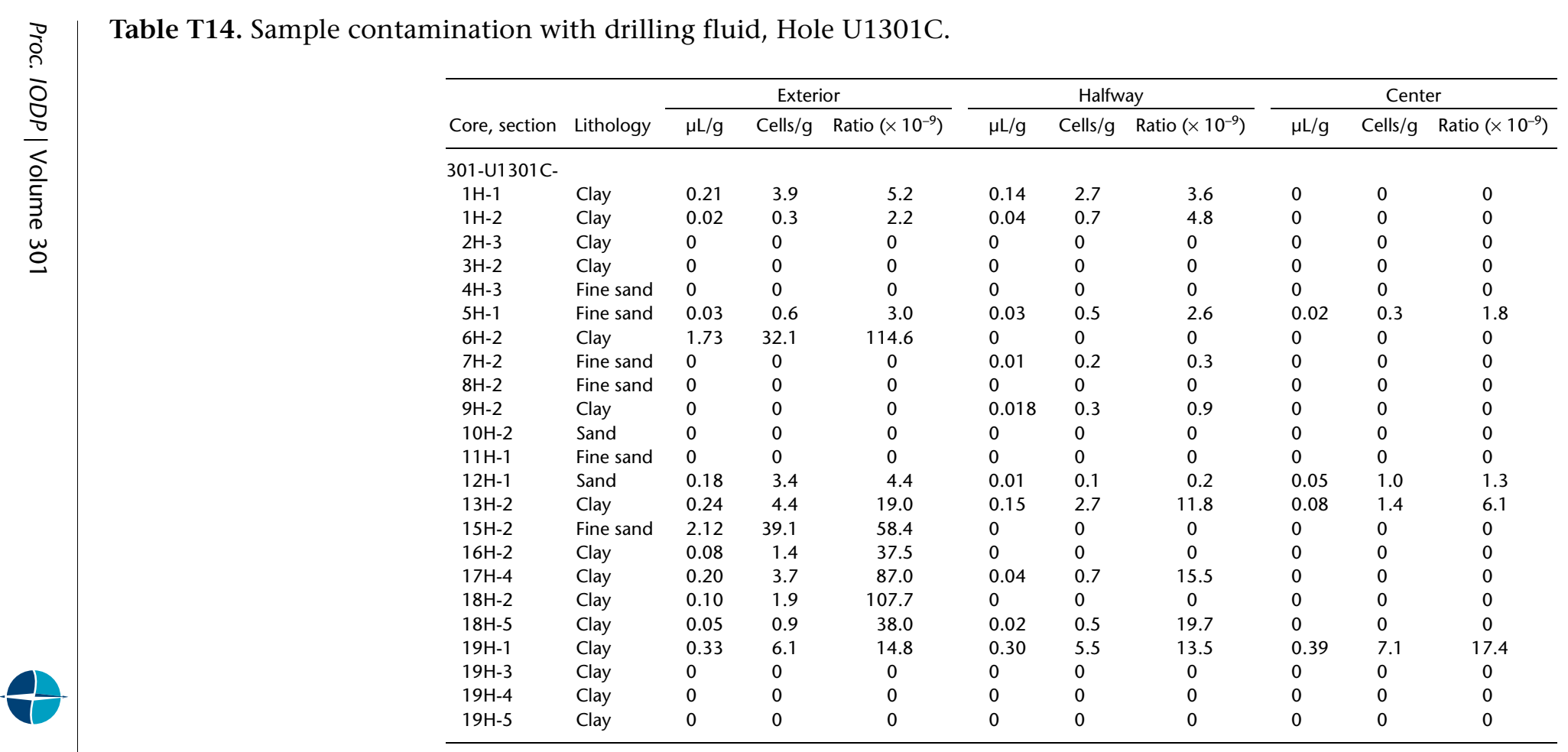

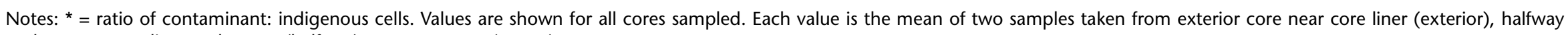
between core liner and center (halfway), or core center (center). 
Table T15. Estimated cell densities and morphological features under microscopic observation of acridine orange-stained cells, Hole U1301C.

\begin{tabular}{|c|c|c|c|c|}
\hline Core, section & $\begin{array}{l}\text { Depth } \\
\text { (mbsf) }\end{array}$ & $\begin{array}{l}\text { Cell density } \\
\left(\text { cells } / \mathrm{cm}^{3}\right)\end{array}$ & $\begin{array}{c}\text { Standard } \\
\text { deviation } \\
\left(\text { cells } / \mathrm{cm}^{3}\right)\end{array}$ & Remarks \\
\hline \multicolumn{5}{|l|}{ 301-U1301C- } \\
\hline $1 \mathrm{H}-1$ & 0.20 & $7.5 \times 10^{8}$ & $\pm 2.6 \times 10^{8}$ & High content of diatom ooze, tiny cocci \\
\hline $1 \mathrm{H}-2$ & 2.50 & $1.4 \times 10^{8}$ & $\pm 5.2 \times 10^{7}$ & Tiny cocci \\
\hline $2 \mathrm{H}-3$ & 8.53 & $1.5 \times 10^{8}$ & $\pm 6.5 \times 10^{7}$ & Tiny cocci \\
\hline $3 \mathrm{H}-2$ & 16.83 & $4.4 \times 10^{8}$ & $\pm 1.9 \times 10^{8}$ & Tiny cocci, a few rods \\
\hline $4 \mathrm{H}-3$ & 27.91 & $2.7 \times 10^{8}$ & $\pm 6.9 \times 10^{7}$ & Tiny cocci \\
\hline $5 \mathrm{H}-1$ & 33.60 & $1.9 \times 10^{8}$ & $\pm 6.6 \times 10^{7}$ & Tiny cocci \\
\hline $6 \mathrm{H}-2$ & 44.60 & $2.8 \times 10^{8}$ & $\pm 4.4 \times 10^{7}$ & Cocci, rods, bright signals \\
\hline $7 \mathrm{H}-2$ & 54.80 & $5.9 \times 10^{8}$ & $\pm 1.5 \times 10^{8}$ & Tiny cocci, a few rods \\
\hline $8 \mathrm{H}-2$ & 63.60 & $3.7 \times 10^{8}$ & $\pm 1.3 \times 10^{8}$ & Tiny cocci, aggregates \\
\hline $9 \mathrm{H}-2$ & 73.74 & $4.0 \times 10^{8}$ & $\pm 8.1 \times 10^{7}$ & Tiny cocci, many rods $(\sim 1 \%)$, aggregates, bright signals \\
\hline $10 \mathrm{H}-2$ & 82.60 & $3.5 \times 10^{8}$ & $\pm 1.1 \times 10^{8}$ & Aggregates, tiny cocci, a few rods \\
\hline $11 \mathrm{H}-1$ & 90.76 & $5.8 \times 10^{8}$ & $\pm 1.6 \times 10^{8}$ & Tiny cocci, a few aggregates \\
\hline $12 \mathrm{H}-1$ & 100.10 & $7.6 \times 10^{8}$ & $\pm 2.4 \times 10^{8}$ & Tiny cocci, short rods, bright signals \\
\hline $13 \mathrm{H}-2$ & 111.20 & $2.3 \times 10^{8}$ & $\pm 8.8 \times 10^{7}$ & Cocci, weak signals \\
\hline $15 \mathrm{H}-2$ & 180.50 & $6.7 \times 10^{8}$ & $\pm 1.7 \times 10^{8}$ & Tiny cocci, some rods \\
\hline $15 \mathrm{H}-5$ & 184.40 & $4.4 \times 10^{8}$ & $\pm 1.5 \times 10^{8}$ & Tiny cocci, some rods \\
\hline $16 \mathrm{H}-2$ & 189.52 & $1.7 \times 10^{8}$ & $\pm 4.9 \times 10^{7}$ & Tiny cocci \\
\hline $17 \mathrm{H}-4$ & 240.30 & $4.3 \times 10^{7}$ & $\pm 3.6 \times 10^{7}$ & A few cocci, some rods, weak signals \\
\hline $18 \mathrm{H}-2$ & 248.03 & $1.8 \times 10^{7}$ & $\pm 1.4 \times 10^{7}$ & Tiny cocci \\
\hline $18 \mathrm{H}-5$ & 252.42 & $2.3 \times 10^{7}$ & $\pm 2.1 \times 10^{7}$ & Very few cocci \\
\hline $19 \mathrm{H}-1$ & 256.46 & $4.1 \times 10^{8}$ & $\pm 1.3 \times 10^{8}$ & Tiny cocci, rods \\
\hline $19 \mathrm{H}-3$ & 259.46 & $7.5 \times 10^{7}$ & $\pm 3.3 \times 10^{7}$ & Tiny cocci \\
\hline $19 \mathrm{H}-4$ & 260.30 & $1.7 \times 10^{8}$ & $\pm 5.8 \times 10^{7}$ & Tiny cocci, rods, one aggregate \\
\hline $19 \mathrm{H}-5$ & 261.80 & $2.3 \times 10^{8}$ & $\pm 6.6 \times 10^{7}$ & Tiny cocci, rods \\
\hline
\end{tabular}

Table T16. Contamination of individual samples with drilling fluid and microbes, Hole U1301B.

\begin{tabular}{|c|c|c|c|c|c|c|c|c|}
\hline \multirow{3}{*}{$\begin{array}{l}\text { Core, } \\
\text { section }\end{array}$} & \multicolumn{6}{|c|}{ Exterior } & & \\
\hline & \multicolumn{2}{|c|}{ Untreated } & \multicolumn{2}{|c|}{$2 \times$ washed } & \multicolumn{2}{|c|}{ Flamed } & \multicolumn{2}{|c|}{ Interior } \\
\hline & $\mu \mathrm{L} / \mathrm{g}$ & Cells/g & $\mu \mathrm{L} / \mathrm{g}$ & Cells/g & $\mu \mathrm{L} / \mathrm{g}$ & Cells/g & $\mu \mathrm{L} / \mathrm{g}$ & Cells/g \\
\hline \multicolumn{9}{|c|}{ 301-U1301B- } \\
\hline 1R-1 & 0.33 & 6.2 & ND & ND & 0.01 & 0.1 & 0.00 & 0.1 \\
\hline $2 \mathrm{R}-2$ & 1.42 & 26.2 & ND & ND & 0.03 & 0.5 & 0.03 & 0.5 \\
\hline $4 R-4$ & 0.05 & 0.9 & 0.03 & 0.6 & 0.08 & 1.5 & 0.08 & 1.5 \\
\hline $5 \mathrm{R}-1$ & 24.47 & 452.7 & 1.45 & 26.8 & 0.03 & 0.5 & 0.05 & 0.9 \\
\hline $6 \mathrm{R}-1$ & 0.88 & 16.3 & 0.99 & 18.3 & 0.03 & 0.5 & 0.02 & 0.4 \\
\hline 9R-1 & 0.08 & 1.4 & 0.02 & 0.4 & 0.01 & 0.1 & 0 & 0 \\
\hline 11R-1 & 6.68 & 123.5 & 0.14 & 2.6 & 0 & 0 & 0.01 & 0.3 \\
\hline 14R-2 & 0.03 & 0.5 & 0.03 & 0.6 & 0 & 0 & 0 & 0 \\
\hline 17R-1 & 3.86 & 71.5 & 2.54 & 47.0 & 0.04 & 0.8 & 0.07 & 1.3 \\
\hline 20R-1 & 0.10 & 1.9 & 0.08 & 1.5 & 0 & 0 & 0.02 & 0.5 \\
\hline $23 R-2$ & 0.06 & 1.1 & 0.03 & 0.5 & 0.02 & 0.3 & 0.02 & 0.3 \\
\hline 26R-1 & 0 & 0 & 0.04 & 0.7 & 0 & 0 & 0 & 0 \\
\hline 30R-1 & 0 & 0 & 0.08 & 1.6 & 0.00 & 0.1 & 0 & 0 \\
\hline $33 R-2$ & 0 & 0 & 0 & 0 & 0 & 0 & 0 & 0 \\
\hline $36 \mathrm{R}-3$ & 0.75 & 13.8 & 0.34 & 6.3 & 0.05 & 0.9 & 0.03 & 0.6 \\
\hline
\end{tabular}

Note: ND = not determined. 
Table T17. Onboard cultivation results from basalt rock samples, Hole U1301B.

\begin{tabular}{|c|c|c|c|c|c|}
\hline Core & $\begin{array}{l}\text { Sample } \\
\text { code }\end{array}$ & Media & $\begin{array}{c}\text { Incubation } \\
\text { temp. } \\
\left({ }^{\circ} \mathrm{C}\right)\end{array}$ & $\begin{array}{c}\text { Cell } \\
\text { growth }\end{array}$ & Morphology \\
\hline \multicolumn{6}{|c|}{ 301-U1301B- } \\
\hline 1R-1 & CULT & Ep & 20 & w & Rod \\
\hline 1R-1 & MBSTE & Mono & 70 & + & Cocci, attached to iron particles \\
\hline $2 \mathrm{R}-2$ & CULT & Ep & 20 & ++ & Chain rod \\
\hline $2 \mathrm{R}-2$ & CULT & $\mathrm{Ag}$ & 20 & ++ & Vibrio \\
\hline $2 \mathrm{R}-2$ & CULT & Tc & 37 & w & Rod \\
\hline $3 \mathrm{R}-2$ & CULT & Mono & 70 & + & Cocci, attached to iron particles \\
\hline $4 \mathrm{R}-1$ & MBSTE & Mono & 70 & + & Cocci, attached to iron particles \\
\hline $5 \mathrm{R}-3$ & CULT & Tc & 37 & w & Rod and cocci \\
\hline 15R-1 & MBLIN & Tc & 55 & w & Rod \\
\hline 17R-1 & CULT & $\mathrm{Ag}$ & 37 & + & Cocci \\
\hline 20R-1 & CULT & Tc & 55 & w & Cocci aggregate? \\
\hline $23 R-2$ & CULT & Ep & 70 & w & Cocci \\
\hline 30R-1 & CULT & Tc & 70 & w & Cocci \\
\hline 33R-1 & CULT & Tc & 55 & w & Rod \\
\hline
\end{tabular}

Notes: CULT/MBLIN = cultivation by Inagaki and Nakagawa, MBSTE = cultivation by Steinsbu and Engelen. Ep = epsilon-Proteobacteria, Mono = monomer, $\mathrm{Ag}=$ Archaeoglobales, $\mathrm{Tc}=$ Thermococcales. $\mathrm{w}=$ weak growth, $+=$ slightly turbid, $++=$ highly turbid. 
Table T18. Synthesis of moisture and density with physical properties, Hole U1301C. (See table notes. Continued on next two pages.)

\begin{tabular}{|c|c|c|c|c|c|c|c|c|c|c|c|}
\hline \multirow{2}{*}{$\begin{array}{l}\text { Core, section, } \\
\text { interval }(\mathrm{cm})\end{array}$} & \multirow{2}{*}{$\begin{array}{l}\text { Depth } \\
\text { (mbsf) }\end{array}$} & \multicolumn{2}{|c|}{ Density $\left(\mathrm{g} / \mathrm{cm}^{3}\right)$} & \multirow{2}{*}{$\begin{array}{c}\text { Porosity } \\
\text { (\%) }\end{array}$} & \multicolumn{3}{|c|}{$P$-wave velocity $(\mathrm{m} / \mathrm{s})$} & \multirow{2}{*}{$\begin{array}{l}\text { Thermal } \\
\text { conductivity } \\
(\mathrm{W} / \mathrm{m} \cdot \mathrm{K})\end{array}$} & \multirow{2}{*}{$\begin{array}{l}\text { Shear } \\
\text { strength } \\
(\mathrm{kPa})\end{array}$} & \multirow{2}{*}{ Sediment } & \multirow{2}{*}{$\begin{array}{l}\text { Sediment } \\
\text { unit }\end{array}$} \\
\hline & & Bulk & Grain & & $x$ & $y$ & z & & & & \\
\hline 301-U1301C- & & & & & & & & & & & \\
\hline $1 \mathrm{H}-2,36-66$ & 1.86 & 1.37 & 2.76 & 80.3 & 1512 & 1503 & 1497 & 0.86 & 1 & Mud & IA \\
\hline $1 \mathrm{H}-3,45-52$ & 3.45 & 1.40 & 2.72 & 77.8 & 1505 & & 1486 & 0.85 & & Mud & IA \\
\hline $1 \mathrm{H}-4,15-20$ & 4.65 & 2.03 & 2.75 & 41.9 & & & & 1.01 & & Sand & IA \\
\hline $2 \mathrm{H}-1,50.5-70$ & 5.61 & 1.47 & 2.81 & 75.3 & 1554 & 1525 & 1500 & 0.96 & 3 & Mud & IA \\
\hline $2 \mathrm{H}-2,36-38$ & 6.96 & 2.05 & 2.80 & 42.5 & & & & & & Sand & IA \\
\hline $2 \mathrm{H}-2,103-122$ & 7.63 & & & & 1509 & 1501 & 1488 & 0.91 & 3 & Mud & IA \\
\hline $2 \mathrm{H}-3,19-31$ & 8.29 & 1.48 & 2.80 & 74.1 & & 1501 & 1498 & 0.90 & & Mud & IA \\
\hline $2 \mathrm{H}-4,60-73$ & 10.20 & 1.51 & 2.76 & 72.0 & 1533 & & 1515 & 1.01 & & Mud & IA \\
\hline $2 \mathrm{H}-4,128.5-133$ & 10.86 & & & & & & & & 5 & Mud & IA \\
\hline $2 \mathrm{H}-5,32-41$ & 11.42 & 1.62 & 2.80 & 66.3 & 1515 & 1497 & 1492 & & & Mud & IA \\
\hline $2 \mathrm{H}-5,57-58$ & 11.67 & & & & & & & 1.05 & & Mud & IA \\
\hline $2 \mathrm{H}-6,13-23$ & 12.73 & & & & & & & & 7 & Mud & IA \\
\hline $2 \mathrm{H}-6,75-84$ & 13.35 & & & & 1532 & & 1539 & 0.94 & & Mud & IB \\
\hline $2 \mathrm{H}-6,100-102$ & 13.60 & 1.61 & 2.79 & 66.8 & & & & & & Mud & IB \\
\hline $3 \mathrm{H}-1,69$ & 15.29 & & & & & 1521 & & & & Mixed & IB \\
\hline $3 \mathrm{H}-1,70-71$ & 15.30 & & & & & & & 1.18 & & Mud & IB \\
\hline $3 \mathrm{H}-1,75-82$ & 15.35 & 1.58 & 2.83 & 69.0 & 1513 & & 1521 & & & Mixed & IB \\
\hline $3 \mathrm{H}-1,115-121$ & 15.75 & & & & & & & 0.98 & 9 & Mud & IB \\
\hline $3 \mathrm{H}-2,30-32$ & 16.40 & 1.95 & 2.76 & 46.4 & & & & & & Sand & IB \\
\hline $3 \mathrm{H}-2,39-51$ & 16.49 & & & & 1519 & 1508 & 1500 & 1.09 & & Mixed & IB \\
\hline $3 \mathrm{H}-3,67-75$ & 18.27 & 2.01 & 2.78 & 44.0 & & & 1602 & 1.51 & & Mixed & IB \\
\hline $3 \mathrm{H}-3,80-81$ & 18.40 & & & & 1641 & 1528 & & & & Mud & IB \\
\hline $3 \mathrm{H}-3,110-111$ & 18.70 & & & & & & & 1.33 & & Mixed & IB \\
\hline $3 \mathrm{H}-4,20-24$ & 19.30 & 1.67 & 2.80 & 63.4 & 1526 & & & & & Mud & IB \\
\hline $3 \mathrm{H}-4,30-31$ & 19.40 & & & & & 1565 & 1540 & & & Mixed & IB \\
\hline $3 \mathrm{H}-4,40-41$ & 19.50 & & & & & & & 1.47 & & Sand & IB \\
\hline $3 \mathrm{H}-5,45-46$ & 21.05 & & & & & & & 1.80 & & Sand & IB \\
\hline $3 \mathrm{H}-5,54.5-73$ & 21.14 & 1.84 & 2.79 & 53.6 & 1626 & 1631 & 1515 & & 9 & Mixed & IB \\
\hline $3 \mathrm{H}-5,100-101$ & 21.60 & & & & & & & 1.48 & & Mixed & IB \\
\hline $3 \mathrm{H}-6,25-28$ & 22.34 & & & & & & & & $7^{*}$ & Mud & IB \\
\hline $3 \mathrm{H}-6,40-41$ & 22.50 & & & & & & & 1.21 & & Mud & IB \\
\hline $3 \mathrm{H}-6,80-82$ & 22.90 & 2.05 & 2.76 & 40.6 & & & & 1.61 & & Sand & IB \\
\hline $3 \mathrm{H}-6,92-98$ & 23.02 & & & & 1566 & & 1551 & & & Mixed & IB \\
\hline $3 \mathrm{H}-7,10-23$ & 23.41 & 1.20 & 2.77 & 44.2 & & 1543 & 1587 & 1.43 & & Mixed & IB \\
\hline $3 \mathrm{H}-7,49-49$ & 23.79 & & & & 1683 & & & & & Sand & IB \\
\hline $4 \mathrm{H}-1,20-21$ & 24.30 & & & & & & & 1.37 & & Sand & IB \\
\hline $4 \mathrm{H}-1,68-81$ & 24.78 & 2.07 & 2.75 & 39.5 & & & & 1.42 & 5 & Sand & IB \\
\hline $4 \mathrm{H}-1,106-109$ & 25.16 & & & & 1542 & 1524 & 1528 & & & Mixed & IB \\
\hline $4 \mathrm{H}-2,37-41$ & 25.97 & & & & & & & & 6 & Sand & IB \\
\hline $4 \mathrm{H}-2,68-69$ & 26.28 & & & & 1582 & 1581 & 1563 & & & Mixed & IB \\
\hline $4 \mathrm{H}-2,77-81$ & 26.37 & 1.74 & 2.79 & 59.1 & & & & 1.09 & & Mud & IB \\
\hline $4 \mathrm{H}-3,25-56$ & 27.35 & 2.05 & 2.75 & 40.8 & 1726 & & & 1.68 & 7 & Sand & IB \\
\hline $4 \mathrm{H}-4,15-30$ & 28.75 & 1.97 & 2.75 & 45.1 & 1667 & 1657 & 1647 & & 18 & Mixed & IB \\
\hline $4 \mathrm{H}-4,40-41$ & 29.00 & & & & & & & 1.14 & & Mixed & IB \\
\hline $4 \mathrm{H}-4,120-121$ & 29.80 & & & & & & & 1.85 & & Sand & IB \\
\hline $4 \mathrm{H}-5,9-21$ & 30.19 & 1.99 & 2.76 & 44.3 & 1579 & 1578 & 15842 & 1.58 & & Mixed & IB \\
\hline $4 \mathrm{H}-6,20-21$ & 31.80 & & & & & & & 1.47 & & Sand & IB \\
\hline $4 \mathrm{H}-6,40-41$ & 32.00 & & & & & & & 1.15 & & Mud & IB \\
\hline $4 \mathrm{H}-6,84-100$ & 32.44 & 1.75 & 2.77 & 58.4 & 1518 & 1555 & 15232 & & 32 & Mud & IB \\
\hline $4 \mathrm{H}-7,15-19$ & 33.25 & & & & & & & & 25 & Mud & IB \\
\hline $4 \mathrm{H}-7,24-26$ & 33.34 & 1.77 & 2.78 & 57.6 & & & & & & Mud & IB \\
\hline $4 \mathrm{H}-7,42$ & 33.52 & & & & & 1542 & 1532 & & & Mixed & IB \\
\hline $4 \mathrm{H}-7,45-46$ & 33.55 & & & & & & & 1.10 & & Mud & IB \\
\hline $5 \mathrm{H}-1,77-98$ & 34.37 & 2.16 & 2.78 & 35.1 & & & & 1.43 & 4 & Sand & IB \\
\hline $5 \mathrm{H}-3,61-63$ & 35.97 & 2.09 & 2.77 & 38.9 & & & & & & Sand & IB \\
\hline $6 \mathrm{H}-1,32-43$ & 43.42 & 1.75 & 2.77 & 58.6 & 1534 & & 1524 & 1.04 & 29 & Mud & IB \\
\hline $6 \mathrm{H}-2,37.5-40$ & 44.97 & & & & & & & & 30 & Mud & IB \\
\hline $6 \mathrm{H}-2,75-76$ & 45.35 & & & & & & & 1.37 & & Sand & IB \\
\hline $6 \mathrm{H}-2,84-105$ & 45.44 & 1.73 & 2.77 & 59.5 & 1524 & & 1527 & & & Mud & IB \\
\hline $6 \mathrm{H}-3,35-37$ & 46.45 & 2.11 & 2.79 & 38.8 & & & & & & Sand & IB \\
\hline $6 \mathrm{H}-4,17-17$ & 47.77 & & & & 1532 & & & & & Mud & IB \\
\hline $6 \mathrm{H}-4,105-119$ & 48.65 & 1.82 & 2.82 & 55.6 & & & 1556 & 1.13 & 49 & Mud & IB \\
\hline $6 \mathrm{H}-5,30-31$ & 49.40 & & & & & & & 1.57 & & Sand & IB \\
\hline $6 \mathrm{H}-5,75-87.5$ & 49.85 & 1.77 & 2.77 & 57.4 & 1563 & & & & 56 & Mud & IB \\
\hline $6 \mathrm{H}-6,9-9$ & 50.69 & & & & 1520 & & & & & Mud & IB \\
\hline $6 \mathrm{H}-6,12-14.5$ & 50.72 & & & & & & & 1.11 & 38 & Mud & IB \\
\hline
\end{tabular}


Table T18 (continued).

\begin{tabular}{|c|c|c|c|c|c|c|c|c|c|c|c|}
\hline \multirow{2}{*}{$\begin{array}{l}\text { Core, section, } \\
\text { interval (cm) }\end{array}$} & \multirow{2}{*}{$\begin{array}{l}\text { Depth } \\
\text { (mbsf) }\end{array}$} & \multicolumn{2}{|c|}{ Density $\left(\mathrm{g} / \mathrm{cm}^{3}\right)$} & \multirow{2}{*}{$\begin{array}{l}\text { Porosity } \\
\text { (\%) }\end{array}$} & \multicolumn{3}{|c|}{$P$-wave velocity $(\mathrm{m} / \mathrm{s})$} & \multirow{2}{*}{$\begin{array}{l}\text { Thermal } \\
\text { conductivity } \\
(\mathrm{W} / \mathrm{m} \cdot \mathrm{K})\end{array}$} & \multirow{2}{*}{$\begin{array}{c}\text { Shear } \\
\text { strength } \\
(\mathrm{kPa})\end{array}$} & \multirow{2}{*}{ Sediment } & \\
\hline & & Bulk & Grain & & $\mathrm{x}$ & $y$ & z & & & & unit \\
\hline $6 \mathrm{H}-6,30-32$ & 50.90 & 2.10 & 2.72 & 36.5 & & & & & & Sand & IB \\
\hline $6 \mathrm{H}-7,12-13$ & 52.22 & & & & & & & 1.73 & & Sand & IB \\
\hline $6 \mathrm{H}-7,45-47$ & 52.55 & 1.83 & 2.77 & 53.8 & & & & & & Mud & IB \\
\hline 7H-1, 30-35 & 52.90 & 1.79 & 2.84 & 57.7 & & & & & $30^{*}$ & Mud & $\mathrm{IB}$ \\
\hline 7H-1, 40-41 & 53.00 & & & & & & & 1.29 & & Mixed & IB \\
\hline 7H-1, 88-88 & 53.48 & & & & 1556 & & & & & Mud & IB \\
\hline 7H-2, 9-18.5 & 54.19 & 1.79 & 2.80 & 56.8 & & & & & 49 & Mud & IB \\
\hline 7H-2, 30-31 & 54.40 & & & & & & & 1.42 & & Sand & IB \\
\hline 7H-3, 17-18 & 55.77 & & & & & & & 1.10 & & Mixed & $\mathrm{IB}$ \\
\hline 7H-3, 46-48 & 56.06 & 2.12 & 2.73 & 35.4 & & & & & & Sand & IB \\
\hline $8 \mathrm{H}-1,12-19$ & 62.22 & 2.07 & 2.73 & 38.8 & & & & 1.64 & & Sand & IB \\
\hline $8 \mathrm{H}-1,57-68$ & 62.67 & & & & & & 1723 & & & Sand & IB \\
\hline $8 \mathrm{H}-1,83-83$ & 62.93 & & & & 1607 & & & & & Mixed & IB \\
\hline $8 \mathrm{H}-2,94-98$ & 64.54 & 1.91 & 2.84 & 51.2 & & & & 1.44 & & Mixed & IB \\
\hline $8 \mathrm{H}-2,105-105$ & 64.65 & & & & & & 1752 & & & Sand & IB \\
\hline $8 \mathrm{H}-2,115-115$ & 64.75 & & & & 1613 & & & & & Mixed & IB \\
\hline $8 \mathrm{H}-3,80-82$ & 65.90 & 2.01 & 2.77 & 43.9 & & & & & & Sand & $\mathrm{IB}$ \\
\hline $8 \mathrm{H}-4,80-97$ & 67.40 & 1.98 & 2.75 & 44.5 & 1803 & & 1821 & & & Sand & IB \\
\hline $9 \mathrm{H}-1,67-71$ & 72.27 & 1.99 & 2.77 & 44.6 & 1564 & & & 1.44 & & Mud & IB \\
\hline $9 \mathrm{H}-1,130.5-133$ & 72.90 & & & & & & & & 64 & Mud & IB \\
\hline $9 \mathrm{H}-2,35-36$ & 73.45 & & & & & & & 1.18 & & Mud & IB \\
\hline $9 \mathrm{H}-3,67-76$ & 75.27 & 1.88 & 2.80 & 51.6 & 1575 & & & 1.27 & & Mud & IB \\
\hline $9 \mathrm{H}-4,67-76$ & 76.77 & 1.92 & 2.79 & 49.3 & 1575 & & & 1.25 & 74 & Mud & IB \\
\hline $9 \mathrm{H}-5,16-19$ & 77.61 & & & & & & & 1.24 & 80 & Mud & IB \\
\hline $9 \mathrm{H}-6,15-19$ & 79.25 & & & & & & & 1.16 & 80 & Mud & IB \\
\hline $9 \mathrm{H}-6,70-78$ & 79.80 & 1.98 & 2.79 & 46.2 & 1583 & & & & & Sand & IB \\
\hline $9 \mathrm{H}-6,125-126$ & 80.35 & & & & & & & 1.68 & & Sand & IB \\
\hline $9 \mathrm{H}-7,25-26$ & 80.85 & & & & & & & 1.27 & & Mixed & IB \\
\hline $9 \mathrm{H}-7,36-40$ & 80.96 & 2.19 & 2.74 & 32.3 & 1483 & & & & & Sand & IB \\
\hline $9 \mathrm{H}-7,55-56$ & 81.15 & & & & & & & 1.72 & & Sand & $\mathrm{IB}$ \\
\hline $10 \mathrm{H}-1,43-52$ & 81.53 & 2.05 & 2.80 & 42.2 & 1624 & & & & & Sand & IB \\
\hline $10 \mathrm{H}-2,80-82$ & 83.40 & 1.60 & 1.88 & 33.2 & 1595 & & & & & Sand & IB \\
\hline $10 \mathrm{H}-3,50-56$ & 84.60 & 1.82 & 2.76 & 54.2 & 1786 & & & & & Sand & IB \\
\hline $10 \mathrm{H}-4,70-75$ & 86.30 & 1.99 & 2.76 & 44.2 & 1574 & & & & & Sand & IB \\
\hline $10 \mathrm{H}-5,75-75$ & 87.85 & & & & 1754 & & & & & Sand & IB \\
\hline $10 \mathrm{H}-6,70-72$ & 89.30 & 1.93 & 2.74 & 47.4 & & & & & & Sand & IB \\
\hline $10 \mathrm{H}-7,40-46$ & 90.50 & 2.04 & 2.75 & 40.9 & 1625 & & & & & Sand & IB \\
\hline $11 \mathrm{H}-1,8-10$ & 90.68 & 2.16 & 2.74 & 34.1 & & & & & & Sand & IB \\
\hline $11 \mathrm{H}-2,29-31$ & 92.39 & & & & & & & & 74 & Mud & IB \\
\hline $11 \mathrm{H}-2,54-76$ & 92.64 & 1.93 & 2.86 & 50.4 & 1467 & & & 1.25 & & Mud & IB \\
\hline $11 \mathrm{H}-2,130-131$ & 93.40 & & & & & & & 1.6 & & Sand & IB \\
\hline $11 \mathrm{H}-3,45-46$ & 94.05 & & & & & & & 1.19 & & Mud & IB \\
\hline $11 \mathrm{H}-3,80-81$ & 94.40 & & & & & & & 1.68 & & Sand & IB \\
\hline $11 \mathrm{H}-3,98-100$ & 94.58 & 2.05 & 2.77 & 41.1 & & & & & & Mixed & IB \\
\hline $11 \mathrm{H}-3,119-119$ & 94.79 & & & & 1449 & & & & & Mud & IB \\
\hline $13 \mathrm{H}-1,45-52$ & 110.05 & & & & & & & 1.12 & 51 & Mud & IB \\
\hline $13 \mathrm{H}-1,60-62$ & 110.20 & 2.67 & 3.64 & 37.2 & & & & & & Mud & IB \\
\hline $13 \mathrm{H}-1,70-71$ & 110.30 & & & & & & & 1.01 & & Mud & IB \\
\hline $13 \mathrm{H}-3,10-27$ & 112.70 & 1.78 & 2.80 & 57.3 & 1434 & & & 1.12 & 123 & Mud & IB \\
\hline 13H-CC, 10-12 & 113.40 & 2.15 & 2.83 & 37.6 & & & & & & Mixed & IB \\
\hline $15 \mathrm{H}-1,23-26$ & 178.33 & 2.18 & 2.77 & 33.7 & & & & 1.78 & & Mixed & IB \\
\hline $15 \mathrm{H}-1,90-91$ & 179.00 & & & & & & & 1.01 & & Mixed & IB \\
\hline $15 \mathrm{H}-2,26-31$ & 179.86 & 1.82 & 2.79 & 55.0 & 1555 & & & & 96 & Mud & IB \\
\hline $15 \mathrm{H}-2,60-61$ & 180.20 & & & & & & & 1.45 & & Sand & IB \\
\hline $15 \mathrm{H}-2,80-81$ & 180.40 & & & & & & & 1.13 & & Mud & IB \\
\hline $15 \mathrm{H}-3,24-26$ & 181.34 & & & & 1593 & & & 1.13 & & Mud & IB \\
\hline $15 \mathrm{H}-3,35-37$ & 181.45 & & & & & & & & 54 & Mud & IB \\
\hline $15 \mathrm{H}-3,85-86$ & 181.95 & & & & & & & 1.38 & & Sand & $\mathrm{IB}$ \\
\hline $15 \mathrm{H}-3,95-97$ & 182.05 & 1.81 & 2.77 & 55.1 & 1556 & & & & & Mud & IB \\
\hline $15 \mathrm{H}-4,15-16$ & 182.75 & & & & & & & 1.25 & & Sand & IB \\
\hline $15 \mathrm{H}-4,19$ & 182.79 & & & & & & & & 221 & Mud & IB \\
\hline $15 \mathrm{H}-4,28-30$ & 182.88 & 1.82 & 2.79 & 54.9 & 1583 & & & & & Mud & IB \\
\hline $15 \mathrm{H}-4,60-61$ & 183.20 & & & & & & & 0.99 & & Mud & IB \\
\hline $15 \mathrm{H}-5,9-11$ & 184.19 & 1.72 & 2.76 & 59.6 & 1614 & & & 1.12 & 184 & Mud & IB \\
\hline $15 \mathrm{H}-6,20-47$ & 185.50 & 1.97 & 2.75 & 45.2 & 1657 & 1686 & 1655 & 1.52 & 10 & Sand & IB \\
\hline $16 \mathrm{H}-1,47-49$ & 188.07 & & & & & & & & $184^{*}$ & Mud & IB \\
\hline $16 \mathrm{H}-1,47-53$ & 188.07 & 1.79 & 2.80 & 56.8 & & & & 1.16 & 147 & Mud & IB \\
\hline $16 \mathrm{H}-1,75-75$ & 188.35 & & & & 1519 & & & & & Mud & IB \\
\hline
\end{tabular}


Table T18 (continued).

\begin{tabular}{|c|c|c|c|c|c|c|c|c|c|c|c|}
\hline \multirow{2}{*}{$\begin{array}{l}\text { Core, section, } \\
\text { interval }(\mathrm{cm})\end{array}$} & \multirow{2}{*}{$\begin{array}{l}\text { Depth } \\
\text { (mbsf) }\end{array}$} & \multicolumn{2}{|c|}{ Density $\left(\mathrm{g} / \mathrm{cm}^{3}\right)$} & \multirow{2}{*}{$\begin{array}{l}\text { Porosity } \\
\text { (\%) }\end{array}$} & \multicolumn{3}{|c|}{$P$-wave velocity $(\mathrm{m} / \mathrm{s})$} & \multirow{2}{*}{$\begin{array}{c}\text { Thermal } \\
\text { conductivity } \\
(\mathrm{W} / \mathrm{m} \cdot \mathrm{K})\end{array}$} & \multirow{2}{*}{$\begin{array}{l}\text { Shear } \\
\text { strength } \\
(\mathrm{kPa})\end{array}$} & \multirow{2}{*}{ Sediment } & \multirow{2}{*}{$\begin{array}{c}\text { Sediment } \\
\text { unit }\end{array}$} \\
\hline & & Bulk & Grain & & $x$ & $\mathrm{y}$ & $z$ & & & & \\
\hline $16 \mathrm{H}-1,85-86$ & 188.45 & & & & & & & 1.19 & & Mud & IB \\
\hline $16 \mathrm{H}-2,8-18$ & 189.18 & 1.88 & 2.81 & 52.2 & 1591 & & & 1.12 & 172 & Mud & IB \\
\hline $16 \mathrm{H}-3,7-10$ & 190.67 & 1.92 & 2.77 & 48.6 & & & & & 86 & Mixed & IB \\
\hline $16 \mathrm{H}-3,25-26$ & 190.85 & & & & 1716 & 1742 & 1699 & & & Sand & IB \\
\hline $17 \mathrm{H}-1,20-21$ & 236.00 & & & & & & & 1.10 & & Mixed & II \\
\hline $17 \mathrm{H}-1,37-39$ & 236.17 & 1.68 & 2.79 & 62.9 & & & & & & Mixed & II \\
\hline $17 \mathrm{H}-1,80-81$ & 236.60 & & & & & & & 1.30 & & Mixed & II \\
\hline $17 \mathrm{H}-1,88-90$ & & & & & & & & & $159 *$ & Mud & II \\
\hline $17 \mathrm{H}-1,96-106$ & 236.76 & 1.86 & 2.76 & 51.8 & 1578 & & & & & Mud & II \\
\hline $17 \mathrm{H}-2,70-80$ & 238.00 & 1.89 & 2.82 & 52.0 & 1610 & & & 1.19 & $172^{*}$ & Mud & II \\
\hline $17 \mathrm{H}-3,5$ & 238.85 & & & & & & & & 221 & Mud & II \\
\hline $17 \mathrm{H}-3,75-84$ & 239.55 & 1.93 & 2.83 & 50.0 & 1600 & & & 1.22 & & Mud & II \\
\hline $17 \mathrm{H}-4,130-148$ & 241.60 & 1.95 & 2.77 & 47.2 & 1664 & & & & 221 & Mud & II \\
\hline $17 \mathrm{H}-5,29-36$ & 242.09 & 1.93 & 2.77 & 47.9 & 1614 & & & & & Mud & II \\
\hline $17 \mathrm{H}-5,65-66$ & 242.45 & & & & & & & 1.28 & & Mud & II \\
\hline $17 \mathrm{H}-6,63-70$ & 243.93 & 1.90 & 2.78 & 50.0 & 1594 & & & & & Mud & II \\
\hline $17 \mathrm{H}-6,100-101$ & 244.30 & & & & & & & 1.23 & & Mud & II \\
\hline $17 \mathrm{H}-7,29-46$ & 245.09 & 1.90 & 2.80 & 50.7 & 1603 & & & 120 & & Mud & II \\
\hline $18 \mathrm{H}-1,8-8$ & 246.38 & & & & 1576 & & & & & Mixed & II \\
\hline $18 \mathrm{H}-1,62-76$ & 246.92 & 1.59 & 2.83 & 68.7 & & & & 1.00 & & Mixed & II \\
\hline $18 \mathrm{H}-1,96.5-101$ & 247.30 & & & & & & & 1.16 & 142 & Mud & II \\
\hline $18 \mathrm{H}-2,5-16$ & 247.85 & 1.83 & 2.80 & 54.7 & & & & 1.00 & 177 & Mud & II \\
\hline $18 \mathrm{H}-3,35-36$ & 249.65 & & & & & & & 1.24 & & Mud & II \\
\hline $18 \mathrm{H}-3,46.5-58$ & 249.76 & 1.87 & 2.79 & 52.1 & 1586 & & & & 216 & Mud & II \\
\hline $18 \mathrm{H}-3,80-81$ & 250.10 & & & & & & & 1.10 & & Mud & II \\
\hline $18 \mathrm{H}-4,28-46$ & 251.08 & 1.90 & 2.80 & 50.5 & 1607 & & & 1.23 & & Mud & II \\
\hline $19 \mathrm{H}-1,18-20$ & 255.98 & & & & & & & 1.12 & 177 & Mixed & II \\
\hline $19 \mathrm{H}-1,28-30$ & 256.08 & 1.60 & 2.93 & 69.8 & & & & & & Mud & II \\
\hline $19 \mathrm{H}-2,20-21$ & 257.50 & & & & & & & 1.03 & & Mud & II \\
\hline $19 \mathrm{H}-2,24-31$ & 257.54 & 1.76 & 2.76 & 58.0 & 1568 & & & & & Mud & II \\
\hline $19 \mathrm{H}-3,10-11$ & 258.90 & & & & & & & 1.21 & & Mud & II \\
\hline $19 \mathrm{H}-3,18-31$ & 258.98 & 1.86 & 2.81 & 53.3 & 1595 & & & 1.15 & & Mud & II \\
\hline
\end{tabular}

Notes: For a complete listing of multisensor track, natural gamma ray, and gamma ray attenuation data, see the Janus database (iodp.tamu.edu/ database/index.html). ${ }^{*}=$ unreliable Torvane result.

Table T19. Demonstration of sampling bias toward clay layers.

\begin{tabular}{lc}
\hline \multicolumn{1}{c}{ Hole U1301C } & Sand (\%) \\
\hline Described section & 53 \\
Thermal conductivity & 26 \\
Velocity & 19 \\
MAD properties & 31 \\
Shear strength & 11 \\
\hline
\end{tabular}

Notes: The described section (cored section minus catwalk samples) was $\sim 53 \%$ sand and gravel. Other values show the percentage of measurements of each type that were made in sand layers. $M A D=$ moisture and density. 
Table T20. Summary of samples recovered from basement used for moisture and density and velocity determination, Hole 1301B. (See table note. Continued on next three pages.)

\begin{tabular}{|c|c|c|c|c|c|c|c|c|c|c|c|c|c|}
\hline \multirow{2}{*}{$\begin{array}{l}\text { Core, section, } \\
\text { interval }(\mathrm{cm})\end{array}$} & \multirow{2}{*}{$\begin{array}{l}\text { Depth } \\
\text { (mbsf) }\end{array}$} & \multicolumn{2}{|c|}{ Density $\left(\mathrm{g} / \mathrm{cm}^{3}\right)$} & \multirow{2}{*}{$\begin{array}{l}\text { Porosity } \\
\text { (\%) }\end{array}$} & \multicolumn{3}{|c|}{$P$-wave velocity $(\mathrm{m} / \mathrm{s})$} & \multirow{2}{*}{$\begin{array}{l}\text { Thermal } \\
\text { conductivity } \\
(\mathrm{W} / \mathrm{m} \cdot \mathrm{K})\end{array}$} & \multirow[b]{2}{*}{ Lithology } & \multirow{2}{*}{$\begin{array}{l}\text { Igneous } \\
\text { structure }\end{array}$} & \multirow{2}{*}{$\begin{array}{c}\text { Igneous } \\
\text { unit }\end{array}$} & \multirow[b]{2}{*}{ Alteration } & \multirow{2}{*}{$\begin{array}{l}\text { PMAG } \\
\text { sample }\end{array}$} \\
\hline & & Bulk & Grain & & $x$ & $y$ & $z$ & & & & & & \\
\hline \multicolumn{14}{|l|}{ 301-U1301B- } \\
\hline $1 \mathrm{R}-1,0-3$ & 351.20 & 1.87 & 2.23 & 30.3 & & & & & Aphyric basalt & Breccia & $1 \mathrm{~A}$ & Moderate to high & \\
\hline 1R-1, 4-12 & 351.24 & & & & & & & 1.17 & Aphyric basalt & Breccia & $1 \mathrm{~A}$ & Moderate to high & \\
\hline 1R-1, 125-127 & 352.45 & 2.84 & 2.90 & 3.5 & 5237 & & 5304 & & Sparsely phyric & Lava & 1B & Slight & \\
\hline 2R-1, 73-79 & 357.83 & 2.71 & 2.81 & 5.3 & 4844 & 4905 & 5202 & & Moderately to highly phyric & Pillow & $1 \mathrm{C}$ & Slight to moderate & \\
\hline 2R-1, 105-118 & 358.15 & & & & & & & 1.69 & Moderately to highly phyric & Pillow & $1 \mathrm{C}$ & Slight to moderate & \\
\hline 2R-1, 137-139 & 358.47 & & & & 5331 & 5480 & 5551 & & Moderately to highly phyric & Pillow & 1C & Slight to moderate & $\mathrm{x}$ \\
\hline $2 \mathrm{R}-2,22-24$ & 358.76 & & & & 5000 & 5104 & 5111 & & Moderately to highly phyric & Pillow & $1 \mathrm{C}$ & Slight to moderate & $\mathrm{x}$ \\
\hline $2 \mathrm{R}-2,115-120$ & 359.69 & 2.76 & 2.85 & 4.9 & 5171 & 5237 & 5240 & & Moderately to highly phyric & Pillow & $1 \mathrm{C}$ & Slight to moderate & \\
\hline $2 \mathrm{R}-2,129-137$ & 359.83 & & & & & & & 1.69 & Moderately to highly phyric & Pillow & $1 \mathrm{C}$ & Slight to moderate & \\
\hline $2 \mathrm{R}-3,3-5$ & 360.07 & & & & 4940 & 4937 & 5019 & & Moderately to highly phyric & Pillow & $1 \mathrm{C}$ & Slight to moderate & $x$ \\
\hline $2 \mathrm{R}-3,34-43$ & 360.38 & & & & & & & 1.74 & Moderately to highly phyric & Pillow & $1 \mathrm{C}$ & Slight to moderate & \\
\hline $2 \mathrm{R}-3,123-127$ & 361.27 & 2.93 & 2.96 & 1.9 & 5620 & 5754 & 5720 & & Moderately to highly phyric & Pillow & $1 \mathrm{C}$ & Slight to moderate & \\
\hline $2 \mathrm{R}-3,142-144$ & 361.46 & & & & & & 5380 & & Moderately to highly phyric & Pillow & 1C & Slight to moderate & \\
\hline $3 R-1,31-33$ & 361.41 & 2.77 & 2.85 & 4.0 & 5025 & 5024 & 5125 & & Moderately to highly phyric & Pillow & $1 \mathrm{C}$ & Slight to moderate & \\
\hline $3 R-1,35-42$ & 361.45 & & & & & & & 1.68 & Moderately to highly phyric & Pillow & $1 \mathrm{C}$ & Slight to moderate & \\
\hline $3 R-1,130-132$ & 362.40 & & & & 5025 & 5123 & 5218 & & Moderately to highly phyric & Pillow & $1 \mathrm{C}$ & Slight to moderate & $\mathrm{x}$ \\
\hline $3 R-2,41-47$ & 363.01 & & & & & & & 1.65 & Moderately to highly phyric & Pillow & $1 \mathrm{C}$ & Slight to moderate & \\
\hline $3 R-2,58-60$ & 363.18 & 2.79 & 2.87 & 4.5 & 5235 & 5198 & 5224 & & Moderately to highly phyric & Pillow & $1 \mathrm{C}$ & Slight to moderate & \\
\hline $3 R-2,88-90$ & 363.48 & & & & 5154 & 5176 & 5218 & & Moderately to highly phyric & Pillow & $1 \mathrm{C}$ & Slight to moderate & $x$ \\
\hline $4 \mathrm{R}-1,110-112$ & 367.70 & 2.73 & 2.84 & 6.1 & 5029 & 4904 & 5181 & 1.72 & Moderately to highly phyric & Pillow & $1 \mathrm{C}$ & Slight to moderate & \\
\hline $4 \mathrm{R}-2,23-25$ & 368.29 & & & & 5363 & 5322 & 5372 & & Moderately to highly phyric & Pillow & 1C & Slight to moderate & $\mathrm{x}$ \\
\hline $4 \mathrm{R}-2,125-132$ & 369.31 & & & & & & & 1.73 & Moderately to highly phyric & Pillow & 1C & Slight to moderate & \\
\hline $4 \mathrm{R}-3,4-12$ & 369.43 & & & & & & & 1.67 & Moderately to highly phyric & Pillow & $1 \mathrm{C}$ & Slight to moderate & \\
\hline $4 \mathrm{R}-3,27-29$ & 369.66 & & & & & 4901 & 4910 & & Moderately to highly phyric & Pillow & $1 \mathrm{C}$ & Slight to moderate & $\mathrm{x}$ \\
\hline $4 R-3,123-125$ & 370.62 & & & & & & 5371 & & Moderately to highly phyric & Pillow & 1C & Slight to moderate & \\
\hline $4 \mathrm{R}-3,132-134$ & 370.71 & 2.82 & 2.88 & 3.2 & 5162 & 5124 & 5113 & & Moderately to highly phyric & Pillow & $1 \mathrm{C}$ & Slight to moderate & \\
\hline $4 \mathrm{R}-4,20-28$ & 371.04 & & & & & & & 1.69 & Moderately to highly phyric & Pillow & 1C & Slight to moderate & \\
\hline $5 R-1,37-39$ & 376.67 & & & & 5130 & 5092 & 5079 & & Moderately to highly phyric & Pillow & $1 \mathrm{C}$ & Slight to moderate & $x$ \\
\hline $5 R-1,55-57$ & 376.85 & 2.83 & 2.89 & 3.1 & 5152 & 5198 & 5216 & & Moderately to highly phyric & Pillow & $1 \mathrm{C}$ & Slight to moderate & \\
\hline $5 \mathrm{R}-1,67-74$ & 376.97 & & & & & & & 1.65 & Moderately to highly phyric & Pillow & $1 \mathrm{C}$ & Slight to moderate & \\
\hline $5 R-2,104-106$ & 378.84 & 2.88 & 2.93 & 2.8 & 5534 & 5528 & 5426 & 1.73 & Moderately to highly phyric & Pillow & $1 \mathrm{C}$ & Slight to moderate & \\
\hline $5 R-3,49-58$ & 379.79 & & & & & & & 1.74 & Moderately to highly phyric & Pillow & $1 \mathrm{C}$ & Slight to moderate & \\
\hline $5 R-3,101-103$ & 380.31 & 2.80 & 2.87 & 3.8 & 5410 & 5486 & 5603 & & Moderately to highly phyric & Pillow & $1 \mathrm{C}$ & Slight to moderate & \\
\hline $6 \mathrm{R}-1,41-43$ & 386.41 & 2.74 & 2.85 & 5.7 & 4808 & 5002 & 5016 & 1.62 & Moderately to highly phyric & Pillow & $1 \mathrm{C}$ & Slight to moderate & \\
\hline $6 \mathrm{R}-1,64-66$ & 386.64 & & & & 5184 & 5255 & 5064 & & Moderately to highly phyric & Pillow & $1 \mathrm{C}$ & Slight to moderate & $\mathrm{x}$ \\
\hline $6 \mathrm{R}-2,35-37$ & 387.80 & 2.90 & 2.95 & 2.6 & 5500 & 5566 & 5625 & 1.65 & Moderately to highly phyric & Pillow & $1 \mathrm{C}$ & Slight to moderate & \\
\hline 7R-1, 29-31 & 395.89 & & & & 4968 & 5209 & 5051 & & Moderately to highly phyric & Pillow & $1 \mathrm{C}$ & Slight to moderate & $\mathrm{x}$ \\
\hline $7 R-2,4-6$ & 397.14 & 2.66 & 2.77 & 6.1 & 4751 & 4809 & 4800 & 1.67 & Moderately to highly phyric & Pillow & $1 \mathrm{C}$ & Slight to moderate & \\
\hline $8 R-1,25-27$ & 405.45 & 2.81 & 2.87 & 3.5 & & & & 1.76 & Moderately to highly phyric & Pillow & $1 \mathrm{C}$ & Slight to moderate & \\
\hline $9 \mathrm{R}-1,17-19$ & 410.37 & 2.69 & 2.82 & 7.1 & & & & & Moderately to highly phyric & Pillow & $1 \mathrm{C}$ & Slight to moderate & \\
\hline $9 \mathrm{R}-1,30-32$ & 410.50 & & & & & & & 1.70 & Moderately to highly phyric & Pillow & $1 \mathrm{C}$ & Slight to moderate & \\
\hline 10R-1, 25-27 & 415.05 & 2.76 & 2.89 & 6.8 & & & & & Moderately to highly phyric & Pillow & $1 \mathrm{C}$ & Slight to moderate & \\
\hline $10 \mathrm{R}-1,86-88$ & 415.66 & 2.64 & 2.75 & 6.2 & 4950 & 4947 & 5103 & & Moderately to highly phyric & Pillow & $1 \mathrm{C}$ & Slight to moderate & \\
\hline $10 \mathrm{R}-1,95-97$ & 415.75 & & & & & & & 1.66 & Moderately to highly phyric & Pillow & 1C & Slight to moderate & $\mathrm{x}$ \\
\hline $10 \mathrm{R}-2,73-75$ & 416.98 & 2.80 & 2.88 & 4.6 & & & & & Moderately to highly phyric & Pillow & $1 \mathrm{C}$ & Slight to moderate & \\
\hline $10 R-2,90-96$ & 417.18 & & & & & & & 1.70 & Moderately to highly phyric & Pillow & $1 \mathrm{C}$ & Slight to moderate & \\
\hline $11 \mathrm{R}-1,80-82$ & 425.20 & & & & & & 5424 & & Sparsely to moderately phyric & Massive & $2 \mathrm{~A}$ & Slight & \\
\hline 11R-1, 88-90 & 425.28 & 2.76 & 2.86 & 5.5 & 5104 & 5112 & 5087 & 1.74 & Sparsely to moderately phyric & Massive & $2 \mathrm{~A}$ & Slight & \\
\hline
\end{tabular}


Table T20 (continued).

\begin{tabular}{|c|c|c|c|c|c|c|c|c|c|c|c|c|c|}
\hline \multirow{2}{*}{$\begin{array}{l}\text { Core, section, } \\
\text { interval }(\mathrm{cm})\end{array}$} & \multirow{2}{*}{$\begin{array}{l}\text { Depth } \\
\text { (mbsf) }\end{array}$} & \multicolumn{2}{|c|}{ Density $\left(\mathrm{g} / \mathrm{cm}^{3}\right)$} & \multirow{2}{*}{$\begin{array}{l}\text { Porosity } \\
\text { (\%) }\end{array}$} & \multicolumn{3}{|c|}{$P$-wave velocity $(\mathrm{m} / \mathrm{s})$} & \multirow{2}{*}{$\begin{array}{c}\text { Thermal } \\
\text { conductivity } \\
(\mathrm{W} / \mathrm{m} \cdot \mathrm{K})\end{array}$} & \multirow[b]{2}{*}{ Lithology } & \multirow{2}{*}{$\begin{array}{l}\text { Igneous } \\
\text { structure }\end{array}$} & \multirow{2}{*}{$\begin{array}{c}\text { Igneous } \\
\text { unit }\end{array}$} & \multirow[b]{2}{*}{ Alteration } & \multirow{2}{*}{$\begin{array}{l}\text { PMAG } \\
\text { sample }\end{array}$} \\
\hline & & Bulk & Grain & & $x$ & $y$ & z & & & & & & \\
\hline 12R-1, 39-41 & 429.29 & 2.79 & 2.88 & 5.0 & 4925 & 4962 & 5114 & 1.76 & Sparsely to moderately phyric & Massive & $2 \mathrm{~A}$ & Slight & \\
\hline $12 \mathrm{R}-1,91-93$ & 429.81 & & & & 5540 & 5385 & 5490 & & Sparsely to moderately phyric & Massive & $2 \mathrm{~A}$ & Slight & $\mathrm{x}$ \\
\hline 12R-1, 93-95 & 429.83 & & & & 5424 & 5524 & 5489 & & Sparsely to moderately phyric & Massive & $2 \mathrm{~A}$ & Slight & $\mathrm{x}$ \\
\hline $13 R-1,36-38$ & 430.26 & 2.87 & 2.92 & 3.0 & 5434 & 5405 & 5384 & 1.79 & Sparsely to moderately phyric & Massive & $2 \mathrm{~A}$ & Slight & \\
\hline $13 \mathrm{R}-1,68-70$ & 430.58 & & & & 5382 & 5430 & 5340 & & Sparsely to moderately phyric & Massive & $2 \mathrm{~A}$ & Slight & $\mathrm{x}$ \\
\hline $13 R-2,3-5$ & 431.36 & 2.68 & 2.80 & 6.7 & 5013 & 5168 & 5186 & 1.77 & Sparsely to moderately phyric & Massive & $2 \mathrm{~A}$ & Slight & $\mathrm{x}$ \\
\hline $14 \mathrm{R}-1,81-83$ & 434.81 & & & & 4838 & 4842 & 4815 & & Sparsely to moderately phyric & Massive & $2 \mathrm{~B}$ & Slight to moderate & $x$ \\
\hline $14 \mathrm{R}-1,101-103$ & 435.01 & 2.79 & 2.90 & 6.2 & 5038 & 5027 & 5098 & 1.77 & Sparsely to moderately phyric & Massive & $2 \mathrm{~B}$ & Slight to moderate & \\
\hline $14 \mathrm{R}-2,125-127$ & 435.25 & 3.03 & 3.11 & 3.5 & & & & & Sparsely phyric & Pillow & 3 & Slight to moderate & \\
\hline $14 \mathrm{R}-2,21-23$ & 435.71 & 2.67 & 2.80 & 7.4 & & & & 1.67 & Sparsely phyric & Pillow & 3 & Slight to moderate & \\
\hline $15 \mathrm{R}-1,19-25$ & 443.79 & & & & & & & 1.65 & Sparsely phyric & Pillow & 3 & Slight to moderate & \\
\hline $15 R-1,108-110$ & 444.68 & 2.69 & 2.78 & 5.4 & 4839 & 4801 & 4835 & & Sparsely to moderately phyric & Massive & $4 \mathrm{~B}$ & Slight & \\
\hline $15 R-1,113-115$ & 444.73 & & & & 4925 & 4983 & & & Sparsely to moderately phyric & Massive & $4 \mathrm{~B}$ & Slight & $\mathrm{x}$ \\
\hline 15R-2, 9-11 & 445.19 & & & & 4634 & 4615 & 4542 & & Sparsely to moderately phyric & Massive & $4 \mathrm{~B}$ & Slight & $\mathrm{x}$ \\
\hline $15 R-2,20-22$ & 445.30 & 2.68 & 2.86 & 9.4 & 4728 & 4753 & 4716 & & Sparsely to moderately phyric, vesicular & Massive & 4B & Slight & \\
\hline $15 R-2,93-95$ & 446.03 & & & & 5118 & 5017 & 5093 & & Sparsely to moderately phyric & Massive & $4 \mathrm{~B}$ & Slight & $\mathrm{x}$ \\
\hline 15R-2, 107-118 & 446.17 & & & & & & & 1.71 & Sparsely to moderately phyric & Massive & 4B & Slight & \\
\hline $15 R-3,10-12$ & 446.70 & & & & & 5399 & 5356 & & Sparsely to moderately phyric & Massive & 4B & Slight & $\mathrm{x}$ \\
\hline $15 R-3,59-66$ & 447.19 & & & & & & & 1.76 & Sparsely to moderately phyric & Massive & $4 \mathrm{~B}$ & Slight & \\
\hline $15 \mathrm{R}-3,81-83$ & 447.41 & & & & 5405 & 5389 & 5450 & & Sparsely to moderately phyric & Massive & $4 \mathrm{~B}$ & Slight & $\mathrm{x}$ \\
\hline $15 R-3,144-146$ & 448.04 & 2.78 & 2.85 & 3.8 & 5384 & 5394 & 5352 & & Sparsely to moderately phyric & Massive & $4 \mathrm{~B}$ & Slight & \\
\hline $15 R-4,21-23$ & 448.31 & & & & 4580 & 4616 & 4614 & & Sparsely to moderately phyric & Massive & $4 \mathrm{~B}$ & Slight & $\mathrm{x}$ \\
\hline $15 R-4,65-67$ & 448.75 & 2.79 & 2.93 & 7.1 & 4506 & 4596 & 4414 & & Sparsely to moderately phyric & Massive & $4 C$ & Slight & \\
\hline $15 R-4,101-103$ & 449.11 & & & & 5310 & 5387 & 5418 & & Sparsely to moderately phyric & Massive & $4 C$ & Slight & $\mathrm{x}$ \\
\hline $15 R-4,121-131$ & 449.31 & & & & & & & 1.79 & Sparsely to moderately phyric & Massive & $4 C$ & Slight & \\
\hline $15 R-5,13-15$ & 449.73 & 2.77 & 2.90 & 6.7 & & & & & Sparsely to moderately phyric & Massive & $4 C$ & Slight & \\
\hline $16 \mathrm{R}-1,18-26$ & 453.38 & & & & & & & 1.66 & Sparsely to moderately phyric & Pillow & 5 & Slight to moderate & \\
\hline $16 \mathrm{R}-1,107-109$ & 454.27 & & & & 4356 & 4416 & 4632 & & Sparsely to moderately phyric & Pillow & 5 & Slight to moderate & $\mathrm{x}$ \\
\hline $16 \mathrm{R}-1,144-146$ & 454.64 & 2.68 & 2.79 & 5.7 & 5308 & 5254 & 5285 & & Sparsely to moderately phyric & Pillow & 5 & Slight to moderate & \\
\hline $17 \mathrm{R}-1,0-8$ & 461.40 & & & & & & & 1.57 & Sparsely to moderately phyric & Pillow & 5 & Slight to moderate & \\
\hline 17R-1, 73-75 & 462.13 & 2.77 & 2.94 & 8.8 & 4782 & 4783 & 4568 & & Sparsely to moderately phyric & Pillow & 5 & Slight to moderate & \\
\hline $18 \mathrm{R}-1,96-98$ & 471.96 & 2.74 & 2.85 & 5.8 & 4891 & 4879 & 4783 & 1.77 & Sparsely to moderately phyric & Massive & 6 & Slight & \\
\hline $18 \mathrm{R}-2,0-12$ & 472.30 & & & & & & & 1.82 & Sparsely to moderately phyric & Massive & 6 & Slight & \\
\hline $18 \mathrm{R}-2,13-15$ & 472.43 & 2.78 & 2.88 & 5.4 & 4921 & 4949 & 4888 & & Sparsely to moderately phyric & Massive & 6 & Slight & \\
\hline $18 \mathrm{R}-2,16-18$ & 472.46 & & & & & & 5514 & & Sparsely to moderately phyric & Massive & 6 & Slight & \\
\hline $18 \mathrm{R}-2,32-34$ & 472.62 & & & & 5305 & 5334 & 5305 & & Sparsely to moderately phyric & Massive & 6 & Slight & $\mathrm{x}$ \\
\hline $18 \mathrm{R}-2,78-80$ & 473.08 & 2.55 & 2.87 & 17.3 & 3989 & 3979 & 3914 & & Sparsely to moderately phyric, vesicular & Massive & 6 & Slight & \\
\hline $18 \mathrm{R}-2,108-110$ & 473.38 & & & & 4965 & 4954 & 5003 & & Sparsely to moderately phyric & Massive & 6 & Slight & $\mathrm{x}$ \\
\hline $18 \mathrm{R}-3,11-13$ & 473.67 & 2.75 & 2.85 & 5.6 & 4780 & 4772 & 4857 & 1.79 & Sparsely to moderately phyric & Massive & 6 & Slight & \\
\hline $18 \mathrm{R}-3,112-114$ & 474.68 & & & & 5234 & 5266 & 5304 & & Sparsely to moderately phyric & Massive & 6 & Slight & $\mathrm{x}$ \\
\hline $18 \mathrm{R}-5,5-7$ & 476.38 & & & & 4962 & 5058 & 5028 & & Moderately to highly phyric & Pillow & $7 \mathrm{~A}$ & Slight to moderate & $\mathrm{x}$ \\
\hline $19 \mathrm{R}-1,30-32$ & 476.40 & 2.88 & 2.95 & 3.7 & & & & 1.63 & Moderately to highly phyric & Pillow & $7 \mathrm{~A}$ & Slight to moderate & \\
\hline 19R-1, 32-34 & 476.42 & 2.75 & 2.84 & 5.1 & 5166 & 5284 & 5273 & & Moderately to highly phyric & Pillow & $7 \mathrm{~A}$ & Slight to moderate & \\
\hline $19 \mathrm{R}-1,51-53$ & 476.61 & & & & 5112 & 5121 & 5108 & & Moderately to highly phyric & Pillow & $7 \mathrm{~A}$ & Slight to moderate & $x$ \\
\hline $19 \mathrm{R}-1,105-107$ & 477.15 & & & & 5291 & 5265 & 5355 & & Moderately to highly phyric & Pillow & $7 \mathrm{~A}$ & Slight to moderate & \\
\hline $19 \mathrm{R}-2,57-59$ & 478.14 & 2.86 & 2.91 & 2.5 & 5477 & 5548 & 5469 & 1.69 & Moderately to highly phyric & Pillow & $7 \mathrm{~A}$ & Slight to moderate & \\
\hline $20 \mathrm{R}-1,62-64$ & 481.22 & 2.74 & 2.85 & 6.4 & & & & & Moderately to highly phyric & Pillow & $7 \mathrm{~A}$ & Slight to moderate & \\
\hline 20R-1, 72-74 & 481.32 & & & & 5191 & 5275 & 5028 & & Moderately to highly phyric & Pillow & $7 \mathrm{~A}$ & Slight to moderate & $\mathrm{x}$ \\
\hline
\end{tabular}


Table T20 (continued).

\begin{tabular}{|c|c|c|c|c|c|c|c|c|c|c|c|c|c|}
\hline \multirow{2}{*}{$\begin{array}{l}\text { Core, section, } \\
\text { interval }(\mathrm{cm})\end{array}$} & \multirow{2}{*}{$\begin{array}{l}\text { Depth } \\
\text { (mbsf) }\end{array}$} & \multicolumn{2}{|c|}{ Density $\left(\mathrm{g} / \mathrm{cm}^{3}\right)$} & \multirow{2}{*}{$\begin{array}{l}\text { Porosity } \\
\text { (\%) }\end{array}$} & \multicolumn{3}{|c|}{$P$-wave velocity $(\mathrm{m} / \mathrm{s})$} & \multirow{2}{*}{$\begin{array}{l}\text { Thermal } \\
\text { conductivity } \\
(\mathrm{W} / \mathrm{m} \cdot \mathrm{K})\end{array}$} & \multirow[b]{2}{*}{ Lithology } & \multirow{2}{*}{$\begin{array}{l}\text { Igneous } \\
\text { structure }\end{array}$} & \multirow{2}{*}{$\begin{array}{c}\text { Igneous } \\
\text { unit }\end{array}$} & \multirow[b]{2}{*}{ Alteration } & \multirow{2}{*}{$\begin{array}{l}\text { PMAC } \\
\text { sample }\end{array}$} \\
\hline & & Bulk & Grain & & $x$ & $y$ & $z$ & & & & & & \\
\hline 20R-1, 117-119 & 481.77 & 2.78 & 2.86 & 4.1 & 5231 & 5261 & 5320 & 1.78 & Moderately to highly phyric & Pillow & $7 \mathrm{~A}$ & Slight to moderate & \\
\hline $21 \mathrm{R}-1,24-26$ & 490.44 & 2.86 & 2.92 & 3.6 & & & & & Moderately to highly phyric & Pillow & $7 \mathrm{~A}$ & Slight to moderate & \\
\hline $21 \mathrm{R}-1,60-62$ & 490.80 & & & & 5227 & 5246 & 5115 & & Moderately to highly phyric & Pillow & $7 \mathrm{~A}$ & Slight to moderate & $\mathrm{x}$ \\
\hline $21 \mathrm{R}-1,109-111$ & 491.29 & 2.88 & 2.93 & 2.7 & 5200 & 5233 & 5366 & & Moderately to highly phyric & Pillow & $7 \mathrm{~A}$ & Slight to moderate & \\
\hline $21 \mathrm{R}-1,112-120$ & 491.32 & & & & & & & 1.80 & Moderately to highly phyric & Pillow & $7 \mathrm{~A}$ & Slight to moderate & \\
\hline $21 \mathrm{R}-2,61-63$ & 492.17 & 2.70 & 2.83 & 7.3 & 4739 & 4853 & 4845 & 1.64 & Highly phyric & Pillow & $7 \mathrm{~B}$ & Slight to moderate & \\
\hline $21 \mathrm{R}-3,20-22$ & 493.19 & 2.73 & 2.83 & 5.8 & 4924 & 5008 & 4913 & & Highly phyric & Pillow & $7 \mathrm{~B}$ & Slight to moderate & \\
\hline $21 \mathrm{R}-3,46-48$ & 493.45 & & & & & 5046 & 5199 & & Highly phyric & Pillow & $7 \mathrm{~B}$ & Slight to moderate & $\mathrm{x}$ \\
\hline $21 \mathrm{R}-3,51-61$ & 493.50 & & & & & & & 1.70 & Highly phyric & Pillow & $7 \mathrm{~B}$ & Slight to moderate & \\
\hline $21 \mathrm{R}-3,118-120$ & 494.17 & & & & 5312 & & 5600 & & Highly phyric & Pillow & $7 \mathrm{~B}$ & Slight to moderate & $\mathrm{x}$ \\
\hline $21 \mathrm{R}-4,3-5$ & 494.52 & 2.92 & 2.97 & 2.5 & 5319 & 5400 & 5682 & & Highly phyric & Pillow & $7 \mathrm{~B}$ & Slight to moderate & \\
\hline $21 \mathrm{R}-4,62-64$ & 495.11 & & & & & & 5898 & & Highly phyric & Pillow & $7 \mathrm{~B}$ & Slight to moderate & \\
\hline $21 \mathrm{R}-4,71-73$ & 495.20 & & & & & & & 1.84 & Highly phyric & Pillow & $7 \mathrm{~B}$ & Slight to moderate & $\mathrm{x}$ \\
\hline 21R-4, 75-77 & 495.24 & 2.85 & 2.91 & 3.4 & 5211 & 5331 & 5222 & & Highly phyric & Pillow & $7 B$ & Slight to moderate & \\
\hline $22 \mathrm{R}-1,23-25$ & 495.63 & & & & 5572 & 5716 & 5637 & & Highly phyric & Pillow & $7 \mathrm{~B}$ & Slight to moderate & $\mathrm{x}$ \\
\hline $22 \mathrm{R}-1,51-53$ & 495.91 & 2.73 & 2.84 & 6.0 & 5067 & 5249 & 5149 & 1.73 & Highly phyric & Pillow & $7 \mathrm{~B}$ & Slight to moderate & \\
\hline $22 \mathrm{R}-2,6-8$ & 496.89 & 2.66 & 2.79 & 7.1 & 5069 & 5187 & 5106 & 1.71 & Highly phyric & Pillow & $7 B$ & Slight to moderate & \\
\hline $22 \mathrm{R}-2,60-62$ & 497.43 & & & & 5328 & 5432 & 5486 & & Highly phyric & Pillow & $7 \mathrm{~B}$ & Slight to moderate & $x$ \\
\hline $23 \mathrm{R}-1,15-23$ & 500.05 & & & & & & & 1.62 & Highly phyric & Pillow & $7 \mathrm{~B}$ & Slight to moderate & \\
\hline $23 \mathrm{R}-1,31-33$ & 500.21 & 2.78 & 2.87 & 4.8 & 5136 & 5298 & 5258 & & Highly phyric & Pillow & $7 B$ & Slight to moderate & \\
\hline $23 \mathrm{R}-2,10-12$ & 501.46 & & & & 5034 & 5056 & 5051 & & Highly phyric & Pillow & $7 \mathrm{~B}$ & Slight to moderate & $\mathrm{x}$ \\
\hline $23 \mathrm{R}-2,56-62$ & 501.92 & & & & & & & 1.64 & Highly phyric & Pillow & $7 \mathrm{~B}$ & Slight to moderate & \\
\hline $23 \mathrm{R}-2,84-86$ & 502.20 & 2.71 & 2.82 & 5.8 & 5032 & 5084 & 5128 & & Highly phyric & Pillow & $7 B$ & Slight to moderate & \\
\hline 23R-2, 141-143 & 502.77 & & & & 5319 & 5190 & 5236 & & Highly phyric & Pillow & $7 \mathrm{~B}$ & Slight to moderate & $\mathrm{x}$ \\
\hline $23 \mathrm{R}-3,26-28$ & 503.12 & 2.74 & 2.83 & 5.4 & 5099 & 5086 & 5142 & & Highly phyric & Pillow & $7 \mathrm{~B}$ & Slight to moderate & \\
\hline 24R-1, 102-104 & 506.92 & & & & & & 5631 & & Highly phyric & Pillow & $7 B$ & Slight to moderate & \\
\hline $24 \mathrm{R}-1,114-116$ & 507.04 & 2.75 & 2.84 & 5.1 & 5270 & 5360 & 5327 & 1.75 & Highly phyric & Pillow & $7 \mathrm{~B}$ & Slight to moderate & \\
\hline 24R-2, 17-19 & 507.39 & 2.82 & 2.89 & 3.9 & 5236 & 5400 & 5325 & 1.76 & Highly phyric & Pillow & $7 \mathrm{~B}$ & Slight to moderate & \\
\hline $25 \mathrm{R}-1,75-77$ & 510.25 & 2.71 & 2.82 & 5.9 & 5060 & 5187 & 5158 & 1.72 & Highly phyric & Pillow & $7 B$ & Slight to moderate & \\
\hline $25 \mathrm{R}-2,75-77$ & 511.66 & 2.67 & 2.80 & 7.4 & 4933 & 4936 & 4867 & 1.68 & Sparsely to moderately phyric, vesicular & Pillow & 7C & Slight to high & \\
\hline $26 \mathrm{R}-1,27-29$ & 515.77 & 2.69 & 2.85 & 8.6 & & & & & Sparsely to moderately phyric, vesicular & Pillow & $7 C$ & Slight to high & \\
\hline $27 \mathrm{R}-1,20-22$ & 519.20 & 2.77 & 2.85 & 4.4 & 5173 & 5256 & 5254 & & Sparsely to moderately phyric, vesicular & Pillow & $7 \mathrm{C}$ & Slight to high & \\
\hline $27 \mathrm{R}-1,48-55$ & 519.48 & & & & & & & 1.69 & Sparsely to moderately phyric, vesicular & Pillow & 7C & Slight to high & \\
\hline $27 \mathrm{R}-1,122-124$ & 520.22 & 2.86 & 2.95 & 4.5 & & & & & Sparsely to moderately phyric, vesicular & Pillow & $7 C$ & Slight to high & \\
\hline $27 R-2,9-16$ & 520.59 & & & & & & & 1.63 & Sparsely to moderately phyric, vesicular & Pillow & 7C & Slight to high & \\
\hline $27 \mathrm{R}-2,26-28$ & 520.76 & 2.62 & 2.79 & 9.3 & 4944 & 5029 & 5039 & & Sparsely to moderately phyric, vesicular & Pillow & 7C & Slight to high & \\
\hline $27 \mathrm{R}-2,28-30$ & 520.78 & 2.85 & 2.93 & 4.3 & 5047 & & 5096 & & Sparsely to moderately phyric, vesicular & Pillow & $7 C$ & Slight to high & \\
\hline $28 \mathrm{R}-1,50-52$ & 529.10 & 2.71 & 2.83 & 6.9 & 4963 & 5052 & 4999 & & Sparsely to moderately phyric, vesicular & Pillow & 7C & Slight to high & \\
\hline $28 \mathrm{R}-1,64-70$ & 529.24 & & & & & & & 1.70 & Sparsely to moderately phyric, vesicular & Pillow & 7C & Slight to high & \\
\hline $29 \mathrm{R}-1,14-16$ & 532.34 & 2.71 & 2.82 & 5.9 & & & & & Sparsely to moderately phyric, vesicular & Pillow & $7 C$ & Slight to high & \\
\hline 30R-1, 99-101 & 536.19 & & & & & & & 1.68 & Sparsely to moderately phyric, vesicular & Pillow & 7C & Slight to high & $\mathrm{x}$ \\
\hline 30R-1, 110-112 & 536.30 & 2.88 & 2.95 & 4.0 & & & & & Sparsely to moderately phyric, vesicular & Pillow & 7C & Slight to high & \\
\hline $31 \mathrm{R}-1,0-2$ & 544.40 & 2.84 & 2.92 & 4.1 & & & & & Sparsely to moderately phyric, vesicular & Pillow & $7 C$ & Slight to high & \\
\hline $31 \mathrm{R}-1,45-53$ & 544.85 & & & & & & & 1.69 & Sparsely to moderately phyric, vesicular & Pillow & 7C & Slight to high & \\
\hline $32 \mathrm{R}-1,14-24$ & 550.14 & & & & & & & 1.68 & Sparsely to moderately phyric, vesicular & Pillow & 7C & Slight to high & \\
\hline 32R-1, 119-121 & 551.19 & 2.76 & 2.84 & 4.2 & 5116 & 5125 & 5035 & & Sparsely to moderately phyric, vesicular & Pillow & 7C & Slight to high & \\
\hline $32 \mathrm{R}-2,15-17$ & 551.59 & 2.84 & 2.94 & 5.2 & & & & 1.75 & Sparsely to moderately phyric, vesicular & Pillow & 7C & Slight to high & \\
\hline $32 \mathrm{R}-2,23-25$ & 551.67 & 2.74 & 2.87 & 6.9 & & & & & Sparsely to moderately phyric, vesicular & Pillow & $7 C$ & Slight to high & \\
\hline $32 \mathrm{R}-2,44-46$ & 551.88 & & & & & & 5043 & & Sparsely to moderately phyric, vesicular & Pillow & 7C & Slight to high & \\
\hline $32 \mathrm{R}-3,57-59$ & 553.51 & 2.70 & 2.81 & 6.0 & & & & & Sparsely to moderately phyric, vesicular & Pillow & 7C & Slight to high & \\
\hline
\end{tabular}


Table T20 (continued).

\begin{tabular}{|c|c|c|c|c|c|c|c|c|c|c|c|c|c|}
\hline \multirow{2}{*}{$\begin{array}{l}\text { Core, section, } \\
\text { interval }(\mathrm{cm})\end{array}$} & \multirow{2}{*}{$\begin{array}{l}\text { Depth } \\
\text { (mbsf) }\end{array}$} & \multicolumn{2}{|c|}{ Density $\left(\mathrm{g} / \mathrm{cm}^{3}\right)$} & \multirow{2}{*}{$\begin{array}{c}\text { Porosity } \\
\text { (\%) }\end{array}$} & \multicolumn{3}{|c|}{$P$-wave velocity $(\mathrm{m} / \mathrm{s})$} & \multirow{2}{*}{$\begin{array}{l}\text { Thermal } \\
\text { conductivity } \\
(\mathrm{W} / \mathrm{m} \cdot \mathrm{K})\end{array}$} & \multirow[b]{2}{*}{ Lithology } & \multirow{2}{*}{$\begin{array}{l}\text { Igneous } \\
\text { structure }\end{array}$} & \multirow{2}{*}{$\begin{array}{c}\text { Igneous } \\
\text { unit }\end{array}$} & \multirow[b]{2}{*}{ Alteration } & \multirow{2}{*}{$\begin{array}{l}\text { PMAG } \\
\text { sample }\end{array}$} \\
\hline & & Bulk & Grain & & $\mathrm{x}$ & y & z & & & & & & \\
\hline $33 R-1,136-138$ & 555.36 & 2.78 & 2.86 & 4.9 & 5029 & 5089 & 5158 & 1.72 & Sparsely to moderately phyric, vesicular & Pillow & 7C & Slight to high & \\
\hline $33 R-2,131-133$ & 556.81 & 2.70 & 2.81 & 5.9 & 4613 & 5054 & 4987 & 1.67 & Sparsely to moderately phyric, vesicular & Pillow & 7C & Slight to high & \\
\hline $34 \mathrm{R}-2,73-75$ & 562.83 & 2.67 & 2.78 & 6.4 & 4643 & 4643 & 4643 & & Sparsely to moderately phyric, vesicular & Pillow & 7C & Slight to high & \\
\hline 34R-2, 95-101 & 563.05 & & & & & & & 1.70 & Sparsely to moderately phyric, vesicular & Pillow & 7C & Slight to high & \\
\hline $35 \mathrm{R}-1,113-115$ & 564.73 & 2.55 & 2.79 & 13.9 & & & & 1.37 & Aphyric to sparsely phyric & Breccia & $8 \mathrm{~A}$ & Moderately to high & \\
\hline $35 \mathrm{R}-2,114-116$ & 566.21 & 2.83 & 2.90 & 3.6 & 5243 & 5289 & 5260 & 1.81 & Sparsely to moderately phyric, vesicular & Flow/pillow & $8 \mathrm{~B}$ & Slight & $\mathrm{x}$ \\
\hline $35 \mathrm{R}-2,133-135$ & 566.40 & & & & & & 5898 & & Sparsely to moderately phyric, vesicular & Flow/pillow & $8 B$ & Slight & \\
\hline $36 \mathrm{R}-2,16-18$ & 574.86 & 2.76 & 2.86 & 5.3 & 4994 & 5094 & 5036 & 1.63 & Moderately to highly phyric & Flow/pillow & $8 \mathrm{C}$ & Slight to moderate & $\mathrm{x}$ \\
\hline $36 \mathrm{R}-3,12-14$ & 576.29 & 2.80 & 2.88 & 4.3 & & & & 1.70 & Moderately to highly phyric & Flow/pillow & $8 \mathrm{C}$ & Slight to moderate & \\
\hline
\end{tabular}

Note: $\mathrm{PMAG}=$ paleomagnetism . 
Table T21. Thermal measurements, Hole U1301C.

\begin{tabular}{lccccl}
\hline \multicolumn{1}{c}{ Core } & $\begin{array}{c}\text { Depth } \\
(\mathrm{m})\end{array}$ & Tool & $\begin{array}{c}T_{\text {eq }}\left({ }^{\circ} \mathrm{C}\right) \\
\text { 301-U1301C- }\end{array}$ & $\begin{array}{c}\text { Uncertainty } \\
\left({ }^{\circ} \mathrm{C}\right)\end{array}$ & \multicolumn{1}{c}{ Comments } \\
Bottom water & 0 & APCT-12 & 1.88 & 0.005 & Consistent with predrilling site surveys \\
$3 \mathrm{H}$ & 24.1 & APCT-12 & 10.4 & 0.3 & Equilibrium temperature not used in later calculations \\
$5 \mathrm{H}$ & 43.1 & APCT-12 & 11.5 & 0.3 & Some tool motion \\
$9 \mathrm{H}$ & 82.2 & DVTP-1 & 20.1 & 0.1 & Considerable tool motion \\
$14 \mathrm{H}$ & 134.2 & DVTP-1 & ND & ND & Tool did not penetrate undisturbed formation \\
$17 \mathrm{H}$ & 247.4 & DVTP-1 & 58.2 & 0.3 & Considerable tool motion \\
\hline
\end{tabular}

Notes: Depths have uncertainties of $\pm 1.0 \mathrm{~m}$. Tool 12 was used for all APCT tool deployments. The DVTP used probe tip 1 , with thermistors F and G. Equilibrium temperatures were estimated by extrapolation of modeled tool response, as described in the text. Temperature uncertainty was estimated based on the least-squares best fit of the observational data to the modeled tool response, in addition to variability in estimated temperatures based on thermal conductivities of 1.0 to $1.5 \mathrm{~W} / \mathrm{m} \cdot \mathrm{K}$. APCT $=$ advanced piston corer temperature tool, DVTP $=$ Davis-Villinger Temperature Probe, ND = not determined.

Table T22. Summary of logging operations, Hole U1301B.

\begin{tabular}{llrccc}
\hline \multirow{2}{*}{ Tool string } & Direction & Top & Bottom & $\begin{array}{c}\text { Interval logged (mbsf) } \\
\text { (mbsf) }\end{array}$ & $\begin{array}{c}\text { Depth shift } \\
(\mathrm{m})\end{array}$ \\
\hline \multirow{2}{*}{ Triple combo } & Down log & 0 & 552 & 265 & -2666 \\
& Main (up log) & 300 & 579 & 265 & -2666 \\
\multirow{5}{*}{ UBI } & Repeat (up log) & 0 & 455 & 265 & -2666 \\
& Pass 1 (up log) & 325 & 425 & 265 & -2673 \\
\multirow{5}{*}{ FMS-sonic } & Pass 2 (up log) & 335 & 425 & 265 & -2673 \\
& Casing (up log) & 0 & 337 & 246 & -2673 \\
\multirow{5}{*}{ WST } & Pass 1 (up log) & 302 & 423 & 265 & -2667 \\
& Pass 2 (up log) & 312 & 424 & 265 & -2667 \\
& Casing (up log) & 197 & 342 & 236 & -2667 \\
& Station & 359 & 413 & 265 & -2668 \\
\hline
\end{tabular}

Notes: Depth shift $=$ seafloor at $2667.84 \mathrm{mbrf}$. Vertical seismic profile stations are in the following locations: (1) $413.6 \mathrm{mbsf}$ (3081.4 mbrf), 19 shots recorded (72-90); (2) 402.2 mbsf (3073 mbrf), 4 shots recorded (91-94); (3) 382.2 mbsf (3050 mbrf), 21 shots recorded (95-115); (4) 363.9 mbsf (3031.7 mbrf), 16 shots recorded (116-131); and (5) $358.8 \mathrm{mbsf}$ (3026.6 mbrf), 15 shots recorded (132-146). UBI = Ultrasonic Borehole Imager, FMS = Formation MicroScanner, WST = Well-Seismic Tool. 